Ks. Józef Wołczański

Kraków

\title{
Korespondencja abp. Józefa Teodorowicza z różnymi osobami w sprawie Teresy Neumann $\mathrm{z}$ lat 1930-1938
}

\section{Wprowadzenie}

Lata 30. XX stulecia obfitowały w bogatą korespondencję abp. Józefa Teodorowicza $\mathrm{z}$ wieloma osobami na temat fenomenu Teresy Neumann z Konnersreuth. Hierarcha prowadził szeroko zakrojone konsultacje zarówno z ówczesnymi sławami naukowymi w dziedzinie medycyny z Europy Zachodniej i Polski, jak też szukał zwolenników własnych poglądów na tzw. kwestię Konnersreuth.

Centralną postacią owego dyskursu była niemiecka stygmatyczka i wizjonerka Teresa Neumann. Urodziła się 8/9 IV 1898 r. w Konnersreuth (Bawaria). Jej rodzicami byli Ferdynand - krawiec i rolnik oraz Anna z d. Grillmeier. Miała dziesięcioro rodzeństwa. W latach 1918-1925 wskutek doznanych obrażeń fizycznych przebywała unieruchomiona w domu rodzinnym. Po odzyskaniu sprawności ruchowej pomagała w pracach gospodarczych. W 1926 r. została obdarzona stygmatami, które utrzymały się do jej śmierci. Podczas ekstaz przeżywała mękę Chrystusa, doznawała objawień, przepowiadała przyszłe wydarzenia, a cierpienia ofiarowała w intencji bliźnich. Od roku 1922 do śmierci nie spożywała żadnych pokarmów i napojów, przyjmując jedynie Komunię św. W latach 1927 i 1928 została poddana badaniom lekarskim, które nie wykazały mistyfikacji. Odwiedzało ją wielu gości zarówno z ciekawości, jak też z inspiracji religijnych. W dobie hitlerowskiego nazizmu czynniki polityczne interesowały się jej osobą, bowiem nie kryła swego negatywnego nastawienia do reżimu, ale nie podjęły żadnych form represji. Zmarła 18 IX 1962 r. w Konnersreuth i tam została pochowana. W 2005 r. zainicjowano na szczeblu diecezjalnym jej proces beatyfikowacyjny ${ }^{1}$.

Sława niemieckiej stygmatyczki dotarła $\mathrm{w}$ okresie międzywojennym również do Polski, ispirując szczególnie dwóch kościelnych hierarchów do szczegółowych badań naukowych. Byli to: zwierzchnik Kościoła archidiecezji lwowskiej obrządku ormiańskokatolickiego abp Józef Teodorowicz i ordynariusz diecezji tarnowskiej, były profesor teologii dogmatycznej na Wydziale Teologicznym Uniwersytetu Lwowskiego,

${ }^{1}$ Neumann Therese, w: DBE, Bd. 7, herausg. von W. Killy, R. Vierhaus, München 1998, s. 387; Ch. Köppl, Neumann Therese, w: NDB, Bd. 19, red. zbior., Berlin 1998, s. 162-1163; S. Szpetnar, Teresa Neumann: stygmatyczka z Konnersreuth, Kraków 1931², passim; A. Krzesiński, Niezwykte dzieje Teresy Neumann $z$ Konnersreuth, Warszawa 1927; K. Pietrzyk, Teresa Neumannn stygmatyczka $z$ Konnersreuth, Warszawa 1992, passim; A. Spiegl, Życie i śmierć Teresy Neumann z Konnersreuth, Częstochowa 2014, passim. 
bp prof. dr hab. Franciszek Lisowski. Odwiedzili kilkakrotnie Teresę Neumann, m.in. w 1930 i 1931 r. stając się zdecydowanymi orędownikami tezy o nadprzyrodzonym charakterze jej przeżyć2.

Na tego typu poglądy zareagował wykładowca psychologii i filozofii na Uniwersytecie Gregoriańskim w Rzymie o. prof. Paweł Siwek SJ nie podzielający zapatrywań obu hierarchów, a zwłaszcza abp. Teodorowicza. Wywiązał się głośny spór naukowy o szerokim rezonansie, którego finał rozegrał się w kongregacjach Stolicy Apostolskiej. Jego geneza sięga roku 1930, kiedy to jezuita pod wpływem lektury książki autorstwa proboszcza parafii Münchenreuth ks. Leopolda Witta Konnersreuth im Lichter der Religien und der Wissenschaft: Die Leiden einer Glücklichen. Heimatblümchen aus dem Stiftland, 1-2 Teil: Das kleine Leben der stigmatisierten Jungfrau Therese Neumann von Konnenrsreuth. Nach ihren eigenen mündlichen Darstellungen (Wladsassen $1927^{2}$ ) odwiedził Teresę Neumann w czasie jej ekstazy. Po powrocie do Krakowa wygłosił jeszcze tego samego roku na temat Konnersreuth prelekcję w Sodalicji Mariańskiej Mężczyzn podkreślając złożoność zachodzących tam zjawisk, które po części można wytłumaczyć racjonalnie, inne zaś muszą zostać poddane dalszym badaniom ${ }^{3}$.

Równolegle na gruncie lwowskim fenomenem Konnersreuth zainteresował się abp Józef Teodorowicz podejmujący w swoim nauczaniu i pisarstwie m.in. problematykę ascetyczną i mistyczną. Kilkakrotnie odwiedzał Teresę Neumann w towarzystwie wspomnianego wyżej bp. Franciszka Lisowskiego. Jak sam przyznawał, „[...] uwikłał się w sprawę Konnersreuth pod wpływem Ks. Biskupa Lisowskiego [...]"', pod jego też wpływem zaprezentował na ten temat prelekcję najpierw we Lwowie, a później w Krakowie. Mianowicie w listopadzie 1930 r. przybył on do Krakowa z planem wygłoszenia analogicznej konferencji poświęconej Teresie Neumann. Zanim do tego doszło, odbył kilka spotkań konsultacyjnnych z o. Siwkiem, uzupełniając swoją wiedzę o niektórych zjawiskach psychologicznych. W grudniu 1930 r. hierarcha rzeczywiście zrealizował swoje zamierzenie, przypisując wszakże wydarzeniom w Konnersreuth charakter nadprzyrodzony $^{5}$. Stanowisko to wywołało spore zamieszanie w krakowskim środowisku naukowym, co sprowokowało o. Siwka do ogłoszenia na początku 1931 r. na łamach "Przeglądu Powszechnego" rozprawy Konnersreuth $w$ świetle nauki i religii ${ }^{6}$. Kilka miesięcy później ukazała się obszerna książka pod tym samym tytułem wydana przez krakowską oficynę Księży Jezuitów ${ }^{7}$. Autor dowodził, iż wszystkie nadzwyczajne zjawiska $\mathrm{z}$ wyjątkiem wieloletniego niespożywania pokarmów i napojów doświadczane przez Teresę Neumann można wyjaśnić racjonalnie. Postulował zatem poddanie mistyczki klinicznym badaniom celem rozwiązania tej niezwykłej zagadki. Według opinii o. Siw-

2 S. Szpetnar, Teresa Neumann, s. 179.

${ }^{3}$ P. Siwek, Z wiara przez życie. Pamiętnik, oprac. S. Kolarski, Kraków-Budzów 2005, s. 204.

${ }^{4}$ Zob. w niniejszej publikacji: J. Wołczański, Korespondencja abp. Józefa Teodorowicza z o. Włodzimierzem Ledóchowskim, dokument 6.

${ }^{5}$ P. Siwek, $Z$ wiara przez życie, s. 205-207.

6 Tenże, Konnersreuth $w$ świetle nauki i religii, PP, 48(1931), t. 189, s. 3-20, s. 182-194.

7 Toż, Kraków 1931, ss. 276. 
ka, jego publikacja zyskała w Polsce wręcz entuzjastyczną aprobatę, czego wyrazem były liczne gratulacje ze strony naukowych autorytetów i pochlebne recenzje . $^{8}$

Znając zainteresowanie abp. Teodorowicza tematem Konnersreuth, o. prof. Siwek niezwłocznie przesłał mu 24 XI 1931 r. egzemplarz swojej książki. Cztery dni później wyszła ze Lwowa do Rzymu, gdzie przebywał o. Siwek, odpowiedź lwowskiego hierarchy, w której zakwestionował on stosowane przez jezuitę metody badań zjawisk mistycznych, zarzucając mu przeakcentowanie aspektu fizjologicznego i naturalistycznego w opisie fenomenu Teresy Neumann. Jednocześnie zaanonsował złożoną do druku w redakcji „Ateneum Kapłańskiego” własną interpretację owych wydarzeń ${ }^{10}$. Reagując na owe zarzuty, o. prof. Siwek w liście do Lwowa z 6 XII 1931 r. dowodził, iż nie traktuje niezwykłych w swej istocie zjawisk w Konnersreuth jako mistycznych, bowiem Kościół nie wypowiedział się w tej materii. Przytaczał nienaturalne zachowania Teresy Neumann możliwe do wyjaśnienia metodami racjonalnymi, co tym samym wykluczało konieczność uznania je za nadprzyrodzone. Stosując tę metodę opisu jezuita powoływał się na apele kilku papieży z przełomu XIX i XX stulecia, wzywających katolickich uczonych do uwględniania w swych badaniach rezultatów osiągnięć nauk szczegółówych. Oddalał jako nadinterpretację pomawianie go o stanowisko sceptyczne i hiperktyczne w stosunku do Teresy Neumann, bo jego zamiarem miała być jej obrona przy uwzględnieniu krytycznych metod opisu, nie zaś przypuszczanie nań ataków ${ }^{11}$.

Abp Teodorowicz ustosunkował sie do tych uwag w piśmie z 11 I 1932 r. Uznał rozprawę o. Siwka za „[...] typ infiltracji racjonalizmu w badania mistyczne [zauważane] u wielu katolickich profesorów"12. Jego zdaniem podejście jezuity do kwestii zagadnień mistycznych dyskredytuje jego książkę jako poważne i obiektywne opracowanie. Przytaczał anonimowo opinie czytelników, zarzucających rozprawie tendencyjność, jałowość wywodów, wewnętrzne sprzeczności, aprioryczne uprzedzenie względem Teresy Neumann, a nawet wywoływanie zgorszenia wśród młodzieży ${ }^{13}$. Poruszony tak poważnymi zarzutami, o. Siwek w liście z 16 I 1932 r. bronił się dowodząc, iż zasadniczym motywem wydania książki były wyłącznie inspiracje religijne, a jej publikacja doszła do skutku dzięki aprobacie generała Zakonu o. Włodzimierza Ledóchowskiego. Za niesprawiedliwe i krzywdzące uznał zarzuty o deprecjonowanie mistyki, zapowiadając kategoryczną i nieustępliwą przed nimi obronę. Jako profesor papieskiego Uniwersytetu Gregoriańskiego nie mógł sobie pozwolić, aby oskarżano go o racjonalizm i propagowanie zgorszenia młodzieży. W tej sytuacji z ubolewaniem musiał podjąć narzuconą mu przez krytyka polemikę, choć był świadomy jej szkodliwych skutków społecznych w polskim społeczeństwie. $Z$ determinacją pisał: „Raz rozpoczętą polemikę będę z łaską Pana

8 Tenże, Z wiara przez życie, s. 207-208.

9 Zob. w niniejszej publikacji: J. Wołczański, Korespondencja abp. Józefa Teodorowcza z różnymi osobami w sprawie Teresy Neumann, dokument 20.

10 Tamże, dokument 21.

11 Tamże, dokument 22.

12 Tamże, dokument 24.

13 Tamże. 
Jezusa prowadził do ostatniego tchu, ale z zarzutów powyższych muszę się oczyścić, bo tego wymaga moje stanowisko" ${ }^{14}$. W kolejnym piśmie skierowanym pod lwowski adres ormiańskiego hierarchy, jezuita ponownie odpierał insynuowane mu zarzuty, w tym oskarżenie o nieuznawanie mistyki. Dowodził, iż opinia ta jest mylna, pozostaje natomiast kwestią dyskusyjną istota mistyki. Nie zamierzał siać zgorszenia swoją książką, lecz uwględniając naukowe metody bronić religii katolickiej przed kompromitującymi publikacjami na temat Teresy Neumann. W ferworze dodawał: „Zarzut racjonalizmu, gorszyciela publicznego uważam za absolutnie krzywdzący. Będę się z niego czyścił aż do ostateczności, aż do upadłego... Żadne względy, żadne rady nie wstrzymają mię tutaj. Ekscelencja doskonale rozumie, że profesor «Papieskiego Uniwersytetu» i to w Rzymie, nie może pozwolić, by zaciążył na nim zarzut «racjonalisty czy gorszyciela», a choćby tylko człowieka nieznającego metody naukowej. [...] Raz podjętą polemikę będę z łaską Pana Jezusa prowadził do ostatniego tchu, ale z zarzutów powyższych muszę się oczyścić, bo tego wymaga sumienie. Pozwolenia potrzebne oczywiście mam"15.

Tymczasem abp Teodorowicz opublikował od stycznia do kwietnia 1932 r. na łamach "Ateneum Kapłańskiego" obszerny artykuł Zjawiska mistyczne $i$ ich tłumaczenia ${ }^{16}$ $\mathrm{w}$ formie polemiki z dziełem o. Siwka. Ten ostatni opracował pisemną relację na pracę lwowskiego hierarchy, którą jesienią 1932 r. pozytywnie zaopiniowali do druku krakowscy cenzorzy, po czym przesłano ją do redakcji „Ateneum Kapłańskiego”. Tam jednak zwlekano z publikacją rozprawy, wskutek czego jezuita zażądał jej zwrotu i przekazał do Wydawnictwa Apostolstwa Modlitwy w Krakowie ${ }^{17}$.

Równolegle do tych działań generał Zakonu o. Ledóchowski w trosce o uniknięcie skandalu polecił przełożyć na język francuski inkryminowaną książkę o. Siwka Konnersreuth $w$ świetle nauki $i$ religii, a następnie nakazał wybitnym profesorom z Uniwersytetu Gregoriańskiego, w tym o. Josephowi de Guilbertowi SJ wykładowcy teologii mistycznej tamże, opracowanie krytycznych recenzji. Wszystkie opinie okazały się pozytywne, a ich autorzy domagali się wydania pracy w wersji francuskiej dla cudzoziemców. Przeciwny tej sugestii był sam o. Siwek, obawiając się perspektywy walki na dwóch frontach: w Polsce i we Francji. Jego stanowisko poparł o. Ledóchowski, dlatego zaniechano planowanej edycji ${ }^{18}$.

O poszczególnych etapach relacji o. Siwka z abp. Teodorowiczem informowany był pisemnie przez podwładnnego na bieżąco generał Zakonu oo. Jezuitów. Już w liście z 29 I 1932 r. napisanym pod wrażeniem pierwszego fragmentu polemicznego artykułu z „Ateneum Kapłańskiego“ atakowany autor donosił generałowi o oskarżeniach ze strony lwowskiego hierarchy o brak ortodoksji, tendencyjność i sianie wątpliwości przeciw wierze. $\mathrm{Z}$ pewną przesadą narzekał na dominujący „[...] mściwy, ironiczny ton,

14 Tamże, dokument 25.

15 Tamże, dokument 26.

${ }_{16}$ J. Teodorowicz, Zjawiska mistyczne i ich ttumaczenia, AK, 18(1932), t. 29, z. 1, s. 1-16; z. 2, s. 105-121; z. 3, s. 209-229; z. 4, s. 313-338.

17 P. Siwek, $Z$ wiara przez życie, s. 210.

18 Tamże. 
posądzenie o świadome fałszowanie dokumentów, przekazywanie faktów tendencyjne [...]"19. Zapowiadał tym samym replikę, licząc na zgodę ze strony generalnego przełożonego. W pierwszym wszakże odruchu o. Ledóchowski nie był skłonny zaakceptować pomysłu o. Siwka, o czym nie omieszkał powiadomić listownie 25 I 1932 r. ormiańskiego arcybiskupa. Obawiał się bowiem negatywnego społecznego rezonansu polemiki obu duchownych. W zamian oczekiwał wycofania z publicznej przestrzeni obarczania młodego jezuity zarzutem braku ortodoksji, czego nie potwierdzała lektura jego książki. Gdyby jednak hierarcha podtrzymywał owe oskarżenia, wówczas zakaz polemiki byłby nieaktualny ${ }^{20}$.

Zapewne wzgląd na wieloletnią znajomość abp. Teodorowicza z o. Ledóchowskim, ale chyba i pojednawczy ton pisma tegoż ostatniego sprawiły, iż ormiański hierarcha w liście z 13 II 1932 r. adresowanym do Rzymu zapowiedział zmianę zakończenia drukowanych w odcinkach na łamach „Ateneum Kapłańskiego” swego polemicznego artykułu. Mianowicie obiecał wyraźnie podkreślić prawowierność o. Siwka, ale nie krył urazy pod jego adresem, iż ten przypisał mu, jako biskupowi, zbytnią łatwowierność w ocenie zjawisk zachodzących w Konnersreuth, a zarazem narzucanie takiej samej postawy czytelnikom książki. Reakcję Zakonu oo. Jezuitów ustami jednego z jego członków wobec stanowiska biskupów (Lisowskiego i Teodorowicza) względem Teresy Neumann określił mianem swego rodzaju wrogiej kampanii. Coraz mocniej autor pisma przenosił ciężar polemiki z meritum sprawy na grunt osobisty: przypisania mu naiwności i bezkrytycznej łatwowierności o ocenie kwestii Konnersreuth ${ }^{21}$.

Zapowiedziana korekta na korzyść o. Siwka ostatniej części artykułu drukowanego w „Ateneum Kapłańskim” nie doszła wszakże do skutku rzekomo z winy redakcji periodyku, która opublikowała go w pierwotnej, radykalnej wersji. Ubolewając nad tym conajmniej dwuznacznym incydentem, abp Teodorowicz informował o nim o. Ledóchowskiego krótkim listem z 22 IV 1932 r. ${ }^{22}$ Zapewne uznając niewywiązanie się hierarchy ze złożonej obietnicy za prawo do publicznej obrony atakowanego o. Siw$\mathrm{ka}$, generał Zakonu pozwolił mu w maju $1932 \mathrm{r}$. na kontynuację polemiki z arcybiskupem ormiańskim. Lojalnie zawiadomił 2 V 1932 r. o tym fakcie zainteresowanego hierarchę ${ }^{23}$.

Brak wyraźnego odcięcia się lwowskiego hierarchy od oskażeń ferowanych pod adresem jezuity mocno nim wstrząsnął. W tej sytuacji otuchy dodawał mu sam generał Zakonu, zapewniając go listownie 21 XI 1932 r. o poparciu jego stanowiska i poglądów, a zarazem swej neutralności względem lwowskiego arcybiskupa ${ }^{24}$. Po ukazaniu

${ }_{19}$ Zob. w niniejszej publikacji: J. Wołczański, Wybór korespondencji o. Włodzimierza Ledóchowskiego $z$ o. prof. Pawtem Siwkiem SJ, dokument 5.

${ }^{20}$ Zob. w niniejszej publikacji: tenże, Korespondencja abp. Józefa Teodorowicza $z$ o. Włodzimierzem Ledóchowskim SJ, dokument 5.

${ }^{21}$ Tamże, dokument 6.

22 Tamże, dokument 7.

${ }^{23}$ Tamże, dokument 8.

${ }^{24}$ Zob. w niniejszej publikacji: J. Wołczański, Wybór korespondencji o. Włodzimierza Ledóchowskiego SJ z o. prof. Pawtem Siwkiem SJ, dokument 7. 
się zaś edycji książkowej poprzedniej wersji artykułów drukowanych w „Ateneum Kapłańskim", obecnie pod rozszerzonym tytułem Zjawiska mistyczne i ich tłumaczenia (Konnersreuth) (Poznań 1933), o. Siwek zdawał sobie sprawę, iż siła rażenia publikacji będzie o wiele większa niż poprzednio wskutek zasięgu nie zaś meritum. Dzieląc się swymi wrażeniami z o. Ledóchowskim komunikował mu pisemnie w 1933 r., iż nie żałuje dotychczasowej polemiki, w czym utwierdziła go opinia o. prof. Józefa Innocentego Bocheńskiego OP wykładowcy rzymskiego Angelicum. Uczony ten uznał za stratę czasu lekturę książki abp. Teodorowicza, a zarazem komunikował o pełnym poparciu dla stanowiska ormiańskiego hierarchy w środowisku polskich oo. Dominikanów w Rzymie. $\mathrm{Z}$ tego powodu nie mógł ogłosić drukiem swego zapatrywania, choć tekst miał już gotowy ${ }^{25}$. O. Siwek cytował też wypowiedź o. prof. Guilberta SJ uznającego postawę abp. Teodorowicza za skandaliczną i zarzucającą mu nieznajomość metody krytyki historycznej. Pogląd ten podzielał zresztą atakowany jezuita, mając świadomość, iż z ignorantem w dziedzinie metody pracy naukowej nie sposób dojść do porozumienia. Dodawał: „Potem jest zgryźliwym, tak nienawistnie do mnie usposobionym, że we wszystkim widzi tylko złą wolę, tendencję do fałszowania. Mimo to odpowiedź godna, spokojna - jak poprzednia - osiągnie ten skutek, że duchowieństwo polskie, które w Polsce stoi na poziomie bardzo niskim i dlatego łatwo daje się uwieść temu, co głośniej krzyczy, pozna dokładniej moją właściwą tezę. Ks. Arc[ybiskup] bowiem ją w niemiłosierny sposób poprzekręcał"26. Pomimo tych obiekcji o. Siwek zapowiedział opracowanie kolejnej repliki na wspomnianą książkę ormiańskiego arcybiskupa. Mając wszakże świadomość, że ogłoszenie jej drukiem może ze „względów wyższych” okazać się niewykonalne, a na nim pozostanie znamię oskarżeń o brak orientacji w dziedzinie teologii mistycznej, sugerował o. Ledóchowskiemu gotowość opuszczenia Uniwersytetu Gregoriańskiego i udania się do Francji, aby tam kontynuować pracę badawczo-naukową bez zajęć dydaktycznych ${ }^{27}$.

Tego rozwiązania generał rzecz jasna nie przyjął. Tymczasem abp. Teodorowicz na gruncie polskim rozwinął szeroką kampanię przeciwko o. Siwkowi, a nawet Zakonowi oo. Jezuitów, oskarżając ich o prowadzenie walki z biskupami. W takim kontekście o. Ledóchowski pozwolił atakowanemu zakonnikowi na kolejną replikę w formie książkowej. Z początkiem wiosny $1933 \mathrm{r}$. ukazała się nowa rozprawa o. Siwka Metody badań zjawisk nadprzyrodzonych. Problem Konnersreth (Kraków 1933). Zdaniem autora, publikacja ta „[...] była dla abp. Teodorowicza gromem z jasnego nieba“ ${ }^{28}$. Nie spodziewał się bowiem dalszego ciągu polemiki, choć jej kontynuację jezuita wyraźnie zapowiedział. Autor dowodził, iż źródłem zatargu z ormiańskim duchownym jest odmienna koncepcja mistyki i jej relacji z charyzmatami udzialanymi przez Boga ludziom. Te ostatnie należy badać pod kątem możliwości wyjaśnienia ich jako zjawisk naturalnych, a dopiero w razie

\footnotetext{
${ }^{25}$ Tamże, dokument 8.

${ }^{26}$ Tamże.

27 Tamże.

${ }^{28}$ P. Siwek, $Z$ wiara przez życie, s. 214.
} 
przekroczenia barier sił przyrody można uznać je za interwencję czynników nadprzyrodzonych. Odmiennego zdania był abp Teodorowicz ${ }^{29}$.

Według relacji jezuity, wielu polskich dostojników kościelnych na czele z prymasem kard. Augustem Hlondem, jak też liczne grono świeckich autorytetów naukowych, gratulowało mu sukcesu solidaryzując się z nim w polemice z abp. Teodorowiczem ${ }^{30}$. Równolegle do głosów uznania toczyła się agitacja przeciw o. Siwkowi, inspirowana - jego zdaniem - przez lwowskiego polemistę. Sam zaś hierarcha dzielił się z korespondentami swym przekonaniem o negatywnej recepcji dzieła o. Siwka w polskim społeczeństwie ${ }^{31}$. Zdeterminowany jezuita przygotował kolejną polemiczną publikację „Dwie mistyki““32 kontunując tym samym dyskusję z dziełem lwowskiego hierarchy Zjawiska mistyczne $i$ ich tłumaczenia (Poznań 1933). W rozmowie z o. Ledóchowskim zagroził, iż jeśli nie otrzyma zgody na jej publikację lub władza zakonna zaniecha wdrożenia procesu kanonicznego przeciwko abp. Teodorowiczowi w kongregacjach Stolicy Apostolskiej, zrezygnuje z katedry uniwersyteckiej ${ }^{33}$. Wspomniany maszynopis nigdy jednak nie doczekał się druku.

Generał Zakonu zwlekał z reakcją z kilku powodów. Nade wszystko obawiał się wskutek nowych emocji zgonu abp. Teodorowicza cierpiącego na choroby krążenia. Poza tym nie wierzył w zmianę zapatrywań hierarchy, ani też w rychłe zakończenie naukowego sporu. Początkowo opowiedział się za propozycją o. Jana Rostworowskiego SJ gotowego opublikować pojednawczy artykuł w „Przeglądzie Powszechnym“, ale wycofał się z tego pomysłu z obawy przed eskalacją konfliktu rozciągniętego na teren redakcji periodyku i jezuickiego Wydawnictwa Apostolstwa Modlitwy. Rozważał też opcję zaangażowania znawcy zagadnień teologii mistycznej o. Guilberta SJ w charakterze obrońcy atakowanego współbrata, ale i ten wariant upadł z obawy przed „umiędzynarodowieniem" sporu toczącego się dotąd w granicach Polski. Pozostało ostateczne wyjście: złożenie skargi przeciwko abp. Teodorowiczowi w urzędach watykańskich z powodu oskarżeń jezuity o racjonalizm oraz propagowanie publicznego zgorszenia, co też niebawem nastąpiło ${ }^{34}$.

Tymczasem w roku 1934 nadal trwała korespodencja między o. Ledóchowskim a ormiańskim hierarchą i poproszonym przez generała oo. Jezuitów na arbitra w sporze prymasem Polski kard. Augustem Hlondem. Rządca Kościoła ormiańskiego w liście do prymasa z 31 I 1934 r. nie widział jednak możliwości pojednania, bowiem obok kwestii naukowych wchodził w grę aspekt moralny: obraza godności biskupiej przez wytknięcie

29 Tamże, s. 211-214.

30 Tamże, s. 215-217.

31 Zob. w niniejszej publikacji: J. Wołczański, Korespondencja abp. Józefa Teodorowicza z bp. Henrykiem Przeździeckim, dokument 12.

32 APJK, sygn. 2650, P. Siwek, Dwie mistyki. Uwagi krytyczne do dzieła ks. arcybiskupa Teodorowicza „Zjawiska mistyczne i ich tłumaczenia” (1933 r.), Rzym 1934, mps.

33 P. Siwek, Z wiara przez życie, s. 219.

34 Tamże, s. 219-220. 
mu ignoracji oraz obarczenie zarzutami braku ortodoksji katolickiej ${ }^{35}$. Poza tym, abp Teodorowicz w liście do o. Ledóchowskiego z 26 II 1934 r. nie przebierając w słowach oskarżył o. Siwka o kłamstwo i pychę, złą wolę oraz ponownie o obrazę godności ${ }^{36}$. Generał zachowując wszelkie kanony kultury, pismem z 31 III 1934 r. stanowczo odrzucił te insynuacje jako fałszywe, wykazując swemu rozmówcy wiele dowodów jego nieuczciwego postępowania względem przeciwnika. Zaprotestował więc przeciw ustawicznemu zniesławianiu jezuity na forum ogólnopolskim, apelując o zakończenie sporu. Proponował ogłoszenie na łamach „Ateneum Kapłańskiego" deklaracji podpisanych przez obu przeciwników łagodzących bądź nawet niwelujących dotychczasowe zarzuty ${ }^{37}$. W poszukiwaniu dróg porozumienia, kard. Hlond konferował w maju 1934 r. z generałem oo. Jezuitów w Rzymie. Ustalono, iż o. Ledóchowski porozumie się osobiście z abp. Teodorowiczem w sprawie rozwiązania konfliktu ${ }^{38}$.

Odpowiedzią ze strony ormiańskiego hierarchy był kilkunastostronicowy elaborat z 14 V 1934 r. o charakterze rekapitulacji dotychczasowych utarczek i pretensji pod adresem Zakonu oo. Jezuitów, generała i samego o. Siwka. Zamiast gotowości kompromisu, pojawiła się w nim groźba wniesienia skargi do Stolicy Apostolskiej, czyli analogicznego kroku do zapowiadanego wcześniej przez o. Ledóchowskiego, wobec braku możliwości pojednania. Skarga ta miała dotyczyć kwestii rzekomego ataku słownego podczas wykładów na hierarchę w murach Gregorianum, propagowanie tez teologicznych niezgodnych z Magisterium Kościoła oraz poniżenie go epitetem łatwowiernego i bezkrytycznego fideisty ${ }^{39}$.

Skoro dotychczasowe próby zażegnania sporu między obu duchownymi zawiodły, generał o. Ledóchowski wniósł skargę do Stolicy Apostolskiej. Już wkrótce okazało się, że zwycięstwo przechylało się na korzyść oo. Jezuitów ${ }^{40}$. W ślad za tym polscy biskupi podjęli energiczne starania, aby przerwać proces kanoniczny i wycofać skargę, bowiem sytuacja miała skandaliczny posmak: oskarżenie arcybiskupa przez Zakon przed najwyższą instancją w Kościele. Przekonywali generała o lekceważącej recepcji w kompetentnych sferach argumentacji abp. Teodorowicza, obiecywali wywarcie nań wpływu celem zaprzestania dalszych ataków wobec o. Siwka, a nawet wyrażali gotowość powierzenia katedry teologii dogmatycznej na Wydziale Teologicznym Uniwersytetu Jagiellońskiego jezuicie o. Marianowi Morawskiemu. W zamian oczekiwali od o. prof. Siwka zaniechania dalszych badań nad kwestią Teresy Neumann. Po długich pertraktacjach o. Ledóchowski w roku 1935 przystał na te warunki, choć nie satysfakcjonowały one

${ }^{35}$ Zob. w niniejszej publikacji: J. Wołczański, Korespondencja abp. Józefa Teodorowicza z różnymi osobami z sprawie Teresy Neumann, dokument 176.

${ }^{36}$ Zob. w niniejszej publikacji: tenże, Korespondencja abp. Józefa Teodorowcza $z$ o. Włodzimierzem Ledóchowskim SJ, dokument 10.

37 Tamże, dokument 12.

${ }^{38}$ Zob. w niniejszej publikacji: J. Wołczański, Korespondencja abp. Józefa Teodorowicza z różnymi osobami w sprawie Teresy Neumann, dokument 198.

${ }^{39}$ Zob. w niniejszej publikacji: tenże, Korespondencja abp. Józefa Teodorowicza $z$ o. Wtodzimierzem Ledóchowskim SJ, dokument 13.

${ }^{40}$ P. Siwek, $Z$ wiara przez życie, s. 220. 
o. Siwka. Zgodnie z jego przewidywaniami, abp Teodorowicz nie zaprzestał aktywności pisarskiej, publikując w języku niemieckim książkę Konnersreuth im Lichte der Mystik und Psychologie (Salzburg-Leipzig 1936). Nie wymieniając w niej nazwiska oponenta ponownie przypuścił nań atak. Pomimo apeli z obszaru Niemiec o reakcję na tę publikację, jezuita nie podjął rzuconej rękawicy posłuszny warunkom rozejmu, a nade wszystko sugestiom przełożonego generalnego ${ }^{41}$.

Niespodziewanie pomoc przyszła z najmniej oczekiwanej strony. Oto 11 XI 1936 r. podczas sesji plenarnej Kongregacji Świętego Oficjum w Rzymie zapadła decyzja odnośnie do twórczości pisarskiej abp. Teodorowicza. Mianowicie otrzymał on zakaz jakichkolwiek tłumaczeń i edycji ostatniej niemieckojęzycznej publikacji, polecono mu dotychczasowy nakład wycofać z obiegu księgarskiego, sam zaś autor miał zaniechać dalszych działań w przedmiocie Konnersreuth ${ }^{42}$. Spełniając dezyderaty rzymskiej Kongregacji, abp Teodorowicz zakomunikował je Wydawnictwu Antoniego Pusteta w Salzburgu, wycofując wcześniejszą zgodę na przekład książki na język francuski i angielski. W piśmie do kard. Hlonda z 27 III 1937 r. zwierzał się z pragnienia poznania motywów decyzji Kongregacji. Zwrócił się w tej sprawie do ormiańskiego biskupa rezydującego w Rzymie w tej kwestii, ale jego pismo do watykańskiej instancji pozostało bez odpowiedzi $^{43}$. W tej sytuacji opracował z datą 27 III 1937 r. pismo w języku francuskim do papieża Piusa XI z prośbą o wyjaśnienia ${ }^{44}$. Doręczycielem dokumentu miał być kard. Hlond. Konkludując swój list do prymasa nie krył, iż dekret Kongregacji był dlań „ciosem moralnym“ nie tylko ze względu na zniweczenie długoletniego wysiłku badawczego, ale nade wszystko z powodu zakwestionowania wartości naukowych jego wszystkich prac naukowych ${ }^{45}$. Tymczasem kard. Hlond nie krył pesymizmu wywołanego negatywnymi skutkami watykańskiej decyzji; 29 III 1937 r. pisał do abp. Teodorowicza: „Jestem wprost przerażony obrotem, jaki wzięła sprawa wiadomej publikacji. Najserdeczniej z Waszą Ekscelencją współczuję, bo wmyślam się w tragizm położenia"46. Niespełna dwa miesiące później spełnił prośbę lwowskiego hierarchy podczas wizyty w Rzymie w maju 1937 r. Papież okazał zdziwienie po lekturze petycji, co sugerowało nieznajomość faktów lub zapomnienie ${ }^{47}$. Ale jeszcze tego samego miesiąca abp Teodorowicz otrzymał pismo z Kongregacji Świętego Oficjum datowane 28 V 1937 r. niwelujące poprzedni dekret ${ }^{48}$. Informując o tym fakcie ormiańskiego hierarchę 26 VI 1937 r. prymas Hlond gratulował mu sukcesu, dopatrując się ingerencji samego papieża ${ }^{49}$.

41 Tamże, s. 220-223.

42 Zob. w niniejszej publikacji: J. Wołczański, Korespondencja abp. Józefa Teodorowicza z różnymi osobami w sprawie Teresy Neumann, dokument 268.

43 Tamże, dokument 269.

44 Tamże, dokument 291.

45 Tamże, dokument 290 i 298.

46 Tamże, dokument 293.

47 Tamże, dokument 298.

48 Tamże, dokument 300.

49 Tamże, dokument 301. 
Dalsze losy sporu na linii abp Teodorowicz - o prof. Siwek przerwała śmierć pierwszego z nich w 1938 r., a później wybuch II wojny światowej. Po jej zakończeniu, o. Siwek powrócił do badań rozpoczętych w latach międzywojennych. Kiedy ukazała się angielska wersja pracy abp. Teodorowicza z 1936 r. Mystical Phenomena in the Life of Theresa Neumann (St. Louis Mo.-London 1940), jezuita wykładający wówczas na Facultades Católicas w Rio de Janeiro opublikował nowe prace nawiązujące do tej problematyki ${ }^{50}$. Nieco później, jako profesor Uniwersytetu Forhan w Nowym Jorku, wydał drukiem rozprawę z tego samego zakresu: Une stigmatisée de nos jours. Ėtude de psychologie religieuse (Paris 1950) i wersję angielska The Riddle of. Konnersreth. A Psychological and Religious Study (Milwaukee 1953, Dublin 1954²). Ponadto w następnych latach ogłosił 12 artykułów poświęconych tym zagadnieniom ${ }^{51}$. Wielkim uznaniem cieszyła się zwłaszcza wspomniana wyżej publikacja książkowa, zyskując pełną pochwałę i aprobatę ówczesnego sekretarza rzymskiej Kongregacji Obrzędów abp. Alfonsa Garinciㄹㄹ ${ }^{52}$ Gest ten stanowił swoiste zadośćuczynienie dla o. prof. Pawła Siwka za uciążliwy, a przy tym upokarzający spór z nieprzejednanym abp. Józefem Teodorowiczem.

Podejmując polemikę z o. Pawłem Siwkiem, od roku 1931 profesorem filozofii, psychologii metafizycznej i doświadczalnej na Uniwersytecie Gregoriańskim w Rzymie, ormiański hierarcha jako laik w tych dziedzinach wiedzy szukał fachowych konsultantów zarówno na gruncie polskim, jak i zagranicznym. Nawiązał zatem korespondencję z licznymi osobami specjalizującymi się w badaniach medycznych i teologicznych nad zjawiskami, których doświadczała Teresa Neumann, jak również z dostojnikami Kościoła katolickiego. Byli to m.in.: kard. August Hlond - prymas Polski, kard. Michael Faulhaber - ordynariusz archidiecezji Monachium i Freising (Niemcy), bp Michael Buchberger - ordynariusz diecezji Ratyzbona (Niemcy), bp François Agagianiann rektor Papieskiego Kolegium Ormiańskiego w Rzymie, późniejszy kardynał i prefekt Kongregacji Rozkrzewiania Wiary, ks. Joseph Naber - proboszcz parafii Konnersreuth, o. Włodzimierz Konopka SJ - prowincjał Zakonu oo. Jezuitów w Krakowie, o. Odo Staudinger OSB - opat klasztoru oo. Benedyktynów w Salzburgu (Austria), ks. prof. Franz Xaver Wutz - wykładowca biblistyki w Instytucie Filozoficzno-Teologicznym w Eichstätt (Niemcy), ks. prof. Franz Xaver Mayr - wykładowca chemii, biologii i geografii tamże, dr Rudolf Maria Hynek - czeski lekarz, dr Théodore Witry - specjalista chorób nerwowych w Trewirze, Metzu (Niemcy) i Luksemburgu, dr Eugène Willemin - lekarz francuski, Friedrich von Lama - austriacki pisarz i dziennikarz, obrońca Teresy Neumann i inni. Problematyka owych listów dotyczy zarówno zagadnień ściśle merytorycznych natury medycznej i teologicznej, jak również formalnej, odnośnie do tłumaczenia na język niemiecki i druku publikacji abp. Teodorowicza oraz polemiki z przeciwnikami jego stanowiska w kwestii Konnersreuth.

${ }^{50}$ P. Siwek, Les guérisons de Therèse Neumann à la lumière de la médicine, BANM, 113(1941), s. 31-41; tenże, Les stigmates, AAB, 42(1944), t. 66, s. 120-136; tenże, A psicanálise, San Paulo 1945.

${ }^{51}$ R. Darowski, Ks. Pawet Siwek SJ: koleje życia i spuścizna pisarska, CT, 49(1979), nr 1, s. 176-178.

${ }^{52}$ P. Siwek, Z wiara przez życie, s. 223-228. 
Zespół listów pomieszczonych w niniejszej części liczy 328 jednostek. Oryginały bądź kopie przechowywane są w Archiwum Fundacji Kultury i Dziedzictwa Ormian Polskich w Warszawie i Archiwum Księży Salezjanów w Krakowie. Zdecydowaną większość dokumentów stanowią pisma napływające do abp. Teodorowicza, o wiele mniejsza kolekcja to odpowiedzi tegoż na listy. Kwerenda podjęta w instytucjach austriackich i niemieckich celem zaprezentowania pełnej wymiany dokumentów nie przyniosła pozytywnych rezultatów. 


\section{Dokument 1}

Oryg.: AFKDOPW, teczka 144: Spuścizna abp. Józefa Teodorowicza, sygn. 1059/420 (8) [7], List ks. Stanisława Szpetnara do abp. Józefa Teodorowicza, Krosno 12 IX 1930 r.

$\dagger$

\section{Wasza ${ }^{a}$ Miłość!}

Mam w sercu i pamięci arcymiłą rozmowę z Waszą Miłością w Marienbadzie! ${ }^{53}$ Mówiliśmy wtenczas wiele o Konnersreuth. Miałem wielką ochotę dostać się z Waszą Miłością do Panny Neumann ${ }^{54}$, wtenczas jednak nie dawano pozwoleń. Mówiłem z Teresą w tym roku w maju. Wspomnienia ogłosiłem w „Powściągliwości i Pracy” ${ }^{5}$. Myślę wydać broszurę w tej sprawie ${ }^{56}$. Czytałem krótką wzmiankę w „Przewodniku Katolickim” ${ }^{7}$ o Waszej bytności w Konnersreuth.

Mówiliśmy wtenczas wiele o świątobliwych Polakach. Sercanki drukują pracę ks. Świątka ${ }^{58}$. Mam pod ręką kilka arkuszy wydrukowanych. Po przeczytaniu tych arkuszy zacząłem pisać projekt artykułu w tej sprawie. Zacząłem go ze względu na to, że jest dość świątobliwych Polaków, których żywoty będą w I tomie. Mówiłem z O. Świątkiem $^{59}$. Mam zamiar wydać także żywoty świątobliwych zakonodawców Polaków ${ }^{60}$. Ośmielam się załączyć broszurkę o św. Tadeuszu ${ }^{61}$.

W październiku będę we Lwowie, to przyjadę do Miłości Waszej. Bardzo mnie Wasza Miłość wziąłeś za serce tym, że przyjąłeś życzliwie moje słowa: „Myśl niezapisana ucieknie”.

Całuję ręce Waszej Miłości

\section{Krosno $^{63}$, dnia 12 IX 1930}

ks. Stanisław Szpetnar ${ }^{62}$

a Tekst pisany czarnym atramentem na 2,5 stronicach papieru formatu A4.

${ }^{53}$ Marienbad - od XIX w. popularny kurort o skali europejskiej na terenie Czech.

${ }^{54}$ Zob. w niniejszej publikacji: J. Wołczański, Korespondencja abp. Józefa Teodorowicza z abp. Adamem Stefanem Sapieha, dokument 91.

55 „Powściągliwość i Praca” - miesięcznik wydawany przez Zgromadzenie Księży Michaelitów w l. 18982006 o tematyce pedagogicznej, społecznej i kulturalnej.

${ }^{56}$ S. Szpetnar, Teresa Neumann: stygmatyczka $z$ Konnersreuth, Kraków $1931^{2}$.

57 Zob. w niniejszej publikacji: J. Wołczański, Korespondencja abp. Józefa Teodorowicza z abp. Adamem Stefanem Sapieha, dokument 20.

${ }^{58}$ F. Świątek, Świętość Kościoła w Polsce w okresie rozbiorowym i porozbiorowym, t. 1, Kielce 1930; t. 2: Życiorysy świątobliwych Polaków i Polek ostatnich wieków, Miejsce Piastowe 1932.

59 Świątek Franciszek (1889-1976), święcenia kapłańskie w 1915 r.w Zgromadzeniu oo. Redemptorystów, 19151917 przebywał w Maksymówce i Tuchowie, 1917-1924 nauczyciel gimnazjalny zakonnego Małego Seminarium w Mościskach, Krakowie i Stawkach k. Torunia, 1924-1939 misjonarz i rekolekcjonista zamieszkały w Mościskach, Krakowie, Tuchowie, Warszawie i Wilnie, 1939-1952 przebywał w Wilnie (ZSRR), 1952-1959 w Brasławiu (ZSRR), 1962-1964 w Polsce, 1964-1976 ponownie w Wilnie. Był autorem prac hagiograficznych i popularno-religijnych. M. Brudzisz, Świątek Franciszek, w: SPTK, t. 7, red. L. Grzebień, Warszawa 1983, s. 287-289.

${ }^{60}$ Zamysł ten nie doczekał się jednak realizacji.

${ }^{61}$ Bibliografia prac drukowanych ks. Szpetnara nie wykazuje tej publikacji. T. Śliwa, Szpetnar Stanistaw, w: SPTK, t. 7, red. L. Grzebień, Warszawa 1983, s. 233-234.

${ }^{62}$ Szpetnar Stanisław (1883-1952), święcenia kapłańskie w 1908 r. w Przemyślu, 1908-1910 wikariusz par. Krosno, 1910-1912 prefekt męskiego Seminarium Nauczycielskiego w Krośnie, 1912-1923, 1929-1931 prefekt Szkoły Realnej i Gimnazjum tamże, 1923-1929 dyrektor żeńskiego Prywatnego Seminarium Nauczycielskiego tamże, 1931-1952 kapelan klasztoru ss. Niepokalanek w Jarosławiu, 1933-1939 nauczyciel Gimnazjum ss. Niepokalanek tamże. Był autorem artykułów traktujących o wychowaniu młodzieży i rozprawek ascetyczno-religijnych. T. Śliwa, Szpetnar Stanistaw, w: SPTK, t. 7, s. 233.

${ }^{63}$ Krosno - miasto powiatowe, woj. Lwów. 


\section{Dokument 2}

AFKDOPW, teczka 145: Spuścizna abp. Józefa Teodorowicza, sygn. 1038/420 (8) [7], List prof. Friedricha Ritter von Lamy do abp. Józefa Teodorowicza, Gauting bei München 2 XII 1930 r.

Gauting b[ei] München, 2. Dezember 1930

Excellenz ${ }^{\mathrm{a}}$, Hochwürdigster Herr Erzbischof!

Verbindlichsten Dank für die gütige Antwort, die Sie meinem Brief zuteilwerden haben lassen. Würde es sich bei den Konnersreuther Vorgängen nicht um so eminent wichtige Dinge handeln, ich würde es sicher nicht gewagt haben, Eu[re] Excellenz zu belästigen. Ihre Absicht, sich selbst in einer Publikation zu äussern, begrüsse ich aus ganzem Herzen, denn leider hat bei uns die Theologie sich noch nicht anders als in negativer Kritik ausgesprochen; es fehlt der deutschen Theologie auch eingestandenermassen an Verständnis für Mystik; in Moral und Dogmatik, ja, da ist man zuhause. Was den Verlag dafür betrifft, so ist es mir ein Leichtes, ihn zu besorgen; ein halbes nutzend wartet darauf und ich brauche nur anfragen um der zustimmenden Antwort sicher zu sein. Der Verlag meiner Bücher, die „Badenia“ in Karlsruhe ${ }^{64}$ erschiene mir geeignet, weil sie durch den Vertrieb meiner Publikationen in Verbindung mit den Interessenten, also mit jenen ist, die für den Absatz vor allem in Frage kommen. Wenn Eu[re] Excellenz zustimmen, vermittle ich sofort das Weitere. Der Verlag ist ausgesprochen katholisch und sehr leistungsfähig.

Vielen Dank für die Angaben über die polnische Literatur über Konnersreuth; zugleich mit Ihrem Brief kam auch - ungebeten - ein solcher von Hochw[ürdigen] H[er] rn Szpetnar mit verschiedenen Anfragen. Hochw[ürdigen] H[errn] Krzesinski ${ }^{65}$ habe ich einmal auf einem Kongress kennen gelernt; falls Eu[re] Excellenz die Güte haben wollten, mich wissen zu lassen, an welcher Universität er Dozent ist, wäre ich sehr dankbar.

Bezüglich der vertraulichen Angelegenheit, mit der die Beilage Ihres Briefes in Verbindung steht, habe ich sofort Schritte unternommen, um bald die Beantwortung durch Therese zu erhalten. In dem anderen Fall muss ich bitten, mir wenigstens den Namen als Stichwort anzugeben um anfragen zu können.

Natürlich stehe ich sehr gerne zur Verfügung, Ihre Arbeit bezüglich letzter Verbesserungen am Stil durchzusehen. Ich bitte noch um Mitteilung, welchen Umfang voraussichtlich Ihre Arbeit haben wird.

a Tekst pisany maszynowo na 1,5 stronicy papieru formatu A4. Autograf odręczny czarnym atramentem.

${ }^{64}$ Karlsruhe - miasto w południowo-zachodnich Niemczech w kraju związkowym Badenia-Wirtembergia.

${ }^{65}$ Właściwie: Krzesiński Andrzej (1884-1964), święcenia kapłańskie w 1910 r. w Krakowie, dr teologii i filozofii, w 1924 r. habilitacja z filozofii, 1925-1928 wykładowca filozofii na Wydziale Teologii Katolickiej Uniwersytetu Warszawskiego, w 1930 r. na Wydziale Teologicznym UJ, 1936-1937 przebywał na Dalekim Wschodzie, 1939-1964 pracował w USA prowadząc działalność naukową i społeczno-polityczną, autor publikacji filozoficznych, psychologicznych i społeczno-politycznych. P. Taras, Krzesiński Andrzej Jan, w: $E K$, t. 9, red. zbior. Lublin 2002, kol. 1444-1445. 
Die gewünschte Zusendung meiner Bücher werde ich sofort veranlassen und bin in aufrichtiger Verehrung ergebenst

F[riedrich] R[itter] von Lama ${ }^{66}$

P.S. Die Arbeit $\mathrm{Eu}[\mathrm{rer}]$ Excellenz erachte ich als ungemein notwendig, denn selbst die zuständige kirchliche Behörde ist vollkommen unorientiert und der Hoch[würdige] Herr Bischof Buchberger ${ }^{67}$ hat selbst vor einiger Zeit geklagt: Das Bedauerliche ist. dass ich in meiner ganzen Diözese niemand habe, der von Mystik etwas versteht.

\section{Dokument 3}

Oryg.: AFKDOPW, teczka 145: Spuścizna abp. Józefa Teodorowicza, bsygn., List prof. Friedricha Ritter von Lamy do abp. Józefa Teodorowicza, Gauting bei München 5 XII 1930 r.

Gauting b[ei] München, 5. Dezember 1930

Eure $^{\mathrm{a}}$ Excellenz, Hochwürdigster Herr Erzbischof !

Soeben geht mir von meinem Verlag, „Badenia“, A. G. für Verlag und Druckerei in Karlsruhe, Baden, die Mitteilung zu, dass sie gerne bereit ist, den Verlag Ihres Buches zu übernehmen. In ihrem Auftrag bringen ich dies Eurer Excellenz hiemit zur Kenntnis. Der Verlag wünscht das Buch gleichzeitig mit meinem neuen „Konnersreuther Jahrbuch 1930“, das spätestens im März erscheint, herauszubringen und anzuzeigen. Bezüglich des weiteren, rein geschäftlichen Teils, bitte ich, sich mit dem Verlag direkt auszusprechen; selbstverständlich soll damit nicht gesagt sein, dass, wenn es gewünscht wird, ich auch gerne bereit bin, mitzuwirken.

Um die Revision ehestens vornehmen zu können, bitte ich Eure Excellenz, mir das Manuskript ehestens zugehen zu lassen.

Mit der Versicherung aufrichtiger Verehrung Euerer Excellenz ergebenster Friedr[ich] R[itter]von Lama

${ }^{66}$ Lama Friedrich von (1876-1944), austriacki katolicki pisarz i dziennikarz, należał do zwolenników i propagatorów Teresy Neumann z Konnersreuth, wydawał w latach 1929-1936 rocznik „Kronika Konnersreuther" rejestrujący informacje na ten temat, był autorem licznych poblikacji poświęconych niemieckiej mistyczce m.in.: Therese Neumann von Konnersreuth. Eine Stigmatisierte unserer Zeit (Bonn 1927, 1928²), Worte aus dem Jenseits oder wie Therese Neumann den kleinen Weg der geistigen Kindheit ging und dabei durch die heilige Theresia vom Kinde geführt wurde (Waldsassen 1930), Der Weg der Therese Neumann von Konnersreuth 1898-1935 (Karlsruhe 1935), Zur Aufklärung über Konnersreuth (Leipzig 1938). W 1. 19381944 więziony przez hitlerowców i zamordowany w Monachium. M. Berger, Lama Friedrich Georg Ritter von und zu Büchsenhausen, w: BBKL, Bd. 23, Nordhausen 2004, kol. 883-893.

${ }^{67}$ Zob. w niniejszej publikacji: J. Wołczański, Korespondencja abp. Józefa Teodorowicza z prof. Stefanem Dąbrowskim, dokument 32.

a Tekst pisany maszynowo na $1 \frac{1}{2}$ stronicy papieru formatu A4. Autograf odręczny czarnym atramentem. 


\section{Dokument 4}

Oryg.: AFKDOPW, teczka 138: Spuścizna abp. Józefa Teodorowicza, sygn. 1014/420 (8) [7], List o. Józefa Andrasza SJ do abp. Józefa Teodorowicza, Kraków 12 I 1931 r.

Kraków, dnia 12 stycznia 1931

Ekscelencjo! ${ }^{\mathrm{a}}$

Myślę, że już oba zeszyty „Wiadomości Katol[ickich]”68 i „Civitta”69 przywędrowały do Krynicy ${ }^{70}$. Mnie dość silny atak reumatyczny internował w pokoju, więc zasięgnąłem telefonicznie u samego redaktora „W[iadomości[ K[atolickich]” potrzebnych informacji. Przy czym Pani Włodkowa ${ }^{71}$ okazała się tak uprzejmą, że chętnie wypożyczyła numeru "Civitta" i posłała oba zeszyty swego pisma. Za te ostatnie zapłaciłem ze zbyt wysokiej prenumeraty, jaką Ekscelencja złożył na poczet prenumeraty „Posłańca”72.

O. Siwek ${ }^{73}$ powiada, że istotnie wówczas, kiedy rozmawiał z Księdzem Arcybiskupem nie miał jeszcze zamiaru pisania o Konnersreuth. Widocznie dyskusje z Ekscelencją przyczyniły się do skrystalizowania tematu w jego głowie i przyspieszyły pożyteczne artykuły. Ale zupełnie niespodziewanym dla mnie rezultatem rozmowy z Ekscelencją u Ks. Metropolity ${ }^{74}$ jest Tajberówna ${ }^{75}$ i jej sprawa. Będę się musiał w przyszłości mieć trochę na ostrożności w rozmowach z Ks. Arcybiskupem...

Z Tajberówną miałem raz dopiero konferencję - przestudiowawszy [...] dokładnie jej sprawę i niektóre wątpliwości dogmatyczne, które nastręczała. Istotnie zdaje się być

a Tekst pisany czarnym atramentem na dwóch stronicach papieru formatu zeszytowego.

68 „Wiadomości Katolickie” - dwutygodnik poświęcony kwestiom religijnym w Polsce i na świecie, wydawany i redagowany przez Zofię Włodkową w Krakowie 1923-1935.

69 Właściwie: „La Civitta Cattolica” - czasopismo założone przez oo. Jezuitów włoskich w Neapolu w 1850 r. istniejące do dziś, podejmuje szeroko rozumianą problematykę kultury z katolickiego punktu widzenia.

${ }^{70}$ Krynica - miasto i znany kurort w Małopolsce Zachodniej.

${ }^{71}$ Włodkowa Zofia (1890-1981), dr filozofii, prezes Sodalicji Mariańskiej Ziemi Krakowskiej, 1927-1937 prezes Sodalicji Pań Wiejskich Ziemi Krakowskiej, 1935-1939 i 1945-1948 prezes Katolickiego Stowarzyszenia Kobiet Akcji Katolickiej archidiec. krakowskiej, podczas II wojny światowej działała w AK, tłumaczka dzieł z dziedziny teologiczno-filozoficznych. J. Duda, Ród Włodków i jego zastugi dla Wieliczki i okolicy, Wieliczka 2009, s. 15-19.

${ }^{72}$ Właściwie: „Posłaniec Serca Jezusowego” - jezuicki miesięcznik założony w 1872 r. przez ks. Stanisława Stojałowskiego, zawieszony w latach 1941-1945 i 1953-1981, wychodzący do dziś. Zajmuje się propagowaniem kultu Serca Jezusa, wspierał idee Dzieła Poświęcenia Rodzin i Krucjaty Eucharystycznej. „Posłaniec Serca Jezusowego", w: EWJ, oprac. L. Grzebień, Kraków 1996, s. 531-532.

${ }^{73}$ Zob. w niniejszej publikacji: J. Wołczański, Korespondencja abp. Józefa Teodorowicza z abp. Adamem Stefanem Sapieha, dokument 101.

${ }^{74}$ Odniesienie do krakowskiego metropolity abp. Adama Stefana Sapiehy (1867-1951).

75 Tajber Zofia (1890-1963), ze środowiska Białej Podlaskiej, poprzez Żytomierz trafiła do Krakowa z pomysłem założenia żeńskiego zgromadzenia zakonnego poświęconego czci Najświętszej Duszy Chrystusa; od 1920 r. pozostawała pod duchowym kierownictwem oo. Jezuitów, w 1923 r. powołała do życia „Katolickie Stowarzyszenie dla pogłębienia życia religijnego ku czci Przenajświętszej Duszy Chrystusa Pana” zatwierdzone jako Zgromadzenie Zakonne w 1949 r. przez kard. A.S. Sapiehę. W 1960 r. kard. S. Wyszyński wydał dekret negujący jej przeżycia religijne i praktyki jako objawione; w 1993 r. zainaugurowano w Krakowie jej proces beatyfikacyjny. O. Filek, Promieniować Chrystusem. M. Paula Zofia Tajber (1890-1963), Założycielka Zgromadzenia Sióstr Najświętszej Duszy Chrystusa Pana, Kraków 2008, passim.

b Wyraz nieczytelny. 
tak, jak u Ekscelencji mówiłem: pewną nieścisłość i przesadę w wyrażeniach biorą niektórzy niemal za herezję. Sama Tajberówna przedstawia się tak pełną uległości i chętną na wszystkie pouczenia, że mi trochę zawód sprawiła. Myślałem, że będzie trochę czupurniejszą. Zresztą zobaczymy. Powiadają, że z[e] świątobliwymi niewiastami trzeba ostrożnie.

Ponieważ wiem, że Ekscelencja zawsze się trochę interesował „Bibl[ioteką] życia wewn[ętrznego]"76, więc donoszę, że obecnie w przygotowaniu są dwa nowe tomy - pierwszy to rekolekcje $\mathrm{e}^{77} \mathrm{O}$. Crawleya ${ }^{78}$, rzecz dawniejsza, ale dobra, drugi to bardzo oryginalne konsyderacje na tematy życie wewnętrznego ${ }^{79}$ jednego z belgijskich jezuitów O. Charle$\mathrm{sa}^{80}$. Sadzę, że Ekscelencję zainteresują.

Czekam niecierpliwie, kiedy się wreszcie ukaże pierwsza cześć życiorysu Chrystusa? ${ }^{81}$ Ręce Waszej Arcybiskupiej Mości całuję z prośbą o memento ${ }^{82}$, Sługa w Chrystusie Ks. Józef Andrasz Tj ${ }^{83}$

P.S. A propos owego [... $]^{c}$, to jednak ks. Urban ${ }^{84}$ stara się być obiektywny. Dwa razy go ratują spośród głosów lewicowo-radykalnych i wzrost głosów niemieckich. Daj Boże naszej Polsce jak najlepiej! Łączę pozdrowienia dla Czcig[odnego] Księdza Proboszcza i Jego Sufragana ${ }^{85}$.

${ }^{76}$ Biblioteka Życia Wewnętrznego - seria edytorska obejmująca przekłady dzieł ascetycznych i mistycznych powołana do życia w 1922 r. Funkcję redaktora pełnił o. Józef Andrasz SJ. W latach 1921-1936 ukazało się 41 tytułów, w latach 1939-1950 jedynie 2. Biblioteka Życia Wewnętrznego, w: EWJ, s. 44.

77 Publikacja ta wydana m.in. w j. francuskim Retraite sacerdotae (Paris 1936) nie ukazała się w polskim przekładzie anonsowanym cyklu wydawniczym. W j. polskim opublikowano po II wojnie światowej inną pracę tegoż autora: Jezus, król mitości (Poznań 1948).

${ }^{78}$ Crawley Boevey Eduardo (1875-1960), duchowny peruwiański, święcenia kapłańskie w Zgromadzeniu Księży Sercanów, imię zakonne Mateusz, propagator idei intronizacji Serca Jezusa w rodzinach, od 1918 r. generalny dyrektor Dzieła Intronizacji, twórca tzw. godziny świętej - ruchu nocnej adoracji rodzinnej i stanowej, autor licznyc publikacji religijno-scetycznych. J. Duchniewski, Crawley Boevey Eduardo, w: $E K$, t. 3, red. zbior., Lublin 1985, kol. 624-625.

${ }^{79}$ Publikacja ta ukazała się we wspomnianej serii dopiero po II wojnie światowej: P. Charles, Modlitwa wszystkich rzeczy, Warszawa 1950.

${ }^{80}$ Charles Pierre (1883-1954), święcenia kapłańskie w 1910 r. w Zakonie oo. Jezuitów, belgijski teolog, misjolog, podróżnik i pisarz ascetyczny, wykładowca w Seminariach Duchownych oraz na Wydziale Misjologii na Gregorianum, współtwórca Tygodni Misjologicznych, autor ok. 280 publikacji. J. Duchniewski, Charles Pierre, w: EK, t. 3, kol. 81-82.

${ }^{81}$ Aluzja do dzieła J. Teodorowicza: Jezus Chrystus, t. 2: Od Betlejem do Nazaretu, Poznań 1932.

82 Łac.: pamiętaj! Tu w znaczeniu: pamiętaj w modlitwie.

${ }^{83}$ Zob. w niniejszej publikacji: J. Wołczański, Korespondencja abp. Józefa Teodorowicza z abp. Adamem Stefanem Sapieha, dokument 94.

c Wyraz nieczytelny.

${ }^{84}$ Zob. w niniejszej publikacji: J. Wołczański, Wybór korespondencji generała o. Włodzimierza Ledóchowskiego SJ z o. prof. Pawtem Siwkiem SJ, dokument 7.

${ }_{85}$ Aluzja do proboszcza parafii rzymskokatolickiej w Krynicy, u którego podczas kuracji mieszkał abp. Teodorowicz. Z kolei „sufragan” proboszcza to żartobliwe określenie lwowskiego hierarchy ormiańskiego. 


\section{Dokument 5}

AFKDOPW, teczka 145: Spuścizna abp. Józefa Teodorowicza, sygn. 1036/420 (8) [7], List prof. Friedricha Ritter von Lamy do abp. Józefa Teodorowicza, Gauting bei München 2 IV 1931 r.

Excellenz $z^{\mathrm{a}}$, hochwürdigster Herr Erzbischof!

Gauting b[ei] München, 2. April 1931

Vielen Dank für alle Mitteilungen, besonders für jene über die Stigmen Theresas. Ihre Erklärung ist mir deswegen von grösster Wichtigkeit, weil tatsächlich eine Umbildung der Stigmen vorliegt, die schon am Karfreitag 1930 vollendet war. Vor zwei Jahren begann die kreisrunde Form, die Gerlich ${ }^{86}$ noch festgestellt hatte, in eine mehr viereckige und dann in die rechteckige Form überzugehen und an Ostern (1930) hatten sich aus dem verkrusteten Blut die Nägel selbst gebildet. Hierüber besitze ich die ganz genaue Beschreibung durch den Versailler Arzt Dr. Louis ${ }^{87}$, der am Ostermorgen eine Untersuchung vornehmem durfte. Ich brauche auf die Bedeutung dieser Entwicklung, die alle Autosuggestionshypothesen glatt umwirft, nicht einzugehen. Merkwürdig ist nur, dass das Phänomen bisher gänzlich unbeachtet geblieben ist. Ihre Beschreibung berührt also jene von Dr. Gerlich nicht im geringsten, Sie haben beide Recht.

Es wäre sehr zu wünschen, wenn es Eu[rer] Excellenz möglich wäre, das $\mathrm{MS}^{88}$ bald zum Druck übergeben zu können. Der Salvator-Verlag in Mülhausen, der die französische Ausgäbe meiner Konnersreuther Bücher verlegt hat, bewirbt sich heimit jetzt schon um das Recht, auch von Ihrer Schrift eine französische Ausgabe herstellen zu dürfen; die Honorarbedingmagen können erst aufgestellt werden, wenn der Umfang des Buches feststeht. In meinem Jahrbuch über das laufende Jahr 1931 werde ich Ihrem Buche wohl besondere Beachtung zuwenden und ich bitte heute schon, mir zu gestatten, dasselbe mit Ihrem Bilde schmücken zu dürfen. Ich benütze die Gelegenheit, meine ergebensten Wünsche zum heiligen Osterfest zu entbieten und bin aufrichtigst ergeben

F[riedrich] R[itter]von Lama

\section{Dokument 6}

Oryg.: AFKDOPW, teczka 142: Spuścizna abp. Józefa Teodorowicza, sygn. 927/420 (8) [7], List ks. A. Meyera do abp. Józefa Teodorowicza, Guémar 4 IV 1931 r.

Guémar ${ }^{89}$, le 4. April 1931

a Tekst pisany maszynowo na jednej stronicy papieru formatu A4. Autograf odręczny czarnym atramentem.

${ }^{86}$ Zob. w niniejszej publikacji: J. Wołczański, Korespondencja abp. Józefa Teodorowicza z prof. Stefanem Dąbrowskim, dokument 64.

87 Osoba niezidentyfikowana.

${ }^{88}$ Skrót nieznany.

${ }^{89}$ Guémar - miejscowość k. Strasburga w Alzacji. 
Euere $^{\mathrm{a}}$ Eminenz!

Durch $\mathrm{H}[\mathrm{errn}]$ von Lama erfahre ich, dass Eure Eminenz in den nächsten Tagen eine Broschüre über Therese Neumann veröffentlichen werden. Als großer Freund von Konnersreuth freue ich mich aufrichtig, dass nach dem Hochw[ürdigen] Herrn Erzbischof Dr. Waitz ${ }^{90}$ auch nun ein Kirchenfürst das Wort für die K[onnersreuter] Geschehnisse ergreift. Habe die Werke Lamas, Waitz etc. ins französische übertragen lassen. Dieselben finden kein großes Interesse. Aus diesem Grunde gestatte ich mir, schon vor Erscheinen Ihres Werkes die Berechtigung der Übersetzung ins französische zu sichern. Die Bedingungen wollen Euere Eminenz selber unterschreiben. Ich füge ein Verzeichnisunserer Verlagsbroschuren bei.

Indem ich Euerer Eminenz im [... $]^{\mathrm{b}}$ meine innigsten Dankanspruches bitte ich Eure Eminenz den Ausdruck meiner tiefsten Ehrerbietung zu empfangen

Meyer

Pfarrer

\section{Dokument 7}

Kopia: AFKDOPW, teczka 136: Spuścizna abp. Józefa Teodorowicza, bsygn., Kopia listu abp. Józefa Teodorowicza do ks. A. Meyera, Lwów 10 IV 1931 r.

Kopia $^{a}$

Hochverehrter Herr Pfarrer!

Es hat mir schon Herr v[on] Lama geschrieben, dass Sie bereit wären meine Arbeit über Konnerseruth ins Französische zu übersetzen. Selbstverständlich bin ich damit einverstanden und ich danke Ihnen für das Vertrauen welches Sie mir entgegenbringen, indem Sie den Inhalt meines Buches noch nicht kennen. Ich schreibe: „meines Buches“, denn ich glaube, dass in meiner Arbeit die Grenzen einer Broschüre überschritten werden. Ich versuche nämlich das Problem von Konnersreuth kritisch auf der psychologischen und mystischen Grundlage zu bearbeiten. Wiewohl Sie so gut sind, dass Sie schon jetzt Ihre Bereitwilligkeit zum Übersetzen zeigen, und wiewohl ich Ihre Bereitwilligkeit prinzipiell annehme, so überlasse ich Ihnen die volle Freiheit, nach dem Erscheinen des Buches einen endgültigen Entschluss zu fassen.

Mit dem Ausdruck meiner ausgezeichneten Hochachtung.

Lwów, 10 IV 1931

a Tekst pisany czarnym atramentem na 1,5 stronicy papieru format zeszytowego. W lewym górnym rogu karty tytułowej nadruk firmowy: „Paroisse de Guémar Haut-Rhin, Diocèse de Strasbourg (Alsau)”.

${ }_{90}$ Zob. w niniejszej publikacji: J. Wołczański, Wybór korespondencji o. Włodzimierza Ledóchowskiego SJ $z$ o. prof. Pawtem Siwkiem SJ, dokument 12.

b Tekst nieczytelny.

a Tekst pisany czarnym atramentem ręką kopisty na jednej stronicy papieru formatu A4. Brak autografu autora. 


\section{Dokument 8}

Oryg.: AFKDOPW, teczka 145: Spuścizna abp. Józefa Teodorowicza, sygn. 1035/420 (8) [7], List prof. Friedricha Ritter von Lamy do abp. Józefa Teodorowicza, Gauting bei München 11 IV 1931 r.

Eure $^{\mathrm{a}}$ Excellenz, hochwürdigster Herr Erzbischof!

Gauting b[ei] München, 11. April 1931

Es sei mir gestattet, in aller Ehrfurcht die dringende Ritte auszusprechen, wenn irgend möglich doch recht bald die Arbeit über Therese Neumann einzureichen, damit sie in Druck kommt. Man ist in Regensburg vollkommen unorientiert, schenkt dort allen Einflüsterungen selbst ausgesprochen Ungläubiger Gehör, hat keine Ahnung von psychologischer Differenzierung und völlig unerfahren. In der Beurteilung mystischer Phänomene neigt man aus Angst, ein Fehlurteil zu fällen, lieber zu einer rein natürlichen Erklärung;man spricht sie nur deswegen nicht aus, weil man sie dann auch begründen muss und das kann man nicht. Der Versuch, die Verantwortung auf die Schultern der Kongregation des Hl. Offiziums abzuwälzen, ist gescheitert; in Rom urteilt man nämlich ganz gegenteilig und ist von der Uebernatürlichkeit der Phänomene längst überzeugt. Ihre Schrift würde daher eine befreiende Tat bedeuten, für die man gerade in Regensburg sicher besonders dankbar wäre, wenn man es natürlich auch niemals eingestehen würde.

Ich bitte, mir dieses Drängen nicht überzunehmen und bin mit der Versicherung aufrichtiger Ergebenheit

F[riedrich] R[itter] von Lamab

\section{Dokument 9}

Oryg.: AFKDOPW, teczka 145: Spuścizna abp. Józefa Teodorowicza, sygn. 926/420 (8) [7], List dr. Eugène Willemina do abp. Józefa Teodorowicza, Vichy 13 V 1931 r.

Vichy $^{91}$, le 13 Mai 1931

Monseigneur ${ }^{\mathrm{a}}$,

J'ai été voir Thérèse Neumann avec Monsieur l' abbé Meyer en novembre 1928, comme le relate le livre de von Lama "Konnersreuth en 1928”. Depuis lors je me suis beaucoup occupé de la question de Konnersreuth et j'ai donné de très nombreuses conférences sur Thérèse Neumann.

Mon confrère, le docteurLouis de Versailles, a fait paraitre précisément aux Editions Salvator de Mulhouse créées par M[onsieur] l'abbé Meyer, une très petite brochure sur les extases de Thérèse, du vendredi saint et du dimanche de Pâques 1930. Il y parle de

a Tekst pisany maszynowo na jednej stronicy papieru formatu A4. Autograf odręczny czarnym atramentem.

b Autograf sporządzony czarnym atramentem.

${ }^{91}$ Vichy - miejscowość i gmina w środkowej Francji, w regionie Owernia-Rodan-Alp.

a Tekst pisany maszynowo na jednej stronicy papieru formatu A4. Brak ciągu dalszego i autografu autora. W lewym górnym rogu karty tytułowej nadruk firmowy: „Dr Eugène Willemin, Chalet de l'Empereur”. 
stigmates des mains de Thérèse. D'après ce que je croyais, ces stigmates ne saignaient plus depuis la première année de leur apparition, excepté les vendredis saints; le R[évérend] $\mathrm{P}$ [ère] Morard ${ }^{92}$, dominicain qui habite Albertinum à Fribourg (Suisse), et que j"ai été voir tout récemment à ce sujet, m'a appris que les stigmates des mains et des pieds saignaient chez Thérèse pendant tous les vendredis de carême durant les extases ainsi que les vendredis saints et les dimanches de Pâques. Or, le docteur Louis affirme dans sa petite brochure les stigmates de Thérèse Neumann affectent à la face dorsale des mains l'apparence d'une tête de clou, et à la face palmaire l'apparence d'une pointe de clou rabattu.

J'ai été dîner chez le docteur Louis à Versailles et je l'ai revu peu de jours après, le 16 avril 1931, à une conférence qu'il a faite à Paris devant les médecins de la Conférence de St Luc. Naturellement, je ne pouvais pas le contredire d'une façon formelle, mais je lui ai fait observer très loyalement qu'il affirmait une chose dont personne n'avait parlé jusqu'ici. Je lui ai dit mon regret de n'avoir lu sa brochure que la veille du vendredi saint 1931, sans quoi j'aurais fait prier M[onsieuer] le curé $\mathrm{Naber}^{93}$ de surveiller d'une manière toute particulière les stigmates de Thérèse pour voir si ceux-ci prenaient réellement l'apparence d'un clou. A part François d'Assise ${ }^{94}$, je crois qu'un seul stigmatisé a présenté une saillie de chair ayant l'apparence d'un clou; Thérèse serait la première en tout cas présentant un clou enfoncé de la face dorsale vers la face palmaire: ceci serait contradiction formelle avec ce que représentent tous les crucifix de la terre où la tête du clou est dans la face palmaire des mains du Sauveur, et où la pointe du clou sort par la face dorsale pour pénétrer dans le bois de la croix. Mais cette anomalie n'aurait aucune importance, l'apparence d'un clou au niveau des stigmates nous rappellerait plus directement que le stigmate est dû à ce qu'un clou a perforé les mains [... $]^{\mathrm{b}}$.

\section{Dokument 10}

Oryg.: AFKDOPW, bsygn., Spuścizna abp. Józefa Teodorowicza, List z redakcji czasopisma „Münchner Neuenste Nachrichten" do abp. Józefa Teodorowicza, Monachium 17 VI 1931 r.

München, 17. Juni 1931

Abteilung: Baron Aretin

Bei Antwort wird die Angabe dieser Abteilung gebeten

SENDLINGERSTR[ASSE] 80

FERNRUF 9296

${ }^{92}$ Morard Meinrad-Stéfane (1880-1967), święcenia kapłańskie w Zakonie oo. Dominikanów, wykładał egzegezę w Grazu, 1931-1937 prof. filozofii na Uniwersytecie we Fryburgu Szwajcarskim, w roku akad. 1934/35 dziekan Wydziału Teologicznego tamże, w 1932 r. poznał Teresę Neumann poświęcając się badaniom nad jej fenomenem; był autorem m.in. pracy Le fait de Konnersreuth, „Nova et vetera”, 1929, nr 4, s. 380-412. R. Ruffieux, Histoire de l'université de Fribourg 1889-1989, Fribourg 1992, s. 973.

${ }_{93}$ Naber Joseph (1874-1967) - niemiecki duchowny rzymskokatolicki, 1913-1967 proboszcz parafii pw. św. Wawrzyńca w Konnersreuth.

${ }^{94}$ Zob. w niniejszej publikacji: J. Wołczański, Korespondencja abp. Józefa Teodorowicza z o. Wtodzimierzem Ledóchowskim SJ, dokument 13.

b Brak dalszego ciągu. 


\section{Seiner Exzellenz}

Dem Hochwürdigsten Herrn Erzbischof Dr. J. Teodorowicz

München

Durch Boten Abtei St. Bonifaz

Hochwürdigster ${ }^{a}$ Herr Erzbischof,

Verabredungsgemäss erlaube ich mir, beiliegend die wichtigsten der in den „Münchner Neuesten Nachrichten" ${ }^{\prime 95}$ erschienenen Artikel über Konnersreuth zu senden.

Leider war es mir nicht möglich, den von Professor Johannes Bauer ${ }^{96}$ über das Aramäische in Konnersreuth aufzutreiben.

Ich verharre in aufrichtiger Verehrung Eu[rer] Exzellenz ganz ergebenster.

Anlagen.

\section{Dokument 11}

Oryg.: AFKDOPW, teczka 144: Spuścizna abp. Józefa Teodorowicza, sygn. 1053/420 (8) [7], List o. Odo Staudingera OSB do abp. Józefa Teodorowicza, Salzburg 22 VI 1931 r.

\section{Exzellenz! ${ }^{a}$ Hochwürdigster Herr Erzbischof!}

Salzburg ${ }^{97}$, 22. Juni 1931

Letzten Freitag, den 19. M[ai] nachts kam ich von meiner Belgienreise zurück, bei der ich auch einen Abstecher nach Konnersreuth machte. Als ich am anderen Morgen vom Besuche $\mathrm{Eu}[\mathrm{re}]$ Gnaden und dem Wunsche, mich zu sprechen erfuhr, tat und tut mir das noch lange sehr leid, dass ich nicht einen Tag früher gekommen.

Es hätte mich sehr gefreut, mit Ew[ere] Exzellenz über Konnersreuth mich unterhalten zu dürfen. Meines Erachtens arbeitet P[ater] Alois Mager ${ }^{98}$ viel zu oberflächlich und unselbständig in puncto Konnersreuth. Wie war er begeistert und ergriffen, als er dort war! Hätte er seine Besuche wiederholt, so wäre seine dort gewonnene Überzeugung nur gestärkt worden. Seit er aber mit Prof. Wunderle ${ }^{99}$ vor. Jahr zusammengekommen, wird er viel zu viel negativ von ihm beeinflusst. Und die neue Schrift von Dr. Gerlich drängt ihn noch mehr auf Wunderles Seite. Für Wunderle ist Konnersreuth „eine lächerliche Geschichte, ein Skandal“. Für viele, demütigen, kindlichen Sinnes dorthin gekommen sind, ist es zu einer Quelle reicher Gnaden geworden.

a Tekst pisany maszynowo na jednej stronicy papieru. W lewym górnym rogu nadruk firmowy: „«MÜNCHNER NEUESTE NACHRICHTEN» SCHRIFTLEITUNG”.

95 „Münchner Neuesten Nachrichten” - niemiecki dziennik wydawany w l. 1848-1945.

96 Osoba niezidentyfikowana.

97 Salzburg - austriackie miasto położone w Alpach nad rzeką Salzach.

a Tekst pisany czarnym atramentem na dwóch kartach papieru formatu zeszytowego.

${ }_{98}$ Zob. w niniejszej publikacji: J. Wołczański, Korespondencja abp. Józefa Teodorowicza z bp. Henrykiem Przeździeckim, dokument 10.

${ }_{99}$ Zob. w niniejszej publikacji: tenże, Korespondencja abp. Józefa Teodorowicza $z$ o. Wtodzimierzem Ledóchowskim SJ, dokument 13. 
Mit Spannung sehe ich dem von der „Badenia“ angekündigten Buche Ew[ere] Exzellenz entgegen. Es wird gewiss ein wertvoller Beitrag zur Wahrheit und Klarheit über Konnersreuth werden. Und Konnersreuths beste Waffe ist die Wahrheit!

Genehmigen Ew[ere] erzbischöflichen Gnaden den Ausdruck meines ehrfurchtsvollen Ergebung in Christo

$\mathrm{P}$ [ater] Odo Staudinger OSB ${ }^{100}$

\section{Dokument 12}

Oryg.: AFKDOPW, teczka: Spuścizna abp. Józefa Teodorowicza, sygn. 1017/420 (8) [7], List nieznanego autora do abp. Józefa Teodorowicza, Salzburg 17 VII 1931 r.

Salzburg I, 17 VII 1931

Postfach 80

$\mathrm{Eu}[\mathrm{re}]^{\mathrm{a}}$ Hochwürdigste Exzellenz!

Noch denke ich gerne der $[. . .]^{\mathrm{b}}$ unseres Beisammenseins und dessen, was sie uns für die Zukunft erhoffen lassen. Denn in Regensburg vernahm ich natürlich gleich, Prof. Wunderle und P[ater] Mager seien beim Bischof gewesen und jetzt wieder Besuchssperre über Konnersreuth verhängt worden. Ich besuchte den Karmelitenprior, P[ater] Aloys ${ }^{101}$, wo beide Herrn gewohnt haben, und erzählte ihnen von P[ater] Magers Versicherung uns gegenüber, es sei von der Ubernatürlichkeit Konnersreuths überzeugt. Da schüttelte der den Kopf: „Dann verstehe ich den P[ater] Mager wirklich nicht mehr“. Auch P[ater] Odo Staudinger gab zu, er könne das widerspruchsvolle Wesen seines Confraters nur durch nervöse Überarbeitung sich erklären, sonst nicht mehr.

Ich bedauere nur den Regensburger Oberhirten dabei; denn von Dr. Scheglmann ${ }^{102}$, dem früheren Generalvicar oder dem Dompfarrer, der als früherer Pfarrer von Waldsassen ebenso die Sache wirklich kennt, lässt er sich nicht beraten. Auf P[ater] Odos Staudinger habe ich wieder geschrieben, wie ich mir die nächste oberwirtliche Anordnung denke, nur um aus dem ständigen Wechsel von Erlaubnis und Verbot herauszukommen, der bei Vielen nicht gerade zur Stärkung der kirchlichen Autorität dient. Meine Wünsche gingen ja noch weiter. Aber P[ater] Odo wagte doch nicht, meine Gedanken vorzuschlagen, sodass ich dieselben Ew[ere] Exzellenz überlasse und vielleicht doch noch Gutes herauskommt dabei.

Denn nach dem Prof. Wundrele doch nicht wagt, Dr. Gehrlich mit seinen Beweisen vor Gericht zu fordern, will anscheinend Regensburg die Praxis wiederaufzunehmen,

${ }^{100}$ Staudinger Otto - rzymskokatolicki duchowny austriacki, członek Zakonu oo. Benedyktynów w klasztorze w Salzburgu, autor publikacji poświęconych Teresie Neumann m.in.: Die Leidensblume von Konnersreuth (Salzburg 1930); Der Heiland ist gut! Auffallende Heilungen und Bekehrungen durch Konnersreuth. Lieblingsworte der Therese Neumann (Salzburg 1931).

a Tekst pisany czarnym atramentem na czterech stronicach papieru formatu A4. Brak zakończenia.

b Wyraz nieczytelny.

${ }^{101}$ Osoba niezidentyfikowana.

102 Scheglmann Alfons Maria (1858-1937), rzymskokatolicki duchowny niemiecki, wikariusz generalny w Regensburgu, autor m.in. pracy Geschichte der Säkularisation im rechtsrheinischen Bayern, Bd. 3, Regensburg 1903-1908. 
die mir der Domdechant erklärte: wir wollen dafür sorgen, dass Konnersreuth vergessen wird - was ich nicht gerade als übernatürliche Klugheit bezeichnen kann, wenn zur selben Zeit auf meinem Schreibtisch vom fernen Australien sich die Nachrichten häufen über das dort wachsende Interesse an Konnersreuth. Nicht nur darum meine ich, Eu[re] Exzellenz dürften Ihre Arbeit jetzt ebenso [... $]^{c}$ veröffentlichen wie seiner Zeit beispielsweise die hochwürdigsten Herren von Feldkirch, Oklahoma, Cleveland, sondern es durfte auch sehr beitragen, die Katholiken Polens und Deutschlands einander zu nähern. Das liegt nicht nur in der Absicht des lieben Heilands, sondern ich hoffe, Eu[re] Exzellenz werden es noch erfahren und erleben, welch weitere Schritte er in dieser Hinsicht tut...

Wegen der Frage, was P[ater] Mager denn mit [... $]^{\mathrm{d}}$.

\section{Dokument 13}

Oryg.: AFKDOPW, teczka 138: Spuścizna abp. Józefa Teodorowicza, sygn. 928/420 (12) [7], List bp. Michaela Buchbergera do abp. Józefa Teodorowicza, Regensburg 21 VII 1931 r.

Regensburg, 21. Juli 1931

$\mathrm{Eu}[\mathrm{re}]^{\mathrm{a}}$ Excellenz!

Schweren Herzens gebe ich die Erlaubnis zu mehreren Besuchen in Konnersreuth, denn Vater Neumann ${ }^{103}$ begegnet manchen Bischöfen und Priestern nicht mit der Achtung, welche ein katholischer Mann dem priesterlichen und bischöflichen Amt schuldig ist. Er hat erst vor kurzem einem amerikanischen Bischof die Türe gewiesen.

Ew[erer] Excellenz bitte ich in Ihrer Schrift mit dem Urteil recht zurückhaltend zu sein. Vater Neumann verweigert seinem Bischof die Möglichkeit, wieder einmal eine Untersuchung über die Nahrungslosigkeit und andere Phänomene vorzunehmen; wir müssen sie einfach glauben, weil uns seit Jahren der eigentliche Beweis fehlt. Und da halte ich es für meine Pflicht, sehr zurückhaltend zu sein mit dem Urteil, damit nicht etwa einmal der Kirche die Schuld gegeben werde, wenn etwas, was im guten Glauben angenommen wird, sich als irrig erweisen sollte. Ich habe keinen Grund, irgendwie an eine absichtliche Täuschung zu denken, aber auch hier gilt: Errare humanum est ${ }^{104}$.

Indem ich mich Ew[erer] Excellenz bestens empfehle habe ich die Ehre zu bestehen

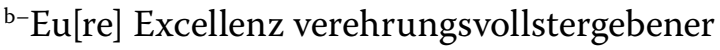

$$
\begin{gathered}
\text { † Michael }{ }^{105} \\
\text { ep[isco }] \text { p }[\mathrm{u}] \text { s Ratisbonen[sis }]^{-\mathrm{b}}
\end{gathered}
$$

c Wyraz nieczytelny.

d Brak zakończenia.

a Tekst pisany maszynowo na jednej stronicy papieru formatu A4. W lewym górnym rogu karty nadruk firmowy: „Der Bischof von Regensburg“.

103 Zob. w niniejszej publikacji: J. Wołczański, Korespondencja abp. Józefa Teodorowicza z prof. Stefanem Dąbrowskim, dokument 39.

104 Łac.: błądzić jest rzeczą ludzką.

b-b Tekst sporządzony czarnym atramentem.

105 Zob. w niniejszej publikacji: J. Wołczański, Korespondencja abp. Józefa Teodorowicza z prof. Stefanem Dąbrowskim, dokument 32. 


\section{Dokument 14}

AFKDOPW, teczka 145: Spuścizna abp. Józefa Teodorowicza, sygn. 1034/420 (8) [7], List prof. Friedricha Ritter von Lamy do abp. Józefa Teodorowicza, Gauting bei München 15 VIII 1931 r.

Excellenz $z^{\mathrm{a}}$, Hochwürdigster Herr Erzbischof!

Gauting, 15. August 1931

Wie ich höre, waren Eure Excellenz letzten Freitag in Begleitung zweier Hochwürdigster Herr Bischöfe sowie des polnischen Botschafters beim Vatikan in Konnersreuth. Ich habe mich über diese Nachricht sehr gefreut, denn der Besuch wird Ihnen jedenfalls jene Feststellungen ermöglicht haben, deren Sie noch für Ihr Buch bedurften. Im Interesse des Konnersreuther Schrifttums, an dem ich durch Abfassung meines Jahrbuchs beteiligt bin, wage ich die Bitte, mir das gütigst mitzuteilen, was mitgeteilt werden darf. Wer waren die beiden bischöflichen Begleiter? Ich vermute, dass der Herr Botschafter S[eine] Exc[ellenz] Herr Skrzynski ${ }^{106}$ war, der mir als k.u.k. Botschaftsrat noch wohlbekannt ist. Für den Fall, das Euer Excellenz ohne Ihre Begleiter über diesen Besuch je etwas publizieren, würde ich ergebenst bitten, Zusendung veranlassen zu wollen. Die Uebersetzung besorge ich mir dann schon. Sehr lieb wäre es mir, wenn ich recht bald einen Teil des Manuskriptes erhalten würde; ich bitte dringendst darum und bin ergebensten Grüssen, Euer Excellenz in aufrichtiger Verehrung erg[ebener]

F[riedrich] R[itter] von Lama

\section{Dokument 15}

Kopia: AFKDOPW, teczka 136: Spuścizna abp. Józefa Teodorowicza, sygn. 1465/185 [4], List abp. Józefa Teodorowicza do nieznanego polskiego biskupa, Lwów 17 IX 1931 r.

Wasza ${ }^{a}$ Ekscelencjo!

Do życzenia waszej Ekscelencji wyrażone w piśmie o uczczeniu obchodu zastosuję się. Pozwolę sobie tylko zwrócić uwagę, że jeżeli przez gazety nie będzie powszechnie wiadomy cel dzwonienia o naznaczonej godzinie, to nikt nie będzie wiedział, dlaczego właściwie to się dzieje.

Przy tej sposobności zanoszę prośbę do Waszej Ekscelencji o bliższe informacje w sprawie stygmatyka piekarza. Zależy mi przede wszystkim na tym, ażeby lekarze stwierdzili, czy te stygmaty nie były sztuczne, przez niego samego zrobione. Po drugie, ponieważ zawsze otrzymanie stygmatów łączy się z ekstazami, należałoby stwierdzić, czy też ten człowiek ma jakieś ekstatyczne stany. Jeśliby te dwa pytania wypadły na korzyść stygmatyka, w takim razie po konferencji biskupiej udałbym się tam.

\footnotetext{
a Tekst pisany maszynowo na jednej stronicy papieru formatu A4. Autograf odręczny czarnym atramentem.

106 Właściwie: Skrzyński. Zob. w niniejszej publikacji: J. Wołczański, Listy abp. Józefa Teodorowicza do abp. Józefa Bilczewskiego, dokument 150.

a Tekst pisany maszynowo na jednej stronicy papieru formatu A4. Brak personaliów adresata i autografu autora pisma.
} 
Tymczasem łączę dla waszej Ekscelencji najoddańsze wyrazy czci najgłębszej. Lwów, dnia 17 września 1931

\section{Dokument 16}

Kopia: AFKDOPW, teczka 136: Spuścizna abp. Józefa Teodorowicza, sygn. 1463/185 [4], List abp. Józefa Teodorowicza do ks. prałata Stanisława Szpetnara, Lwów 17 IX 1931 r.

\section{Przezacny ${ }^{\mathrm{a}}$ Księże Prałacie!}

Czynię zadość życzeniu Księdza Prałata i zdaję sprawę z przebiegu poznania relikwii przez Teresę Neuman.

W czasie jej ekstaz piątkowych przyniosłem relikwiarz Księdza Prałata i podałem go proboszczowi, który w mojej obecności podał relikwiarz Teresie Neumann. „A, hier ist etwas vom Heiland"107 - rzekła z błogim uśmiechem na twarzy i chociaż w tym stanie nic nie widzi, to jednak palcem dotknęła właśnie tego miejsca, w którym były relikwie św. Krzyża. Nie wiedziałem sam przedtem gdzie one są, później stwierdziłem bardzo wyraźnie obserwując miejsce, które palcem swym dotknęła. Następnie proboszcz wziął jej rękę i przesunął po tej relikwii. Wtedy wstrząsnęła się boleśnie cała, zadrgały jej ręce i zawołała: „A, es schmärzt”108; tak samo, gdy proboszcz drugą jej rękę przesunął po relikwiarzu, wstrząs ten nastąpił. Dzieje się to u niej zawsze, ile razy się zetknie z prawdziwą relikwią św. Krzyża. Potem dodała przesuwając palcem po rąbku relikwiarza: „Hier ist auch etwas vom denen, die mit Heiland waren"109.

Równocześnie jednak odezwała się z zastrzeżeniem jednym co do pewnych autentyczności tych drugich relikwii.

Podając to do wiadomości Księdza Prałata, łączę dla Niego wyrazy prawdziwego szacunku.

Lwów, dnia 17 września 1931

\section{Dokument 17}

Oryg.: AFKDOPW, teczka 145: Spuścizna abp. Józefa Teodorowicza, sygn. 367/90 [5], List z Wydawnictwa Antona Pusteta do abp. Józefa Teodorowicza, Salzburg 2 X 1931 r.

Seine Exzellenz

Hochwürdigsten Herrn

Erzbischof Dr. Josef Theodorowicz

Lemberg

a Tekst pisany maszynowo na 1,5 stronicy papieru formatu A4. Brak nazwiska adresata i autografu autora listu.

107 Niem.: tu jest coś świętego (Jezusowego).

108 Niem.: to boli.

109 Niem.: tu jest coś od tych, którzy byli z Jezusem. 


\section{BETRIFTT IHRE NACHRICHT VOM UNSER ZEICHEN DATUM 2. 10. [19]31}

Eure $^{\text {a }}$ Exzellenz!

Als Verleger und Herausgeber der Katholischen Kirchenzeitung möchten wir Eu[rer] Exzellenz verbindlichst danken, für die uns freundlichst überlassene Homilie für unsere Kirchenz[eitug]. Wir verbinden damit gern den aufrichtigen Wunsch, dass wir noch öfters die Freunde haben werden, Eu[re] Exzellenz als Mitarbeiter der Kirchenz[eitug] begrüßen zu dürfen.

Der Schriftleiter unserer Kirchenz[eitug] Hochwürden Herr Dr. Dillersberger ${ }^{10}$ teilte $^{2}$ uns nun an diesem Tage mit, dass Eu[re] Exzellenz ein Buch über Therese Neumann von Konnersreuth vorbereiten.

Wir gestatten uns ergebenst anzufragen, ob Eu[re] Exzellenz die Herausgabe dieses Buches bereits einem Verlag übertragen haben oder ob die Möglichkeit noch offen ist, dass wir uns dafür bewerben können. In diesem Falle wären wir Eu[rer] Exzellenz zu ausserordentlichem Dank verbunden, wenn das Buch unserem Verlag zur Herausgabe anvertraut werden würde.

Als Pressevereinsanstalt gerade in jüngster Zeit mit der Aufgabe betraut sich ganz jenen katholischen Bestrebungen zu widmen, die in Salzburg aus dem Plan um die Errichtung einer katholischen Universität zu wachsen beginnen, wäre es uns eine aufrichtige Freude unsere Arbeit auch in den Dienst einer katholisch-gesunden Aufklärung und Berichterstattung über Konnersreuth zu stellen. Wenn sich auch unsere Kirchenz[eitug] dieser Aufgabe bereits widmet - einer der letzten Leitartikel Dr. Dillersbergers über Konnersreuth fand ein recht dankbares Echo - so wäre es uns doch erwünscht, auch unserem eigentlichen Verlag in noch stärkerem Masse für diese Aufgabe heranzuziehen. Dürfen wir Eu[re] Exzellenz bitten wir uns die Stellungsname zu unserer Bitte baldmöglichst bekannt zu geben?

Mit dem Ausdruck unserer aufrichtigen Ergebenheit sind wir Eu[rer] Exzellenz.

Ergebenster.

\section{Dokument 18}

Oryg.: AFKDOPW, teczka 141: Spuścizna abp. Józefa Teodorowicza, sygn. 930/420 (8) [7], List kapelana wojskowego i redaktora ks. Karla Koliska do abp. Józefa Teodorowicza, Brno 14 X 1931 r.

Brno, Falkensteiner[strasse] 42, am 14. Oktober 1931

\footnotetext{
a Tekst pisany maszynowo na jednej stronicy papieru formatu A4. W górnej centralnej części karty nadruk firmowy: „VERLAG ANTON PUSTET SALZBURG, Anstalten des katholischen Preßvereins der Diözese Seckau, SIEGMUND-HAFFNER-GASSE NR. 18,TEL.259”. U dołu pisma podłużna pieczęć: „VERLAG ANTON PUSTET SALZBURG".

110 Osoba niezidentyfikowana.

b Autograf nieczytelny.
} 
$\dagger$

Eure $^{\text {a }}$ Exzellenz! Hochwürdigster Herr Erzbischof!

Unlängst las ich, dass E[ure] Exzellenz in Konnersreuth waren und ein Interview über diesen Besuch in Wien dem Korrespondenten des „Neuen Wiener Journal“111 und der „Neuen Freie Presse“ gaben. In unserem Tagblatt „Lidove Listy" ${ }^{112}$ las ich einen kurzen Bericht, dass E[ure] Exzellenz ein wissenschaftliches Werk über Konnersreuth verfassen werden.

Da ich selbst am 22. Juni d[ieses] J[ahres] in Konnersreuth war und jetzt an der Übersetzung des Büchleins von P[ater] Odo von Staudinger O.S.B. „Der Heiland ist gut“ (Lieblingswort von Therese Neumann) arbeite und meinen Lesern das Neueste über Konnersreuth bringen will, so bitte ich höflichst, mir wenigsten in einem Satze wissen bitten zu wollen, ob das Obige auf Wahrheit beruht und was E[ure] E[xzellenz] über Konnersreuth urteilen. Ich bin überzeugt, dass Therese Neumann ein begnadetes Mädchen ist.

Da mein Bruder Mons[ignore] Alois Kolisek ${ }^{113}$, Theologieprofessor in Bratislava am 25. 8. l[etzen] J[ahres] gestorben ist, so dieses unverändertes Briefpapier.

Ich kenne E[ure] E[xzellenz] persönlich, da ich im Jahr 1918 als Feldsuperioratsleiter beim IV. Generalkommando in Lwów war, als Nachfolger vom Feldsuperior Varady ${ }^{114}$. Ich erlaube mir ein Bildchen beizuschliessen. Wir waren sechs Brüder - Priester, leider sind wir jetzt bloß zwei am Leben!

Indem ich meines unterfälligsten Ersuchens bei E[urer] Exzellenz sicher bin, verbleibe ich in Christo E[urer] E[xzellenz] ergebenster Diener

Karl Kolisek ${ }^{115}$

pens[ionierter] Feldsuperior und Redakteur

\section{Dokument 19}

Oryg.: AFKDOPW, teczka 145: Spuścizna abp. Józefa Teodorowicza, sygn. 1039/420 (8) [7], List prof. Friedricha Ritter von Lamy do abp. Józefa Teodorowicza, Gauting bei München 10 XI 1931 r.

Excellenz $z^{\mathrm{a}}$, hochwürdigster Herr Erzbischof!

Gauting, Bayern, 10 November. 1931

Ich bin tief gerührt ob Ihrer mitfühlenden Worte zur Erkrankung meines guten Sohnes und danke von ganzem Herzen für dieselben, mehr aber noch für die gütige

\footnotetext{
a Tekst pisany czarnym atramentem na 1,5 stronicy papieru formatu A4.

111 „Neues Wiener Journal” - austriacki dziennik ukazujący się w l. 1893-1939 w Wiedniu.

112 „Lidove Listy” - periodyk czeski ukazujący się w 1. 1922-1945, nakład wynosił 10000-15000 egzemplarzy.

${ }^{113}$ Kolisek Alois (1868-1931), czeski duchowny rzymskokatolicki, dr teologii, wykładowca dyscyplin teologicznych w Bratysławie, prałat papieski, polityk, członek Zgromadzenia Narodowego Czechosłowacji, obrońca praw Słowaków przed Węgrami, organizator pielgrzymek religijnych do Lourdes i Rzymu.

${ }^{114}$ Osoba niezidentyfikowana.

115 Kolisek Karl - czeski duchowny katolicki, kapelan armii austrowęgierskiej XIX/XX w..

a Tekst pisany maszynowo na 5 1/2 stronicy papieru formatu A4. Autograf odręczny czarnym atramentem.
} 
Versicherung, dass Sie seiner sogar beim heiligen Messopfer gedenken sollen. Ich schulde es meinem Kind, alles zu tun, was ich für dasselbe tun kann, und bete daher täglich um Besserung; ich danke aber auch Gott, dass ich nicht beunruhigt bin, sondern bis heute wenigstens meine absolute Ergebung in Gottes Willen bewahrt habe.

Was mir Excellenz über Ihren Besuch bei Therese Neumann mitteilten, ist mir zwar in den Einzelnheiten neu, aber es überrascht mich nicht. Ich fühle mich nun verpflichtet. Nachstehendes mitzuteilen, was ich sonst für mich behalten hätte, obwohl auch andere davon Kenntnis besitzen. Sie werden dann das Verhalten des Herrn Neumann ganz zu begreifen wissen.

Einer der Hauptgründe jener Besuchssperre, die der Hochw[ürdigen] Herr Bischof von Regensburg über Therese Neumann verhängt hat und der Sie Ihr peinliches Erlebnis verdanken, war, dass S[eine] Exc[ellenz] Herr Bischof Schmid von Grüneck ${ }^{116}$ in Chur ${ }^{117}$ als persönlicher Bekannter des Hauses Neumann in Konnersreuth seinen Besuch gemacht hatte, ohne sich um eine Erlaubnis in Regensburg zu bewerben. Genannter Kirchenfürst hatte Wochen zuvor, als Therese Neumann ihre kranke Schwester nach dem Allgäu begleitete und somit nahe der Schweizer Grenze weilte, die Stigmatisierte zu einem Besuch in Chur eingeladen und sie war der Einladung gefolgt. Dies war der zweite Grund des bischöflichen Zornes in Regensburg. Man mutete ihr zu, selbst dafür die Erlaubnis einzuholen, obwohl, wie S[eine] Eminenz Kardinal Faulhaber ${ }^{118}$ bei Erörterung die ser Dinge die Diskussion mit dem scharfen und klaren Worte abschnitt: Therese Neumann ist keine Ordensperson! Der Herr Bischof von Chur aber vertrat den Standpunkt, dass er zu einem Privatbesuch bei Bekannten keiner fremden bischöflichen Erlaubnis bedürfe, und die Eltern haben sich jederzeit das Recht gewahrt, nach Belieben Bekanntenden Zutritt in ihr Häuschen zu gestatten. Die Besuchssperre wurde vom Regensburger Ordinarius telegraphisch von der Firmungsreise aus angeordnet und lautete, es dürfe keine Ausnahme gemacht werden. Inzwischen hatte ein weiterer Vorfall den bischöflichen Zorn noch genährt. Der Herr Bischof hatte einer Malerin die Erlaubnis erteilt, Therese Neumann zu malen. Die sehr anmassend auftretende Malerin bestand in Konnersreuth auf ihrem Recht (!), aber Therese Neumann lehnte es ab, dem Verlangen zu entsprechen; sie lässt sich grundsätzlich nicht malen und verfolgt unnachsichtlich die Verbreitung ihrer Porträts, soweit es ihr möglich ist. Die Eltern haben bisher in dieser Sache elf Gerichtsurteile erwirkt. Der Herr Bischof war über diesen Ungehorsam noch wütender, obwohl ihm keinerlei Recht zustand, eine solche Erlaubnis irgendjemanden zu geben. Das war die Sachlage, als Eure Excellenz Ihren Besuch machten. Das Verhalten des Herrn Neumann dürfte damit sehr wohl verständlich sein. Wie ich hörte,

${ }^{116}$ Schmid von Grűneck Georg (1851-1932), święcenia kapłańskie w 1875 r. w Chur, dr prawa kanonicznego, 1908-1932 biskup diec. Chur, 1925-1932 przewodniczący Konferencji Episkopatu Szwajcarii. Schmid von Grüneck Georg, w: DBDL, herausg. von E. Gatz, Berlin 1983, s. 343.

117 Chur - najstarsze miasto w Szwajcarii, stolica kantonu Gryzonia.

118 Faulhaber von Michael (1869-1952), niemiecki duchowny, święcenia kapłańskie w 1892 r. w Würzburgu, profesor Starego Testamentu na Uniwersytecie w Strasburgu, 1917-1952 arcybiskup-metropolita Monachium i Fryzyngi, od 1921 r. kardynał. Faulhaber Michael von, w: DBE, Bd. 3, herausg. von W. Killy, München 1996, s. 235. 
hat denn auch der amerikanische Bischof, der ebenfalls abgewiesen worden war, nicht verfehlt, in Regensburg vorzusprechen und dort das zu machen, was man hierzulande einen „Krach“ nannt; er war an der richtigen Stelle. Der Familie Neumann liegt es gänzlich fern, irgendeinen Konflikt mit dem Diözesanbischof zu betreiben oder gar zu verschärfen, aber die Eltern sind nicht gewillt, die fortgesetzte Verletzung ihrer unbestreitbaren Rechte zu ertragen, eine Verletzung, die allmählich zur Willkür ausartet.

Dabei hätte Herr Neumann allen Grund, erbittert zu sein. Denn [... $]^{\mathrm{b}}$ eines Tages schickte der Hochw[ürdigen] $\mathrm{H}$ [err] Bischof Buchberger eine geistliche Kommission nach Konnersreuth, die den Eintritt der Freitagsekstase genau beobachten und festsellen sollte, ob seitens der Eltern beim Hervortreten der Bluttränen irgendwie mitgewirkt werde. Die Kommission blieb jedoch im Wirtshaus hinterm Bierkrug sitzen, konnte daher nichts beobachten und berichtete, sie habe nicht feststellen können, dass seitens der Eltern nichts unternommen werde um die Blutung zu bewirken. Dem Herrn Bischof kam zu Ohren, dass seine Kommission im Wirtshaus hocken geblieben sei und er sprach sich darüber gegenüber einem meiner Bekannten empört aus. Bei der nächsten bayrischen Bischofskonferenz berichtete der Herr Bischof, seine Kommission habe nicht festgestellt, dass die Eltern nicht (!) mitwirken; Herr Neumann schmiere eben seiner Resel das Blut ins Gesicht. Der Herr Bischof von Würzburg, über die Sachlage genau unterrichtet, stellte den Sachvorhalt fest. Herrn Neumann kam das Wort seines Bischofs zu Ohren und die Wikrung kann man sich vorstellen. Die Folde all dieser Dinge ist, dass sich ein zwar begreiflicher aber doch auch sehr bedauerlicher Gegensatz zwischen S[eine]r Eminenz Kardinal Faulhaber und dem Hochw[ürdigen] Herrn Bischof Buchberger herausgebildet hat, aus dem jener kein Hehl macht. Obwohl ich nicht dem sogenannten Konnersreuther Kreis angehöre, der über diese Dinge am besten unterrichtet ist, sind mir dieselben dennoch zur Kenntnis gekommen, ein Beweis, dass die Zahl der Wissenden schon eine bedenklich grosse ist. Ich meinerseits teile solche Dinge auch in diesem Fall nur vertraulich mit; die Mitteilung will einzig dem Zwecke dienen. Eurer Excellenz zu ermöglichen, das Geschehene zu verstehen und das Verhalten des Herrn Neumann zu rechtfertigen.

Und nun zu der mir höchst peinlichen Angelegenheit des Verlags Ihres Buches. Ich kann mir sehr wohl denken, wer jener Jesuitenpater ist, von dem jenes Bedenken kommt. Ich muss aber dieses Bedenken als gänzlich unbegründet ablehnen. Die Badenia ist ein alter Verlag grossen Stils, das Unternehmen beschäftigt 300 Personen und seine Verlagstendenz wird wahrlich nicht durch die paar Büchlein bestimmt, die ich in jenem Verlag publiziert habe. Niemanden wird es einfallen, ein in einem Verlag erscheinendes Werk nach einem anderen Buch beurteilen, das etwa im selben Verlag erschienen ist; wer so etwas behauptet, der hat die Dinge wissentlich falsch dargestellt. Es dürfte Eurer Excellenz bekannt sein, dass hierzulande ein Buch nach seinem Inhalte beurteilt wird; höchstens spricht dabei noch der Ruf des Verfassers mit. Aber der Umstand, dass im gleichen Verlag noch ein anderes Buch erschienen wäre, wird bei

\footnotetext{
b Brak tekstu.
} 
niemanden mitsprechen. So z. B. wird niemand deswegen, weil der Verleger Dieterich in Jena ${ }^{119}$ ein notorischer Protestant ist, annehmen, dass die im gleichen Verlag erschienenen Exercitia Spiritualia des hl. Ignatius ${ }^{120}$ deswegen eine protestantische Tendenz beisetzen und das Prestige, also zu deutsch das Ansehen und der gute Ruf des hl. Ignatius dadurch Schaden gelitten hätte. Ganz entschieden aber muss ich der Behauptung entgegentreten, der Verlag Badenia. gehöre irgendwie zum sogenannten Konnersreuther Kreise. Wer gehört denn überhaupt diesem Kreis an, wenn man schon von einem solchen ernstlich sprechen kann (denn das Wort wurde von Wunderle geprägt)? Herr Professor Wutz ${ }^{121}$ hat sich von Anfang an die grösste wissenschaftliche Mühe gegeben, die Tatsachen in Konnersreuth, soweit sie ihn als Priester und Orientalisten interessieren, zu erforschen. Damit wurde er natürlich mit der Familie Neumann befreundet. Das Gleiche tat Dr. Gerlich, der zwar ein Studienkollege von Prof. Wutz war, aber an Konnersreuth von dem Gesichtspunkt des Protestanten und Redakteurs herantrat und dieselbe Forschungsarbeit übernahm. Endlich zog Pfarrer Naber, der jedes ernste Studium förderte, während seiner wiederholten Abwesenheit von Konnersreuth den Kapuziner $\mathrm{P}$ [ater] Ingbert $\mathrm{Naab}^{122}$, Guardian des Klosters in Eichstätt ${ }^{123}$ heran; [... $]^{\mathrm{c}}$ vertrat den Pfarrer bei Therese wiederholt als Beichtvater und lernte diese somit sehr gut kennen. Diese kleine Gruppe ist unter sich gut befreundet, aber es ist nicht wahr, wie Wunderle es hinzustellen sucht, dass sie einen Kreis um Therese bilden, der irgendjemanden auszuschliessen suche. Ich selbst aber gehöre nicht zu diesem Freundschaftskreis, wenn ich auch die Herren kenne. Gerlich lernte ich in diesem Jahr (!) in München kennen, Wutz habe ich ein einzigesmal in Eichstätt für 5 Minuten gesprochen, P[ater] Naab kenne ich persönlich nicht, Pfarrer Naber kenne ich von meinen Besuchen in Konnersreuth. Mein Freund und Berater war von Anfang an der 82-jährige Prälat Domdekan Dr. Molz ${ }^{124}$ in Speyer ${ }^{125}$, mein Begleiter in Konnersreuth; von seiner grossen Erfahrung habe ich Nutzen gezogen, dazu ist er ein gründlicher Theologe, war unter Kardinal Bettinger ${ }^{126}$ Generalvikar und zudem noch 16 Jahre lang Beichtvater der Stigmatisierten

119 Jena - miasto w środkowych Niemczech w Turyngii.

120 Aluzja do św. Ignacego Loyoli. Zob. w niniejszej publikacji: J. Wołczański, Korespondencja abp. Józefa Teodorowicza $z$ o. Włodzimierzem Ledóchowskim SJ, dokument 13.

${ }^{121}$ Zob. w niniejszej publikacji: tenże, Korespondencja abp. Józefa Teodorowicza z prof. Stefanem Dabrowskim, dokument 43.

${ }^{122}$ Naab Ingbert (1885-1935), święcenia kapłańskie w 1910 r. w Zakonie oo. Kapucynów, wykładowca teologii oraz przełożony w Eichstätt, Regensburgu, Passau, w swoich publikacjach i naukach występował przeciw ideologii niemieckiego narodowego socjalizmu; utrzymywał kontakty z Teresą Neumann. W. Witetscheck, Pater Ingbert Naab. Ein Prophet wider den Zeigeist (1885-1935), Regensburg 1985, passim.

${ }^{123}$ Eichstätt - miasto powiatowe w Bawarii w Niemczech.

c Wyraz wpisany ręcznie, nieczytelny.

${ }^{124}$ Moltz Friedrich - niemiecki duchowny rzymskokatolicki, kanonik Kapituły Katedralnej w Spirze, duchowy opiekun mistyczki i stygmatyczki Barbary Pfister, autor pracy jej poświęconej: Barbara Pfister, eine pfälzische Stigmatisierte (Speyer 1928, 2008²).

${ }^{125}$ Speyer - niemieckie miasto w kraju związkowym Nadrenia-Palatynat.

126 Bettinger Franziscus von (1850-1917), święcenia kapłańskie w 1873 r. w Spirze (Niemcy), 1895-1909 kanonik katedralny w Spirze, 1909-1917 arcybiskup Monachium i Fryzyngii, w 1914 r. kreowany kardynałem. Bettinger Franziscus, w: DBDL, s. 49-50. 
Barbara Pfister ${ }^{127}$ von Wattenheim ${ }^{128}$. Daneben beriet ich mich noch mit meinem Bruder P[ater] Severin von Lama ${ }^{129}$, der nicht nur Theologe, sondern, wie ich ganz vertraulich bemerken möchte, selbst praktischer Mystiker ist.

Als der Rhenania-Verlag in Bonn, der meine beiden ersten Bücher verlegt hatte, fallierte, übernahm die Badenia, die Forderungen hatte, den Rest der beiden Auflagen und hat dann auch Jahrbuch 1929 und 1930 verlegt. Aber auch sie hat nicht das Allergeringste mit jenem Konnersreuther Kreis zu tun oder je zu tun gehabt. Mir genügte es, zu wissen, dass es eine leistungsfähige katholische Firma ist, in deren Aufsichtsrat auch ein Vertreter des erzbischöflichen Ordinariats Freiburg sitzt. Die Firma hat durch Verbreitung meiner Bücher Verbindung mit dem grössten Teil der Interessenten für Konnersreuth in der ganzen Welt, was die Verbreitung Ihres Werkes stark erleichtert. Im Uebrigen glaube, dass niemand die Firma Kösel \& Pustet zum Konnersreuther Kreis rechnen wird, weil sie Gerlichs Werk verlegt hat. Es steht selbstverständlich Eurer Excellenz frei, nach Ihrem Belieben zu handeln; die Gründe aber, die jener Pater S. J. angeführt hat, stimmen nicht. Es müsse andere, ungenannte mitsprechen.

Herr Pfarrer Naber ist heute noch Pfarrer von Konnersreuth; er ist nicht versetzt worden. Unter dem Einfluss des Geredes, wenn Pfarrer Naber wegkäme, würden auch die Phänomene aufhören, wurde ihm vor anderthalb Jahren nahegelegt, freiwillig sich um eine andere Pfarrei zu bewerben.

Da es unter Drohungen (!) geschah, bat der Pfarrer tun Angabe der Gründe entsprechend dem Kirchenrecht, worauf alles weitere unterblieb. Seitdem zirkuliert das Gerede von seiner Versetzung.

Zum Schluss teile ich Eurer Excellenz die erfreuliche Tatsache mit, dass noch ein Konnersreuth ähnlicher Fall in Deutschland existiert. Die betreffende Person gehört ihrer Abstammung nach sowohl dem deutschen wie dem polnischen Volke an und die sie beschützende und führende Freundin ist die ehrwürdige Gemma Galgani ${ }^{130}$. Es soll aber noch alles in Verborgenheit gehalten bleiben; so wünscht diese es. Stigmatisation ist geheimnisvoll angekündigt, aber noch nicht aufgetreten. Wenn ich einmal darüber Näheres schreiben darf, werde ich es gerne tun. Inzwischen bin ich mit der Versicherung meiner aufrichtigen Ergebenheit in aller Verehrung

F[riedrich] R[itter] von Lama

127 Pfister Barbara (1867-1909), niemiecka mistyczka i stygmatyczka. F. Molz, Barbara Pfister, eine pfälzische Stigmatisierte, Speyer 1928; $2008^{2}$.

128 Wattenheim - miejscowość w kraju związkowym Nadrenia-Palatynat (Niemcy), miejsce urodzenia mistyczki Barbary Pfister.

${ }^{129}$ Lama Severin von (1883-1878), niemiecki zakonnik ze Zgromadzenia Najświętszego Serca, egzorcysta, mistyk, brat Friedricha von Lamy, autor kilku książek teologicznych. L. Gutwenger, Severin von Lama (1883-1978). Zwischen Charisma und Dämonen, Stein am Rhein 1982, passim.

130 Św. Gemma Galgani (1878-1903), włoska mistyczka i stygmatyczka, beatyfikowana w 1933 r., kanonizowana w 1940 r. J. Zbiciak, Gemma Galgani, w: EK, t. 5, red. zbior., Lublin 1989, kol. 938-939. 


\section{Dokument 20}

Oryg.: AFKDOPW, teczka 144: Spuścizna abp. Józefa Teodorowicza, sygn. 1013/420 (8) [7], List o. prof. Pawła Siwka SJ do abp. Józefa Teodorowicza, Rzym 24 XI 1931 r.

Roma (101), li 24 list[opada] 1931

Piazza della Pilotta

Ekscelencjo ${ }^{\mathrm{a}}$,

Znając zainteresowanie Ekscelencji sprawą Konnersreuth ośmielam się złożyć niniejszym w najgłębszym hołdzie egzemplarz poświęcony temu zagadnieniu ${ }^{131}$. Jest to studium ściśle naukowe, toteż nawet prosiłem Wydawnictwo, by nie bić więcej egzemplarzy ponad 500 (zdaje się, że jednak nieco więcej wydrukowano ze względu na to, że rzecz ma być na tyle przystępnie napisana, że może ją wziąć do rąk każdy człowiek z wykształceniem uniwersyteckim).

Przepraszam najszczerzej, że teraz dopiero spełniam moją powinność. Przyczyną tego opóźnienia było to, że dn[ia] 7 sierp[nia] wyjechałem do Monachium i pozostałem tam aż do rozpoczęcia roku szkoln[ego)], tj. do listopada. Po przyjeździe do Rzymu znalazłem wprawdzie kilka egzemplarzy mej książki świeżo wydrukowanej, atoli tyle zwaliło się naraz pracy, żem o wszystkim innym formalnie zapomniał, by z dnia na dzień wydołać wykładom, które musiałem rozpocząć z listopadem, a nie jak to dawniej było w planie, w lutym. Ponadto drukuję podręcznik z psychol[ogii] racjonalnej dla uczniów zeszytami względnie arkuszami - tyle się drukuje, ile zdążą z dnia na dzień przygotować. Ponadto wciągnęli mnie francuscy filozofowie do kolekcji dzieł z filozofii: „Les maitres de la pensee religieuse". Mnie usilnie proszono o napisanie książki pt.: „Spinoza et le panthéisme religieux"132. Mam za rok rzecz odstawić. To wszystko tłumaczy, jak widzi Ekscelencja, moje opóźnienie.

Całuję z czcią ręce Ekscelencji i polecam się pokornie modlitwom, sługa w Chrystusie najniższy

Ks. Siwek T) ${ }^{133}$

PS. Po napisaniu listu dostałem list od pewnego prof[esora] uniwers[ytetu] z Polski. „Jest to - pisze mi - jedna z tych publikacji (pisze o mojej «Konnersreuth»), które najwięcej nadają się do odmłodzenia wiary katolickiej, a nawet do torowania jej dróg tam, gdzie przedtem panowała niewiedza lub niechęć do katolicyzmu". Potem przedstawia swe udręki religijne i kończy: „Po takich szarpiących rozważaniach spadają jak rosa z niebios ożywcze fakta... które O. Profesor omawia".

a Tekst pisany czarnym atramentem na 2 stronicach papieru formatu zeszytowego. W lewym górnym rogu karty tytułowej nadruk firmowy: „Pontificia Universita Gregoriana”.

${ }^{131}$ P. Siwek, Konnersreuth w świetle nauki i religii, Kraków 1931.

${ }_{132}$ Tenże, Spinoza et le panthéisme religieux, Paris 1937.

${ }^{133}$ Zob. w niniejszej publikacji: J. Wołczański, Korespondencja abp. Józefa Teodorowicza z abp. Adamem Stefanem Sapieha, dokument 101. 


\section{Dokument 21}

Kopia: AFKDOPW, teczka 134: Spuścizna abp. Józefa Teodorowicza, sygn. 1607/184 [7], List abp. Józefa Teodorowicza do o. prof. Pawła Siwka SJ, Lwów 28 XI 1931 r.

\section{Czcigodny ${ }^{\mathrm{a}}$, Drogi Ojcze!}

Książka o Konnersreuth łaskawie mi przez Ojca nadesłana, żywo odświeżyła we mnie ten miły kontakt, jaki miałem z Ojcem zeszłego roku w Krakowie i wspólnie prowadzone rozmowy. Otóż z serca Ojcu za pamięć o mnie dziękuję. Jednakże mi osobiście żal i przykro donieść Ojcu, że w sprawie tej książki jest w jednej redakcji pism naszych gotowy mój artykuł, który umieściłem, jako rozprawę teologiczną o zjawiskach mistycznych i o metodach ich tłumaczenia ${ }^{134}$. Musiałem stanąć $w$ tej rozprawie na wręcz przeciwnym stanowisku, jakie Drogi Ojciec w swoich metodach zajął. Pisząc swoją książkę, a wiedząc, że ja przygotowuję moją o Konnersreuth, z pewnością spodziewał się Drogi Ojciec, iż nie wolno mi pominąć milczeniem dzieła napisanego z takim talentem i z taką bogatą znajomością zjawisk fizjologicznych. Odpowiedź z mej strony była nieunikniona, ale nie dlatego i nie ze względu na moją książkę napisałem tę rozprawę. Chodziło mi o coś daleko ważniejszego, mianowicie o próbę rozstrzygnięcia, czy metody podjęte w badaniu zjawisk przez Ojca, są w zjawiskach mistycznych dopuszczalne. Doszedłem do przekonania, że bez względu na to, czy zjawiska w Konnersreuth są prawdziwe czy nie, są takie metody niedopuszczalne.

Piszę o tym Drogiemu Ojcu całkiem szczerze. Studia moje nad mistyką prowadzę nie od dzisiaj. Fenomena mistyczne prawdziwe i nieprawdziwe są mi znane z bezpośredniej obserwacji. Otóż na tej podstawie doszedłem do przekonania, że mam obowiązek wypowiedzieć się jasno w tak ważnej i doniosłej kwestii, od której rozwiązania będzie na przyszłość iść w Polsce krytyka zjawisk mistycznych. Jedno mi tylko jest osobiście przykre i bolesne, iż przypuszczam, że taka krytyka może być przez Kochanego Ojca bardzo przykro odczuta. Ale przeważyły u mnie względy na ogólną sprawę, bo udawano się do mnie z prośbą z różnych stron $\mathrm{z}$ tym przedstawieniem, iż wpływ tej książki na młode zwłaszcza umysły nie jest dobry. Przekonałem się też o tym sam. Wyolbrzymienie bowiem pierwiastka fizjologicznego i naturalnego w krytyce objawów mistycznych przenosi łatwo czytelnik niekrytyczny na same dogmaty wiary. Potrzeba więc bardzo jasno przedstawić rolę i miejsce, jakie ma teologia mistyczna w badaniu takich zjawisk. Sympatia i szacunek osobisty dla Drogiego Ojca wytłumaczą Ojcu moje szczere wynurzenia; z góry gorąco przepraszam, jeśliby coś w mojej pracy osobiście Ojca dotknąć miało.

Łączę bardzo serdeczne i bardzo oddane wyrazy czci

Lwów, dnia 28 listopada 1931

† J[ózef] Teodorowicz ${ }^{\mathrm{b}}$

\footnotetext{
a Tekst pisany maszynowo $\mathrm{z}$ wyjątkiem autografu autora na dwóch stronicach papieru formatu A4.

${ }_{134}$ J. Teodorowicz, Zjawiska mistyczne i ich ttumaczenia, AK, 18(1932), t. 29, z. 1, s. 1-16; z. 2, s. $105-$ 121; z. 3, s. 209-229; z. 4, s. 313-338.

b Autograf sporządzony czarnym atramentem.
} 


\section{Dokument 22}

Oryg.: AFKDOPW, teczka 144: Spuścizna abp. Józefa Teodorowicza, sygn. 1010/420 (8) [7], List o. prof. Pawła Siwka SJ do abp. Józefa Teodorowicza, Rzym 6 XII 1931 r. Kopia: Toż, AFKDOPW, teczka 144: Spuścizna abp. Józefa Teodorowicza, sygn. 1010/420 (8) [7].

Rzym, 6/XII [19]31

Ekscelencjo! ${ }^{\mathrm{a}}$

Dziś wieczorem otrzymałem list Ekscelencji od ks. prałata Zakrzewskiego ${ }^{135}$. Śpieszę z podzięką najserdeczniejszą za niego i za szczerą życzliwość Ekscelencji dla mnie.

Czytanie rzeczonego listu nasunęło mi pewne uwagi. Mam silną nadzieję, że ich wyrażenie wobec Ekscelencji z całą prostotą i szczerością rozjaśni pewne niejasności. Mocno ufam, że przyjąć raczy Ekscelencja moje uwagi z tą samą dobrocią i wyrozumiałością, jaką mię raczył dotychczas darzyć.

Są to uwagi luźne, których szersze rozprowadzenie i głębsze uzasadnienie będzie może kiedyś wymagało z mej strony szczegółowej pracy naukowej. Ujmę je dla jasności w punkta:

1) Ja bynajmniej nie traktuję mistyki jako takiej w mej książce. Twierdzić to, byłoby zakładać jako rzecz udowodnioną, co właśnie jest in questione ${ }^{136}$ : mianowicie, że Teresa Neumann ma de facto stany mistyczne w ścisłym tego słowa znaczeniu (petitio pricipii $^{137}$ ).

2) Nawet nie traktuję mistycyzmu danej osoby za taki uznanego przez Kościół św. Bo Kościół tu nic nie orzekł, lecz z całą swobodą pozwala badać rzecz. Toteż wśród „wątpiących" jest cały fakultet teol[ogiczny] w Würzburgu ${ }^{138}$ i szereg najwybitniejszych osobistości w Niemczech.

3) Chodzi mi tylko o ten drobny punkt: czy ta dziewczynka, którą niektórzy podają za mistyczkę jest naprawdę taką; a jeśli tak, to które spośród jej dziwnych stanów pozwalają nam na pewno ją za taką uznać. I tutaj stosuję ścisłą krytykę. Ale dlaczego tak ścisłą? Bo oto ta dziewczynka nie jest wolna od cienia. Cieniem są na niej szalone spazmy, skręty, miotania się po ziemi aż do wyłamania zębów... co wszystko naprowadza mimo woli na myśl: czy to nie była choroba nerwów? Cieniem na niej dalej, to zachowanie się jej tak zgoła różne od innych, tych, których się czci w Kościele jako „mistyków”; ona narzucała się z pokazywaniem swych stygmatów... itd. Cieniem na niej, ta niecierpliwość i nieuprzejmość dla wątpiących w jej stany... Cieniem na niej to postępowanie ks. Nabera, które nie zgadzało się z miarami Doktorów Kościoła, w szczególności św. Jana od Krzyża ${ }^{139}$

a Tekst pisany czarnym atramentem na 6,5 stronicach papieru formatu zeszytowego.

135 Zakrzewski Zdzisław (1870-1936), święcenia kapłańskie w 1896 r. w Poznaniu, 1896-1899 wikariusz par. Śrem, 1899-1900 wikariusz par. Kościan, 1900-1924 proboszcz par. Golejewko, 1924-1931 proboszcz par. Wolsztyn, 1931-1936 proboszcz par. Dolsk; autor utworów literackich i historycznych. M. Banaszak, Zakrzewski Zdzisław, w: SPTK, t. 7, s. 465-466.

136 Lac.: jest przedmiotem badania.

137 Łac.: domaganie się początku dowodu (błędne koło w dowodzeniu).

138 Würzburg - niemieckie miasto w Bawarii, siedziba rejencji Dolna Frankonia.

139 Św. Jan od Krzyża (1542-1591), hiszpański karmelita, mistyk, reformator Zakonu oo. Karmelitów, autor rozpraw teologicznych, Doktor Kościoła. 
doktora mistyki (str. 88 i nast[ępne]). Cieniem na niej fakt, że nie chce się poddać badaniom lekarskim, na które świeżo bardzo wymownie skarżył mi się w ordynariacie ratysbońskim wikariusz gener[alny] (dn[ia] 8 sierpnia). Użalał mi się na „nieposłuszeństwo ojca Teresy” i na jakiś „impertynencki list ks. Nabera do biskupa” w tej sprawie, wreszcie na nierówne „traktowanie” zbliżających się do Teresy. Zakończył: „Das alles muss uns verdächtig sein"140. Prosił mię, bym się podjął badań w Konnersreuth. Wymówiłem się od tego zaszczytu. Cieniem na niej to, to pochopność do interesowania innych swą osobą. Czy tak postępowali święci mistycy?

4) Ja nie stosuję „nowej metody do mistyki”. Bo jeśli ktoś nie otrzymał specjalnego objawienia co do Teresy Neumann, a z drugiej strony nie przyjmuje za senzystami i modernistami specjalnego „sensus religiosus”41, do „wyczuwania” rzeczy Bożych, to zostaje nam droga refleksji rozumu. Ta refleksja musi być tu specjalnie ostrożna, bo chodzi o specjalnie ciemny kawałek. Tak radzą wszyscy pisarze ascetyzmu. I Kościół do kanonizacji nie potrzebuje długich formalności. Bez nich przez całe szeregi wieków kanonizował. Dziś żąda specjalnych, bardzo mozolnych indagacji cudów, do których zawsze wciąga ludzi fachowych w medycynie.

5) O[ciec] św. Pius XI ${ }^{142}$ w alokucji (1925) do Zjazdu Tomist[ycznego] słowy płomiennymi nawoływał „do studium nauk nowożytnych” i do korzystania z nich w obronie re-

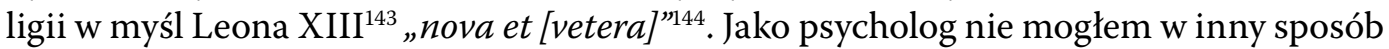
odpowiedzieć ojcowskiemu wezwaniu... Fizyka dzisiejsza tak różna od fizyki średniowiecznej; chemia nowożytna tak odbiega od alchemii! Czyżby tylko psychologia musiała stać na tym samym poziomie, na którym ją postawili mędrcy greccy: Aryst[oteles], Plato[n]?

6) Tamtego roku w paźdz[ierniku] i list[opadzie] cały szereg wybitnych osobistości Krakowa zwracał się z sumieniem zakłopotanym do mnie w sprawie Konnersreuth dzisiaj dostaję cały szereg podziękowań, a figurują w nich imiona profesorów uniwers[ytetu] i Członków Akademii Umiejętn[ości]. List jednego z nich zacytowałem Waszej Ekscelencji... Ludzie tracą wiarę widząc pochopność niektórych w zjawiskach nadprzyrodzonych. (Cały szereg moich kolegów na Sorbonie i w College de France potracili wiarę).

7) Św. Małgorzata Alac[oque ${ }^{145}$. miała światłego św. de la Colombiere ${ }^{146}$. Czy ks. Naber może nam dać równą rękojmię?

${ }^{140}$ Niem.: to wszystko musi wydawać się podejrzanym.

${ }^{141}$ Lac.: zmysłu religijnego.

${ }_{142}$ Zob. w niniejszej publikacji: J. Wołczański, Listy abp. Józefa Teodorowicza do abp. Józefa Bilczewskiego, dokument 130.

${ }_{143}$ Zob. w niniejszej publikacji: tenże, Korespondencja abp. Józefa Teodorowicza z abp. Adamem Stefanem Sapieha, dokument 14.

${ }^{144}$ Łac.: stare i nowe.

145 Św. Małgorzata Maria Alacoque (1647-1690), francuska zakonnica Zakonu ss. Wizytek, mistyczka, propagatorka kultu Najświętszego Serca Jezusowego, beatyfikowana w 1864 r., kanonizowana w 1920 r.

${ }_{146}$ Św. Klaudiusz de la Colombière (1641-1682), francuski jezuita, miosjonarz w Anglii, kierownik duchowy św. Małgorzaty Alacoque, beatyfikowany w 1929 r., kanonizowany w 1992 r. 
8) Jeśli ja żądam, by Teresę oddano do badań, to tylko powtarzam to, co powtarza ciągle Ordynariat ratysboński ojcu Teresy (wraz z Ordynariatem cały szereg księży w Niemczech). Zarzut robiony za to pod moim adresem dosięga Ordynariatu ratysbońskiego.

9) Moje stanowisko nie jest „sceptyczne” ani „hiperkrytyczne”. Nie jest sceptyczne, bo przyjmuję możliwość rozeznania stanów mist[ycznych]. Niech mi Teresa da choć jeden obiektywny dowód: znajomość rzeczy przyszłych, uzdrowienie choroby „organicznej”. Ja cudów w Lourdes bronię (str. 215 sq. „W pogoni za Nieskończ[onością]”147), tyko że u Teresy nie widzę uzdrowienia takiego. Nie jest „hiperkrytyczne” bo stoję na stanowisku poleceń Kościoła, Doktorów i przykładów Władzy duchownej, która tak troskliwie i długo badała Bernadetkę $e^{148}$ w Lourdes, Limpias ${ }^{149}$, Środzie ${ }^{150}$ (o czym mi wczoraj wspominał ks. Zakrzewski z oburzeniem na szkodę, jaką pochopność wywołała).

10) Owszem, kończę nadzieją. W fakcie niejedzenia widzę cud. Chodziłoby tylko o jego bliższe stwierdzenie. To tak łatwo zrobić! Dać ją do innego miejsca. Bo w Konnersreuth, jak sam wikariusz gener[alny] mi mówił, jest coś „verdächtig”151.

11) Bronię dobrej sławy Konnersreuth (nie ma tam oszustwa świadomego), chodzi o to, by wrogom Kościoła zamknąć raz usta, a to zrobi Teresa przez zastosowanie się do poleceń biskupich!

12) Pisałem do „«Przeglądu» ${ }^{152}$ na zaproszenie”. Pisałem resztę, tj. część krytyczną w osobnej odbitce jako studium. Toteż zarzut odpada, że „niekrytyczni mogą źle zrozumieć". To nie jest pisane dla „niekrytycznych”.

Oto parę uwag, niepowiązanych - ot jak mi się nasunęły po przeczytaniu listu Ekscelencji. Znając Ekscelencję, ufam głęboko, że nie weźmie mi mej otwartości „das Wissenschaftlers" ${ }^{153}$ za złe. Wolę je szczerze w zaufaniu powierzyć Waszej Ekscelencji, niż drukiem ogłaszać. Gdyby atoli Wasza Ekscelencja uważał, że charakteru polemicznego nie wolno Mu usuwać ze swego artykułu, to upraszam z całą pokorą nie brać mi za złe, jeśli dla chwały Bożej pozwolę sobie wydrukować odpowiedź. Bardzo będę zobowiązany Waszej Ekscelencji o wyrażenie formalnego Swego przyzwolenia, tym bardziej, że będę musiał wytaczać cały szereg punktów delikatnych, mniej więcej nawet osobistych osób wmieszanych w kwestię Konnersreuth (materiał mam obfity, zebrany świeżo w Monachium).

Całuję z najgłębszą czcią ręce Waszej Ekscelencji i proszę o łaskawą pamięć w modlitwach, niegodny sługa w Chrystusie

Siwek

147 P. Siwek, W pogoni za nieskończonością. Konferencje apologetyczne, Kraków 1930.

148 Św. Bernadeta Soubirous (1844-1879), francuska zakonnica Zgromadzenia Sióstr od Miłości i Nauczania Chrześcijańskiego, wizjonerka, świadek maryjnych objawień w Lourdes, beatyfikowana w 1925 r., kanonizowana w $1933 \mathrm{r}$.

${ }^{149}$ Limpias - gmina w prowincji Kalabria ( północna Hiszpania), w l. 1919-1920 w miejscowym kościele katolickim pojawiły się oznaki ożywienia figury Chrystusa rozpiętego na krzyżu i kolejnych etapów agonii.

150 Aluzja do niezidentyfikowanych wydarzeń w Środzie Wielkopolskiej.

151 Niem.: podejrzane.

152 Odniesienie do „Przeglądu Powszechnego”.

153 Niem.: naukowca. 


\section{Dokument 23}

AFKDOPW, bsygn., teczka: Spuścizna abp. Józefa Teodorowicza, List prof. Friedricha Ritter von Lamy do abp. Józefa Teodorowicza, Gauting bei München 30 XII 1931 r.

Excellenz ${ }^{\mathrm{a}}$, Hochwürdigster Herr Erzbischof!

Gauting, 30. Dezember 1931

Ich möchte diese Tage nicht vergehen lassen, ohne in aller geziemenden Bescheidenheit meine aufrichgen und ergebenen Wünschen für das vor der Tür stehende neue Jahr hiemit auszusprechen. Ich bitte den göttlichen Heiland, er möge Eure Excellenz mit ganz besonderer Liebe umfassen und seinen heiligen Willen durch Sie zu erfüllen. Ich glaube, die Kirche geht entscheidenden Tagen entgegen, wenngleich Gottes Langmut diese doch etwas länger hinausschieben wird, als menschliche Voraussicht es sich erwarten würde. Die hochernsten Worte, die der Heilige Vater in seiner Weihnachtsansprache nochmals an die Welt gerichtet hat, sind vielleicht eine letzte Warnung gewesen, die aber leider noch einmal überhört werden wird. Da alles von Gott seinen Ausgang hat, wird dann wirklich die Weltgeschichte das Weltgericht sein.

Immer wieder gehen mir Anfragen zu, bis wann das Buch Eurer Excellenz über Konnersreuth zu erwarten sei. Ohne mir herausnehmen zu wollen, Ihre Beschlüsse zu beeinflussen, darf ich wohl sagen, dass ich es als grosse Erleichterung empfinden würde, wenn es letztlich bei der Wahl des Verlags Badenia bleiben würde, denn schliesslich wäre es doch ich gewesen, der ihr diese peinliche und von der Oeffentlichkeit nicht verstandene Beiseitesetzung verursacht haben würde.

Mit der Versicherung aufrichtigster Ergebenheit begrüsse ich Eure Excellenz. Ihr

Friedrich R[itter] von Lama

\section{Dokument 24}

Kopia: AFKDOPW, teczka 134: Spuścizna abp. Józefa Teodorowicza, sygn. 1608/184 [7], Pismo abp. Józefa Teodorowicza do o. prof. Pawła Siwka SJ, bmr. [11 I 1932 r.].

\section{Czcigodny ${ }^{\mathrm{a}}$ Ojcze!}

Jak wnoszę z ostatniego listu Ojca, sądzi Ojciec, że praca moja ma wyłącznie na oku krytykę książki Ojca i Jego stosunek do Teresy Neumann. Ale w takim razie ograniczyłbym się do krótszej lub dłuższej recenzji książki Ojca, nie opatrując jej koniecznie aż moim podpisem.

Lecz nawet gdybym poszedł dalej, gdybym przypuścił, że praca Ojca wydana gorączkowo, szybko, tuż przed ukazaniem się mojej książki była pisana nie bez celów

a Tekst pisany maszynowo na jednej stronicy papieru formatu A4. Autograf własnoręczny czarnym atramentem.

a Tekst pisany maszynowo na czterech stronicach papieru formatu A4. Brak zakończenia, autografu autora i datacji. 
ubocznych na moje stanowisko w odczytach krakowskich i na przypuszczalne stanowisko w mej książce, to jeszcze i wtedy wystarczyłoby mi zupełnie rozprawić się z pracą Ojca w książce samej. Jeżeli to czynię, to dla celu innego. Książka Ojca jest w moim przekonaniu typem infiltracji racjonalizmu $\mathrm{w}$ badania mistyczne $\mathrm{u}$ wielu katolickich profesorów. Pisze Ojciec o Würzburgu? Słusznie. Ale to tylko dowód dla mnie, że istotnie książka Ojca jest typowym symptomem. Zasada racjonalistyczna ruguje mistykę w obserwacjach stanów mistycznych, posługując się nią tylko i wyłącznie cytatami dla swoich tez. Ta metoda występuje wybitnie w książce Ojca. „Ja bynajmniej nie traktuję pisze Ojciec - mistyki jako takiej w mej książce". Niestety, zupełnie to prawda. Czyni to nawet Ojciec z zasady, bo uważa, że twierdzić to, byłoby uważać za rzecz dowiedzioną, co właśnie jest „in questione”... Oczywiście takie twierdzenie nie wytrzymuje żadnej krytyki, lecz nie chodzi tu o to, by się z Ojcem o niej rozprawiać, ale o to, by stwierdzić na podstawie książki i słów Ojca, że Ojciec w imię psychologii i fizjologii przesądza o niewytłumaczalności stanów mistycznych, w tym wypadku u Teresy Neumann.

Wyjaśniwszy Ojcu o co idzie, mogę przy tej sposobności zapewnić Ojca, że nie tylko niesłusznie spotyka mnie zarzut, jakobym nie doceniał znaczenia nauk psychologicznych, ale przeciwnie, pisząc o książce Ojca, ze szczególnym uznaniem podnoszę wielką znajomość Ojca w tym zakresie. Mogę też Ojca zapewnić, że Jego zarzut skierowany ku mnie, jakobym metody Ojca uważał za nowe, również nie jest usprawiedliwiony. Jeżeli mam szczerze Ojcu powiedzieć, to jest wręcz inaczej; ja uważam metody Ojca już trochę za zestarzałe, bo najnowszy prąd w krytycznych badaniach u badaczy nie stojących na stanowisku katolickim, ale agnostycznym już uwzględnia kryteria mistyczne w analizie stanów mistycznych, których Ojciec nie uwzględnia.

Co do samej Teresy Neumann, na której jak widzę, Ojciec skupił głównie swoją argumentację, to nie zajmuję się nią w krytyce książki Ojca ex professo ${ }^{154}$; uczynię to dopiero w mej książce. Zajmując się metodami badania Ojca, wystąpiłbym tak samo przeciwko książce Ojca, gdybym we wszystkim nawet podzielał sąd negatywny Ojca o Teresie Neumann. Skoro już jednak o tym sądzie mówię, to trudno mi się oprzeć wrażeniu, że cytaty o Teresie Neumann w książce Ojca, niepoparte żadnym odnośnikiem źródeł skąd je Ojciec zaczerpnąt, że nakręcanie sztuczne, a nawet fantastyczne odtwarzanie szczegółów jej życia wewnętrznego, np. w autosugestii co do ran, że pominięcie zupełnym milczeniem najistotniejszych dla krytyka znamion jej stanów mistycznych poza ekstazą i charyzmatami, że podstawienie stanów ekstatycznych u Teresy Neumann w najistotniejszych punktach niezgodnie z rzeczywistością, że to wszystko obok innych jeszcze znamion nie przyczynia się u czytelnika do pogłębienia przekonania, że ma w książce Ojca do czynienia z poważnym i obiektywnym studium. Daruje mi Ojciec, że tak szczerze o tym mówię, ale Ojciec sam się ode mnie domagał takiej szczerości.

W końcu, jak uważam z ostatniego i przedostatniego listu Ojca, zdaje się widocznie Ojcu, że tylko ja jeden zajmuję stanowisko negatywne wobec książki Ojca i rozumiem dobrze to stanowisko autora, poparte pochwałami książki ze strony czytelników i to jak

154 Łac.: $\mathrm{z}$ urzędu, z powołania. 
mi Ojciec pisze, czytelników poważnych. Mam wobec tego niesłychanie przykrą rolę wobec Ojca donieść Mu w interesie prawdy, że są też i inni, bardzo poważni czytelnicy, którzy mają jednak odmienne zdanie od tych pierwszych. Jeślibym zebrał ich głosy, to sprowadziłbym ich do trzech kategorii sądu.

Czytelnicy pierwszej kategorii mówił mi: Od każdego, który mi wyświetla problem jakiś domagam się przede wszystkim tego, aby mi ten problem rozwiązał, albo pozytywnie, albo negatywnie. Ale jeżeli mnie autor prowadzi przez długi labirynt rozmaitych kwestii i kwestyjek, aby mi w końcu powiedzieć, że nic właściwie nie wie i nic o tych kwestiach powiedzieć nie umie czy nie może, to z rozczarowaniem odrzucam jego książkę.

Czytelnik drugiej kategorii zarzuca książce Ojca tendencyjność, zwłaszcza wobec Teresy Neumann. Mówił mi poważny uczony w Krakowie po przeczytaniu książki Ojca: Nie znam zupełnie problemu Konnersreuth i zgoła się nim nie interesuję, ale z całości odnoszę wrażenie bardzo tendencyjnej książki.

Trzecia kategoria znowu zarzuca książce Ojca, że jest pełna sprzeczności. Jeden z naszych biskupów, zupełnie nie interesujący się sprawą Konnersreuth, a znany ze swej wysokiej kultury intelektualnej, powiedział mi: Ależ to książka, której autor jest w ciągłej sprzeczności ze sobą. Tezy jego i konkluzje ostateczne kłócą się wprost ze sobą.

Są i tacy, którym się książka Ojca istotnie podoba, ale wśród nich, niestety, są tacy, u których powód upodobania nie mógłby nigdy zadowolić Ojca. Były na przykład u mnie dwie panie wysoko wykształcone i znające gruntownie zasady wiary, obie znane działaczki należące do Kongregacji Sacre Coeur. Czy wie Ojciec z czym do mnie przyszły? Oto ni mniej ni więcej z tym, abym miał wykład o książce Ojca skierowany przeciwko niej. Spytałem się oczywiście, dlaczego z tym do mnie przychodzą. Bo książka ta - odpowiedziały - wiele złego czyni wśród młodzieży. Chwali ona autora tej książki z tego przede wszystkim powodu, że im wykazał, że nauka dzisiejsza a czynnik nadprzyrodzony nie dadzą się pogodzić.

Z pewnością za złe zrozumienie idei książki nie można czynić odpowiedzialnym autora, ale czy wyolbrzymianie przez Ojca psychologii i fizjologii w Jego analizie, kosztem pryncypiów mistycznych jednak nie stwarzają u czytelnika sugestię, która z konkretnego fak $[\ldots]^{\mathrm{b}}$.

\section{Dokument 25}

Oryg.: AFKDOPW, teczka 144: Spuścizna abp. Józefa Teodorowicza, sygn. 1012/420 (8) [7], 1012/420 (8) [7], List o. prof. Pawła Siwka SJ do abp. Józefa Teodorowicza, Rzym 16 I 1932 r. Kopia: Toż, APJK, sygn. 4622, Siwek Paweł SJ. Korespondencja z lat 1932-1984.

Roma (101), li 16 stycz[nia] 1932

Piazza della Pilotta

b Brak dalszego ciągu. 


\section{Ekscelencjo ${ }^{\mathrm{a}}$,}

Chociaż jestem szalenie obarczony pracą (drukowanie wykładów arkuszami, które muszą być zawsze na lekcje gotowe oraz gotowaniem książki, w której się mam rozprawić z panteizmem do naukowej kolekcji dzieł: „Les maitres de la pense'e [religieuse]”, a która według formalnego kontraktu musi być odstawiona za kilka miesięcy), przerywam całą pracę, aby Ekscelencji za list podziękować.

Proszę z głębi duszy nie brać moich oświadczeń w ostatnim liście do Ekscelencji wyrażonych za „zarzuty skierowane” ku Ekscelencji. Są to pewne tylko refleksje, które mi się nasunęły gdym wniknął w treść listu Ekscelencji.

Ja szczerze mogę powiedzieć, że od szeregu osób bardzo wybitnych dostaję zapewnienie, że „Właśnie ta książka utoruje drogę do nawrócenia na katolicyzm wielu ateistów z inteligencji polskiej, a obojętnych zagrzeje i utwierdzi”. Jeślim pisał ją, tom pragnął gorąco tylko chwały Bożej. Nie mam najmniejszej racji [... $]^{\mathrm{b}}$ Teresę Neumann. Moja sympatia głęboka dla niej przebija prawie z każdej strony książki. Jeślim stosował do niej krytykę wymagającą to dlatego, że jej przeszłość pod względem elementarnej medycyny jest naprawdę bardzo ciemna. Świeżo pisał mi pewien specjalista psychiatrii, że pracą moją ,jest zachwycony”.

Ale ponieważ Ekscelencji chodzi o O. Generała ${ }^{155}$ i zapewnia mię o tym, że raczy rzecz „w zupełnej dyskrecji” zachować, to powiem $\mathrm{Mu}$, że istotnie miałem od O. Generała formalne pozwolenie na napisanie książki; owszem, miałem nawet kierunek wytyczony. Otóż ten kierunek w pełni nakrywał się z moimi poglądami. Tu po przybyciu do Rzymu komunikował mi natychmiast O. Asystent, że O. Generał zaraz przeczytał ową książkę i „że jest bardzo rad, żem dokładnie po jego myśli napisał” i tak też kwestię załatwiłem czekając na sąd Kościoła.

Bałem się trochę, że O. Generał będzie może niezadowolony z tego, że w kwestii niejedzenia stanąłem otwarcie po stronie „cudu” - jednak moje obawy były złudne, O. Generał bardzo rad w całości.

Że będą „niezadowoleni” niektórzy, to już w recenzji O. Rostworowski ${ }^{156}$ (w „Przeglądzie") podkreślił z naciskiem. Lecz gdyby ktoś chciał mi zrobić zarzuty, że moimi metodami podkopuję "samą" mistykę, to uważałbym to za krzywdę największą i będę się czyścił, choćbym miał iść aż do ostateczności. Żadne względy, absolutnie żadne względy, nie mogą mię tu zatrzymać.

Ekscelencja rozumie doskonale, że nie tylko wypada mi skorzystać z pozwolenia Przełożonych, ale że mam ścisły obowiązek sumienia to uczynić, bo przecież profesor „Papieskiego Uniwersytetu” i to w Rzymie nie może dopuścić, by zaciążył na nim zarzut „racjonalisty”, czy „gorszyciela młodzieży”! Proszę mi zatem za złe nie brać, bo naprawdę wyłącznie tylko obowiązek sumienia zmusza mię do podjęcia zaofiarowanej mi przez Ekscelencję polemiki. Robię to z największym bólem bo wiem, jakie zasługi ma

a Tekst pisany czarnym atramentem na czterech stronicach papieru formatu A4. W lewym górnym rogu karty tytułowej formowy nadruk: „Pontificia Universita Gregoriana”.

b Wyraz nieczytelny.

155 Aluzja do ówczesnego generała Zakonu oo. Jezuitów o. Włodzimierza Ledóchowskiego.

156 Zob. w niniejszej publikacji: J. Wołczański, Korespondencja abp. Józefa Teodorowicza z bp. Henrykiem Przeździeckim, dokument 12. 
Ekscelencja wobec narodu naszego i na jaką cześć zasłużył sobie Ekscelencja od każdego syna tego narodu; wiem ponadto, że ta polemika dużo może złego w polskiej inteligencji zrobić - a i mnie samego tylko odciągnąć od rozpoczętych prac (gotuję II tom „W Pogoni za Nieskończ[onością]”, o „duszy” ${ }^{157}$, gdzie rozprawić się będzie trzeba raz na zawsze $\mathrm{z}$ reinkarnacją tak szkodliwą dla wiary naszej młodzieży), lecz jeśli taka wola Boża, cóż robić. Raz rozpoczętą polemikę będę z łaską Pana Jezusa prowadził do ostatniego tchu, ale z zarzutów powyższych muszę się oczyścić bo tego wymaga moje stanowisko. Pozwolenia wszystkie mam już.

Całuję z czcią najgłębszą ręce Ekscelencji i proszę pokornie o błogosławieństwo arcypasterskie, sługa w Chr[ystusie]

Siwek

P.S. Co dotyczy zakazu O Generała dotyczącego pisania o Konnersreuth, to opiewa on: „Nasi nie mają rozstrzygać sprawy ni w tę, ni w ową stronę lecz zajmować stanowisko wyczekujące. A zatem «non constat» ${ }^{158}$, czy od Boga, czy od innych przyczyna".

\title{
Dokument 26
}

Oryg.: AFKDOPW, bsygn., teczka: Spuścizna abp. Józefa Teodorowicza, List o. Pawła Siwka SJ do abp. Józefa Teodorowicza, Rzym 17 I 1932 r.

\author{
Roma, (101), li 17 stycz[nia] 1932 \\ Piazza della Pilotta
}

Ekscelencjo $^{\mathrm{a}}$,

Chociaż jestem formalnie zawalony pracą (drukowaniem arkuszami wykładów, które muszą być zawsze na lekcję gotowe oraz gotowaniem do pewnej naukowej kolekcji francuskiej „Les maiters de la pensee [religieuse]” książki, w której się mam na prośbę francuskich uczonych katolickich rozprawić z panteizmem ${ }^{159}$ ), przerywam pracę całkowicie, by Ekscelencji za list dzisiaj otrzymany podziękować.

Pozwoli Ekscelencja, że dam króciutkie wyjaśnienia na poruszone problemy, ale z całą otwartością i swobodą „naukowca” piszącego do "naukowca”, bo taką rolę raczył wziąć na siebie Ekscelencja w ostatnim liście.

Bardzo wdzięczny jestem Ekscelencji za uprzejme uwagi, ale otwarcie powiem, że mnie niestety nie przekonują. Uwagi zamieszczone w poprzednim moim liście w pełni podtrzymuję nadal. Rozumiem gdzie jest przyczyna nieporozumienia: jak zaznaczyłem wtedy, owe moje uwagi to tylko "luźne uwagi” jakby conclusions sans premisses ${ }^{160}$. Wystarcza atoli je ując $\mathrm{w}$ formę syntetyczną w opracowaniu literackim, by wystąpiła

157 P. Siwek, Wędrówka dusz. Reinkarnacyjne utopie, Warszawa 1937.

${ }^{158}$ Łac.: nie jest pewne (nie stwierdza się).

a Tekst pisany czarnym atramentem na 8 stronicach papieru formatu zeszytowego. W lewym górnym rogu karty tytułowej firmowy nadruk: „Pontificia Universita Gregoriana”.

159 P. Siwek, Spinoza et le panthéisme religieux, Paris 1937.

${ }^{160}$ Fr.: wnioski bez przesłanek. 
ich wartość. Nietrudno mi będzie wykazać, że celem książki nie jest bynajmniej to, co w liście Ekscelencji czytam. Pisał mi kiedyś profesor uniwers[ytetu], (filozof), że książka moja utoruje drogę do nawrócenia szerokim kołom inteligencji naukowców w Polsce, a w innych ożywi wiarę i sympatię do Kościoła. Pisał mi przed paru dniami pewien psychiatra, dyrektor szpitala nerwowych i profesor, że pracą moja "jest zachwycony" i że do pewnego ściśle lekarskiego czasopisma wygotował 10 stron pisma maszynowego sprawozdanie naukowe z mej książki.

Nie dla schlebienia swej ambicji to piszę, ale dlatego, że ludzie naprawdę naukowi nie widzą znów takich „sprzeczności” w książce, jakie znajduje interlokutor Ekscelencji: "Ależ to książka, której autor jest w ciągłej sprzeczności ze sobą".

Takie zdanie kategoryczne bez nuance’ów ${ }^{161}$ mimo woli nawodzi na myśl słowa wielkiego biskupa franc[uskiego] d'Hulsta ${ }^{162}$ wyrzeczone w parlamencie: „Messieurs, qui ne distingue pas, confond"163. To, że ma być „wysokiej kultury intelektualnej” nie zmienia rzeczy, bo Ekscelencja doskonale wie, jak tego rodzaju qualitatif ${ }^{164}$ jest elastyczny! Doświadczenie psychologiczne pokazuje, że ocena tak kategoryczna na jaką sobie pozwolił ów interlokutor, jest zawsze wyrazem uczucia zaślepiającego. Nie ma co takich słuchać; gdyby był zwrócił uwagę na wszystkie nuance'e moich twierdzeń, zastrzeżeń itd., na pewno sąd jego byłby inny. Niechże choć na jednym szczególe wykaże od początku do końca konsekwencję!

Drugi interlokutor, który a tout prix ${ }^{165}$ żądał, by „pozytywnie albo negatywnie” koniecznie rozwiązać każdy problem, zdradza osłupiający brak naukowego wyrobienia. Ot przychodzi ktoś do mnie i mówi: „Ile wynosi powierzchnia trójkąta, którego podstawa równa się $5 \mathrm{~m}$ ?”. Ja na to: „Ależ takiego zadania nikt na świecie nie rozwiąże, owszem i Bóg sam nie rozwiąże”. Dlaczego? „Bo do esencji trójkąta należy powierzchowność, a ty mi podajesz samą tylko liniowość - jeden wymiar". Jeśli mój interlokutor się uprze przy swoim, to siądę i wypracuję mu długi zawikłany dowód za pomocą rachunku różniczkowego i całek, by mu wykazać, że takie zadanie nie da się rozwiązać. Otóż zastosowanie jasne. Wziąwszy na uwagę genezę choroby Teresy, jej zachowanie się ze swymi karyzmatami ${ }^{166}$ (zupełnie inne niż u znanych mistyków!), jej nieposłuszeństwo dla władzy kościelnej o którym mi w sierpniu mówił jeden z wikariuszów generalnych Ratysbony (owszem nawet i to mi wspomniał, że Teresa w najlepsze gwarzyła i śmiała się z Gerlichem w czasie mszy św.) itd. itd., powiadam: non constat de supernaturalitate ${ }^{167}$ dotąd. „Verba in contrarium non sunt certa. Voilà ma position, a moi ${ }^{168}$. Ja nie mówię o mistyce w ogóle!

\footnotetext{
$161 \mathrm{Z}$ j. francuskiego: niuansów.

162 Osoba niezidentyfikowana.

163 Fr.: panowie, kto nie rozróżnia, ten myli (miesza).

164 Fr.: jakościowy; tu: wyznacznik.

165 Fr.: za wszelką cenę.

166 Forma zgodna z oryginałem; powinno być: charyzmatami.

167 Łac.: nie stwierdza się nadprzyrodzoności.

168 Łac. i fr.: słowa przeciwstawne nie są godne zaufania. Oto moja opinia.
} 
Co dotyczy tych dwóch pań, to ks. Rostworowski ${ }^{169} \mathrm{z}$ góry powiedział w recenzji („Przeglądzie”), że będą tacy „bezwzględni admiratorzy Teresy”, którym praca moja „podobać się nie będzie”. Lecz poprzez takie osoby przechodzi się do porządku dziennego, bo to jest według moralistów „scandalum pusillanimorum”!170

Co dotyczy „metod” w mistyce, to z bliska śledziłem dyskusję na ten temat między szeregiem psychologów, wśród których i wybitny O. Maréchal ${ }^{171} \mathrm{z}$ Lowanium. Cała kwestia nie jest dla mnie w tym, czy istnieje mistyka. Ja osobiście w nią wierzę! Chodzi tylko o to, gdzie się zaczyna, co jest jej istotą (O. Maréchal, „Etudes sur la psychologie des mystiques”), czy zjawiska somatyczne należą do „istoty” mistyki, czy nie (tekst jeden zacytowałem sam). Ci, co stoją na stanowisku „indyjskiej mistyki” oczywiście podają cały szereg kryteriów ściśle „somatycznych”! Co dotyczy „odtwarzania fantastycznego” psychiki Teresy, to dopiero [co] wyżej zacytowałem sąd psychiatry-profesora.

Co do historycznych szczegółów, to wprawdzie nie zawsze cytowałem źródło, ale to tylko robiłem, gdy źródło było znane powszechnie. W szczegółach więcej uderzających, rzadszych zawsze cytowałem. Takiego postępowania wymagała ode mnie „metoda naukowa" pisania.

Co dotyczy zgorszenia, to odpowiadam krótko: więcej zgorszenia dają ci, co rzeczy niepewne podają za karyzmaty, w ten sposób podkopują wiarę, sprowadzają ruinę w duszach; mogę zacytować cały szereg ludzi, co stracili wiarę w ten sposób lub przynajmniej zrażają się do niej. Jeśli zabrałem się do pracy nad Konnersreuth, to dla chwały Bożej takie mi świadectwo daje sumienie i dziękuję gorąco Bogu, gdy słyszę, ile dobrego robi ona dla umiłowania wiary wśród sfer uniwersyteckich. Do badań nie mamy żadnego „sentymentu religijnego", lecz „rozum oświecony wiarą”: rozum, a więc zdrowy rozsądek, nauka fachowa w świetle dogmatów i zasad teologów katolickich. Moja wymagająca krytyka stosowana do Teresy jest wynikiem chęci obrony katolicyzmu i jego rehabilitacji wobec kompromitujących wydawnictw o Teresie Neumann, które sfery intelektualne w Polsce żywo zaniepokoiły.

Ponieważ Ekscelencja życzy sobie znać stosunek mej książki do O. Generała ${ }^{172}$ i ze swej strony raczył mię zapewnić o swej „zupełnej dyskrecji”, to powiem: istotnie miałem od O. Generała formalne pozwolenie na napisanie książki, owszem miałem nawet kierunek wytyczony ten sam, który obowiązuje i kilka innych prowincji: Nasi ${ }^{173}$ nie mają rozstrzygać sprawy Konnersreuth apodyktycznie ni w tę, ni w ową stronę, lecz zająć stanowisko wyczekujące; a zatem „non constat ${ }^{\text {174 }}$ jest nam wskazane. Otóż ta dyrektywa

169 Zob. w niniejszej publikacji: J. Wołczański, Korespondencja abp. Józefa Teodorowicza z bp. Henrykiem Przeździeckim, dokument 12.

170 Łac.: nieprawość ludzi małej wiary.

171 Maréchal Joseph (1878-1944), święcenia kapłańskie w 1908 r. w Zakonie oo. Jezuitów, dr biologii, 1915-1939 prof. historii filozofii na Uniwersytecie w Lowanium, autor m.in.: Etudes sur la psychologie des mystiques (t. 1-2, Bruges 1924-1937). J. Herbut, Maréchal Joseph, w: EK, t. 11, red. zbior., Lublin 2006, kol. 1264-1265.

172 Odniesienie do ówczesnego generała Zakonu oo. Jezuitów o. Włodzimierza Ledóchowskiego.

${ }^{173}$ Określenie używane przez oo. Jezuitów w odniesieniu do członków Zakonu.

${ }^{174}$ Łac.: to nie jest pewne. 
w przedziwny sposób harmonizowała z moimi poglądami zdobytymi na drodze badań owych zjawisk. Zaraz przy pierwszym widzeniu się z O. Asystentem zakomunikował mi tenże ostatni, że O. Generał natychmiast przeczytał moją książkę i że jest z niej bardzo rad, że tak doskonale odpowiada jego intencjom i karci niedowiarków, i przesadnych admiratorów.

Zarzut racjonalizmu, gorszyciela publicznego uważam za absolutnie krzywdzący. Będę się z niego czyścił aż do ostateczności, aż do upadłego... Żadne względy, żadne rady nie wstrzymają mię tutaj. Ekscelencja doskonale rozumie, że profesor „Papieskiego Uniwersytetu” i to w Rzymie, nie może pozwolić, by zaciążył na nim zarzut „racjonalisty czy gorszyciela", a choćby tylko człowieka nieznającego metody naukowej. Proszę mi zatem za złe nie brać - bo naprawdę wyłącznie tylko obowiązek ścisły sumienia zmusza mię do podjęcia zaofiarowanej przez Ekscelencję polemiki. Robię to z największym bólem, bo wiem, jakie zasługi na Ekscelencja wobec narodu naszego i na jaką cześć zasłużył sobie Ekscelencja od każdego syna tego narodu; zdaję sobie w całej pełni sprawę ponadto z tego, że polemika ta może dużo złego dla dusz inteligencji polskiej zrobić, a i mnie samego tylko oderwie na szereg może lat od rozpoczętych prac (zbieram materiał do ciągu dalszego: „W pogoni za Niesk[ończonością]”, o „duszy”, gdzie trzeba będzie raz rozprawić się na serio z reinkarnacją, a nadto materializmem i determinizmem grasującymi w Polsce). Lecz jeśli taka wola Boża! Raz podjętą polemikę będę z łaską Pana Jezusa prowadził do ostatniego tchu, ale z zarzutów powyższych muszę się oczyścić, bo tego wymaga sumienie. Pozwolenia potrzebne oczywiście mam. Zresztą czy w tym wypadku (gdzie chodzi o jasny obowiązek sumienia sub peccato ${ }^{175}$ ) potrzebne ono w ogóle było?!

Całuję z najgłębszą czcią ręce Ekscelencji, proszę pokornie o błogosławieństwo i przepraszam za śmiałość, do niej upoważniała mię dobroć Ekscelencji i jego charakter „naukowca", który raczył wziąć na się

Siwek

\section{Dokument 27}

Oryg.: AFKDOPW, teczka 145: Spuścizna abp. Józefa Teodorowicza, sygn. 1065/420 (8) [7], List dr. Eugène Willemina do abp. Józefa Teodorowicza, Paryż 24 I 1932 r.

Paris, le 24 Janvier 1932 9, av. Hoche

Monseigneur,

J'a temps que Thérèse Neumann a été appelée à Rome par Pie XI en mai 1931. Le fait est caché à Rome et à Konnersreuth; vous avez dû connaître bien le cas où un fait vrai ayant été affirmé, est formellement nié et démenti le lendemain dans „Osservatore Romano": cela ne veut rien dire sinon que le Pape ne voulait qu'on en parlât.

175 Łac.: pod grzechem.

a Tekst pisany czarnym atramentem na czterech stronicach papieru formatu notesowego. 
Je suis convaicu que le fait est vrai, étant donné la personne qui me l'a dit; elle m’a autorisé à en parler en particulier, mais m'a prié de n'en rien dire en public dans une conférence puisque le désir du Pape est évidemment de n'être pas trop en avant, pour ne paraître juger définitivement et favorablement le cas de T[hérèse] N[eumann].

Un prêtre aurait accompagné à Rome Thérèse (outre un membre de la famille); c'est le $\mathrm{R}$ [évérend] $\mathrm{P}$ [ère] von Lama des Pères d'Issoudun ${ }^{176}$, le frère du journaliste.

Si Votre Grandeur va à Konnersreuth, par le curé Naber, par von Lama, par le R[évérend] $\mathrm{P}$ [ère] von Lama, elle pourra être documentée. J'ai tenu à lui citer le fait, au cas où elle ne le connaitrait pas, non pas pour qu'elle le publie, si le Pape Pie XI préfère le silence, mais pour qu'elle le sache. Si Pie XI a vu Thérèse en extase et a causé avec elle (ce qui est très probable) et a permis en Septembre qu'elle revienne à voir les Pèlerins, $[\ldots]^{\mathrm{b}}$ et stigmates viendraient de Dieu. J'ai pensé que cela intéresserait V[otre] Grandeur et fortifierait ses convictions, c'est le seul but de cette lettre.

Que V[otre] Grandeur ne prenne pas la peine de me répondre et veuille bien agréer mon très profond respect.

Dr Willemin ${ }^{177}$

\section{Dokument 28}

Oryg.: AFKDOPW, teczka 145: Spuścizna abp. Józefa Teodorowicza, sygn. 932/420 (8) [7], List prof. Friedricha Ritter von Lamy do abp. Józefa Teodorowicza, Gauting bei München 31 I 1932 r.

Eure $^{\text {a }}$ Excellenz, Hochwürdigster Herr Erzbischof!

Gauting, 31. Januar 1932

Es sollte mich freuen, wenn meine heutigen Mitteilungen Eurer Excellenz ein wenig von Nutzen sein konnten. Als Eu[re] Excellenz in Ihren Briefen bei Erwähnung des Namens des P[ater] Siwek S.J. und seiner Pariser Studien den Namen Janet ${ }^{178}$ nannten, da tauchte in meiner Erinnerung ein Hinweis auf, den ich vor mehreren Jahren in der Münchener Allgemeinen Rundschau veröffentlicht hatte. Vor einigen Wochen, als ich mich an die Vorarbeit für mein neues Jahrbuch machte, ging ich der Sache nach und fand die Notiz, ein Hinweis auf einen Artikel des französischen Jesuiten P[ater] Rou$\mathrm{re}^{179}$ in den Etudes 64. année, tome $190 \mathrm{Nr}$. 4 vom 20. Februar 1927, betitelt: Une Extatique à la Salpétrière. D'après un noueau livre du Dr. Pierre Janet. In diesem Referat wird gezeigt, wie Janet einer reinen Hysterikerin aufgesessen ist, die nach den elementaren Regeln der Pastoraltheologie und Eskese niemals eine wirkliche Ekstatikerin war und ist. Falls Eu[re] Excellenz damit gedient ist, bin ich gerne bereit, das Heft, solange

176 Issoudun - miejscowość w Rejonie Centralnym Francji, w departamencie Indre.

b Fragment nieczytelny.

177 Willemin Eugène - dr medycyny, francuski lekarz zamieszkały w Paryżu.

a Tekst pisany maszynowo na 2,5 stronicy papieru formatu A4. Autograf odręczny czarnym atramentem.

178 Zob. w niniejszej publikacji: J. Wołczański, Korespondencja abp. Józefa Teodorowicza z prof. Stefanem Dąbrowskim, dokument 13.

179 Roure Lucien - francuski jezuita, autor m.in. Doctrines et problèmes (Paris 1900). 
es benötigt wird, zu überlassen. Es lässt sich ausgezeichnet gegen Siwek und seine Wissenschaft verwenden.

Ich habe gestern mit Dr. Gerlich gesprochen und dabei erfahren, dass Prof. Wutz polnisch kann; er hat wahrend des Krieges sogar polnisch gepredigt. Ich würde daher im Interesse der Sache bitten, sowohl den Artikel P[ater] Siweks wie auch Ihren Gegenartikel ihm zukommen zu lassen. Als selbstverständlich nehme ich an, dass Eure Excellenz Siweks Drohung unbeachtet lassen. Es liegt ganz im Gegenteil im Interesse aller, die für Konnersreuth eintreten, dass nichts unterlassen wird, was zur Klärung beitragen kann und dass auch das, was dagegen zu sprechen scheint, nicht unterdrückt wird. Ich weiss so ziemlich, was mit den "geheimen Akten" angedeutet wird; es ist ja nicht das erstemal, dass das von dieser Seite (Regensburg) aus geschieht. S[eine] Exc[ellenz] Msgr. Buchberger hat in gleicher Offensive schon einmal Dr. Westermayr ${ }^{180}$-Freising vorgeschoben, der in gleicher Weise mit den Geheimsten operierte und so erfuhr ich dann, was dahinter steckte: Dinge, die für Konnersreuth niemals nachteilig sind oder werden, wohl aber manchen kirchlichen Behörden und ihren allzu voreiligen Urteilssprüchen. All das sind längst keine Geheimnisse. Wenn übrigens P[ater] Siwek den Streit um die Sache, der in Interesse der Waheit geführt wird, auf das persönliche Gebiet zu schieben droht, so will es mir scheinen, dass er damit zugibt, dass sie sachlich nicht angreifbar ist. Was vom „Ungehorsam des Vaters Theresens" zu halten ist, werden. Eu[re] Excellenz wissen.

Er behauptet, keine kirchliche Behörde könne ihn mit Recht zwingen, sein. Kind einer sog[ennante] neutralen Klinik auszuliefern und ich glaube, man muss ihm Recht geben. Mit dem „impertinenten Brief Pfarrer Nabers“ dürfte wohl jener gemeint sein, in dem Pfarrer Naber auf die Drohung mit seiner Absetzung auf das kirchliche Gesetzbuch hinwies, dessen Bestimmungen massgebend sind. Eure Excellenz wissen aus meinen früheren Mitteilungen, dass man in Regensburg keine gerade Linie verfolgt, sondern ein doppeltes Spiel treibt. Man fürchtet die Verantwortung für eigenes Vorgehen und so schickt man andere vor und überlässt es ihnen, sich möglicherweise zu blamieren. Gemelli ${ }^{181}$ hat inzwischen auf die Versuche Wunderles und Magers, ihn in den Streit hereinzuziehen und gegen Konnersreuth vorzuschieben, mit einer Erklärung erwidert, dass er sich an diesem Streit nicht beteilige. Riese Erklärung war eine öffentliche!

Es ist mir nicht bekannt, dass ausser den beiden ersten Artikeln Waldmanns ${ }^{182}$ über das „Rätsel von Brooklyn“ noch ein dritter erschienen ist; ich werde mich aber

180 Zob. w niniejszej publikacji: J. Wołczański, Korespondencja abp. Józefa Teodorowicza z o. Wtodzimierzem Ledóchowskim SJ, dokument 13.

${ }^{181}$ Gemelli Agostino (1878-1959), włoski lekarz, święcenia kapłańskie w 1908 r. w Zakonie oo. Franciszkanów, autor publikacji poświęconych problemom pogodzenia wiary chrześcijańskiej z nowoczesną kulturą, inicjator powołania do życia katolickiego uniwersytetu Najświętszego Serca w Mediolanie i jego rektor 1921-1959, organizator Papieskiej Akademii Nauk i jej prezes 1936-1959, jego imię otrzymała otwarta w 1964 r. poliklinika w Rzymie. B. Brzuszek, Gemelli Agostino, w: EK, t. 5, kol. 936-938.

182 Osoba niezidentyfikowana. 
erkundigen. Dagegen werde ich den Metzer Nervenarzt Dr. Witry ${ }^{183}$, der in Wien gegen Mager aufgetreten war, bitten, er möge Eurer Excellenz seine Erwiderung in der "Schildwache“ zuschicken, die er gegen P[ater] Thurstons ${ }^{184}$ Arbeit über Mollie Fancher ${ }^{185}$ geschrieben hat. Es scheint mir überaus bezeichnend, dass jener Herren der Wissenschaft, die hinsichtlich der Erforschung des Falles Konnersreuth in ihren Forderungen nicht streng genug sein können und denen nichts genügt, im Falle Mollie Fancher auf diese selben Forderungen ohne weiteres verzichten. Das ist offene Parteilichkeit aber keine unparteiische Wissenschaft mehr. Ich möchte bemerken, dass neben P[ater] Siwek in derselben Gregoriana jetzt auch P[ater] Leiber ${ }^{186}$ wirkt, der, wie man mir vor einiger Zeit schrieb, heute überzeugter Anhänger des übernatürlichen Charakters der Konnersreuther Mystik ist.

Soviel für heute. Ich kann Eurer Excellenz nicht genug für die Gebetshilfe danken, die Sie meinem Sohn zuteil werden lassen. In einem haute angekommenen Briefe teilt er freudig mit, dass auch die letzte Untersuchung des Sputums keine Bazillen mehr aufgewiesen habe; es geht, wenn auch langsam, vorwärts.

Mit der Versicherung meiner aufrichtigen Verehrung ergebenst

F[riedrich] R[itter] von Lama

\section{Dokument 29}

Oryg.: AFKDOPW, teczka 145: Spuścizna abp. Józefa Teodorowicza, sygn. 1067/420 (8) [7]-1082/420 (8) [7], List dr. Théodore Witry do abp. Józefa Teodorowicza, Metz 2 II 1932 r.

Metz $^{187}, 2$ II 1932

Hochwürdigsten ${ }^{a}$ Herr Erzbischof!

Eu[re] Eminenz!

183 Zob. w niniejszej publikacji: J. Wołczański, Korespondencja abp. Józefa Teodorowicza z prof. Stefanem Dąbrowskim, dokument 23.

184 Thurston Herbert Henry Charles (1856-1939), angielski duchowny rzymskokatolicki, święcenia kapłańskie w 1890 r. w Zakonie oo. Jezuitów, 1880-1887 wykładowca w Beaumont College,, autor kilkuset p;ublikacji z dziedziny spirytyzmu, liturgii, życia duchowego, historii, kultu świętych i relikwii; zjawisko stygmatów rozpatrywał w kategorii wpływów sugestii. C. C. Martindale, Father Herbert Thurston, S.J. 18561939, SIQR, 1939, t. 28, nr 112, s. 662-666.

${ }^{185}$ Fancher Mollie (1848-1916), Amerykanka, przez 46 żyła w transie przykuta do łóżka, wykazując przy tym wielką aktywność życiową.

${ }^{186}$ Leiber Robert (1887-1967), duchowny niemiecki, święcenia kapłańskie w 1917 r. w Zakonie oo. Jezuitów, historyk Kościoła, 1924-1958 najbliższy współpracownik kard. Eugenio Pacellego/Piusa XII, 1930-1958 prof. historii Kościoła na Uniwersytecie Gregoriańskim w Rzymie. K.H. Heufeld, Leiber Robert, w: NDB, Bd. 14, red. zbior., Berlin 1984, s. 116-117.

${ }^{187}$ Metz - miasto w północno-wschodniej Francji nad rzeką Mozelą.

a Tekst pisany czarnym atramentem na dwóch stronicach papieru formatu A4. W lewym górnym rogu karty tytułowej nadruk firmowy: „Docteur Witry, maladies nerveuses \& du sang, Metz, Place St. Thièbault, 39 , tèlèphone 1767 , pathologie sexuelle-psychanalyse”. 
Mit gleicher Post sende ich Eure Eminenz zwei Nummer der "Schildwache“ mit einer Arbeit von mir, worin auch Fr[eu]l[ein] Resl Neumann aus Konnersreuth ${ }^{188}$ erwähnt wird. Ein Buch von mir über die Lothringer Mystikerin und Stigmatisierte Katharina Fillgang ${ }^{189}$ wir im Frühjahr erscheinen. Ein anderes ist in Bearbeitung über die große englischen Mystikerin und Stigmatisierte, Therese Higginson ${ }^{190}$, deren Prozess jetzt kurz nach ihrem Tode vor der Ritenkongregation schwebt.

Am nächsten Freitag fahre ich auf einige Tage zur Untersuchung einer Stigmatisierten mit wunderbaren Kommunionen und in der Fastenzeit noch zu zwei anderen Stigmatisierten.

Herr Domdekan Prälat Molz aus Speyer hat mich gebeten, Ihnen meine kleine Arbeit zu senden.

Ich empfehle mich Eu[rer] Eminenz und verbleibe Hochwürdigster Herr Erzbischof in Verehrung und Hochachtung Ihr sehr ergebener

Witry

\section{Dokument 30}

Oryg.: AFKDOPW, teczka 145: Spuścizna abp. Józefa Teodorowicza, sygn. 1049/420 (8) [7], List ks. prof. Franza Wutza do abp. Józefa Teodorowicza, Eichstätt 23 II 1932 r.

Eichstätt ${ }^{191}$, 23. II. [1]932

Hochwürdigster ${ }^{a}$ Herr Erzbischof!

Eure Exzellenz!

Entschuldigen Sie bitte meine Verspätung; ich hatte nahezu 14 Tage mit Lungenentzündung zu tun und musste fleißig da Bett hüten.

So viel ich weiß, hat Vater Neumann vor 14 Tagen seine Antwort nach $R^{b}$. abgesandt; sie ist abschlägig, stellt aber einige Bedingungen, deren Einlösung Zeit erfordern wird. Unter einem halben Jahr glaube ich kaum, dass eine Beobachtung sich verwirklichen lassen wird. Von R. kam noch keine Rückäußerung, wenigstens hörte ich bis heute noch nichts davon. Die Predigt im Dom zu R. war ein schwere Missgriff, ebenso dass der Reverendissimus v[on] R. den Bürgermeisterei von K[onnersreuth] beauftragte, auf Vater, Resl, Pfarrer und Benefiziat einzuwirken, dass die Untersuchung zustande komme. Vater hat dem Bürgermeister erklärt, dass die Sache keine Gemeindeangelegenheit werden soll. Sie sehne, dem Vater wird die Sache nicht gerade leicht gemacht!

Mir den ehrerbietigsten, ergebensten Grüßen

Prof. Franz Wutz

188 Zdrobniałe forma określająca tożsamość Teresy Neumann.

189 Osoba niezidentyfikowana.

190 Higginson Teresa Helena (1844-1905), angielska nauczycielka, mistyczka i stygmatyczka, w l. 80. XIX w. miała rzekomo objawienia Jezusa, co nie zostało oficjalnie potwierdzone przez Kościół.

${ }^{191}$ Eichstätt - miasto powiatowe w Bawarii w Niemczech.

a Tekst pisany czarnym atramentem na 1,5 stronicy papieru formatu A4.

b Kryptonim nierozwiązany. 


\section{Dokument 31}

Kopia: AFKDOPW, bsygn., teczka: Spuścizna abp. Józefa Teodorowicza, List abp. Józefa Teodorowicza do bp. Kazimierza Tomczaka, Lwów 3 IV 1932 r.

\section{Wasza ${ }^{a}$ Ekscelencjo!}

Bardzo serdeczne i oddane podziękowanie składam Waszej Ekscelencji za tak łaskawą zawsze, a dla mnie tak cenną pamięć. Cieszę się osobno, że Waszej Ekscelencji odpowiada moja praca o biednym Siwku ${ }^{192}$, którego z miesiąca na miesiąc muszę, niestety, kruszyć; jak jednak widzi Wasza Ekscelencja z 3-go numeru, idzie mi wprost o rzeczy zasadnicze i fundamentalne w mistyce.

Chciałem właśnie posłać Waszej Ekscelencji moją książkę i oto dowiaduję się, że już ją Wasza Ekscelencja zamówił. Zobowiązuje mnie ona teraz już do zakasania rąk dla dalszych tomów; nie będzie ich jednak dwanaście, ale jak przypuszczam dwa, a najwyżej trzy ${ }^{193}$.

Jeszcze raz dziękuję Waszej Ekscelencji i łączę bardzo serdeczne i oddane wyrazy czci głębokiej.

Lwów, dnia 3 kwietnia 1932

J[ego] E[kscelencja] Najprzew[ielebniejszy] Ks. Biskup

Kazimierz Tomczak ${ }^{194}$

Łódź - koło Katedry

\section{Dokument 32}

Kopia: AFKDOPW, teczka 136: Spuścizna abp. Józefa Teodorowicza, sygn. 1346/420 (12) [7], List abp. Józefa Teodorowicza do ks. prof. Józefa Archutowskiego, Lwów 3 IV 1932 r.

\section{Czcigodny ${ }^{\mathrm{a}}$, Przezacny Księże Profesorze!}

Jestem niezmiernie zobowiązany Księdzu Profesorowi za krytykę w „Głosie Narodu"195, za którą składam moje gorące podziękowanie. Jedyną jej wadą jest tylko to jedno, iż jest nazbyt łaskawa i pobłażliwa, doprawdy nad miarę wartości mej pracy, ale poza tym tak subtelnie ona wnika $w$ najdelikatniejsze psychologiczne odcienia, z taką zawodową znajomością odważa problemy, tak $\mathrm{z}$ wysoka je ujmuje nie gubiąc się w drobiazgach, że przez te i przez inne zalety swoje ma ona dla mnie wartość przecenną. Zresztą

\footnotetext{
a Tekst pisany maszynowo na jednej stronicy papieru formatu A4. Brak autografu autora listu.

192 J. Teodorowicz, Zjawiska mistyczne i ich ttumaczenia, AK, 18(1932), t. 29, z. 1, s. 1-16; z. 2, s. $105-$ 121; z. 3, s. 209-229; z. 4, s. 313-338.

193 Odniesienie do tryptyku J. Teodorowicza: Jezus Chrystus, t. 1: Od Jahwe do Mesjasza (Poznań 1936), t. 2: Od Betlejem do Nazaretu (Poznań 1932), t. 3: Herold Chrystusa na tle epoki (Poznań 1937).

194 Tomczak Kazimierz (1883-1967), święcenia kapłańskie w 1907 r. w Warszawie, wykładowca miejscowego Seminarium Duchownego, 1927-1967 biskup pomocniczy diecezji łódzkiej. P. Nitecki, Biskupi, s. 210.

a Tekst pisany na jednej stronicy papieru formatu A4. Brak autografu autora.

195 J. Archutowski, Żywot Jezusa Chrystusa, GN, 39(1932), nr 85, s. 5.
} 
wszyscy krytyką tą się zachwycają. Dla mnie ma ona szczególniejszą wartość ze względu na to, iż pod wielu względami zostałem utwierdzony i umocniony w tym, w czym jeszcze po omacku chodziłem, zdając się jedynie na moje wyczucie. Tak na przykład dotyczy to kwestii apologetycznej i sposobu jej ujmowania.

Jeszcze raz Księdzu Profesorowi z serca dziękuję, czując się szczerze zobowiązanym i łączę przy tej sposobności wyrazy prawdziwie oddane głębokiej czci.

Lwów, dnia 3 kwietnia 1932

\section{Dokument 33}

Kopia: AFKDOPW, teczka 136: Spuścizna abp. Józefa Teodorowicza, sygn. 1205/420 (12) [7], List abp. Józefa Teodorowicza do ks. Adama Bogdanowicza, Lwów 10 IV 1932 r.

Mója Drogi!

Bardzo Ci dziękuję za Twój list i dobrze, że poruszasz sprawę O. Siwka. Przede wszystkim za mała jest jego osoba, ażeby wchodziła w grę w tej rozprawie, w której mi nie idzie o jedną książkę więcej o Konnersreuth, ale o coś nieporównywanie więcej, bo o system i metodę. To prawda, że będąc w Krakowie z odczytami o Konnersreuth ${ }^{196}$ poznałem się z O. Siwkiem i rozmawiałem z nim na ten temat; ale on właśnie okazał się wysoce nielojalnym, bo mając gotową pracę o Konnersreuth ani słówkiem mi o tym nie wspomniał i o tym zamilczał. Jedyne kwestie, jakie były między nami poruszane dotyczyły zagadnień z psychologii nowoczesnej, a właśnie w krytyce z uznaniem te strony jego pracy podnoszę.

Tymczasem O. Siwek w swej książce ${ }^{197}$ anonimowo ale z przytykami ironicznymi wyraża się o tym kimś, który w swej naiwności bierze to za dowód znajomości świątyni jerozolimskiej, że Teresa mówiła o bramie Nikanora ${ }^{198}$. W inny wprawdzie sposób on to napisał, bo przekręcił rzecz, ja właśnie ten argument wysuwałem na publicznym odczycie w Krakowie i on musiał sobie z tego zdawać sprawę, że każdy czytelnik jego książki, który słuchał mego odczytu będzie wiedział, o kim mowa. Ja oczywiście zupełnie na to nie zważam, to jest drobnostka, ale skoro poruszasz sprawę lojalności, to dlatego wspominam o niej.

Następnie O. Siwek był przygotowany na to, że jeżeli on wyda swoją pracę o Konnersreuth przeciwstawiwszy stanowisko, jakie zająłem ja i biskup Lisowski ${ }^{199}$, to jeden $\mathrm{z}$ nas da na to odpowiedź. Ostrzegł o tym ówczesnego prowincjała Ks. biskup Lisowski po pierwszym artykule O. Siwka, który się ukazał w „Przeglądzie Powszechnym”

\footnotetext{
a Tekst pisany maszynowo na dwóch stronicach papieru formatu A4. Brak personaliów odbiorcy i autografu autora listu.

196 Abp Teodorowicz wygłosił w roku 1930 w Krakowie wykłady otwarte poświęcone Teresie Neumann.

197 P. Siwek, Konnersreuth w świetle nauki i religii, Kraków 1931.

198 Aluzja do architektury świątyni jerozolimskiej; Brama Nikanora prowadziła na Dziedziniec Mężczyzn. Została ufundowana przez Żyda z Aleksandrii, jako wotum za ocalenie z rozbitego okrętu.

199 Zob. w niniejszej publikacji: J. Wołczański, Korespondencja abp. Józefa Teodorowicza z abp. Adamem Stefanem Sapieha, dokument 77.
} 
wykazując, jak niewłaściwą to będzie rzeczą, jeżeli jezuici choćby pośrednio wystąpią przeciw biskupom i powiedział, że biskupi wówczas milczeć nie będą. Kiedy mi przysłał O. Siwek swoją książkę, napisałem mu lojalnie, że zmuszony będę wystąpić przeciwko jego stanowisku; wtedy odpisał mi w sposób zupełnie się niekwalifikujący do bliższego określenia ${ }^{200}$.

Taki jest mój stosunek w tej sprawie do O. Siwka. Na odpowiedź jego jestem z góry przygotowany, a jednak mimo oczekiwania wątpię, czy ta odpowiedź nastąpi, bo co nareszcie on może odpowiedzieć ${ }^{201}$. Przecie ja go zbijam jego własnymi słowami. Wtedy, kiedy ten jezuita zapowiedział dosadną odpowiedź, nie wiedział jeszcze, co ja napiszę, bo dopiero w trzecim zeszycie zaczęła się właśnie moja rozprawa z O. Siwkiem. Mnie się zdaje, że oni się dobrze namyślą zanim się zdecydują na odpowiedź. Ja z niej w końcu tylko rad będę, bo mi ona nastręczy sposobność jeszcze silniejszego zadokumentowania tez przewodnich mistyki.

Dziękuję Ci raz jeszcze za Twój list i serce, i przesyłając moje błogosławieństwo najserdeczniej Cię pozdrawiam. Czy Ty pisałeś o mitrze biskupiej dla stanisławowskiego proboszcza? ${ }^{202}$

Lwów, dnia 10 kwietnia 1932

\section{Dokument 34}

Oryg.: AFKDOPW, teczka 145: Spuścizna abp. Józefa Teodorowicza, sygn. 1067/420 (8) [7]-1082/420 (8) [7], List dr. Théodore Witry do abp. Józefa Teodorowicza, Metz 15 IV 1932 r.

Metz, 15.April 1932

Vertraulich $^{\mathrm{a}} \mathrm{u}[$ nd] privat

\section{Eminenz! $!^{203}$}

Nehmen Sie meinen tiefgefühlten Dank entgegen für Ihren liebenswürdigen Brief und Ihre große Güte im Hinweis auf das Irenikon. Ich sende ihnen mit gleicher Post die zwei Nummern der „Schildwache“ worin „Konnersreuth erwähnt" ist. Eine eingehende medizinische Notiz habe ich mir nach den 2 Besuchen bei der Resch gemacht. Ich sollte in dieser Fastenzeit in der Karwoche auf drei Tage hinfahren, war aber leider durch Familienverhältnisse daran verhindert. Der Hochw[ürdigste] Herr Bischof von

${ }^{200}$ Zob. dokument 22 niniejszej części.

201 Wbrew przypuszczeniom abp. Teodorowicza, o. Siwek opublikował kolejną książkę traktującą o dyskutowanym zagadnieniu: Metody badań zjawisk nadprzyrodzonych. Problem Konnersreuth, Kraków 1933.

${ }^{202}$ Funkcję proboszcza parafii i kościoła ormiańskokatolickiego w Stanisławowie pełnił w latach 19191936 ks. Franciszek Komusiewicz (1881-1936).

a Tekst pisany czarnym atramentem na sześciu stronicach papieru formatu A4. W lewym górnym rogu karty tytułowej nadruk firmowy: „Docteur Witry, maladies nerveuses \& du sang, Metz, Place St. Thièbault, 39 , tèlèphone 1767 , pathologie sexuelle-psychanalyse”.

${ }^{203}$ Błędne określenie statusu kościelnego lwowskiego hierarchy ormiańskiego; tytuł eminencji przysługiwał kardynałom, zaś arcybiskupom - ekscelencji. 
Regensburg hat mir auch Einsicht in die Akten gestattet. In Deutschland lebt der Kampf noch immer um Konnersreuth, und in England will P[ater] Thurston S.J. der Mystik, der Ekstase und der Stigmatisation immer weiter den $[. .]^{\mathrm{b}}$ mit dem alten abgedroschenen, leeren Wort: Hysterie und Massensuggestion.

Ja, Eminenz, ich habe 17 Stigmatisierte gesehen und beobachtet und untersucht. Es waren deren natürlich darunter, deren Stigmata aus Krankheiten des Organismus, bei einem sehr stark ausgeprägten religiösen Empfinden, herrührten. Andere waren Schwindler, die sich die Stigmata beibrachten, andauernde Konversionen herbeiführten und wo der Zufall bei einer, die noch dabei Transvestitin war, ein für die Umgebung längere Zeit sicheres Wunder schuf, das dann durch den Exorzisten der Diözese aufgeklärt wurde. Aber es sind deren doch auch darunter, wo das Eingreifen des persönlichen Gottes unbestreitbar sicher ist. Das ist z[um] B[eispiel] meine feste Überzeugung für Konnersreuth.

In Würzburg lebt eine Stigmatisierte, ferner eine junge stigmatisierte Nonne in der Diözese Casenza (die Universität Neapel ${ }^{204}$ hat diesen Fall genau untersucht). In Deutschland lebt noch eine junge, seit kurzem stigmatisierte Nonne.

Im Februar dieses Jahres habe ich, mit Erlaubnis des Diözesanbischofs, eine Stigmatisierte aus der Bretagne besucht und untersucht.

Mit Erlaubnis des Hochw[ürdigsten] Herrn Bischofs von Trier war ich in Trier wegen der Stigmatisierten Göbel ${ }^{205}$. Das Fräulein hat die Stigmata, aber sie rühren von Erkrankung des Organismus her, und ich stimme völlig mit den 2 Theologen, die sie beobachtet haben, überein, dass weder göttliche noch diabolische Einflüsse dabei vorkommen. Bei der im vorigen Jahr verstorbenen stigmatisierten Nonne Maria v[on] Jesus Laudi ${ }^{206}$ in Neapel glaube ich (meine persönliche Meinung, da die Kirche später darüber entscheiden wird) dass unser Herr $\mathrm{u}[\mathrm{nd}]$ Heiland dieser heiligmäßigen Frau ganz besondere Gnadengaben schenkte. Es ist mir unsympathisch, dass heute viele Ordensleute alles Übernatürliche diabolisch erklären wollen. Ich denke eine Religion ohne Mystik ist ein totes Wort, und unser Herr Gott ist ein lebendiger Gott, der auch heute noch Wunder wirkt. Als ich auf dem Religionskongress in Wien, voriges Jahr, Konnersreuth gegen den Benediktinerpater Mager aus Salzburg verteidigte, traten nach mir zwei Protestanten auf die Tribüne und erklärten, dass sie glauben, dass unser Herr Jesus heute noch Wunder wirkt. Momentan arbeite ich mich durch einen Haufen Manuskripte über wunderbare Kommunionen von mystischen Stigmatisierten der modernen Zeit. P[ater] Thurstan schreibt glatt, diese („hysterischen“) Stigmatisierten hätten dabei mit der Hostie Taschenspielerkunststücke gemacht und die Beobachter wären leichtgläubig gewesen. Dabei liegt unter vielen eine genaue Beobachtung der mirakulösen Kommunion durch einen Professor der Medizin und durch Ungläubige vor. Ich kenne zwei lebende Fälle. Der eine ist noch nicht restlos geklärt. Glauben Sie

\footnotetext{
b Wyraz nieczytelny.

${ }^{204}$ Neapol - włoskie miasto nad Zatoką Neapolitańską.

${ }^{205}$ Osoba niezidentyfikowana.

206 Osoba niezidentyfikowana.
} 
nicht, Eminenz, dass in Polen eine Vortragstournee uber Stigmatisation und wunderbare Kommunionen (mit Projektionsbildern) im Anschluss an das von Ihnen zu erwartende Buch über Konnersreuth, in französischer Sprache, möglich und nützlich wäre? Ich habe die beiden Brüder Janet persönlich öfter, früher, in Paris getroffen, aber bei solchen Rationalismus kann man nicht mehr mitreden, muss man auch als Mediziner das weitest gehende Entgegenkommen zeigt.

Ich wünsche Eu[rer] Eminenz den größten Erfolg für das von so vielen erwartete Buch über Konnersreuth ferner eine gute Gesundheit und zeichne in Verehrung und ergebenster Hochachtung

Witry

P.S. Ich selbst habe momentan 3 Stigmatisierte in Behandlung: (Erkrankungen des Organismus) eine Mutter nebst Tochter und einen Priester, der das Symptom der Levitation fühlt. Über alle meinen Fälle führe ich natürlich Krankengeschichten wie in der Klinik.

\section{Dokument 35}

Oryg.: AFKDOPW, teczka: Spuścizna abp. Józefa Teodorowicza, sygn. 1067/420 (8) [7]-1082/420 (8) [7], List dr. Théodore Witry do abp. Józefa Teodorowicza, Metz 3 V 1932 r.

Metz, le 3 Mai 1932

Eminenz! $!^{\mathrm{a}}$

Ich danke Ihnen herzlich für Ihren freundlichen Brief vom 27. April. Im Prinzip ist die Vortragstournee mit Projectionsbildern fertig. Nun muss ich meine Photographien als Projectionsphotos noch machen lassen. Ferner ist meine Frau zur Kur in einem südfranzösischen Bad und kommt erst gegen Ende Mai zurück. Am 3 Juni, am Herz-Jesu Feste, werde ich in Konnersreuth sein.

So ist es mir leider unmöglich jetzt im Mai nach Polen zu kommen, so gerne ich den Wunsch Euer, Eminenz erfüllt hätte. Die Damen von Katolicki Związek Polek ${ }^{207}$ haben mir gestern geschrieben und wünschen die Vortragstourneen im Herbst. Ich werde mich mit Ihnen in Verbindung setzen, um alles zu arrangieren. Die Vorträge finden auf Deutsch oder Französisch, oder nur auf Französisch, wenn gewünscht, statt. Eur. Eminenz kennen die Verhältnisse in Polen.

Ich füge mich Ihren Wünschen und verbleibe in tiefer Verehrung und Hochachtung, Ihr sehr ergebener

Witry

a Tekst pisany czarnym atramentem na dwóch stronicach papieru format listowego. W lewym górnym rogu karty tytułowej nadruk firmowy: „Docteur Witry, Maladies nerveuses et du sang, Metz, Place St. Thiébauld 39, telephone 1767, pathologie sexuelle”.

${ }^{207}$ Katolicki Związek Polek - polska organizacja narodowo-patriotyczna założona na Górnym Śląsku w 1914 r., sympatyzująca politycznie z Chrześcijańską Demokracją. 


\section{Dokument 36}

Oryg.: AFKDOPW, teczka 141: Spuścizna abp. Józefa Teodorowicza, sygn. 978/420 (8) [7], List redaktora ks. Bolesława Kunki do abp. Józefa Teodorowicza, [Włocławek] 9 V 1932 r.

L. 98/32

Dnia 9. 5. 1932

Celssissime ac Excellentissime Domine! ${ }^{208}$

W uprzejmej odpowiedzi na depeszę Waszej Arcypasterskiej Mości donoszę, że zapowiedzianego artykułu O. Siwka jeszcze nie otrzymałem. Sam nie tylko myślałem, ale już byłem zdecydowany ten artykuł posłać do Waszej Ekscelencji dla poczynienia wyjaśnień i udzielenia w ogóle odpowiedzi tak, ażeby jedno z drugim jednocześnie mogło być drukowane.

Przy tej sposobności pozwolę sobie dorzucić wiadomość, że O. Siwek w rozprawach ze swoimi krytykami bywa złośliwy, ironiczny. W takich razach z Jego rękopisu usuwałem to wszystko, co wnosiło do krytyki pierwiastek osobistych podrażnień. Ze stanowiskiem redakcji godził się, nie zgłaszał sprzeciwu. Gdyby tak inni krytycy-recenzenci postępowali jak to uczynił Wasza Ekscelencja, który potrafił swego przeciwnika oświecić, podnieść, wesprzeć, otoczyć życzliwością, na pewno raźniej postępowałby rozwój piśmiennictwa teologicznego wśród duchowieństwa.

Zechce Wasza Arcypasterska Mość łaskawie przyjąć wyrazy mej najgłębszej czci wraz z serdecznym ucałowaniem Jego ręki

Ks. Bolesław Kunka 209

\section{Dokument 37}

Oryg.: AFKDOPW, teczka 145: Spuścizna abp. Józefa Teodorowicza, sygn. 1083/420 (8) [7], List ks. prof. Franza Wutza do ks. Johanna Westermayra, Eichstätt 9 V 1932 r.

Eichstätt, 9. Mai 1932

Sehr geehrter Herr Subregens!

$\mathrm{Zu}$ Ihrem Brief vom 5. d. M. mit angelegtem Artikel teile ich mit: Ich habe keinerlei Interesse an der Nichtveröffentlichung Ihres Artikels; ich empfehle Ihnen vielmehr Wahrung Ihres Interesses. Dagegen wünsche ich, dass Ihre Anschriften an mich, zumal sie jetzt einen nur schlecht verhüllten Erpressungscharakter annehmen, ein Ende

a Tekst pisany czarnym atramentem na jednej stronicy papieru formatu A4. W lewym górnym rogu nadruk firmowy: „Redakcja Ateneum Kapłańskiego, Włocławek, Seminarium Duchowne”.

${ }^{208}$ Lac.: najwspaniomyślniejszy i najznakomitszy panie.

${ }^{209}$ Kunka Bolesław (1889-1969), święcenia kapłańskie w 1914 r. w Petersburgu dla diec. włocławskiej, 1914-1918 duszpasterz w Murmańsku (Rosja), 1918-1939 i 1945-1952 wykładowca w Seminarium Duchownym we Włocławku, 1929-1932 redaktor „Ateneum Kapłańskiego”, 1939-1945 więziony w niemieckich obozach koncentracyjnych, od 1945 r. ponownie w diec. włocławskiej: 1948-1952 rektor Seminarium Duchownego, 1952-1963 duszpasterz i urzędnik Kurii Diecezjalnej, 1963-1969 emeryt. K. Rulka, Kunka Bolestaw, w: SPTK, t. 6, red. L. Grzebień, Warszawa 1983, s. 270-272.

a Tekst pisany maszynowo na $1 / 2$ stronicy papieru formatu A4. 
finden. Im Übrigen bin ich nicht befugt, Privaterklärungen auf öffentliche Anwürfe weder für die Oberin von Zell noch für Th[erese] N[eumann] entgegenzunehmen.

Ergebenst

gez.: Professor Franz Wutz

\section{Dokument 38}

Kopia: AFKDOPW, teczka 136: Spuścizna abp. Józefa Teodorowicza, sygn. 1186/420 (12) [7], List abp. Józefa Teodorowicza do nieznanego polskiego duchownego, Lwów 11 V 1932 r.

Przewielebny ${ }^{\mathrm{a}}$, Kochany Księże!

Dziękuję za otrzymany list i sprawę Czcigodnego Księdza przekazałem Teresie Neumann do Konnersreuth. Wiem o tym, źe takie łączenie się z jej ofiarami zwłaszcza ze strony kapłanów osiąga skutki, które w takich razach ponosi ona przez osobne cierpienia.

Zasyłam Kochanemu Księdzu moje serdeczne wyrazy czci.

Lwów, dnia 11 maja 1932

\section{Dokument 39}

Kopia: AFKDOPW, teczka 137: Spuścizna abp. Józefa Teodorowicza, sygn. 1246/420 (12) [7], List abp. Józefa Teodorowicza do ks. redaktora Bolesława Kunki, [Lwów 1932 r.].

\section{Czcigodny ${ }^{\mathrm{a}}$ Księże Redaktorze!}

Przesyłam Księdzu Redaktorowi list tu załączony ${ }^{\mathrm{b}}$, który proszę uprzejmie zamieścić przed artykułem O. Siwka. Równocześnie przesyłam „Odpowiedź na odpowiedź”, którą proszę umieścić zaraz bezpośrednio po artykule tego autora.

Myślałem, że odpowiedź O. Siwka będzie rzeczowa i dlatego nie przywiązywałem do tego wagi, czy mi wypadnie odpowiedzieć sumarycznie na końcu, czy też kolejno. Przeczytawszy jednak pracę O. Siwka doszedłem do przekonania, że jest to odpowiedź przebiegłego gracza, a nie człowieka, któremu zależy na prawdzie. Zamiast się bronić przed zarzutami, on mi wciąż insynuuje i to zupełnie świadomie pojęcia, jakich nie miałem, a potem je zbija. W takich warunkach moja odpowiedź po sześciu miesiącach byłaby musztardą po obiedzie. Ja muszę ustawicznie i bezpośrednio póki pamięć o tych przekrętach jest świeża wciąż prostować, wciąż wyjaśniać. $Z$ tego względu, iż w pierwszym liście Ksiądz Redaktor zostawił mi do woli jak odpowiadać, czy kolejno, czy na ostatku, wybieram tę pierwszą drogę, którą uważam za konieczną sine qua non.

a Tekst pisany maszynowo na $\frac{1}{2}$ stronicy papieru formatu A4.

a Tekst pisany maszynowo na 1,5 stronicy papieru formatu A4. Brak adresata, datacji i autografu autora.

b Brak owego dokumentu. 
Z drugiego listu Księdza Redaktora wnoszę, że Ksiądz Redaktor miałby trudności w pomieszczaniu tego tekstu i mojej odpowiedzi, ale na to - sądzę - w ostatecznym razie znalazłby się sposób, gdyby przepołowić tak artykuł O. Siwka jak mój odnośną odpowiedźc. Tak na przykład, w tym wypadku gdzie mowa o cudach, można by przejść parę cudów O. Siwka i umieścić analogiczne odpowiedzi moje. Oczywiście straci na tym ogromnie ciągłość i całość obrazu, ale to już mniejsza rzecz wobec samej sprawy. Dla samej redakcji technicznie będzie to obojętne, czy się najpierw ukaże odpowiedź O. Siwka a potem moja, czy też w tym samym periodzie czasu ukażą się obie równocześnie. Ze względu zaś na zainteresowanie czytelników sądzę, że będzie ono daleko większe, jeżeli odpowiedź O. Siwka a potem moja będą się ukazywały równocześnie. Dlatego raz jeszcze gorąco proszę Księdza Redaktora, aby chciał uwzględnić ten w tym wypadku niezbędny postulat $\mathrm{z}$ mej strony.

Łączę przy tej sposobności dla Czcigodnego Księdza Redaktora wyrazy głębokiej czci.

\section{Dokument 40}

Kopia: AFKDOPW, teczka 131: Spuścizna abp. Józefa Teodorowicza, sygn. 1178/420 (12) [7], List abp. Józefa Teodorowicza do ks. redaktora Bolesława Kunki, Lwów 12 V 1932 r.

\section{Przezacny ${ }^{a}$ Księże Redaktorze!}

Dziękuję za list i szczególniej jeszcze dziękuję za tak łaskawe słowa Księdza Redaktora.

Co do Siwka to wątpię o tym, że jeżeli nie on sam, to ci, którzy za nim dzisiaj stoją bardzo będą dbać o formę jego polemiki wobec mnie. Boję się tylko jednego: boję się tego, że zechce on w mnóstwie drobiazgów i różnorodnych omówieniach utopić sedno rzeczy. W takim razie będzie on dążył do rozwodnienia i rozszerzenia artykułu; ale i na to jestem przygotowany i spokojnie czekam na dalszy rozwój rzeczy.

Tymczasem łączę dla Księdza redaktora bardzo serdeczne i oddane wyrazy, prosząc zarazem o przysłanie rachunku za wysyłane zeszyty. Rachunek proszę nadesłać pod adresem ks. kanonika Leona Isakowicza ${ }^{210}$, Lwów, ul. Skarbkowska 12.

Lwów, dnia 12 maja 1932

Przew[ielebny] Ks. Red[aktor] Kunka

Włocławek - Sem[inarium] duch[owne]

\footnotetext{
c Forma zgodna z oryginałem; poprawnie powinno być: odnośną odpowiedzią.

a Tekst pisany maszynowo na jednej stronicy papieru formatu A4. Brak autografu autora.

${ }^{210}$ Zob. w niniejszej publikacji: J. Wołczański, Listy abp. Józefa Teodorowicza do abp. Józefa Bilczewskiego, dokument 141.
} 


\section{Dokument 41}

Oryg.: AFKDOPW, teczka 145: Spuścizna abp. Józefa Teodorowicza, sygn. 1029/420 (8) [7], List prof. Friedricha Ritter von Lamy do abp. Józefa Teodorowicza, Gauting bei München 27 V 1932 r.

Eure $^{\text {a }}$ Excellenz, Hochwürdigster Herr Erzbischof !

Gauting, 27. Mai 1932

Zehn Tage lang von zu Hause abwesend beeile ich mich nunmehr nach meiner Rückkehr, Ihren Brief vom 19. des zu beantworten. Ich habe meinen Sohn besucht, damit er wieder einmal ein Stückchen Heimat und Familie geniessen konnte, und bin sehr befriedigt über die Fortschritte, die die Genesung gemacht hat. Deo gratias!

Herr Professor Wutz ist in puncto Brief schreiben als Unicum bekannt und auch ich konnte mit ihm bisher erfolgreich immer nur telephonisch durch Herrn Dr. Gerlich verkehren. Was Ihren s. Z. an ihn gerichteten Brief betrifft, so scheint irgendein Missgeschick oder Missverständnis entstanden zu sein. Ich weiss bestimmt, dass er damals deswegen nach Konnersreuth gefahren ist und dort drei läge lang auf Eure Excellenz gewartet hat. Ueber die näheren Umstände bin ich nicht unterrichtet. Ich werde der Rache aber soweit ich es vermag nachgehen und hoffe zu einem befriedigenden Ergebnis zu gelangen; ich werde dann darüber sofort berichten.

Was mir Eure Excellenz über die Polemik mit P[ater] Siwek schreiben, interessiert mich ausserordentlich und es scheint mir sehr gut, dass Sie mir davon Mitteilung gemacht haben. Wenn die Jesuiten in Rom sich hinter Siwek stellen, dann dürfen Eure Excellenz darauf gefasst sein, dass Siwek von seinem Ordensbruder P[ater] Leiber Sukkurs erhält, der neben ihm an der gleichen Gregoriana wirkt. Dieser ist bekanntlich der Verfasser eines Artikels über Konnersreuth in den „Stimmen der Zeit“"211 1927, der dann auch als Sonderschrift erschienen ist. Leiber wurde nun von P[ater] Richstätter S. J. ${ }^{212}$ bearbeitet und gegen Konnersreuth eingenommen. Richstätter verbreitet seit 3 Jahren eine Anzahl Einwände gegen Konnersreuth, aber nur unter der Hand, niemals offen Dieselben stützen sich auf persönliche Unkenntnis, denn Richstätter war niemals in K[onnersreuth] und man kann wirklich von einem Kampf gegen Windmühlen sprechen. Richstätter wurde vom Generalat in Rom jede weiere derartige Tätigkeit in Sachen Konnersreuth verboten, da er auch Exerzitien zur Hetze gegen Therese Neumann missbrauchte, indem er ihre Wundmale lächerlich machte. Von mir öffentlich zur Rede gestellt, leugnete er scheinbar, indem er eine sophistische Ausrede gebrauchte, die man so oder so deuten konnte. Vor Richstätters Argumenten also hat P[ater] Leiber, ohne Prüfung, kapituliert. Dazu kommt, dass gegenüber Leiber eine zweite Beeinflussung von Deutschland her erfolgt ist, vor der er ebenfalls ohne Prüfung die Regel gestrichen hat. Sie ging von dem Freisinger

\footnotetext{
a Tekst pisany maszynowo na 2,5 stronicach papieru formatu A4. Autograf odręczny czarnym atramentem.

${ }^{211}$ „Stimmen der Zeit" - czasopismo o profilu religijno-kulturowym wydawane przez niemieckich oo. Jezuitów od 1865 r. do dziś.

${ }^{212}$ Richstätter Karl (1864-1949), święcenia kapłańskie w 1890 r. w Kolonii (Niemcy), w 1894 r. wstąpił do Zakonu oo. Jezuitów, zasłynął jako wybitny misjonarz ludowy, współpracownik czasopisma „Aszese und Mystik“, autor licznych publikacji poświęconych mistyce i nabożeństwu ku czci Serca Jezusowego. J. Stiesli, Richstaetter Karl, w: DHCJ, t. 4, red. Ch.E.O’Neill, J.M. Nomígez, Roma-Madrid 2001, s. 3357-3358.
} 
Sub-Regens Dr. Westermayr aus, der zum Wunderle-Kreis gehört. Westermayr hat in einer Rezension mein Jahrbuch 1930, Berras Schrift über Th[erese] Neumann und das Buch des P[ater] Dorsaz ${ }^{213}$ heruntergesetzt und als unwissenschaftlich abgelehnt. Wissenschaftlich allein sei die Broschüre von Wunderle-Mager. Da auch Prof. Wutz dabei eingegriffen war, trat dieser aus seiner Reserve hervor und es gab in der Beilage zum Münchener „Bayrischen Kurie“ eine Diskussion zwischen Wutz und Westermayr, die für den letzteren mit einer fürchterlichen Niederlage geendet hat. Westermayr hat nun jene Artikel, die seine Angriffe enthalten, nach Rom an P[ater] Leiber geschickt, nicht aber die Erwiderungen von Wutz und mir, wie dies P[ater] Leiber einem seiner Ordensgenossen, einem Belgier, schrieb, und auf diese ganz und gar einseitige aber eben deswegen auch gänzlich haltlose Information gestützt hat er nun sein Urteil gebildet. Ich teile Eurer Excellenz diese Einzelheiten mit, weil zu erwarten ist, dass Siwek gegen Konnersreuth aus diesen Quellen seine Argumente schöpfen wird. Ich stehe gegebenenfalls gern zu Diensten. Leider besitze ich die Belege nur in einem Exemplar und bin selbst derzeit in eine Polemik mit P[ater] Mager verwickelt, wobei ich sie benötige.

Ihre Broschüre habe ich erhalten und ich würde eine deutsche Ausgabe sehr begrüssen. denn über diesen Gegenstand bedarf unsere deutsche Wissenschaft noch der allerersten Anleitungen; bisher hat man die Probleme durch Hochmut, Anmassung und Unwissenheit zu lösen versucht. Es freut mich, zu hören, dass Ihr Werk über Konnerereuth nun fertig ist.

Ich vermute, dass es P[ater] Bleienstein ${ }^{214}$ sein wird, der die Revision besorgt, Es scheint mir nicht unangebracht, darauf hinzuweisen, dass in diesem Fall die Ordenssolidarität soweit gehen könnte, dass Bleienstein seinen von Ihnen angegriffenen Ordensbrüdern Handlangerdienste leisten würde. Es dürfte notwendig sein, sich dagegen durch eine entsprechende Versicherung der Schweigepflicht zu schützen.

Soviel für heute. Mit der Versicherung meiner aufrichtigen Verehrung bin ich Eurer Excellenz stets ergebener

F[riedrich] R[itter] von Lama

\section{Dokument 42}

Oryg.: AFKDOPW, teczka 145: Spuścizna abp. Józefa Teodorowicza, sygn. 1030/420 (8) [7], List prof. Friedricha Ritter von Lamy do abp. Józefa Teodorowicza, Gauting bei München 31 V 1932 r.

Gauting, 31. Mai 1932

Excellenz ${ }^{\mathrm{a}}$, Hochwürdigster Herr Erzbischof !

${ }^{213}$ Osoba niezidentyfikowana.

${ }^{214}$ Bleienstein Heinrich (1884-1960), niemiecki duchowny katolicki, święcenia kapłańskie w 1907 r., w 1912 r. wstąpił do Zakonu oo. Jezuitów, 1915-1918 kapelan wojskowy, do 1925 r. duszpasterz akademicki i ojciec duchowny w Tybindze, od 1917 r. redaktor periodyku „Zeitschrift für Aszese und Mystik” (później „Geist und Leben”), 1929-1944 pracował w Monachium.

a Tekst pisany maszynowo na jednej stronicy papieru formatu A4. Autograf odręczny czarnym atramentem. 
Um die Sache mit Herrn Professor Wutz ins Geleise zu bringen, hielt ich es für das Beste, nach Eichstätt zu fahren und persönlich mit ihm zu reden. Das tat ich letzten Samstag und das Ergebnis meiner Aussprache mit ihm ist folgendes: Er hat weder Ihren nach München gerichteten Brief noch Ihre Broschüre erhalten. Beides scheint nach München gesandt worden zu sein; er hat aber seinen Wohnsitz in Eichstätt. Er hatte z[ur] Z[eit] nur die Broschüre P[ater] Siweks und dessen Artikel erhalten, vermutlich von diesem selbst, denn ein Absender war nicht angegeben. Ich übergab Herrn Professor Wutz jenes Exemplar Ihrer Broschüre, das Sie mir gesandt hatten und bitte Sie, mir an dessen Stelle ein anderes Exemplar zu schicken. Bei Wutz traf ich P[ater] Ingbert Naab O.M.Cap. und grundsätzlich gesprochen würde P[ater] Ingbert Ihre Broschüre sehr gerne (deutsch) in der Sammlung Konnersreuth er Stadien herausgeben bzw. sie darin aufnehmen, doch kann er das letzte Wort erst sprechen, wenn er den deutschen Wortlaut vor sich hat; er kann leider nicht polnisch. Zwischen Eu[rer] Excellenz und Herrn Prof. Wutz scheint eine Verkettung von Bingen vorzuliegen, die ganz so aussieht, als sei eine Macht am Werk, die die Beziehung und ihr Zustandekommen um jeden Preis verhindern möchte.

Wolle Eure Excellenz also in Hinkunft Zuschriften an Herrn Hochschul-professor Dr. Franz Wutz nach Eichstätt, Bayern, richten; Sie können dann sicher sein, dass alles klappt. Bei Wutz habe ich beste Dispositionen gefunden.

In ausgezeichneter Verehrung ergebenst

F[riedrich] R[itter] von Lama

\section{Dokument 43}

Oryg.: AFKDOPW, teczka 144: Spuścizna abp. Józefa Teodorowicza, sygn. 1051/420 (8) [7], List o. Odo Staudingera OSB do abp. Józefa Teodorowicza, Salzburg 24 V 1932 r.

Salzburg, 24. Mai 1932

Exzellenz ${ }^{\mathrm{a}}$, Hochwürdigster Herr Erzbischof!

Recht herzlich danke ich Eu[rer] Exzellenz für den gütigen Brief und die erfreulichen Nachrichten. Gottlob, dass nun das Werk vollendet ist. So reich die Konnersreuther Literatur ist, so fehlt uns dennoch ein Werk, dass die Vorgänge in K[onnersreuth] im Lichte der mystischen Kriterien genügend scharf prüft.

Da ich sehr viel Interesse dafür habe, bitte ich Exzellenz, das Manuskript mir gütigst senden zu wollen. Ich glaube zwar nicht, dass ich kritische Winke geben kann, denn meine Kenntnisse sind zu rudimentär. Doch da ich den Streit in Deutschland aufmerksam verfolge, alles was pro et contra geschrieben wird, prüfe, könnte mir vielleicht dieser oder jene Punkt einfallen, der ergänzt werden könnte.

\footnotetext{
a Tekst pisany czarnym atramentem na dwóch kartach papieru formatu zeszytowego. W lewym górnym rogu karty tytułowej graficzne wyobrażenie procesji Bożego Ciała z inskrypcją: „13. Hic est panis, qui de coelo descendit”. W prawym górnym rogu inkskrypcja: „+ PAX CHRISTI”.
} 
Neulich habe ich einen Aufsatz über „Konnersreuth und Rom“ vollendet, der die mystischen Beziehungen der Theresa Neumann zum kirchlichen Lehramt und zum Hl. Vater darstellt. Dieser Punkt ist ja auch ein Kriterium der Mystik. Nach Erscheinen werde ich Ew[ere] Exzellenz ein Exemplar senden.

Über Mollie Fancher, die gegen Konnersreuth herangezogen wird, erschien eine Arbeit vom Psychiater Witry in der "Schildwache“. Eine unparteiliche Stellungnahme zum Streit Gerlich/Wunderle. Mager bringen derzeit Aufsätze von Domkapitular De Hov$\mathrm{re}^{215}\left(\right.$ Gent $\left.^{216}\right)$ in der "Schildwache“. Vielleicht hat sie v[on] Lama, der die Herausgabe besorgt, bereits Ew[ere] Exzellenz zugesandt. Andernfalls will ich dafür sorgen.

Morgen fahre ich nach Konnersreuth und gedenke bis 3. Juni zu bleiben. Werde bei Frau Metzgermeister Rosner ${ }^{217}$ wohnen. Wenn ich dort etwas für Ew[ere] Exzellenz tun kann, bin ich gern dazu bereit. Erzabt Petrus Klotz ${ }^{218}$ ist jetzt in Meran ${ }^{219}$. Freue mich schon jetzt auf Besuch und Vorträge Ew[ere] Exzellenz bei den Hochschulwochen.

In aller Ehrfurcht empfiehlt sich Ew[ere] erzbischöflichen Gnaden ergebenst P[ater] Odo Staudinger OSB

\section{Dokument 44}

Kopia: AFKDOPW, teczka 127: Spuścizna abp. Józefa Teodorowicza, sygn. 1235/420 (12) [7], List abp. Józefa Teodorowicza do ks. mgr. Adama Bogdanowicza, Lwów 24 V 1932 r.

Kochany ${ }^{\mathrm{a}}$ Adasiu! 220

Dziękuję Ci za Twój list i za Twoją bardzo cenną informację o artykule w karmelitańskim piśmie. Otóż ja ten numer zamówiłem dla siebie przez księgarnię Ossolineum, ale ze względu na pospiech przyślij mi Ty numer swój.

Nie rozumiem tego, co to znaczy, że do tej pory Siwek nie dał żadnej odpowiedzi. Może być, że i ja na parę dni do Dżurowa ${ }^{221}$ się wybiorę.

Tymczasem najserdeczniej Cię pozdrawiam i błogosławię, zasyłając Twej Czcigodnej Matce głębokie ukłony $[. . .]^{\mathrm{b}}$.

Lwów, dnia 24 maja 1932

215 Osoba niezidentyfikowana.

${ }^{216}$ Gent - Gandawa; miasto w północno-zachodniej Belgii, w rejonie Flandrii.

217 Osoba niezidentyfikowana.

${ }^{218}$ Klotz Petrus Karl (1878-1967), święcenia kapłańskie w 1901 r. w Zakonie oo. Benedyktynów, dr filozofii, 1909-1916 podróżował po wielu krajach świata utrwalając swoje wrażenia w formie książek, 1922-1931 opat klasztoru św. Piotra w Salzburgu, w 1925 r. dodatkowo wybrany opatem klasztoru św. Józefa, doprowadził do powstania Kolegium św. Benedykta - instytucji naukowej Austriackiej Kongregacji Benedyktynów w Salzburgu, 1925-1931 przewodniczący Austriackiej Kongregacji Benedyktynów, 1932-1967 przebywał w Caldaro i Wiedniu. E. Sauser, Klotz Petrus Karl, w: BBKL, Bd. 20, Nordhausen 2002, kol. 863-864.

${ }_{219}$ Meran - włoskie miasto i gmina w regionie Trydent-Górna Adyga, w prowincji Bolzano.

a Tekst pisany maszynowo na $1 / 2$ stronicy papieru formatu A4. Brak autografu autora.

${ }_{220}$ Zob. w niniejszej publikacji: J. Wołczański, Listy abp. Józefa Teodorowicza do abp. Józefa Bilczewskiego, dokument 141.

${ }^{221}$ Dżurów - gmina w pow. Śniatyn, woj. Stanisławów.

b Brak zakończenia. 


\section{Dokument 45}

Oryg.: AFKDOPW, teczka 144: Spuścizna abp. Józefa Teodorowicza, sygn. 1054/420 (8) [7], List o. Odo Staudingera OSB do abp. Józefa Teodorowicza, Salzburg 4 VI 1932 r.

Exzellenz ${ }^{\mathrm{a}}$, Hochwürdigster Herr Erzbischof!

Von Konnerseruth kam ich diesmal früher zurück als ich zuerst vorhatte. Ich war dort vom 25.-27. Mai. Meine Absicht war, ziemlich viele Fragen im erhobenen Ruhestand unterzubringen. Aber Pfarrer Naber sagte mir, er bekomme nur noch äußern selten eine Antwort. Er legte ihm am 27. Mai meine Fragen, es waren ziemlich viele, und die eines Schweizer Priesters vor. Keine einzige wurde beantwortet. Als ich nach Salzburg zurückkam, überraschte mich die Mitteilung eines Mitbruders, Resl habe ihm schon 1929 gesagt, die Antworten im erhobenen Ruhezustand würden mit der Zeit ganz ausbleiben. Auch ein Beweis, dass die früheren Antworten nicht suggeriert waren.

Meinen Aufsatz „Konnersreuth und Rom“ werde ich Exzellenz möglichst bald senden. Die „Schildwache“ mit den Aufsätzen „Wissenschaftswahn“ gegen Wunderle, Mager und Konnersreuther Jahrbuch habe ich bereits für Exzellenz bestellt. Das Jahrbuch wird nicht vor Juli erscheinen. Von Lama hat diesmal Schwierigkeiten wegen des Imprimatur.

Vielen Dank für das Buch Ew[ere] Exzellenz. Schade, dass ich es der Resl nicht mehr in die Hände legen konnte. Die Antwort, falls überhaupt eine gegeben worden wäre, hätte sicher anders gelautet als bei der Broschüre von Wunderle und Mager. Da sagte sie nämlich nach dem Bericht von Kaplan Fahsel ${ }^{222}$ an Geistl[ichen] Rat K. Hock ${ }^{223}$ (In der Ekstase) auf den Namen Wunderle deutend: „Der Heiland soll alles so machen, wie er (Wunderle) es haben will“. Und den Finger auf Magers Namen legend: „Döss is a guata Moa, aber er sagt alles nach, was der andere ihm vorsagt“. Die Broschüre war in Konnersreuth noch vollkommen unbekannt.

Lama gehört nicht zum Konnersreuther Kreis. Zu diesem zähle ich nur: Familie Neumann, Pfarrer Naber, Gerlich und Wutz, vielleicht auch noch Benefiziat Härtle ${ }^{224}$. Wohl ist v[on] Lama ein entschiedener Freund und Verteidiger von Konnersreuth. Das Buch Ew[ere] Exzellenz könnte genauso gut in der „Badenia“ erscheinen wie bei Pustet, das meine 2 Konnersreuther Büchlein in 440000 Stück gedruckt hat, die ja auch fur Konnersreuth eintreten. Weder Lama noch ich gehören zum Konnersreuther Kreis. Zudem hätte „Badenia“ schon einen großen Kreis von Lesern, die sich dafür interessieren. Nun würde ich mir Inserate zugunsten des Konnersreuther Jahrbuches verbitten. Ob es nicht besser ist, mit der deutschen Ausgabe zu warten bis die angedrohten Dokumente von P[ater] Siwek erschienen sind? Wegen der ekstatischen Person werde ich mich bei Gelegenheit erkundigen.

\footnotetext{
a Tekst pisany czarnym atramentem na czterech kartach papieru formatu zeszytowego.

${ }^{222}$ Fahsel Helmut - niemiecki duchowny rzymskokatolicki pracujący w 1. 30. XX wieku w Berlinie, autor m.in. pracy poświęconej Konnersreuth.

${ }^{223}$ Osoba niezidentyfikowana.

224 Osoba niezidentyfikowana.
} 
Für jede weiter Auskunft gern bereit, empfehle ich mich als Ew[ere] Exzellenz ehrfurchtsvoll ergebener

$\mathrm{P}$ [ater] Odo Staudinger OSB

\section{Dokument 46}

Kopia: AFKDOPW, teczka 127: Spuścizna abp. Józefa Teodorowicza, sygn. 1262/420 (12) [7], List abp. Józefa Teodorowicza do ks. Adama Bogdanowicza, Lwów 14 VI 1932 r.

Kochany ${ }^{\mathrm{a}}$ Adasiu!

Przypominam Ci jeszcze obietnicę Twoją powtórzenia tego, coś mi napisał o warunku cudu; z jednej strony warunkiem tym jest nagłość uzdrowienia, z drugiej jednak strony ta nagłość nie tak się ma rozumieć, jak to rozumie O. Siwek.

Podziękuj przy tej sposobności Twej Matce za jej dobry list, na który Jej odpiszę. Pozdrawiam Cię serdecznie i Bogu oddaję. Zapewne wiesz, że matka ks. Isakowicza umarła.

Lwów, dnia 14 czerwca 1932

Przew[ielebny] Ks. Mgr A[dam] Bogdanowicz

Horodenka 225

\section{Dokument 47}

Oryg.: AFKDOPW, teczka 144: Spuścizna abp. Józefa Teodorowicza, sygn. 1052/420 (8) [7], List o. Odo Staudingera OSB do abp. Józefa Teodorowicza, Salzburg 2 VII 1932 r.

Exzellenz! ${ }^{\text {!a }}$ Hochwürdigster Herr Erzbischof!

Salzburg, am 2. Juli 1932

Ein Mitbruder in Niederösterreich bitte mich um Aushilfe auf einer Pfarrei vom 7.-21. August. Da Exzellenz am 19. und 20. August gütigst hier Vorlesungen halten werden, möchte ich nicht für alle Tage Ihres Hierseins abwesend sein. Erlaube mir darum die höfliche Anfrage, ob ich Exzellenz noch am 22. August oder später in Salzburg sprechen kann. Wenn das nicht möglich wäre, würde ich nur Aushilfe bis 15. August versprechen, da sie unter der Woche bis 21. nicht nötig ist.

Um gütigen Beschied bittet Ew[ere] Exzellenz ehrfurchtsvoll ergebener

$\mathrm{P}$ [ater] Odo Staudinger OSB

a Tekst pisany maszynowo na $1 \frac{1}{2}$ stronicy papieru formatu A4. Brak autografu autora.

${ }^{225}$ Horodenka - miasto powiatowe, woj. Stanisławów.

a Tekst pisany czarnym atramentem na $1 \frac{1 / 2}{2}$ karty papieru formatu zeszytowego. 


\section{Dokument 48}

Oryg.: AFKDOPW, teczka 144: Spuścizna abp. Józefa Teodorowicza, sygn. 1060/420 (8) [7], List ks. prałata Stanisława Szpetnara do abp. Józefa Teodorowicza, Konnersreuth 6/7 VII 1932 r.

Konnersreuth, 6/7 1932

Ekscelencjo! ${ }^{\mathrm{a}}$

Czekam na Teresęę ${ }^{226}$. Ne wróciła jeszcze z prymicji ks. Rothschilda ${ }^{227}$. Nie ma też ks. Nabera. Byłem w Monachium, mówiłem z D[okto]rem Gerlichem. Zarzucił mnie tysiącem pytań, na które odpowiadałem secundum posse ${ }^{228}$. Prosił mnie, bym pisał artykuły do jego pisma: „Der gerade Weg”229. O Boże! Za mało władam językiem niemieckim. Duch kędy chce tak wie[je] ${ }^{230}$. Może Ekscelencja zapali się do pytań D[okto] ra Gerlicha:

1) Dlaczego Rusini tak bardzo Polaków nienawidzą, dlaczego piszą memoriały, artykuły, że takiego uścisku, jaki mają Rusini w Polsce nie ma żaden naród na świecie? Mówiłem tu wiele o unii.

2) Dlaczego was Moskale tak nienawidzą, dlaczego stale nastrajają opinię niemiecką, należy raz [z] Polską skończyć, należy jeszcze raz ścisnąć z dwu stron Polskę.

3) Co myślicie o przyszłej wojnie Niemców z Polską? Mówiłem, że Polska nie zacznie, ale jeśli Niemcy zaczną, to będzie to polska wojna, jakiej jeszcze nie było. Polska wie, że to będzie raz na zawsze być lub nie być.

4) Co należy czynić, by uniknąć okropności wojny Polski z Niemcami? Mówiłem mu, należy wymodlić drugiego Jonasza ${ }^{231}$.

a Tekst pisany czarnym atramentem na 2 stronicach papieru formatu A4.

${ }^{226}$ Odniesienie do osoby Teresy Neumann (1898-1962).

${ }^{227}$ Rothschild Bruno (1900-1932), pochodził z rodziny niemieckich Żydów, był aptekarzem, w roku 1926/27 odwiedził Teresę Neumann w Konnersreuth i poznał tam dr. Fritza Gerlicha nawróconego w 1931 r. na katolicyzm z kalwinizmu, zaprzyjaźnił się też z Edytą Stein; w 1928 r. przeszedł na katolicyzm przyjmując imię Paweł, jego matką chrzestną była Teresa Neumann; 29 VI 1932 r. w Eichstätt przyjął święcenia kapłańskie, po czym został kapelanem w Arbergu. Zmarł 24 XII 1932 r. na atak serca na dworcu kolejowym w Norymberdze. F. Leimkugel, Vom Provisor zum Priester - Das kurze Leben des Bruno Paul Rothschild, GPh, 45(1993), s. 28-30.

${ }^{228}$ Łac.: zgodnie z możliwościami.

229 „Der gerade Weg” - niemieckie czasopismo polityczne wydawane w Monachium w latach 19321933, funkcję redaktora naczelnego pełnił dr Fritz Gerlich. Periodyk wyróżniał się jednoznacznie negatywnym stosunkiem do polityki narodowego socjalizmu Adolfa Hitlera. W marcu 1933 r. gazeta została przez władze państwowe zakazana i przestała wychodzić.

${ }^{230}$ Cytat z Ewangelii J 3, 8.

${ }^{231}$ Nawiązanie do biblijnego proroka Jonasza - żył w VIII w. przed Chr., na Boże polecenie udał się do stolicy Asyrii - Niniwy, wroga Izraela, nawołując do nawrócenia. Kiedy mieszkańcy posłuchali jego apelu, Bóg zaniechał zapowiedzianej kary. 
5) Co sądzić o przyszłych losach świata? Mówiłem mu o przepowiedniach ks. Markiewicza $^{232}$, o przepowiedniach ${ }^{233}$, którymi się interesował ks. prymas Dalbor ${ }^{234}$.

6) Wie sehen das Christusbewusstsein Geistlichen in Polen als unsere Aufgabe für das [... ${ }^{\mathrm{b}}$ Russland ${ }^{235}$.

7) Co dalej? Mówiłem mu, że modlitwa wpływa na losy świata. On na to: „Jako konwertyta były jeszcze tego dobrze nie rozumiem. Napiszcie mi dużo o tym”. Mówiłem mu, że są o tym zdania w „Dziejach duszy” ${ }^{236}$. A może, że Ksiądz Arcybiskup chwyci za pióro. Słabo władam językiem niemieckim. Do takich tematów nie mam materiału pod ręką nawet na miejscu w Jarosławiu ${ }^{237}$. Duch kędy chce tchnie. Jadę na kongres do Velehradu 13-17 lipca ${ }^{238}$. Wrócę do Jarosławia około 24/7 - tam będę czekał na wiadomości lub wezwanie do Lwowa, by te tematy omówić. Ks. Arcybiskup mógłby od ręki napisać.

Całuję ręce Waszej Miłości

ks. Stanisław Szpetnar

\section{Dokument 49}

Kopia: AFKDOPW, teczka 128: Spuścizna abp. Józefa Teodorowicza, sygn. 1247/420 (12) [7], List abp. Józefa Teodorowicza do prof. Aleksandra Dąbrowskiego, Lwów 10 VII 1932 r.

\section{Przezacny ${ }^{\mathrm{a}}$ Panie Profesorze!}

Przesyłam Panu Profesorowi część dalszą do poprawienia i przepisania. Na razie można by opuścić część II-gą, którą Pan Profesor ma w ręku, a natomiast byłoby wskazane przepisanie części III-ciej i o ile się jeszcze uda coś z części IV-tej. Te rzeczy są gotowe.

${ }^{232}$ Markiewicz Bronisław (1842-1912), święcenia kapłańskie w 1867 r. w Przemyślu, 1867-1885 duszpasterz i wykładowca w Instytucie Teologicznym w Przemyślu, w 1886 r. we Włoszech wstąpił do Zgromadzenia Księży Salezjanów, po powrocie do kraju założył ośrodek wychowawczy dla młodzieży w Miejscu Piastowym na Podkarpaciu, powołał do życia Zgromadzenie Księży Michalitów i Sióstr Michalitek oraz Towarzystwo Powściągliwość i Praca. Był autorem wielu publikacji o charakterze dydaktycznym i religijnym. Beatyfikowany w 2005 r. w Warszawie. J. Misiurek, Markiewicz Bronisław, w: EK, t. 11, red. zbior., Lublin 2006, kol. 1405-1406.

${ }^{233}$ Przesłania te zawarte zostały w książkach: B. Markiewicz, Trzy słowa do starszych w narodzie polskim, Lwów 1887; Bój bezkrwawy, Miejsce Piastowe 1913.

${ }^{234}$ Zob. w niniejszej publikacji: J. Wołczański, Listy abp. Józefa Teodorowicza do abp. Józefa Bilczewskiego, dokument 130.

b Wyraz nieczytelny.

${ }^{235}$ Niem.: jak pan widzi świadomość chrześcijańską duchownych w Polsce, jako nasze zadanie wobec Rosji.

${ }^{236}$ Nawiązanie do popularnego dzieła św. Teresy z Liesieux: Dzieje duszy.

237 Jarosław - miasto powiatowe, woj. Lwów.

${ }^{238}$ Szósty kongres ekumeniczny w Velehradzie miał miejsce w dniach 13-17 VII 1932 r. Szerzej na temat istoty i znaczenia owych konferencji zob.: L. Górka, Velehrad - symbol pojednania. W setna rocznicę inicjacji Kongresów Welehradzkich (1907-2007), RT, 2006-2007, t. 53-54, z. 7, s. 73-86.

a Tekst pisany maszynowo na jednej stronicy papieru formatu A4. Brak autografu autora pisma. 
Rzeczy już przepisane raczy Pan Profesor odesłać do mojej sekretarki p[anny] Olgi Hrycajówny ${ }^{239}$, ul. Ormiańska 13, ona zaś wraz z listami odeśle je pod adresami, jakie jej zostawiam. Tak samo, kiedy Pan Profesor powróci z wakacji zechce się łaskawie zgłosić do p[anny] Hrycajówny, a ona już będzie miała u siebie i wyda Panu Profesorowi dalsze części do przepisania.

Życzę Panu Profesorowi dobrych wywczasów i łączę wyrazy prawdziwie oddane głębokiego poważania.

Lwow, dnia 10 lipca 1932

Jaśnie] W[ielmożny] P[an] Prof. Aleksander Dąbrowski

Lwów, ul. Śniadeckich 3

\section{Dokument 50}

Oryg.: AFKDOPW, teczka 145: Spuścizna abp. Józefa Teodorowicza, sygn. 1067/420 (8) [7]-1082/420

(8) [7], List dr. Théodore Witry do abp. Józefa Teodorowicza, Metz 14 VII 1932 r.

Metz, le 14 Juillet 1932

Eminenz ${ }^{\mathrm{a}}$,

Ich danke Ihnen ergebenst für Ihren günstigen Brief. Wenn Eu[re] Eminenz mit dem Kardinal zusammentreffen werden, können Sie ihm die Versicherung geben, dass meine Vorträge sich streng auf den Vorschriften der katholischen Kirche aufbauen und für Ihre Ehre wirken sollen. Ich werde Ihnen auch in großen Umrissen darüber berichten.

Wenn Sie nach Konnersreuth kommen, dann bitten Sie den Pfarrer Naber, er möge Ihnen das ärztliche Zeugnis zu Abschrift geben (aber nur zu Ihrem persönlichen Gebrauche, nicht für andere Schriftsteller) das ich dem Pfarrer Naber gleich nach der Untersuchung der Resl am 6 Juni montags Abends geschrieben und übergeben habe. Ich habe mir leider keine Abschrift gemacht. Ich erhielt gestern Mitteilung aus dem Rheinland, dass dort eine Person seit langen Jahren auch nur von der hlg. Eucharistie lebt. Ich werden sie besuchen gehen.

Ich verbleibe, Eminenz mit dem Ausdruck tiefer Verehrung und Hochachtung, Ihr ergebener

Witry

\section{Dokument 51}

Oryg.: AFKDOPW, teczka 145: Spuścizna abp. Józefa Teodorowicza, sygn. 1029/420 (8) [7], List prof. Friedricha Ritter von Lamy do abp. Józefa Teodorowicza, Gauting bei München 27 VII 1932 r.

${ }^{239}$ Osoba niezidentyfikowana.

a Tekst pisany czarnym atramentem na dwóch stronicach papieru formatu listowego. W lewym górnym rogu karty tytułowej nadruk firmowy: „Docteur Witry, Maladies nerveuses et du sang, Metz, Place St. Thiébauld 39, telephone 1767, pathologie sexuelle". 
Excellenz $z^{\mathrm{a}}$, Hochwürdigster Herr Erzbischof !

Gauting b[ei] München, 27. Juli 1932

Heute nachmittags erhielt ich den mir gütigst zugesandten ersten Teil Ihres Manuskriptes und ich beeile mich, vor allem diese Aufmerksamkeit meinen verbindlichsten Dank auszusprechen. Ich werde wunschgemäss das Uebersandte auch den erwähnten Herren zur Kenntnisnahme zuleiten. Die Anmerkung, dass die deutschen Professoren nicht gemeint seien, sollte m. E. besser unterbleiben, denn es wird sonst sicher mit dieser Stelle Missbrauch getrieben. Ich würde mir allenfalls erlauben, eine veränderte Formulierung vorzuschlagen, denn getroffen soll jeder sein, der zu der einen oder anderen genannten Kategorie gehört. Und diese Herren zu schonen liegt kein Grund vor; sie treiben es doch etwas gar zu bunt.

Herr Professor Wutz hat Ihren Brief erhalten, wie ich auf telephonische Anfrage erfuhr. Eure Excellenz schreiben in Ihrem Briefe den Namen unrichtig, nämlich Mutz anstatt Wutz; es gibt, ich glaube, in München einen Professor Mutz und diesem Umstand ist es viellaicht zuzuschreiben, dass frühere Briefe nicht an die beabsichtigte Adresse kamen.

Vor vier Tagen erhielt ich endlich nach dreimonatlichem Warten das erzbischöfliche Imprimatur für mein neues Jahrbuch.

Nochmals auf Ihre Arbeit zurückkommend bitte ich mir im Interesse der Arbeit ergebenst anzuraten, es möchte meinem Bruder, Oberstudienrat Karl von Lama in Ingolstadt, eine nochmalige letzte stilistische Revision übertragen werden, damit die Arbeit etwas in jeder Hinsicht Vollendetes wird.

Ich bin in aufrichtiger Verehrung ganz ergebenst

F[riedrich] R[itter] von Lama

\section{Dokument 52}

Oryg.: AFKDOPW, teczka 145: Spuścizna abp. Józefa Teodorowicza, sygn. 1067/420 (8) [7]-1082/420 (8) [7], List dr. Théodore Witry do abp. Józefa Teodorowicza, Metz 29 VII 1932 r.

Metz, le 29 juin 1932

Eminence ${ }^{\mathrm{a}}$,

Pourriez-vous demander à Madame Lubianskaja ${ }^{240}$, présidente de l'Union des Femmes Catholiques à Lwow, l'adresse des présidentes des Unions des Femmes Catholiques à Varsovie, Cracovie et dans les autres villes avec un siège épiscopal? Je pourrais alors arranger un voyage de conférences.

a Tekst pisany maszynowo na jednej stronicy papieru formatu A4. Autograf odręczny czarnym atramentem.

a Tekst pisany czarnym atramentem na dwóch stronicach papieru formatu notesowego. W lewym górnym rogu karty tytułowej nadruk firmowy: „Docteur Witry maladies nerveuses et du sang Metz place St. Thiébault, 39 téléphone 1767. Pathologie sexuelle-psychanalyse”.

${ }^{240}$ Osoba niezidentyfikowana. 
Est-ce que Madame peut me donner aussi l'adresse de l'Union des Femmes Catholiques à Prague et à Budapest et le Centre de toutes les Unions de Femmes Catholiques du monde?

Je lui adresse déjà mes remerciements et hommages très profonds.

Veuillez permettre, Eminence, que je dépose à vos pieds l'expression de mes sentiments très respectueux et reconnaissants

P. S. Je viens de finir mon travai: „Wunderbare Kommunionen bei Stigmatisierten der Neuzeit".

\section{Dokument 53}

Oryg.: AFKDOPW, teczka 145: Spuścizna abp. Józefa Teodorowicza, sygn. 1067/420 (8) [7]-1082/420 (8) [7], List dr. Théodore Witry do abp. Józefa Teodorowicza, Metz 1 VIII 1932 r.

Metz, le 1 August 1932

E[ure $]^{a}$ Eminenz,

Ich sende Ihnen anbei die gewünschten Angaben über die Struktur meiner Vorträge um sie dem Herrn Kardinal unterbreiten zu können.

In Verehrung und Hochachtung

Witry

\section{Dokument 54}

Oryg.: AFKDOPW, teczka 145: Spuścizna abp. Józefa Teodorowicza, sygn. 1067/420 (8) [7]-1082/420 (8) [7], List dr. Théodore Witry do abp. Józefa Teodorowicza, Metz 1 VIII 1932 r.

Metz, le 1 August 1932

Eminenz ${ }^{\mathrm{a}}$,

In großen Zügen würden meine Vorträge folgende Struktur haben: Einleitende Erklärungen des Begriffes Stigmatisation. Ihr Vorkommen nur in der katholischen Kirche. Hinweis auf den hlg. Paulus ${ }^{241}$ und den hlg. Franziskus. Kurzes historisches [... $]^{\mathrm{b}}$ über die Stigmatisierten seit dem hlg. Franziskus. Reputation oder rationalistische Erklärungen der Stigmatisation.

a Tekst pisany czarnym atramentem na dwóch stronicach papieru format listowego. W lewym górnym rogu karty tytułowej nadruk firmowy: „Docteur Witry, Maladies nerveuses et du sang, Metz, Place Saint Thiébauld 39, telephone 1767, pathologie sexuelle-psychanalise”.

${ }^{241}$ Zob. w niniejszej publikacji: J. Wołczański, Korespondencja abp. Józefa Teodorowicza z o. Włodzimierzem Ledóchowskim SJ, dokument 4.

a Tekst pisany czarnym atramentem na dwóch stronicach papieru format listowego. W lewym górnym rogu karty tytułowej nadruk firmowy: „Docteur Witry, Maladies nerveuses et du sang, Metz, Place Saint Thiébauld 39, telephone 1767, pathologie sexuelle-psychanalise”.

b Wyraz nieczytelny. 
Andere Phänomene bei Stigmatisierten: Levitation, wunderbare Kommunionen u.s.w. Die Stigmatisierten der Neuzeit: Louise Lateau ${ }^{242}$, Galgani, Higginson, Maes ${ }^{243}$, Fällung ${ }^{244}$, Schäfer ${ }^{245}$, Elena Jahenny ${ }^{246}$, Therese Neumann und andere. Alles begleitet von Projectionsbildern. Schluss: Was Für und Wider der Menschen gegen die Stigmatisierten.

Unterwerfungsmuster die von der Vorsicht der Bischöfe und Rom gefällten Sprüche über Mystik, Ekstasen und Stigmatisationen. Diskussionen halte ich für schädlich und unfruchtbar in diesen Vorträgen.

Ich wünsche Eur[e] Eminenz eine gute Gesundheit und zeichne mit Verehrung und Ergebenheit

Witry

\section{Dokument 55}

Oryg.: AFKDOPW, teczka 145: Spuścizna abp. Józefa Teodorowicza, sygn. 1027/420 (8) [7], List prof. Friedricha Ritter von Lamy do abp. Józefa Teodorowicza, Gauting 4 VIII 1932 r.

Gauting b[ei] München, 4.August 1932.

Excellenz ${ }^{\mathrm{a}}$, Hochwürdigster Herr Erzbischof!

Als einmal in einer Aussprache mit Herrn Prälat Dr. Geiger ${ }^{247}$ davon die Rede war, Professor Wutz habe Therese das Versprechen gegeben, zu ihren Lebzeiten nichts über sie zu schreiben, meinte der greise Herr Prälat, dieses Versprechen sei ganz überflüssig gewesen, denn Wutz sei als so schreibfaul bekannt, dass er auch ohne Versprechen keine Feder anrührt. mir hat Wutz telephonisch vor ein paar tagen gesagt, er werds Ew[ere] Excellenz schreiben, worauf ich ihm Ihre Marienbader Adresse mitteilte. Ich habe nun noch einen Schritt getan, um seine Schreibmaschinerie in Gang zu bringen. Ich hege noch die Hoffnung, dass es hilft.

Nun etwas anderes. Eure Excellenz waren in Konnersreuth. Wenn ich nun eine Bitte ausspreche, so wünsche ich, Eure Excellenz möchten sich nicht durch den einen oder anderen kleinen Dienst meinerseits zu etwas verpflichtet fühlen; meine Bitte möchte damit nichts zu tun haben. Sie besteht darin, mir über diesen Besuch gütigst einen ausführlichen Bericht zukommen zu lassen. Ich weiss, es ist viel verlangt, aber die immer mehr geübte Zurückhaltung von Besuchern setzt die Existenz meines Jahrbuches immer

${ }^{242}$ Lateau Louise (1850-1883), belgijska mistyczka i stygmatyczka, w 1868 r. otrzymała stygmaty. Kościół nie wypowiedział się aprobująco na ten temat. M. Didry, A. Wallemacq, Belgian Mystic of the Nineteenth Century: Louise Lateau of Bois d'Haine, 1850-1883, London 1931, passim.

${ }^{243}$ Osoba niezidentyfikowana.

${ }^{244}$ Osoba niezidentyfikowana.

${ }^{245}$ Osoba niezidentyfikowana.

246 Właściwie: Marie-Julie Jahenny (1850-1941), francuska mistyczka i stygmatyczka, w 1873 r. otrzymała stygmaty. Kościół nie wypowiedział się pozytywnie w tej kwestii.

a Tekst pisany maszynowo z wyjątkiem autografu autora pisma na 1,5 stronicy papieru formatu A4.

${ }^{247}$ Osoba niezidentyfikowana. 
mehr in Frage. Seine Aufgabe ist ja vor allem, Positives zu bringen. Das was ich allein bei meinen Besuchen erlaube, ist wenig, damit kann man kein Buch ausfüllen; es ist oft auch belanglos. Das Buch kann nur dann an der Mission Theresens mitwirken, wenn fortlaufend Einzelheiten über diese und über die Entwicklung der Phänomene, sowie über das persönliche Verhalten und Geistesleben der Stigmatisierten berichtet wird. Ich will keine Indiskretionen, aber daneben gibt es noch viel, was der Stärkkung des öffentlichen Glaubenslebens dient und zu erbauen gesignet ist. Letztlich soll damit das Wirken Gottes in den Vordergrund treten. Deswegen bitte ich herzlich um gütige Mitthilfe.

Ich hoffe, diesen Sommer die Zeit zu finden zu ausführlichen Mittsilungen über die Existenz das Antichrist und seines in Vorberei tung befindlichen Reiches. Die letzte Encyklika $^{b}$ des Heiligen Vaters gibt mir die Gewissheit, dass Rom über die ihm 1929 zugegangenen Originalmitteilungen bereits zustimmend entschieden hat; auch andere Aesserungen des papstes bestätigen dies. Vielleicht ist es mir gestattet, schon im nächsten Jahrbuch darüber Einiges zu sagen.

Ich glaube, nichts Unrechtes zu begehen, wann ich Ew[ere] Excellenz die Abschrift eines Scriptums beilege, das mir von dem mir befreundeten Seelenführer eines ausserordentlich begnadeten Mädchens zugeht; es ist jene, von der im Jahrbuch 1930 auf S. 189 in Verbindung mit der ehrw. Gemma Galgani die Rede ist.

Ich bin in aufrichtiger Verehrung ergebenst

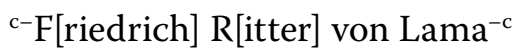

\section{Dokument 56}

Oryg.: AFKDOPW, teczka 145: Spuścizna abp. Józefa Teodorowicza, sygn. 1028/420 (8) [7], List prof. Friedricha Ritter von Lamy do abp. Józefa Teodorowicza, Gauting 11 VIII 1932 r.

Exzellenz ${ }^{\mathrm{a}}$, Hochwürdigster Herr Erzbischof!

Sofort nach Empfang Ihrer Karte setzte ich mich telefonisch mit Herrn Prof. W[... $]^{\mathrm{b}}$ in Verbindung und erfuhr von ihm, dass Sie ihn selbst bereits angerufen hatten. Somit wissen Sie, dass er kommenden Sonntag zu Hause in $\mathrm{E}^{\mathrm{c}}$. sein wird und Sie dort erwartet. Schon heute spreche ich meinen wärmsten Dank für die gütige Erfüllung meiner bitte aus.

Wie stets in Verehrung auf aufrichtiger Ergebenheit, Ihr

F[riedrich] R[itter] von Lama

Gauting, 11 VIII [19]32

${ }^{\mathrm{b}}$ Forma zgodna z oryginałem; poprawnie winno być: Enzyklika.

c-c Fragment napisany czarnym atramentem.

a Tekst pisany maszynowo z wyjątkiem autografu nadawcy na rewersie karty pocztowej. Na awersie nota: „S[eine] Excellenz Msgr. Dr. J. Teodorowicz im Notre Dame-Kloster in Marienbad, Tschechoslovakei”. Nad adresem nadruk: „Postkarte”, dwa niemieckie znaczki pocztowe oraz okrągły stempel: „Gauting, 11. 8. [19]32".

b Wyraz nieczytelny.

c Skrót nierozwiązany. 


\section{Dokument 57}

Oryg.: AFKDOPW, teczka 138: Spuścizna abp. Józefa Teodorowicza, sygn. 983/420 (8) [7], List bp. Michaela Buchbergera do abp. Józefa Teodorowicza, Regensburg 12 VIII 1932 r.

Regensburg, 12. August 1932

E[ure $]^{a}$ Exzellenz!

Beehre ich mich den Empfang des Manuskriptes über Konnersreuth ganz ergebenst zu bestätigen. Ich hoffe am 15. August auf einige Tage nach Marienbad ${ }^{248}$ kommen und $^{2}$ mit Eu[rer] Exzellenz über den Fall Konnersreuth persönlich sprechen zu können. Das Manuskript werde ich mitnehmen.

Genehmigen $\mathrm{Eu}[\mathrm{re}]$ Exzellenz den Ausdruck meiner hohen Verehrung, in der ich die Ehre habe zu bestehen Eu[rer] Exzellenz ${ }^{\text {b- }}$ ganz ergebener

$$
\dagger \text { Michael }^{-\mathrm{b}}
$$

Bischof von Regensburg

\section{Dokument 58}

Oryg.: AFKDOPW, teczka 140: Spuścizna abp. Józefa Teodorowicza, sygn. 959/420 (12) [7], List ks. Härtla do abp. Józefa Teodorowicza, Konnersreuth, 18 VIII 1932 r.

Konnersreuth, 18.8.[19]32

Ehrwürdige ${ }^{a}$ Exzellenz!

Erw[ürdige] Exzellenz danke ich hiermit herzlich für die zurückgesandten Zeitungen. Auf die Anfrage Erw[[ürdige] Exzellenz bezűglich der Vorwürfe, Th[erese] N[eumann] zeige ihre Wunden und trage sie offen, kann ich folgendes sagen:

1. Resl hat am Anfang ihre Wunden verbunden gehabt und sie stets zu getragen.

2. Resl zeigt sie stets nur dann, wenn sie dazu aufgefordert wird, sei es durch eine sich interessierende Person selbst oder durch einen der Ansehenden (so wie es zum Beispiel bei Dr. Lebsche ${ }^{249}$, wo sie wohl nicht von Dr. L[ebsche] selbst dazu aufgefordert wurde, wohl aber wiederholt dazu von der anwesenden Krankenschwester gedrängt wurde, dieses Eingeklammerte bitte ich nur für ihre Person zu behalten).

3. Resl hatte einmal Gelegenheit gehabt, ihre Wunde zu zeigen, aber eine Person, die sie nicht die Th[erese] N[eumann] erkannte, fortwährend sie fragte, ob sie denn wehe

a Tekst pisany maszynowo na 1,5 stronicy papieru formatu A4. W lewym górnym rogu karty tytułowej firmowy nadruk: „Der Bischof von Regensburg”.

${ }^{248}$ Marienbad - miasto w Czechach, od XIX w. było popularnym kurortem odwiedzanym przez europejskie sfery arystokratyczne.

b-b Fragment pisany czarnym atramentem.

a Tekst pisany czarnym atramentem na dwóch stronicach papieru formatu A4. Tekst z tzw. kurrentschriftu przepisała Pani Gerlinde Stohl - dyrektorka Muzeum w Sierndorfie an der March (Austria), za co zechce przyjąć szczere podziękowanie.

249 Osoba niezidentyfikowana. 
Füsse habe, da sie verbunden seien; hat es aber trotzdem nicht getan, uberhaupt immer geschickt ausweichende Antworten gegeben.

4. Auf einer Fotografie sieht man Resl mit einer Krankenschwester und Pfarrer Naber mit offener Hand und deutlich zu sehender Wunde. Erklärung: Während eines Freitags, an dem die Leiden ausfielen, während sehr viele Leute hier, vielleicht so 2000, wenn man sich recht erinnert. Alle Leute, die schon wegen des Nichteintretens des Leidens [... $]^{\mathrm{b}}$ enttauscht waren, verlangten dringend, wenigstens die Wunden sehen zu dürfen. Pfarrer Naber und die Krankenschwester wirkten auf Th[erese] N[eumann] ein, sie möge die Wunden auf dem Weg vom Pfarrhof zur Kirche offen tragen; denn die Leute wollten es und würden dann zufrieden sein. Endlich gab Th[erese] N[eumann] nach. Pfarrer Naber sagte, er würde das heute auch nicht mehr machen. Also von Eitelkeit keine Spur, sondern lediglich, wollen wir sagen, Unerfahrenheit. In solchen Fällen würden auch die Pharisäer, die Konnersreuth so scharf beobachten, manche Unerfahrenheit begehen.

5. Th[erese] N[eumann] tragt die Wunden vielfach offen, wenn sie im Garten arbeitet (das auch erst heuer), also aus Zweckmässigkeitsgründen und in grosser Hitze (da auch nur im engsten Bekanntenkreise); bei der Gartenarbeit sind auch nur ihre engsten Bekannten und Verwandten um sie.

Ich weiss nicht, Exzellenz, dass diese Herren gar so wenig wissen und immer gleich an allem Anstoss nehmen und es ais Fehler auslegen. Mögen ihnen = diesen Herren einmal der Heiland im Geiste nachsichtiger sein wegen der Selbstgefälligkeit und Selbstzufriedenheit und ihres falschen Argwohnes.

Ich glaube, Erw[ürdige] Exzellenz hiermit gedient zu haben, entschuldigen Sie mich, dass es so lange dauerte mit der Antwort. Ich musste zuerst noch anderes erledigen.

In tiefster Ehrfurcht

Härtl ${ }^{250}$

Benefiziat

\section{Dokument 59}

Oryg.: AFKDOPW, teczka 145: Spuścizna abp. Józefa Teodorowicza, sygn. 166/90 [5], List z Wydawnictwa Antona Pusteta do abp. Józefa Teodorowicza, Salzburg 22 VIII 1932 r.

22. August 1932

A u tore $n^{a}-$ Vertrag

Zwischen S[eine]r Exzellenz, dem Hochwürdigsten Herrn Erzbischof Dr. Josef Theodorowicz, Lwów, Polen, im vorliegenden Vertrag "der Autor“ genannt, und dem

\footnotetext{
b Wyraz nieczytelny.

${ }^{250}$ Osoba niezidentyfikowana.

a Tekst pisany maszyniowo na jednej stronicy papieru formatu A4. W górnej centralnej partii karty nadruk firmowy: „Verlag Anton Pustet Pressevereinsanstalten der Diözese Secau SALZBURG SIEGMUND-HAFFNER-GASSE 18, FERNSPRECHER NR. 259, DRAHTANSCRIFT PUSTET SALZBURG”.
} 
Verlag Anton Pustet ${ }^{251}$, Salzburg, Pressvereinsanstalten der Diözese Seckau, im vorliegenden Vertrag mit „Verlag Pustet“ bezeichnet, wird nachstehender Autorenvertrag abgeschlossen:

1) Der Autor übergibt dem Verlag Pustet, das druckfertige Manuskript seines Werkes „Konnersreuth im Lichte der Psychologie und Mystik“ mit dem Recht der alleinigen Vervielfältigung und Verfügung für sämtliche erscheinenden Auflagen und dem Recht der Übertragung in fremden Sprachen. Die Ausgabe in polnischer Sprache bleibt dem Autor vorbehalten. Der Autor verpflichtet sich, das druckfertige Manuskript bis längstens ultimo Dezember 1932 zu liefern.

2) Der Verlag Pustet verpflichtet sich zu einer ersten Auflage von 3000 Exemplaren, zuzüglich der für Dedikations-und Besprechungszwecke vorgesehenen Anzahl, die 10\% der Auflage nicht übersteigen dürfen. Format und Ausstattung des Buches obliegen dem Verlag, wobei Wünsche und Vorschläge des Autors nach Möglichkeit berücksichtigt werden. Die Höhe später erscheinender Auflagen wird im Einvernehmen mit dem Autor festgesetzt.

3) Der Autor erhält ein Honorar von 10\% vom Ladenpreis des broschierten Exemplars von allen erscheinenden Auflagen. Die Auszahlung des Honorars für die erste Auflage erfolgt derart, dass ein Drittel des für die erste Auflage ausmachenden Betrages bei Erscheinen des Buches zahlbar ist, das zweite Drittel nach Absatz von 1000 Exemplaren und das restliche Drittel ein halbes Jahr nach diesem Zeitpunkt.

4) Von Honorarbeträgen, die der Verlag aus der Begebung des Übersetzungsrechtes in fremde Sprachen erhält, bekommt der Autor einen Anteil von 50\% ausbezahlt.

5) Der Autor erhält von jedem Tausend einer jeden erscheinenden Auflage 10 gebundene Freiexemplare. Weitere Exemplare stellt der Verlag mit 40\% Rabatt zur Verfügung.

Der Verlag:

b-VERLAGSBUCHHANDLUNG

ANTON PUSTET

BUCHDRUCKEREI UND HANDEL ${ }^{-b}$

$[\ldots]^{\mathrm{d}}$
Der Autor:

$+\mathrm{J}[\mathrm{osef}]$ Teodorowicz ${ }^{\mathrm{c}}$

${ }^{251}$ Wydawnictwo Anton Pustet jest najstarszą firmą edytorską w Salzburgu. Swoją genezę wywodzi od nazwiska Antona Pusteta, który przybył do Salzburga z Regensburga w Bawarii, przejmując miejscową drukarnię i księgarnię, nadając firmie nową nazwę własną. W $1922 \mathrm{r}$. instytucję przejęło wydawnictwo Graz Styria. W 1. 1930-1937 kierował nią Otto Müller. W 1963 r. wydawnictwo i drukarnia zostały ostatecznie przejęte przez Salzburg Press Association, zaś w 2002 r. firma zakończyła swoją działalność. Źródło: Verlag Anton Pustet - Wikipedia, https://de.wikipedia.org/wiki/Verlag_Anton_Pustet. Dostęp: 11 XI 2017 r.

b-b Podłużna pieczęć.

Autograf odręczny napisany czarnym atramentem.

d Autograf nieczytelny. 


\section{Dokument 60}

Oryg.: AFKDOPW, teczka 40492: Spuścizna abp. Józefa Teodorowicza, sygn. 982/420 (8) [7], List kard. Michaela Faulfabera do abp. Józefa Teodorowicza, München 22 VIII 1932 r.

München 2 M-Promenadestr.7, den 22.August 1932

S[eine]r ${ }^{a}$ Exzellenz

Herrn Erzbischof Joseph Theodoramar ${ }^{\mathrm{b}}$ - Lemberg

z. Zt. Salzburg-Hochschulkurse

\section{Eure Exzellenz!}

Mit grösstem Bedauern habe ich ihren geschätzten Besuch in München verfehlt, weil ich zur Bischofskonferenz in Fulda ${ }^{252}$ abreisen musste. Es sei mir gestattet, für den mir zugedachten Besuch ehrerbietigst zu danken. Da ich auf die Rückreise Euerer Exzellenz nicht hoffen kann, weil ich in den, nächsten 14 Tagen wieder abwesend sein werde, muß ich auf diesem Wege versuchen, das Manuskript über Konnersreuth wieder in Ihre Hände zu legen. Es ist Euer Exzellenz gewiß nicht unbekannt, daß der zuständige Bischof von Regensburg gegenwärtig den Besuch in Konnersreuth wieder vollständig gesperrt hat und daß die zuständige oberhirtliche Stelle mehr und mehr in reservierter Weise die Frage behandelt. Es ist für die katholische Sache, der wir doch alle dienen wollen, kein Vorteil, wenn der zuständige Bischof, der vor der Zukunft die Verantwortung trägt, nicht genügend sicheres Material besitzt, um ein abschliessendes Urteil zu fällen, während unsere Gäste aus Amerika und anderen Ländern, die ein paar Wochen in Konnersreuth waren, schon die Stunde für ein abschliessendes Urteil gekommen glauben Ich bitte deshalb, über das Manuskript, das Euere Exzellenz mir gütig überlassen haben, ein Urteil nicht abgeben zu müssen, abgesehen davon, daß mir jetzt zwischen den beiden Bischofskonferenzen in Fulda und Freising die ruhige Stunde fehlt, um das Manuskript zu lesen.

In Ehrfurcht bleibe ich Eurer Exzellenz ${ }^{\text {c- }}$ ergebenster

M[ichael] Card. Faulhaber ${ }^{-c}$

\section{Dokument 61}

Oryg.: AFKDOPW, teczka 144: Spuścizna abp. Józefa Teodorowicza, sygn. 1055/420 (8) [7], List o. Odo Staudingera OSB do abp. Józefa Teodorowicza, Salzburg 28 VIII 1932 r.

Salzburg, Erzabtel St. Peter, am 28. VIII. 1932

a Tekst pisany maszynowo, $\mathrm{z}$ wyjątkiem fragmentu zaznaczonego $\mathrm{w}$ opisie, na 1,5 stronicy papieru formatu A4.

b Zapis zgodny z oryginałem.

${ }^{252}$ Fulda - niemieckie miasto w kraju związkowym Hesja, w rejencji Kassel.

$c-c$ Fragment napisany czarnym atramentem przez autora pisma. 


\section{Exzellenz! ${ }^{\mathrm{a}}$}

Hochwürdigster Herr Erzbischof!

$\mathrm{Da}$ ich nicht mehr die Freude Ihrer Gegenwart genieße, erlaube ich mir, mit einem Brieflein auf unseres Thema „Konnersreuth“ zurückzukommen. Ich meine, das Beste wäre es, wenn Exzellenz auf der Rückreise mit Kardinal Faulhaber sprechen und um seinen Rat bezüglich Ihres Werkes fragen würden. Denn wenn die wichtigsten mystischen Kriterien: Demut, Gehorsam [... $]^{\mathrm{b}}$ nicht zugunsten der Therese N[eumann] sprechen, oder Therese derzeit darin noch nicht genügend geprüft ist, wird es wohl besser sein, mit der Veröffentlichung des Werkes abzuwarten und zwar so lange bis alle mystischen Kriterien zugunsten von Konnersreuth sprechen. Vielleicht reden Exzellenz dem Herrn Kardinal zu, er möge Resl veranlassen, dass sie sich auf 1 Jahr in ein Frauenkloster begebe, das auch $\mathrm{H}$ [errn] Bischof Buchberger genehm ist. nur so dürfte die Entspannung zwischen Konnersreuth und Regensburg möglich werden. Es wird gut sein, zuerst Kardinal Faulhaber zu fragen, wann und wo Exzellenz ihn sprechen können.

Recht guten Kurerfolg und beste Erholung wünschend, empfiehlt sich Ew[ere] Exzellenz ehrfurchtsvoll ergebener

Bitte viele Grüße an die lh[nen] Schwestern.

$\mathrm{P}$ [ater] Odo Staudinger

Dokument 62

AFKDOPW, teczka 140: Spuścizna abp. Józefa Teodorowicza, sygn. 958/420 (8) [7], List ks. Härtla do abp. Józefa Teodorowicza, Konnersreuth 29 VIII 1932 r.

Excellenz! $!^{\mathrm{a}}$

Konnersreuth, 29. 8. [19]32

Hochwürdigster Herr Erzbischof!

Von ganzem Herzen danke ich Eu[rer] Excellenz für Ihr gnädiges Schreiben. Wie $\mathrm{Eu}[\mathrm{re}]$ Excellenz selbst, halte auch ich die gehörten Reden für übertrieben. Wir haben Beweise, dass gerade zur Zeit unser hochw[ürdiger] Oberhirte zur Th[erese] $\mathrm{N}$ [eumann] gut eingestellt ist. Fall Rothschild: Es ist der Herr, der früher israelitischer Apotheker war u[nd] heuer am 29.6 in Eichstätt zum Priester geweiht wurde, nachdem er seiner Zeit auf die Ereignisse in K[onnersreuth] hin sich taufen liess. Der fragliche Brief wurde von ihm schon vor 2 Jahren geschrieben. Roth[schild] studierte wohl damals schon in Eichstätt Theologie, war aber in die Diözese noch nicht aufgenommen. Er bekam daraufhin Schwierigkeiten in Eichstätt (Exc[ellenz] Buchberger hatte den Brief nach Eichstätt gesandt) $u$ [nd] berief sich damals dem jetzt verstorb[enen]

a Tekst pisany czarnym atramentem na dwóch kartach papieru formatu pocztówki. W lewym górnym rogu nadruk firmowy: „Schriftleitung des Benedictus-Boten”. W górnej partii karty na centralnym miejscu graficzna inskrypcja: „+ PAX”.

b Tekst nieczytelny.

a Tekst pisany maszynowo na 1,5 stronicy papieru formatu A4. 
damaligen Eichst. Oberhirten gegenüber ausdrücklich darauf, dass er eigentlich noch Apotheker sei.

Th[erese] N[eumann] hat ihn weder zur Abfassung noch bei der Abfassung des Briefes beeinflusst, hatte von seinem Vorhaben nicht einmal Kenntnis, da sie ihn in der Zeit zwischen seinem Entschluss dazu $\mathrm{u}[\mathrm{nd}]$ der Abfassung überhaupt nicht traf (der Gedanke dazu drängte sich ihm ganz plötzlich in der Kirche auf). Er war auch von niemand anderem dazu beeinflusst $u[n d]$ damals 30 Jahre alt, also in einem Alter, wo man schon selbst denkt $u[n d]$ urteilt. Ueberhaupt möchte ich bei dieser Gelegenheit ausdrücklich feststellen, dass sowohl Th[erese] N[eumann] als auch jeder andere an der Sache K[onnersreuth]. Beteiligter seine Briefe u.s.f. selbst abfasst ohne sich der anderen zu bedienen.

Uebrigens glaube ich, dass die ganze Sache längst abgetan ist; wir wenigstens wissen $\mathrm{u}$. hören nichts mehr davon. Indem ich hiermit $\mathrm{Eu}[\mathrm{re}]$ Excellenz gedient zu haben glaube verbleibe ich Eu[rer] Excellenz ehrfurchtsvollst ergebener

Benefiziat Härtl

\section{Dokument 63}

AFKDOPW, teczka 138: Spuścizna abp. Józefa Teodorowicza, sygn. 984/420 (8) [7], List bp. Michaela Buchbergera do abp. Józefa Teodorowicza, Regensburg 29 VIII 1932 r.

$\mathrm{Eu}[\mathrm{re}]^{\mathrm{a}}$ Exzellenz!

Regensburg, 29. August 1932

Leider habe ich $\mathrm{Eu}[\mathrm{re}]$ Exzellenz in Marienbad nicht mehr angetroffen, daher übersende ich das Manuskript über den Fall Konnersreuth durch die Post. Ich habe dasselbe durchgesehen und nichts gefunden, was gegen eine Drucklegung sprechen würde. Nur ein paar Stellen habe ich angemerkt, in denen die sprachliche Fassung missverständlich sein könnte. Wissenschaftlich allerdings muß ich den Fall anders beurteilen. Wir müssen vor allem über die Tatsachen absolut sicher sein, dann erst können wir unsere Folgerungen daraus ziehen. Erst muß ein Fall mit aller Klarheit und Sicherheit festgestellt sein, dann kann man über die Methoden und Faktoren der Beurteilung leicht einig werden. Die Frage, ob Theree Neumann nichts isst und trinkt, ist eine Tatsachenfrage. Es ist kein imbilliges Verlangen, daß diese Tatsache mit der größten Gewissenhaftigkeit und Gründlichkeit geprüft wird. Ist der Beweis dafür erbracht, dann ist derselbe von weittragendem apologetischem Werte. Daher ist es so zu bedauern, daß Therese Neumann und ihr Vater auf den Wunsch einer verlässigen neuen Prüfung nicht eingehen wollen. So lange das nicht geschieht, hat alle Erörterung des Falles keinen rechten tragfähigen Boden unter sich.

a Tekst pisany maszynowo na 1,5 stronicy papieru formatu A4. W lewym górnym rogu karty tytułowej firmowy nadruk: „Der Bischof von Regensburg”. 


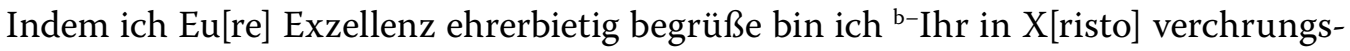
vollergebener

† Michael ${ }^{-b}$

Bischof von Regensburg

\section{Dokument 64}

Oryg.: AFKDOPW, teczka 141: Spuścizna abp. Józefa Teodorowicza, sygn. 1093/420 (8) [7], List dr. A. Ludwiga do NN, Freising 31 VIII 1932 r.

Lieber $^{\mathrm{a}}$ Herr Kollege!

Freising, 31.8.[19]32

So sehr ich die Ehre schatzen muss, von Herrn Erzbischof Theodorowicz hier besucht zu werden, so kann ich doch dem hohen Herrn eine Reise nach Freising nicht zumuten, es sei denn, dass er sich für die hiesigen Kunstschätze interessiert und da muss ich hier den Fuhrer machen. Meine Ansicht uber Konnersreuth ist folgende: Weder Stigmatisation, noch Hellsehen (räumliches und zeitliches) beweisen für die Übernatur. Sie kommen (wenigstens Hellsehen und teilweise Stigmat.) auch bei medial veranlagten Professoren vor. Dagegen kann ich die absolute Nahrungslosigkeit nicht natürlich erklaren. Gleich Ihnen und dem Herrn Erzbischof bin ich überzeugt, dass die „offenbar im erh. Ruhezustand" ihrem gerade da zuweilen hellsehenden Unterbewusstsein entstammen. Gleich der „Prophetin von Schippach Barbara Weigand ${ }^{253}$ (über die ich seiner Zeit in „Theologie und Glaube" schrieb) schreibt sie [... ${ }^{\mathrm{b}}$ weise diese Erkenntnisse, die manchmal trügerische sind, Christus zu, weshalb ich schon vor zwei Jahren durch den hiesigen Subregens, Dr. Westermaier ${ }^{254}$ den Herrn Bischof von Regensburg ersuchen liess, das Orakelwesen einzustellen. Es kann sonst einmal zu einem rechten Schamassel kommen. Die Umgebung der guten Therese ist ganz einseitig supernaturalistisch eingestellt, auch Herr Lama. Ich hatte nie die Absicht, nach Landshut zu ziehen, wohl aber hatte ich in München gemietet, war aber nicht ausgezogen und blieb vorläufig hier. Ich bin vom 1 . bis 6. September in Mittenwald und würde mich freuen, wenn Sie mich hier besuchen würden. Also vom 7. September an bin ich hier. Wenn also der Hochw[ürdigen] Herr Erzbischof hier herfahren will, bin ich da und würde ihn am Bahnhof abholen, wenn er mich vorher benachrichtigt, mit welchem Zug er kommt.

Empfangen Sie die herzlichsten Grüsse Ihres Erg. Kollegen

$\operatorname{Ludwig}^{255}$

b-b Fragment pisany czarnym atramentem.

a Tekst pisany czarnym atramentem na dwóch połówkach karty papieru formatu karty pocztowej. Tekst z tzw. kurrentschriftu przepisała Pani Gerlinde Stohl - dyrektorka Muzeum w Sierndorfie an der March (Austria), za co zechce przyjąć szczere podziękowanie.

${ }^{253}$ Osoba niezidentyfikowana.

b Wyraz nieczytelny.

${ }^{254}$ Właściwie: Westermayr.

${ }^{255}$ Ludwig A. - prof. dr, wykładowca w Wyższej Szkole we Freisingu. 


\section{Dokument 65}

Kopia: AFKDOPW, bsygn., teczka: Spuścizna abp. Józefa Teodorowicza, List abp. Józefa Teodorowicza do bp. Michaela Buchbergera, bmr. [1932 r.].

Exzellenz! $!^{\mathrm{a}}$

Herzlichst danke ich Eurer Exzellenz für die beiden letzten Briefe. Speziell bin ich zu dank Eurer Exzellenz dazu verpflichtet, dass Eure Exzellenz sich so liebenswürdig meines Manuskripts angenommen hat. Das Manuskript ist in Lemberg, man hat mir von dort mir den Brief Eurer Exzellenz geschickt, aber ich werde alien Anweisungen Eurer Exzellenz nachkommen. Ich glaube aber aus dem, was mir Eure Exzellenz schreibt, dass es doch ein irgendein Missverständnis im Spiele sein muss, welches ich vielleicht dadurch verschuldet habe, dass ich nicht genügend Eurer Exzellenz über den Plan meiner ganzen Arbeit informiert habe. Das Manuskript, welches ich Eurer Exzellenz zugeschickt habe, ist nur ein einleitender Teil und ich nehme in diesem Teile meine Einstellung zu Konnersreuth, weder pro noch contra.

Es folgen nach diesem einleitenden Teile noch etwa circa 10 Teile, wo ich mich mit dem Problem selbst befasse. Über die Notwendigkeit der Feststellung der Tatsachen habe ich im ersten Teil geschrieben, den Eure Exzellenz zu Handen bekommen werden. Es ist mir sehr daran gelegen, auch prinzipiell einig mit Eurer Exzellenz zu sein, deshaib werde ich Eurer Exzellenz sehr verbunden sein, wenn Eure Exzellenz auf die anderen Teile meiner Arbeit die Aufmerksamkeit widmen konnte. Ob ich aber nicht zu viel verlange?

Jetzt komme ich zu der eigentlichen Sache, das ist zu der Vorstellung meines Planes, indem ich ungemein bereue, dass ich mit Eurer Exzellenz nicht personlich vorsprechen kann. Mein Plan ist folgender: in Eichstätt ist die Benediktinerin Äbtissin eine hochintellektuelle und kluge Frau, zu der Therese Neumann das grösste Vertrauen hat. Es ware das einfachste und das beste, dort die Kontrolle durchzuführen, wo man auch seitens der Familie keinen Reibungen hoffentlich begegnen wird und wo die praktische Behandlung des ganzen Problems in den Händen einersehr verständigen Person liegen wird, die zugleich das Vertrauen Thereses besitzt. Die Ärzte mussten natürlich dazu herbeigezogen werden. Es kommt mir in den Sinn, ob nicht Dr. Witry aus Metz sich dazu nicht am besten eignen würde? Er ist ein Nervenarzt, er hat spezielle Praktik in der Forschung der Stigmatisation und in dieser Hinsicht ausser jeder Konkurrenz, und er besitzt dabei das Vertrauen der Familie, speziell des Vaters, der mir erzählt hat, dass er ihm gerne alle Forschungen machen zuliess, weil er in ihm einen ernsten und zuverlässigen Mann kennen gelernt hat. Dr. Witry wird so wie so eine Reise in kürzerer Zeit (Oktober) nach Tschechoslowakei, Ungarn und Polen vornehmen, er wurde, wie ich glaube, bereit sein, wenigstens eine Oberaufsicht anzunehmen, und falls er nicht

Tekst pisany czarnym atramentem na dwóch stronicach papieru formatu A4. Brak autografu autora, miejsca wystawienia dokumentu, datacji oraz zakończenia. Tekst z tzw. kurrentschriftu przepisała Pani Gerlinde Stohl - dyrektorka Muzeum w Sierndorfie an der March (Austria), za co zechce przyjąć szczere podziękowanie. 
ständig die ganze Zeit in Eichstätt weilen könnte, wenigstens könnte er die Anordnungen treffen, welche die anderen Ärzte befolgen wurden. Er ist ein Mann der Idee, und ich glaube, dass er auBer der Reisekosten und Gehalts nichts verlangen wird.

Therese müsste unter der Kontrolle der vereideten Personen, etwa 3, wenigstens 2 Monate bleiben. In diesem Rahmen lässt sich, wie ich hoffe, der Plan durchführen, und zwar ohne Aufsehen, und eine in die wissenschaftliche Forschung ganz befriedigende Weise. Wenn Eure Exzellenz damit einverstanden ist, so fahre ich nach Eichstätt, um zu erfahren, ob die Äbtissin geneigt wäre, diese Last auf ihre Schultern zu nehmen, und dann schreibe ich Eurer Exzellenz.

\section{Dokument 66}

Kopia: AFKDOPW, bsygn., teczka: Spuścizna abp. Józefa Teodorowicza, List abp. Józefa Teodorowicza do NN, bmr.

Hochverehrter ${ }^{a}$ Herr!

Ich bin besorgt, was eigentlich in Betreff der Herausgabe des Briefes über Konnersreuth vorgeht? Das Manuskript wurde an den Herrn Mut ${ }^{256}$ verschickt, aber er schreibt gar nichts, er hat nicht einmal berichtet, ob er das Manuskript bekommen hat. Ich fürchte, ob ihm nicht etwas passierte, und deshalb auf jeden Fall wende ich mich direkt an Sie. Wichtig waren mir diejenigen Stellen zu verbessern, welche im Maschinendruck geschrieben sind. Da Dr. Radlo ${ }^{257}$ jetzt mehrere Tage in Konnersreuth gewesen ist, so wäre es gut, im Vorwort noch den Passus hinzufügen. „Ich bin mehrere Tage in Konnersreuth gewesen, und ich habe mit Erlaubnis der Familie um Therese N[eumann] die Untersuchungen vom medizinischen Standpunkt geführt". Da die Arbeit Dr. Hyneks ${ }^{258}$ in kurzer Zeit erscheint, bitte die Stellen im Briefe, wo diese Arbeit zitiert wird, genau anzuführen. Im Vorwort soll noch informiert werden, dass die Antwort auf die letzte Publikation Dr. Deutsch ${ }^{259}$ „Arztliche Kritik an Konnersreuth!" separat erscheinen wird. Wären Sie bereit, die Antwort auf diese Publikation im Druck veröffentlichen? Diese Antwort ist schon bereits im Manuskript fertig. Bitte mich jedenfalls benachrichtigen zu wollen.

Ich verbleibe mit dem Ausdruck meiner tiefen Hochachtung

† Teodorowicz

Für das Sekretariat des E[rzbischof] T[eodorowicz]

a Tekst pisany czarnym atramentem na jednej stronicy papieru format zeszytowego. Brak miejsca wystawienia dokumentu i datacji. Tekst z tzw. kurrentschriftu przepisała Pani Gerlinde Stohl - dyrektorka Muzeum w Sierndorfie an der March (Austria), za co zechce przyjąć szczere podziękowanie.

${ }^{256}$ D.W. Mut [właściwie: W. Dunkel] - pisarz i wydawca niemiecki publikujący prace ascetyczno-religijne.

257 Zob. w niniejszej publikacji: J. Wołczański, Korespondencja abp. Józefa Teodorowicza z prof. Stefanem Dąbrowskim, dokument 43.

${ }^{258}$ Tamże, dokument 42.

259 Tamże, dokument 16. 


\section{Dokument 67}

Oryg.: AFKDOPW, teczka 142: Spuścizna abp. Józefa Teodorowicza, sygn. 1001/420 (8) [7], List ks. prof. dr. Franza Mayra do abp. Józefa Teodorowicza, Obersalzberg 2 IX 1932 r.

Ehrw[ürdigster $]^{\mathrm{a}}$ Exzellenz,

Obersalzberg bei Berchtesgaden, dem 2.9.[19]32

Hochverehrter hochwürdigster Herr Erzbischof!

Heute bin ich bereits in der angenehmen Lage, Ehrw[ürdigster] Exzellenz ein Schreiben von Herrn Geheimrat Hochschulprofessor Dr. Ludwig (Freising) zu übermitteln, das Sie gewiss sehr interessieren wird. Wie Exzellenz hiemit erfahren, ist H[errn] Prof. Ludwig vom 7. 8. an in Freising und steht Ihnen gern zur Verfügung. Freising, ein altes interessantes Städtchen, liegt nahe bei München auf der Strecke München-Regensburg.

In dem Brief, den ich an $\mathrm{He}[\mathrm{r}] \mathrm{r}[\mathrm{n}]$ Geheimrat Ludwig richtete, legte ich ihm zu seiner Orientierung kurz auch die Grundlinien Ihrer Ansicht über Konnersreuth dar. Bezüglich der Äußerungen der Therese N[eumann] im erhobenen Ruhezustand schrieb ich ihm, dass Eure Exzellenz wie auch ich der Ansicht seien, dass diese Äußerungen wirklich lediglich dem Unterbewusstsein der Therese selbst entstammten. Wenn sie nicht als übernatürlich zu betrachten sind, können sie doch keinen anderen Ursprung haben. Herr Geheimrat scheint das „wirklich“ in meinem Brief übersehen zu haben. Er ist, wie sein Brief zeigt, der Anschauung, dass die "Offenbarungen im erh. Ruhezustand“ aus dem Unterbewusstsein der Resl kommen, anscheinend ohne Ausnahme.

In Betreff der Stigmatisation, auf die wir in Salzburg leider nicht zu sprechen kamen, möchte ich nachholen, dass ich sie bei der Resl für recht, das heißt für übernatürlich bedingt halte. Meines Wissens wurde noch kein Fall natürlicher (medialer) Stigmatisation berichtet, bei der die Wunden und die Blutungen solchen Umfang besaßen und so lange Zeit vorhanden waren.

Indem ich mich Ehr[würdigster] Exzellenz aufs Höflichste empfehle und Sie bitte, mich in Ihr Gebet einzuschließen, verbleibe ich in vorzüglicher Hochachtung Ehr[würdigster] Exzellenz ergebenster

Prof. Dr. Franz Mayr ${ }^{260}$ (Eichstätt) zur Zeit Obersalzberg bei Berchtesgaden

P.S. Auch die auffallende Heilung der Therese N[eumann] von der Lähmung, der Blindheit, der Blinddarmentzündung $\mathrm{u}[\mathrm{nd}] \mathrm{s}[\mathrm{o}] \mathrm{w}$ [eiter] ebenso wie ihre vorübergehenden Krankheitszustände bei Sühneleiden kann ich mir nicht natürlich erklären. Das Wichtigste für die Beurteilung der Frage bleibt aber zweifellos die Nahrungslosigkeit.

a Tekst pisany czarnym atramentem na dwóch stronicach papieru formatu A4. Tekst z tzw. kurrentschriftu przepisała Pani Gerlinde Stohl - dyrektorka Muzeum w Sierndorfie an der March (Austria), za co zechce przyjąć szczere podziękowanie.

${ }^{260}$ Mayr Franz Xaver (1887-1974), dr botaniki, święcenia kapłańskie w 1923 r. we Freisingu, 1924-1958 prof. chemii, biologii oraz geologii w Kolegium Filozoficzno-Teologicznym w Eichstätt, twórca Muzuem Jury tamże. Źródło: Diözesangeschichtsverein Eichstätt e.V.: Mayr, Prof. Dr. Franz Xaver, https://eidgv.bistum-eichstaett.de/memoriale/mayr-franz-xaver/. Dostęp: 11 XI 2017 r. 


\section{Dokument 68}

Oryg.: AFKDOPW, teczka 138: Spuścizna abp. Józefa Teodorowicza, sygn. 986/420 (8) [7], List bp. Michaela Buchbergera do abp. Józefa Teodorowicza, Regensburg 5 IX 1932 r.

Regenburg, 5. September 1932

$\mathrm{Eu}[\mathrm{re}]$ Exzellenz! ${ }^{\mathrm{a}}$

Mit dem Ausdruck verehrungsvollen Dankes bestätige ich den Empfang Ihren Schreibens vom 1. September. Gerne würde ich mit Ihnen den Fall „Konnersreuth” durchbesprechen, aber ich bin während des ganzen Septembers fast Tag für Tag von Regensburg abwesend und kann das Arbeitsprogramm jetzt nicht mehr ändern. So wird nichts übrig bleiben, als da $\beta$ wir uns schriftlich über die wichtigsten Punkte verständigen.

Ich gestatte mir Eu[rer] Exzellenz aufmerksam zu machen auf die eben erschienene Schrift „Um Konnersreuth“ von Dr. Josef Deutsch, Chefarzt des Dreifaltigkeitshospitals Lippstadt, Westphalen. Die Schrift ist nur im Maschinendruck erschienen, aber der Chefarzt wird sicher die Güte haben Ihnen ein Exemplar zu überreichen. Unter dem gleichen Titel ist eine beachtenswerte Broschüre erschienen von Dr. med. H[ans] Heermann $^{261}$ in Essen ${ }^{262}$. Dieselbe ist von der Bonifatiusdruckerei in Paderborn ${ }^{263} \mathrm{zu}$ beziehen. Eine neue verlässige Prüfung und Untersuchung des Falles ist unbedingt wünschenswert.

Genehmigen Eu[rer] Exzellenz den Ausdruck meiner hohen Verehrung in der ich die

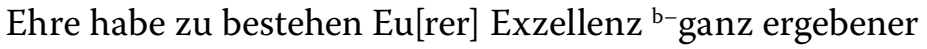

$$
\begin{gathered}
\text { † Michael } \\
\text { ep[isco }] \mathrm{p}[\mathrm{u}] \mathrm{s} \text { Ratisbonen[sis }]^{-\mathrm{b}}
\end{gathered}
$$

\section{Dokument 69}

Kopia: AFKDOPW, teczka 136: Spuścizna abp. Józefa Teodorowicza, sygn. 934/420 (12) [7], List abp. Józefa Teodorowicza do bp. Michaela Buchbergera, Badgastein 7 IX 1932 r.

Exzellenz! $!^{\mathrm{a}}$

dzt. Badgastein, 7. September 1932

Herzlichst danke ich Eu[rer] Exzellenz für die beiden letzten Briefe. Speziell bin ich Ew[erer] Exzellenz dafür zu Dank verpflichtet, dass Ew[erer] Exzellenz sich so

a Tekst pisany maszynowo na jednej stronicy papieru formatu A4. W lewym górnym rogu karty nadruk firmowy: „Der Bischof von Regensburg“.

${ }^{261}$ Zob. w niniejszej publikacji: J. Wołczański, Korespondencja abp. Józefa Teodorowicza z prof. Stefanem Dąrowskim, dokument 16.

${ }^{262}$ Essen - niemieckie miasto w zachodniej części kraju w kraju związkowym Nadrenia Północna-Westfalia.

${ }^{263}$ Paderborn - niemieckie miasto we wschodniej części kraju związkowego Nadrenia Północna-Westfalia.

b-b Tekst napisany czarnym atramentem.

a Tekst pisany maszynowo na 3,5 stronicach papieru formatu A4. Brak adresata i autografu autora. 
liebenswürdig meines Manuskriptes angenommen haben. Das Manuskript ist in Lemberg, man hat mir von dort nur den Brief Ew[erer] Exzellenz geschickt und ich werde trachten, allen Anweisungen Ew[erer] Exzellenz nachzukommen. Ich glaube aber aus dem, was mir Ew[erer] Exzellenz schreiben, dass doch irgend ein Missverständnis im Spiele sein muss, welches ich vielleicht dadurch verschuldet habe, dass ich nicht genügend Ew[erer] Exzellenz über den Plan meiner ganzen Arbeit informiert habe. Das Manuskript, welches ich Ew[erer] Exzellenz zugeschickt habe, ist nur ein einleitender Teil und ich nehme in diesem Teile keine Einstellung zu Konnersreuth weder pro noch contra. Es folgen noch diesem einleitenden Teile noch etwa zehn Teile, wo ich mich mit dem Problem selbst befasse. Über die Notwendigkeit der Feststellung der Tatsachen habe ich im ersten Teile geschrieben, den Ew[erer] Exzellenz zu Händen bekommen worden. Es ist mir sehr daran gelegen, auch prinzipiell einig mit Ew[erer] Exzellenz zu sein, deshalb würde ich Ew[erer] Exzellenz sehr verbunden sein, wenn Ew[erer] Exzellenz den anderen Teilen meiner Arbeit dieselbe Aufmerksamkeit schenken würden. $\mathrm{Ob}$ ich aber nicht zu viel verlange? Jedenfalls kann ich Ew[erer] Exzellenz versichern, dass ich die genaueste Untersuchung der mystischen Phänomene bei Therese durchgeführt habe und dass ich dank dem Vertrauen, das sie mir entgegengebracht hat, viel Neues und Unbekanntes und für die Forschung ausserordentlich Wichtiges mir mitgeteilt hat.

Ich verhalte mich zu den Phänomenen rein objektiv, ohne einerseits alles übernatürlich zu deuten und ohne die Möglichkeit der Beimischung des menschliches "Ichs" in ihren ekstatischen Aussagen auszuschliessen, andererseits aber ohne mich ausschliesslich auf rein psychologische Motive mit Ausschaltung der mystischen zu beschränken. Ein hochangesehener deutscher Jesuit hat mir gesagt, dass eine solche Besprechung Kennersreuths viel zur Beruhigung der Gemüter beitragen werde.

Dabei habe ich auch die Phänomene sowohl mit den medizinischen Autoritäten wie auch mit den Kennern der Theologie und Mystik (P[ater] Lagrange ${ }^{264}$ ) eingehend besprochen.

Jetzt käme ich zu der eigentlichen Sachlage d. i. zu der Vorstellung meinen Planes, indem ich ungemein bedauere, dass ich bei Ew[erer] Exzellenz nicht persönlich versprechen kann. Mein Plan ist folgender: In Eichstätt ist die Äbtissin der Benediktinerinnen, eine hochkulturelle und kluge Frau, zu der Therese Neumann das größte Vertrauen hat. Es wäre das einfachste und das beste dort die Kontrolle durchzuführen, wo man hoffentlich seitens der Familie keinen Reibungen begegnen wird und wo die praktische Behandlung des ganzen Problems in den Händen einer sehr verständigen Person liegen wird, die zugleich das Vertrauen Thereses besitzt. Die Ärzte würden natürlich dazu hereinbezogen werden. Da kommt mir in den Sinn, ob nicht Dr. Witry aus Metz sich am besten dazu eignen würde? Er ist ein Nervenarzt. Er hat speziell Praxis in der Forschung der Stigmatisation und in dieser Hinsicht ist er ausser Konkurrenz und er besitzt dabei das Vertrauen der Familie, speziell des Vaters, der uns erzählt hat, dass es ihm freistelle, alle Beobachtungen zu machen, weil er in ihm einen ernsten und zuverlässigen Mann

\footnotetext{
${ }^{264}$ Zob. w niniejszej publikacji: J. Wołczański, Wybór korespondencji o. Włodzimierza Ledóchowskiego SJ $z$ o. prof. Pawtem Siwkiem SJ, dokument 8.
} 
kennen gelernt hat. Dr. Witry wird ohnedies eine Reise in kurzer Zeit (Oktober) nach der Tschechoslowakei, Ungarn und Polen vornehmen; er würde, wie ich glaube, bereit sein, wenigstens eine Oberaufsicht anzunehmen und falls er nicht die ganze Zeit in Eichstätt weilen könnte, wenigstens die Anordnungen treffen würde, welche die anderen Ärzte befolgen würden. Er ist ein Mann der Idee, und ich glaube, dass er ausser den Reisekosten und dem Gehalt nichts verlangen wird. Ich könnte ihm evtl. schreiben. Therese müsste unter der Kontrolle der vereidigten Personen etwa drei, wenigstens aber zwei Monate bleiben. In diesem Rahmen lässt sich, wie ich hoffe, den Plan durchführen u.zw. ohne Aufsehen und u. zw. in einer, die wissenschaftliche Forschung ganz befriedigenden Weise. Falls Eu[re] Exzellenz damit einverstanden sind, so fahre ich nach Eichstätt, um zu erfahren, ob die Äbtissin bereit wäre, diese Lust auf ihre Schultern zu nehmen und dann schreibe ich Eu[rer] Exzellenz. Ausserdem könnte Therese Neumann und ihre ganze Familie vereidigt werden $u$. zw. wann sie zum letzten Male gegessen und getrunken hat. Diesen Eid sind sie bereit, Eu[rer] Exzellenz jederzeit abzulegen. Therese dürfte noch dazu den Eid ablegen, dass sie seit 1929 keine Ausscheidungen mehr habe, was auch gewiss der Gegenstand der Kontrolle sein würde.

Selbstverständlich ruht das Hauptgewicht in der Lösung auf Therese Neumann selbst. Ich habe schon Exzellenz geschrieben, wie willig sie sich einer solchen Kontrolle unterziehen möchte. Wie ernst es ihr darum ist, zeigt die Tatsache, dass sie mit einer anderen Priorin schon den ganzen Plan besprochen hat, wie ich das von ihr unmittelbar vernommen habe.

Der Pfarrer hat mir zwar leise angedeutet, dass sie nicht genügend mit den Schwierigkeiten rechne, die sich ihr von Seiten des Vaters in den Weg stellen werden, doch hat sie mir von ihrer Bereitwilligkeit im vorigen und in diesem Jahre ohne jeden Vorbehalt gesprochen, sonst könnten Eu[rer] Exzellenz sie ev[en]t[uel]l zu sich kommen lassen. Ich weiss, wie sie gerne alles mit Ew[erer] Exzellenz besprechen möchte. Und dann hätten $\mathrm{Eu}[\mathrm{rer}]$ Exzellenz Gelegenheit gehabt, ihr den Wunsch Eu[rer] Exzellenz zu unterbreiten. Dann ist sie schon allein und unmittelbar verantwortlich.

Ich danke herzlichst für die Angabe des Briefes, die ich gleich bestellen werde. $\mathrm{Ob}$ aber die Doktoren sehen von der Tatsache des völligen Mangels an Ausscheidungen bei ihr etwas wüssten? Ich erlaube mir, den Brief express zu schicken, damit man denselben $\mathrm{Eu}[\mathrm{rer}]$ Exzellenz dort zustelle, wo Eu[rer] Exzellenz sich gerade befinden.

Ich ersuche Eu[rer] Exzellenz um gütige Antwort, damit ich weiss, wie ich es einrichten soll und ich verbleibe mit dem Ausdrucke meiner ergebensten und tiefsten Hochachtung $[\ldots]^{\mathrm{b}}$.

\section{Dokument 70}

Oryg.: AFKDOPW, teczka 138: Spuścizna abp. Józefa Teodorowicza, sygn. 986/420 (8) [7],List bp. Michaela Buchbergera do abp. Józefa Teodorowicza, Regensburg 8 IX 1932 r.

\footnotetext{
b Brak zakończenia.
} 
$\mathrm{Eu}[\mathrm{re}]$ Exzellenz! ${ }^{\mathrm{a}}$

Regensburg, 8. September 1932

Aufs Wärmste danke ich Ew[erer] Exzellenz für das freundliche Schreiben, das ich eben erhalten habe und für alle Bemühungen, um Klärung und sichere Feststellung der Erscheinungen von Konnersreuth.

Bevor wir nun weiter in der Sache vorgehen möchte ich abwarten, wie von der Familie Neumann der Auftrag aufgenommen wird, den ich ihr im Namen der bayerischen Bischofskonferenz übermittle. Ich gebe Ew[erer] Exzellenz streng vertraulich Kenntnis von diesem Auftrag.

Die Bischofskonferenz hält mit mir die nun immer dringlichere auch von katholischen Ärzten geforderte neue Prüfung im Interesse des Ansehens der Familie Neumann und auch der katholischen Kirche für unbedingt notwendig. Ich werde diesen Auftrag nach Konnersreuth übermitteln und zugleich jede Unterstützung für die Durchführung in Aussicht stellen. Geht die Familie Neumann auf diesen Auftrag ein, so wird ihre Monographie über den Fall Neumann vollständig geklärten geebneten Weg vor sich haben. Geht sie nicht darauf ein, dann glaube ich sollte kein Bischof mehr über die Sache öffentlich schreiben, den es besteht die Gefahr, da $\beta$ dann Bischof gegen Bischof ausgespielt wird.

Indem ich Eu[re] Exzellenz ehrerbietigst begrüße, bin ich Ew[erer] Exzellenz verehrungsvollst ergebener

\author{
† Michael ${ }^{\mathrm{b}}$ \\ Bischof von Regensburg
}

\title{
Dokument 71
}

Oryg.: AFKDOPW, teczka 139: Spuścizna abp. Józefa Teodorowicza, sygn. 937/420 (8) [7], List dr. Josefa Deutscha do abp. Józefa Teodorowicza, Lippstadt 10 IX 1932 r.

S[eine $]^{\mathrm{a}}$ Exzellenz

Lippstadt den z.Z. Hahnenklee Harz 10. IX. 1932

dem hochwürdigsten Herrn Erzbischof

Josef Teodorowicz

Hotel Walgarten

z. Z. Bad Gastein

$\mathrm{Eu}[\mathrm{re}]$ Gnaden!

a Tekst pisany maszynowo na $1 \frac{1}{2}$ stronicy papieru formatu A4. W lewym górnym rogu karty nadruk firmowy: „Der Bischof von Regensburg”.

b Autograf czarnym atramentem.

a Tekst pisany maszynowo na $1 / 2$ stronicy papieru formatu A4. Autograf odręczny czarnym atramentem. W lewym górnym rogu karty nadruk firmowy: „Dr Deutsch. Facharzt für Chirurgie und Fraeunkrankheiten Chefarzt des Dreifaltigkeitshospotals Telefon: 2430“. 
Der Brief Eu[rer] erzbischöflichen Gnaden trifft mich hier wo ich zur Erholung weile. Ich werde mit gleicher Post nach Hause schreiben und den Auftrag erteilen Eu[rer] Gnaden die gewünschte Schrift umgehend zu zusenden.

$\mathrm{Eu}[\mathrm{rer}]$ erzbischöflichen Gnaden sehr ergebener

Dr. Deutsch

\section{Dokument 72}

Oryg.: AFKDOPW, teczka 145: Spuścizna abp. Józefa Teodorowicza, sygn. 1067/420 (8) [7]-1082/420 (8) [7], List dr. Théodore Witry do abp. Józefa Teodorowicza, Metz 23 IX 1932 r.

Metz, le 23 Sept[ember] 1932

$\mathrm{Eu}[\mathrm{re}]^{\mathrm{a}}$ Exzellenz!

Hochwürdigster Herr Erzbischof!

Ich habe im Juni dieses Jahres, als ich mit dem Herrn Erzbischof von Prag in Konnersreuth war, die Resl, wie ich Ihnen schrieb, genau und lange untersucht und dann dem Herr Pfarrer Naber ein kurzes Attest übergeben zu seinem Privatgebrauche. Da ich mit in der Eile der Abreise keine Kopie davon gemacht habe, bat ich jetzt den Herrn Pfarrer Naber um eine solche für meine Privatakten. Er ließ mir mitteilen, dass er Eu[rer] Eminenz das betr. Attest mitgegeben habe. Darf ich um Eu[re] Eminenz ergebenst bitten, mir eine Anschrift dieses meines Attestes vom 6. 6. Juni 32 aus Konnersreuth zukommen zu lassen? Ich wäre Ihnen sehr dankbar dafür. Hier ist der Kampf um Konnersreuth jetzt am lebhaftesten seitens einer Reihe kath[olischen] Ärzte und Theologen. Letzte äußerst scharfe Streitschrift gegen Dr. Gerlich und Fahsch für die Hysterie: „Um Konnersreuth“ von Dr. med. Deutsch in Lippstadt. Manuskript.

Ich verbleibe Eu[rer] Eminenz in tiefer Verehrung und Hochachtung, ergebenster

Witry

P.S. Wie steht es mit den Vorträgen?

\section{Dokument 73}

Oryg.: AFKDOPW, teczka 141: Spuścizna abp. Józefa Teodorowicza, sygn. 995/420 (8) [7], List dr. A. Ludwiga do abp. Józefa Teodorowicza, Freising 24 IX 1932 r.

Ehr[würdigste $]^{a}$ Exzellenz!

Freising, 24. 09. [19]32

a Tekst pisany czarnym atramentem na dwóch stronicach papieru format listowego. W lewym górnym rogu karty tytułowej nadruk firmowy: „Docteur Witry, Maladies nerveuses et du sang, Metz, Place Saint Thiébauld 39, telephone 1767, pathologie sexuelle-psychanalise”.

a Tekst pisany czarnym atramentem na trzech stronicach papieru formatu karty pocztowej. Tekst z tzw. kurrentschriftu przepisała Pani Gerlinde Stohl - dyrektorka Muzeum w Sierndorfie an der March (Austria), za co zechce przyjąć szczere podziękowanie. 


\section{Hochwürdigster Herr Erzbischof!}

Heute sprach ich Herrn Subregens Dr. Westermaier, der ebenfalls weiss, dass zuweilen sog. Somnambulen in ihrem "morganatischen Schlaf” voraus verkundeten, wann derselbe wieder eintreten werde, was auch dann geschah. Es scheint sich da um eine Art „posthypnotischem Befehl” und zwar „autohypnotischen” zu handeln.

Exzellenz wissen, dass ein Hypnotiseur dem Hypnotisierten den Befehl erteilen kann, nach einer genau bestimmten Zeit, irgendeine genau bezeichnete Handlung auszuführen. Der Hypnotisierte erwacht und weiss in seinem Tagesbewusstsein nichts von dem in der Hypnose erteilten Befehl. Ist aber die bestimmte Zeit gekommen, so führt er, ohne zu wissen, warum, jene Handlung aus. Meines Wissens finden sich solche Beispiele auch bei Prof. Dr. Perty ${ }^{265}$ : „Die mystischen Erscheinungen [in] der menschlichen Natur”, Leipzig, Verlag Winter 1861; wohl auch in Justinus Kerners ${ }^{266}$ „Magikon” 5 Bände und vielleicht bei Du Prel ${ }^{267}$ : „Experimentalpsychologie”, Leipzig Friedrich 1891 oder seiner „Entdeckung der Seele durch die Geheimwissenschaften”, Leipzig Günther 1894. Wenn ich im kirchlichen Handlexikon von Dr. Buchberger in meinem Artikel "Stigmatisation" die Theorie aufstellte, dass die Natur und Gnade zusammenwirken, so könnte ich eine Art natürlicher Stigmatisation vorführen (auch im Bild!) in meinem Artikel „Autosuggestive Stigmatisation” (Jahrgang 1930 der „Zeitschrift fur Parapsychologie", Seite 229) und auch der bekannte Berliner Chirurg und Philosoph Dr. Schleich ${ }^{268}$ bringt Beispiele in seinen Werken "Gedankenmacht und Hysterie" (Berlin, Rowohlt 1920) und vom „der Gedanken”, „Von der Seele” (beide Berlin, Verlag Fischer). Ferner Du Prel „Magie etc.” - Finden sich also viele Analogien zu einzelnen Phänomenen von Konnersreuth. So ist doch bei Therese N[eumann] die Quelle eine andere, nämlich das tiefinnerliche religiös-sakramentale Leben, also die katholische Mystik! Deshalb schrieb ich in meinem Artikel über Konnersreuth in der „Zeitschrift für Parapsychologie“ 1927: „Ohne christliche Mystik keine Lösung der Ratsel von Konnersreuth”.

Ehrw[ürdigster] Exzellenz danke ich nochmals für den [... $]^{\mathrm{b}}$ Besuch und alle mir dabei erwiesene Liebe und Gute.

In Ehrfurcht Eurer Exzellenz ganz ergebener

Dr. Ludwig

265 Perty Maximilian Josef Anton (1804-1884), niemiecki entomolog i filozof przyrody, prof. Uniwersytetu w Bernie, autor m.in. prac: Die mystischen Erscheinungen in der menschlichen Natur (1861), Zur Kenntniss kleinster Lebensformen (1852), Grundzüge der Ethnographie (1859). S. Kirschner, Maximilian Perty, w: NDB, Bd. 20, Berlin 2001, s. 204.

${ }^{266}$ Kerner Justinus (1786-1862), niemiecki poeta, pisarz spirytualistyczny.

${ }^{267}$ Du Prel Carl (1839-1899), niemiecki filozof, okultysta, autor m.in. dzieł: Die Philosophie der Mystik (1885), Der Spiritismus (1893), Die Magie als Naturwissenschaft (1899). T. Weimann, Du Prel Carl Ludwig August Friedrich Maximilian Alfred, w: NDB, Bd. 4, Berlin, 1959, s. 200.

${ }^{268}$ Osoba niezidentyfikowana.

b Wyraz nieczytelny. 


\section{Dokument 74}

Oryg.: AFKDOPW, teczka 145: Spuścizna abp. Józefa Teodorowicza, sygn. 1067/420 (8) [7]-1082/420 (8) [7], List dr. Théodore Witry do abp. Józefa Teodorowicza, Metz 30 IX 1932 r.

Metz, 30. 9. 1932

$\mathrm{Eu}[\mathrm{re}]^{\mathrm{a}}$ Exzellenz!

Ich habe im Juni dieses Jahres dem Pfarrer Naber aus Konnersreuth ein Attest betr[eff] meine Untersuchung von Therese Neumann gegeben und habe keine Abschrift davon bekommen. Nun sagt Pfarrer Naber, er habe Ew[ere] Exzellenz das Attest mitgegeben. Darf ich um eine Abschrift desselben für meine Privatakten bitten.

Ich habe vor einigen Tagen ein Manuskriptbuch von Dr. Deutsch über Konnersreuther vom Verfasser zugeschickt bekommen, der „Nasophilia hysterica“ bei Freul[ein] Neumann diagnostiziert. Die Arbeit ist sehr wichtig als Streitschrift gegen Band II. von Dr. Gerlich.

Ich wünsche Eu[rer] Exzellenz eine gute Gesundheit und verbleibe in tiefer Verehrung und Hochachtung Ihr sehr ergebener

P.S. Was macht der kath[olischer] Frauenbund?

Witry

\section{Dokument 75}

Oryg.: AFKDOPW, teczka 144: Spuścizna abp. Józefa Teodorowicza, sygn. 1050/420 (8) [7], List o. Odo Staudingera OSB do abp. Józefa Teodorowicza, Salzburg 3 X 1932 r.

Salzburg, Erzabtel St. Peter, am 3. X. 1932

Exzellenz! ${ }^{\text {a }}$ Hochwürdigster Herr Erzbischof!

Hoffe, dass Exzellenz sich in Bachgastein gut erholt haben und glücklich wieder in Lemberg angekommen sind. Nun wird wieder große Arbeit auf Ihren Schultern lasten.

Ich bin am 20. Sept[ember] nach Salzburg zurückgekehrt. Gespannt bin ich auf gütige Nachricht, was Exzellenz von Bischof Buchberger gehört haben. Bitte recht sehr um gefällige Mitteilungen. Soeben erhalte ich vom Thomas-Verlag, Berlin W9 einen Zettel, der das Erscheinen eines neuen Werkes meldet: „Der gerade Aufstieg. Eine Harmonie von Konnersreuth und Vaticanum“. Von P[ater] Matthäus Kurz ${ }^{269} \mathrm{O}[\mathrm{rdo}]$ Cist[erciensis], 132 S., RM.1.80

In ehrfurchtsvoller Ergebenheit empfiehlt sich Eu[rer] Exzellenz

$\mathrm{P}$ [ater] Odo Staudinger OSB

a Tekst pisany czarnym atramentem na dwóch stronicach papieru formatu A4. W lewym górnym rogu karty tytułowej nadruk firmowy: „Docteur Witry, maladies nerveuses \& du sang, Metz, Place St. Thièbault, 39 , tèlèphone 1767 , pathologie sexuelle-psychanalyse”.

a Tekst pisany czarnym atramentem na dwóch kartach papieru formatu pocztówki. W lewym górnym rogu nadruk firmowy: „Schriftleitung des Benedictus-Boten”. W górnej partii karty na centralnym miejscu graficzna inskrypcja: „+ PAX”.

269 Osoba niezidentyfikowana. 


\section{Dokument 76}

Oryg.: AFKDOPW, teczka 145: Spuścizna abp. Józefa Teodorowicza, sygn. 1067/420 (8) [7]-1082/420 (8) [7], List dr. Théodore Witry do abp. Józefa Teodorowicza, Metz 14 X 1932 r.

Metz, 14. X. 1932

Ew[ere $]^{a}$ Exzellenz!

Ich danke bestens für Ihren gütigen und liebevollen Brief und für alle Ihre Bemühungen betr[eff] der Vorträge in Polen. Sie haben Recht: es ist schwer die drei Komitees der kathol[ischen] Frauenbünde von Warschau, Posen und Lemberg unter einen Hut zu bringen. Ich habe dem Abbe Korniłowicz ${ }^{270}$ in Warschau geschrieben.

Ich bin auch ganz Ihrer Meinung, dass nur ein Chirurge oder ein Anatompathologe auf die Streitschrift von Dr. Deutsch antworten kann. Die Broschüre greift ja nur Dr. Gerlich und Dr. Seidl ${ }^{271}$ an (Gerlich, Bd. II) und geht den tiefsten Ursachen und Geschehnissen von Konnersreuth aus dem Wege. Die paar Sätze und Allgemeinplätze über Hysterie besagen nichts. Es ist gut, dass die bayrischen Bischöfe, wie Ew[ere] Exzellenz mir schreiben, jetzt Therese Neumann einladen, längere Zeit in ein Krankenhaus zu gehen. Das kann aber nur eine Überwachung mit den größten Kautelen sein, um zu sehen, ob Therese nicht isst und nicht trinkt, keine Fäzes und keinen Urin ausscheidet.

Ich hoffe, dass Ew[ere] Exzellenz meine Bitte erfüllen werden und zeichne in Verehrung und Hochachtung ergebenst

Witry

\section{Dokument 77}

Oryg.: AFKDOPW, teczka 140: Spuścizna abp. Józefa Teodorowicza, sygn. 957/420 (8) [7], List ks. Härtla do abp. Józefa Teodorowicza, Konnersreuth 17 X 1932 r.

Excellenz! $!^{\mathrm{a}}$

Hoch[würdiger] $\mathrm{H}[\mathrm{err}]$ Erzbischof!

Für die mir gewidmeten Zeilen danke ich Eu[rer] Excellenz von ganzen Herzen. Da ich zu jener Zeit noch nicht in Konnersreuth war, als die bezeichneten Ereignisse sich

a Tekst pisany czarnym atramentem na 2,5 stronicach papieru formatu A4. W lewym górnym rogu karty tytułowej nadruk firmowy: „Docteur Witry, maladies nerveuses \& du sang, Metz, Place St. Thièbault, 39 , tèlèphone 1767, pathologie sexuelle-psychanalyse”.

${ }^{270}$ Korniłowicz Władysław (1884-1946), święcenia kapłańskie w 1912 r. w Krakowie, 1914-1916 kapelan Zakładu i Szkoły Gospodarczej w Kuźnicach, 1916-1918 wikariusz i katecheta par. Siennica, 1918-1921 kapelan wojskowy, 1922-1928 wykładowca liturgiki na KUL i dyrektor konwiktu księży studentów, 1930-1946 przebywał w Laskach $\mathrm{k}$. Warszawy; był autorem licznych publikacji z dziedziny ruchu liturgicznego. Z. Wit, Korniłowicz Wtadysław, w: EK, t. 9, red. zbior., Liblin 2002, kol. 862-863.

271 Osoba niezidentyfikowana.

a Tekst pisany czarnym atramentem na $\frac{1}{2}$ stronicy papieru formatu A4. Tekst z tzw. kurrentschriftu przepisała Pani Gerlinde Stohl - dyrektorka Muzeum w Sierndorfie an der March (Austria), za co zechce przyjąć szczere podziękowanie. 
dort abspielten, habe ich darüber keine persönlich Gewissheit und kann ich Eu[rer] Excellenz darüber Näheres nicht mitteilen.

Ihr Ehrfurcht und Hochachtung Ergebenster

Benef[iziat] Härtl

\section{Dokument 78}

Oryg.: AFKDOPW, teczka 141: Spuścizna abp. Józefa Teodorowicza, sygn. 994/420 (8) [7], List dr. A. Ludwiga do abp. Józefa Teodorowicza, Freising 19 X 1932 r.

Ehr[würdigster $]^{\text {a }}$ Exzellenz!

Freising, 19. X. [19]32

Ehrwürdigster Herr Erzbischof!

Mit Herrn Subregens, Dr. Westermaier ${ }^{272}$ habe ich Rücksprache genommen. Es ist im Bayrischen Kurier keine Nummer erschienen, die eine Zusammenstellung seiner Artikel über Konnersreuth beziehungsweise seiner Polemik gegenüber Dr. Wutz enthielte. Er findet leider auch keine Exemplare seiner Artikel mehr, um sie Ehrw[ürdiger] Exzellenz zu senden. Er will aber in der nächsten Woche die einzelnen Punkte seiner Kritik zusammenstellen und ich muss dieselben dann sogleich in eingeschriebenen Brief Ihnen zusenden.

Unterdessen verkündeten die Zeitungen, dass die hochwerten Bischöfe Bayerns auf einer Untersuchung der Nahrungslosigkeit bestehen. Darauf drängte ich schon seit fünf Jahren. Es muss sich nun zeigen, ob die Eltern der Therese und diese selbst auf den Wunsch eingehen. Wenn nicht, so wäre dies eine schlimme Wendung in der Sache Konnersreuth. Denn frommen Katholiken muss der Wunsch bzw. das Verlangendes Kirchlichen von Gott gesetzten Oberheiten Befehl sein!

Nehmen Exzellenz meine Versicherung entgegen, dass ich täglich zu rückderke an den liebenswürdigen bescheidenen hohen Prälaten, der mein Haus durch seine Anwesenheil beglückt hat.

In ehrfürchtiger tiefer Verehrung Ehr[würdigster] Exzellenz

Ergebenster

Dr. Ludwig

\section{Dokument 79}

Kopia: AFKDOPW, teczka 131: Spuścizna abp. Józefa Teodorowicza, sygn. 1623/184 [4], List abp. Józefa Teodorowicza do ks. redaktora Bolesława Kunki, Lwów 20 X 1932 r.

a Tekst pisany czarnym atramentem na 2,5 stronicach papieru formatu listowego. W lewym górnym rogu karty tytułowej nadruk firmowy: „Dr. A. Ludwig Hochschulprofessor”. Tekst z tzw. Kurrentschriftu przepisała Pani Gerlinde Stohl - dyrektorka Muzeum w Sierndorfie an der March (Austria), za co zechce przyjąć szczere podziękowanie.

${ }^{272}$ Właściwie: Westermayr. 


\section{Czcigodny ${ }^{\mathrm{a}}$ Księże Redaktorze!}

Przeczytałem cały manuskrypt O. Siwka i w moim przekonaniu nie zawiera on w sobie nic, co by mnie przyniewolić mogło do zmiany mego zasadniczego stanowiska. Moje stanowisko zaś określiłem w mej pierwszej pracy ${ }^{273}$ : uważam za zgubną tę metodę w badaniach zjawisk mistycznych, którą za pomocą nauk jak psychologia i medycyna przesądza w jakimkolwiek kierunku, choćby tylko przez non constat ${ }^{274}$ o problemach teologii mistycznej. Będę miał sposobność na tle dalszej dyskusji Szan[ownego] autora jeszcze jaśniej i silniej tę tezę rozwinąć, uważam bowiem ten problem za niezwykle ważny.

Już teraz wszakże zaznaczam na wstępie, iż tego głównego problemu nic przesłonić nie zdoła: ani najobszerniejsze i najpiękniejsze rozprawy mistyczne, ani kwestia uzdrowień Teresy Neumann i wszelkie rozstrzygania o tym, czy te uzdrowienia były cudowne, czy też nie, ani osobiste walory Teresy Neumann, ani kwestia dotycząca jej stanów mistycznych, ani też inne szczegóły, chociaż cenne, rozpatrywane w tej sprawie. Wszystko to są tylko akcesoria, które w dyskusji o tyle tylko mają wartość, o ile się zbiegają w niej $\mathrm{z}$ tym zasadniczym problemem.

1) Dlatego z takim naciskiem podkreślam samą istotę zagadnienia, jakie poruszyłem w mej pracy, aby w tym istnym obrazie szczegółów, jakie w swej bardzo obszernej a zupełnie nowej rozprawie Szan[owny] autor rozwija, ten główny i zasadniczy problem nie został przez masę dyskusji jakby przytłoczony, albo z pola zepchnięty.

Ale mam jeszcze inny, bardzo poważny powód, dla którego uważam za wskazane na samym wstępie przypomnieć, co było głośnym i zasadniczym celem mej pracy.

2) Nie tyko ze względu na masę szczegółów całkiem nowego dzieła o Konnersreuth, ale i ze względu na metodę polemiki autora uważam za konieczne zwrócić uwagę na wstępie, o co właściwie wyłącznie idzie w tej rozprawie. Albowiem metoda autora polega na tym, że autor ustawicznie usiłuje zepchnąć mnie ze stanowiska, jakie zająłem na stanowisko mi obce, ideom przeze mnie wyłożonym wręcz przeciwnie. Zbyt jasno określiłem moje stanowisko, by się pozwolić zeń wyrugować przez formalne uczepianie się słów lub zwrotów, albo przez odłączenie mojej myśli od związku, jaki ona miała lub przez podsuwanie pod moje wyrazy sensu, jakiego one zupełnie nie miały. Znajduję w tej rozprawie O. Siwka czasem przytaczane ustępy moich słów, znajduję w odpowiedzi przytoczony zastęp medycznych powag, znajduję nawet skrzętnie wyzbierane teksty listów pochwalnych dla autora, znajduję autorytet rozgłośnego dzieła kardynała Lambertini, późniejszego papieża Benedykta XIV ${ }^{275}$, ale nie znajduję jednego; nie znajduję mojej myśli, nie znajduję wyjaśnionego mego stanowiska, nie znajduję odpowiedzi na to właśnie moje zasadnicze stanowisko przedstawione przez autora nieraz w wyrwanych z kontekstu słowach, ale w całości z gruntu zmienione.

a Tekst pisany maszynowo na 5,5 stronicach papieru formatu A4. Brak autografu autora oraz datacji dziennej i miesięcznej.

${ }^{273}$ J. Teodorowicz, Zjawiska mistyczne i ich ttumaczenia, AK, 18(1932), t. 29, z. 1, s. 1-16; z. 2, s. $105-$ 121; z. 3, s. 209-229; z. 4, s. 313-338.

274 Łac.: nie jest stwierdzone; nie wiadomo.

${ }^{275}$ Zob. w niniejszej publikacji: J. Wołczański, Korespondencja abp. Józefa Teodorowicza z prof. Stefanem Dąbrowskim, dokument 50. 
Czytając tę odpowiedź autora odnoszę takie wrażenie, jakie odnosi ktoś, kto otrzymał list wprawdzie pod swoim adresem, ale zamieniony i przeznaczony właściwie dla jakiegoś innego adresata. $\mathrm{Z}$ tą próbą autora będę zmuszony gruntownie się rozprawić, ale taka rozprawa znowu mimo woli pociągnie za sobą konieczne w tym razie odchodzenie od właściwego tematu.

3) Miałem jeszcze inny powód, dla którego zwracam zaraz na wstępie uwagę, iż chodziło mi w mej pracy o rozwinięcie zasadniczego problemu, a nie o wszelkie kwestie osobiste, ani też o rozstrzyganie samego problemu Konnersreuth. Oto sposób ujęcia dyskusji przez autora przyniewala mnie, aby przypomnieć czytelnikowi i ten główny cel pracy mojej, i tylokrotnie, i tak wyraźne moje zastrzeżenia, iż dotykam kwestii metod bez względu na to, czy zjawiska w Konnersreuth są prawdziwe, czy fałszywe, czy Teresa Neumann żyje prawdziwym życiem wewnętrznym, czy też nie.

Otóż sądziłem, że po tylokrotnych i tak jasnych zastrzeżeniach miałem wszelkie prawo liczyć na to, że autor w swej odpowiedzi to moje zasadnicze stanowisko uszanuje. Tymczasem, niestety, stało się inaczej. Mianowicie autor stara się przedstawić mnie w tej pracy, jako partyjnego obrońcę tak Teresy Neumann, jak cudowności w Konnersreuth. Tego wprawdzie autor jasno nie wyraża, ale ta idea jest tak przejrzysta w jego rozprawie, tak występuje zaraz od wstępu aż do ostatniej kropki zakończenia, iż czytelnik, który by nie czytał mojej rozprawy i moich kategorycznych zastrzeżeń musiałby przejść do przekonania, iż się znajduje w jednym z dwóch obozów walczących w problemie Konnersreuth. Mój obóz, jak to wciąż podsuwa sugestywnie O. Siwek, to obóz tzw. Konnersreuthzirkel ${ }^{276}$; w przedstawieniu O. Siwka blisko ja tu stoję, może nie bezpośrednio, ale bądź co bądź intencjami. Jaki to obóz, o tym się dowiaduje czytelnik zaraz z pierwszej karty polemicznej O. Siwka. Jest to obóz łatwowiernych, jeżeli nie fanatycznych ludzi, obóz, który rozdmuchuje mętne i niezdrowe kierunki, jakie przepływają teraz przez świat, obóz, który chce wszędzie widzieć cuda i zżyma się na tych, którzy w imię poważnej nauki i badań krytycznych jemu się przeciwstawiają i znajduje się w walce $\mathrm{z}$ nimi.

$\mathrm{Na}$ samym wstępie swej rozprawy autor przedstawia cały szereg imion poważnych profesorów i badaczy, słowem elity intelektualnej, która się temu pierwszemu obozowi przeciwstawia; przeciwstawia krytycyzm łatwowierności, naukę - naiwnej wierze.

Oto jest punctum saliens ${ }^{277}$ całej krytyki polemicznej autora polegającej na podsuwaniu mi idei, jakich nie miałem. Stąd pochodzi cała usilność autora, aby problem Konnersreuth sprowadzić z dziedziny metodycznej na dziedzinę merytoryczną. Nie dam się autorowi oczywiście ściągnąć z mojego raz zajętego stanowiska. Skoro autor ma moich dotychczasowych wywodów za mało, to służę mu dalszymi i w rozprawie nie zostanę mu dłużnym w odpowiedzi. Przed rozprawą wszakże tyle zaznaczę, iż wziąłem się do pracy i do napisania książki o Konnersreuth głównie w tym celu, aby problem ten z jednostronnego i jakoby partyjnego stanowiska przenieść na stanowisko krytyczne i nadpartyjne. O tym, że nie szedłem za żadnym podmuchem łatwowiernej bezkrytyczności rozsądzi najlepiej moja rozprawa. Nadmienię tu tylko, iż poczuwam się tak bardzo do odpowiedzialności wobec Kościoła i krytycznej nauki za każde niemal moje słowo, iż

\footnotetext{
${ }^{276}$ Niem.: krąg (obóz) Konnersreuth.

277 Łac.: punkt główny, zasadniczy.
} 
wstrzymuję się dotąd z wydaniem mojej książki o Konnersreuth, które uzależniam od pewnych warunków dziś jeszcze nieziszczonych. Nie mam pretensji, by praca moja rozstrzygała problem Konnersreuth, rozstrzyganie o tym problemie w ogóle nie należy do mnie; sądzę jednak, że o jakąś partyjność w rozwiązaniu problemu Konnersreuth nikt mnie oskarżać nie będzie. I mogę dziś już z uznaniem podnieść, że właściwie ci ludzie, o których O. Siwek sądzi, iż stoją w obozie mnie przeciwnym, najbardziej właśnie mnie zachęcali do wydania książki o Konnersreuth; nie znając jeszcze mej pracy ufali mi, że stanę na stanowisku nadpartyjnym. Także i pod krytycznym i naukowym względem uczyniłem co mogłem, aby w miarę moich sił problem był ze stanowiska nowoczesnej nauki i teologii rozpatrzony.

Nie żałowałem na to ani czasu, ani trudu; odbywałem liczne konferencje, jeździłem $\mathrm{w}$ tym celu do różnych miast zagranicznych, konferowałem także z naszymi uczony$\mathrm{mi}$, aby w tym tak skomplikowanym problemie iść za najnowszym postępem nauki, jak i utwierdzić go o teologię mistyczną. Sądzę, że wobec taktyki autora to słówko osobistej apologii nie będzie zbyteczne.

Łączę przy tej sposobności dla Czcigodnego Księdza Redaktora wyrazy głębokiego szacunku i poważania.

Lwów, dnia $[\ldots]^{\mathrm{b}} 1932$

\section{Dokument 80}

Kopia: AFKDOPW, teczka 127: Spuścizna abp. Józefa Teodorowicza, sygn. 1288/420 (12) [7], List abp. Józefa Teodorowicza do ks. dr. Stanisława Brossa, Lwów 22 X 1932 r.

Kochany ${ }^{\mathrm{a}}$, Przezacny Księże Doktorze!

Bardzo dziękuję za list, lecz mam nadzieję, że już osobiście sprawę omówię z Księdzem Doktorem w Poznaniu. Niestety, praca o Konnersreuth znowu się odwleka skutkiem tego, że Siwek w odpowiedzi poumieszczał w „Ateneum” nową książkę rozłożoną na czas sześciu miesięcy. Musiałem wciąż myśleć o odpowiedzi. No, ale po powrocie z Poznania wezmę się do rzeczy.

Jeszcze raz dziękuję Księdzu Doktorowi i łączę bardzo serdeczne i oddane wyrazy.

[P.S.] Co też Księdzu Doktorowi do głowy przychodzi z Karskąa ${ }^{278}$ i Darowską? ${ }^{279}$ Niechże one sobie trochę wypoczną.

Lwów, dnia 22 października 1932

Ks. Dr Bross ${ }^{280}$ - Poznań

[al.] Marcinkowskiego 22

b Brak tekstu; z innego źródła wiadomo, że dokument nosił datację 20 X 1932 r.

a Tekst pisany maszynowo na jednej stronicy papieru formatu A4. Brak autografu autora.

${ }^{278}$ Zob. w niniejszej publikacji: J. Wołczański, Korespondencja abp. Józefa Teodorowicza z abp. Adamem Stefanem Sapieha, dokument 76.

279 Tamże, dokument 15.

${ }_{280}$ Zob. w niniejszej publikacji: J. Wołczański, Korespondencja abp. Józefa Teodorowicza z prof. Stefanem Dąbrowskim, dokument 33. 


\section{Dokument 81}

Oryg.: AFKDOPW, teczka 145: Spuścizna abp. Józefa Teodorowicza, sygn. 1033/420 (8) [7], List ks. prałata Johanna Westermayra do abp. Józefa Teodorowicza, Freising 24 X 1932 r.

Freising, den 24. Oktober 1932

Exzellenz! ${ }^{\text {a }}$

Hochwürdigster Herr Erzbischof! Gnädigster Herr!

Es hat mir ehrfurchtsvollst Unterzeichnetem sehr leid getan, daß Eure Exzellenz mich bei Ihrem Freisinger Aufenthalt nicht antreffen konnten. Wie mir Herr Geh[eim]rat Hochschulprofessor Ludwig, der hochverdiente Forscher und Schriftsteller auf dem Gebiet der Parapsychologie, mitteilte, wünschen Eure Exzellenz Kenntnis zu erhalten von den Gründen, die mich zu meiner zurück-und abwartenden Haltung gegenüber der Konnersreuther Mystik bestimmten. Diese Reserve wurde zunächst von persönlichen Erfahrungen in Ko[nnersreuth] beeinflußt. Abgesehen von einigen wenig erfreulichen Umständen, die nach meinen Beobachtungen die Ko[nnersreuth] er Vorgänge mitunter begleiten, wurde mein Glaube an die göttliche Sendung der Th[erese] Neumann ins Wanken gebracht durch eine recht verworrene und nicht widerspruchslose Auskunft, die sie mir im erhobenen Ruhezustand über eine mir von einem Augustinerpater mitgegebene Reliquie und den Ordensmann, von dem die Reliquie war, erteilte, sodann durch einen mir von ihr wieder im Zustand der erhobenen Ruhe bezüglich einer Beichtangelegenheit gegebenen Rat, dessen Befolgung nicht nur nach meiner Überzeugung, sondern auch nach dem Urteil eines Moralprofessors einen direkten Bruch des Beichtsiegels involviert hätte. Ich wurde dadurch veranlaßt, mich in das Studium der mystischen Kriterienlehre zu vertiefen. Im Lichte derselben gewannen für mich manche Tatsachen und Umstände der Ko[nnersreuth]er Mystik als recht bedenkliche und ungünstige Zeichen Bedeutung. Als solche sind nach meiner Ansicht anzusprechen:

1) Das ungewöhnlich starke Vorherrschen äußerer und akzidenteller Phänomene gegenüber der Innennystik: jene Phänomene können (z.B. nach dem Hl. Ignatius, vgl. „Zeitschr[ift] f[ür] Aszese und Mystik“ 1930 H.2 S.176 ff.) zum Zweck der Täuschung auch vom Teufel bewirkt sein; soweit nicht natürliche supranormale Beursachung in Frage kommt;

1) Die Häufigkeit der Privatoffenbarungen, namentlich im Zusammenhalt mit derem häufigen Inhalt: Auskunft über das jenseitige Schicksal Abgeschiedener, über Dinge ohne religiöse Bedeutsamkeit;

2) Die Selbstsicherheit, mit der Th[erese] N[eumann] a) jedem Zweifel an ihrer göttlichen Begnadigung und der göttliche Bewirkung ihrer Visionen, Offenbarungen usw. unzugänglich ist, ganz im Gegensatz zu den großen Mystikern, die gerade bei außergewöhnlichen Begnadigungen, bei nicht rein geistigen Visionen usw. immer in größter Furcht vor Täuschungen lebten; b) sich als Organ und „Stimme Christi“ betrachtet, was

a Tekst pisany maszynowo na dwóch stronicach papieru formatu A4. Autograf odręczny czarnym atramentem. 
nach Benedikt XIV ein besonders bedenkliches signum ist; c) über jene aburteilt, die Zweifel an ihrer göttlichen Begnadigung hegen (Beispiele könnte ich anführen);

3) Die psychischen Zustände, namentlich a) der sog[ennanten] Eingenommenheit mit der kleinkindlichen Betrachtungs-und Ausdrucksweise, die nach meiner Überzeugung nie und nimmer als göttlich bewirkt, sondern nur als psychologisches Phänomen erklärt werden kann und in der Geschichte der echten Mystik kaum jemals Vorgekommen ist; b) der Erinnerungslosigkeit bezüglich des ihr im Zustand der erhobenen Ruhe Geoffenbarten, die gleichfalls von der Mystik als negatives Zeichen bewertet wird.

Was das Phänomen ihrer Nahrungslosigkeit betrifft, so wird diese von katholischen Ärzten in Zweifel gezogen (vgl. Heermann, besonders auch die Schrift des Dr. med. Deutsch „Um Konnersreuth“; bisher nur im Manuskript erschienen und erhältlich vom Verfasser, Chefarzt in Lippstadt, Westfalen, Dreifaltigkeitsspital), ist aber auch im Falle ihrer Tatsächlichkeit kein ganz sicherer Beweis der Übernatürlichkeit der Ko[nnersreu]ther Mystik, da zur Sichersteilung der göttlichen Verursachung dieser Nahrungslosigkeit bei Th[erese] N[eumann] nicht alle Bedingungen erfüllt sind, die Benedikt XIV in seinem Werk „De servorum Dei beatificatione et beatorum canonizatione“ lib. IV. pars I, cap. 27 „De longa abstinentia a cibo et potu“ verlangt.

Meine Bedenken gegen Ko[nnersreuth] habe ich seinerzeit in einem Referat in München in der Marianischen Kongregation der Priester vorgetragen; zum Teil sind sie auch angeführt in einer Arbeit von mir über Klerus und Mystik, Grundsätzliches, Pastorelles und Literaturbericht über Mystik (u[nd] Ko[nnersreuth]), die ich, veranlaßt durch Dr. Dubowy $^{281}$ - Braunsberg ${ }^{282}$, dem Verlag Badenia-Karlsruhe auf dessen Wunsch angeboten habe, ohne bisher eine Antwort erhalten zu haben.

Ich bitte Eure Exzellenz, von dem, was ich bezüglich der Auskunft in einer Beichtangelegenheit berichtet habe, keinen literarischen Gebrauch zu machen.

Ehrfurchtsvollst verharrt Eurer Exzellenz untertänigstergebenster

${ }^{\mathrm{b}-M s g r . ~ D r . ~ J o h[a n n] ~ W e s t e r m a y r ~}{ }^{-\mathrm{b}}$

Subregens am Klerikalseminar

\section{Dokument 82}

Kopia: AFKDOPW, teczka 136: Spuścizna abp. Józefa Teodorowicza, sygn. 1304/420 (12) [7], List abp. Józefa Teodorowicza do ks. dr. Stefana Wyszyńskiego, Lwów 9 XI 1932 r.

\section{Przezacny ${ }^{a}$ Księże Redaktorze!}

${ }^{281}$ Dubowy Ernst (1891-1945), dr teologii oraz filozofii, święcenia kapłańskie we Wrocławiu, wikariusz katedralny tamże, rektor Seminarium Duchownego i prof. teologii pastoralnej Akademii Państwowej w Braunsbergu, 1941-1945 kapelan domu sióstr zakonnych w Zủlz, autor licznych publikacji z dziedziny teologii pastoralnej. G.S., Dubowy Ernst, w: DLL, Bd. 6, herausg. von K. Feichenfeld, Zürich-München 1971, s. 604.

${ }^{282}$ Braunsberg - Braniewo; miasto położone na Równinie Warmińskiej nad rzeką Pasłęką w ówczesnych Prusach Wschodnich.

b-b Fragment napisany czarnym atramentem.

a Tekst pisany maszynowo na jednej stronicy papieru formatu A4. Brak autografu autora listu. 
Niestety, list Księdza Redaktora doszedł dopiero później do rąk moich po moim wyjeździe z Włocławka. Żałuję niezmiernie, że nie miałem sposobności zetknąć się z Księdzem Redaktorem, dlatego na tej drodze składam Księdzu Redaktorowi życzenia serdeczne dla Jego tak trudnej, tak odpowiedzialnej, ale i też i tak owocnej pracy.

Telegraficznie zażądany manuskrypt O. Siwka natychmiast po przybyciu do Lwowa wysłałem. Nie rozumiem, co to znaczyć ten krok ze strony Ojców? ${ }^{283}$ Przypuszczam, że doszła ich pogłoska, iż ja nie myślę milczeć, ale będę stale odpowiadał i to może było powodem wycofania manuskryptu.

W razie, gdyby to wycofanie było definitywne, to prosiłbym księdza Redaktora o zwrot mojego artykułu, którego ogłoszenie będzie bezprzedmiotowe.

Łączę wyrazy prawdziwie oddane głębokiego poważania.

Lwów, dnia 9 listopada 1932

Przew[ielebny] Ks. Stefan Wyszyński ${ }^{284}$

Włocławek ${ }^{285}$ - Sem[inarium] duch[owne]

\section{Dokument 83}

Kopia: AFKDOPW, teczka 136: Spuścizna abp. Józefa Teodorowicza, sygn. 1300/420 (12) [7], List abp. Józefa Teodorowicza do ks. dr. Aleksandra Żychlińskiego, Lwów 11 XI 1932 r.

\section{Przezacnya Księże Prałacie!}

Śpieszę donieść, że w ostatniej chwili telegraficznie wycofany został przez prowincjała Jezuitów manuskrypt ojca Siwka. Trochę podejrzewam o to Księdza Prałata i Jego interwencję; w takim razie byłoby to bardzo szczęśliwe, albowiem nie próbowano by już z pewnością innych dróg, które by miały tym fatalniejszy rezultat. Wtedy już bowiem skompromitowano by się do szczętu.

We wspomnieniu tak miłej i ciepłej pogadanki wieczornej z Księdzem Prałatem pozostaję szczerze oddany.

Lwów, dnia 11 listopada 1932

Przew[ielebny] Ks. Prałat Żychliński ${ }^{286}$

Poznań - Sem[inarium] duch[owne]

${ }^{283}$ Aluzja do oo. Jezuitów.

${ }^{284}$ Wyszyński Stefan (1901-1981), święcenia kapłańskie w 1924 r. we Włocławku, 1925-1929 studia specjalistyczne na KUL uwieńczone doktoratem, 1932-1939 redaktor naczelny „Ateneum Kapłańskiego”, działacz społeczno-oświatowy w chrześcijańskich związkach zawodowych, w okresie II wojny światowej ukrywał się na Lubelszczyźnie, 1945-1946 rektor Seminarium Duchownego we Włocławku, 1946-1948 biskup ordynariusz lubelski, 1948-1981 arcybiskup metropolita gnieźnieński i warszawski, w 1953 r. kreowany kardynałem, prymas Polski, 1953-1956 internowany przez władze komunistyczne. A. Micewski, Kardynat Wyszyński. Prymas i maż stanu, Paris 1982, passim.

285 Włocławek - miasto nad Wisłą, historyczna stolica Kujaw.

a Tekst pisany maszynowo na jednej stronicy papieru formatu A4. Brak autografu autora listu.

286 Żychliński Aleksander (1889-1945), święcenia kapłańskie w 1913 r. dla archidiec. poznańskiej, dr teologii, 1918-1939 wykładowca w Seminarium Duchownym w Poznaniu, 1927-1929 rektor Seminarium 


\section{Dokument 84}

Oryg.: AFKDOPW, teczka 144: Spuścizna abp. Józefa Teodorowicza, sygn. 1047/420 (8) [7], List o. Odo Staudingera OSB do abp. Józefa Teodorowicza, Salzburg 26 XI 1932 r.

Salzburg, Erzabtel St. Peter, am 26. XI. 1932

Exzellenz! $!^{\mathrm{a}}$

Hochwürdigster Herr Erzbischof!

Habe gestern bei Pustet mit Direktor Müller ${ }^{287}$ in Ihrer Angelegenheit gesprochen. Er betrachtet die neue Lage als eine vis major und besteht nicht auf Einhaltung des Termins. Wenn die Antwort von Konnersreuth eine endgültige negative sein wird, wird er wahrscheinlich das Werk gar nicht mehr wollen. Wenn dagegen Therese in eine Klinik kommt, möchte er das Werk bald herausbringen. Er meint, durch die Arbeit des P[ater] Siwek sollten sich Exzellenz nicht abhalten lassen, das Manuskript bald abzuschließen.

Wenn P[ater] Siweks wichtigste Argumente nicht hineingearbeitet werden könnten, könnte eine neue Gegenschrift verfasst werden. Gegner wird es noch auf Jahrzehnte geben.

Ich würde es sehr bedauern, wenn es zu keiner Untersuchung käme. Ich meine, Bischof Buchberger und Vater Neumann könnten sich doch auf einer mittleren Linie einigen. Oder sollte das Heiland dagegen sein wie einst bei Gemma Galgani? Habe beiliegenden Aufsatz geschrieben. Er ist noch nicht erschienen. Wenn Exzellenz etwas oder viel an ihm auszusetzen haben, wäre ich für gütige Mitteilung sehr dankbar.

Genehmigen hochwürdigster Herr Erzbischof den Ausdruck meiner vorzüglichen Verehrung als Ew[ere] Exzellenz ehrfurchtsvoll ergebener

$\mathrm{P}$ [ater] Odo Staudinger OSB

\section{Dokument 85}

Oryg.: AFKDOPW, teczka 145: Spuścizna abp. Józefa Teodorowicza, sygn. 1067/420 (8) [7]-1082/420 (8) [7], List dr. Théodore Witry do abp. Józefa Teodorowicza, Metz 1 XII 1932 r.

Metz, 1. XII. [19]32

Eure $^{\text {a }}$ Exzellenz!

Hochwürdigster Herr Erzbischof!

Duchownego w Gnieźnie, 1939-1945 poza archidiecezją na terenie Polski. Autor publikacji z dziedziny teologii życia wewnętrznego. M. Banaszak, Żychliński Aleksander, w: SPTK, t. 7, s. 519-523.

a Tekst pisany czarnym atramentem na dwóch kartach papieru formatu pocztówki. W lewym górnym rogu nadruk firmowy: „Schriftleitung des Benedictus-Boten”. W górnej partii karty na centralnym miejscu graficzna inskrypcja: „+ PAX”.

287 Müller Otto (?-1956), austriacki przedsiębiorca, 1930-1937 kierownik Wydawnictwa Antoniego Pusteta w Salzburgu, 1937-1938 kierował oficyną wydawniczą pod swoim nazwiskiem, po przejęciu jej przez władze nazistowskie drukował nadal, odzyskując własność po II wojnie światowej. Instytucja funkcjonuje do naszych czasów.

a Tekst pisany czarnym atramentem na dwóch stronicach papieru format listowego. W lewym górnym rogu karty tytułowej nadruk firmowy: „Docteur Witry, Maladies nerveuses et du sang, Metz, Place St. Thiébauld 39, telephone 1767, pathologie sexuelle”. 
Ich habe eine kleine Broschüre über wunderbare Kommunionen (Fernkommunionen) bei Stigmatisierten, auch bei Theresa Neumann, geschrieben. Würden Eure Exzellenz, als Autorität auf dem Gebiete der Mystik und Stigmatisation mir dafür das Imprimatur geben? Ich werde Ihnen dann die Arbeit einsenden. Von Warschau habe ich einen derart sonderbaren Brief des Herrn, an den Eure Exzellenz mich verwiesen hatten, bekommen, dass ich glatt ablehnen musste für Warschau. Ich hoffe, dass Gott Eur[e] Exzellenz Gesundheit und Wohlergeben schenkt und zeichne in tiefer Verehrung und Ergebenheit

Witry

P.S. Genaueres über die neuen Beobachtungen der Fr[eu]l[ein] Resl in Würzburg habe ich seit Wochen nicht gehört.

\section{Dokument 86}

Oryg.: AFKDOPW, teczka 145: Spuścizna abp. Józefa Teodorowicza, sygn. 973/420 (8) [7], Nota ks. Henryka Weryńskiego, Kraków 2 XII 1932 r.

\section{P[leno $]^{\mathrm{a}}$ T[itulo $]^{288}$ !}

Bardzo mi zależy na umieszczeniu komunikatu w nowej książce o Konnersreuth. Gdyby - broń Boże - nie konweniował Wam, proszę o łaskawe odesłanie. Umieszczę gdzie indziej. Ale proszę - dajcie - go in extenso ${ }^{289}$, to naprawdę rewelacyjna publikacja. Bardzo proszę!

Z czcią powinną i oddaniem

Ks. Henryk Weryński ${ }^{290}$

${ }^{\mathrm{b}-K s . ~ H e n r y k ~ W e r y n ́ s k i ~}$

Kraków, ul. Tarłowska 8 ${ }^{-b}$, dnia 2 grudnia 1932

\section{Dokument 87}

Oryg.: AFKDOPW, teczka 144: Spuścizna abp. Józefa Teodorowicza, sygn. 1046/420 (8) [7], List o. Odo Staudingera OSB do abp. Józefa Teodorowicza, Salzburg 5 XII 1932 r.

Salzburg, Erzabtei St. Peter, am 5. XII. 1932

\footnotetext{
a Tekst pisany czarnym atramentem na $1 \frac{1}{2}$ stronicy papieru formatu A4. Adresat nieznany. W lewym dolnym rogu podłużna pieczęć w personaliami autora.

${ }^{288}$ Łac.: z zachowaniem należnych tytułów.

289 Łac.: w całości.

290 Zob. w niniejszej publikacji: J. Wołczański, Korespondencja abp. Józefa Teodorowicza z abp. Adamem Stefanem Sapieha, dokument 101.

b-b Podłużna pieczęć.
} 


\section{Exzellenz! $!^{\mathrm{a}}$}

Hochwürdigster Herr Erzbischof!

Recht sehr danke ich Exzellenz für Ihren und Prof. Wutz's Brief. Auch freut s mich, dass mein Aufsatz „Th[erese] N[eumann] und Gemma G[algani]“ Ihnen zur Ursache frohen Lachens wurde.

Wenn Exzellenz wieder Authentisches über Th[erese] N[eumann], besonders was die Untersuchung anbelangt, erfahren, so würde ich jetzt schon wieder um gütige Mitteilung bitten.

Bis dahin und noch länger wollen wir mit dem H[ei]l[ige] Vater Pius XI. „Therese Neumann ganz der Leitung der göttlichen Vorsehung überlassen“. So sagte er einem Jesuiten!

In ehrfurchtsvoller Ergebenheit grüßt

P[ater] Odo Staudinger OSB

\section{Dokument 88}

Oryg.: AFKDOPW, teczka 142: Spuścizna abp. Józefa Teodorowicza, sygn. 999/420 (8) [7], List o. Aloisa Magera OSB do abp. Józefa Teodorowicza, Salzburg 5 XII 1932 r.

Salzburg, 5. XII. [19]32

Eurer ${ }^{a}$ Exzellenz,

danke ich verbindlichst für die Übersendung Ihres Manuskriptes. Leider wird es nicht möglich sein, den längeren Text zu bringen. Der Kurze ist aber so ausgezeichnet, dass er ein Bild zu geben vermag von dem ganzen Reichtum und der Tiefe Ihrer Vorträge. Der Druck des Buches ist im vollen Gang. Es muss vor Weihnachten noch auf dem Büchermarkt erscheinen. Darum das Drängen und Eilen. Wie steht es mit Konnersreuth?

Mit ehrfurchtsvollem Ringkuss bin ich Eueren Exzellenz in X[rist]o ergebenster $\mathrm{P}$ [ater] Alois Mager OSB

\section{Dokument 89}

Kopia: AFKDOPW, teczka 136: Spuścizna abp. Józefa Teodorowicza, sygn. 1338/420 (12) [7], List abp. Józefa Teodorowicza do kard. Augusta Hlonda, Lwów 14 XII 1932 r.

\section{Wasza ${ }^{a}$ Eminencjo!}

Prawdziwie wzruszył mię Wasza Eminencja swą pamięcią o mnie i o mej pracy. Niesłychanie mi się przydadzą oba wycinki przysłane mi przez Waszą Eminencję, zwłaszcza

a Tekst pisany czarnym atramentem na dwóch kartach papieru formatu pocztówki. W lewym górnym rogu nadruk firmowy: „Schriftleitung des Benedictus-Boten”. W górnej partii karty na centralnym miejscu graficzna inskrypcja: „+ PAX”.

a Tekst pisany czarnym atramentem na dwóch kartach papieru formatu pocztówki.

a Tekst pisany maszynowo na 2,5 stronicach papieru formatu A4. Brak autografu autora tekstu. 
ucieszyłem się informacją z artykułu Gerlicha, iż interwencja moja u niego i u profesora Wutza odniosła pożądany skutek. Natarłem na nich obu bardzo silnie, ażeby u ojca Teresy Neumann wymogli zmianę jego nieprzejednanego stanowiska. Dotąd o tym nikomu nie mówiłem, ale skoro to już Gerlich ogłosił, to dziś mogę powiedzieć, że odpowiedź Neumanna, która nie jest negatywna, jest ratunkiem całej sytuacji. Ojciec Teresy niezawodnie postawił Episkopatowi warunki ze swej strony i należy się spodziewać, że jakiś kompromis przyjdzie do skutku. Udawał się do mnie Kaczyński ${ }^{291} \mathrm{z}$ tą sprawą, być więc bardzo może, że coś o tym napisze.

Tu mam wiele bardzo kłopotów skutkiem zajść młodzieży, związanych z zamordowaniem jednego z nich przez żydab; mam jednak nadzieję, że uda się młodzież ochronić przed nieopatrznymi i bardzo dla niej szkodliwymi krokami. Był tu Rostworowski ${ }^{292}$, redaktor „Dnia Polskiego" ${ }^{293}$ z odczytem, w którym zaatakował Episkopat, mówiąc, że chociaż odbywa konferencję w Warszawie, to jednak nie uznał za stosowne odezwać się w sprawie młodzieży. O młodzieży wyrażał się jak najgorzej; w godzinę po jego odczycie już się ukazała odezwa nasza. Po odczycie sami członkowie jego klubu uprosili księdza Ciemniewskiego ${ }^{294}$, aby zabrał głos w dyskusji.

Ten w grzecznej bardzo formie, ale dał panu Rostworowskiemu ciętą odprawę. Powiedział mu, że Księża Biskupi mają różne sposoby wpływania na sytuację, jak na przykład w tym wypadku na młodzież, które nie muszą być koniecznie zaraz publiczne i dlatego uważa za wysoce niewłaściwe atakowanie Episkopatu za to, co się komuś dla braku głębszej znajomości sprawy nie podoba.

Wywlekanie na forum publiczne jednej ze spraw broszury Łubieńskiego ${ }^{295}$ uważa ksiądz Ciemniewski również za wysoce niewłaściwe, bo należałoby tę sprawę załatwić z Nuncjaturą, a nie używać jej jako środka krytyki. Co do oskarżenia młodzieży, której odbierają autonomię uniwersytetu, której nie dopuszczają do niego, nakładając na nią wielkie taksy, chyba aż zanadto wiele okazuje cierpliwości; nie w niej, ale poza nią trzeba szukać przyczyny złego.

Pozwalam sobie dołączyć list i odezwę pana Sikorskiego ${ }^{296}$, która jest niezawodnie bardzo poczciwą i gorącą, ale wskutek „Cyrenejczyka i Weroniki” trochę osobliwa. Ja

${ }^{291}$ Zob. w niniejszej publikacji: J. Wołczański, Korespondencja abp. Józefa Teodorowicza z abp. Adamem Stefanem Sapieha, dokument 85.

b Zapis zgodny z oryginałem.

${ }^{292}$ Rostworowski Wojciech Hilary (1877-1952), absolwent prawa, działacz Ligi Narodowej i Stronnictwa Demokratyczno-Narodowego, od 1926 r. w szeregach propiłsudczykowskiego Stronnictwa Prawicy Narodowej, 1925-1939 szef Zarządu Polskiej Agencji Publicystycznej, 1927-1933 redaktor naczelny dziennika „Dzień Polski”, 1930-1939 senator RP, 1939-1945 mieszkał w Szczakach, 1945-1952 przebywał w Zalesiu k. Warszawy. J. Molenda, Rostworowski Wojciech Hilary, w: PSB, t. 32, red. zbior., Wrocław-Warszawa-Kraków 1989-1991, s. 246-250.

${ }^{293}$ „Dzień Polski” - dziennik wydawany w latach 1924-1933 w Warszawie pod redakcją Alfonsa Dziaczkowskiego.

${ }^{294}$ Zob. w niniejszej publikacji: J. Wołczański, Korespondencja abp. Józefa Teodorowicza z abp. Adamem Stefanem Sapiehą, dokument 27.

${ }^{295}$ Zob. w niniejszej publikacji: tenże, Korespondencja abp. Józefa Teodorowicza z abp. Józefem Bilczewskim, dokument 133.

${ }^{296}$ Osoba niezidentyfikowana. 
mu odpisałem, że się stosuję do jego życzenia i odsyłam odezwę tam, gdzie należy, jemu nie pisząc jednak bliżej, że ją odsyłam Waszej Eminencji.

Korzystam z tej sposobności, ażeby raz jeszcze Waszej Eminencji podziękować i przesyłam nieurzędowe wprawdzie, ale bardzo gorące i bardzo oddane życzenia świąteczne.

Całuję pierścień Waszej Eminencji w najgłębszej czci.

Lwów, dnia 14 grudnia 1932

\section{Dokument 90}

Kopia: AFKDOPW, teczka: Spuścizna abp. Józefa Teodorowicza, sygn. 1743/64 [5], Pismo Szczepana Jeleńskiego z Działu Wydawniczego Drukarni i Księgarni św. Wojciecha w Poznaniu do abp. Józefa Teodorowicza, Poznań 28 XII 1932 r.

$\mathrm{J}[\mathrm{ego}]^{\mathrm{a}} \mathrm{E}[\mathrm{kscelencja}]$

Najprzew[ielebniejszy] Ks. Arc[ybiskup] Józef Teodorowicz

we Lwowie

Pałac Arcybiskupi

W odpowiedzi prosimy powołać się na znak:

Nr. dz. 2904/32

B.W.

Ekscelencjo, Najdostojniejszy Księże Arcypasterzu!

Poznań, dnia 28 grudnia 1932

Mamy już ostatnie dni grudnia, a dotychczas ani rozprawy o Teresie Neumann ${ }^{297}$, ani drugiego tomu „Żywota Jezusa Chrystusa” ${ }^{298}$ poczta nam nie dostarcza. W czasie ostatniej rozmowy Wasza Ekscelencja był łaskaw zapewnić, że z końcem grudnia rękopis broszury o Teresie Neumann na pewno otrzymamy. W oczekiwaniu tego postaraliśmy się już tak zorganizować przekład i druk, iżby żadnej zwłoki nie było. Tłumaczenia ma dokonać p[ani] Drużbacka ${ }^{299}$ pod kontrolą ks. dr. Brossa.

Wdzięczni będziemy za słówko wiadomości, jak sprawy z obu dziełami tymi stoją, gdyż i o dalszy tom „Żywota Jezusa Chrystusa” czytelnicy tomu pierwszego ${ }^{300}$ się dopominają.

Przy zbliżającym się Nowym Roku pozwalamy sobie złożyć Waszej Ekscelencji najlepsze i najszczersze życzenia, a wśród nich to właśnie nas dotyczące, aby obie wyżej wymienione książki Waszej Ekscelencji jak najrychlej mogły ukazać się w druku.

Wyrazy czci najgłębszej łączymy

a Tekst pisany maszynowo z wyjątkiem autografu autora pisma na jednej stronicy papieru formatu A4. W górnej partii karty nadruk firmowy: „DRUKARNIA I KSIĘGARNIA ŚW. WOJCIECHA” i logo instytucji. Niżej nadruk: „Poznań, Al. Marcinkowskiego 22, Adres telegraficzny: Albertinum, PKO Poznań 200.032. Konto bankowe: Bank Związku Spółek Zarobkowych, Pozna. Telefony: Dykekcja 3614, Nr zbiorczy 3613”.

${ }^{297}$ J. Teodorowicz, Zjawiska mistyczne i ich ttumaczenia (Konnersreuth), Poznań 1933.

298 Tenże, Jezus Chrystus, t. 2: Od Betlejem do Nazaretu, Poznań 1932.

299 Osoba niezidentyfikowana.

300 J. Teodorowicz, [Jezus Chrystus], t. 1: Od Jahwe do Mesjasza, Poznań 1936. 


\section{DRUKARNIA I KSIĘGARNIA ŚW. WOJCIECHA \\ Dział Wydawniczy \\ ${ }^{\mathrm{b}-S z c z e p a n ~ J e l e n ́ s k i ~}{ }^{-\mathrm{b} 301}$}

\section{Dokument 91}

Kopia: AFKDOPW, teczka: Spuścizna abp. Józefa Teodorowicza, bsygn., List abp. Józefa Teodorowicza do prof. dr. Aleksandra Dąbrowskiego, Lwów 29 XII 1932 r.

Przezacnya Panie Profesorze!

Dziękuję serdecznie za łaskawe życzenia i wzajemnie je przesyłam Panu Profesorowi. Ucieszyłem się, że praca idzie w tak niesłuchanie szybkim tempie. Teraz wyjadę na parę tygodni po Trzech Królach do Krynicy i mam nadzieję [z]obaczyć się z Panem Profesorem zaraz po powrocie.

Co do Konnersreuth, to dzienniki rozpuszczają tendencyjne i fałszywe wiadomości; sprawa bowiem jest na najlepszej dziś drodze.

Zasyłam Panu Profesorowi wyrazy głębokiego poważania i czci.

Lwów, dnia 29 grudnia 1932

J[aśnie] W[ielmożny] Pan Prof. Dr Al[eksander] Dąbrowski

Lwów, [ul.] Śniadeckich 3

\section{Dokument 92}

Kopia: AFKDOPW, teczka 131: Spuścizna abp. Józefa Teodorowicza, sygn. 1355/420 (12) [7], List abp. Józefa Teodorowicza do Szczepana Jeleńskiego, Lwów 4 I 1933 r.

Przezacny ${ }^{\mathrm{a}}$ Panie!

W odpowiedzi na łaskawy list Pański zaznaczam najpierw co do Teresy Neumann, że wydanie niemieckie mej pracy opóźniam. Powodem opóźnienia jest zarządzenie biskupów bawarskich co do nadzoru w kwestii jej niejedzenia. Otóż oświadczyłem memu nakładcy niemieckiemu, że przed ostatecznym rozstrzygnięciem tej sprawy nie mogę wydać mej pracy. Sprawa cała, jak mi wiadomo z pewnego źródła, jest na najlepszej drodze, albowiem ojciec Teresy Neumann zgodził się w zasadzie na to, ażeby córkę oddać pod obserwację; muszę jednak zaczekać aż to nie nastąpi.

b-b Tekst sporządzony czarnym atramentem.

${ }^{301}$ Zob. w niniejszej publikacji; J. Wołczański, Korespondencja abp. Józefa Teodorowicza z prof. Stefanem Dąrowskim, dokument 8.

a Tekst pisany maszynowo na $1 \frac{1}{2}$ stronicy papieru formatu A4. Brak autografu autora.

a Tekst pisany maszynowo na jednej stronicy papieru formatu A4. Brak autografu autora. 
Co do żywotu Chrystusa Pana ${ }^{302}$, to właśnie nad nim intensywnie pracuję; mam nadzieję, że przed wakacjami, a może i wcześniej, będą gotowe działy: „Pełnia czasów”, „Blask ewangelii”, „W blasku i mocy cudów”. Będzie to razem jeden duży tom.

Dziękując raz jeszcze Panu za życzenia, wzajemnie najlepsze życzenia na ten rok zasyłam i łączę wyrazy głębokiego poważania.

Lwów, dnia 4 stycznia 1933

W[ielmożny] Pan Jeleński

Poznań - Księg[arnia] św. Wojciecha

\section{Dokument 93}

Oryg.: AFKDOPW, teczka 144: Spuścizna abp. Józefa Teodorowicza, sygn. 1088/420 (8) [7], Opracowanie ks. prałata Stanisława Szpetnara pt.: „W obronie Teresy Neumann” doręczone abp. Józefowi Teodowiczowi, [Jarosław luty 1933 r.].

\section{$\mathrm{W}^{\mathrm{a}}$ obronie Teresy Neumann}

W „Ilustrowanym Kurierze Codziennym” ukazał się cały szereg artykułów o Teresie Neumann, stygmatyczce z Konnersreuth, które wzbudziły zaniepokojenie w opinii katolickiej, obraziły wielu w ich najdelikatniejszych uczuciach; mam na myśli artykuły od numeru 339 roku $1932^{303}$. Początkowe artykuły opierały się na wywodach ks. Wunderlego ogłoszonych w belgijskim piśmie „Soir”304, a następnie powtórzonych w czasopiśmie niemieckim „Das Fränkische Volksblatt” ${ }^{\text {} 05} \mathrm{z}$ dnia 24 listopada 1924. Wywody ks. Wunderlego były dalszym ciągiem jego nieprzychylnych enuncjacji o Teresie Neumann. Na artykuł ks. Wunderlego posypało się w Niemczech mnóstwo odpowiedzi. Dalsze artykuły w „Kurierze” wzięły za podstawę drugą książkę O. Siwka TJ o Teresie Neumann z tytułem: „Metody badań nadprzyrodzonych - problem Konnersreuth"306.

Na pierwszą książkę O. Siwka TJ odpowiedział Ks. Arcybiskup Teodorowicz w „Ateneum Kapłańskim” w całym szeregu artykułów. Pierwsza książka O. Siwka o Teresie Neumann z tytułem „Konnersreuth w świetle nauki i religii” trzyma się jeszcze pewnego umiaru, choć musi wzbudzić mnóstwo zastrzeżeń. Druga książka O. Siwka pod płaszczykiem interesu naukowego wyrządza ciężką krzywdę Teresie. Krzywda wyrządzona Teresie

302 Aluzja do dzieła autora pt.: Żywot Chrystusa.

a Tekst pisany maszynowo $\mathrm{z}$ wyjątkiem autografu autora listu i ostatniego zdania na trzech stronicach papieru formatu A4. Brak miejsca wystawienia dokumentu i datacji.

${ }^{303}$ Ks. H.W., Wokoto „stygmatyczki z Konnersreuth” rozgorzała ożywiona polemika. Rewelacyjna publikacja o Teresie Neumann, IKC, 23(1932), nr 339, s. 4; Teresa $z$ Konnersreuth nie chce się poddać badaniom, IKC, 23(1932), nr 349, s. 6.

${ }^{304}$ Właściwie: „Le Soir” - belgijski dziennik w j. francuskim o profilu socjaldemokratycznym, ukazujący się od 1887 r. do dziś.

305 „Das Fränkische Volksblatt” - niemiecki dziennik o profilu katolickim, wydawany od 1900 r. dla obszaru Dolnej Frankonii.

306 Właściwie: P. Siwek, Metody badań zjawisk nadprzyrodzonych. Problem Konnersreuth, Kraków 1933. 
na jej dobrym imieniu jest tym większa, że Teresa sama stoi poza całą dyskusją, Teresa sama się nie broni. O. Siwek zebrał wszystko, co nieprzychylnego powiedziano o Teresie i taką charakterystyką obdarzył polskie społeczeństwo. Nie mam zamiaru wykazywać punkt po punkcie jak dalece O. Siwek mija się z prawdą, to jest obowiązkiem według mego zdania Księdza Arcybiskupa Teodorowicza. Za swój obowiązek uważam ku uspokojeniu opinii publicznej powiedzieć, co następuje. Dopóki człowiek żyje jest ciągle w próbie. Za życia człowieka zazwyczaj władza kościelna się nie wypowiada, nie wypowie się też zapewne w sprawie wydarzeń w Konnersreuth. Mogą być zdania podzielone w sprawie dziwnych wydarzeń w Konnersreuth. I nikt się tym nie gorszy. Nic dziwnego, gdy ktoś poważny rozprawia, czy wydarzenia w Konnersreuth naturalnym sposobem wytłumaczyć się dadzą. Teologia wielokrotnie rzeczy nadnaturalne przez naturalne wyjaśnia. I nic w tym dziwnego, gdy ktoś usiłuje ustawić granicę, gdzie graniczy Stwórca i natura. Taka dyskusja byłaby zupełnie na miejscu, ta by się przyczyniła do lepszego wyjaśnienia rzeczy.

Książka O. Siwka do tej poważnej literatury naukowej nie należy. Książka ta, w płaszczyk naukowy ubrana, wyrządza krzywdę ciężką Teresie i dlatego sama na siebie wyrok wydaje. Bezpodstawnie nikomu krzywdy wyrządzać nie wolno. Co się stać może w przyszłości tego nie wiemy, ale twierdzimy stanowczo, że dotychczasowe wypadki nie dają O. Siwkowi podstawy do tak ciężkich wyroków. Gdyby O. Siwek tak napisał o pierwszej z brzegu dziewczynie, to by jej ciężką krzywdę wyrządził. Uczyniwszy z Teresy Neumann oszustkę, histeryczkę zasłania swoje wywody bardzo wygodnym parawanem, że sąd swój zawiesza i powiada "non constat" - nie wiadomo. Bardzo to wygodne stanowisko. Takie stanowisko rzetelnej logice, rzetelnej nauce ciężką krzywdę wyrządza. Nie można tego w żaden sposób pojąć, żeby wolno było komukolwiek bezpodstawnie krzywdę wyrządzać.

Gorszy się O. Siwek z wielu rzeczy. Na takie zgorszenie jest osobne określenie w Piśmie św. Twierdzi O. Siwek, że nawet w Konsystorzu w Regensburgu spotkał [przejawy] niechęci do Teresy. Być może. Ale wszystkim wiadomo, że Konsystorz w Regensburgu wydał tysiące pozwoleń, by można Teresę odwiedzić. Podtrzymuje O. Siwek twierdzenie, że koło przyjaciół Teresy jest nieprzychylne nowym badaniom i że w tym duchu wpływa na Teresę. To nieprawda! Prawdą jest, że między ojcem Teresy a władzą duchowną toczą się układy. Ojciec żąda gwarancji, by w czasie badań nic złego się Teresie nie stało. Tak się rzecz ma teraz (koniec lutego 1932).

Jeśli chodzi o artykuły w „Kurierze”, to jeśli one brały za punkt wyjścia wywody ks. Wunderlego, a potem O. Siwka, to one inne być nie mogły. Przykrym jest tylko to, że dla sprawiedliwości powinno się też podać, że nie wszyscy tak sądzą jak ks. Wunderle lub O. Siwek. Jest bogata już literatura o Teresie, która podaje wiadomości oparte na istotnym stanie rzeczy. Sprawa ta jest poważniejsza niż by się zdawać mogło. Ona już nie zejdzie z porządku dziennego.

Przeciw opinii krzywdzącej O. Siwka można by przytoczyć zdania wielu biskupów, kapłanów, ludzi świeckich, lekarzy. Teresę odwiedził arcybiskup monachijski kardynał Faulhaber. Na polski język przetłumaczono książkę biskupa Waitza ${ }^{307}$. Świeżo wyszła

307 Zob. w niniejszej publikacji: J. Wołczański, Wybór korespondencji o. Włodzimierza Ledóchowskiego SJ z o. prof. Pawtem Siwkiem SJ, dokument 12. 
w języku niemieckim książka arcybiskupia praskiego („Eindrücke von Konnersreuth” von Erzbischof Karl Kaspar ${ }^{308}$, Badenia in Karsruhe). Jeśli ks. Siwek ma się za powagę naukową, to przeciw niemu możemy postawić także wielu ludzi poważnych. $Z$ całą stanowczością podtrzymuję zdanie, że dotychczasowe wypadki nie upoważniają nikogo do krzywdzących sądów. Opinii katolickiej możemy przypomnieć ten fakt, że ludzie świątobliwi byli za życia prześladowani. To wszystko już było. O Bernadecie Soubirous twierdzili lekarze, że objawienia jej to halucynacje na jawie, a sama Bernadeta dostała pomieszania zmysłów. Twierdził to Dr Voisin ${ }^{309}$ wtenczas, kiedy Bernadeta prowadziła świątobliwy żywot w klasztorze w Nevers ${ }^{310}$. Prześladowania te posłużyły ku temu, że się sprawa więcej rozgłosiła. Dziś pisma katolickie podają wiadomość, że Bernadeta będzie podniesiona na ołtarze ${ }^{311}$.

Bardzo uczonym wywodom O. Siwka przeciwstawiamy sprawdzian, jaki Pan Jezus sam postawił: „Z owoców ich poznacie je”312. Z całą stanowczością podtrzymujemy twierdzenie, że Teresa ten sprawdzian dotąd przetrwała. Twierdzenia te opieram na tym, że byłem sam dwa razy w Konnersreuth w r. 1930 i 1932. Czytam to, co się pisze o Teresie w książkach i w prasie zagranicznej. Mówiłem w Austrii, Czechach i Niemczech z tymi, którzy tą sprawą się stale zajmują. Jestem w tym szczęśliwym położeniu, że tego co napisałem w mojej popularnej broszurze o Teresie Neumann wydanej u Michalitów w Krakowie ${ }^{313}$, jeśli o rzeczy istotne idzie, w niczym zmieniać nie potrzebuję. Ponad wielce uczone wywody jest jeszcze potężny argument - to zdrowy sąd ogółu. Ten przetrwa, a opinie wielce uczone spoczną w lamusie.

b-Tyle od siebie, całą książką odpowie Ks. Arcybiskup Teodorowicz.

Ks. Stanisław Szpetnar-b

\section{Dokument 94}

Oryg.: AFKDOPW, bsygn., teczka: Spuścizna abp. Józefa Teodorowicza, List prof. Friedricha Ritter von Lamy do abp. Józefa Teodorowicza, Gauting 11 II 1933 r.

Gauting, 11. Februar 1933

308 Właściwie: Kašpar Karel (1870-1941), duchowny czeski, święcenia kapłańskie w 1893 r. w Rzymie, dr teologii oraz prawa kanonicznego, 1893-1896 wikariusz par. Svojšíně, 1898-1907 wikariusz par. pw. św. Mikołaja w Pradze, 1907-1920 kanonik Kapituły św. Wita w Pradze, 1920-1921 bp pomocniczy diec. Hradec Králové, 1921-1931 bp ordynariusz tamże, 1931-1941 abp metropolita Pragi, w 1935 r. kreowany kardynałem. M. M. Buben, Encyklopedie českých a moravských sídelních biskupů, Praha 2000, s. 165-169.

309 Osoba niezidentyfikowana.

${ }^{310}$ Nevers - miasto w środkowej Francji (Burgundia) nad Loarą.

311 Określenie nieprecyzyjne, bowiem Bernadeta Soubirous już w 1925 r. została beatyfikowana, co oznaczało wyniesienie jej na ołtarze. Kanonizacja zaś miała miejsce w $1933 \mathrm{r}$.

312 Ewangelia Mt 7, 20.

${ }^{313}$ S. Szpetnar, Teresa Neumann: stygmatyczka z Konnersreuth, Kraków $1931^{2}$

b-b Stąd do końca tekstu czarnym atramentem ręką autora tekstu. 


\section{Exzellenz $z^{\mathrm{a}}$, hochwürdigstrer Herr Erzbischof !}

Ich bin soeben aus München zurückgekehrt, wo ich mit Herrn Dr. Gerlich Ihren Brief gründlich durchbesprochen habe. Also Siwek ist nun doch herausgerückt, obwohl auch er die erste Voraussetzung für die Beurteilung solcher Phänomene, nämlich ihnen persönlich gegenüberzutreten, niemals erfüllt hat. Gerlich hat sich nicht aufgeregt darüber, denn viele der Argumente Siweks sind allzu töricht und geradezu kindisch. Ich bin fast überzeugt, dass Siweks Broschüre auch in deutscher Sprache erscheinen wird, denn die Wunderlclique wird sich diesen fetten Bissen sicherlich nicht entgehen lassen. Daher empfehle ich jetzt schon, Ihre eigene Arbeit, sobald sie fertig ist, übersetzen zu lassen, damit, wenn es nötig ist, damit sofort hervorgetreten werden kann, ehe die Arbeit Siweks noch eine grössere Wirkung erreicht hat. Und nun zu den einzelnen Einwänden.

1) Wenn Siwek sich auf Benedikt XIV. wegen der Ekstasen beruft, dann ist natürlich zuerst diese Quelle genau zu kontrollieren. Bekanntlich operieren in letzter Zeit auch Mager und Wunderle mit Benedikt XIV, aber sie verwenden ein verstümmeltes, also dem Sinne nach verfälschtes Zitiat, wie ja De Hovre nachgewiesen hat. Gemma Galgani hat dem ausführlichen Werke P[ater] Germanos ${ }^{314}$, ihres Seelenführers zufolge, ihre Ekstasen nicht vorausgesagt, d.h. das gilt im Allgemeinen. Von der Freitagsekstase wusste sie ja mit ziemlicher Sicherheit, dass sie sich samt den Stigmen einstellte (bis der Heiland sie wegnahm) und so konnte sie diese Ekstase in einem Falle voraussagen: Ich habe Ihnen in der Anlage einen ausführlichen Auszug aus P[ater] Germanos Buch darüber gemacht, der auch insoferne von Bedeutung ist, weil da auch der Bischof Gemmas a.o. Phänomene von einem von einem Arzte untersuchen lassen wollte, aber gegen den Willen Gottes, worauf ihm eben jedes Untersuchungsobjekt entzogen wurde, bis er sich dem Willen Gottes fügte. In diesem Falle also hat Gemma, weil vom Heiland entsprechend instruiert und beauftragt, eine Ekstase voraussagen können. Was die mit Visionen verbundenen Ekstasen betrifft, so findet sich bei P[ater] Germano keinerlei Beleg irgendeiner Vorhersage, übrigens war bei Gemma die Ekstase, ich möchte fast sagen, ein Dauerzustand, denn sie sah z[um] B[eispiel] fast immer ihren Schutzengel an ihrer Seite und so oft sie ihn anblickte um mit ihm zu sprechen, war sie in Ekstase, und wenn sie den Blick wieder abwendete, war sie ausser Ekstase; das war fast wie eine elektrische Ein- und Ausschaltung.

Resl wei $\beta$ natürlich jetzt aus langjähriger Erfahrung, ob die Freitagsekstase kommt: die liturgischen Regeln und die Wiederholung vermitteln ihr dieses Wissen. Immerhin blieb z[um] B[eispiel] vor zwei Jahren unerwarteter Weise die Passionsekstase aus, da sie auf den 26. Juli, das Namensfest ihrer Mutter fiel. Dies war ein Novum und von niemand erwartet. Resl kann im Zustand der erhobenen Ruhe, der ja meist identisch mit der Kommunionekstase ist, voraussagen, wann die nächste Vision u.a. zu erwarten ist, aber in diesem Zustand ist so bekanntermassen nicht sie, ihr Geist, der spricht, sondern nur ihr Mund und sie weiss nachher eben so wenig wie vorher, was sie gesagt hat.

a Tekst pisany maszynowo na dwóch stronicach papieru formatu A4. Brak zakończenia i autografu autora.

314 Osoba niezidentyfikowana. 
2) Der Artikel des ungarischen Pfarrers ist mir unbekannt. Es kommt vor, dass Personen, die sehr von sich eingenommen sind und diese Gesinnung mit nach Konnersreuth bringen, dort stark gedemütigt werden. Ew[erer] Exzellenz wissen selbst, dass es bei den Freitagsekstasen (und bei anderen haben Fremde keinen Zutritt) höchst würdig zugeht und dass die Behauptung, sie würden „zum Spektakel erniedrigt“ den Tatsachen widerspricht. Wenn der zuständige Bischof sogar schriftliche Besuchserlaubnisscheine ausstellen lässt, kann man sicher sein, dass alles in Ordnung ist. Dass Therese keine Vergnügungsfahrten im Auto macht, ist wohl auch bekannt. Sie verlässt Konnersreuth hauptsächlich deswegen öfters, um allen Besuchern sich zu entziehen und ganz verborgen und unbelästigt zu leben. Aber sie selbst wie diejenigen, die sie dann und wann besucht (z[um] B[eispiel] Wutz) legen Gewicht darauf, dass in die Zeit solcher Besuche keine Freitagsekstasen fallen, daher kehrt sie an solchen Freitagen, d. h. am Vortage, Donnerstag, nach Hause zurück. An „Vergnügungsfahrten“ ist mir nur eine solche am Osterfest auf Einladung von Prof. Wutz in Erinnerung, an der Pfarrer Naber und Herr Neumann noch teilnahmen, um Resl nach der schweren Karwochen Erholung in frischer Frühlingsluft zu bieten und sie die erwachsene Natur geniessen zu lassen, da sie sich an jeder aufblühenden Blume freut. Übrigens ist Therese auch schon ausserhalb des Bettes von der Ekstase überrascht worden, z[um] B[eispiel] beim Briefschreiben.

3) „Sofort Therese zu einem Würdenträger fährt ..." Resl hat bisher auf besondere Einladung den + Bischof Schmid von Chur besucht, als sie ihre damals kranke Schwester Ottilie ${ }^{315}$ nach dem Allgäu ${ }^{316}$ begleitete, wo diese längere Zeit verbrachte, um sich für eine nachfolgende Operation noch zu kräftigen. Der zweite Besuch bei einem Würdenträger war in Speyer; Resl hätte der Cousine des † Priesters Rotschild versprochen, wenn sie einmal getauft würde, die Taufpatenstelle zu übernehmen und zu kommen. Die Taufe sollte zuerst in Bamberg ${ }^{317}$ stattfinden, da aber Fr[eu]l[ein] Herrmann ${ }^{318}$ von ihrer dort lebenden Mutter verstossen wurde, fand die Taufe in Speyer statt, wo Fr[eu][ [ein] $\mathrm{H}$ [errmann] die Schule besuchte. Resl sollte zuerst bei H[errn] Domdekan Molz, ihrem (und meinem) altem Freunde wohnen, der $\mathrm{H}$ [ohwürdigen] $\mathrm{H}$ [errn] Bischof lud sie aber ein, bei ihm zu wohnen (auch Prof. Wutz und Rotschild!). Zu anderen Würdenträgern ist Resl nicht gefahren. Unwahr ist, dass sich dabei „in auffallender Weise ihre Ekstasen mehrten. Resl hatte in Chur nur die Kommunionekstase, weil sie eben kommunizierte, und in Speyer infolge des Festes der Kreuzauffindung einen Teil der Freitagsekstase. Die Zeitungen hatten vorher keine Silbe darüber geschrieben, sondern erst post factum; die grosse Menge versammelte", als Resl von Leuten, die sie in Konnersreuth besucht hatten, erkannt wurde. Sie suchte sich ihnen so gut es ging zu entziehen und so geschah alles, um sich nicht den Blicken der Leute auszusetzen. In Chur hatte überhaupt niemand Kenntnis von ihrer Anwesenheit; es sprach sich erst nach der Abreise herum. Die beiden Besuche fanden nur ein einzigesmal statt. Resl fragte mich einmal, was sie tun solle,

\footnotetext{
${ }^{315}$ Osoba niezidentyfikowana.

316 Allgäu - niemiecki region geograficzny w południowo-zachopdniej Szwabii (Bawaria).

317 Bamberg - niemieckie miasto w kraju związkowym Bawaria.

318 Osoba niezidentyfikowana.
} 
wenn sie je wieder nach Regensburg käme, ob sie den $\mathrm{H}$ [ohwürdigen] H[errn] Bischof Buchberger besuchen solle. Ich erwiderte, sie solle das nur dann, wenn ein wirkliches und wichtiges Anliegen den Besuch notwendig mache; andernfalls nicht, denn es würde sonst heißen, die bilde sich zuviel ein, wenn sie einem Bischof ihre Aufwartung mache.

4) Der „nervöse Anfall“ bei der Überwachung war ein - Sühneleiden für Prof. Ewald. Ewald glaubte in Konnersreuth an die Echtheit und war davon überzeugt; er ist aber in Erlangen unter dem Druck des Dekans der med[izinische] Fakultät, Dr. Specht ${ }^{319}$ schwach geworden und umgefallen.

5) Resl zeigt „ungebeten“ ihre Stigmen. Ich kenne nur einen solchen Fall aus einer Beschreibung; dabei waren des Besuchers Blicke auf ihre Hände gerichtet und so sagte sie, auf diese stumme Bitte hin, sie wolle sie ihm zeigen. Ich verweise Sie auf Jahrbuch 1931 S. 165; jener Besucher wurde durch jene Berührung des Stigmas von dem ihn jahrelang beherrschenden unwiderstehlichen Hang zur Onanie befreit! Da wird Resl wohl auf eine jener Eingebungen hin gehandelt haben! Wenn Resl die Wundmale zeigt, handelt sie einer Weisung der hl. Theresia ${ }^{320}$ entsprechen und gegen ihre eigenen Neigung; die Heilige hatte damals - es war am Anfang! - gesagt, dass dadurch viele zum Glauben kommen werden; wie die Worte wörtlich lauteten, ist mir nicht bekannt. Naber erzählte vor Jahren davon.

6) Wunsch des Bischofs von Regensburg. Es ist eine Lüge, dass „man dem Bischof mit einem scharfen «nein» geantwortet hat"; wahr ist, dass Herr Neumann sich erlaubt hat, den Wunsch mit der Frage zu erwidern, welchem Zweck die Überführung seiner Tochter in eine Klinik dienen sollte und welche Bürgschaften man geben könne, dass ihr nichts widerfahre. Seitdem ist $u$. W. nichts weiter geschehen, d. h. in den letzten acht Tagen. Ich hörte nur, der H.H. Bischof solle über diese Antwort [... $]^{\mathrm{b}}$.

\section{Dokument 95}

Kopia: AFKDOPW, teczka 127: Spuścizna abp. Józefa Teodorowicza, sygn. 1344/420 (12) [7], List abp. Józefa Teodorowicza do ks. dr. Stanisława Brossa, Lwów 12 II 1933 r.

\section{Kochany ${ }^{\mathrm{a}}$, Drogi Księże Doktorze!}

Piszę tylko parę słówek w sprawie wiadomej. Przyszła mi jeszcze inna myśl do głowy, która omówiłem z panem Lewakiem ${ }^{321} \mathrm{z}$ Ossolineum. Mianowicie, wobec trudności w przesyłaniu korekty z Poznania, podjęłoby się Ossolineum druku mojej odpowiedzi. Mówił mi pan Lewak, że mając różne rozrachunki z księgarnią św. Wojciecha, można by sprawę $\mathrm{w}$ ten sposób uskutecznić, że Ossolineum drukowałoby dla św. Wojciecha i św. Wojciech cały nakład wziąłby na siebie i odpowiednio rozrzucił.

\footnotetext{
319 Osoba niezidentyfikowana.

320 Zob. w niniejszej publikacji: J. Wołczański, Korespondencja abp. Józefa Teodorowicza z abp. Adamem Stefanem Sapieha, dokument 29.

b Brak kontynuacji tekstu.

a Tekst pisany maszynowo na jednej stronicy papieru formatu A4. Brak autografu autora.

${ }^{321}$ Zob. w niniejszej publikacji: J. Wołczański, Korespondencja abp. Józefa Teodorowicza z prof. Stefanem Dabrowskim, dokument 8.
} 
Przyznaję, że to by mi najbardziej odpowiadało, gdyż w przeciągu dwu tygodni podejmie się pan Lewak wydać całą książkę; wobec zaś tylu odnośników do różnych autorów, korekta bardzo staranna a rychła mogłaby być przeprowadzona li tylko tu na miejscu.

Polecam się dobremu sercu Księdza Doktora i pozostaję w tak miłych i ciepłych wspomnieniach z Krynicy, zawsze oddany.

Lwów, dnia 12 lutego 1933

Ks. Dr Bross

Poznań - [Al.] Marcinkowskiego 22

\section{Dokument 96}

Kopia: AFKDOPW, teczka 136: Spuścizna abp. Józefa Teodorowicza, sygn. 1381/420 (12) [7], List abp. Józefa Teodorowicza do ks. dr. Stefana Wyszyńskiego, Lwów 12 II 1933 r.

Przezacny ${ }^{\mathrm{a}}$ Księże Redaktorze!

Wobec tego, że przygotowuję odpowiedź O. Siwkowi w osobnej książce, proszę najuprzejmiej Księdza Redaktora o przysłanie mi części manuskryptu dotyczącego cudów.

Łączę przy tej sposobności szczere i oddane wyrazy z wysokim poważaniem.

Lwów, dnia 12 lutego 1933

Ks. red[aktor] Wyszyński

Włocławek - Sem[inarium] duch[owne]

\section{Dokument 97}

Oryg.: AFKDOPW, teczka 145: Spuścizna abp. Józefa Teodorowicza, sygn. 1063/420 (8) [7], List ks. rektora Johanna Westermayra do abp. Józefa Teodorowicza, Freising 14 II 1933 r.

Exzellenz! $!^{\mathrm{a}}$

Fernsprecher Nr. 222

Hochwürdigster Herr Erzbischof!

Gnädigster Herr!

Euere Exzellenz hatten die große Güte, mir ehrfurchtsvollst Unterzeichnetem in liebenswürdigster Beantwortung meines Briefes Ihre mit sehr wertvolle Ansicht über den Konnersreuther Komplex zur Kenntnis zu bringen. Seit Übernahme der Regentie des Erzb[ischöflichen] Klerikalseminars mit beruflichen Arbeiten ständig überlastet

\footnotetext{
a Tekst pisany maszynowo na jednej stronicy papieru formatu A4. Brak autografu autora.

a Tekst pisany maszynowo $\mathrm{z}$ wyjątkiem autografu autora sporządzonego czarnym atramentem na jednej stronicy papieru formatu A4. W lewym górnym rogu karty nadruk firmowy: „Direktion des Erzb[ischöflichen] Klerikalseminars Freising, Postscheckkonto: München 18318“.
} 
komme ich leider erst jetzt dazu, Eurer Exzellenz den ehrerbietigsten Dank auszusprechen. Ihre Darlegungen haben auf mich Eindruck gemacht. Doch kann ich noch immer zu keinem abschließenden Urteil gelangen. Vielleicht finde ich in den Osterfeien Zeit. Eurer Exzellenz meine noch nicht überwundenen Bedenken vorzutragen.

Ehrfurchtsvollst verharrt Eurer Exzellenz ergebenster

Msgr. Dr. Joh[ann] Westermayr

Regens

\section{Dokument 98}

Kopia: AFKDOPW, teczka 127: Spuścizna abp. Józefa Teodorowicza, sygn. 1372/420 (12) [7], List abp. Józefa Teodorowicza do ks. dr. Stanisława Brossa, Lwów 22 II 1933 r.

Kochany ${ }^{a}$, Przezacny Księże Prałacie!

Bardzo dziękuję Księdzu Prałatowi za oba listy i za tak wspaniały rezultat interwencji. Właśnie otrzymałem od pana Jeleńskiego list, w którym mi robi nadzieję, że rzecz da się ułożyć z Ossolineum.

Ja już dobijam moją pracę i boję się tylko, czy to wszystko razem nie będzie zbyt wielką bombą. Ale trudno! Ksiądz Prałat pchnął mię na te drogi i już dziś niepodobna mi $\mathrm{z}$ nich schodzić.

Cieszę się nadzieją [z]obaczenia się tu we Lwowie z Księdzem Prałatem bo liczę na to, że swej obietnicy dotrzyma. Tymczasem jeszcze raz dziękując, ślę bardzo serdeczne i bardzo oddane wyrazy prawdziwej czci.

Lwów, dnia 22 lutego 1933

Ks. Prałat Bross

\section{Dokument 99}

Kopia: AFKDOPW, teczka 131: Spuścizna abp. Józefa Teodorowicza, sygn. 1371/420 (12) [7], List abp. Józefa Teodorowicza do Szczepana Jeleńskiego, Lwów 22 II 1933 r.

\section{Przezacny ${ }^{\mathrm{a}}$ Panie!}

Dziękuję najuprzejmiej za list i cieszę się możliwością rozwiązania sprawy taką, która mi ułatwi szybkie wykończenie pracy. Na pośpiechu bardzo mi zależy, bo ze wszech stron budzi się wielkie zainteresowanie na moją odpowiedź. Odpowiedź moja będzie jednak szerzej zakrojona. Właściwie obrabiam w niej cały problem Konnersreuth ze stanowiska kryteriów mistycznych na tle tej rozprawy. Z drugiej strony nie przesądzam niczego o samym problemie Konnersreuth, tj. nie wchodzę w to, czy te zjawiska są prawdziwe, czy też nie.

a Tekst pisany maszynowo na jednej stronicy papieru formatu A4. Brak autografu autora.

a Tekst pisany czarnym atramentem na jednej stronicy papieru formatu A4. Brak autografu autora. 
Pod tym względem ma moja praca szerszy zakres; obok tego jednak w samej polemice będą się też ścierać i wyświetlać teologiczne wywody.

Życząc Panu wypoczynku miłego, łączę wyrazy prawdziwie oddane głębokiego poważania.

Lwów, dnia 22 lutego 1933

J[aśnie] W[ielmożny] Pan Jeleński

\section{Dokument 100}

Kopia: AFKDOPW, teczka 137: Spuścizna abp. Józefa Teodorowicza, sygn. 961/420 (12) [7], List abp. Józefa Teodorowicza do nieznanego niemieckiego adresata, Lwów luty $1933 \mathbf{r}$.

Hochgeehrter ${ }^{\mathrm{a}}$ Herr!

Ich schreibe diesen Brief im Waggon ganz unter dem Eindruck des Pamphlets über Konnersreuth, den Prof. Siwek jetzt in polnischer Sprache veröffentlicht hat. Selbstverständlich neben Theresa Neumann, die unter derartigen Form fast verhöhnt ausgelacht wird, figuriert auch der Konnersreuther-Zirkel. „Der dumme Pfarrer“, nicht wörtlich so genannt, aber so dargestellt; der, den Terror ausübende Schriftsteller und von Hause aus Protestant Gerlich, sie haben auch ihren Teil dabei bekommen. Dagegen alle Namen der Gegner werden grossgezogen um zu zeigen, dass alles, was Intellekt, Kritik, Wissenschaft ist, gegen Konnersreuth Stellung nimmt. Es ist möglich, dass das frühere Buch Siwek's und diese Antwort, die er mir gibt, ins Deutsche übersetzt wird; darum schreibe ich eine Gegenschrift.

Es ist mir sehr viel daran gelegen, damit meine Gegenschrift in kürzester Zeit erscheine, da schon jetzt die polnische, am meisten verbreitete Zeitung triumphierend ausruft: „Sensation! Wie es noch nicht gegeben hat: die Legende von Konnersreuth ist begraben worden!“ („Ilustrowany Kurier Codzienny“, Kraków). Ich wende mich aus diesem Grunde an Sie mit der Bitte in dieser schweren Stunde mir behilflich sein zu wollen und ich bitte Sie speziell mir gewisse Punkte zu beleuchten. Wenn Sie selbst Manches zu beantworten nicht im Stande sind, so bitte den Pfarrer, oder Professor Wutz oder Professor Gerlich zu befragen.

1) Ob es Ihnen bekannt ist, dass Gemma Galgani ihre Ekstasen vorausgesagt hat, so z. B. dass dieselben wie auch speziell die Stigmen dann und dann verschwinden werden, oder etwas ähnliches. Siwek beruft sich auf Benedikt XIV und erklärt, dass die Voraussage der Ekstasen ihrerseits das sicherste Merkmal ihrer Wahrheit sei. Ich will ihm Gemma Galgani als Beweis gegenüberstellen.

2) Kennen Sie den gehässigen Artikel des ungarischen Pfarrers, speziell seine Worte über ihre Ekstasen? Ich will nämlich wissen, ob sich in diesem Artikel der Passus befindet: „Die Ekstasen werden zum Spektakel erniedrigt... . Noch am Donnerstag fährt Theresa mit Auto ... etc. ... und Donnerstagabends zieht sie das frische weisse Hemd an,

a Tekst pisany maszynowo na ośmiu stronicach papieru formatu A4. Brak autografu autora. 
legt sich ins Bett und wartet auf das wunderbare Phänomen des bitteren Leidens unseres Herrn".

3) „Gibt es nicht viel zu denken - schreibt Siwek - dass sehr bemerkenswert ist die Erscheinung, so oft Therese mit Auto zu einem Würdenträger fährt, so mehren sich dann wie es bemerkt wurde, in auffallender Weise ihre Ekstasen ... . Die Zeitungen schreiben weit und breit darüber, die grosse Menge versammelt sich“. Ich kenne Ihren Aufsatz im letzten Bande Ihres Buches über iIhren Besuch bei zwei Bischöfen. Aber sind diese Besuche öfters stattgekommen? Und wie oft? (mehr weniger).

4) Die Nonnen, welche Therese Neumann „bewacht" haben, sollen bei ihr den „nervösen Anfall" konstatiert haben. Hat Ewald darüber geschrieben?

5) „Ungebeten hat sie ihre Stigmen spontan aus eigenem Anlass gezeigt“. Hier gehören die Fragen: a) ob es in der Zwischenzeit gewesen ist, wo sie schon die Stigmen besass, aber noch keine Handschuhe trug? b) ob sie dem Willen des Pfarrers diesbezüglich folgt und wie fern? Über den ersten Punkt hat sie mir Benefiziat Härtel schon geschrieben.

6) Man hat mir in Regensburg darüber geklagt, dass seitens Konnersreuth kein Gehör dem Bischöfe gegeben wird, der nach Konnersreuth den Brief geschickt haben soll, mit dem entscheidenden Wunsch, damit Therese Neumann irgend einer katholischen Anstalt übergeben würde. Wer? Man hat (dem Bischof) mit dem scharfen „nein“ geantwortet ohne jede Rücksicht. Man hat schon darüber gedacht, den Pfarrer Naber durch einen anderen zu ersetzen. Ob ein solcher Wunsch, und zwar ein entschiedener, wirklich seitens des Bischofs erfolgte? An wen wurde er gerichtet? Wer und wie der Betreffende darauf geantwortet hat?

7) Aus „Theologie und Glaube“ Heft 2. 1932 zitiert Siwek folgenden Satz: „Es ist anders der Fall, wenn Therese Neumann über dieselben Reliquien sich verschiedenartig erklärt, oder wenn sie eine echte Reliquie für eine falsche erklärt. Das eine wie das andere hat in Konnersreuth stattgefunden. Noch einfacher ergibt sich die Erforschung dieser Fähigkeiten, wenn man Theresa Neumann zwischen den gesegneten und nicht gesegneten Gegenständen wählen lässt ..... In der Tat hat ein Pilgermit seinem Begleiter diese Proposition dem Pfarrer in Anwesenheit Therese Neumann gemacht. Aber der Pfarrer widersetzte sich mit der Begründung: „Das haben wir bisher nicht versucht: einen Misserfolg würde man uns übel auslegen“.

8) Konnersreutherzirkel. „Anstatt dem Wunsche des Ordinariats zu entsprechen und Therese ins Spital zwecks der notwendigen Erforschungen zu übergeben, wirft der Konnersreuther-Zirkel über die Zweifelnden die drohende Prophetie: «Wie Spanien die Strafe Gottes erreichte, weil es Limpias weggeworfen hat, so droht dieselbe Strafe Deutschland, wenn es Konnersreuth nicht anerkennt»“. („Wie steht es heute um Konnersreuth?" von Dr. Wunderle, „Fränkisches Volksblat“, Würzburg, 2 Juni 1932).

9) Der Ihnen bekannte Fall mit dem Leiber wegen des Verbotes des Lesens der hl. Messe am Altar der hl. Theresia vom Kinde Jesu wird wiederholt.

10) „Es hat mir einer meiner Freunde, ein Augenzeuge des Vorfalls folgendes erzählt. Er wartet in der Sakristei mit zwei anderen Priestern um die hl. Messe zu zelebrieren“. 
Da erscheint der Pfarrer Naber und sagt: „Heute ist kein Leiden Theresens. Sie hat in der Nacht die Vision gehabt, in der ihr gesagt wurde, dass sie in Rücksicht auf das Fest der hl. Theresia frei von dem Leiden bleibt. Sie will sich ausruhen, gut ausruhen. Es dürfen deshalb die Besuche Theresens nur zwischen 3 - 5 Nachmittag stattfinden. Wenn der Pfarrer diese Anordnung nicht durchführt, so entzieht der Heiland seine Gnaden von Konnersreuth (!). Sie werden mich somit entschuldigen - sagt der gerührte Pfarrer Naber - aber ich kann nicht dem Gebote des Heilands entgegen wirken“. Dasselbe hat er den Leuten in der Kirche wiederholt. Aber schon um 10 Uhr drängt sich die Menge in das Haus Therese Neumanns gegen das an die Tür des Hauses angezettelte Verbot und der Heiland hat seine Gnaden Konnersreuth nicht entzogen.

11) Der Freund Konnersreuth soll öffentlich dem Prof. Wunderle erklärt haben ... dass „ihn Theresa Neumann nie gemacht hat“. Das soll als ein Beispiel angeführt werden, dass Theresa nur denjenigen geneigt ist, welche an ihre übernatürliche Visionen glauben. („Wie steht es heute um Konnersreuth?“ „Fränkisches Volksblatt“, Würzburg, 2 Juni 1932).

12) Wie ist der wörtliche Text? „Ich kehre von Konnersreuth geärgert zurück - klagt im Ordinariat ein Priester. Ich habe gesehen, wie Theresa Neumann mit Gerlich mich während der hl. Messe unterhalten hat".

13) Der ungarische Priester sagt, dass Theresa Neumann mit dem Pfarrer öfters (wie oft?) mit Auto kommt, um Blumen zu übernehmen. Ärgerniss.

14) Theresa soll ihn beim Abschied nicht gegrüßt haben: „Gelobt sei Jesus Christus“, oder wenigstens „Grü $\beta$ Gott“. Sie sprach irritiert mit ihm (dem ungarischen Priester).

15) „Warum wischt man nicht das Blut von ihren Augen während ihrer Ekstasen weg, und erst nach Abschluss derselben?" Effekt soll ein Priester dabei gesagt haben.

16) Sessel mit dem elektrischen Apparat geheizt in ihrem Zimmer - erzählt ein Priester (von weniger Belag).

17) $\mathrm{Ob}$ ihr Bett weicher ist als andere in Konnersreuth?

18) Sie besucht gern die hohen Würdenträger? Wie oft und wen?

19) Die „Augsburger Postzeitung“ 3 Februar 1932 - Westermayr - Siwek beruft sich auch auf diesen Artikel.

20) „Bekannt ist ihre Antipathie gegen die «Gelehrten» und allgemein gegen die Wissenschaft".

21) „Ein deutscher Prälat - lesen wir in den «Erinnerungen aus Konnersreuth» des ungarischen Priesters 1930 ... erzählte mir, die Ärzte behaupten, dass wenn eine Person durch 4 Wochen nichts isst und trinkt, so trocken ihre Nerven aus und sie stirbt. Nach dieser Bemerkung ging er zum Bischof mit der bitte, damit derselbe in Betreff dieses Punktes neue Nachforschungen anordnen könnte. Der Bischof hat ihn zum Pfarrer Naber geschickt. Es geht somit der Prälat zum Pfarrer; dieser begibt sich zu Resl. Resl gibt die Antwort, dass sie den Heiland fragen wird, was sie tun dürfe. Und Jesus sagt ihr: «Die Antwort ist bei Vater». Es geht somit der Prälat zu Vater Neumann. Er hat noch nicht den Satz zu Ende gebracht, als die donnernde Stimme ihm zurief: Schauen's dass Sie hinauskommen!" Und er machte so einen Lärm, dass man das Geschrei im ganzen 
Dorfe hören konnte! ... Und der Prälat fügt hinzu: „Eine derartige Demütigung habe ich noch nie in meinem Leben erlitten!“

22) „War das die Antwort des Heilands?“ Fragt Siwek. Westermayr erklärt, dass Theresa Neumann in halbbewüstlichen Zustande - natürlich in der subjektiven Überzeugung, sie sei die Stimme Christi, erteilt den Rat, den man mit den positiven Vorschriften der Ethik und mit den klaren Gesetzen der Askese sich nicht vereinigen lässt. („Konnersreuth in der theologischen Kritik“ - „Augsburger Postzeitung“, Sonntagbeilage Nr. 24, 12/VII, 1930).

23) Wie ist das für ein Rat gewesen? Der ungarische Priester: „Ich habe bei Theresa Neumann nicht diese große Ehrfurcht gefunden, welche die grossen Heilungen dem Diener Gottes bezeugten“.

Das wären die Hauptwortwürfe. Diejenigen Fälle an denen mir besonders gelegen ist, bezeichne ich mit dem roten Bleistift. Ausserdem will ich noch wissen, wie oft mehr weniger sie mit dem Auto fährt? (Nicht Postwagen).

Wenn in der "Schildwache“ etwas erschienen ist, (die Kontroverse mit Westermayr) so bitte mir diese Nummer zuschicken zu lassen.

Ich bitte Sie noch mich über den Verlauf der Dinge in Betreff des Wunsches der bayerischen Bischöfe benachrichtigen zu wollen. Es ist mir sehr viel daran gelegen. Ich bitte Sie mich entschuldigen zu wollen, dass ich Sie belästige, aber das beste Mittel das Erscheinen dieses Pamphlets in der deutschen Sprache zu verhindern, wäre dasselbe in der polnischen Sprache totzuschweigen.

Ist Dr. Witry nicht krank? Er liess meine zwei Briefe unbeantwortet. Ich verbleibe mit dem Ausdruck meiner tiefen Hochachtung.

Lwów, [...] ] /II 1933

[P.S.] In der Erzählung Witt ${ }^{322}$ von dem Schrecken Theresens während des Brandes und dem, was Gerlich geschrieben hat, und Therese mir erzählte, sehe ich einen Wiedersatz, den Siwek ausnützt, den Siwek ausnützt. Wie ist das zu erklären?

\section{Dokument 101}

Oryg.: AFKDOPW, teczka 139: Spuścizna abp. Józefa Teodorowicza, sygn. 987/420 (8) [7], List bp. Michaela Buchbergera do abp. Józefa Teodorowicza, Regensburg 8 III 1933 r.

Regensburg, den 8. März 1933

Eure $^{\mathrm{a}}$ Exzellenz!

Hochwürdiger Herr Erzbischof!

\footnotetext{
b Brak tekstu.

${ }^{322}$ Witt Leopold - niemiecki duchowny rzymskokatolicki, proboszcz parafii Műnchenreuth, autor m.in. publikacji: Konnersreuth im Lichter der Religien und der Wissenschaft (Wladsassen 1927²).

a Tekst pisany maszynowo na jednej stronicy papieru formatu A4. W lewym górnym rogu karty nadruk formowy: „Der Bischof von Regensburg“.
} 
Für das gütige Schreiben vom 6. März bitte ich den Ausdruck meines verehrungsvollen Dankes genehmigen zu wollen. Die Mitteilungen aus dem Buche des P[ater] Siwek sind mir wertvoll. Ich halte es für inkorrekt, da $\beta$ sein fremder Priester und Ordensmann den zuständigen kirchlichen Oberen in einen Pressestreit über Konnersreuth heranzieht. Ich zweifle auch sehr, ob die Angaben über das Verhalten des Regensburger Ordinariates richtig und begründet sind. Es wäre Zeit, da $\beta$ wenigstens die Priesters nicht in der Öffentlichkeit sich herumstreiten in einer Sache, in welche sie nicht genügend Einblick haben und die durch diese Auseinandersetzungen nicht geklärt, sondern immer mehr verwirrt werden müssen.

Genehmigen Eu[rer] Exzellenz den Ausdruck meiner hohen Verehrung, mit der ich die Ehre habe zu bestehen.

${ }^{\mathrm{b}} \mathrm{-} \mathrm{Eu}[\mathrm{rer}]$ Exzellenz ehrerbietigster gegebener

† Michael $^{-b}$

Bischof von Regensburg

\section{Dokument 102}

Kopia: AFKDOPW, teczka 130: Spuścizna abp. Józefa Teodorowicza, sygn. 1386/420 (12) [7], List abp. Józefa Teodorowicza do kard. Augusta Hlonda, Lwów 22 III 1933 r.

Waszaa $^{a}$ Eminencjo!

Bardzo dziękuję za list pasterski ${ }^{323}$ najłaskawiej mi przesłany. Po raz pierwszy spotykam się $\mathrm{z}$ ujęciem parafii $\mathrm{w}$ tak nowoczesnym duchu, na tak szerokim podłożu w związku i z ruchem liturgicznym, i z akcją katolicką. Należy się Waszej Eminencji istotnie gorąca podzięka za ten podarunek dla Kościoła w Polsce.

Korzystam ze sposobności, ażeby udzielić Waszej Eminencji małej ploteczki. Założyłem się z księdzem biskupem Przeździeckim ${ }^{324}$ w Krynicy o to, czy Wasza Eminencja do Rzymu pojedzie, czy też nie pojedzie. Ja twierdziłem, że nie, on zaś na pewno, że tak. Dzięki Bogu, że przegrał: bo Bogiem a prawdą byłem bardzo zaniepokojony nie o mój zakład, ale o brak nominacji na prefekta propagandy ${ }^{325}$. Na szczęście dziś ta rzecz jest już przesądzona ${ }^{326}$.

Przy tej sposobności jeszcze raz dziękuję Waszej Eminencji za posyłki w sprawie Konnersreuth; już mam gotową odpowiedź O. Siwkowi, którą w tych dniach drukuję $e^{327}$.

\footnotetext{
b-b Tekst pisany czarnym atramentem.

a Tekst pisany na maszynie w objętości dwóch stronic papieru formatu A4. Brak autografu autora.

323 A. Hlond, O życiu parafialnym. Wielkopostny list pasterski. Poznań 1 III 1933 r., MK, 48(1933), nr 3, s. $1-12$.

${ }^{324}$ Zob. w niniejszej publikacji: Józef Wołczański, Listy abp. Józefa Teodorowicza do abp. Józefa Bilczewskiego, dokument 148.

325 Aluzja do Kongregacji Propagandy Wiary w Stolicy Apostolskiej.

326 W 1. 1933-1960 funkcję tę pełnił kard. Pietro Fumasoni Biondi.

327 J. Teodorowicz, Zjawiska mistyczne i ich ttumaczenia (Konnersreuth), Poznań 1933.
} 
Pisał do mnie prałat Münch ${ }^{328}$, że chce tu przyjechać w sprawie Adama ${ }^{329}$; przyjeżdża z aktami i chce mię odwiedzić. Ale tu najmniej o mnie chodzi, bo trzeba przede wszystkim, by się zobaczył z Waszą Eminencją. Dlatego gdyby Wasza Eminencja był łaskawie donieść mi w paru słowach, kiedy będzie w Poznaniu, a kiedy wyjeżdża do Rzymu, to byłbym bardzo zobowiązany, bo bym mu to zaraz zakomunikował.

Tymczasem jeszcze raz bardzo dziękuję Waszej Eminencji, łączę najoddańsze wyrazy czci najgłębszej.

Lwów, dnia 22 marca 1933

\section{Dokument 103}

Oryg.: AFKDOPW, teczka 145: Spuścizna abp. Józefa Teodorowicza, sygn. 921/420 (8) [7], List prof. Friedricha Ritter von Lamy do abp. Józefa Teodorowicza, Gauting 26 III 1933 r.

Gauting, 26. März 1933

Excellenz ${ }^{\mathrm{a}}$, Hochwürdigster Herr Erzbischof!

Ihre Mitteilungen haben mich sehr gefreut und ich hoffe, dass Ihres Arbeit eines tages auch in deutscher Sprache erscheinen wird, sodass wir auch in unserem Lande, w osich ja der eigentliche Kampf un Konnersreuth abspielt, ihre Vorteile geniessen können. Es tut mir leid, dass die PP. Jesuiten sich zu dieser Campagne Siweks hergegeben haben. Aber ich muss sagen, dass diese Herren in ihrem eigenen Orden, gerade innerhalb der deutschen Provinz, ihre Gegner haben. Einer von ihnen, z[ur] Z[eit] in Amerika, ist dort der wackerste Streiten pro Therese Neumann. Inzwischen hat Mager seinen alten faden weitergesponnen. Er hat in Paris im Institut Catholique über Konnersreuth gesprochen, immer wieder das alte Geschwätz incl[usive] Mollie Fancher und Benedikt XIV. Sein Vortrag wurde in den „Etudes Carmélitaines” veröffentlicht. Im Anschluss daran ist ein Artikel pro Konn[ersreuth] des Freiburger Universitäts-Professor P[ater] Lavaud ${ }^{330}$ $\mathrm{O}[\mathrm{rdo}] \operatorname{Pr}$ [aedicatorum] veröffentlicht und zum Schluss kommt nochmals Mager zum Wort, wobei er u[nter] a[ndere] sagt, er lehne es als Wissenschaftler ab, auf De Hovre von Lama zu erwidern, weil alles, was wir veröffentlichten, unwissenschaflich sie. Er ist also am Ende seiner Weisheit und sucht nun seine Blamage durch die kindische Auswurde zu verdecken. Ich denke, De Hovre wird ihm die Antwort nicht shuldig bleiben.

Was mit dem „Geraden Weg” ist? Das ist eine traurige Geschichte. Am 5. März wurde die Redaktion von Nationalsozialisten überfallen und Dr. Gerlich schmerz misshandelt in das Gefängnis geschleppt, wo er seitdem ist, ohne dass man über sein Schicksal Sicheres wüsste. Es sind sogar manche Zweifel nicht unberechtigt, dass er infolge der

${ }^{328}$ Osoba niezidentyfikowana.

${ }^{329}$ Zob. w niniejszej publikacji: J. Wołczański, Korespondencja abp. Józefa Teodorowicza z abp. Adamem Stefanem Sapieha, dokument 119.

a Tekst pisany maszynowo z wyjątkiem autografu autora pisma na 1,5 stronicy papieru formatu A4.

330 Zob. w niniejszej publikacji: J. Wołczański, Korespondencja abp. Józefa Teodorowicza z bp. Henrykiem Przeździeckim, dokument 10. 
Misshandlungen gestorben ist; jedenfalls musste die Behörde neulich zugeben, dass er geistliche Hilfe in Anspruch genommen hat. Seine Frau erhielt bis heute keinen Zutritt, auch sonst niemand, wärend den Polizeicommuniqués wenig Glauben beizumessen ist. Ich empfehle Dr. Gerlich sehr Ihnen Gebete. Natürlich kann auch ich ihm nichts zukommen lassen. Wenn ich etwas über ihn erfahre, werde ich es Ew[ere] Excellenz mitteilen.

Es beleuchtet die Zustände in unseren geistlichen theologischen Kreisen, dass die Schrift des Dr. Deutsch die kirchliche Druckbewilligung der bischöflichen Behörde von Paderborn erhielt und dass Kardinal Schulte ${ }^{331}$ dem Dr. Deutsch zu sejner Schrift einen herzlichen Glückwunschbrief geschrieben hat. Ich wundere mich darűber nicht im geringsten, weil mir eben zu sehr bekannt ist, wie sehr unser deutscher Klerus vom Rationalismus vergiftet ist.

Was die Nahrungslosigkeit bei Resl betrifft, so haben Sie Recht; die absolute Nahrungslosigkeit begann erst nach den Heilungen. Die Erscheinungen der h[ei]l[ige] Teresia, in denen dieses sich in voller Gestalt zeigte, begannen erst 1928 und, wenn ich mich nicht ganz irre, war es am 30. September jenes Jahres, dass ihr die Heilige ankündigte, się werde von jetzt an keiner irdischen Speise mehr benötigen.

Dr. Witry sollte über so viele Rechtskenntnis verfügen, um zu wissen, dass Sie, was die Approbierung einer Arbeit von ihm betrifft, als kirchliche Behörde nicht zuständig sind; er soll die Apostolische Konstitution nachschlagen, da kann er finden, an wen er sich zu wenden hat. Wenn er in Metz das Imprimatur nicht erhalt, soll er sich eben einen Verleger in einer Diözese suchen, deren Kirchlichenbehörde ihn keine Schwierigkeiten bereitet.

Ich begrüsse E[were] Excellenz in ergebenster Verehrung

${ }^{\mathrm{b}}$-F[riedrich] R[itter] von Lama ${ }^{-\mathrm{b}}$

\section{Dokument 104}

Kopia: AFKDOPW, teczka 127: Spuścizna abp. Józefa Teodorowicza, sygn. 1396/420 (12) [7], List abp. Józefa Teodorowicza do ks. dr. Stanisława Brossa, Lwów 2 IV 1933 r.

Kochany ${ }^{a}$ Księże Prałacie!

Bardzo dziękuję za przesłane mi dokumenta tak wymowne dla obrazu duszy ich autora. Jeszcze raz dziękuję Księdzu Prałatowi za łaskawe pośrednictwo.

Praca już jest oddana do druku i mam nadzieję, że już rychło się ukaże ${ }^{332}$. Jestem właśnie na wyjezdnym do Warszawy. Kiedy się doczekam spełnienia obietnicy ze strony Księdza Prałata odwiedzenia Lwowa?

${ }^{331}$ Schulte Joseph (1871-1941), niemiecki duchowny rzymskokatolicki, święcenia kapłańskie w 1895 r. w Paderborn, 1909-1920 biskup diecezji Paderborn, 1920-1941 metropolita archidiec. Kolonii, w 1921 r. kreowany kardynałem; był przeciwnikiem komunizmu i nazizmu. Schulte Joseph, w: BDL, s. 680-682.

b-b Fragment napisany czarnym atramentem.

a Tekst pisany maszynowo na jednej stronicy papieru formatu A4. Brak autografu autora.

${ }_{332}$ Aluzja do drukowanej w poznańskim Wydawnictwie św. Wojciecha pracy abp. J. Teodorowicza: Zjawiska mistyczne i ich ttumaczenia (Konnersreuth), Poznań 1933. 
Tymczasem najserdeczniej pozdrawiam i wyrazy oddanej czci dla Księdza Prałata łączę.

Lwów, dnia 2 kwietnia 1933

Ks. Prałat Bross

Poznań - [al.] Marcinkowskiego 22

\section{Dokument 105}

Kopia: AFKDOPW, bsygn., teczka: Spuścizna abp. Józefa Teodorowicza, List abp. Józefa Teodorowicza do ks. Adama Bogdanowicza, [Lwów] 25 IV 1933 r.

25/IV [1]933

$\dagger$

Kochany ${ }^{\mathrm{a}}$ Adamie!

Za życzenia serdecznie Ci dziękuję. Konkurs na kanonię rozpisany i cieszę się, że w czasie niedługim [z]obaczę Cię na stałe we Lwowie.

Wypocznij dobrze na wsi, oczekuję Twojej pracy. Polemiki z Wichrem ${ }^{333}$ nie mogłem dostać. Siwek w druku, jezuici ogromnie czatują i wypytują. Mam nadzieję, że Matce we Lwowie się polepszy.

Najserdeczniejsze wyrazy zasyłam.

\section{Dokument 106}

Oryg.: AFKDOPW, teczka 145: Spuścizna abp. Józefa Teodorowicza, sygn. 1026/420 (8) [7], List prof. Friedricha Ritter von Lamy do abp. Józefa Teodorowicza, Gauting 29 V 1933 r.

Excellenz ${ }^{\mathrm{a}}$, Hochwürdigster Herr Erzbischof !

Gauting, 29. Mai 1933

Ich darf wohl annehmen, dass Sie meine Mitteilungen über die Behandlung, die der arme Dr. Gerlich seitens der Nationalsozialisten erfahren hat, über sein seitheriges Schicksal erhalten haben. Seither liegt nichts weiter vor, als dass man immer noch nichts Sicheres über ihn weiss, auch nicht darüber, ob er noch lebt. Würden die Behörden in

\footnotetext{
a Nota na rewersie karty wizytowej. Tekst pisany czarnym atramentem. Brak autografu autora.

333 Wicher Władysław (1888-1969), święcenia kapłańskie w 1912 r. w Krakowie, dr teologii, 1915-1919 duszpasterz i katecheta w Dziekanowicach, Lipniku k. Białej i Żywcu, 1919-1923 zastępca prof. teologii moralnej na Wydziale Teologicznym UJ, w 1923 r. habilitacja, w 1928 r. prof. nadzwyczajny, w 1938 r. prof. zwyczajny, 1937-1939 dziekan fakultetu, 1939-1940 więziony w obozie koncentracyjnym Sachsenhausen, 1940-1945 duszpasterz w Dziekanowicach, 1945-1954 kontynuował pracę na UJ, 1954-1957 prof. w Akademii Teologii Katolickiej w Warszawie, 1948-1958 redaktor periodyku „Polonia Sacra”; był autorem publikacji naukowych i popularnych z dziedziny teologii moralnej. L. Grzebień, Wicher Wtadysław, w: SPTK, t. 7, s. 392-395.

a Tekst pisany czarnym atramentem na dwóch stronicach papieru formatu zeszytowego.
} 
der Lage sein, etwas zu ihrer Entlastung mitzuteilen, weil durch die Ereignisse, die eines Tages ja doch zur Kenntnis der Oeffentlichkeit kommen werden, im In- und Auslände ihr Ruf schweren Schaden gelitten hat, so wäre sicherlich längst eine Freilassung Gerlichs erfolgt. Wie ich aus sicherer Quelle hörte, hat nichts in Oesterreich die Antipathie gegen den deutschen Nationalsozialismus so. sehr gestärkt, wie das, was man dort über die Behandlung Dr. Gerlichs erfahren hat (einschliesslich der Ermordung seines Mitarbeiters Dr. Bell $\left.{ }^{334}\right)$.

Ich benütze die Gelegenheit, höflichst anzufragen, wie es bezüglich Ihrer Schrift gegen Siwek steht? Ist sie schon erschienen? Es wäre sehr zu wünschen, wenn nunmehr, da die Diskussion über Konnersreuth anscheinend zum Stillstand gekommen ist, Ihr Werk darüber erscheinen würde. Mein neues Jahrbuch wird demnächst der kirchlichen Zensurbehörde eingereicht werden; voriges Jahr vergingen drei Monate, bis endlich das Imprimatur den Bestimmungen des Kirchenrechts gemäss erteilt war.

Mit verehrungsvollen Grüssen und der Versicherung aufrichtiger Ergebenheit F[riedrich] R[itter] von Lama

\section{Dokument 107}

Oryg.: AFKDOPW, teczka 145: Spuścizna abp. Józefa Teodorowicza, sygn. 922/420 (8) [7], List prof. Friedricha Ritter von Lamy do abp. Józefa Teodorowicza, Gauting 4 VI 1933 r.

Gauting, 4 Juni 1933

Excellenz ${ }^{\mathrm{a}}$, Hochwürdigster Herr Erzbischof!

Ich will die Morgenstunden dieses heiligen Pfingstfestes dazu verwenden. Ihren Brief zu beantworten. Ueber Herrn Dr. Gerlich wissen auch wir noch immer nichts Zuverlässiges; die (jetzt nationalsozialistischen) Polizeibehörden scheinen Grund zu haben, sehr viel zu verbergen, weil Gerlich noch immer so abgeschlossen gehalten wird. Uebrigens scheint Dr. Gerlich und sein Schicksal von der göttlichen Vorsehung zum Werkzeug für grosse Dinge gebraucht zu sein. Mein Bruder schreibt mir aus Oesterreich, dass die in den österreichischen Zeitungen verbreiteten Meldungen über das Dr. Gerlich bereitete Schicksal fast schlagartig bewirkt haben, dass bei den österreichischen Katholiken alle Sympathien für den Nationalsozialismus zerstört wurden. Und Hand in Hand damit ging das grosse Erwachen des Oesterreichertums, so dass Oesterreich heute für den Nationalsozialismus bereits vollkommen verloren ist. Damit scheint Gott die grosse Mission vorzubereiten und einzuleiten, die Oesterreich, wie ich weiss, in den nächsten drei Jahrzehnten zu erfüllen hat, während der Hochmut, der jetzt bei uns von neuem sein Haupt erhebt, von Gott nochmals gezüchtigt werden und ganz gebrochen wird. Deutschland wird esst dann wieder von Gott zu einer grossen Mission herangezogen, wenn seine Anmassung, die im Protestantismus ihre Wurzeln hat, gänzlich und

${ }^{334}$ Osoba niezidentyfikowana.

a Tekst pisany maszynowo na trzech stronicach papieru formatu A4. Autograf własnoręczny czarnym atramentem. 
von Grund aus beseitigt ist. Dies wird in den kommenden Jahren, die mit 1955 enden, geschehen.

Gebe Gott, dass Ihr Buch gegen Siwek recht bald auch deutsch herauskomme. Da Siwek ja nur das, was deutscherseits gegen Konnersreuth vorgebracht wurde, gesammelt wiedergegeben hat, haben wir. das grösste Interesse daran, dass Ihre Erwiderung auch in deutscher Sprache herauskommt. Nun käme mir folgender Gedanke. Infolge der gänzlichen Besuchssperre in Konnersreuth wird das, was aller Voraussicht nach über das Jahr $1933 \mathrm{zu}$ berichten ist, so minimal sein, dass es einer Veröffentlichung nicht wert ist. Würden Sie mir daher gestatten, dass ich dann an dessen Stelle Ihre Schrift gegen Siwek veröffentliche?

Damit wäre unter allen bisherigen Streit einmal ein dicker Abschlusstrich gezogen, es wäre von autoritativer Seite das gesagt, was gesagt werden muss. Ich würde dringendst um diese Ermächtigung bitten; die geschäftliche Seite der Reiche würde keine Schwierigkeit bereiten.

Wann es zu einer Lösung des Konfliktes mit Regensburg kommt, ist gar nicht zu sagen. Der frühere greise Generalvikar von Regensburg, Dr. Scheglmann, der ja die Verhältnisse sehr genau kennt, sagte mir vor einiger Zeit: Ueberall anderswo wäre die Sache Konnersreuth längst entschieden, nur in Regensburg geschieht das nicht, hier wird man nie zu einen Entscheidung kommen, Man kommt aus dem Zaudern und Schwanken nicht heraus.

Nun zu Dr. Witry. Vor allem muss ich sagen: es ist tief bedauerlich, dass alle ärztlichen Gegner Konnersreuths fortgesetzt in der Oeffentlichkeit sprechen und wühlen und verdächtigen, während, wenn einmal ein katholischer Arzt auf Grund wirklicher Untersuchung zu einem entgegengesetzten, einem günstigen Urteil kommt, alles getan wird, dies geheim zu halten. Ich setze mich über diese persönlichen Rücksichten hinweg. Witry hat mir auch verboten, sein Gutachten zu veröffentlichen, aber er hat inhaltlich das Gleiche in einem Privatbriefe an S[einer] Excellenz Erzbischof Kaspar von Prag geschrieben und dieser hat in einem Originalbeitrag zu meinem neuen Jahrbuch (1932) Witrys Worte und Urteil wörtlich angeführt und mich damit zur Veröffentlichung ermächtigt. Auf Wunsch stelle ich Ihnen den Originalbrief S[eine]r Excellenz zur Verfügung. Inliegend der Abdruck der Stelle, von dem auch Sie, Excellenz, jeden Gebrauch machen dürfen. Ich glaube, es ist heute Pflicht, das, was für Konnersreuth spricht in die Oeffentlichkeit zu bringen. Fragen Sie bei Dr. Witry gar nicht erst an, ob er einverstanden ist oder nicht. Witry ist ein guter Mann, scheint mir aber den Fehler zu haben, dass er gerne fremdes Wasser auf die eigene Mühle leitet, aber keinen Tropfen eigenen Wassers für anders Mühlen übrig hat. Es ist ein gewisser Gelehrtenegoismus, der im Interesse der Rache, um die es geht, absolute Rücksicht nicht beanspruchen darf.

Ich an Ihrer Stelle würde unter allen Umständen die Rache vor die Person stellen und Witrys Gutachten veröffentlichen, etwa mit dem Vermerk, dass es ohnehin in weitesten Kreisen verbreitet ist. Wenn Eure Excellenz Gelegenheit haben, Konnersreuth $\mathrm{zu}$ besuchen, sollten Sie es unbedingt tun. Es handelt sich darum, Gottes Werk jene 
Aufmerksamkeit zu erweisen, die wir ihm schulden, Und jeder Besuch kann dazu beitragen, in dem einen oder anderen Punkt neue Klärung zu bringen. Ich würde ganz entschieden dazu raten, den Besuch auszuführen.

Es wäre sehr gut - im Interesse der Sache Konnersreuth - wenn Sie der katholischen Presse ein kurzes Referat über Ihre Schrift gegen P[ater] Siwek zugehen lassen wollten (aber nicht zu kurz); es sollte dabei der Zweck der Schrift und ein Ueberblick über ihren Inhalt gegeben werden. Für die nötige Verbreitung will ich gerne sorgen. Das letzte Bändchen der „Etudes Carmélitaines“ enthält Arbeiten und Diskussionen über Konnersreuth, die Eure Excellenz sehr interessieren dürften; ich würde es ohne weiteres schicken, wenn ich nicht fürchtete, es gibt Ihnen Anlass, Ihre Schrift noch mehr zu erweitern, wodurch das Erscheinen neuerdings hinausgeschoben würde. Das sollte aber nicht sein. Es sind dort auch Protokolle von Augenzeugen über die Ereignisse von Beauraing veröffentlich, die mich zwingen, dieselben als von Gott kommend abzuweisen und sogar die Möglichkeit eines dämonischen Agens anzunehmen. Ueberhaupt steht fest dass Besessenheitsfälle immer mehr zunehmen, ein Zeichen der Zeit.

Ich begrüsse Euere Excellenz mit dem Ausdruck meiner aufrichtigen Verehrung ganz ergebenst

F[riedrich] R[itter] von Lama

\section{Dokument 108}

Oryg.: AFKDOPW, teczka 141: Spuścizna abp. Józefa Teodorowicza, sygn. 1727/64 [5], Pismo Szczepana Jeleńskiego z Działu Wydawniczego Drukarni i Księgarni św. Wojciecha w Poznaniu do abp. Józefa Teodorowicza, Poznań 8 VI 1933 r.

$\mathrm{J}[\mathrm{ego}]^{\mathrm{a}} \mathrm{E}[\mathrm{kscelencja}]$

Najprzew[ielebniejszy] Ks. Arc[ybiskup] Józef Teodorowicz

we Lwowie

ul. Ormiańska

Pałac Arcybiskupi

W odpowiedzi prosimy powołać się na znak:

Nr. dz. 1181/33.

B.W.

a Tekst pisany maszynowo z wyjątkiem autografu autora pisma na 1,5 stronicy papieru formatu A4. W górnrej partii karty nadruk firmowy: „DRUKARNIA I KSIĘGARNIA ŚW. WOJCIECHA. Sp[ółka] z o[graniczoną] o[dpowiedzialnością]” i logo instytucji. Niżej nadruk: „Poznań, Al. Marcinkowskiego 22, Adres telegraficzny: Albertinum, PKO Poznań 200.032. Konto bankowe: Bank Związku Spółek Zarobkowych, Poznań. Telefony: Dyrekcja 3614, Nr zbiorczy 3613". 
Poznań, dnia 8 czerwca 1933

Ekscelencjo, Najdostojniejszy Księże Arcypasterzu!

W dniu 6 b.m. otrzymaliśmy z Ossolineum pierwsze zawiadomienie o tym, że praca Waszej Ekscelencji o Teresie Neumann jest już w drukarni a zarazem, że jest już na ukończeniu i liczy circa 500 stronic. Z załączonej przy niniejszym piśmie kopii naszego listu do p[ana] dyr[ektora] Lewaka przekona się Wasza Ekscelencja, jak bardzo niespodzianą była dla nas ta wiadomość.

Równocześnie niemal odwiedził nas ks. dr Bross przywożąc pewne dalsze szczegóły o tym wydawnictwie. Między innymi nadmienił, iż rzecz ta $\mathrm{z}$ zamierzonej broszury przeistoczyła się w wielki tom, dlatego, że Wasza Ekscelencja połączył odpowiedź ks. Siwkowi z pracą swą zasadniczą o Teresie Neumann. Pozwalamy sobie wyrazić żal pod adresem Waszej Ekscelencji, iż w tej sprawie nie był łaskaw porozumieć się z nami, skoro my mieliśmy być wydawcami dzieła. Byliśmy bowiem zdecydowanie przeciwni temu połączeniu ze względów wydawniczych. Nieporównanie łatwiej byłoby rozprzedać dwie mniejsze książki o bądź co bądź odmiennym założeniu niż jeden wielki tom, który z konieczności kosztować będzie kwotę wysoką, zwłaszcza dla czytelników obecnie tak zubożałych. Poza tym inną sferę czytelników zainteresowałaby polemika z ks. Siwkiem, inną zaś pogląd Waszej Ekscelencji na zjawiska w Konnersreuth. Wreszcie polemiczna broszura ma niewątpliwie krótszy żywot niż rozprawa tak gruntowna i światła o mistyce na tle wydarzeń aktualnych.

Obecnie, nie znając całości dzieła, nie możemy ocenić, na jaki zasięg czytelników liczyć może. Obawiamy się, że z uwagi na objętość odstraszającą zazwyczaj ludzi mniej tym zagadnieniom oddanych, nakład należałoby ustalić dość niski, co niekorzystnie wpłynie na cenę dzieła, podwyższając ją znacznie.

Sprawa cała jest obecnie tak zawiła, że trudno nam samym szukać jej rozwiązania i dlatego, zarówno jak do p[ana] dyr[ektora] Lewaka, zwracamy się do Waszej Ekscelencji z prośbą o wskazówki i propozycje, jakie znaleźć by można w tej sytuacji wyjście.

Z czcią głęboką

DRUKARNIA I KSIĘGARNIA ŚW. WOJCIECHA Dział Wydawniczy ${ }^{\mathrm{b}-}$ Sz[czepan] Jeleński ${ }^{-\mathrm{b}}$

Polecony!

Załącznik!

\section{Dokument 109}

Oryg.: AFKDOPW, teczka 138: Spuścizna abp. Józefa Teodorowicza, sygn. 330/91 [5], List ks. dr. Stanisława Brossa do abp. Józefa Teodorowicza, Poznań 9 VI 1933 r.

b-b Tekst sporządzony czarnym atramentem.

c Brak owego dokumentu. 
L. dz. $4684 / 33$

Poznań, dn[ia] 9 czerwca 1933

Aleje Marcinkowskiego 22

$\dagger$

Ekscelencjo!

Bardzo się zasmuciłem dzisiejszym listem Waszej Ekscelencji. Bardzo zależało mi na tym artykule, lecz w całej pełni przyznaję rację Waszej Ekscelencji.

W sprawie książki o Teresie Neumann rozbiła się szkuta ${ }^{335}$. Św. Wojciech ma ogromne pretensje do $\mathrm{p}$ [ana] Lewaka. Prosiłem ich, by dla informacji odpis listu do niego nadesłali także Waszej Ekscelencji. Ze względu na to, że oni swego czasu pisali do p[ana] Lewaka by im doniósł, gdy rozpocznie druk książki, uważam, że byłoby dobrze, by Wasza Ekscelencja odpisał im, że był przekonany o tym, że przeprowadzenie technicznej strony załatwi p[an] Lewak, zaś stronę honorarium polecił Wasza Ekscelencja mnie załatwić.

Co do tego ostatniego, zażądałem $10 \%$. Na $15 \%$ nie chcieli się zgodzić. Przy końcu nie chcieli zawrzeć kontraktu na piśmie oświadczając, że w ogóle nie wiedzą jak wybrnąć z całej sprawy, gdyż całość przekroczyła rozmiary pierwotnej broszury. Tłumaczyłem im, że to była konieczność, gdyż Ekscelencja nie mógł dać tylko samej odpowiedzi O. Siwkowi, lecz musiał się zająć całym zagadnieniem.

Swoją drogą dziwię się p[anu] Lewakowi, dlaczego im nie doniósł, gdy rozpoczął druk pracy, tak jak się był z nimi umówił. W każdym razie prosiłbym uprzejmie w razie zapytania z ich strony do Waszej Ekscelencji, by był łaskaw im odpisać w myśl mojej propozycji, gdyż ewentualne pretensje mogą mieć jedynie do p[ana] Lewaka, a nie do Waszej Ekscelencji. Jestem przekonany, że całość dobrze się załatwi.

Łączę wyrazy najgłębszej czci i synowskiego przywiązania szczerze oddany sługa

Ks. Stanisław Bross

\section{Dokument 110}

Kopia: AFKDOPW, teczka 127 i 136: Spuścizna abp. Józefa Teodorowicza, sygn. 1870/420 (12) [7], List abp. Józefa Teodorowicza do dyrektora Wydawnictwa św. Wojciecha Szczepana Jeleńskiego w Poznaniu, 17 VI 1933 r.

\section{Przezacny ${ }^{\mathrm{a}}$ Panie Dyrektorze,}

Prawdziwą niespodzianką, a muszę dodać, bardzo przykrą był dla mnie list Panów. Wydawnictwo św. Wojciecha ma do mnie pretensję, żem się z nim nie porozumiał w sprawie książki i jej wydania. Jakże to? Czyż Wydawnictwo o tym nie wiedziało, że delegatem moim dla wszelkich umów z Księgarnią św. Wojciecha był ksiądz dr Bross? A któż, jeśli nie Księgarnia św. Wojciecha zwróciła się do mnie przez pośrednictwo

a Tekst pisany maszynowo z wyjątkiem autografu autora na 1,5 stronicy papieru formatu A4. W lewym górnym rogu nadruk firmowy: „Ks. dr Stanisław Bross Dyrektor Naczelnego Instytutu Akcji Katolickiej w Polsce”.

${ }^{335}$ Szkuta - beznapędowy statek pozbawiony pokładu do transportu śródlądowego.

a Tekst pisany maszynowo na pięciu stronicach papieru formatu A4. Brak autografu autora pisma. 
ks. Brossa, którego w tej roli uznała, ażeby w bibliograficznym piśmie ogłosić tytuł mojego dzieła o Konnersreuth, które się pojawi w Wydawnictwie św. Wojciecha. Któż więc - pytam - w takim razie ponosi odpowiedzialność za wszelkie braki i niedokładności umowy? Przecież chyba tylko Wydawnictwo św. Wojciecha. Jeżeli miało zastrzeżenia co do charakteru tej pracy, albo jeśli miało warunki ze swej strony, to ono i tylko ono wyłącznie ponosi odpowiedzialność za to. Tak samo Księgarnia św. Wojciecha zgodziła się na to, że druk dzieła obejmie Ossolineum; z chwilą, gdy tak się stało, skądże ja przychodzę do tego, abym ponosił odpowiedzialność za wszystko to, co ze związku handlowego Księgarni św. Wojciecha z Ossolineum w kwestii objętości książki wynika.

Stwierdziwszy to muszę prosić uprzejmie Pana ażeby mi nie wziął za złe, iż skieruję Wydawnictwo św. Wojciecha we wszelkich kwestiach dotyczących wydania moich książek do księdza dr. Brossa, w którym Wydawnictwo uznało delegata z mojej strony dla wszelkich umów z Wydawnictwem.

Zaznaczywszy to moje zasadnicze stanowisko potrącę tu jeszcze o szczegóły poruszone w Pańskim liście. Pierwsze: książka ma wynosić nie 500 stron, ale jak mi mówiono przeszło 400; wobec tego, że mierzyłem te strony miarą mojej pracy z "Ateneum” ${ }^{336}$, a strony tej książki są o $56 \%$ mniejsze od strony w „Ateneum”, przeto praca moja redukuje się właściwie mierząc ją tą miarą do jakich 200 stron w stosunku do mej poprzedniej pracy, która liczyła stron 80 . Jeżeli wliczę jeszcze $\mathrm{w}$ tę nową pracę teksty powtórzone z mojej rozprawy poprzedniej, to różnica między pracą dawną a nową nie przedstawia się znowu tak bardzo odmiennie. Co do mnie, nie wyznaczałem ściśle ile stron moja praca obejmie, ale kiedy na moje zapytania otrzymałem od pana Lewaka odpowiedź, że arkusz druku bije Ossolineum w jednym dniu, więc przypuszczalnie zawsze myśląc o stronach „Ateneum” obliczyłem sobie, że w takim razie dzieło może się ukazać w jakichś dwu tygodniach. Jeszcze raz powiadam, że to było tylko czysto moje przypuszczenie i o ile Wydawnictwo interesowało się tą kwestią, to jego już rzeczą było utrzymać niezbędny w takim razie kontakt $\mathrm{z}$ wydawnictwem Ossolineum. Nie mogę za to odpowiadać, iż Wydawnictwo, jak to widać z listu Pańskiego, wolało raczej poprzestać na przypuszczeniu, że w ogóle cała sprawa nie jest aktualna niż się wprost u źródła o właściwym stanie rzeczy poinformować.

Drugie: nie rozumiem skąd Wydawnictwo św. Wojciecha przychodzi to na myśl, ażeby wyrażać obawy o założenia mojego dzieła i przychodzi do wniosku, że założenie pierwotne zostało zmienione? Przecież nikogo bliżej nie informowałem o tym, jaka jest treść mojej książki. Jeżeli Wydawnictwo św. Wojciecha miało jakiekolwiek wątpliwości, to rzeczą jego było poinformować się o niej bliżej przez pośrednictwo ks. Brossa jakie jest moje założenie; to zaś należało uczynić nie dopiero po ogłoszeniu mojej książki w biuletynie literackim, a więc już po przesądzeniu faktu, ale przedtem.

Proszę darować, że tak jasno piszę i sprawę nazywam po imieniu, ale w takich razach sądzę, że jest to jedyna droga dla przecięcia wszelkich nieporozumień. A teraz, co do samej kwestii. Co do roli mej pracy to jest tu widoczne nieporozumienie. Otóż niezawodnie mogłem obrać drogę nieporównanie krótszą, ograniczając się w polemice

\footnotetext{
336 Właściwie: „Ateneum Kapłańskiego”.
} 
z O. Siwkiem do prostego wykazania fałszywego przedstawienia stanu rzeczy w Konnersreuth, jako też błędnego przedstawienia moich tez. To byłoby zupełnie wystarczające dla osobistej obrony mojego stanowiska, ale sądziłem, że pomijając wszystkie inne względy nie mogłem angażować Wydawnictwa w takie połowiczne załatwianie sprawy. Obrałem więc drogę tę, o której Panu pisałem, tj. polemikę sprowadziłem do tez zasadniczych. Na dowód jak bardzo ludzie czekają na takie rozwiązanie rzeczy niech będzie drobny przykład. Widziałem się z jednym z OO. Jezuitów, który był zajęty przy Wydawnictwie Ojców i ten mi teraz właśnie powiedział, jak się cieszy na to, że właśnie przez polemikę problem Konnersreuth wyjaśni się krytycznie i naukowo.

To było moje pierwsze założenie, o jakim doniosłem Panu w moim liście i nigdy na jotę tego założenia nie zmieniłem. Dlatego uważam, że Pańskie przypuszczenie jakobym rozbijał książkę na dwa różne problemy: problem ogólny i problem partykularny, na poglądy moje o Konnersreuth i O. Siwka, na szczęście nie odpowiada prawdziwemu stanowi rzeczy. Albowiem ja wcale nie rozwijam problemu Konnersreuth jako takiego używając polemiki z O. Siwkiem jako tylko jakiegoś parawanu do mojego celu. Nie! Ja się ściśle trzymam tylko w granicach polemiki z O. Siwkiem i o tyle, o ile ta polemika z natury rzeczy do tego mnie zmusza wyjaśniam w zasadniczy sposób kwestie partykularne i polemiczne. Dlatego obawy Pańskie co do charakteru samej książki są Bogu dzięki zbyteczne.

Ponieważ bardzo mnie to obeszło, że Panowie są tak niezadowoleni z mej książki, byłem w jednej chwili gotów na skreślenie z niej wszystkiego, co tylko bezpośrednio i ściśle z samą kwestią rozprawy się nie wiązało. Uprosiłem w tym celu jednego teologa i znawcę mistyki, przy tym znanego pisarza, ażeby on przejrzał dokładnie mój manuskrypt i wykreślił z niego wszystko, co bez szkody dla rozprawy polemicznej da się opuścić. Właśnie teraz oddał mi bardzo dokładnie przeczytany manuskrypt i skreślił z niego jakich[ś] 30 stron. Zrobiłem więc wszystkiego ${ }^{\mathrm{b}}$, co w tych warunkach uczynić się dało.

Kończę moje uwagi oświadczeniem, iż będzie mi niewymownie przykro, jeśli Wydawnictwo św. Wojciecha, które tak wysoko cenię i z którym tak jestem związany będzie $\mathrm{z}$ mej pracy niezadowolone. Na to - niestety - nie umiem zupełnie poradzić. Pocieszam się tylko tym jednym, że jeżeli jakie wydawnictwo, to Wydawnictwo św. Wojciecha stać na to, ażeby chociaż w wyjątkowym wypadku pozwoliło sobie na luksus ideowości.

Czy Ksiądz Prałat Kłos ${ }^{337}$ otrzymał moją krytykę jego książki? Czy z niej skorzystał? Łączę przy tej sposobności dla Pana Dyrektora wyrazy głębokiego poważania. ${ }^{c-}$ List ten w odpisie posyłam Księdzu D[okto]rowi Brossowi ${ }^{-c}$.

Lwów, dnia 17 czerwca 1933

b Zapis zgodny z oryginałem; powinno być: wszystko.

337 Kłos Józef (1870-1938), święcenia kapłańskie w 1893 r. w Poznaniu, redaktor „Przewodnika Katolickiego” i „Wiadomości dla Duchowieństwa”, 1914-1918 poseł do Reichstagu, w 1919 r. poseł do Sejmu Ustawodawczego, członek rady nadzorczej Drukarni i Księgarni św. Wojciecha w Poznaniu. P. Nitecki, Kłos Józef, w EK, t. 9, red. zbior., Lublin 2002, kol. 193-194.

${ }^{c-c}$ Nota czarnym atramentem ręką autora listu. 


\section{Dokument 111}

Oryg.: AFKDOPW, teczka 144: Spuścizna abp. Józefa Teodorowicza, sygn. 1004/420 (8) [7], List

o. Josefa Schrijversa CSsR do abp. Józefa Teodorowicza, Bruksela 18 VI 1933 r.

Excellence ${ }^{a}$ Révérendissime,

Je viens d'être rappelé inopinément de Cologne pour être provincial des Rédemptoristes en Belgique. Je regrette de n' avoir pu, avant le départ, faire mes adieux ni à Votre Excellence ni à n'importe qui, car je n'ai reçu ma nomination qu'en arrivant à Rome.

Que Votre Excellence veuille bien me recommander à Dieu dans ses prières, me donner sa sainte bénédiction et me croire son très humble et très dévoué serviteur en $\mathrm{N}[\mathrm{o}-$ tre] S[eigneur]

Jos[ef] Schrijvers CSsR Sup[érieur] Prov[incial]

Bruxelles, rue Belliard 28, Belgique 18 VI 1933

\section{Dokument 112}

Oryg.: AFKDOPW, teczka 138: Spuścizna abp. Józefa Teodorowicza, sygn. 334/91 [5], List ks. dr. Stanisława Brossa do abp. Józefa Teodorowicza, Poznań 28 VI 1933 r.

L. dz. $4811 / 33$

Poznań, 28 czerwca 1933 Aleje Marcinkowskiego 22

$\dagger$

Ekscelencjo! ${ }^{\mathrm{a}}$

Wszystkie listy Waszej Ekscelencji, za które najuprzejmiej dziękuję, zastałem w domu już po powrocie z Wilna. Piszę dlatego do Jego Ekscelencji Ks. Arcyb[isku]p[a] Sapiehy ${ }^{338}$, czy w przyszłym tygodniu będzie w Krakowie, aby go móc odwiedzić.

Manuskrypt Waszej Ekscelencji o Konnersreuth posłałem do Kurii Arcybiskupiej celem uzyskania „Imprimatur”. Doniosłem o tym p[anu] Dyr[ektorowi] Lewakowi, który mi go przysłał prosząc go zarazem, by odpisał na ostatni list Działu Wydawniczego.

Co do tego ostatniego, to na razie nie mogę nic pewnego Waszej Ekscelencji donieść, gdyż p[an] Jeleński jest na urlopie wypoczynkowym. Po jego powrocie w sobotę doniosę zaraz Waszej Ekscelencji jak sprawy stoją.

Łączę wyrazy uszanowania i najgłębszej czci pozostając z synowskim przywiązaniem szczerze oddany sługa

Ks. Stanisław Bross

a Tekst pisany czarnym atramentem na jednej stronicy papieru formatu zeszytowego.

${ }^{338}$ Zob. w niniejszej publikacji: J. Wołczański, Listy abp. Józefa Teodorowicza do abp. Józefa Bilczewskiego, dokument 2 .

a Tekst pisany na maszynie z wyjątkiem autografu autora na jednej karcie papieru formatu A4. W lewym górnym rogu nadruk firmowy: „Ks. dr Stanisław Bross Dyrektor Naczelnego Instytutu Akcji Katolickiej w Polsce". 


\section{Dokument 113}

Oryg.: AFKDOPW, teczka 138: Spuścizna abp. Józefa Teodorowicza, sygn. 345/91 [5], List ks. dr. Stanisława Brossa do abp. Józefa Teodorowicza, Poznań 3 VII 1933 r.

Poznań, dn[ia] 3/VII 1933

Ekscelencjo $^{\mathrm{a}}$,

Ostatni list do Ks[ięgarni] Św. W[ojciecha] rozpętał tutaj burzę. Mają ogromny żal, że nie zawiadomiono ich o tym, że dzieło do takich rozmiarów się powiększyło. Wobec mnie oświadczyli, że traktowali mnie jako „życzliwego doradcę”, nie mieli natomiast oświadczenia Waszej Ekscelencji na „piśmie” (!), że jestem Jego pełnomocnikiem w tej sprawie. Na początku oświadczyli, że na mocy takiego rozprowadzenia oni zupełnie od wydania odstępują. Tłumaczyłem im jak mogłem, że tutaj nieporozumienie, że Ks. Arcybiskup sam nie zorientował się na początku, że to się tak powiększa, że ja podczas swej ostatniej bytności we Lwowie dowiedziałem się o tych rozmiarach etc. - po długiej walce stanęło dziś na tym, że biorą na siebie nakład - płacą papierem za druk Ossolineum - proponują 10\% honorarium + 20 egz[emplarzy] autorskich lub też 150 egz [emplarzy] +20 egz[emplarzy]. W tych dniach napiszą list do Waszej Ekscelencji w tej sprawie. Po odbiorze manuskryptu z Kurii odeślę natychmiast go do p[ana] Lewaka.

Całuję ręce Waszej Ekscelencji z największą czcią i synowskim przywiązaniem, szczerze oddany

Ks. Stanisław Bross

\section{Dokument 114}

Oryg.: AFKDOPW, teczka 141: Spuścizna abp. Józefa Teodorowicza, sygn. 1729/64 [5], Pismo Szczepana Jeleńskiego z Działu Wydawniczego Wydawnictwa i Księgarni św. Wojciecha w Poznaniu do abp. Józefa Teodorowicza, Poznań 4 VII 1933 r.

Jego $^{\mathrm{a}}$ Ekscelencja

Najprz[ewielebniejszy] Ks. Arc[ybiskup] Józef Teodorowicz

we Lwowie

Pałac Arcybiskupi

W odpowiedzi prosimy powołać się na znak:

Nr. dz. 1322/33.

B.W.

a Tekst pisany czarnym atramentem na dwóch stronicach papieru formatu karty pocztowej. Brak autografu autora.

a Tekst pisany maszynowo z wyjątkiem autografu autora pisma na 3,5 stronicy papieru formatu A4. W górnej partii karty nadruk firmowy: „DRUKARNIA I KSIĘGARNIA ŚW. WOJCIECHA. Sp[ółka] z o[graniczoną] o[dpowiedzialnością]” i logo instytucji. Niżej nadruk: „Poznań, Al. Marcinkowskiego 22, Adres telegraficzny: Albertinum, PKO Poznań 200.032. Konto bankowe: Bank Związku Spółek Zarobkowych, Poznań. Telefony: Dyrekcja 3614, Nr zbiorczy 3613". 
Ekscelencjo, Najdostojniejszy Księże Arcybiskupie!

Poznań, dnia 4 lipca 1933

Przepraszamy za opóźnienie z odpowiedzią na Jego list z dnia 18 u[biegłego] m[iesiąca], spowodowanie nieobecnością w Poznaniu p[ana] S[zczepana] Jeleńskiego.

Sprawa dzieła Waszej Ekscelencji, drukowanego w Ossolineum, od naszej strony przedstawia się jak następuje:

1. Na życzenie Waszej Ekscelencji wbrew wszelkim zwyczajom i z wyraźną szkodą dla naszych zakładów graficznych, które obecnie cierpią na brak pracy - zgodziliśmy się na druk dziełka we Lwowie, aby ułatwić Najdostojniejszemu Autorowi korektę tej rzeczy, jako bardzo pilnej, a niewielkich względnie rozmiarów.

2. Wasza Ekscelencja przesyłając rękopis drukarni Ossolineum nie raczył nas ani słówkiem choćby przez swego sekretarza o tym powiadomić.

3. Co ważniejsze, nie zostaliśmy również powiadomieni ani słówkiem przez Najdostojniejszego Autora, że rzecz ta uległa przemianom, że rozrosła się pod piórem, że z dziełka przeistoczyła się w dzieło trzykrotnie większej objętości. O tym wszystkim dowiedzieliśmy się ubocznie, gdy drukarnia zażądała papieru na książkę 30-arkuszową.

4. Ks. Dr. Brossa, o którym dotychczas w żadnym liście poprzednim nie było oświadczenia, że jest on Waszej Ekscelencji „delegatem dla wszelkich umów z Księgarnią św. Wojciecha", uważaliśmy za życzliwego obustronnie orędownika tych spraw, chętnie pośredniczącego w pertraktacjach w miarę udzielanych mu przez Waszą Ekscelencję wskazówek i informacji.

5. Ks. Dr. Bross nie był jednak również powiadomiony o przebiegu prac Waszej Ekscelencji nad tym dziełem i przywiózł nam ostatnio wiadomość ze Lwowa o rozrośnięciu się tej książki do rozmiarów nieprzewidywalnych, już po otrzymaniu przez nas wiadomości tej z Ossolineum.

6. Z tych wszystkich przesłanek, jak również z treści ostatniego listu Waszej Ekscelencji wnosić musimy, że uznani zostaliśmy przez Waszą Ekscelencję za obowiązanych do podejmowania usilnych zabiegów, aby przez drukarnię Ossolineum albo przez ks. dra Brossa wywiadywać się o stanie pracy przez nas wydawanej, poza tym oprócz poniesienia kosztów wydawnictwa nie mieliśmy - zdaje się - w oczach Najdostojniejszego Autora żadnej innej roli w tej sprawie.

7. Zamieszczona wreszcie na końcu ostatniego listu Waszej Ekscelencji uwaga, że dzieło to będzie okazją „ażeby Wydawnictwo św. Wojciecha chociaż w wyjątkowym wypadku pozwoliło sobie na luksus ideowości" - jest ukoronowaniem wszystkiego, co nas z okazji wydania tej książki ze strony Waszej Ekscelencji spotkało.

Otóż pozwolimy sobie oświadczyć, że nie z uwagi na nasze osoby, lecz ze względu na powagę reprezentowanej przez nas instytucji przeciw takiemu traktowaniu naszego Wydawnictwa nawet ze strony Najdostojniejszych, Najzasłużeńszych i Najmilszych nam Autorów stanowczo się zastrzegamy.

Przechodząc zaś do sprawy samej w jej obecnym stadium pośpieszamy donieść, że ze względu na znaczną objętość książki nakład jej ustalić zamierzamy na $1000+100$ egzemplarzy. Aby cenę możliwie obniżyć, w kalkulacji uwzględnimy ściśle tylko nasze koszty handlowe, zrzekając się na wydawnictwie tym wszelkiego zysku. 
Ks. Dr Bross w imieniu Waszej Ekscelencji proponował, iżby honorarium ustalić według zwykłej normy $15 \%$ od ceny katalogowej. Skala ta wydaje nam się zbyt wysoka wobec konieczności obniżenia ceny książki. Proponujemy więc ze swej strony albo - prócz 20 egzemplarzy autorskich - gotówką 10\% ceny katalogowej 1000 egzemplarzy, płatne jednak w miarę rozprzedaży w obliczeniach kwartalnych, albo - 150 egzemplarzy dzieła, czyli 15\% egzemplarzami.

Uprzejmie prosimy Waszą Ekscelencję o oświadczenie się, która z tych propozycji bardziej Mu odpowiada, albo o wysunięcie ze swej strony innego sposobu porozumienia.

Nadesłane odbitki zostały przekazane Cenzurze tutejszej, aczkolwiek - skoro druk dzieła dokonywać się będzie we Lwowie - wystarczało „Imprimatur” lwowskie. Sądzimy, iż najwłaściwszą porą wydania tej książki będzie koniec września, względnie październik. W okresie rozpoczętej obecnie kanikuły niewskazane byłoby wypuszczanie tak poważnego wydawnictwa na rynek księgarski.

Piszemy się ze czcią głęboką

DRUKARNIA I KSIĘGARNIA ŚW. WOJCIECHA Dział Wydawniczy ${ }^{\mathrm{b}} \mathrm{Sz}[\mathrm{czepan}]$ Jeleński ${ }^{\mathrm{b}}$

Polecony!

P.S. Ustępy dotyczące udziału w tej sprawie ks. dr. Brossa ustaliliśmy w porozumieniu z ks. Brossem.

\section{Dokument 115}

Kopia: AFKDOPW, bsygn., teczka: Spuścizna abp. Józefa Teodorowicza, List z Wydawnictwa św. Wojciecha do ks. dr. Stanisława Brossa, Poznań 12 VII 1933 r.

Przewielebny ${ }^{\mathrm{a}}$ Ks. Dr Stanisław Bross

w Poznaniu

Koszt techniczny egzemplarza (zestaw, druk, papier, okładka, broszura) wyniesie ponad 4 zł. Przy maksymalnej cenie sprzedanej książki zł 12, po odliczeniu rabatu hurtowni, kosztów handlowych, honorarium, otrzymamy - jak to mieliśmy sposobność Szan[ownemu] Ks. Doktorowi wyjaśnić - na pokrycie kosztów technicznych zł 3,84. Nie tylko więc nie osiągniemy zysku, lecz poniesiemy pewną drobną stratę, nawet jeżeli dzieło rozejdzie się w całości i dość szybko.

Poza korektami autorskimi Ossolineum zapytywało, kto ma pokryć wynagrodzenie p[ani] dr Marii Chmielewskiej ${ }^{339}$, która pracowała przy adiustowaniu dzieła. Odpowiedzieliśmy oczywiście, że pokryć to może tylko Najdost[ojniejszy] Autor.

b-b Tekst sporządzony czarnym atramentem.

a Tekst pisany maszynowo na jednej stronicy papieru formatu A4. Brak autografu autora pisma i miejsca wystawienia dokumentu.

339 Osoba niezidentyfikowana. 
Powracając do sprawy honorarium moglibyśmy więc zaakceptować układ następujący: Księgarnia św. Wojciecha pokrywa drukarni Ossolineum należne tej ostatniej od J[ego] Ekscelencji zł 707. Pozostałą należność (przy przewidywanej cenie 12 zł za egzemplarz i 10\% honoraium autorskiego od tej ceny) wynoszącą zł $493(1200-700=$ zł 493) wypłacimy Najdost[ojniejszemu] Autorowi w ratach kwartalnych w miarę rozchodzenia się jego dzieła.

Przedkładając sprawy te Szan[ownemu] Ks. Doktorowi prosimy o ich przedstawienie J[ego] Ekscelencji i zakomunikowanie wyniku nam swego z Najdost[ojniejszym] Autorem porozumienia.

Wyrazy wysokiego poważania łączymy.

\section{Dokument 116}

Kopia: AFKDOPW, teczka 127: Spuścizna abp. Józefa Teodorowicza, sygn. 331/91 [5], List z Wydawnictwa św. Wojciecha do ks. dr. Stanisława Brossa, Poznań 17 VII 1933 r.

Przewielebny ${ }^{a}$ Ks. Dr Stanisław Bross

w Poznaniu

Al. Marcinkowskiego 22

Nr dz. 1424/33 B.W.

[Poznań] 17 lipca 1933

Szanowny Księże Doktorze!

Szan[owny] Ks. Doktor w imieniu J[ego] E[kscelencji] ks. arc[ybiskupa] Teodorowicza zaproponował nam, ażeby porozumienie w sprawie honorariom za dzieło „Zjawiska mistyczne..." ustalić na zasadzie $10 \%$ od ceny katalogowej, z czego zł 600 wypłacić mielibyśmy jednorazowo, resztę zaś w rozliczeniach postnumerando ${ }^{340}$. Zachodzi jednak ta okoliczność, że w rachunku, jaki przysłało Ossolineum figuruje pozycja korekt autorskich w wysokości zł 907. Suma ta winna być w całości pokryta przez Najdost[ojniejszego] Autora, ponieważ zasadniczo wydawca powinien otrzymać rękopis ostatecznie wykończony $\mathrm{i}$ ten rękopis wydrukować zgodnie z jego brzmieniem. Wszyscy wydawcy i my w ich liczbie przewidują tylko bardzo niewielkie poprawki autorskie, których koszt zasadniczo nie powinien przekraczać $3 \%$ ceny zestawu wynoszącej w tym wypadku zł 2078. Przy druku dzieła „Od Betleem do Nazaretu” ${ }^{341}$ wyjątkowo pokryliśmy korekty autorskie wynoszące 200 zł. I to byłoby maximum, które moglibyśmy zastosować i tym razem. Przypadłoby więc do pokrycia ze strony Jego Ekscelencji jeszcze zł 707. Oczywiście kwotę zł 707 możemy w rozliczeniach z Ossolineum pokryć, a odciągnąć ją od honoraium. [...] $]^{\mathrm{b}}$.

a Tekst pisany maszynowo na jednej stronicy papieru formatu A4. Brak zakończenia i autografu autora.

340 Płatne po odbiorze towaru.

${ }^{341}$ J. Teodorowicz, Jezus Chrystus, t. 2: Od Betlejem do Nazaretu, Poznań 1932.

b Brak zakończenia. 


\section{Dokument 117}

Oryg.: AFKDOPW, teczka 145: Spuścizna abp. Józefa Teodorowicza, sygn. 1730/64 [5], List z Wydawnictwa Zakładu Narodowego im. Ossolińskich we Lwowie do abp. Józefa Teodorowicza, Lwów 19 VII 1933 r.

Lwów, 19 lipca 1933

L. 1186

ul. Ossolińskich l[okal] 11, tel. 1-68, 38-59

Jego ${ }^{a}$ Ekscelencja

Ks. Arcybiskup Dr Józef Teodorowicz

Lwów

Kierownik naszego Wydawnictwa otrzymał dnia 17-go b.m. z Drukarni i Księgarni Św. Wojciecha w Poznaniu następującej treści pismo z dnia 13-go b.m.: „W odpowiedzi na dwa ostatnie listy (z dn[ia] 8 i 10 b.m.) donosimy, że nie otrzymaliśmy dotychczas definitywnej odpowiedzi od ks. Arc[ybiskupa] Teodorowicza co do projektowanego nakładu i honorarium. Przed ustaleniem tej sprawy nie można przystąpić do druku. Wynagrodzenie p[ani] dr Chmielewskiej w żadnym razie nie może nas obciążyć. Co do pokrycia należności popieram to jak już zaznaczyliśmy w liście z dnia 22 marca r[oku] b[ieżącego] nastąpić ono może tylko tymże samym papierem, na którym dzieło ma być drukowane według ceny wówczas podanej i to przesłanego w jednej partii. Jakiekolwiek inne załatwienie tej sprawy mogłoby nas narazić na przykrości ze strony Centropapieru. Pozwalamy sobie rzucić tu projekt taki: Czy by nie było dla Panów korzystniejsze, gdyby Panowie swą należność za zestaw, druk itp. otrzymali w gotowych egzemplarzach obliczonych ewentualnie z $40 \%$ rabatu. Cena egzemplarza będzie prawdopodobnie sięgała zł 15”.

Na pismo to odpowiedzieliśmy w dniu dzisiejszym: „W uprzejmym powołaniu się na pismo W[ielmożnych] Panów z 13-go b.m. donosimy, iż równocześnie zwracamy się do Jego Ekscelencji ks. Arc[ybiskupa] Teodorowicza w sprawie nakładu pracy pt.: «Zjawiska mistyczne i ich tłumaczenia». Nie możemy niestety zgodzić się na pokrycie naszego rachunku za skład i druk tej pracy w gotowych egzemplarzach, gdyż jak W[ielmożnym] Panom wiadomo, mamy tylko jedną księgarnię we Lwowie. Naturalnie polecimy tej naszej księgarni ażeby energicznie zajęła się sprzedażą tej pracy i wzięła ją w komis od W[ielmożnych] Panów. Pokrycie naszego rachunku może według nas nastąpić tylko jak poprzednio ustaliliśmy, papierem z fabryki W[ielmożnych] Panów lub ostatecznie wzajemnym rozliczeniem się".

a Tekst pisany maszynowo na 1,5 stronicy papieru formatu A4. W lewym górnym rogu karty tytułowej nadruk firmowy: „Wydawnictwo Zakładu Narodowego imienia Ossolińskich we Lwowie. Konto żyrowe: Bank Polski Oddział we Lwowie. Rachunek bieżący: PKO Warszawa Nr 141599 Bank Gospodarstwa Krajowego Oddział we Lwowie Bank Związku Spółek Zarobkowych Oddział we Lwowie”. Na końcu pisma podłużna pieczęć: „Wydawnictwo Zakładu Narodowego im. Ossolińskich we Lwowie” i dwa nieczytelne autografy. Brak autografu autora. 
Wobec tego prosimy Jego Ekscelencję o łaskawe ostateczne ustalenie z drukarnią Św. Wojciecha warunków umowy, a przede wszystkim nakładu, o ile nam wiadomo 1100 egzemplarzy. Skład względnie matryce możemy trzymać do ewentualnego drugiego nakładu. Odpowiedź Jego Ekscelencji do drukarni Św. Wojciecha jest dla nas bardzo ważna, gdyż chcielibyśmy ostatecznie przystąpić do druku tej pracy.

Łączymy wyrazy głębokiej czci i hołdu.

\section{Dokument 118}

Oryg.: AFKDOPW, teczka 138: Spuścizna abp. Józefa Teodorowicza, sygn. 333/91 [5], List ks. dr. Stanisława Brossa do abp. Józefa Teodorowicza, Poznań 20 VII 1933 r.

Poznań, dn[ia] 20/VII 1933

Aleje Marcinkowskiego 22

Ekscelencjo $^{\mathrm{a}}$,

Przesyłam uprzejmie Waszej Ekscelencji list Księgarni ${ }^{342}$ do łaskawej wiadomości, prosząc zarazem o łaskawe wskazówki, czy się na propozycję zgodzić. Byli bardzo twardzi i dopiero po długich perswazjach zgodzili się na wypłacenie $600 \mathrm{zl}$, lecz wyjechali z tymi korektami. Dziś jeszcze raz u nich byłem - są nieubłagani.

Chciałbym im tak zaproponować. Te 493 zł Księgarnia wypłaca zaraz Ekscelencji + 30 egzempl[arzy] (chcą tylko dać 12). Koszta korektorskie płaci Księgarnia. Domagałem się, by oni zapłacili także p[ani] Chmielewskiej - nie godzą się absolutnie na to. Bardzo uprzejmie proszę o ostateczną decyzję. „Imprimatur” już załatwione - papier na druk w tych dniach wychodzi.

Uprzejmie proszę o łaskawe pozwolenie Waszej Ekscelencji na przedruk tej „mowy” w „Ruchu” ${ }^{343}$. Serdecznie dziękuję Waszej Ekscelencji za modlitwę o zdrowie Matki. Dzięki Bogu już lepiej.

Całuję z największą czcią ręce Waszej Ekscelencji i pozostaję z synowskim przywiązaniem szczerze oddany

Ks. Stanisław Bross

\section{Dokument 119}

Oryg.: AFKDOPW, teczka 138: Spuścizna abp. Józefa Teodorowicza, sygn. 329/91 [5], List ks. dr. Stanisława Brossa do abp. Józefa Teodorowicza, Poznań 20 VII 1933 r.

L. dz. $74 / 33$

Poznań, dn[ia] 20/VII 1933

a Tekst pisany czarnym atramentem na dwóch stronicach papieru formatu A4. W lewym górnym rogu karty tytułowej firmowy nadruk: „Dyrektor Naczelnego Instytutu Akcji Katolickiej w Polsce. L. dz.”

${ }^{342}$ Księgarnia św. Wojciecha w Poznaniu.

343 Właściwie: „Ruch Katolicki. Organ Akcji Katolickiej w Polsce” - miesięcznik wydawany w 1. 19311939 w Poznaniu, redaktor ks. Stanisław Bross. 
Aleje Marcinkowskiego 22

$\dagger$

Ekscelencjo ${ }^{a}$, Najdostojniejszy Księże Arcypasterzu!

Sam chodziłem około wydania książki bardzo pilnie, tak że się dałem św. Wojciechowi niemile we znaki. Skutek jednakże był osiągnięty. Książka wreszcie wydana i mam nadzieję, że Wasza Ekscelencja jest już w jej posiadaniu.

Bardzo żałowałem, że nie było Waszej Ekscelencji w Częstochowie. Ogromne tłumy się zebrały. Manifestacja była wspaniała ${ }^{344}$.

Łączę wyrazy najgłębszej czci i pozostaję z synowskim przywiązaniem szczerze oddany

Ks. Stanisław Bross

\section{Dokument 120}

Kopia: AFKDOPW, teczka 136: Spuścizna abp. Józefa Teodorowicza, sygn. 1450/420 [12], List abp. Józefa Teodorowicza do dyrektora Wydawnictwa i Księgarni św. Wojciecha w Poznaniu Szczepana Jeleńskiego, Lwów 20 VII 1933 r.

\section{Odpis!}

Wielmożny ${ }^{\mathrm{a}}$ Panie Dyrektorze!

Zgadzam się na podane mi warunki umowy, tj. 20 egzemplarzy autorskich i 10 procent honorarium, a tylko proszę o przekazanie mi całej kwoty bez uzależniania jej wysyłki od rozsprzedaży.

Łączę wyrazy głębokiego poważania.

Lwów, dnia 20 lipca 1933

\section{Dokument 121}

Oryg.: AFKDOPW, teczka 141: Spuścizna abp. Józefa Teodorowicza, sygn. 1731/64 [5], List Szczepana Jeleńskiego z Działu Wydawniczego Drukarni i Księgarni św. Wojciecha w Poznaniu do abp. Józefa Teodorowicza, Poznań 27 VII 1933 r.

$\mathrm{J}[\mathrm{ego}]^{\mathrm{a}} \mathrm{E}[\mathrm{kscelencja}]$

Najprz[ewielebniejszy] Ks. Arc[ybiskup] Józef Teodorowicz

a Tekst pisany maszynowo $\mathrm{z}$ wyjątkiem autografu autora na jednej stronicy papieru formatu A4. W lewym górnym rogu karty tytułowej firmowy nadruk: „Ks. dr Stanisław Bross Dyrektor Naczelnego Instytutu Akcji Katolickiej w Polsce".

${ }^{344}$ Nawiązanie do ogólnopolskiego Zjazdu Katolickiego 6 VII 1932 r. w Częstochowie.

a Tekst pisany na $1 \frac{1}{2}$ stronicy papieru formatu A4. Brak autografu autora listu.

a Tekst pisany maszynowo $\mathrm{z}$ wyjątkiem autografu autora pisma na jednej stronicy papieru formatu A4. W górnej partii karty nadruk firmowy: „DRUKARNIA I KSIĘGARNIA ŚW. WOJCIECHA. Sp[ółka[ z o[graniczoną] o[dpowiedzialnością]” i logo instytucji. Niżej nadruk: „Poznań, Al. Marcinkowskiego 22, Adres telegraficzny: Albertinum, PKO Poznań 200.032. Konto bankowe: Bank Związku Spółek Zarobkowych, Poznań. Telefony: Dyrekcja 3614, Nr zbiorczy 3613". 
we Lwowie

Pałac Arcybiskupi

W odpowiedzi prosimy powołać się na znak:

Nr. dz. 1497/33.

B.W.

Ekscelencjo, Najdostojniejszy Księże Arcybiskupie!

Poznań, dnia 27 lipca 1933

Potwierdzamy odbiór listu z dnia 20 b.m., w którym Wasza Ekscelencja wyraził zgodę na proponowane przez nas warunki w sprawie wydania dzieła „Mistyczne zjawiska...”. Ks. Dr. Bross doniósł nam następnie, że Wasza Ekscelencja zgadza się również na potrącenie z przypadającego Mu honorarium zł 1200 - kosztów korekt autorskich, wynoszących zł 707. Życzy sobie natomiast Wasza Ekscelencja, aby ilość egzemplarzy autorskich podnieść z 20 na trzydzieści oraz aby reszta honorarium w sumie zł 493 przekazana $\mathrm{Mu}$ została w niedługim czasie. Uprzejmie powiadamiamy, iż na życzenia te zgadzamy się, pieniądze przekażemy w pierwszej dekadzie sierpnia, egzemplarze zaś po wyjściu dzieła z druku.

Wyrazy czci głębokiej łączymy

DRUKARNIA I KSIĘGARNIA ŚW. WOJCIECHA Dział Wydawniczy

${ }^{\mathrm{b}}$ Szczepan Jeleński ${ }^{-\mathrm{b}}$

P.S. Termin ukazania się dzieła Waszej Ekscelencji zależeć będzie obecnie od pośpiechu, w jakim druku dokona Ossolineum.

\section{Dokument 122}

Oryg.: AFKDOPW, teczka 138: Spuścizna abp. Józefa Teodorowicza, sygn. 328/91 [5], List ks. Stanisława Brossa do abp. Józefa Teodorowicza, Poznań 28 VII 1933 r.

Poznań, dn[ia] 28/VII 1933

$\dagger$

Ekscelencjo $^{\mathrm{a}}$,

Wreszcie targ z Działem Wyd[awniczym] Księg[arni] Św. Wojciecha ubity. Płacą więc całą sumę za korekty autorskie 907 zł do Ossolineum, Waszej Ekscelencji przesyłają zaraz 493 zł i 30 egz[emplarzy] autorskich. Potwierdzenie tej umowy w tych dniach do Waszej Ekscelencji nadejdzie.

Mam nadzieję, że Wasza Ekscelencja pozwala mi na łaskawy przedruk swej przemowy, o której wspominałem i stąd wysyłam ją do druku. Mamusię wczoraj pierwszy raz wysadzili z łóżka. Mam w Bogu nadzieję, że wszystko będzie dobrze. Bóg zapłać

\footnotetext{
b-b Tekst sporządzony czarnym atramentem.

a Tekst pisany czarnym atramentem na dwóch stronicach papieru formatu karty pocztowej.
} 
Ekscelencji za modlitwę. Prymas daje rekolekcje na Pińszczyźnie, przed tygodniem dawał w Polskiej Wsi ${ }^{345}$ ziemiankom.

Łączę wyrazy najgłębszej czci i synowskiego przywiązania, szczerze oddany sługa

Ks. Stanisław Bross

\section{Dokument 123}

Kopia: AFKDOPW, teczka 127: Spuścizna abp. Józefa Teodorowicza, sygn. 1456/420 (12) [7], List abp. Józefa Teodorowicza do ks. dr. Stanisława Brossa, Lwów 31 VII 1933 r.

Kochany ${ }^{\mathrm{a}}$, Drogi Księże Doktorze!

Jeszcze raz serdeczną i gorącą składam podziękę za tak szczęśliwe doprowadzenie do skutku pertraktacji z Wojciechem ${ }^{346}$.

Przedruk mojej pracy to taki drobiazg, że nawet nie zwróciłem nań uwagi, za co Kochanego Księdza Doktora przepraszam; oczywiście najchętniej się godzę.

Cieszę się bardzo, że stan zdrowia Matki tak się poprawił; Bóg chce oszczędzić sercu Księdza Doktora tak oddanego Jego sprawom tego naturalnego oparcia, jakim jest serce matki. Tylko widzę, że Ksiądz Doktor jakoś nie wybiera się nigdzie, a chyba to potrzebne choćby już tylko dla uspokojenia nerwów. Tego roku i ja siedzę we Lwowie, bo zapadłem na zdrowiu skutkiem nieoględnego stosowania Roentgena przez lekarzy na mój reumatyzm. Na reumatyzm Roentgen zdaje się niewiele pomógł, ale za to zaatakował mi serce. Dziś mam się już lepiej i w tych dniach gdzieś się wybiorę, najprawdopodobniej do Kaltenleutgeben pod Wiedniem. Tymczasem wykańczam Konnersreuth po niemiec$\mathrm{ku}^{347}$, bo chciałbym zrzucić co prędzej ten ciężar z siebie, ażeby się zabrać do „Życia Chrystusa".

Łączę dla Kochanego Księdza Doktora bardzo oddane i bardzo serdeczne wyrazy czci i przyjaźni.

[P.S.] Prosiłbym bardzo o przysłanie mi sprawozdania, które Ksiądz Prałat spisał z pobytu naszego w Konnersreuth; piszę właśnie w tej kwestii.

Lwów, dnia 31 lipca 1933

Ks. Dr Stanisław Bross

Poznań - [al.] Marcinkowskiego 22

\section{Dokument 124}

Kopia: AFKDOPW, teczka 131: Spuścizna abp. Józefa Teodorowicza, sygn. 1454/420 (12) [7], List abp. Józefa Teodorowicza do Szczepana Jeleńskiego, Lwów 31 VII 1933 r.

\footnotetext{
${ }^{345}$ Polska Wieś - miejscowość w Wielopolsce.

a Tekst pisany czarnym atramentem na 1,5 stronicy papieru formatu A4. Brak autografu autora.

${ }^{346}$ Właściwie: z Wydawnictwem i Księgarnią św. Wojciecha w Poznaniu.

347 J. Teodorowicz, Konnersreuth im Lichte der Mystik und Psychologie, Salzburg-Leipzig 1936.
} 


\section{Przezacny ${ }^{\mathrm{a}}$ Panie Dyrektorze!}

Cieszę się, że układ nasz jest definitywnie załatwiony; to mi pozwała dołączyć jeszcze parę uwag, które mi się nasuwają. Otóż uważam, że wydanie książki o Konnersreuth przeze mnie było wprost nie do pomyślenia bez bardzo gruntownej rozprawy z O. Siwkiem. Albowiem on nagromadził jak nikt dotąd cały negatywny materiał przeciw Konnersreuth, z którym już w książce pozytywnie rozprawiać się trudno. Potrafił on też zachwiać pod wpływem artykułów „Ilustrowanego Kuriera” ${ }^{348}$ w ogóle opinię w całej Polsce o Konnersreuth. Utarła się opinia, że Konnersreuth to nic innego jak zjawisko histeryczki, jeśli już nie wprost oszustki. Otóż ja sam z początku myślałem, że w odpowiedzi O. Siwkowi wydam tylko broszurę, ale w miarę jak wchodziłem w temat widziałem, że to jest czystym niepodobieństwem.

Ponieważ Panowie chcieli wydać książkę o Konnersreuth, dlatego bez względu na to, jakie obecnie będzie stanowisko Panów, to w tym założeniu i dla wydawnictwa samego niewiele by się zdała moja książka, gdyby jej nie poprzedziła bardzo gruntowna i bardzo zasadnicza rozprawa z wszystkimi możliwymi zarzutami, bo i osobistymi, i teologicznymi, i psychopatycznymi. Trudno mi o swej własnej pracy wydawać sąd, ale oddałem ją pod osądzenie ks. metropolity Szeptyckiego ${ }^{349}$, dobrego teologa i znawcy mistyki. Pomijam jego zbyt łaskawe słowa uznania dla mojej pracy, zaznaczę tylko, iż w liście do mnie pisanym wyraził przekonanie, że praca ta $\mathrm{z}$ wielkim będzie pożytkiem w ogóle dla problemu tego rodzaju i to właśnie ze względów zasadniczego opracowania.

Wiem, że Panom przykra była moja aluzja do księgarni św. Wojciecha, ale wtedy, kiedy ja pisałem byłem przekonany, że Panowie chcą się wycofać w wydawnictwie już po publicznym zaangażowaniu mojego nazwiska w biuletynie wydawniczym księgarskim zapowiadającym wyjście mojego dzieła. Sądziłem, że sposób, jakim się posłużyłem był jeszcze najdelikatniejszy dla napiętnowania sprawy, która na szczęście w moich przewidywaniach okazała się nierealna. Dlatego tylko mogę dać wyraz mojemu szczeremu zadowoleniu z tego, iż racja, która wywołała moją uwagę polegała na pozorach, które się okazały potem niczym więcej jak tylko pozorami.

Korzystam z tej sposobności, aby załączyć dla Pana Dyrektora wyrazy najgłębszego szacunku i poważania.

Lwów, dnia 31 lipca 1933

J[aśnie] W[ielmożny] P[an

Szczepan Jeleński

Poznań

${ }^{a}$ List pisany maszynowo na dwóch stronicach papieru formatu A4. Brak autografu autora.

348 Właściwie: „Ilustrowanego Kuriera Codziennego”.

${ }^{349}$ Zob. w niniejszej publikacji: J. Wołczański, Listy abp. Józefa Teodorowicza do abp. Józefa Bilczewskiego, dokument 3 . 


\section{Dokument 125}

Kopia: AFKDOPW, teczka 134: Spuścizna abp. Józefa Teodorowicza, sygn. 1472/420 (12) [7], List abp. Józefa Teodorowicza do o. Josefa Schrijversa CSsR, Lwów 9 VIII 1933 r.

\section{Wielce ${ }^{\mathrm{a}}$ Czcigodny Ojcze Prowincjale!}

Prawdziwą niespodzianką było dla mnie otrzymać przez pośrednictwo OO. Redemptorystów nowe dziełko Ojca dla kapłanów ${ }^{350}$.

Najpierw ucieszyła mnie i wzruszyła łaskawa pamięć Czcigodnego Ojca Prowincjała o mnie, za co serdecznie dziękuję; ale potem cieszę się niezmiernie tym przecennym podarunkiem dla kapłanów, jakim jest niewątpliwie ta książka. Odbiega ona swoją formą i swoim ujęciem rzeczy od wszystkich podobnych dotychczasowych prac. Albowiem treść cała tej książki jest niczym innym, jak tylko dialogiem kapłana z Chrystusem. Wszystkie refleksy tu się właśnie w tym dialogu mieszczą, w nim się zbiegają i z niego wychodzą. I dlatego jest w tej książce tchnienie czegoś bardzo bezpośredniego, ciągła mowa $\mathrm{z}$ serca do serca; a jednak równocześnie nie ma nawet śladu w tej książce tych tak częstych jednostronności, które się zwykły mieszać z dialogiem, a więc nie ma żadnego sentymentalizmu w uczuciach, nie ma też żadnej monotonności. Są tu rozebrane na tym tle wszystkie obowiązki kapłana, wszystkie też jego przeniewierstwa i winy; w niczym Ojciec nie oszczędza przeniewierstw i win, przeciwnie, wytyka je i podnosi. Ale dzięki właśnie temu, że wszystko jest oparte o Chrystusa i zjednoczenie z Nim, wzbudzi ta praca Ojca i te rozmyślania niezmierną ufność w miłosierdzie i żywą wiarę w miłość Chrystusową. Stąd wszędzie podnosi ta praca dusze choćby nawet w upadku ku nadziei i żałującej, i bolejącej miłości.

Opóźniam się z podziękowaniem za tę książkę, byłem bowiem teraz chory skutkiem przepracowania a także skutkiem nieostrożnie mi przez lekarzy zaleconego roentgenowania.

Praca, która jest odpowiedzią O. Siwkowi jest już wydrukowana i z początkiem września ukaże się na półkach księgarskich. Pozwolę sobie ją wówczas przesłać Ojcu Prowincjałowi. Przeczytał ją od deski do deski metropolita Szeptycki; bardzo rad jest z tej pracy. Ma on nadzieję, że przyniesie dużo dobrego. Oby tak było! Kosztowała mnie ta praca wiele wysiłku i urosła do rozmiarów książki, która ma przeszło 400 stron druku.

Mówił mi metropolita Szeptycki, że będzie to wielkie upokorzenie dla jezuitów w ogóle, jednak bardzo zasłużone i jak on sądzi dla nich skuteczne.

Modlę się, aby Bóg dał siły Ojcu Prowincjałowi do nowego tak odpowiedzialnego i tak ciężkiego urzędu.

Polecając się łaskawym modłom, łączę wyrazy bardzo głębokiej i bardzo oddanej czci i wdzięczności.

Lwów, dnia 9 sierpnia 1933

O. Prowincjał Schrijvers

Belgia

a Tekst pisany maszynowo na 2,5 stronicy papieru formatu A4. Brak autografu autora.

${ }^{350}$ J. Schrijvers, Message de Jésus à son Prêtre, Bruxelles 1933. 


\section{Dokument 126}

Oryg.: AFKDOPW, teczka 145: Spuścizna abp. Józefa Teodorowicza, sygn. 1025/420 (8) [7], List Friedricha Ritter von Lamy do abp. Józefa Teodorowicza, Gauting bei München, 24 VIII 1933 r.

Excellenz $z^{\mathrm{a}}$, hochwürdigster Herr Erzbischof!

Gauting b[ei] München, 24 VIII [19]33

Ich habe von Ihrer wohlbegründeten Entscheidung bezüglich einer Verdeutschung Ihrer Schrift gegen P[ater] Siwek Kenntnis genommen. Bis heute haben sich Siweks Gesinnungsgenossen und Materiallieferanten nicht gerührt, um aus seiner Broschüre Kapital zu schlagen, man hat daher auch keinen Grund, derselben durch Bekanntgabe Verbreitung zu geben. Inzwischen habe ich von der erzbischöflichen Behörde in München wenige Tage nach der Einreichung das Imprimatur für mein neues Konnersreuther Jahrbuch erhalten, das in den ersten Septembertagen erscheinen wird; der Druck war im Frühjahr viel durch die üblichen politischen Eingriffe in wirtschaftliche Betriebe verzögert worden. Wie ich höre, werden in Konnersreuth jetzt allmälich wieder Besuche zugelassen, wenn auch nicht in grösserer Zahl. Resl war inzwischen auch in Trier und ich hoffe, nächste Woche nähere Mitteilungen zu erhalten. Damit wird allmälich auch das Interesse für Konnersreuth wieder erwachen und Sie dürfen es dann schon wagen, Ihr Buch zu veröffentlichen. Bezüglich Gerlichs, der noch immer im Gefängnis ist, hörte ich, dass er eine grosse seelische Läuterung durchgemacht hat. Ueber Regensburg hört man wenig Günstiges; der Klerus klagt, dass die beiden rationalistischen Professoren Waldmann und Engert ${ }^{351}$, entschiedene Gegner von Konnersreuth, unbehindert ihre verderblichen Lehren verbreiten dürfen und Excellenz nicht die Entschiedenheit zu einem Eingreifen aufbringt. Ich vermute, Resl weiss um Gerlichs Schicksal wohl Bescheid, aber sie spricht nicht darüber, weil es für jenen von Nachteil sein könnte. Für Eure Excellenz dürfte die Einreise kein Risiko bedeuten; ich glaube nicht, dass man wagen würde, Schwierigkeiten zu bereiten und damit gegen den Geist des neuen Konkordates zu verstossen. Die Arbeit von P[ater] Lavaud kenne ich; er sandte sie mir vor der Veröffentlichung und hat mir geschrieben, er werde Mager künftig ignorieren, weil dieser es an der nötigen wissenschaftlichen Gewissenhaftigkeit fehlen lasse. Bezüglich Bearaing hin ich natürlich nur auf fremde Berichte angewiesen. Aber wenn z[um] B[eispiel] die Kinder es versäumen, ihre Sonntagspflicht zu erfüllen und dies damit begründen, dass sie statt dessen „zu den Erscheinungen gehen“, so kann ich niemals glauben, dass die Muttergottes durch ihr Erscheinen eine solch schwere Pflichtverletzung gegen Gott unterstützt; hier stimmt etwas nicht. Daher habe ich in der Oeffentlichkeit bisher zu Zurückhaltung geraten; im übrigen ist es aber nicht meine Sache, dazu Stellung zu nehmen.

Ich gebe in nächster Zeit die grosse Biographie der seligen Gemma Galgani heraus (aus dem Italienischen) und erhoffe mir eine gute Wirkung; da die Leute theoretische Werke über Mystik ja doch nicht lesen, muss man sie auf dem Umwege über die Praxis

Tekst pisany maszynowo na 1,5 stronicy papieru formatu A4. Autograf odręczny czarnym atramentem.

351 Osoba niezidentyfikowana. 
und das Leben in dieses Gebiet einführen; es wird dann auch der Beurteilung Konnersreuths zugute kommen.

Ich bitte, mir zu erlauben, ein besonderes Familienanliegen zu empfehlen und um dessen Einbeziehung in Ihr Gebet bitten zu dürfen. Ich darf wohl mit Resls Gruss schliessen: der Hailand sei mit Ihnen !

In Verehrung ergebenst Ihr

Friedr[ich] R[itter] von Lama

\section{Dokument 127}

Oryg.: AFKDOPW, teczka 145: Spuścizna abp. Józefa Teodorowicza, sygn. 1024/420 (8) [7], List Friedricha Ritter von Lamy do abp. Józefa Teodorowicza, Gauting bei München 2 IX 1933 r.

Excellenz $z^{\mathrm{a}}$, hochwürdigster Herr Erzbischöf!

Gauting, 2. September 1933

Nun wird es doch notwendig werden, die Zurückhaltung gegenüber P[ater] Siwek auf dem deutschen Sprachgebiet aufzügeben, denn jetzt hat sich der „Evangelische Presseverband" der Broschüre Siweks angenommen und in allen protestantischen Blattern wird ein triumphierender Artikel verbreitet, Siwek bedeute Rom, Roma locuta, die Freunde Konnersreuths freien blamiert, von Rom preisgegeben, die ganze Sache sei damit zu Ende, alles war Aberglaube und Trug u.s.w. Ich wurde bereits, von einem katholischen Blatte zu einer Erwiderung aufgefordert und es lässt sich nicht umgehen, nunmehr in die Erörterung des „Falles Siwek“ einzutreten. Daher bitte ich Eu[re] Excellenz, die Güte zuhaben, mir die gewichtigsten Stellen Ihrer Widerlegung gütigst zugänglich zu machen und allenfalls Ihr Urteil (wie man es am Schlüsse zusammenfassend anzubringen pflegt) beizufügen. Es wird zweifellos einen harten Kampf geben, denn ich kenne diese Gegner, sie sind ebenso rücksichtslos ie gewissenlos. Der Beweis dafür liegt bereits in dem mir vorliegenden Angriffsartikel. Ich werde selbstverständlich betonen, dass es unzutreffend ist, für die Schrift Siweks den Orden, dem er angehört, verantwortlich zu machen, damit auf diese Weise dem Wunsche, den $\mathrm{Eu}[\mathrm{re}]$ Excellenz in Ihrem letzten Briefe ausgesprochen haben, Rechnung getragen ist. Ich werde bemüht sein, den Streit gewissermassen zu lokalisieren. Da ich leider des Polnischen nicht machtig bin, bin ich in dieser Verteidigung ganz auf Eure Excellenz angewiesen. Ich begrüsse Sie in aurichtiger Verehrung ganz ergebenst

F[riedrich] R[itter] von Lama

Tekst pisany maszynowo na jednej stronicy papieru formatu A4. List odręczny czarnym atramentem. Brak zakończenia i autografu autora. 


\section{Dokument 128}

Kopia: AFKDOPW, teczka 136: Spuścizna abp. Józefa Teodorowicza, sygn. 1474/420 (12) [7], List abp. Józefa Teodorowicza do ks. dr. Stanisława Brossa, Lwów 22 IX 1933 r.

\section{Kochany ${ }^{\mathrm{a}}$, Przezacny Księże Doktorze!}

Ogromnie żałowałem, że tak przelotnie i dorywczo tylko mogłem się widzieć z Księdzem Doktorem i stąd nie miałem sposobności poruszenia i omówienia tylu rzeczy.

Teraz, w tej chwili celem mojego listu jest ażeby gorąco uprosić Księdza Doktora o przynaglenie księgarni św. Wojciecha, by raz nareszcie wydała moją książkę 352 . Mieli ją wydać z początku września; jesteśmy teraz u końca miesiąca, a książki jak nie ma tak nie ma. Urgują mnie o nią zewsząd i ustawicznie się dopytują, tak że już dalsze zwlekanie istotnie jest niemożliwe. Przypuszczam, że jest tu w grze handlarski interes z książkami szkolnymi; w każdym razie polecam Księdzu Doktorowi i kładę na serce tę sprawę, łącząc jak zawsze bardzo serdeczne i bardzo oddane wyrazy czci i przyjaźni.

Lwów, dnia 22 września 1933

\section{Dokument 129}

Oryg.: AFKDOPW, teczka 141: Spuścizna abp. Józefa Teodorowicza, sygn. 1732/64 [5], Pismo Szczepana Jeleńskiego z Działu Wydawniczego Drukarni i Księgarni św. Wojciecha w Poznaniu do abp. Józefa Teodorowicza, Poznań 30 IX 1933 r.

$\mathrm{J}[\mathrm{ego}]^{\mathrm{a}} \mathrm{E}[\mathrm{kscelencja}]$

Najprzew[ielebniejszy] Ks. Arc[ybiskup] Józef Teodorowicz

we Lwowie

ul. Ormiańska

W odpowiedzi prosimy powołać się na znak:

Nr. dz. 2011/33.

B.W.

Poznań, dnia 30 września 1933

a Tekst pisany maszynowo na jednej stronicy papieru formatu A4. Brak autografu autora listu. W prawym dolnym rogu pieczęć: „Księgozbiór gdański kościoła ormiańskiego ze Stanisławowa”.

${ }^{352}$ Uwaga ta odnosi się do książki: J. Teodorowicz, Zjawiska mistyczne i ich ttumaczenia (Konnersreuth), Poznań 1933.

a Tekst pisany maszynowo $\mathrm{z}$ wyjątkiem autografu autora pisma na jednej stronicy papieru formatu A4. W górnej partii karty nadruk firmowy: „DRUKARNIA I KSIĘGARNIA ŚW. WOJCIECHA. Sp[ółka] z o[graniczoną] o[dpowiedzialnością]” i logo instytucji. Niżej nadruk: „Poznań, Al. Marcinkowskiego 22, Adres telegraficzny: Albertinum, PKO Poznań 200.032. Konto bankowe: Bank Związku Spółek Zarobkowych, Poznań. Telefony: Dyrekcja 3614, Nr zbiorczy 3613". 
Ekscelencjo, Najdostojniejszy Księże Arcypasterzu!

W dniach ostatnich wysłaliśmy 20 egzemplarzy autorskich dzieła Waszej Ekscelencji „Zjawiska mistyczne...”, którego wygląd zewnętrzny - mamy nadzieję - zadowala Najdostojniejszego Autora. Pozostałe 10 egzemplarzy doślemy wkrótce.

O „Zjawiskach mistycznych” ukazał się już artykuł w „Przeglądzie Katolickim”. Do różnych czasopism egzemplarze recenzyjne wyślemy w przyszłym tygodniu, w naszym zaś Biuletynie Wydawniczym na miesiąc październik dziełu Waszej Ekscelencji poświęcimy artykuł wstępny.

Wyrazy czci głębokiej łączymy

DRUKARNIA I KSIĘGARNIA ŚW. WOJCIECHA Dział Wydawniczy

${ }^{\mathrm{b}}$ Szczepan Jeleński ${ }^{-\mathrm{b}}$

\section{Dokument 130}

Kopia: AFKDOPW, teczka 127: Spuścizna abp. Józefa Teodorowicza, sygn. 1445/185 [4], List abp. Józefa Teodorowicza do ks. dr. Stanisława Brossa, Lwów 13 X 1933 r.

Przezacny ${ }^{\mathrm{a}}$, Kochany Księże Doktorze!

Do książki wysłanej przeze mnie dołączam raz jeszcze bardzo oddaną i bardzo gorącą podziękę dla Księdza Doktora, który w procesie tworzenia się rozprawy mojej z O. Siwkiem jak i w jego ${ }^{\mathrm{b}}$ dokończeniu tak rozstrzygającą odegrał rolę.

Przypomina sobie zapewne Ksiądz Doktor doskonale, jaka to tragiczna była sytuacja w Krynicy, gdy się sam projekt wykłuwał i gdy moje wahania i niepewności bystrym, i silnym wejrzeniem w sprawę przez Księdza Doktora zostały umorzone. Zawsze będę o tym pamiętał i raz jeszcze za wszystko dziękuję.

Do tych słów dołączam jeszcze świadectwo dla młodych literatów, którzy podjęli się wydawania pisma dla inteligencji skierowanego przeciw prądom Boya ${ }^{353}$, a mającym na celu utwierdzenie idei katolickiej. Jakkolwiek wiem o tym, że przez pryzmat powiększający patrzą oni na kasę Akcji katolickiej, jakkolwiek i do mego świadectwa przywiązuję li tylko platoniczną wartość i znaczenie, to jednak mogę Księdzu Doktorowi bardzo zalecić te młode, bądź co bądź, wybitne talenty.

b-b Tekst sporządzony czarnym atramentem.

a Tekst pisany maszynowo na dwóch stronicach papieru formatu A4. Brak autografu autora.

b Poprawnie: jej.

${ }^{353}$ Zob. w niniejszej publikacji: J. Wołczański, Korespondencja abp. Józefa Teodorowicza z abp. Adamem Stefanem Sapieha, dokument 106. 
Czesław Lechicki ${ }^{354}$ ma wybitny talent, którego dowody złożył pośród innych dzieł w swej pracy o epoce Jana Wazy 355 . Jest on przy tym katolikiem zupełnie pewnych przekonań, dalekich od wszelkich kompromisów. Przekonań religijnych Bieniasza ${ }^{356}$ nie znam, ale jest to również bardzo wybijający się talent pisarski tak, iż sądzę, że warto by poprzeć próbę tych młodych ludzi, którzy może zbyt pospiesznie i nieopatrznie porwali się do wydawania tygodnika zanim pomyśleli o funduszach.

Wiem, że Ksiądz Doktor nic w tej sprawie sam uczynić nie może, ale bodaj czy nie przysłuży się tutaj dobrą swoją radą. Może być, że napiszę do ks. prymasa sam jeszcze w tej sprawie osobno.

Tyle na teraz. Polecając się dobremu i łaskawemu sercu Księdza Doktora, łączę najoddańsze i najserdeczniejsze pozdrowienia.

Lwów, dnia 13 października 1933

Ks. Dr Bross - Poznań

\section{Dokument 131}

Oryg.: AFKDOPW, teczka 140: Spuścizna abp. Józefa Teodorowicza, sygn. 967/420 (8) [7], List dr. Ralpha Waldego Hynka do abp. Józefa Teodorowicza, Praga 24 X 1933 r.

Praha, dne 24 Oktober 1933

Eure $^{\text {a }}$ Exzellenz,

Durch einen Zufall habe ich von einem mir bekannten Jesuiten das Buch über P[ater] Siwek S.J. "Metody badań" (Problem Konnersreuth) ${ }^{357}$ in die Hand bekommen und nachdem ich dasselbe Problem studiert habe, bin ganz empört über die Art und Weise der Ausführungen des Autors und erachte es für meine Pflicht seine Angriffe an Ehre der Th[erese] Neumann zurückzuweisen.

${ }^{354}$ Lechicki Czesław (1906-2001), pochodził z rodziny polsko-ormiańskiej, studiował historię na Uniwersytecie Jana Kazimierza we Lwowie, zajmował się publicystyką, w latach 30. XX stulecia dokonał apostazji przechodząc z Kościoła katolickiego do protestanckiego, w ramach ekspatriacji przybył w $1946 \mathrm{r}$. do Krakowa: pracował w „Czytelniku”, „Książce i Wiedzy”, współpracował z Zakładem Czasopiśmiennictwa PAN i Polskim Słownikiem Biograficznym, 1953-1988 był współpracownikiem służb bezpieczeństwa PRL-u, napisał kilkanaście książek i wiele artykułów, m.in.: Kościót ormiański w Polsce (Lwów 1928), Jezuici i Skarga na dworze Zygmunta III (Lwów 1929), Mecenat Zygmunta III i życie umystowe na jego dworze (Warszawa 1932), W walce z demoralizacja (Miejsce Piastowe 1932), Z dziejów satyry polskiej XVI wieku (Lwów 1933, Prawda o Boyu-Żeleńskim (Warszawa 1933), Dokoła mecenatu Zygmunta III (Lwów 1935). S. Dziki, P. Dubiel, Czesław Lechicki (ur. 30.03.1906 we Lwowie, zm. 19.03.2001 w Krakowie). ZP, 2001, nr 1-2, s. 160-163.

${ }^{355}$ Jan III Waza (1537-1592), od 1569 r. król Szwecji, ojciec Zygmunta III Wazy króla polskiego.

356 Osoba niezidentyfikowana.

a Tekst pisany czarnym atramentem na dwóch stronicach papieru formatu A4. W lewym górnym rogu nadruk firmowy: „Dr. R.W. Hynek, lèkař spisowatel, Praha II, Ječná 37, telefon 31368”.

357 Właściwie: P. Siwek, Metody badań zjawisk nadprzyrodzonych. Problem Konnersreuth, Kraków 1933. 
Nachdem dieses Buch als ein Glied zu Polemik mit Euerer Exzellenz erschienen ist ersuche ich Euere Exzellenz um gütige Zusendung des ganzen Falles im Polnischen und um gefälligste Bekanntgabe, wo meine Antwort, die ich tschechisch oder deutlich schreiben würde, sich in welchem Blatt oder Zeitschrift erscheinen könnte.

P [ater] Siwek macht sich das Problem allzu leicht was ihm nicht passt (z[um] B[eispiel] das Aramäische) die beglaubigte Fastenzeit Th[erese] N[eumann] (vom 14/7-29/7 1927) etc. etc. tut er gar nicht ordentlich erwähnen auch mit anderen Sachen z[um] B[eispiel] Appendicilis wird er allzu leicht fertig.

Ich habe seine Zeit mich recht viel mit der Parapsychologie befasst, sich mit den supranormalen aber nicht übernatürlichen und deswegen hat mich Konnersreuth so angezogen. S[eine] E[xzellenz] unserer Erzbischof Dr. K[arel] Kašpar ist auch ein überzeugter Anhänger von Konnersreuth.

Falls Euerer Exzellenz meine Apologie von Konnersreuth erwünscht erscheint, ersuche ich um baldige Antwort. Meiner Zeit habe ich Eueren Exzellenz auch mein französisches Buch über Konnersreuth zukommen lassen.

In tiefster Demut ergebener

Dr. R[alph] W[aldo] Hynek

\section{Dokument 132}

Oryg.: AFKDOPW, teczka 140: Spuścizna abp. Józefa Teodorowicza, sygn. 951/420 (12) [7], List o. dr. Atanazego Fica OP do abp. Józefa Teodorowicza, Lwów 25 X 1933 r.

Lwów, dnia 25/X 1933

Ekscelencjo! ${ }^{a}$ Najprzewielebniejszy Księże Arcybiskupie!

Mam zaszczyt donieść Waszej Ekscelencji, że w „Sanctum Officium”358 pracują:

1) Rev[erendissi]mus P[ater] Mag[ister] Fr[anciscus] Joannes Lottini ${ }^{359}$, Commissarius Generalis Gongr[egatio] S[ancti] Offici;

2) Adm[irabilis] R[everendissimus] P[ater] Mag[ister] Fr[anciscus] Alphonsus M. Gasperini ${ }^{360}$, Socius primus et Consultor Congr[egatio] S[ancti] Offici;

a Tekst pisany czarnym atramentem na dwóch stronicach papieru formatu zeszytowego. W lewym górnym rogu karty tytułowej firmowy nadruk: „Konwent OO. Dominikanów we Lwowie, Nr telef[onu] 4-44” oraz graficzne wyobrażenie herbu Zakonu.

${ }^{358}$ Kongregacja Świętego Oficjum w Stolicy Apostolskiej.

359 Lottini Joannes Franciscus - włoski duchowny katolicki, do Zakonu oo. Dominikanów wstąpił w 1860 r., profesję złożył w 1876 r., w okresie międzywojennym komisarz generalny Kongregacji Świętego Oficjum Stolicy Apostolskiej. Catalogus Omnium conventum et domorum Provintiarum et Congregationum Sacri Ordinis Praedicatorum necnon fratrum in eisdem commorantium anno 1931, Roma 1931, s. 12; Catalogus generalis Ordinis Praedicatorum, [Romae] 1967, s. 536.

${ }^{360}$ Gasperini Alphonsus Franciscus - włoski duchowny katolicki, do Zakonu oo. Dominikanów wstąpił w 1872 r., profesję złożył w 1890 r., w okresie międzywojennym konsultor Kongregacji Świętego Oficjum Stolicy Apostolskiej. Catalogus Omnium conventum, s. 12; Catalogus generalis, s. 508. 
3) Adm[irabilis] R[everendissimus] P[ater] Lector[is] Ex-Vic[arius] Gen[eralis] Fr[anciscus] Christophorus Bigazzi ${ }^{361}$, Socius secundus et Qualificator Congr[egatio] S[ancti] Offici.

Wszyscy trzej z zakonu dominikańskiego, Włosi. Prezesem Kongregacji S[ancti] Offici jest sam Papież.

Wyrazy najgłębszego hołdu składa

O. Atanazy Fic ${ }^{362}$

\section{Dokument 133}

Oryg.: AFKDOPW, teczka 144: Spuścizna abp. Józefa Teodorowicza, sygn. 1003/420 (8) [7], List o. Josefa Schrijversa CSsR do abp. Józefa Teodorowicza, Bruksela 3 XI 1933 r.

Excellence $^{a}$ Révérendissime,

Un merci pour le magnifique ouvrage dont Votre Excellence m'a fait hommage. J'ai déjà commencé à le lire et il me paraît très solide, je dirai décisif. Votre Excellence ne srattendait certainement pas à devoir composer un si gros ouvrage, mais c'est fait et c'est tant mieux.

Je n'oublie pas nos nombreuses et confiantes conversations d'autrefois. Mais ce temps est passé et je suis rivé à une autre besogne très encombrante. Mais rien ne se fait sans la volonté de Dieu.

En Allemagne c'est Konnersreuth qui alimente les conversations et les discussions. En Belgique, ce sont les séries d' apparitions de la Ste Vierge: à Beauraing 29 fois, à Banneux 8 fois, à Guckerzeele (cela continue encore), à Ekicluve (?) plusieurs fois. Et cela semble continuer encore.

Des centaines d'opuscules ou de livres ont déjà été composés pour ou contre. Des millions de pèlerins ont visité Beauraing cette année. Tout cela ne cesse pas d'être très curieux.

Je me recommande à Vos bonnes prières et reste de Votre Excellence le très humble serviteur en $\mathrm{N}$ [otre] S[eigneur]

Bruxelles, 3 XI 1933

Jos[ef] Schrijvers CSsR

\section{Dokument 134}

Oryg.: AFKDOPW, teczka: Spuścizna abp. Józefa Teodorowicza, bsygn., List dr. Ralpha Waldego Hynka do abp. Józefa Teodorowicza, Praga 4 XI 1933 r.

361 Bigazzi Christophorus Franciscus - włoski duchowny katolicki, do Zakonu oo. Dominikanów wstąpił w 1879 r., profesję złożył w 1890 r., w okresie międzywojennym komisarz generalny Kongregacji Świętego Oficjum Stolicy Apostolskiej. Catalogus Omnium conventum, s. 12; Catalogus generalis, s. 469.

${ }^{362}$ Zob. w niniejszej publikacji: J. Wołczański, Korespondencja abp. Józefa Teodorowicza z prof. Stefanem Dabrowskim, dokument 9.

a Tekst pisany czarnym atramentem na dwóch stronicach papieru formaty zeszytowego. 
Prag, am 4 XI 1933

Euer ${ }^{a}$ Exzellenz!

Durch einen Zufall habe ich von einem mir bekannten Jesuiten das Buch über P[ater] Siwek S.J. „Metody badań" (Problem Konnersreuth) in die Hand bekommen und nachdem ich dasselbe Problem studiert habe, bin ganz empört über die Art und Weise der Ausführungen des Autors und erachte es für meine Pflicht seine Angriffe an Ehre der Th[erese] Neumann zurückzuweisen.

Nachdem dieses Buch als ein Glied zu Polemik mit Euerer Exzellenz erschienen ist ersuche ich Euere Exzellenz um gütige Zusendung des ganzen Falles im Polnischen und um gefälligste Bekanntgabe, wo meine Antwort, die ich tschechisch oder deutlich schreiben würde, sich in welchem Blatt oder Zeitschrift erscheinen könnte.

P [ater] Siwek macht sich das Problem allzu leicht was ihm nicht passt (z.B. das Aramäische) die beglaubigte Fastenzeit Th[erese] N[eumann] (vom 14/7 - 29/7 1927) etc. etc. tut er gar nicht ordentlich erwähnen auch mit anderen Sachen z.B. [...] ${ }^{\mathrm{b}}$ wird er allzu leicht fertig.

Ich habe seine Zeit mich recht viel mit der Parapsychologie befasst, sich mit den supranormalen aber nicht übernatürlichen und deswegen hat mich Konnersreuth so angezogen. S[eine] E[xzellenz] unserer Erzbischof Dr Karel Kašpar ist auch ein überzeugter Anhänger von Konnersreuth.

Falls Euerer Exzellenz meine Apologie von Konnersreuth erwünscht erscheint, ersuche ich um baldige Antwort. Meiner Zeit habe ich Eueren Exzellenz auch mein französisches Buch über Konnersreuth zukommen lassen.

In tiefster Demut ergebener

Dr. W[aldo] Hynek

\section{Dokument 135}

Oryg.: AFKDOPW, teczka 140: Spuścizna abp. Józefa Teodorowicza, sygn. 966/420 (8) [7], List dr. Ralpha Waldego Hynka do abp. Józefa Teodorowicza, Praga 4 XI 1933 r.

\section{Euere $^{\mathrm{a}}$ Exzellenz!}

Für so ein prächtiges und liebevolles Geschenk der Widmung des ausgezeichneten Buches von Eueren Exzellenz erlaube ich mir Eueren Exzellenz meinen tiefsinnigsten Dank auszusprechen.

Soweit ich mich durch flüchtiges Durchblättern desselben überzeugen konnte, enthält es eine gründliche und exzellente Niederlegung aller Einwände von P[ater] Siweks gegen Konnersreuth und seine Botschaft des Gekreuzigten. Ich habe gleich meinem Freund Friedrich v[on] Lama darüber geschrieben und fühle mich direkt ausgezeichnet

Tekst pisany czarnym atramentem na dwóch stronicach papieru formatu zeszytowego.

b Tekst nieczytelny.

a Tekst pisany czarnym atramentem na dwóch stronicach papieru formatu A4. W lewym górnym rogu nadruk firmowy: „Dr. R.W. Hynek, lèkař spisowatel, Praha II, Ječná 37, telefon 31368”. 
durch den Wunsch Euerer Exzellenz eine Rezension über ein so ruhig wissenschaftliches und vortreffliches Werk, das ich vom Herz gern unternehmen würde.

Nichtdestoweniger will ich nochmals die gehobenen Verfehlungen v[on] P[ater] Siwek S.J. auch in "Konnersreuther Sonntagsblatt" korrigieren und damit auch Heermanns einseitige Angriffe gegen das Fasten v[on] Th[erese] N[eumann] das einmal für 14 Tage durch Eidzeugen bestätigt, völlig für seine Über [... $]^{\mathrm{b}}$ genügt, denn ohne ohne Wasser $\mathrm{d}[\mathrm{as}] \mathrm{h}$ [eist] Flüssigkeitzufuhr kann nur möglich eine Mundblaesse 14 Tage existieren.

S[eine] E[xzellenz] den Herrn Erzbischof Dr Karel Kašpar von Prag wird bestimmt das Werk Euerer Exzellenz recht interessieren und freuen, denn das Polnische ist uns Tschechen doch schriftlich leicht zugänglich.

Ich hoffe, dass ich bald Euerer Exzellenz eine gedruckte Nachricht übersenden werde können und indem ich nochmals meinen innigsten Dank für das geschenkte Buch ausspreche zeichne mich in tiefster Hochachtung ergeben

Prag, am 4/XI 1933

Dr. R[alph] W[aldo] Hynek

\section{Dokument 136}

Oryg.: AFKDOPW, teczka 144: Spuścizna abp. Józefa Teodorowicza, sygn. 1048/420 (8) [7], List o. Odo Staudingera OSB do abp. Józefa Teodorowicza, Salzburg 13 XI 1933 r.

Salzburg, Benediktinerkolleg[ium], am 13. XI. [19]33

Exzellenz! ${ }^{\mathrm{a}}$ Hochwürdigster Herr Erzbischof!

Danke Ew[ere] Exzellenz recht sehr für die freundlichen Zeilen, die erfreuliche Nachricht von der Vollendung des Werkes über Konnersreuth und auch die ironischen Bemerkungen. Diese bestärken meinen Glauben, dass die Krankheit Ew[ere] Exzellenz vollkommen überwunden ist. Gaudeo cum gaudente.

Seit 28. Sept[ember] bin ich wieder fest im Geschirr und Aue Bufre. Meinen Brief von August und die "Schildwache“ werden Exzellenz wohl bekommen haben. Zum Glück habe ich auch den 1. Teil Ihres Werkes gefunden, den Exzellenz vor Jahr mir zu senden die Güte hatten. Hatte ich so gut aufbewahrt, dass ich Mühe hatte, ihn zu finden. Könnte eine neue Zelle brauchen, um besser alles verteile zu können. Lege dem Manuskript auch die Erwiderung von Gerlich bei, die besonders im Punkt der Urin - Analyse sehr wichtig ist und m. E. im Werk von Ew[ere] Exzellenz verwertet werden sollte (in der deutschen Ausgabe). Leider konnte Gerlich seine Erwiderung infolge barbarischer Verhaftung nicht vollenden. Neulich sagte mit R[itter] von Lama, Gerlich sei im Gefängnis in Stadelheim (München). Als er dorthin überfuhrt wurde, fand er die Zelle reich mit

\footnotetext{
b Wyraz nieczytelny.

a Tekst pisany czarnym atramentem na dwóch kartach papieru formatu A4. W lewym górnym rogu nadruk firmowy: „Schriftleitung des Benedictus-Boten”. W górnej partii karty na centralnym miejscu graficzne wyobrażenie godła Zakonu oo. Benedyktynów: krzyż z dwiema poprzecznymi belkami stojący na trzech wzniesieniach oraz PAX. Niżej tarczy inskrypcja: „Ut in omnibus glorificetur Deus”.
} 
Blumen geschmückt vor. Offiziere, die seine heimlichen Freunde sind, dürften das getan haben.

Gegenwärtig macht mir mein neues Büchlein „Die Muttergottes Erscheinungen in Belgien 1932/33“363 viel Arbeit. Schon wiederholt glaubte ich, jetzt kann ich es herausgeben, und immer wieder kamen neue Erscheinungen. So verzögert sich die Herausgabe vielleicht bis Januar 1934. Exzellenz sehen, „das Geschäft geht noch immer!“

Ihre köstliche und vollkommen treffende Bemerkung freut mich sehr: „Es muss jetzt um K[onnersreuth] eine Stille herrschen, wenn sie schon nach Wundern greifen müssen“. So ist es tatsächlich. Nur das neue „Konn[ersreuther] Jahrbuch 1932“ dürfte da und dort böses Blut machen. Der arme P[ater] Mager bekommt arge Hiebe. Von ihm und dem Redakteur der Kirchenzeitung unterbreite ich ehrfurchtsvolle Empfehlungen. Letzteres wünscht das polnische Werk über Konnersreuth. Er will darüber etwas durch Graf Ledochowska ${ }^{364}$ für die Kirchenzeitung schreiben lassen und auf die deutsche Ausgabe vorbereiten. Auch bittet er um Beiträge über andre Themata. Was Exzellenz ihm im August in Aussicht stellten, ist noch nicht eingelangt.

Wünsche recht feste, andauernde Gesundheit und viele literarische Freunden. Ehrfurchtsvoll empfiehlt sich Ew[ere] Exzellenz ergebenster

$\mathrm{P}$ [ater] Odo Staudinger OSB

\section{Dokument 137}

Kopia: AFKDOPW, teczka 131: Spuścizna abp. Józefa Teodorowicza, sygn. 1433/185 [4], List abp. Józefa Teodorowicza do ks. prałata Zygmunta Kaczyńskiego, Lwów 13 XI 1933 r.

Przezacny ${ }^{\mathrm{a}}$ Księże Prałacie!

Wyczytałem w K[atolickiej] A[gencji] P[rasowej] wzmiankę o mojej książce. Jest ona wprawdzie krótka, ale oddaje wiernie przewodnią jej myśl. Bardzo jestem za to Księdzu Prałatowi zobowiązany i serdeczną składam podziękę, łącząc wyrazy prawdziwie oddane.

Lwów, dnia 13 listopada 1933

Ks. Prałat Kaczyński - W[arsza]wa, K[atolicka] A[gencja] P[rasowa]

${ }^{363}$ O. Staudinger, Die Muttergottes Erscheinungen in Belgien 1932/33. Nach authentischen Quellen, Innsbruck 1933.

${ }^{364}$ Właściwie: Ledóchowska Urszula (1865-1939), członkini od 1886 r. Zgromadzenia ss. Urszulanek, 1889-1904 nauczycielka i wychowawczyni w szkole prowadzonej przez zakonnice, 1907-1914 pracowała w Petersburgu zakładając m.in. prywatne gimnazjum żeńskie, 1914-1918, przebywała w Skandynawii m.in. w Szwecji i Danii prowadząc pracę pedagogiczno-dydaktyczną, później osiadła w Polsce, gdzie założyła Zgromadzenie ss. Urszulanek Serca Jezusa Konającego z charyzmatem działalności wychowawczej; beatyfikowana w 1983 r., kanonizowana w 2003 r. M. Ziółkowska, Urszula Ledóchowska, w: EK, t. 19, red. zbior., Lublin 2013, kol. 1404-1405; informacje własne autora.

a Tekst pisany maszynowo na $1 \frac{1}{2}$ stronicy formatu A4. Brak autografu autora. 


\section{Dokument 138}

Oryg.: AFKDOPW, teczka 141: Spuścizna abp. Józefa Teodorowicza, sygn. 977/420 (8) [7], List ks. prałata Zygmunta Kaczyńskiego do abp. Józefa Teodorowicza, Warszawa 17 XI 1933 r.

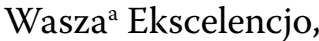

Serdecznie dziękuję Waszej Ekscelencji za łaskawy list. Niestety, notatka w KAP była krótka, gdyż zależało mi zaraz po ukazaniu się książki Waszej Ekscelencji dać o niej wiadomość do prasy. Nie była to zatem wiadomość o charakterze recenzyjnym, ale ściśle kronikarskim. Byłbym natomiast wdzięczny za artykuł recenzyjny o pracy Waszej Ekscelencji. Oczywiście, nie jestem specjalistą w dziedzinie mistyki, gdyby zatem ktoś z profesorów lwowskich mógł napisać, chętnie by KAP wydrukował.

Ująłem swą notatkę $w$ formę pozytywną, aby nie reklamować specjalnie O. Siwka, a poza tym mimo polemiki z nim, ostatnie dzieło Waszej Ekscelencji daje b[ardzo] dużo materiału naukowego, tak że osobiście wiele skorzystałem.

Całuję ręce Waszej Ekscelencji i pozostaję oddanym sługą

Ks. Z[ygmunt] Kaczyński

\section{Dokument 139}

Oryg.: AFKOOPW, teczka 145: Spuścizna abp. Józefa Teodorowicza, sygn. 1023/420 (8) [7], List Friedricha Ritter von Lamy do abp. Józefa Teodorowicza, Gauting bei München 25 XI 1933 r.

\section{Excellenz ${ }^{\mathrm{a}}$, Hochwürdigster Herr Erzbischof !}

Gauting, 25. November 1933

Mit verbindlichstem Dank bestätige ich Ihnen den Empfang Ihres Buches. Mein bisschen Verständnis ermöglichte mir immerhin, einen Ueberblick auf seine Anlage und die behandelten Fragen zu gewinnen und ich habe der Badenia nahegelegt, sich mit $\mathrm{Eu}[\mathrm{rer}]$ Excellenz wegen Herausgabe einer deutschen Ausgabe direkt in Verbindung zu setzen. Ich habe auch erklärt, dass ich gerne bereit bin, die Arbeit in jeder mir möglichen Weise zu fördern. Inzwischen habe ich auf den Artikel des Evangelischen Presseverbandes ausführlich erwidert; meine Erwiderung wird Ihnen in den allernächsten Tagen zugehen.

Ihrem Buche lag auch eine polnische Besprechung desselben von einem Lemberger Domherrn bei. Ich habe sie einem mir bekannten Herrn in Ratibor ${ }^{365}$ mit der Bitte geschickt, sie mir zu übersetzen; ich werde dann in deutschen Blätter nach dieser Vorlage über Ihr Buch schreiben. Auch erwarte ich eine mir von Dr. Hynek versprochene

a Tekst pisany czarnym atramentem na jednej stronicy papieru formatu A4. W lewym górnym rogu nadruk firmowy: „Dyrektor Polskiej Katolickiej Agencji Prasowej”, w prawym górnym rogu nadruk firmowy; „Warszawa [...] Miodowa 17, Tel. 32819”.

a Tekst pisany maszynowo na dwóch stronicach papieru formatu A4. Autograf odręczny czarnym atramentem.

${ }^{365}$ Ratibor (Racibórz) - miasto nad Odrą na Górnym Śląsku. 
ausführliche deutsche Besprechung des Buches, der ich dann ebenfalls weite Verbreitung zu geben mich bemühen werde.

Im „Osservatore ${ }^{\text {“366 }}$ las ich mit Freuden, dass Eu[re] Excellenz von einer schweren Krankheit wieder genesen sind; meine herzliche Gratulation dazu. Ich danke Gott, dass er Sie uns noch erhalten hat.

Inzwischen habe ich mir aus Belgien durch Chan. De Hovre in Gent reichliches Material über die Muttergottes-Erscheinungen in Belgien verschafft und festgestellt, dass die Informationen, die ich darüber erhalten hatte, unrichtig waren. Ich freue mich darüber. Um den Schaden, den ich allenfalls durch mein verfrühtes Urteil angerichtet habe, wieder gutzumachen, habe ich mich auch entschlossen, selbst eine kleine Schrift darüber zu verfassen; sie ist schon in der Druckerei. Ich erhielt sogar prächtige Originalbilder, sie dürfen aber nur in dieser Broschüre reproduziert werden.

Zugleich mit diesem Briefe geht auch das „Konnersreuther Jahrbuch 1932“ an $\mathrm{Eu}[\mathrm{re}]$ Excellenz ab; es ist verspätet erschienen, was sich durch unsere jetzigen politischen Verhältnisse, die wiederholten Eingriffe in die Betriebe erklärt. Eskommen mir Zweifal, ich glaube bereits ein $[. . .]^{\mathrm{b}}$ gesande zu haben.

$\mathrm{Zu}$ Weihnachten erscheint meine deutsche Ausgabe der grossen Lebensbeschreibung der seligen Gemma Galgani, die einst ihr Seelenführer P[ater] Germano a S. Stanislao verfasst hat. Sie solle die Verehrung für Gemma fördern, aber auch helfen, dass das Verständnis für Mystik bei uns etwas wächst. Zugleich ist es ein Akt persönlicher Verehrung für die Selige, der ich durch jenes Mädchen, von dem ich Ihnen s. Z. in München sprach (halb Deutsche, halb Polin), näher stehe als andere. Sie ist eines der Sühneopfer, durch die der Heiland die Welt noch einmal retten wird, und wird durch die sel. Gemma persönlich geführt und beraten; diese instruiert auch ihren Beichtvater. Leider hat sie wiederholt strengen Auftrag gegeben, den ganzen Fall verborgen zu halten. Das Mädchen wird vom Teufel seit zwei Jahren fortgesetzt schwerstens versucht und ich empfehle sie daher - wollen wir sie, wie Gemma, einfach Mariella nennen - dringend Ihrem Gebete.

Ich begrüsse Eu[re] Excellenz mit der Versicherung meiner aufrichtigen Ergebenheit Ihr

F[riedrich] R[itter]von Lama

\section{Dokument 140}

Oryg.: AFKDOPW, teczka 141: Spuścizna abp. Józefa Teodorowicza, sygn. 998/420 (8) [7], List o. Aloisa Magera OSB do abp. Józefa Teodorowicza, Salzburg 29 XI 1933 r.

Euere $^{a}$ Exzellenz!

366 Właściwie: „L'Osservatore Romano”.

b Wyraz nieczytelny. 
Für Ihren gültigen Brief bitte ich Euere Exzellenz meinen ergebensten Dank entgegennehmen zu wollen. Da die Angelegenheit, die er betrifft, von so grosser Wichtigkeit ist, gab ich Ihre Information umgehend durch einen Eilbrief an den Kardinal Innitzer ${ }^{367}$ weiter. Es tagt gerade in Wien die Bischofskonferenz. So kam der Brief von Eurer Exzellenz gerade noch recht. Die Anregung, die Eure Exzellenz geben, ist mir aus tiefster Seele gesprochen. In ganz vertraulicher Aussprache darf man es wohl sagen: der deutsche Episkopat hat in einer Weise versagt, dass die Folgen davon noch gar nicht abzuwehren sind. Der österreichische Episkopat ist noch frei. Er könnte noch ein Wort sprechen. Die Mehrzahl der Katholiken würde es geradezu als eine Erleichterung empfinden. Ich selber stehe wie vor einem Rätsel. Wie war es möglich, dass die Katholiken mit den Bischöfen vor dem Nationalsozialismus so zusammengeknickt sind? Und doch ist der Nationalsozialismus seiner Struktur nach offenkundig eine Häresie. Ob nicht viel Schuld daran der Umstand trägt, dass der Vatikan gegen den Faschismus eine Politik übte, die stillschweigend den Primat der Politik über die Religion anerkennt. Ich komme öfters nach Deutschland. Ich kann nur sagen, dass es denkbar schlecht aussieht. Euere Exzellenz hat ein grosses gutes Werk getan, indem Sie eine so wichtige Anregung in Ihrem Brief gab.

Mit ehrfurchtsvollem Ringkuss und in grösster Verehrung bin ich Euerer Exzellenz in Christus ergebenster

${ }^{\mathrm{b}} \mathrm{P}$ [ater] Alois Mager $\mathrm{OSB}^{-\mathrm{b}}$

\section{Dokument 141}

Kopia: AFKDOPW, teczka 131: Spuścizna abp. Józefa Teodorowicza, sygn. 1663/185 [4], List abp. Józefa Teodorowicza do ks. prałata Zygmunta Kaczyńskiego, Lwów listopad 1933 r.

Kochany ${ }^{a}$ Księże Prałacie!

Dziękuję Księdzu Prałatowi za list łaskawy i jakkolwiek bardzo to trudno choćby przez kogoś innego przygotować artykuł o swojej pracy dla piszącego autora, to jednak chcę uczynić zadość życzeniu Księdza Prałata.

Uważam bowiem, że nie tylko w interesie książki, którą napisałem, ale dla ogólnego zabałamucenia jakie powstało, gdzie nikt właściwie nie wie, o co w tym problemie chodzi, że jest istotnie bardzo wskazane rzecz z właściwego punktu widzenia oświetlić.

Starałem się, ile możności, ażeby nieprzyjemne rzeczy dla O. Siwka i Jezuitów zredukować ad minimum ${ }^{368}$ i sam tylko główny problem wysunąć na czoło.

Dodałem zdanie nazbyt pochlebne dla mnie O. Fica, ale to się łączy już z tymi trudnościami, jakie ma autor, który zmuszony jest oprzeć się o krytykę obcą, jaka jest.

\footnotetext{
a Tekst pisany maszynowo z wyjątkiem autografu autora na $1 \frac{1}{2}$ stronicy papieru formatu A4.

367 Zob. w niniejszej publikacji: J. Wołczański, Korespondencja abp. Józefa Teodorowicza z abp. Adamem Stefanem Sapieha, dokument 103.

b-b Autograf napisany czarnym atramentem.

a Tekst pisany maszynowo na 1,5 stronicy formatu A4. Brak autografu autora i daty dziennej.

368 Lac.: do minimum.
} 
Tymczasem poza O. Ficem, krytyką rzecz[ow]ą i poważną, z wyjątkiem jeszcze artykułu „Przeglądu Katolickiego”, jednak nazbyt z pewnością dla O. Siwka nieprzyjemnego, dotąd nie ukazało się nic w prasie.

Łączę dla Księdza Prałata wyrazy prawdziwie oddane.

Lwów, dnia [... $]^{\mathrm{b}}$ listopada 1933

Ks. Kaczyński - W[arsza]wa - [ul.] Miodowa 17

\section{Dokument 142}

Kopia: AFKDOPW, teczka 130: Spuścizna abp. Józefa Teodorowicza, sygn. 1598/185 [4], Kopia listu abp. Józefa Teodorowicza do kard. Augusta Hlonda, Lwów 1 XII 1933 r.

Wasza ${ }^{a}$ Eminencjo!

Bardzo mnie ucieszyły przysłane mi słowa Waszej Eminencji o mojej książce, które sobie szczególniej cenię.

Jezuici jednak nie dają za przegraną. Posłużyli się ks. biskupem Przeździeckim, który mi w tajemniczy sposób dawał do poznania, iż z pewnych kół mu doniesiono o mych zamiarach tłumaczenia mej książki na język niemiecki i że w takim razie domagano by się ode mnie, abym powiedział, jakie mam zarzuty przeciw Siwkowi contra doctrina christianam $^{369}$. Oświadczył mi swą gotowość pośrednictwa i pomocy, nie mówiąc jednak, między kim ma być to pośrednictwo ${ }^{370}$. Odpowiedziałem mu, że za jego gotowość i chęć serdecznie dziękuję, ale na tak ogólnikowych oświadczeniach nie mogę uczynić żadnego konkretnego kroku nie wiedząc właściwie o co sprawa idzie, kto to jest, kto $\mathrm{b}[\mathrm{is}] \mathrm{k}[\mathrm{u}] \mathrm{p}[\mathrm{owi}]$ Przeździeckiemu o tych sprawach mówił, między kim właściwie on ma pośredniczyćc ${ }^{371}$. Odpisał mi jeszcze bardziej tajemniczo i zagadkowo, ale mimo woli się przyznał skąd to wszystko poszło, bo mnie skierował do Generała OO. Jezuitów ${ }^{372}$.

Prawdopodobnie chciano wybadać, czy ja się noszę z zamiarem tłumaczenia mej książki na język niemiecki. Trzeba jednak wiedzieć Waszej Eminencji, że w Niemczech jest w kursie intensywnie propagowana przez litografowanie broszura O. Siwka. Dotarła ona dziś do kół racjonalistycznych i protestanckich, które z tego robią wielką propagandę przeciwko Ks. Ks. Biskupom i Kościołowi. Nie mam jeszcze w ręku tekstu pisma Związku protestanckiego w którym ten artykuł się pojawił, ale obiecano mi z Niemiec pismo to przysłać.

Równocześnie uderzają na mnie Jezuici na szpaltach „I[lustrowanego] K[uriera] C[odziennego]”, w którym się pojawiają artykuły pisane przez O. Siwka, jak to po stylu jego

b Brak daty dziennej.

a Tekst pisany maszynowo na trzech stronicach papieru formatu A4. Brak autografu autora listu.

369 Łac.: przeciwko doktrynie chrześcijańskiej (katolickiej).

${ }^{370}$ Zob. w niniejszej publikacji J. Wołczański, Korespondencja abp. Józefa Teodorowicza z bp. Henrykiem Przeździeckim, dokument 9.

371 Tamże, dokument 10.

372 Tamże, dokument 11. 
poznać, z których jeden nazywa mnie fideistą, a więc zarzuca mi prawie herezję. Teraz świeżo znowu pojawia się zapowiedź odpowiedzi O. Siwka, znowu z ukłuciem mnie w zwrocie: o entuzjastach Konnersreuth.

Przy tej sposobności polecam Waszej Eminencji O. Kuleszę $e^{373}$, który prosił mnie o to, ażebym go zalecił Waszej Eminencji, gdyż chce wstąpić do Salezjanów. Był on dotąd w Zgromadzeniu Marianów i kierował gimnazjum całym pod Warszawę. Nie widział jednak żadnej przyszłości w tym Zgromadzeniu. Otóż jest [to] znakomity człowiek, przy tym uczony niepośledniej miary, znawca znakomity mistyki, którego pisma są cytowane w katolickiej encyklopedii francuskiej i przez Lagrange'a. Sam jest wewnętrznie uduchowiony, a jak widać posiada przy tym praktyczne organizacyjne zdolności; byłby to więc istotnie najlepszy nabytek dla Salezjanów.

Osobno dołączam jeszcze odpowiedź na poruszone ongi przez ks. Kubinę ${ }^{374}$ kwestię dotacji mej diecezji w związku z programem, który widzę wyszczególniony w programie konferencji. Posyłam Waszej Eminencji na wypadek, gdyby zaszła aktualna tego potrzeba.

Wobec tego, że Rząd jednym Biskupom dał pełną dotację, a drugim zupełnie nic nie daje wnoszę, że może chce nas w ten sposób podzielić. Wasza Eminencja sam o tym najlepiej będzie wiedział jak ważną jest rzeczą, ażeby w tej sprawie zasadniczej Ks. Ks. Biskupi stanęli bardzo silnie i bardzo energicznie. Jeżeli się uda Rządowi jeden wyłom uczynić, to wtedy w ogóle z tymi dotacjami przepadliśmy zupełnie.

Łączę przy tej sposobności dla Waszej Eminencji wyrazy najoddańszej i najgłębsze czci.

Lwów, dnia 1 grudnia 1933

P.S. Dołączam jeszcze Waszej Eminencji list prałata Schoepfera ${ }^{375}$ w sprawie beatyfikacji arcyksiężnej Magdaleny ${ }^{376}$. Z góry mu odpisałem, że wobec zbierania składek na beatyfikację królowej Jadwigi ${ }^{377}$, trudno dziś liczyć na Polskę w tej kwestii tym bardziej, że ta księżna Habsburska zupełnie nikomu dotąd znana nie była. W każdym razie składam ten list w ręce Waszej Eminencji do łaskawego rozstrzygnięcia.

${ }^{373}$ Zob. w niniejszej publikacji: J. Wołczański, Korespondencja abp. Józefa Teodorowicza z abp. Adamem Stefanem Sapieha, dokument 102.

374 Tamże, dokument 82.

375 Schöpfer Ämilian (1858-1936), święcenia kapłańskie w 1880 r. w Wiedniu, dr teologii, od 1887 r. wykładowca Starego Testamentu i języków orientalnych w Seminarium Duchownym w Brixen, współzałożyciel partii Chrześcijańsko-Społecznej w Tyrolu i wydawnictwa, 1896-1923 członek tyrolskiego Landtagu, aktywny publicysta społeczno-polityczny. H. J. W. Kuprian, Schoepfer Aemilian, w: ÖBL, Bd. 11, herausg. von P. Csendes, Wien 1999, s. 105-107.

376 Österreich von Magdalena (1532-1590), córka Ferdynanda I cesarza niemieckiego z dynastii Habsburgów. Założyła wspólnotę pobożnych kobiet, które pod opieką duchową oo. Jezuitów oddawały się modlitwie i praktykom religijnym. Zmarła w opinii świętości. Habsburg Magdalena, w: BLKO, Bd. 7, herausg. von C. von Wurzbach, Wien 1861, s. 1-2.

377 Zob. w niniejszej publikacji: J. Wołczański, Korespondencja abp. Józefa Teodorowicza z abp. Adamem Stefanem Sapieha, dokument 33. 


\section{Dokument 143}

Oryg.: AFKDOPW, teczka 140: Spuścizna abp. Józefa Teodorowicza, sygn. 956/420 (12) [7], List o. dr. Atanazego Fica OP do abp. Józefa Teodorowicza, Lwów, 2 XII 1933.

\section{Ekscelencjo! ${ }^{\mathrm{a}}$}

Mam zaszczyt przesłać z powrotem rękopis tu załączony. Bardzo przepraszam Waszą Ekscelencję, że tak późno oddaję, gdyż i inni ojcowie interesujący się kwestią Konnersreuth chcieli zapoznać się z treścią rękopisu. Dla mnie niektóre rzeczy są wprost rewelacją i utwierdziły mnie jeszcze bardziej w tym stanowisku, jakie zająłem w kwestii Konnersreuth ${ }^{378}$.

Treść rękopisu jest doskonałą i może pójść nawet do Rzymu - i dobrze by było, by tam doszła.

$\mathrm{Z}$ wyrazami najgłębszego hołdu

O. Atanazy Fic

\section{Dokument 144}

Oryg.: AFKDOPW, teczka 145: Spuścizna abp. Józefa Teodorowicza, sygn. $368 / 90$ [5], List z Wydawnictwa Antona Pusteta do abp. Józefa Teodorowicza, Salzburg 4 XII 1933 r.

S[eine]r Exzellenz den hochwürdigsten Herrn

Bischof Theodorowicz

Lwów, Polen

BETRIFFT IHRE NACHRICHT VOM UNSER ZEICHEN M/B DATUM 4.12. [19]33

Euer ${ }^{\text {a }}$ Exzellenz, sehr verehrter Herr Erzbischof!

Der Ordnung halber möchte ich den richtigen Eingang Ihres Manuskriptes über das Leben Jesu bestätigen. Ich habe das Manuskript unserem Lektor zur Durchsicht gegeben und werde Euer Exzellenz baldmöglichst weitere Nachricht zukommen lassen.

Jedenfalls danke ich einstweilen verbindlich dafür und zeichne mit dem Ausdruck tiefster Verehrung Euer Exzellenz ergebenster

a Tekst pisany czarnym atramentem na dwóch stronicach papieru formatu zeszytowego. W lewym górnym rogu karty tytułowej graficzne wyobrażenie herbu Zakonu oo. Dominikanów i nadruk firmowy: "Konwent OO. Dominikanów we Lwowie, Nr tel[efonu] $4-44$ ".

${ }_{378}$ A. Fic, Kwestia Konnersreuth, SCh, 1832, t. 5, nr 7-8, s. 64-75; nr 9, s. 112-123; nr 10, s. 152-173; t. 7, nr 10, s. 215-221.

a Tekst pisany maszyniowo na jednej stronicy papieru formatu A4. W górnej centralnej partii karty nadruk firmowy: „Verlag Anton Pustet Pressevereinsanstalten der Diözese Secau SALZBURG SIEGMUND-HAFFNER-GASSE 18, FERNSPRECHER NR. 259, DRAHTANSCRIFT PUSTET SALZBURG”. 
b-VERLAG ANTON PUSTET

SALZBURG $^{-\mathrm{b}}$

$[\ldots]^{\mathrm{c}}$

\section{Dokument 145}

Oryg.: AFKDOPW, teczka 144: Spuścizna abp. Józefa Teodorowcza, sygn. 1057/420 (8) [7], List ks. prałata Stanisława Szpetnara do abp. Józefa Teodorowicza, Jarosław 5 XII 1933 r.

$\mathrm{J}[\text { ezus] }]^{\mathrm{a}} \mathrm{M}$ [aria] J[ózef]

Ekscelencjo!

Bardzo a bardzo dziękuję za słowo dobre przesłane mi przez Siostrę Fideę ${ }^{379}$. Dobrze się stało, że mogłem zawrzeć z Waszą Ekscelencją osobistą znajomość. Mam przekonanie, że dobre rzeczy już stąd wynikły.

Naprawdę trapię się, że Ksiądz Arcybiskup niedomaga. Przyjmij Ekscelencjo sercem to, co się samo na myśl nasuwa. Daje Pan Bóg talenty, ale talenty są własnością Kościoła, są własnością narodu. Przy przygotowaniu rzeczy do druku są rzeczy, które są rzeczą natchnienia, nasuwających się jak lawina myśli, ale przy przygotowaniu rzeczy do druku jest wiele fizycznej pracy. Otóż, ponieważ Ekscelencja fizycznie jest słabszy przeto radzę, by sobie Ksiądz Arcybiskup wziął kogo[ś] do pomocy, by porządkowął zapiski dotyczące dalszych tomów życia Chrsytusa; w otoczeniu są tacy księża, którzy to robić będą z miłością; mnie jedna nauczycielka przepisała wspaniale do druku moje skromne wydawnictwa. Przekonałem się nieraz, że jak mnie jaka[ś] myśl prześladuje nieustannie to ona ku dobremu jest! Można wiele rzeczy podyktować, to może i świecki inteligentnik ${ }^{380}$ uczynić. Ślęczenie w pozycji pochylonej przy maszynie mocno męczy.

Z całą mocą chcę powiedzieć, że dobrze się stało, że książka o Teresie Neumann już wyszła, oczekuję książki niemieckiej. Nie będzie przesady, jeżeli tu zacytuję św. Jana: "Co było od początku, cośmy słyszeli, cośmy widzieli oczami naszymi, cośmy oglądali i ręce nasze dotykały - i widzieliśmy, i świadczymy, i opowiadamy" (I Jan 1-2). Naprawdę te ustępy, które mówią o mistyce na żywym przykładzie są wspaniałe, naprawdę konterfekt Teresy jest piękny.

Umieściłem swoje myśli w „Głosie Narodu”, w „Wiadomościach Parafialnych” jarosławskich, w „Powściągliwości i Pracy”, ale nie jest [to] żadna recenzja, tylko chcę zwrócić uwagę, że taka książka istnieje. Czytałem sprawozdanie dokładne w „Przeglądzie Katolickim", autor dużo sobie zadał trudu, żeby to sprawozdanie napisać; była krótka wzmianka w dodatku literackim do "Głosu Narodu”. Sprawą tą zajmuje się naprawdę katolicka Polska, również oczekuje i dalszego ciągu życia Chrystusa Pana ${ }^{381}$.

b-b Podłużna pieczęć.

c Autograf nieczytelny.

a Tekst pisany maszynowo z wyjątkiem autografu autora i dopisków na dwóch stronicach papieru formatu A4.

379 Osoba niezidentyfikowana.

${ }^{380}$ Forma zgodna z oryginałem; tu w znaczeniu: inteligent.

381 Aluzja do kilkutomowego dzieła abp. Teodorowicza poświęconego osobie i epoce Chrystusa. 
Powtarzam to, co kiedyś mówiłem Księdzu Arcybiskupowi w Marienbadzaie: żeby tak napisać, tak zdanie zbudować, trzeba mieć natchnienie od Boga.

$\mathrm{Z}$ całą mocą zaznaczam, że nabrałem takiego przekonania w Konnersreuth, że Pan Jezus mocno się „angażował” w Konnersreuth jeśli tak mówić się godzi; ta sprawa jest pewna. Byłbym przyjechał osobiście wyrazić radość, że książka wyszła, ale mi mówił ks. Bogdanowicz wówczas, że wizyty mocno męczą.

Całuję ręce Waszej Miłości

Jarosław, 5/XII [19]33

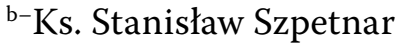

Posyłam zarówno numer „Powściągliwości”, w którym jest mój artykulik

\section{Dokument 146}

Oryg.: AFKDOPW, teczka 138: Spuścizna abp. Józefa Teodorowicza, sygn. 1087/420 (8) [7], List z Wydawnictwa i Drukarni Badenia w Karlsruhe do abp. Józefa Teodorowicza, Karlsruhe 7 XII 1933 r.

Karlsruhe, den 7. Dezember 1933

\section{DIREKTION}

$\mathrm{V} / \mathrm{Ba}$

S[eine]r Exzellenz den Hochwürdigsten Herrn Erzbischof

Dr. J. Teodorowicz

Lemberg/Polen

\section{Eure $^{\text {a }}$ Exzellenz!}

Im Jahre 1931 hatten wir wiederholt Eurer Exzellenz geschrieben wegen der Verlagsüberlassung des von Eurer Exzellenz geschriebenen Werkes über Konnersreuth. Herr Ritter von Lama, der ja auch seiner Zeit uns auf dieses Werk aufmerksam gemacht hat, teilt uns heute mit, das dieses Werk heute nunmehr erschienen ist unter dem Titel „Zjawiska mistyczne i ich tłumaczenia (Konnersreuth)“. Wir hören von ferner von Herrn von Lama, dass Eure Exzellenz sich mit dem Gedanken trägt dieses Werk nun doch in Deutschland herauszugeben. Wir erlauben uns daher Eure Exzellenz nochmals zu bitten, uns den Verlag und Vertrieb dieses Werkes zu übergeben. Sollte Eure Exzellenz die Güte haben unserem Wunsche zu willfahren, so wären wir Ihnen ausserordentlich dankbar, wenn Eure Exzellenz uns gleichzeitig mitteilen würde, ob wir für den Übersetzer sorgen sollen, oder ob Eure Exzellenz selbst einen Herrn bestimmen würde, der für diese Arbeit geeignet und genehm ist.

Da wir in der Lage sind das Werk umgehend in Arbeit zu nehmen und fertig zu stellen, könnte bei Zustimmung Eurer Exzellenz es ermöglicht werden, dass das Werk noch

b-b Fragment sporządzony czarnym atramentem.

a Tekst pisany maszynowo na 1,5 stronicy papieru formatu A4. W lewym górnym rogu karty tytułowej nadruk firmowy: „Badenia in Karlsruhe A.-G. FÜR VERLAG UND DRUCKEREI, Telephon 6235-6237, Postscheck - Konto Karlsruhe 4844, Steinstraße 17-21". 
im Laufe des ersten Halbjahres 1934 herauskäme. Dies wäre umso mehr wünschenswert, als gerade in dieser Zeit wohl keine Veröffentlichungen über Konnersreuth erfolgen werden. Auch unser Verlag wird voraussichtlich im nächsten Jahr keine Folge des Konnersreuther Jahrbuches herausbringen. Das Werk Eurer Exzellenz wäre also das einzige, das im Jahre 1934 in Deutschland erscheinen würde.

Der Ritter von Lama hat sich im übrigen bereit erklärt ebenfalls bei der Herausgabe dieses Werkes uns mit Rat und Tat beizustehen. Da er ausserordentlich bewandert im Konnersreuther Thema ist, so dürfte das ganz bestimmt für die Herausgabe des Werkes von Vorteil sein.

Es würde uns ausserordentlich freuen, wenn Eure Exzellenz unserer Bitte stattgeben würde. In dieser Hoffnung zeichnen wir mit dem Ausdruck unserer tiefsten Verehrung ergebenst

${ }^{\mathrm{b}-B a d e n i a}$ in Karlsruhe Akt.-Ges. für Verlag u[nd] Druckerei ${ }^{-\mathrm{b}}$ $[\ldots]^{\mathrm{c}}$

\section{Dokument 147}

Kopia: AFKDOPW, teczka: 127, Spuścizna abp. Teodorowicza, sygn. 1674/185 [4], List abp. Józefa Teodorowicza do ks. dr. Stanisława Brossa, Lwów 7 XII 1933 r.

Przezacnya , Kochany Księże Doktorze!

Właśnie się zapytywałem o Brata Księdza Doktora pana profesora Ostrowskiego ${ }^{382}$. Wyraził się o nim z największym uznaniem i powiedział, że się zupełnie wyróżnia zdolnościami i solidnością pośród innych; nazwał go wprost człowiekiem przyszłości. Powiedział, że idzie naprzód, nawet poza turą w stosunku do innych. $Z$ tego wnoszę, że on sam będzie go posuwał dalej. Bardzo się cieszę, że mogę Księdzu Doktorowi zakomunikować tak pochlebne oświadczenie o Bracie [w ujęciu] profesora Ostrowskiego.

Otrzymałem list od Steuera ${ }^{383}$, w którym ten mi donosi, że przygotowuje recenzję do kwartalnika teologicznego o książce mojej i książce O. Siwka. Sądzę, że byłoby bardzo wskazane, ażeby Ksiądz Doktor był łaskaw napisać do redaktora „Przeglądu”, by nie czekał na recenzję ks. Steuera, ale oddał ją komu[ś] innemu.

b-b Pieczątka podłużna.

c Autograf nieczytelny.

a Tekst pisany maszynowo na 1,5 stronicy papieru formatu A4. Brak autografu autora.

${ }^{382}$ Prawdopodobnie: Ostrowski Tadeusz (1881-1941), chirurg, kierownik Kliniki Chirurgicznej UJK we Lwowie, 1923-1943 kierownik Katedry Chirurgii Wydziału Lekarskiego UJK, w roku akad. 1937/38 dziekan fakultetu, prezes Towarzystwa Chirurgów Polskich, prekursor nowoczesnych metod operacyjnych w Polsce. W. Rok-Wojtkiewicz, Wydziat Lekarski, w: Academia militans, passim; Z. Albert, Ostrowski Tadeusz, w: PSB, t. 24, red. zbior., Wrocław 1979, s. 578.

${ }^{383}$ Zob. w niniejszej publikacji: J. Wołczański, Korespondencja abp. Józefa Teodorowicza z o. Włodzimierzem Ledóchowskim SJ, dokument 13. 
Wszędzie pozostawił Ksiądz Doktor tutaj po sobie jak zawsze silne wrażenie, gdyż poza hipnozą jakiś magnes ukryty uczepia się duszy Księdza Doktora. Ja z mojej strony osobno dziękuję za tak miłe chwile, które mi Ksiądz Doktor poświęcił.

Łączę przy tej sposobności bardzo i bardzo gorące wyrazy mej czci.

Lwów, dnia 7 grudnia 1933

Ks. Dr Bross - Poznań

\section{Dokument 148}

Kopia: AFKDOPW, teczka: 134, Spuścizna abp. Teodorowicza, sygn. 1671/185 [4], List abp. Józefa Teodorowicza do ks. prałata Stanisława Szpetnara, Lwów 8 XII 1933 r.

Przezacny ${ }^{\mathrm{a}}$ Księże Prałacie!

Dziękuję za list łaskawy, choć nie wiem, czy mam za co dziękować Księdzu Prałatowi, że mnie tak nielitościwie napędzał do odpowiedzi O. Siwkowi.

W czterech miesiącach musiałem napisać tę książkę, no i odpokutowałem za to przemęczeniem. Podobno, jak widzę z organu przybocznego O. Siwka „Ilustrowanego Kuriera Codziennego", przygotowuje on odpowiedź na moją książkę. Przygotowany byłem $\mathrm{z}$ góry na to i dlatego najsilniejsze atuty zostawiłem sobie na koniec. Oczywiście, że „Życie Chrystusa” znowu przez rok prawie cały leżało odłogiem; i to Ksiądz Prałat poczytuje sobie za zasługę.

Podobnie książka sama względnie dobrze idzie mimo duże[j] ceny na te dzisiejsze czasy. Znak byłby to dobry zainteresowania się ludzi problemami mistycznymi.

Łączę dla Księdza Prałata bardzo serdeczne i oddane wyrazy czci i szacunku. Lwów, dnia 8 grudnia 1933

Ks. Prałat Szpetnar - Jarosław - Klasztor

\section{Dokument 149}

Kopia: AFKDOPW, teczka 131 i 136: Spuścizna abp. Teodorowicza, sygn. 1608/184 [7] i 1601/184 [7], List abp. Józefa Teodorowicza do prowincjała oo. Jezuitów o. Włodzimierza Konopki SJ, Lwów 11 XII $1933 \mathrm{r}$.

Wielce ${ }^{a}$ Czcigodny Ojcze Prowincjale!

Wielkie zaufanie jakie mam do osoby Ojca Prowincjała nie dopiero od dziś, ale od dawna usprawiedliwi krok, który teraz czynię.

a Tekst pisany maszynowo na jednej stronicy papieru formatu A4. Brak autografu autora.

a Tekst pisany na maszynie na 3,5 stronicach papieru formatu A4. Brak autografu autora. 
Zostałem zaskoczony przez biskupa Przeździeckiego listem z Rzymu o tak niejasnym i tajemniczym charakterze, że nie mogłem się zorientować co ten list właściwie oznacza, do czego zmierza i przede wszystkim pod czyim wpływem jest napisany.

List ten dotyczący mojej ostatniej książki zapowiadał czy też groził, sam nie wiem, że S[anctum] Officium dowiedziawszy się, że „podobno” ma być moja książka tłumaczona na inne języki chce wiedzieć, jakie zarzuty stawiam O. Siwkowi w mej drugiej książce.

Od razu wiedziałem, że ten list nie ma nic wspólnego z S[anctum] Officium, które się nie zajmuje przecie[ż] tłumaczeniem książek i które jeśli używa kogo[ś] za pośrednika, to nie czyni tego w jakiejś tajemniczości. Ten brak wszelkich konkretnych szczegółów i sama osnowa listu wyglądała mi od razu na jakąś niepoważną robotę, do której był użyty w dobrej wierze biskup Przeździecki. W liście tym Przeździecki ofiaruje mi się na pośrednika i chce mi uczynić przysługę.

W odpowiedzi na ten list napisałem Przeździeckiemu, że jeżeli mam korzystać z pośrednictwa, muszę przede wszystkim wiedzieć między kim to pośrednictwo ma istnieć; jeśli mam korzystać z jego przysług, to muszę wiedzieć na czym one polegają, jednym słowem prosiłem Przeździeckiego o bliższe określenie całej sprawy i zerwanie zasłony tajemniczości, która tu nie miała żadnego usprawiedliwienia, przeciwnie była zupełnie nie na miejscu. Ku mojemu największemu zdziwieniu zamiast bliższej, konkretnej odpowiedzi, otrzymuję jeszcze bardziej tajemniczy list z dopiskiem, który mi się zdawał wyraźnie wskazywać na Generała ${ }^{384}$, jako na źródło właściwe tych gróźb pod moim adresem skierowanych.

Przyznaję, że zarówno ten krok wedle mnie bardzo niepoważnie zrobiony, jak i robota sama dotknęła mnie do żywego. Przyznaję się do tego, że opierając się o słowa Przeździeckiego byłem zmuszony uważać Generała za tego, który w taki sposób posługiwał się pośrednictwem Przeździeckiego. Wtedy odpisałem Przeździeckiemu list z wyraźną tendencją, ażeby się dostał do rąk Generała.

Tymczasem dzisiaj przypadkiem całkiem otrzymałem wiadomość o pewnym szczególe, która mi nie pozwala łączyć w moich przypuszczeniach Generała z pośrednictwem tak niepoważnym Przeździeckiego. Bardzo się tym ucieszyłem, a to ze względu na mój osobisty wysoki bardzo szacunek, jaki zawsze żywiłem i żywię dla osoby Generała. Teraz jednak powstaje obawa we mnie, że ten list, który wysłałem Przeździeckiemu z tą myślą, że dojdzie do rąk Generała, może być użyty dla jakichś całkiem innych celów poza O. Generałem, wcale niepożądanych i całą sprawę komplikujących. Po prostu dziś mam grube podejrzenie, że inspiratorem Przeździeckiego był nie kto inny jak O. Siwek, który znów wplątał O. Generała w tę całą grę, powołując się na niego i posługując się tak charakterystycznym $\mathrm{u}$ niego straszeniem.

Bo on to jest, który w „I[lustrowanym] K[urierze] C[odziennym]” zapowiada niespodzianki dla „entuzjastów Konnersreuth” i grozi rewelacjami naprzód, zamiast te rewelacje bez zapowiedzi napisać; on to jest, który w listach do mnie pisanych wypowiadał groźby, więc przypuszczam, że on to jest w tym wypadku, który po prostu skonstruował

${ }^{384}$ Aluzja do óczesnego generała Zakonu oo. Jezuitów - o. Włodzimierza Ledóchowskiego SJ. 
całą intrygę używając dobrej wiary Przeździeckiego i powołując się oczywiście na samego Generała.

W takim razie, gdyby moje przypuszczenie było słuszne tym bardziej obawiałbym się, zwłaszcza, że Przeździecki w odpowiedzi danej mi w innej sprawie nie wspomina, jakoby ten tak ważny dokument ode mnie otrzymał. Obawiając się niepożądanych komplikacji w tej sprawie, nie mam innego wyjścia jak tylko to, aby wprost Generałowi odpis mego listu do Przeździeckiego przesłać.

Mógłbym to uczynić wprost i bezpośrednio, ale chcę oszczędzić Generałowi konieczności dania mi odpowiedzi, która może mu być bardzo nienaręczną w takiej chwili, zwłaszcza przed nową odpowiedzią o. Siwka na moją książkę, dlatego posługuję się drogą uboczną i przesyłam tekst listu na ręce Ojca Prowincjała z prośbą, by - jeżeli to uzna za stosowne - przesłał ten odpis Generałowi, oczywiście po wyjaśnieniu, że O. Generał nie posługiwał się tutaj tymi sposobami, jakie mi zostały przedstawione w liście Przeździeckiego. Cofam aluzję, którą uczyniłem o tym, że się z jednej strony rozpowszechnia w Niemczech pracę O. Siwka przeciw mnie, kiedy z drugiej strony usiłuje się zamknąć mi usta i to jeszcze jaką drogą? Natomiast z tekstu samego listu niczego nie zmieniam.

Pozwolę sobie przy tej sposobności dołączyć wyrazy mego głębokiego poważania i czci.

Lwów, dnia 11 grudnia 1933

\section{Dokument 150}

Oryg.: AFKDOPW, teczka 145: Spuścizna abp. Józefa Teodorowicza, sygn. 1608/185 [7], List Friedricha Ritter von Lamy do abp. Józefa Teodorowicza, Gauting bei München 11 XII 1933 r.

Excellenz $z^{\mathrm{a}}$, hochwürdigster Herr Erzbischof !

Gauting, 11. Dezember 1933

Inzwischen sind auch Eu[re] Excellenz in den Besitz meines letzten Briefes gelangt, durch den mehrere Fragen Ihrer beiden letzten Briefe bereits beantwortet sind. Auch habe ich inzwischen jene Zeitung an Sie abgeschickt, welche den Artikel des „Evangelischen Presseverbendes" enthielt; zugleich legte ich den Badischen Beobachter bei, der meine Antwort enthält.

Sin zweites Exemplar meines Jahrbuches geht vom Verlag wünsch gemäss ab. Gestern schrieb mir ein Jesuit (!) aus Amerika, das Buch habe begeisterte Aufnahme gefunden; ein Mitbruder habe sofort eines für sich als geistliche Lesung bestellt und insgesamt haben sie 19 Exemplare beim Verlag bestellt! Diese Patres sind alle Gegner Siweks und sie treten drüben wacker für die Wahrheit ein; daher haben wir mehr als je Grund, Siwek's Sache nicht mit der des Ordens zu identifizieren. Als Heermann schrieb, Resl entwende Nahrungsmittel und trage sie in den Falten ihres Rockes nachhause, um sich auf diese Weise zu ernähren, schrieb einer dieser Patres einen Artikel in einem Blatt mit folgenden Erwiderung: Angenommen, dem wäre so: dann ergibt sich: Wie Hynek feststellte, muss der

a Tekst pisany maszynowo na dwóch stronicach papieru formatu A4. Autograf odręczny czarnym atramentem. 
Mensch, um 1 Pfund zuzunehmen, 10 Pfund Nahrung nehmen, wobei die Differenz auf Ausscheidungen kommt. Resl nimmt 1t. eidlich erhärteter Feststellung nach jeder Freitagsekstase um rund 5 Pfund wieder zu, sie muss also zu diesem Zweck 50 Pfund Nahrung in den Falten ihres Rockes heimschleppen und ohne dass es jemand je gesehen hätte, kauen und essen. Da die Frei tagsekstase durchschnittlich 30mal jährlich sich wiederholt und zwar seit 8 Jahren, ergibt sich die Rechnung 8 mal 30 gleich 240 mal 50: ergibt 12000 Pfund oder 120 Zentner in den Falten des Rockes nachhause geschleppte Nahrung, die, ohne dass jemand es bemerkte, gekaut und verzehrt wurde; wieviel auf die ebenfalls von niemand gesehenen Ausscheidungen kommt, kann mansich selbst ausrechnen.

Inzwischen habe ich mir erlaubt, den Verlag Badenia einzuladen, durch Uebernahme des Verlages Ihres Buches die Herausgäbe der deutschen Ausgabe sicherzustellen. Wir brauchen dieses Buch dringend, weil ja. bei uns noch kein Berufstheologe es gewagt hat, sich über Konnersreuth theologisch-wissenschaftlich auszusprechen. Würde das Buch in Salzburg herauskommen, so 1äge als grosses Hindernis die Grenze dazwischen; es ist und bleibt Tatsache, dass sehr viele Leute es scheuen, vom Ausland etwas zu bestellen, weil die Bezahlung Schwierigkeiten bereitet (infolge der Devisenbestimmungen). Und das Hauptabsatzgebist Ihres Buches ist nun einmal Deutschland. Der Verlag bietet alle Gewähr, dass all Ihren Wünschen entsprochen wird und ich würde mich sehr freuen, wenn Sie einig würden. Ich bin bereit, allenfalls durch Stilrevision der Uebersetzung jede Unterstützung zu leihen.

Ich bitte Sie, die Rezension Ihres Buches von P[ater] Fic, O[rdo] Pr[raedicatorum], zu schicken, ich werde alles Material benützen, um für Ihr Buch zu werben.

Einer jener Jesuitenpatres in Amerika schrieb mir, ich möge Eu[rer] Excellenz nahelegen, Ihr Buch samt den Schriften des P[ater] Siwek mit Schreiben an P[ater] Ledochowski $^{385}$ zu schicken; er hat das Vertrauen zu seinem General, dass er fair play spielt.

Glauben Eu[re] Excellenz, dass in Polen Interesse für mein Büchlein über die Muttergottes-Erscheinungen in Belgien bestehen würde? Würde sich ein Verlag dafür interessieren? Mir fehlen leider Beziehungen zu polnischen Verlegern und dem Renaissance-Verlag möchte ich fern bleiben.

Ich begrüsse Eu[re] Excellenz in aufrichtiger Verehrung und Ergebenheit

F[riedrich] R[itter] von Lama

\section{Dokument 151}

Kopia: AFKDOPW, teczka 136: Spuścizna abp. Józefa Teodorowicza, sygn. 936/420 (8) [7], Kopia listu abp. Józefa Teodorowicza do nieznanego adresata, Lwów 12 XII 1933 r.

Hochgeehrter ${ }^{\mathrm{a}}$ Herr!

385 Właściwie: Ledóchowski Włodzimierz SJ. Zob. w niniejszej publikacji: J. Wołczański, Listy abp. Józefa Teodorowicza do abp. Józefa Bilczewskiego, dokument 59.

a Tekst pisany czarnym atramentem ręką kopisty na dwóch stronicach papieru format A4. Brak autografu autora. 
Ich danke Ihnen für Ihren Brief, den ich eben erhalten habe. Wenn ich überhaupt zum Entschluss komme mein Buch ins Deutsche übersetzen zu lassen, so kann ich Sie versichern, dass ich nur Ihnen den Druck dieses Buches anerbiete. Für diese Eventualität konnte ich Ihnen auch einen tüchtigen Übersetzer anempfehlen, und zwar einen Professor hier in Lwów, der in Berlin das Gymnasium absolviert hat, so dass er beinahe besser deutsch als polnisch spricht. Ich kann mich noch nicht in diesem Moment endgültig entschließen, denn einerseits werden von der interessierten Seite große Anstrengungen gemacht, um mich von dem Übersetzen des Buches abzuhalten. Diese Faktoren haben ein persönliches Interesse, um das Buch in deutscher Sprache nicht erscheinen $\mathrm{zu}$ lassen. Andererseits aber werde ich dazu angespornt, dieses Buch übersetzten zu lassen, besonders durch die Theologen, und zwar mit der Begründung, dass in diesem Buche alle mystischen Probleme wissenschaftlich behandelt werden. Man sagt mir, dass dieses Buch ein allgemeines Interesse besitzt, und deshalb wäre es ein Schaden, wenn es in deutscher Sprache nicht erschiene, wo wie man sagt, eine solche wissenschaftliche Abhandlung noch fehlt.

Herr von Lama hatte mich schon dazu bewogen, doch das Buch zu übersetzen und ich war schon entschlossen es zu tun und schrieb ihm auch, dass mein Entschluss fertig ist und zwar aus Rücksicht auf die rationalistische Propaganda, welche mit dem Buch Siwek's getrieben wurde. Aber diese Hemmungsversuche, von denen ich Ihnen schreibe, tauchen jetzt auf. Die sind zwar von keinem festen Gehalt, aber ich brauche doch ein wenig Zeit, um mit denselben fertig zu werden. Deshalb bitte ich Sie noch um Geduld. Ich bemerke dabei, dass dieses Buch nicht mit Buche über Konnersreuth identisch ist, welches ich in Vorbereitung habe und Ihnen in kurzer Zeit zu Ende bringen hoffe.

Ich verbleibe mit dem Ausdruck tiefer Hochachtung.

Lwów, 12/XII 1933

\section{Dokument 152}

Oryg.: AFKDOPW, teczka 144: Spuścizna abp. Józefa Teodorowicza, sygn. 1044/420 (8) [7], List o. Odo Staudingera OSB do abp. Józefa Teodorowicza, Salzburg 14 XII 1933 r.

Salzburg, Benediktinerkolleg[ium], am 14. XII. [19]33

Exzellenz! ${ }^{\mathrm{a}}$ Hochwürdigster Herr Erzbischof!

Gestern las uns P[ater] Alois Mager in kleinem Kreis Ihren Brief an ihn vor, der uns sehr interessierte und mit dessen Anregungen wir ganz einverstanden sind, obwohl oder vielmehr gerade weil wir fast alle Reichsdeutsche sind. Ich z[um] B[eispiel] gehöre im 3. Reich der Provinz Bayern zu. Wie gerne würde ich gerade jetzt Ew[ere] Exzellenz

Tekst pisany czarnym atramentem na dwóch kartach papieru formatu A4. W lewym górnym rogu nadruk firmowy: „Schriftleitung des Benedictus-Boten”. W górnej partii karty na centralnym miejscu graficzne wyobrażenie godła Zakonu oo. Benedyktynów: krzyż z dwiema poprzecznymi belkami stojący na trzech wzniesieniach oraz PAX. Niżej tarczy inskrypcja: „Ut in omnibus glorificetur Deus”. 
als Kardinal von Wien sehen! Ihr Brief wird Kard. Innitzer und Dollfuß ${ }^{386}$ zur Kenntnis gelangen. Denke, dass P[ater] Mager Ew[ere] Exzellenz darüber berichten wird.

Danke recht sehr für den gütigen Brief an mich. Die Kirchenzeitung wird sich sehr glücklich schätzen, wenn Exzellenz selbst eine Zusammenstellung Ihrer Ideen geben. Der Benediktus-Boten hat ebenfalls großen Appetit danach und bittet ebenfalls, sie bringen zu dürfen.

Den Vorwurf der Untreue, obwohl er nicht ganz unberechtigt ist, kann ich nicht gut auf mir sitzen lassen, wenn es auch in so liebenswürdiger, mich erfreuender Art erfolgt wie es Exzellenz tun. Etwas ist im Dez[ember] Heft doch über Th[erese] N[eumann] zu finden, nämlich unterbrachten „Kleine Mitteilungen“: Therese N[eumann] verehrt den Hl. Rock. Im Jan[uar] Heft im Aufsatz über Rothschild wird auch Th[erese] N[eumann] erwähnt.

Es wird mich sehr freuen, wenn Exzellenz mit P[ater] Mager sich verbinden werden für Konnersreuth. Auch ich habe es bereits getan. Den Beweis wird das April- oder Maiheft bringen. Vor etwa einer Viertelstunde brachte er mir einen Aufsatz: „Konnersreuth und seine guten Wirkungen“. Nach einer Einleitung, in der er seine Gegnerschaft gegen Missgriffe und Übergriffe des sogen. Konn[ersreuth] Kreises zu rechtfertigen sucht und seine Hochachtung von Th[erese] N[eumann] betont, veröffentlicht er einen langen Brief einer geistig, religiös und gesellschaftlich hochstehender Dame, in dem sie ihre Bekehrung durch Konnersreuth ergreifbar erzählt und P[ater] Mager bittet, von seiner Gegnerschaft v[on] K[onnersreuth] abzustehen. Man muss P[ater] Mager goldene Brükken bauen und der Redakteur des Ben[edictus] B[oten] will gern das Seinige dazu beitragen. Exzellenz sehen, dass der Schreckschuss: Verbindung mit P[ater] M[ager] ganz daneben gegangen ist.

Wie dieser Ihr Scherz amüsiert mich auch Ihre Überzeugung, dass ich gegen P[ater] Bruno $^{387}$ in Sachen Beauraing ${ }^{388}$ den Sieg davon tragen werde. Auch ich glaube fest, dass meine Nase auch in diesem Fall mich nicht trügt. Erst kürzlich brachte ein Benediktiner von Maredsous ${ }^{389}$, unweit von Beauraing ganz vorzüglich eingeweiht in das dortige Geschehen, in der „Revue Liturgique et Monastique“ einen Aufsatz gegen Univ[ersitäts] Prof[essor] de Graaff ${ }^{390}$, den Verbündeten des P[ater] Bruno. Ich habe bis jetzt noch gar keinen Platz gefunden, ihn zu erwähnen; mir genügen die Tatsachen. Contra facta non valet argumentum.

Von ganzem Herzen für Ihr unverdientes Wohlwollen dankend, bittet um dasselbe auch für weiterhin Ew[ere] Exzellenz ehrfurchtsvoll erg[ebener]

$\mathrm{P}$ [ater] Odo Staudinger OSB

${ }^{386}$ Dollfuß Engelbert (1892-1934), austriacki polityk, 1932-1934 kanclerz i minister spraw zagranicznych, jeden z przywódców Partii Chrześcijańsko-Społecznej, wprowadził rządy oparte o zasady solidaryzmu narodowego i korporacjonizmu. Zginął w zamachu 25 VII 1934 r. Dollfuß Engelbert, w: ÖBL, Bd. 1, herausg. von L. Santifaller, Graz-Köln 1957, s. 192.

387 Bruno de Jésus-Marie - benedyktyn, redaktor „Etudes Carmélitaines”.

388 Beauraing - miejscowość u podnóża masywu Ardenów we wschodniej prowincji Namur w Belgii.

389 Maredsous - miejscowość w Belgii w rejonie Namur z klasztorem oo. Benedyktynów.

390 Osoba niezidentyfikowana. 


\section{Dokument 153}

Oryg.: AFKDOPW, teczka 141: Spuścizna abp. Józefa Teodorowicza, sygn. 6/231 [7], List abp. Karela Kaspara do abp. Józefa Teodorowicza, Praga 15 XII 1933 r.

Eure $^{\mathrm{a}}$ Exzelenz!

Prag, 15 XII [19]33

Geradezu meinen innigsten Dank nicht nur für die gütige Zusendung sondern auch für die liebevolle Herzessgabe $[\ldots]^{\mathrm{b}}$ interessanten Buches über Therese Neumann entgegenzunehmen. Ich habe gleich mit der Lesung begonnen.

Mit vorzüglicher Hochachtung Euer Exzellenz ganz ergebener

† Dr. K[arel] Kašpar

Erzbischof

\section{Dokument 154}

Oryg.: AFKDOPW, teczka 145: Spuścizna abp. Teodorowicza, sygn. 1016/420 (8) [7], List o. Andrzeja Żukowicza SJ do abp. Józefa Teodorowicza, Kraków 17 XII 1933 r.

Ekscelencjo ${ }^{a}$, Najprzewielebniejszy Księże Arcybiskupie!

Kraków, dnia 17 grudnia 1933

W zastępstwie O. Prowincjała Konopki, który na kilka tygodni wyjechał do Rumunii, mam zaszczyt podziękować Waszej Ekscelencji za szczególnie zaufanie, jakie mu okazać raczył, przesyłając odpisy listów we wiadomej sprawie, jako też odpowiedzieć co następuje.

Nie mam najmniejszego wyobrażenia ani co jest treścią owej zagadkowej sprawy o zamiarach św[iętego] Officium względem książki Waszej Ekscelencji, ani też jakiej jej mogło być źródło. To jedno mam przekonanie, że tym źródłem nie był nasz O. Generał. Nie zgadza się to z jego charakterem i sposobem postępowania, któremu, jako jego sekretarz, miałem sposobność przez dwa lata aż do kilku tygodni wstecz z bliska się przypatrzeć. Toteż znając cześć i uszanowanie z jakim O. Generał zawsze się odnosił do osoby Waszej Ekscelencji, nie mógłbym się pisać na twierdzenie Waszej Ekscelencji, że zgromadzenie, gdy chodziło o wydanie drugiej pracy O. Siwka, kierowało się widocznym elementem zniszczenia moralnie Waszej Ekscelencji przed szeroką publicznością. Nie zdziwiły wcale głosy, co do całokształtu dyskusji Waszej Ekscelencji z O. Siwkiem, pozwalam sobie na pewne spostrzeżenia. I tak artykuły w „Kurierze” nie wyszły spod pióra ani też z inspiracji jezuitów. Książkę O. Siwka posłano wprawdzie do redakcji „Kuriera”, jak do innych redakcji, ale nie proszono o taką czy inną ocenę. Artykuł, który ukazał się po wyjściu ostatniej książki Waszej Ekscelencji, ani z O. Siwkiem, ani z tutejszymi

a Tekst pisany czarnym atramentem na jednej stronicy papieru formatu karty pocztowej. W lewym górnym rogu graficzne wyobrażenie herbu hierarchy.

b Wyraz nieczytelny.

a Tekst pisany czarnym atramentem na jednej stronicy papieru formatu A4. 
jezuitami nie miał żadnego związku. Nie wiedzieliśmy nic o nim, a O. Siwek dowiedział się dopiero z wycinka gazety.

Co się zaś tyczy aprobaty na drugą pracę O. Siwka, informuje mnie dyrektor Wydawnictwa, O. Rostworowski, że prosił o nią warunkowo i otrzymał ją też tej myśli, tj. jeżeli praca będzie drukowana, nie było bowiem wówczas pewności, że praca ta wyjdzie. Dodawać nie potrzebuję, że mimo tę niepewność, bezcelową byłaby prośba o aprobatę na książkę, której publikacja nie miałaby żadnych widoków.

Tych kilka spostrzeżeń ośmieliłem się przesłać Waszej Ekscelencji, dziękując raz jeszcze za wielki zaufanie, z jakim Wasza Ekscelencja odnieść się raczył do O. Prowincjała.

Ze czcią najgłębszą całuję pierścień Waszej Ekscelencji i z pokorą o Arcybiskupie błogosławieństwo proszę, najniższy sługa w Chr[ystusie]

ks. Żukowicz SJ ${ }^{391}$

\section{Dokument 155}

Oryg.: AFKDOPW, teczka 140: Spuścizna abp. Józefa Teodorowicza, sygn. 968/420 (8) [7], List dr. Ralpha Waldego Hynka do abp. Józefa Teodorowicza, Praga 22 XII 1933 r.

Praha, dne 22/XII 1933

Euere $^{a}$ Exzellenz!

Endlich kann ich Eurer Exzellenz auch mein Referat über das vortreffliche Buch E[were] Exzellenz ankommen lassen.

Es hat mich längere Zeit in Anspruch genommen, da ich mir auch das Buch Siweks verschaffen musste und dann hat uns lieber Gott ein Töchterlein Miriam - Therese gespendet.

Mit größtem Interesse habe ich gelesen das Buch „Zjawiska mistyczne“ und war riesig erfreut darüber, dass Euere Exzellenz so tapfer und gerecht sich der Sache und Ehre der "Ressl" angenommen hat und dieselbe so mutvoll verteidigt.

Mit gleicher Post sende ich 3. Artikel von unseren „Lidove Listy“. Hoffentlich würden Euere Exzellenz doch was davon verstehen.

Indem ich Euerer Exzellenz segensreiche Weihnachten und glückliches Neujahr 1934 von Herzen wünsche erbitte ich mir zur weiteren Arbeit die Fülle des Segens von E[were] Exzellenz hochachtungsvoll ergeben

Dr. R[alph] W[aldo] Hynek

P.S. Herrn R[itter] v[on] Lama habe ich auch eine recht ausführliche Rezension im Deutschen geschickt.

391 Żukowicz Andrzej (1886-1962), święcenia kapłańskie w 1917 r. w Zakonie oo. Jezuitów, 1919-1923 dyrektor gospodarczy Wydawnictwa Apostolstwa Modlitwy w Krakowie, 1923-1929 redaktor „Posłańca Serca Jezusowego", 1929-1930 superior w Stanisławowie, 1930-1933 sekretarz Asystencji Słowiańskiej w Rzymie, 1933-1957 sekretarz prowincjała Prowincji Małopolskiej. Żukowicz Andrzej, w: EWJ, s. 802.

a Tekst pisany czarnym atramentem na jednej stronicy papieru formatu A4. W lewym górnym rogu nadruk firmowy: „Dr. R.W. Hynek, lèkař spisowatel, Praha II, Ječná 37, telefon 31368”. 


\section{Dokument 156}

Kopia: AFKDOPW, teczka: 131, Spuścizna abp. Teodorowicza, sygn. 1615/184 [7], List abp. Józefa Teodorowicza do ks. prałata Zygmunta Kaczyńskiego, Lwów 22 XII 1933 r.

Kochany ${ }^{a}$ Księże Prałacie!

Bardzo dziękuję za pomieszczenie krytyki, która w poważnych kołach jak najlepsze zrobiła wrażenie. Co do ks. Weryńskiego, to jest on agentem O. Siwka. Wobec tego, że Książę Biskup krakowski ${ }^{392}$ zakazał księżom pisywać do „I[lustrowanego] K[uriera] C[odziennego]", on obchodzi ten zakaz przez swoje pseudonimy. Proszę jego wszystkim powoływaniom się na Księcia biskupa nie dowierzać i zagrozić, że Ksiądz Prałat sam się odniesie do Księcia biskupa z pytaniem, czy to jest jego intencją, ażeby tę sprawę rozdmuchiwać; zobaczy Ksiądz Prałat zaraz jak mu zrzednie mina. Książę biskup krakowski właśnie sam czyni starania, ażeby podać sprostowania faktyczne dementujące tę korespondencję; nie przypuszczał Książę biskup, by to mógł uczynić ks. Weryński.

Książę biskup następnie nie tylko nie był za dalszą odpowiedzią O. Siwka, ale wyraźnie przedstawiał OO. Jezuitom, ażeby zaprzestali wszelkich dalszych odpowiedzi w tej sprawie. Dlatego tę zapowiedź książki tak niesłychanie pretensjonalną, bo któż książkę mającą się ukazać zapowiada, proszę uważać jako chęć osłabienia krytyki przez tego agenta O. Siwka. Jak ze wszystkiego przypuszczam, idzie tu o sprawę pieniężną, bo Weryński znajduje się w trudnych materialnych warunkach, a w „I[lustrowanym] K[urierze] C[odziennym]" doskonale płacą. Niech będzie też wiadomym poufnie Księdzu Prałatowi, że bardzo poważni jezuici przekazywali do mnie, iż z całą krytyką O. Siwka się nie zgadzają, że ją potępiają, że uważają wystąpienie zakonnika w ten sposób, jak on to czyni wobec biskupa, za niewłaściwe w najwyższym stopniu. Nie mogę ujawnić nazwisk tych jezuitów, ale oni odgrywają wybitną rolę i ze swej strony czynią wszystko co mogą, ażeby w Kurii rzymskiej poczynić odpowiednie przedstawienie; niesłychany spryt O. Siwka umiał wybornie wyzyskać wpływy jezuitów niemieckich w Kurii centralnej rzekomo w obronie honoru Gregorianum.

Wracam jeszcze do ks. Weryńskiego. Otóż sama zapowiedź w K[atolickiej] A[gencji] $\mathrm{P}$ [rasowej] jako rzeczy jakiejś nadzwyczajnej odpowiedzi O. Siwka już była narzuceniem z jego strony bardzo niewłaściwym. Bo i cóż w tym tak wielkiego, że O. Siwek myśli dać mi odpowiedź? Dosyć będzie o tym myśleć, kiedy się ukaże sama jego książka i wtedy będzie czas zastanowić się nad tym, czy warto coś o niej wspomnieć. Dla K[atolickiej] A[gencji] P[rasowej] jednak specjalne pomieszczenie tej notatki przez ks. Weryńskiego było z jego strony wysoce nielojalnym i nadużyciem zaufania, bo on tę samą notatkę jakie[ś] dwa tygodnie temu pomieścił już z jarmarczną reklamą i to w „I[lustrowanym] K[urierze] C[odziennym]"; pozwolił więc sobie dopiero potem powiadomić K[atolicką] $\mathrm{A}$ [gencję] $\mathrm{P}[$ rasową].

a Tekst pisany maszynowo na 3,5 stronicach papieru. Brak autografu autora. W prawym górnym rogu karty tytułowej nota atramentem: „Ks. Prałat Kaczyński 22/XII [1][933”.

392 Tytuł przysługujący metropolicie krakowskiemu abp. Adamowi Stefanowi Sapieże. 
Przeciwko podobnym próbkom powinien Ksiądz Prałat bardzo ostro się zastrzec. Recenzja książki O. Siwka polegała tylko jedynie na jej streszczeniu, nie zaś na zajęciu stanowiska ze strony K[atolickiej] A[gencji] P[rasowej]. Używanie K[atolickiej] A[gencji] $\mathrm{P}$ [rasowej] do polemiki jest nie tylko rzeczą wysoce niewłaściwą, ale wprost niedopuszczalną.

Pozwoli Ksiądz Prałat, że zadam dwa pytania Księdzu Prałatowi. Pierwsze: czy prawdą jest, że Ksiądz Prałat w K[atolickiej] A[gencji] P[rasowej] pominął w podaniu oficjalnej mowie Ojca św. w Rzymie do Polaków cały ustęp, który się odnosił do Rządu? I drugie: czy prawdą jest, że Ksiądz Prałat zdając sprawę bardzo szczegółowo z pobytu kardynała Seredy ${ }^{393} \mathrm{w}$ Warszawie pominął umyślnie wzmiankę o jego bytności u Piłsudskiego i herbacie, na którą był kardynał zaproszony?

Dziękując Księdzu Prałatowi za troskę o me zdrowie, które względnie jest wprawdzie dobre, ale niestety jeszcze na podróże dłuższe nie pozwala, łączę dla Księdza Prałata życzenia świąt najlepszych, szczerze oddany.

Lwów, dni 22 grudnia 1933

Właśnie otrzymuję gazetę z Niemiec, w której Protestancki Związek Prasowy posługuje się obiema książkami O. Siwka, ażeby nie tylko uderzyć na mnie nazywając mnie po nazwisku, ale na Episkopat bawarski, którego łatwowierność między wierszami wydrwiwa. A więc w chwili, kiedy XX. Biskupi bawarscy zajmują się dociekaniem tej sprawy, książki O. Siwka są przedstawione jako opinie Gregorianum przeciwko XX. Biskupom. Nie jest wykluczone, że XX. Biskupi bawarscy zechcą tu wystąpić. Mam list ks. b[is]k[u]p[a] bawarskiego z Regensburga, w którego diecezji jest Teresa Neumann wyrażający oburzenie z powodu wystąpień O. Siwka, pisząc mi, jak śmiał zakonnik i kapłan czegoś podobnego się dopuścić, nie znając w dodatku samej sprawy.

\section{Dokument 157}

Kopia: AFKDOPW, teczka 134: Spuścizna abp. Teodorowicza, sygn. 1416/185 [4], List abp. Józefa Teodorowicza do o. Josefa Schrijversa CSsR, Lwów 28 XII 1933 r.

\section{Czcigodny ${ }^{\mathrm{a}}$, Drogi Ojcze Prowincjale!}

Bardzo mnie wzruszyła i ucieszyła pamięć Ojca Prowincjała, który wśród tylu zajęć znalazł jeszcze czas i miejsce, ażeby mi swój list przesłać.

Być w Belgii i znaleźć się blisko Ojca byłoby to istotnie moim gorącym marzeniem po takim osieroceniu, jakie po odejściu Ojca zaznałem; tego jednak roku byłem ciężko chory wskutek umysłowego przepracowania. Zapadłem na wielkie osłabienie i dopiero teraz przychodzę do siebie; Bóg mię widocznie pozostawia jeszcze tu na ziemi. Chciałbym bardzo pokończyć zaczęte prace zwłaszcza „Życie Chrystusa”. Mam też na ukończeniu dzieło o Teresie Neumann.

393 Osoba niezidentyfikowana.

a Tekst pisany maszynowo na 1,5 stronicy papieru formatu A4. Brak autografu autora. 
Co do O. Siwka, to mu w Rzymie postawiono alternatywę: albo zrezygnować z katedry w Gregorianum, albo dać mi odpowiedź; zapowiada więc, że mi odpowie jakkolwiek sami poważni jezuici są tego przekonania, że książka moja jest już definitywną rozprawą z nim. Mam oferty z Niemiec z wydawniczych firm, które same na własną rękę chcą się podjąć wydania mojej książki po niemiecku; waham się jednak jeszcze, czy się na to zgodzić zwłaszcza wobec tego, że i tak przygotowuję dzieło zasadnicze,

Jeszcze raz dziękuję Drogiemu Ojcu Prowincjałowi za wszystko z głębi serca i modlę się o siły dla Niego do spełnienia tak trudnego posłannictwa ${ }^{394}$.

Łączę najoddańsze wyrazy wdzięcznej czci.

Lwów, dnia 28 grudnia 1933

O. Schrijvers - Bruksela

\section{Dokument 158}

Kopia: AFKDOPW, teczka 131: Spuścizna abp. Józefa Teodorowicza, sygn. 1618/184 [7], List abp. Józefa Teodorowicza do ks. prałata Zygmunta Kaczyńskiego, [Lwów 29 XII 1933 r.].

Przezacny ${ }^{\mathrm{a}}$ Księże Prałacie!

Dziękuję Księdzu Prałatowi za wyjaśnienia, z których skorzystałem. Co do O. Siwka, to prawdy w tym jest tyle, że go zaprosił ks. Metropolita ${ }^{395}$ na obiad wtedy, kiedy byłem w Krakowie; chyba na żadną lekcję czasu nie było. Zwyczajem moim jest, że sprawy o których chcę pisać, omawiam z ludźmi fachowymi. W szczególności o Konnersreuth rozmawiałem między innymi z profesorem Allersem ${ }^{396}$ we Wiedniu i innym profesorem monachijskim etc. Żadnemu z nich na myśl nie przyszło nazwać taką pogadankę lekcją. Otóż wiedząc o tym, że O. Siwek świeżo przybył z Paryża, gdzie studiował psychologię, pytałem go o kwestie ogólnopsychologiczne, w szczególności o psychastenię. Byłem o ile sobie przypominam - raz u niego u Jezuitów przez pół godziny. I ten człowiek pozwala sobie mówić o lekcjach jakie mi dawał psychologii!

Otóż kwestia psychastenii nie jest w ogóle przeze mnie poruszana w całej książce o Konnersreuth. Jest to rzecz elementarna, którą się odnajdzie w pierwszym lepszym podręczniku psychologii. Ja chciałem bliżej z nim omówić związek psychologii ze zjawiskami w Konnersreuth; ale on absolutnie w tę kwestię widocznie nie chciał wchodzić. Ukrył w ogóle przede mną, że ma sam pisać rozprawę o Konnersreuth z którą się poprzednio odnosił do znanych racjonalistów niemieckich, nawiązując z nimi stosunki. Poprzestał więc tylko na tym nic nieznaczącym wypowiedzeniu się o psychastenii.

394 Aluzja do objęcia w 1933 r. przez adresata listu funkcji prowincjała oo. Redemptorystów w Belgii.

a Tekst pisany maszynowo na 3,5 stronicach papieru formatu A4. Brak autografu autora i datacji. W górnej partii strony tytułowej nota ołówkiem inną ręką: „Nie poszło, Eksc[elencja] sam wysłał 29/XII [1]933. Ks. Kaczyński K.A.P."

395 Aluzja do metropolity krakowskiego abp. Adama Stefana Sapiehy.

396 Zob. w niniejszej publikacji: J. Wołczański, Korespondencja abp. Józefa Teodorowicza z o. Wtodzimierzem Ledóchowskim SJ, dokument 13. 
Zwykle jak jestem w Krakowie bywam u jezuitów i wtedy odwiedzam O. Andrasza i jemu właśnie wizytę robiłem, a on dopiero zaprowadził mnie do O. Siwka. O. Siwek w największym przede mną ukrywał sekrecie, że ma przygotowaną pracę o Konnersreuth. Kiedy go pytałem o zdanie o moich odczytach w Krakowie to chwalił je, jakkolwiek potem użył właśnie tych odczytów jako głównego motywu do wystąpienia przeciwko mnie swoją książką; Generał bowiem zakazał jezuitom cokolwiek pisać o Konnersreuth z wyrażaniem opinii dodatniej czy ujemnej. Dla niego tylko zrobił wyjątek uwierzywszy mu, że moje odczyty tak źle oddziałały w Krakowie, że koniecznie trzeba im się przeciwstawić.

Cała metoda O. Siwka, a tym samym jego agenta ks. Weryńskiego polega na tym, że stara się wmówić, że tu idzie o dwie metody różne w ocenie wypadków w Konnersreuth. Tymczasem ze stanowiska teologii mistycznej i w ogóle nauki, pomijanie kryteriów jakiejś gałęzi wiedzy w analizie fenomenów jest niedopuszczalne; rozstrzyganie o mistyce bez mistyki jest stanowiskiem niedopuszczalnym. Tymczasem O. Siwek sam mi pisał dwukrotnie, że teologii mistycznej wcale nie używał, a to był przecie[ż] mój główny i jedyny zarzut. Drugi zarzut również dotyczy ogólnej i jedynej metody naukowej, która nakazuje podawać uczonemu prawdziwe fakty, a nie zmyślone. Otóż O. Siwek doskonale czuje piętę Achillesa swojej książki i pragnie przerzucić dyskusję na rzecz merytoryczną, czyniąc ze mnie naiwnie wierzącego - wedle Weryńskiego należącego do szkoły augustiańskiej - i ściśle krytycznego tomistę Siwka.

Otóż K[atolicka] A[gencja] P[rasowa] nie może podawać takich fałszów, które już poprzednio pomieścił Weryński w „I[lustrowanym] K[urierze] C[odziennym]” i które za pośrednictwem Ks. Metropolity zostały sprostowane. Dlatego bardzo proszę Księdza Prałata, jeżeli Ksiądz Prałat chce pomieszczać na szpaltach K[atolickiej] A[gencji] P[rasowej] jakiś rodzaj dalszej dyskusji, wprzód mi przysłać tekst Weryńskiego, a w takim razie ja Księdzu Prałatowi prześlę odpowiedź pod znakiem: Teolog S.T.

O tej rozmowie półgodzinnej z O. Siwkiem o pschychastenii w Krakowie może Ksiądz Prałat napisać ks. Weryńskiemu z odpowiednimi słusznie mu się należącymi uwagami, jeśli będzie uważał to za stosowne.

Jeszcze raz proszę przed wydrukowaniem ewentualnym artykułu Weryńskiego, który nie jest żadnym teologiem i na tych rzeczach kompletnie się nie zna, przysłać mi tekst i ocenę jego stanowiska przeze mnie podaną bezpośrednio w K[atolickiej] A[gencji] P[rasowej] umieścić.

Nawiasem dodając, autor, który wbrew zakazowi Ks. Biskupa krakowskiego pomieści swoje rzekomo teologiczne wywody na szpaltach metafizycznego „Kurierka” krakowskiego w ogóle nie zasługuje na to, by go brać serio i otwierać mu szpalty K[atolickiej] A[gencji] P[rasowej], można mu śmiało nawet to napisać, że najpierw zaszczyca swymi pracami „Kurierka” krak[owskiego], a potem chce powtarzać swe elukubracje w K[atolickiej] A[gencji] P[rasowej].

Co do łączenia nakazu O. Generała z papieżem, to oczywiście jest to naiwne i wprost śmieszne. Trzeba wiedzieć Księdzu Prałatowi, że ja sam z własnej ochoty napisałem do Generała, że nic nie mam przeciwko temu, aby Siwek dał mi odpowiedź. Wiem o tym, że 
O. Generał był przeciwny tej odpowiedzi i tylko na razie zwyciężyli Niemcy i przeważyli na stronę odpowiedzi. Na odpowiedź zdecydował się O. Generał tylko dlatego jedynego, iż jak mi pisał, nie chciał ażeby członka Gregorianum pomawiano o racjonalizm. A więc O. Generałowi wcale nie chodziło o sprawę Konnersreuth, jak to chce przedstawić ten autor, ale jedynie tylko o obronę poniekąd honoru Gregorianum.

Co do papieża zaś, to znane jest jego stanowisko w sprawie Konnersreuth, które publicznie wypowiedział, że sprawę tę oddaje Opatrzności Bożej i jej działaniu.

Co do Gregorianum, to jak pisałem Księdzu Prałatowi, ono skutkiem Siwka zaangażowało się przeciwko Konnersreuth tak, że protestanci i racjonaliści wyzyskują tę kwestię przeciwko Kościołowi. Ja mam dosłowny tekst tych właśnie enuncjacji kół protestanckich. Proszę zważyć, że to się dzieje w chwili, kiedy XX. Biskupi bawarscy wzięli pod obserwację Konnersreuth; dla jezuitów sprawa ta może mieć bardzo a bardzo niepomyślny obrót. Biskupi bawarscy są na stanowisko O. Siwka wprost oburzeni. Proszę więc nie dać się w niczym zbałamucić, a tym mniej zastraszyć temu krakowskiemu agentowi O. Siwka.

Łączę przy tej sposobności serdeczne wyrazy i pozdrowienia dla Księdza Prałata.

Ks. Prałat Kaczyński - Warszawa

Dyrektor K[atolickiej] A[gencji] P[rasowej]

\section{Dokument 159}

Kopia: AFKDOPW, teczka 131: Spuścizna abp. Józefa Teodorowicza, sygn. 1602/184 [7], List abp. Józefa Teodorowicza do prowincjała oo. Jezuitów o. Włodzimierza Konopki SJ, Lwów XII 1933 r.

Wielce ${ }^{a}$ Czcigodny Ojcze Prowincjale!

Przysłano mi wycinek z „Ilustrowanego Kuriera Codziennego” następującej treści: „Dyskusja duchownych o Konnersreuth! Z kół dobrze poinformowanych donoszą, że na dzieło ks. arcybiskupa Teodorowicza o Konnersreuth ukaże się niebawem zwięzła odpowiedź naukowa prof[esora] uniwer[ystetu] ks. dra Pawła Siwka TJ nakładem papieskiego uniwersytetu Gregoriańskiego w Rzymie. Odpowiedź ta będzie niespodzianką dla entuzjastów Teresy Neumann, którzy przypuszczali, że na książce ks. arcyb[iskupa] Teodorowicza skończy się dyskusja”.

W tej właśnie sprawie piszę do O. Prowincjała. Zaznaczam na wstępie, że nic a nic zgoła nie mam i mieć nie mogę, iż O. Siwek myśli mi dać odpowiedź. Jeszcze w roku zeszłym, kiedy O. Prowincjał mi wspomniał, że na książkę moją, którą ja napiszę już żadnej odpowiedzi nie będzie odrzekłem, jak to sobie O. Prowincjał przypomina, iż jest mi to wszystko jedno, czy odpowiedź będzie, czy nie będzie. Wtedy już bowiem znałem dobrze nastroje rzymskie i nie wątpiąc na chwilę w szczerość O. Prowincjała liczyłem

a Tekst pisany na maszynie na 2,5 stronicach papieru formatu A4. Brak datacji dziennej i autografu autora. W prawym górnym rogu karty tytułowej nota czarnym atramentem: „O. Prow[incjał] Konopka XII [1]933". 
się jednak z tym, że się inaczej stanie, jak O. Prowincjał sądzi. Dlatego układając książkę, z góry brałem $w$ rachubę także i ewentualną odpowiedź, i zachowałem sobie dla niej jeszcze potrzebne argumenty.

Piszę o tym O. Prowincjałowi, aby z naciskiem podkreślić, że najzupełniej mi o to nie chodzi, czy O. Siwek przygotuje odpowiedź, owszem, uważam to dla wykończenia całości mojej idei raczej za pożądane. Oczywiście smutne doświadczenie, że każdy występ O. Siwka kończy się dotąd coraz większym zgrzytem, nie będzie mogło i w tym wypadku być wzięte na moją odpowiedzialność. Nie o to mi chodzi i nie w tym celu piszę list do O. Prowincjała.

Chodzi mi o to, że od jakiegoś czasu „Ilustrowany Kurier Codzienny” pomieszcza już to komunikaty Ojców zabarwione wrogą dla mnie tendencją, już to całe artykuły. Wszystkie te uderzenia na mnie są uderzeniami zza płotu, bo autor, który nie chce się podpisywać, ale którego po stylu poznać, posuwa się w swych atakach na mnie aż do podobnego poniżania biskupa katolickiego, jak to było w przedostatnim ataku na mnie. Wtedy „anonimowy teolog” zarzucił mi wprost fideizm, a więc prawie herezję!

Dzisiaj zaś notatka o pojawieniu się dzieła odpowiedzi O. Siwka łączy się znowu z aluzją do mnie; mianowicie w wyraźnej wzmiance o entuzjastach Konnersreuth.

Stwierdzam więc, że ataki na mnie w tej czy innej formie już to w pozornie niewinnej notatce ze strony Ojców skierowane, stale się zaczynają powtarzać w „Ilustrowanym Kurierze Codziennym”. Muszę dlatego te ataki uważać za dalszy ciąg tej walki, która ze strony Zgromadzenia ustawicznie przeciwko mnie trwa. Będąc przekonany o najlepszych zamiarach O. Prowincjała zwracam jednak Jego uwagę, że sprawa wchodzi w ten okres, w którym atak na jednego biskupa i chęć jego poniżenia będzie musiała być oceniona przez innych XX. Biskupów, jako sprawa obchodząca wszystkich.

Łączę dla O. Prowincjała wyrazy głębokiego szacunku i czci.

Lwów, dnia [... $]^{\mathrm{b}}$ grudnia 1933

\section{Dokument 160}

Oryg.: AFKDOPW, teczka 141: Spuścizna abp. Józefa Teodorowicza, sygn. 997/420 (8) [7], List o. Aloisa Magera OSB do abp. Józefa Teodorowicza, Salzburg 3 I 1934 r.

\section{Euere $^{a}$ Exzellenz!}

Hochwürdigster, sehr verehrter Herr Erzbischof!

Noch bin ich nicht dazu gekommen, Euerer Exzellenz für Ihren letzten Brief ergebenst zu danken. Wie den ersten Brief, so sandte ich auch diesen umgehend an Kardinal Innitzer. Euere Exzellenz werden inzwischen aus der Presse erfahren haben, dass die Bischöfe Österreichs inzwischen den Schritt taten, den Euere Exzellenz von ihnen als unumgänglich notwendig erwarteten. Der Hirtenbrief wirkt wie eine Erlösung für die

b Brak daty dziennej.

a Tekst pisany maszynowo z wyjątkiem autografu autora na jednej stronicy papieru formatu A4. 
Katholiken, auch draußen im Deutschen Reich. Die Sprache ist klar und eindeutig. Freilich kommt mir vor, als ob der Hirtenbrief theologisch sehr wenig begründet wäre. Er enthält keine tiefen Gedanken. Verzeihen mir Euere Exzellenz, dass ich mir eine solche Kritik erlaube. Die Sprache gegen den Nationalsozialismus ist bestimmt. Die Sätze sitzen, aber die Begründung müsste tiefer sein. Immerhin müssen wir Gott danken, dass die Bischöfe sich endlich entschlossen, ein entscheidendes Wort zu sprechen. Ich war einige Tage vor Weihnachten in Wien und hatte eine Unterredung mit Dollfuss. Ich sprach ihm von den Anregungen Euerer Exzellenz. Er war sehr erfreut darüber und teilte mir mit, dass sein Hirtenbrief in diesem Sinn auf Weihnachten herauskomme. Er ist doch ein prächtiger Mensch, unser Bundeskanzler, ein guter Katholik durch und durch. Es lässt so leicht und angenehm mit ihm sprechen. Er hat das, was man sagen will, schon begriffen, noch ehe man den Satz vollendet hat. In einer Viertelstunde kann man mit ihm mehr besprechen, als mit anderen in einer ganzen Stunde.

Gern benütze ich die Gelegenheit, Euerer Exzellenz Gottes Gnade und reichsten Segen für das neue Jahr zu wünschen. Nur allein weiss, was es uns bringen wird. Nur der Glaube auf seine Vorsehung gibt einem Mut und Kraft, nicht kleinmütig zu werden. Ich hoffe, dass die österreichische Regierung durchhält. Es wäre nicht auszudenken, was geschehen würde, wenn auch in dieses Land der Nationalsozialismus einzöge. Eine Freude aber erhoffe ich von diesem Jahr, die nämlich, dass wir Euere Exzellenz in Salzburg wiedersehen und begrüssen dürfen.

Wie steht es mit dem Konnersreuth-Buch Euerer Exzellenz? Wie steht es überhaupt um Konnersreuth? Man erfährt gar nichts mehr. Vielleicht sind auch daran die politischen Verhältnisse schuld.

Mit ehrfurchtsvollem Ringkuss und mit verehrungsvollen Grüssen, bin ich Euerer Exzellenz in Christus ergebenster

P[ater] Alois Mager OSB

\section{Dokument 161}

Oryg.: AFKDOPW, teczka 141: Spuścizna abp. Józefa Teodorowicza, sygn. 1015/420 (8) [7], List o. Włodzimierza Konopki SJ do abp. Józefa Teodorowicza, [Kraków] 9 I 1934 r. Kopia: APJK, sygn. 1426, Konopka Włodzimierz TJ. Korespondencja prowincjalska za rok 1934, List o. Włodzimierza Konopki SJ do abp. Józefa Teodorowicza, [Kraków] 9 I 1934 r.

9/I [19]34

Ekscelencjo! ${ }^{\mathrm{a}}$

Najczcigodniejszy Księże Metropolito!

Po powrocie z kilkutygodniowej tułaczki dowiedziałem się od mego zastępcy O. A[ndrzeja] Żukowicza o korespondencji Waszej Ekscelencji, za co śpieszę przesłać

a Tekst pisany na maszynie z wyjątkiem autografu autora na jednej stronicy papieru formatu A4. W lewym górnym rogu nadruk firmowy: „Praep[ositus] Prov[intiae] Pol[onae] Minor SJ, Kraków, Mały Rynek 8, T[e]l[e]ph[on] Nr 11510". 
korne Bóg zapłać, a z mej strony mam zaszczyt zaznaczyć, że w zupełności potwierdzam to, co O. Żukowicz w swym liście napisał. W szczególności jednak ośmielam się zauważyć nie tylko jako ten, który zawsze wielką czcią otaczał Waszą Ekscelencję, ale jako przełożony tej Prowincji, że wystąpienie O. Siwka nie było i nie jest dziełem Zakonu jako takiego. Przyzwyczajeni tradycyjnie do swobody doktrynalnej w kwestiach tzw. disputabiles $^{397}$, traktowaliśmy w ten sposób (przełożeni i cenzorzy) pracę O. Siwka; wprost niezgodną z naszym postępowaniem i celem naszego Instytutu byłaby jakakolwiek bądź zbiorowa akcja w tym kierunku, tym bardziej mająca za cel Waszą Ekscelencję.

Prosząc kornie Waszą Ekscelencję o Arcypasterskie błogosławieństwo polecam się łaskawym modłom, niegodny w X[rys]tt[u]sie sługa

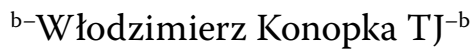

J[ego] Eksc[elencja] Ks. Metropolita

Dr Józef Teodorowicz, Lwów

\section{Dokument 162}

Oryg.: AFKDOPW, teczka 141: Spuścizna abp. Józefa Teodorowicza, sygn. 996/420 (8) [7], List o. Aloisa Magera OSB do abp. Józefa Teodorowicza, Salzburg 10 I 1934 r.

Salzburg, den 10. Januar 1934

Euere $^{a}$ Exzellenz!

Sehr verehrte erzbischöfliche Gnaden!

Mit grossem Interesse las ich das Manuskript über Konnersreuth, das Euere Exzellenz zu senden die grosse Güte hatten. Ich bin mit den Formulierungen ganz einverstanden. Nur eine kleine Berichtigung möchte machen: in Wien habe ich nicht auf dem Katholikentag, sondern auf dem Internationalen religionspsychologischen Kongress gesprochen. Meine persönliche Stellungsnahme zu Konnersreuth kann ich heute dahin charakterisieren, dass ich es in den Syllogismus bringe: Über Tatsachen darf man erst ein Urteil fallen, nachdem man sie aufs genaueste und wiederholt untersucht und geprüft hat. Die Tatsachen von Konnersreuth aber sind bis heute - wenn man von der 14-tägigen Untersuchung der Nahrunslosigkeit 1928 absieht, die aber allgemeins als nicht genügend bezeichnet wird - nicht in dieser Weise untersucht und geprüft worden. Deshalb sind alle Urteile sowohl nach der einen wie nach der anderen Richtung voreilig und nicht beweisend. Ohne jede Diskussion lehne ich mit aller Entschiedenheit die Tatsächlichkeit oder Möglichkeit ab, die Gerlich expressis verbis behauptet hat, nämlich dass Christus selber unmittelbar aus Therese Neumann mit Ausschaltung ihrer Persönlichkeit spricht. Persönlich stehe ich sehr positiv zu Therese Neumann und dem Konnersreuther Geschehen.

\footnotetext{
397 Łac.: dyskusyjnych, spornych.

b-b Tekst pisany czarnym atramentem.

a Tekst pisany maszynowo $\mathrm{z}$ wyjątkiem autografu autora na jednej stronicy papieru formatu A4.
} 
Die Entwicklung der Politik ist sehr unerfreulich. Das Deutsche Reich benimmt sich unglaublich und jedes Gefühl für politischen Anstand, auf den auch der Todfeind einen Anspruch hat, wird Österreich gegenüber verleugnet. Ich vertraue aber auf die göttliche Vorsehung, die bisher sichtbar mit Dollfuss und seiner Regierung war. Die neueste kulturkämpferische Entwicklung in Deutschland wird hoffentlich auch Rom nachdenklich machen und es kein rechtes Vertrauen auf die nationalsozialistische Regierung setzen lassen. Ich gebe auch sehr wenig auf den an sich für Polen günstigen Vertrag, den Deutschland vor kurzem mit dem Heimatland Euerer Exzellenz abgeschlossen hat. Was wird aus dem Hexenkessel noch alles hervorgehen?

Mit ehrfurchtsvollem Ringkuss und mit dem Ausdruck aufrichtigster Verehrung bin ich Eurer Exzellenz in Christo ergebenster

P[ater] Alois Mager OSB

\section{Dokument 163}

Kopia: AFKDOPW, teczka 136: Spuścizna abp. Józefa Teodorowicza, sygn. 1621/184 [7], List abp. Józefa Teodorowicza do nieznanego duchownego, Lwów 11 I 1934 r.

Hochgeehrter ${ }^{a}$ lieber Pater!

Ich schicke für die Redaktion der Kirchenzeitung die Rezension meines Buches, welche Sie gewünscht haben. Den Kern der Rezension bildet der Artikel, der in der Katholischen-Press-Agentur in Warschau erschienen ist. Das Ganze ist vielleicht etwas zu lang, aber Sie können schon kürzen, wie Sie wollen.

Ich verbleibe mit dem Ausdruck meiner tiefen Hochachtung.

Lwów 11/1. 1934

\section{Dokument 164}

Kopia: AFKDOPW, teczka 136: Spuścizna abp. Józefa Teodorowicza, sygn. 1620/184 (7) [7], List abp. Józefa Teodorowicza do nieznanego profesora, Lwów 11 I 1934 r.

\section{Hochgeehrter ${ }^{\mathrm{a}}$ Herr Professor!}

Ich habe jetzt ein Kontroversbuch über Konnersreuth geschrieben, in dem ich mit dem Jesuitenpater Siwek mich auseinandersetze. Einen ganzen Abschnitt habe ich in diesem Buche der Stellung, die der Herr Professor diesem Problem gegenüber einnimmt, gewidmet. Da ich eine Kritik in einer detschen Zeitung bekommen habe, wo mein Buch erwähnt wird, wo diesbezüglich meine Arbeit nicht treu beleuchtet würde, so erlaube ich mir dem Herrn Professor den diesbezüglichen Abschnitt meines Buches in treuer Übersetzung aus dem polnischen zu übersenden. Ich fühle mich dazu verplichtet, weil in diesem Abschnitt auch die Rede von Herrn Professor ist.

a Tekst pisany czarnym atramentem ręką kopisty na $\frac{1}{2} 2$ stronicy papieru format A4. Brak autografu autora.

a Tekst pisany czarnym atramentem na 1,5 stronicy papieru formatu A4. Brak autografu autora pisma. 
Mein eingentliches Buch über Konnersreuth, von dem ich mit dem Herr Professor gesprochen habe, hat eine grosse Verspätung durch dieses Kontroversbuch erbitten. Ich kann jetzt sagen, dass ich in jenem Buche nirgends eine Stellung gegen Się eingenommen habe, im Gegenteil berufe ich mich auf die Zitate aus Ihrem Buche.

Ich verbleibe mit dem Ausdruck meiner tiefen Hochachtung.

Lwów, 11/I 1934

\section{Dokument 165}

Oryg.: APJK, sygn. 1426, Konopka Włodzimierz TJ. Korespondencja prowincjalska za rok 1934, List abp. Józefa Teodorowicza do prowincjała o. Włodzimierza Konopki SJ, Lwów [14] I 1934 r. Kopia: AFKDOPW, teczka 131: Spuścizna abp. Józefa Teodorowicza, bsygn., Kopia listu abp. Józefa Teodorowicza do prowincjała oo. Jezuitów o. Włodzimierza Konopki SJ, Lwów 14 I 1934 r.

Wielce ${ }^{a}$ Czcigodny Ojcze Prowincjale!

Jestem niezmiernie zobowiązany Ojcu Prowincjałowi za list, który dziś otrzymałem. Co do intencji zapatrywań Ojca Prowincjała to nie miałem nigdy najmniejszych pod tym względem wątpliwości. List ten jednak pod wieloma względami uspokaja mnie co do intencji Zgromadzenia, zwłaszcza, że widzę w tej sprawie zasadnicze nieporozumienie. Nie weźmie mi Ojciec Prowincjał za złe, że z całą szczerością wyjaśnię, w czym to nieporozumienie tkwi.

1) Z listu Ojca Prowincjała wnoszę, iż Ojcowie uważają odpowiedź O. Siwka ze stanowiska kwestii naukowych tzw. „dysputabiles” i pod tym względem Zakon pozostawia swobodę doktrynalną swoim członkom. Ale któż, jeśli nie ja na tym stanąłem stanowisku w odniesieniu do O. Siwka, skoro przecie pisałem do O. Generała, a przed ukazaniem się jeszcze jego książki, iż nic nie mam przeciwko temu, aby O. Siwek dał mi odpowiedź, skoro O. Generał uzna to za wskazane; skoro następnie w mej odpowiedzi O. Siwkowi wszędzie podkreślałem, iż nie wchodzę w meritum sprawy w Konnersreuth i pozostawiam mojemu oponentowi jak najdalej idącą swobodę w wyrażaniu jego opinii na problem w Konnersreuth.

Zresztą mając i tak przygotowane i prawie gotowe dzieło o Konnersreth, jakiż bym cel miał w tym, ażeby się zajmować opiniami O. Siwka w sprawie Konnersreuth, chociażby nawet opinie te moim miały być przeciwne. Przecież dzieło o Konnersreuth i tak daleko wyświetlić może i uzasadnić moje stanowisko aniżeli sama tylko kontrowersja.

2) Tylko dzisiaj zupełnie nie idzie o stronę doktrynalną, którą poruszyłem tylko mimochodem w granicach odpowiedzi na pracę O. Siwka, ale idzie mi przede wszystkim i głownie o stronę moralną, która w książce O. Siwka wybija się na pierwszy plan.

a Tekst pisany na maszynie na 11,5 stronicach papieru formatu A4. W oryginalnej wersji autograf autora napisany czarnym atramentem, brak daty dziennej; w kopii brak autografu i daty dziennej. W kopii dokumentu, w prawym górnym rogu karty tytułowej nota czarnym atramentem: „O. Prow[incjał] Konopka 14/I [1]934”. Na ostatniej stronicy poniżej datacji nota pismem maszynowym: „O. Prowincjał Konopka - Kraków". 
Zacznę od rzeczy najmniejszej. Sama forma traktowania mnie, poza szumnym tytułem, jest od początku do końca lekceważąca i poniżająca mnie, gdy tylko można; oprócz wielu innych dowodów na to świadczy o tym wymownie zupełne lekceważenie faktów przeze mnie przytaczanych jako naocznego świadka, przy równoczesnym wyolbrzymianiu wartości anonimowych świadków. Ale to jeszcze najmniejsze. Daleko więcej o tej formie lekceważącej świadczy nie tylko ton, częścią pretensjonalnie pouczający, częścią lubujący się w rozmazywaniu mej rzekomej ignorancji, ale świadczą o tym aluzje i formalne zarzuty wkraczające w dziedzinę moralną, a nawet w dziedzinę wiary.

Tak na przykład O. Siwek (str. 98, 99) zarzuca mi dwoistość charakteru w swej przejrzystej aluzji do mnie, iż co innego o sprawie Konnersreuth myślę, a co innego piszę, a co najboleśniejsze pozwala sobie uczynić mi zarzut na podstawie przekręconego sensu mojej pracy, iż staję przeciwko nauce Kościoła i zasadom wiary w proroctwach. To już chyba nie jest odpowiedź naukowa, ale to jest atak na katolickiego biskupa i to atak wprost niebywały.

Jak już to wykazałem na cytatach, sfałszował O. Siwek z niesłychaną zręcznością, ale i z całą świadomością wszystkie moje tezy, jakie przedstawiłem. Trudno mi wykrztusić to słowo, ale na czoło wybija się O. Siwek przede wszystkim jako fałszerz. To chyba nie jest dziedzina naukowa, ale to jest dziedzina moralna. Każdemu, kto przeczyta moją książkę to właśnie główne wrażenie udzielić się musi, bo co innego są opinie „dysputabiles", a co innego fałszerstwo, chociaż niedokonane przez fałszerstwo samych cytatów, ale dokonane przez opuszczenie i zestawienie.

3) Dzięki tej metodzie osiągnął O. Siwek wśród sfer nieznających mojej pracy pożądany przez siebie rezultat. Wychodzę w tym jego dziele jako człowiek naiwny, bezkrytyczny, który wszędzie tylko widzi cudowność i walczy z wszelkim zdrowym krytycyzmem. Była to kropka nad i; było to dopowiedzeniem już wyraźnym tego, czego w pierwszej książce dopowiedzieć O. Siwek nie śmiał, ale co było tendencją główną jego pierwszej książki, tj. zdezawuowania XX. Biskupów. Oczywiście mogłem śmiało zrezygnować dla osobistych względów z tego, iż mię tak O. Siwek osądził, ale wśród wydawania mej pracy o życiu Chrystusa nie mogłem być obojętny na to, że zakonnik i kapłan, i to profesor Gregorianum pod flagą nauki fałszuje moje wszystkie tezy, pozwala sobie napiętnować mnie jako bezkrytycznego ignoranta.

W niczym ja tu nie przesadzam, tak istotnie było; mam dowody na to, że wiele osób, które przedtem skwapliwie czytały moje książki, nie chciały od chwili pojawienia się krytyki O. Siwka żadnej mojej pracy wziąć do ręki z góry mając uprzedzenie pod wpływem jego lektury do jej charakteru naukowego i krytycznego. A więc konieczność i interes nie mój osobisty, ale sprawy Bożej związany z pracą moją zmusił mnie po prostu do tego, że dając odpowiedź O. Siwkowi jego fałszerstwa zdemaskowałem i jeżeli tego będzie potrzeba zdemaskuję je jeszcze.

Przykro mi niesłychanie, że jeszcze raz wobec łaskawego listu O. Prowincjała zmuszony jestem dotykać kwestii tak przykrych i bolesnych. Ale niech mi Ojciec Prowincjał wierzy, że w ciągu tych kilku miesięcy ja głównie nad tym bolałem, że zmuszony 
byłem do analizy tych krętactw i matactw, które wykazuje cytat, a cytat to jest jak liczba, on się nie da zbałamucić, on ma swoją wymowę, wobec której wszelkie argumenty ustają.

4) Ale nawet, co do wolności dyskusji naukowej, o jakiej Ojciec Prowincjał pisze, to ta była przez O. Generała co do Konnersreuth ograniczona zakazem wydawania sądu o Konnersreuth przez Ojców. Nie może Ojciec Prowincjał się dziwić, iż wiedząc o tym zakazie, który w pierwszej chwili dotknął pracę O. Siwka, byłem o tym przekonany, że wyjątek na rzecz jego uczyniony spowodowały wykłady moje w Krakowie rzekomo gorszące pod względem wiary katolików. Zresztą to nie jest mój domysł; O. Siwek w jednym z listów do mnie pisał, nazywając miesiąc, w którym miałem wykłady w Krakowie, iż opinia wówczas była zaniepokojona pod względem wiary. To chyba jasne. Jego więc pierwsza książka o Konnersreuth była, jak to pisałem, odpowiedzią na stanowisko moje i ks. biskupa Lisowskiego dezawuującą nas publicznie. I tylko dlatego książka ta niby to poważna, neutralna, a w rzeczy samej już przesądzająca problem Konnersreuth wbrew poprzedniemu zakazowi się ukazuje.

Tu już praca O. Siwka nie da się odłączyć od Zgromadzenia. Rozstrzyga o tym udzielone O. Siwkowi wyjątkowe pozwolenie na wydanie jego książki, kiedy uprzednio był dany mu zakaz nawet na ogłaszanie czegoś znacznie mniej wpływowego niż książka, bo zakaz ogłaszania artykułów O. Siwka w czasopiśmie („Przegląd Powszechny”).

A jeżeli to wyjątkowe pozwolenie zostaje użyczone pomimo przedstawienia urzędowego (przez ks. biskupa Lisowskiego ówczesnemu prowincjałowi), że praca zaczęta O. Siwka dezawuuje stanowisko XX. Biskupów, że musi być uważana i będzie uważana jako walka Zakonu z biskupami, że przez to wywoła publiczne zgorszenie - to $\mathrm{w}$ takim razie książka O. Siwka nie ma już znaczenia i charakteru prywatnej opinii jednego z członków Zgromadzenia. Za nią bowiem stoi już najwyższa władza zakonna, a więc Zakon. Nie jest już od tej chwili ta książka jakąś tylko dysertacją naukową, ale jest książką w celach swych bojową, w której Zakon przez jednego ze swych członków występuje przeciw stanowisku zajętemu przez XX. Biskupów. To wprawdzie jest dozwolone, ale trzeba stwierdzić, że przez to samo już pierwsza książka O. Siwka sprzęga się ze Zgromadzeniem. Ta okoliczność, że O. Siwek zapewne podstępnie wyłudził takie pozwolenie, że wyolbrzymił przed włądzą swoją rzekome niebezpieczeństwo dla wiary pochodzące z wykładów biskupów we Lwowie i Krakowie, że wszystko czynił dla swej ambicji osobistej z której był szeroko znany wśród kolegów jeszcze w Paryżu, ta okoliczność - mówię - nic nie zmienia w fakcie samym. O. Siwek pisze swoją książkę, za którą staje jego władza duchowna w warunkach, które jej nadają charakter walki z XX. Biskupami, których łatwowierna naiwność rozdmuchuje prąd fałszywego mistycyzmu. A więc przed wystąpieniami XX. Biskupów potrzeba ratować wiarę i tym, który ją ratuje jest O. Siwek, ale występujący tutaj z mandatu swej zakonnej władzy, której najwyższa głowa osobiście manuskrypt cały czyta.

$\mathrm{Z}$ tego powodu charakter książki O. Siwka sięga nieporównanie głębiej i dalej aniżeli książka każda inna i jest od pierwszego razu sprzęgnięta z całym Zgromadzeniem, w którego ręku jest ona środkiem prowadzącym do celów, o jakich pisałem. 
Odpowiedź O. Siwka, którą mi daje w dalszym ciągu nie da się odłączyć w opinii od samego Zgromadzenia; świadczy o tym znowu już choćby tylko osobne pozwolenie najwyższej władzy O. Siwkowi na bądź co bądź niezwykłą polemikę zakonnika z biskupem; poza różnymi szczegółami, które już wyliczyłem poprzednio, recenzent tej książki na szpaltach pisma Ojców O. Rostworowski niedwuznacznie podsuwa myśl, że ksiązka ta jest atakiem na ascetykę Zakonu, czyli co już jest konsekwencją takiej sugestii, Zakon w swej obronie staje za tą książką. A na prawo i lewo głoszą Ojcowie jeszcze miesiące całe przed ukazaniem się książki, że już teraz nie sam O. Siwek da mi odpowiedź, ale za nią staną co najwybitniejsi uczeni z zakonu Ojców i ci mu będą poddawali materiał naukowy. Wszystko to razem, a nawet co do formy wydrukowanie tej książki w wydawnictwie Ojców świadczy dowodnie o tym, jak trudno jest tę sprawę O. Siwka odłączyć od zbiorowego współdziałania całego Zgromadzenia.

Ale ta sprawa już mnie nie obchodzi, ona może tylko świadczyć o niesłychanej zręczności O. Siwka, z jaką on umie na rzecz swoją skutecznie wszystko obracać. Dotykam tylko tej sprawy mimochodem jedynie dlatego, że Ojciec Prowincjał o wolności doktrynalnej wspomniał. Co do kwestii solidarności Ojców, to tej poświęciłem dużo szczegółów w mych poprzednich listach. W każdym razie pozory przynajmniej podkreślają ją silnie.

Przy tym, proszę Ojca Prowincjała, zupełnie głośno się mówiło i dzisiaj mówi się, że honor Zakonu, a w szczególności honor Gregorianum wymagał i wymaga odpowiedzi. Zupełnie nic nie mam przeciwko temu, że O. Siwek zechce i dzisiaj mi odpowiedzieć, ale stwierdzam, że takie postawienie rzeczy nie dozwala zamknąć odpowiedzi O. Siwka tylko na nim samym, ale wprowadza w łączność z jego pracą całe Zgromadzenie.

Jeszcze raz mocno przepraszam Ojca Prowincjała, że tych spraw z pewnością Jemu przykrych, ale zarówno i dla mnie bardzo bolesnych dotykam jasno i szczerze, ale sądzę, że jest wprost moim obowiązkiem niczego tu nie ukrywać, ale mówić całkiem otwarcie.

Zresztą O. Siwek nawet w zewnętrznych pozorach stara się za wszelką cenę dzisiaj wtłoczyć w społeczeństwo przekonanie, jakoby za nim stało całe Zgromadzenie. Niech weźmie Ojciec Prowincjał dla przykładu pod uwagę drobny, ale znaczący szczegół. Przez swego agenta ks. Weryńskiego ogłąsza na przykład O. Siwek w K[atolickiej] A[gencji] $\mathrm{P}$ [rasowej] zapowiedź odpowiedzi w formie telegraficznej z Cit[ta] Vaticana. Byłoby to wprost śmieszną pretensjonalnością, gdyby nie było tendencyjne i gdyby nie miało na oku wskazanie na łączność między Cit[t]a Vaticana, a odpowiedzią O. Siwka, która gdyby była tylko odpowiedzią naukową, chyba by do podobnej zapowiedzi pretensji rościć nie mogła.

Albo znowu w inspirowanym artykule „I[lustrowanym] K[urierze] C[odziennym]” jest z naciskiem podkreślone, że w drukarni papieskiego uniwersytetu (Gregorianum) ukaże się odpowiedź O. Siwka! Jakżeż chcieć potem, ażeby nie łączono tej książki w ogóle z interesami Zakonu, a w szczególności Gregorianum?

5) Na dowód, że nawet zagranica łączy występ O. Siwka z występem całego Zakonu, a w szczególności Gregorianum, a więc tego mózgu Zakonu, przytaczam jeden ustęp 
z niemieckiego pisma, biorąc z niego tylko wyjątek potrzebny dla potwierdzenia mojej tezy: „Mit diesem Schmerz für Dratzieher des Konnersreuth Kreises (über die Diagnose Rittershaus) aber noch nicht genug, haben nun auch die Jesuiten gegen Therese Neumann Stellung genommen. Hatten da ein paar polnische Geistliche nichts besseres zu tun gewusst, als Therese für «Wahrheit un Sühne» zu eklaären. Von den Jesuiten dieserhalb bose zurechtgewiesen, verstanden die Polen in Galizien es, den Lemberger Erzbischof Theodorowicz für Therese zu gewinnen, der darauf in einem scharfen Artikel die Jesuiten abkanzelte. aber da, wo die Jesuiten eine schwere Gefahr für die katholische Kirche voraussehen, fürchten się sich selbst vor einem polnischen Erzbischof nicht. Der Professor an der päpstlichen Gregorianischen Universität in Rom, Pater Siwek, Mitglied des Jesuitenordens, setzte sich sofort hin und schrieb ein neuses Buch gegen die Neumann. Wir műssen hier einschalten, dass an der genannten Universität, sozusagen unter den Augen des Papstes, kein Buch vor deratiger Tragweite herauszukommt, das nicht vorher die ganze Fakultät billingt. Denn die Gregorianische Universität ist die katholische Universität. Wie die anderen oft genug zu spüren bekommen haben. Professor Pater Siwek S.J. nun erklärt in seinem Buche die meisten der angeblichen Phänomene der Therese für «Fiktionen». Von ihren Ekstasen schreibt er, dass nicht im mindesten die Merkmale auf zeigen, welche die Kirche als Beweise göttlicher Gnade fordere. Therese selbst mache den Eindruck einer Person, die an Theatralischen Benehmen Freude habe".

Poza tym jest aluzja ironiczna pod adresem bawarskich biskupów, a w szczególności arcybiskupa Buchbergera.

Jak widzi Ojciec Prowincjał z tego ustępu, wyzyskują występy O. Siwka koła wrogie Kościołowi w swoim duchu i dla swojej myśli, obciążając tym jednym występem cały Zakon i posługując się niedojrzałą robotą, płytką i dyletancką członka Zgromadzenia przeciw XX. Biskupom. Zgromadzenie więc zostaje wciągnięte dziś w przesądzenie sprawy w Konnersreuth i to w chwili, kiedy badaniem tej sprawy zajęli się biskupi niemieccy.

6) Zechce Ojciec Prowincjał przy tej sposobności przyjąć zapewnienie, że jestem najgłębiej przekonany, iż Ojciec Prowincjał nic z tą sprawą nie ma wspólnego, tak jak i wielu spośród Ojców, ale chodziło o to, aby wykazać, jak w refleksach opinii rzecz się przedstawia i przedstawiać musi i to jest w tej sprawie dla Zgromadzenia wedle mojego zdania po prostu tragiczne. Albowiem Zgromadzenie wyszło z założenia, że nie wolno żadnemu członkowi wypowiadać się za albo przeciw Konnersreuth, tymczasem skutkiem prac O. Siwka epilogiem tego zakazu jest zupełne przesądzenie sprawy Konnersreuth przed badaniem Kościoła i podanie broni w rękę wrogom Kościoła.

Bo przecie[ż] nikt serio nie bierze ostatniego wykrzyknika pełnego nieszczerego afektu O. Siwka w jego książce, w której po zadeptaniu Konnersreuth i po przesądzeniu jego sprawy wyraża nadzieję, że mogą jeszcze przyjść dowody, które wszystko co on powiedział odmienią. Ta gra zbyt grubymi szyta jest nićmi, a nawet zbyt jest naiwna ażeby można kogokolwiek wziąć na nią. Dlatego organ protestancki i racjonalistyczny o ile mówi o przesądzeniu problemu Konnersreuth przez O. Siwka ma zupełną słuszność. 
W końcu niech będzie przekonany Ojciec Prowincjał, że z bolesną mi osobiście sprawą łączę szczerą życzliwość dla Zgromadzenia i ubolewam nad tym, iż moim zdaniem źle zrozumiana chęć ratowania honoru Gregorianum złożyła swój honor w ręce członka tak naukowo do tego problemu nieprzygotowanego, a pod względem moralnym do ujęcia tego problemu tak niedojrzałego.

Zdaje mi się, że Gregorianum znajduje się skutkiem O. Siwka w sytuacji nie do pozazdroszczenia. Bo w czymże właściwie szukać on dziś może obrony swego honoru? Czy w tym, że okryje swym autorytetem fałszerstwa w książce jednego ze swych członków? Bo te przecie[ż] ponad wszelką wątpliwość wykazują mu cytaty; a gdyby ich autor próbował tą samą drogą sztuczek wydostać się z matni, to tylko tym bardziej zostaną one uwidocznione; czy może w tym, że dzisiaj na autorytet Gregorianum powołują się już protestanci i racjonaliści zacierając ręce $\mathrm{z}$ radości, że drażniące ich przez lata i niepokojące zjawiska o znamionach nadprzyrodzonych udaje im się sprzątnąć z drogi przy pomocy Gregorianum?

Jeszcze raz dziękuję Ojcu prowincjałowi ze Jego list łaskawy, za Jego tak cenne dla mnie oświadczenia i łączę dla Ojca prowincjała wyrazy mojej czci głębokiej i oddanej

${ }^{b-}+$ Teodorowicz $^{-b}$

Lwów, dnia $[\ldots]^{\mathrm{c}}$ stycznia 1934

\section{Dokument 166}

Kopia: AFKDOPW, teczka 136: Spuścizna abp. Józefa Teodorowicza, sygn. 1621/184 [7], List abp. Józefa Teodorowicza do nieznanego biskupa, Lwów 15 I 1934 r.

Euer ${ }^{\mathrm{a}}$ Exzellenz!

Ich erlaube mir mein Buch über die „Methoden der Forschung der mystischen Problemen" zu schicken und zu widmen. Leider ist es in der polnischen Sprache geschrieben. Es ist zwar ein Kontroversbuch, aber es berührt, wie ich glaube, alle Problemen, die mit Konnersreuth verbunden sind. Ich erlaubte mir einen Gebrauch von dem Briefe Euer Exzellenz zu machen, ohne Exzellenz zu erwähnen. Ich schicke Euer Exzellenz die wörtliche Übersetzung ins Deutsche des ersten Abschnittes meines Buches.

Ich verbleibe mit dem Ausdruck meiner tiefsten Hochachtung Euer Exzellenz ergeben. Lwów, 15/I 1934

\section{Dokument 167}

Oryg.: AFKDOPW, teczka 145: Spuścizna abp. Józefa Teodorowicza, sygn. 1021/420 (8) [7], List Friedricha Ritter von Lamy do abp. Józefa Teodorowicza, Gauting bei München 15 I 1934 r.

b-b Autograf czarnym atramentem.

Brak daty dziennej.

a Tekst pisany czarnym atramentem ręką kopisty na $1 \frac{1}{2}$ stronicy papieru format A4. Brak autografu autora. 
Excellenz $z^{\mathrm{a}}$, Hochwürdigster Herr Erzbischof!

Gauting, 15. Januar 1934

Im Besitze auch Ihrer letzten Sendung und Zuschrift beehre ich mich, Ihnen meinen verbindlichsten Dank für alles auszusprechen. Inzwischen hat mir auch Dr. Hynek sein umfangreiches Referat über Ihr Buch geschickt. Ich habe es wegen stilistischer Mängel ausgearbeitet und gefeilt. Da mich dann der Verlag Badenia um nähere Angaben über Anlage und Inhalt Ihres Buches bat, um sich darüber zu orientieren und davon weitere Beschlüsse abhängig zu machen, sandte ich jenes Referat an diese. Ich weiss noch nicht, wo ich es veröffentlichen werde, wenn es mir zurückgesandt wird. Auch die letzte umfangreiche Sendung werde ich in Ihrem Interesse zu verwerten bestrebt sein, um auf diese Weise den grossen Dank, zu dem Sie mich verpflichtet haben, abzustatten.

Beim Durchlesen der Uebersetzung habe ich den Eindruck gewonnen, als habe das Wort P[ater] Siweks von der „traurigen Berühmtheit, die ich durch den Prozess Michaelis erlangt habe“, bei Eurer Excellenz die Annahme hinterlassen, als hätte ich in jenem Prozess irgendwie eine nicht einwandfreie Rolle gespielt. Daher gestatte ich mir, in Kürze über die Sache zu berichten.

Seit 1919 machte ich den Versuch Papst Benedikt XV. ${ }^{398}$ vom August 1917, den Frieden wiederherzustellen, zum Gegenstand meines Studiums und gelangte im J[ahre] 1925 zu dem Punkte, beweisen zu können, dass der damalige Reichskanzler Michaelis sinzig aus protestantischer Abneigung gegen den Papst jene Friedensmöglichkeit vereitelt hatte, wobei er am 11. August 1917 den Kaiser und den Kronrat über die Sache belogen hatte. Ich stellte dies u. a. in meinem grossen Buch über Roms Nachkriegspolitik, zu dem mir Papst Pius XI. durch Eminenz Kard. Faulhaber seinen besonderen Segen gesandt hatte, fest und hoffte, Michaelis würde die seine Ehre berührende Anklage nicht auf sich beruhen lassen. Ich glaubte, eine gerichtliche Austragung auf diesem Wege erzwingen zu können, die mir Gelegenheit geboten hätte, meine Anklagen vor der Oeffentlichkeit eines Gerichtes zu beweisen, denn gerade damals beschuldigte der Evangelische Bund den Papst Benedikt im ganzen Land, er sei es gewesen, der aus Hass gegen den deutschen Protestantismus Deutschlands Niederlage gewollt habe. Michaelis liess den Vorwurf der Lüge auf sich sitzen. Im September 1925 verteidigte er sich in einer Synode protestantischer Pastoren gegen mich durch neue Lügen, die der Ex-Hofprediger Döring ${ }^{399}$ am nächsten Tag unter Beifügung von 12 persönlichen Beleidigungen gegen mich wiederholte. Um nun doch die ganze Friedensfrage vor Gericht aufrollen zu können, stellte ich gegen Döring und die Redaktion des Blattes Klage. Drei Jahre lang wussten meine Gegner die Durchführung des Prozesses mit allen Mitteln zu verhindern, dann erreichten sie sogar, dass die Reichsregierung den

a Tekst pisany maszynowo na trzech stronicach papieru formatu A4. Autograf odręczny czarnym atramentem.

398 Benedykt XV (1854-1922), święcenia kapłańskie w 1878 r. w Genui, dr obojga praw i teologii, 1888-1907 pracownik dyplomacji watykańskiej, 1907-1914 biskup Bolonii, w 1914 r. kreowany kardynałem, 1914-1922 papież. Z. Zieliński, Benedykt XV, w: EK, t. 2, red. F. Gryglewicz, R. Łukaszyk, Z. Sułowski, Lublin 1985, kol. 224-225.

399 Osoba niezidentyfikowana. 
Prozess niederschlug, um zu verhindern, dass die Welt die Wahrheit erfahre, wer den Frieden vereitelt habe. Wiederholt hatten mich die Gegner durch hohe Personen zur Zurücknahme der Klage zu bewegen versucht, aber ich wollte die Durchführung des Prozesses im Interesse der geschichtlichen Wahrheit. Als nun der Prozess gewaltsam verhindert war, veröffentlichte ich eine neue Erklärung, in der ich Michaelis auch noch der Dokumentenfälschung beschuldigte. Ich erreichte wenigstens, dass er jetzt Antrag beim Staatsanwalt stellte, es möge gegen mich Offizialklage erhoben werden. In der Voruntersuchung gab ich dem Oberstaatsanwalt Einblick in mein Beweismaterial und er musste zugeben, dass ich den Wahrheitsbeweis führen konnte. Er verständigte nun durch das Auswärtige Amt Mi chaelis, worauf dieser seinen Antrag bei der Staatsanwaltwalt zurückzog; diese teilte mir dann mit, das Verfahren gegen mich sei eingestellt. Damit war zum zwei tenmal die prozessuale Austragung vereitelt, und wieder war der moralische Sieg auf meiner Seite. Zum Abschluss der Angelegenheit veröffentlichte ich voriges Jahr mein Buch (s. beiliegender Prospekt), dessen geschichtliche Feststellungen bis heute unbestritten sind.

Das Traurige an jenem Prozess befindet sich also keineswegs auf meiner Seite, sondern auf der der damaligen deutschen Politiker und der Justiz. Die von P[ater] Siwek gewählten Worte aber erwecken den Anschein, als hätte dabei ich eine traurige Rolle gespielt. Ich werde P[ater] Siwek brieflich um Aufklärung ersuchen und Richtigstellung verlangen.

Und nun noch ein paar Worte zu meiner Erwiderung auf den Artikel des Evangelischen Pressedienstes. Es tut mir ungemein leid, dass ich darin eine Mitteilung machte, die vertraulich hätte bleiben sollen und ich bitte um Vergebung. Ich hatte die Sachlage so beurteilt, dass durch Siweks Veröffentlichung gegen $\mathrm{Eu}[\mathrm{re}]$ Excellenz die Voraussetzungen dafür, dass die ganze Angelegenheit des Zustandekommens immer noch vertraulichen Charakter trage, hinfällig geworden seien, zumal P[ater] Siwek soweit gegangen war, sich auf vertraulichen Mitteilungen des Regensburger „Konsistoriums“ (genau gesagt Generalvikar) zu berufen. Ich werde nunmehr jedenfalls Ihrem erneut unterstrichenen Wunsche voll Rechnung tragen.

Enae dieser Woche werde ich in Konnersreuth sein, um verschiedene Feststellungen aufzunehmen. Das neue Jahrbuch ist nahezu ausverkauft, ein Beweis, dass das Interesse für Konnersreuth noch immer ein starkes ist. Ich gebe mich der Hoffnung hin, dass wir Ihr Buch bald in deutscher Sprache lesen können werden und dass die Verhandlungen mit der Badenia zu einem beiderseits befriedigenden Abschluss kommen.

Mit der erneuten Versicherung meiner aufrichtigen Verehrung und Ergebenheit begrüsse ich Eure Excellenz

F[riedrich] R[itter] von Lama

\section{Dokument 168}

Kopia: AFKDOPW, bsygn., teczka: Spuścizna abp. Józefa Teodorowicza, List abp. Józefa Teodorowicza do nieznanego profesora, Lwów 15 I 1934 r. 


\section{Hochgeehrter ${ }^{\mathrm{a}}$ Herr Professor!}

Ich habe jetzt ein Kontroversbuch über Konnersreuth geschrieben, in dem ich mit dem Jesuitenpater Siwek mich auseinandersetze. Einen ganzen Abschnitt habe ich in diesem Buche der Stellung, die der Herr Professor diesem Problem gegenüber einnimmt, gewidmet. Da ich eine Kritik in einer deutsche Zeitung bekommen habe, wo mein Buch erwähnt wird, wo diesbezüglich meine Arbeit nicht treu beleuchtet wurde, so erlaube ich mir dem Herrn Professor den diesbezüglichen Abschnitt meines Buches in treuer Übersetzung aus dem Polnischen zu übersenden. Ich fühle mich dazu verpflichtet, weil ich diesen Abschnitt auch die Rede von Herrn Professor ist.

Mein eigentliches Buch über Konnersreuth, von dem ich mit dem Herrn Professor gesprochen habe, hat eine große Verspätung durch dieses Kontroversbuch erlitten. Ich kann jetzt sagen, dass ich in jenem Buche nirgends eine Stellung gegen Sie eingenommen haben, im Gegenteil berufe ich mich auf die Zitate aus Ihrem Buche.

Ich verbleibe mit dem Ausdruck meiner tiefen Hochachtung.

Lwów, 15/I 1934

\section{Dokument 169}

Oryg.: AFKDOPW, teczka 138: Spuścizna abp. Józefa Teodorowicza, sygn. 975/420 (8) [7], List ks. dr. Stanisława Brossa do abp. Józefa Teodorowicza, Poznań 16 I 1934 r.

Jego Ekscelencja

Poznań, dn[ia] 16 stycznia 1934

Najprzew[ielebniejszy] Ks. Arcybiskup Teodorowicz

Krynica

$\dagger$

Ekscelencjo $^{\mathrm{a}}$,

Najdostojniejszy Arcypasterzu!

Jak najserdeczniej dziękuję Waszej Ekscelencji za ostatni list, przepraszając zarazem, że dziś dopiero na niego odpisuję. Czekałem, ale na recenzję ks. Steuera, któremu ks. Klawek ${ }^{400}$

a Tekst pisany czarnym atramentem ręką kopisty na 1,5 stronicy papieru format A4. Brak autografu autora pisma.

a Tekst pisany maszynowo $\mathrm{z}$ wyjątkiem autografu autota listu na jednej stronicy papieru formatu A4. W lewym górnym rogu karty tytułowej nadruk firmowy: „Ks. Dr Stanisław Bross Dyrektor Naczelnego Instytutu Akcji Katolickiej w Polsce, L. dz. 187/34".

${ }^{400}$ Klawek Aleksy (1890-1969), święcenia kapłańskie w 1913 r. w Gnieźnie, dr teologii, 1918-1922 wykładowca Pisma św. w Seminarium Duchownym w Gnieźnie i Poznaniu, 1923-1939 prof. Nowego Testamentu i języków starożytnego Wschodu na Wydziale Teologicznym UJK we Lwowie, 1925-1927 dziekan fakultetu, 1933/34 zastępca prorektora uczelni, 1939-1941 więziony przez Niemców w Poznaniu, 1945-1954 kierownik Katedry Egzegezy Starego Testamentu na Wydziale Teologicznym UJ, 1948-1952 dziekan fakultetu, po roku 1954 wykładowca Biblii w krakowskich Seminariach Duchownych, współzałożyciel Polskiego Towarzystwa Teologicznego we Lwowie, 1923-1939 redaktor „Przeglądu Teologicznego (Collectanea Theologica)”, 1948-1954 założyciel i redaktor „Ruchu Biblijnego i Liturgicznego”; współtwórca polskiej biblistyki. B. Szier-Kramarek, Klawek Aleksy, w : EK, t. 9, red. zbior., Lublin 2002, kol. 88-89. 
nic nie odpisywał. W zeszłym tygodniu wręczył mi ją ks. Steuer; recenzję odwrotnie posłałem do „Ateneum Kapłańskiego" ${ }^{\text {" } 01}$, a drukowane odbitki dzisiaj drukiem Waszej Ekscelencji wysyłam.

Bardzo się cieszę, że Wasza Ekscelencja do Krynicy zawitał; Krynica jednak ma być miejscem wypoczynkowym, a nie warsztatem pracy, jak to bywało w zeszłym roku!! Ks. Biskup Radoński ${ }^{402} \mathrm{w}$ tym roku nie jedzie. Ja prawdopodobnie zjawię się w Krynicy po Zjeździe Akcji Katolickiej w Krakowie, t.j. po 7 II [19]34 bm. Mam referat na kursie w Tarnowie. Nie warto mi więc do 5 lutego jechać do Krynicy, by wypoczynek przerywać. Mam nadzieję, że Waszą Ekscelencję jeszcze w Krynicy zastanę. Bardzo szczerze się na to cieszę.

Całując z najgłębszą czcią ręce Waszej Ekscelencji pozostaje szczerze oddany

Ks. Stanisław Bross

\section{Dokument 170}

Oryg.: AFKDOPW, teczka 140: Spuścizna abp. Józefa Teodorowicza, sygn. 976/420 (8) [7], List kard. Augusta Hlonda do abp. Józefa Teodorowicza, Poznań 16 I 1934 r.

Poznań, dnia 16 stycznia 1934

Ekscelencjo! ${ }^{\mathrm{a}}$

Dziękuję za łaskawy list z dnia 1 grudnia i za informacje o dalszym przebiegu sprawy z O. Siwkiem. W międzyczasie prosił mnie O. Ledóchowski o pośrednictwo, bo mu na tym zależy, by polemikę zakończyć. Jedyny punkt z pism Waszej Ekscelencji, który chciałby wyjaśnić, to zarzut racjonalizmu, który tak ogólnie postawiony O. Siwka jako profesora Uniwersytetu Papieskiego dyskwalifikuje.

Już o tym wspomniałem w Warszawie J[ego] Eksc[elencji] Księciu Metropolicie Sapieże, by przy spotkaniu z Waszą Ekscelencją poruszył tę sprawę. Niezależnie od tego piszę o tym Waszej Ekscelencji, zaznaczając, że nie bardzo wiem, jak się do tego pośrednictwa zabrać. Będę Waszej Ekscelencji bardzo wdzięczny za łaskawą informację, czy Wasza Ekscelencja godzi się na to, bym ja w tej roli wszedł w sprawę i jak by zdaniem Waszej Ekscelencji polemikę można zakończyć. Służę chętnie, ale nie chciałbym się narzucać.

O sprawie O. Kuleszy pomówię z Księżmi Salezjanami. Podzielam zupełnie zdanie Waszej Ekscelencji co do zbiórki w Polsce na beatyfikację arcyksiężnej austriackiej Magdaleny. Nikt by u nas tego nie zrozumiał. Mamy dosyć swoich kandydatów, których procesy głównie z powodu braku środków nie poruszają się naprzód.

Słyszę, że Ekscelencja wybiera się do Krynicy. Życzę pomyślnej kuracji i wytchnienia.

${ }^{401}$ J. Teodorowicz, Zjawiska mistyczne i ich ttumaczenia (Konnersreuth), Poznań 1933. Rec.: A. Steuer, AK, 1934, t. 34, s. 83-90.

${ }^{402}$ Radoński Karol (1883-1951), święcenia kapłańskie w 1909 r. w Gnieźnie, duszpasterz par. w Czerniejewie i Poznaniu, redaktor „Przewodnika Katolickiego”, 1927-1929 biskup pomocniczy archidiec. poznańskiej, 1929-1951 bp ordynariusz diec. włocławskiej, 1939-1945 przebywał w Londynie. P. Nitecki, Biskupi, s. 176.

a Tekst pisany na maszynie $\mathrm{z}$ wyjątkiem autografu autora na 2 stronicach papieru formatu A4. W lewym górnym rogu karty tytułowej nadruk firmowy: „Prymas Polski”. 
$\mathrm{Z}$ najgłębszą czcią i oddaniem

${ }^{\mathrm{b}-}+$ August Kard. Hlond ${ }^{-\mathrm{b}} 403$

J[ego] Eksc[elencja] Najprzewielebniejszy

Ks. Arcybiskup Teodorowicz

Arcybiskup Lwowski obrz[ądku] orm[iańskokatolickiego]

Lwów

L.dz. 152/34.Pr.

\section{Dokument 171}

Oryg.: AFKDOPW, teczka 140: Spuścizna abp. Józefa Teodorowicza, sygn. 969/420 (8) [7], List dr. Ralpha Waldo Hynka do abp. Józefa Teodorowicza, Praga 20 I 1934 r.

Euere $^{a}$ Exzellenz!

Mit größter Freude habe ich das Schreiben E[urer] Exzellenz und die Kritiken erhalten und bitte meinen ergebensten und innigste Dank dafür entgegen zunehmen. Gerade in dem Tagblatt „Lidove Listy“ ist eine heftige Verteidigung von P[ater] Siwek durch einen Jesuitenpater Restl gegen mich erschienen und ich erlaube mir dieselbe E[urer]] Exzellenz abzuschicken. Für nächsten komm Tag will ich darauf eine Antwort veröffentlichen und da würde ich E[ure] Exzellenz ergebenst bitten mit gefälligst bekannt zu geben von welchem Autor stammt die ausführliche längere Kritik (ca 22 Seiten) die mir E[ure] Exzellenz gütigst zur Verfügung stellten und dann wo hat E[ure] Exzellenz den Brief von Regensburger Konsistorium (eine vernichtende Verurteilung von Siweks Buch), wie sie P[ater] Fic in zweiter kleineren Kritik erwähnt, abgedruckt.

Ich werde auch bald neue Vorträge über Konn[ersreuth] abhalten und da würde ich schon dies alles erwähnen. Vom Schriftsteller R[itter] von Lama habe ich noch keine Nachricht bekommen, ob er meine ausführliche Rezension des Buches v[on] E[urer] Exzellenz auch erhalten hatte, obwohl es von mir aus recomando abging.

Indem ich Euere Exzellenz ergebenst bitte den Ausdruck meiner tiefsten Hochachtung entgegenzunehmen wollen zeichne mich

Dr. R[alph] W[aldo] Hynek

PS. Dürfte ich noch bitten um gefälligste Bekanntgabe wo Siweks erstes Buch über Konn[ersreuth] erschienen ist und was es kostet, damit ich mir bestellen könnte.

b-b Autograf czarnym atramentem.

${ }^{403}$ Zob. w niniejszej publikacji: J. Wołczański, Korespondencja abp. Józefa Teodorowicza z abp. Adamem Stefanem Sapieha, dokument 70.

a Tekst pisany czarnym atramentem na 1,5 stronicy papieru formatu A4. W lewym górnym rogu karty tytułowej nadruk firmowy: „Dr.R. Hynek, lékaŕ spisovatel, Praha III, Ječná 37, telefon 31368”. 


\section{Dokument 172}

Oryg.: AFKDOPW, teczka: Spuścizna abp. Józefa Teodorowicza, bsygn., List dr. Ralpha Waldo Hynka do abp. Józefa Teodorowicza, Praga 20 I 1934 r.

Praha, dne 20/I 1934

Euere $^{a}$ Exzellenz!

Mit größter Freude habe ich das liebevolle Schreiben E[urer] Exzellenz und die Kritiken erhalten und bitte meinen ergebensten und innigsten Dank dafür entgegen zu nehmen.

Gerade in heutigen "Lidove Listy" ist eine heftige Verteidigung von P[ater] Siwek durch einen Jesuitenpater Restl gegen mich erschienen und ich erlaube mir dieselbe E[were] Exzellenz abzuschicken. Für nächsten kommenden Tag will ich darauf eine Antwort veröffentlichen und das würde ich E[ure] Exzellenz ergebenst bitten mir gefälligst bekanntzugeben von welchem Autor stammt die ausführliche längere Kritik (ca. 22 Seiten) die mir E[ure] Exzellenz gütigst zur Verfügung stellten und dann wo hat E[ure] Exzellenz den Brief von Regensburger Konsistorium (eine vernichtende Verurteilung von Siweks Buch) wie sie P[ater] Fic in zweiter kleineren Kritik erwähnt, abgedruckt.

Ich werde auch bald neue Vorträge über Konn[ersreuth] abhalten und da würde ich schon dies alles erwähnen. Vom Schriftsteller R[itter] von Lama habe ich noch keine Nachricht bekommen, ob er meine ausführliche Rezension des Buches v[on] E[urer] Exzellenz auch erhalten hatte, obwohl es von mir aus per Einschreiben abging.

Indem ich Euere Exzellenz ergebenst bitte den Ausdruck meiner tiefsten Hochachtung entgegenzunehmen wollen zeichne mich

Dr. R[alph] W[aldo] Hynek

P.S. Dürfte ich noch bitten um gefälligste Bekanntgabe wo Siweks erstes Buch über Konn[ersreuth] erschienen ist und was es kostet, damit ich mir bestellen könnte.

\section{Dokument 173}

Kopia: AFKDOPW, teczka 134: Spuścizna abp. Józefa Teodorowicza, sygn. 1639/185 [4], List abp. Józefa Teodorowicza do ks. kanonika Alberta Steuera, Lwów 271934 r.

\section{Przezacny ${ }^{\mathrm{a}}$ Księże Kanoniku!}

Dostałem do rąk recenzję mojej książki napisaną przez Księdza Kanonika i wyrażam Księdzu Kanonikowi szczerą i gorącą podziękę. W tych niewielu stosunkowo stronach zawarł Ksiądz Kanonik ogrom pracy i potrafił z niezwykłą zręcznością i sprawnością ująć całe mnóstwo rozbitych szczegółów w mej książce i zebrać je syntetycznie. Stąd charakter tej recenzji jest niesłychanie poważny i wywody jej są bardzo silne, bo oparte o zebranie faktów. Przy tym uderza w tej recenzji ogromna bezstronność i obiektywność.

a Tekst pisany czarnym atramentem na 1,5 stronicy papieru formatu A4. W lewym górnym rogu nadruk firmowy: „Dr. R.W. Hynek, lèkař spisowatel, Praha II, Ječná 37, telefon 31368”.

a Tekst pisany maszynowo na jednej stronicy papieru formatu A4. Brak autografu autora listu. 
Dziękuję Księdzu Kanonikowi raz jeszcze za to i łączę przy tej sposobności wyrazy mojej głębokiej czci i szacunku.

Lwów, dnia 27 stycznia 1934

Ks. Kanonik Bruno ${ }^{404}$ Steuer - Poznań

\section{Dokument 174}

Oryg.: AFKDOPW, teczka 145: Spuścizna abp. Józefa Teodorowicza, sygn. 1064/420 (8) [7], List ks. rektora Johanna Westermayra do abp. Józefa Teodorowicza, Freising 29 I 1934 r.

Euere $^{a}$ Exzellenz!

Hochwürdigster Herr Erzbischof!

Gnädigster Herr!

Euere Exzellenz haben sich die große Mühe gegeben, mir ehrfurchtsvollst Unterzeichnetem mit unverdienter Aufmerksamkeit in deutscher Übersetzung den in Betracht kommenden Abschnitt zu schicken. Ich habe ihn mit größtem Interesse gelesen und mit angenehmsten Gefühlen von der wohlwollenden Beurteilung meiner Rezensionen Kenntnis genommen. Euere Exzellenz erwerben sich ein nicht geringes Verdienst um die Konnersreuther Sache, indem Sie die mystische Theologie zur maßgeblichen Norm nehmen. Ich habe seinerzeit in den Artikeln der Augsburger Postzeitung auch mit Nachdruck darauf hingewiesen, dass für die Konnersreuther Frage die theologische Mystik an erster Stelle zuständig sei und einige Kriterien derselben als Maßstab an das Konnersreuther Geschehen angelegt. Allerdings kann ich die bisher geübte $\mathrm{Zu}$ rückhaltung eben aus Gründen der Mystiktheologie noch immer nicht ganz aufgeben. Leider gestattet mir die starke berufliche Inanspruchnahme nicht mehr, mich mit der Ko[nnersreuth]er Frage noch ex professo zu beschäftigen.

Ich weiß nicht, ob Euere Exzellenz die Rücksendung Ihres Manuskriptes wünschen. Inzwischen behalte ich es auf. Möge Gott auch das Ko[nnersreut]er Problem einer glücklichen Lösung zuführen!

Ehrfurchtsvollst verharrt Eurer Exzellenz ergebenster

${ }^{\mathrm{b}-W e s t e r m a y r^{-b}}$

Regens

${ }^{404}$ Błąd autora; poprawnie: Albert.

a Tekst pisany maszynowo $\mathrm{z}$ wyjątkiem autografu autora na jednej stronicy papieru formatu A4. W lewym górnym rogu karty nadruk firmowy: „Direktion des Erzb[ischöfliche] Klerikalseminars Freising, Postscheckkonto: München 18318“.

b-b Autograf napisany czarnym atramentem. 


\section{Dokument 175}

Kopia: AFKDOPW, bsygn., teczka: Spuścizna abp. Józefa Teodorowicza, List abp. Józefa Teodorowicza do kard. Augusta Hlonda, Lwów styczeń 1934 r.

\section{Wasza ${ }^{a}$ Eminencjo!}

Piszę trzeci list zupełnie poufny do Waszej Eminencji, który jest praktycznym dopowiedzeniem do listu w sprawie O. Siwka. Po napisaniu już listu do Waszej Eminencji przyszła mi myśl, którą się z Waszą Eminencją dzielę. Dowiedziałem się teraz właśnie, że O. Siwek wykończył manuskrypt, będący odpowiedzią na ostatnią moją książkę, ale władze rzymskie zabroniły mu drukowanie tego manuskryptu. To będzie niezawodnie prawdą, bo mówił o tym superior OO. Jezuitów, zawsze doskonale o przebiegu tej sprawy poinformowany.

Otóż w tych warunkach skłaniałbym się bardziej niż kiedy do tego, by w jakiś sposób O. Generałowi dogodzić i przychodzi mi myśl następująca. Czy by to się przypadkiem nie dało uczynić przez wymianę listów między O. Generałem a mną, które by były ogłoszone na przykład w K[atolickiej] A[gencji] P[rasowej]. W liście swoim musiałby O. Generał dać mi moralne zadośćuczynienie w jakiejś formie; to jest warunek sine qua $n o n^{405}$. Ja zaś z mej strony napisałbym list, w którym bym przytoczył te cytaty z moich prac, w których odcinałem zupełnie O. Siwka od jakichkolwiek podejrzeń o jego przekonaniach racjonalistycznych; podniósłbym co najwyżej i bardzo lekko, że miałem na myśli materialne nieuświadomione stanowisko jego $\mathrm{w}$ stycznych punktach $\mathrm{z}$ racjonalizmem, ale nic ponadto. Kwestia zresztą bliższa formy byłaby już sprawą do późniejszego ewentualnego ułożenia.

Poddaję osądzeniu Waszej Eminencji tę moją myśl, która mi się nasunęła i to pod wpływem rozmowy z ks. arcybiskupem Sapiehą, który tu u mnie bawił.

Jeszcze raz proszę przyjąć ode mnie zapewnienie o mej najgłębszej czci.

Lwów, dnia[... $]^{\mathrm{b}}$ stycznia 1934

\section{Dokument 176}

Kopia: AFKDOPW, teczka 130: Spuścizna abp. Józefa Teodorowicza, bsygn., List abp. Józefa Teodorowicza do kard. Augusta Hlonda, Lwów 31 I 1934 r.

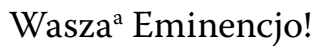

Bardzo dziękuję Waszej Eminencji za list ostatni i najchętniej przyjmuję wszelkie pośrednictwo Waszej Eminencji w tej tak przykrej i bolesnej sprawie.

Jestem gotów pójść w zasadzie w granicach możliwości na wszelkie próby rozwiązania tego problemu, zwłaszcza głównie ze względu na osobę O. Generała, którego

a Tekst pisany maszynowo na dwóch stronicach papieru formatu A4. Brak autografu autora pisma.

$405 \mathrm{Z}$ łac. konieczny, niezbędny.

b Brak daty dziennej.

a Tekst pisany na maszynie o objętości 12 stronic papieru formatu A4. Brak autografu autora pisma. 
nie tylko wysoko cenię, ale dla którego osoby z dawien dawna mam szczególniejszy sentyment.

Ale nie tylko Wasza Eminencja, lecz i ja także nie wiem doprawdy, jakby się można do załatwienia tej sprawy wziąć. Czuję się obowiązany przedstawić Waszej Eminencji, a pośrednio O. Generałowi te trudności, jakie dzisiaj są z tą sprawą połączone. Gdyby próba takiego pośrednictwa była podjęta rok temu przez $\mathrm{O}$. Generała, zanim jeszcze O. Siwek napisał mi odpowiedź, wtedy w moim przekonaniu nie przedstawiałaby ona żadnych trudności. Albowiem wówczas była kwestia otwarta, czy na moją krytykę książki O. Siwka w "Ateneum” ${ }^{306}$ ma przyjść jakieś oświadczenie uzyskane droga jakiejś interwencji, jak na przykład proponowanej dzisiaj, albo też czy kwestia ta ma być pchnięta na tory publicznej dyskusji naukowej. Przyznaję się Waszej Eminencji, że rok temu wstecz bardzo byłbym ucieszony tym projektem, który dziś przychodzi nie tylko ze względu na mnie, na oszczędzenie mi roku pracy i wielkich wysiłków, ale i ze względu na O. Generała, a nawet [na] samo Zgromadzenie. Bo pisać książkę, jaką ja pisać musiałem w odpowiedzi O. Siwkowi, to było dla mnie istotnie ze względu na mój stosunek do O. Generała czymś bardzo bolesnym i moralnie bardzo dotkliwym. Niestety! O. Generał obrał wtedy drogę naukowej publicznej dyskusji udzielając pozwolenia O. Siwkowi, ażeby mi odpowiedział.

Odpowiedź taka, jaką mi dał O. Siwek zmusiła mnie mimo mej chęci i woli do wyczerpującej odpowiedzi, jaką mu dałem w znanej książce. Wedle zdań wielu z XX. Biskupów, od których otrzymywałem listy, podług krytyk uczonych jakie się ukazały dotąd, wedle opinii zwłaszcza jednego zagranicznego pisarza ascetycznego i mistycznego, który po polsku rozumie, książka moja już jest ostateczna i definitywnym załatwieniem na drodze naukowej sporu z O. Siwkiem.

Sądząc po tych różnych głosach już O. Siwkowi nie pozowało nic do odpowiedzi; albowiem nie mógł zaprzeczyć, że świadectwa moje o zjawiskach w Konnersreuth są bezpośrednie i naoczne, i tym samym pobijają jego świadectwa na niewidziane. Nie mógł O. Siwek zaprzeczyć, że się dopuścił zupełnego zniekształcenia moich wszystkich tez rozwiniętych przeze mnie w „Ateneum”, fałszując na całej linii moje myśli, albowiem udowodniłem mu to zestawieniem $\mathrm{w}$ dwu kolumnach cytatów mojej pracy, a tłumaczeniem tych cytatów przez niego. Cytat zaś jest jak liczba w bilansie, którą żadną argumentacją obalić się nie da.

Fałszerstwo więc moich idei - proszę darować ten drastyczny wyraz - jest ponad wszelką wątpliwość oczywiste, a popełnione zostało celowo i programowo z ogromnym sprytem i zręcznością; nie mógł w końcu O. Siwek zaprzeczyć, że jego druga praca wprowadzająca kryteria mistyczne była mimowolnym samooskarżeniem jego książki pierwszej, gdzie tych kryteriów było zupełny brak i gdzie wywody O. Siwka o zjawiskach mistycznych były jedynie oparte o analogie psychopatyczne.

Ale oczywiście wolno było być O. Siwkowi innego zdania i po ukazaniu się mojej książki zapowiedział on szumnie przez agenta swego ks. Weryńskiego aż telegraficznie z Citta Vaticana w K[atolickiej] A[gencji] P[rasowej], że da mi odpowiedź w „Ilustrowanym

406 Właściwie: „Ateneum Kapłańskim”. 
Kurierze Codziennym” przez ks. Weryńskiego pod pseudonimem „Miel”, iż mylą się wszyscy ci, którzy sądzą, że moja książka definitywnie załatwia się z O. Siwkiem. Właśnie nowa książka O. Siwka - pisał ów „anonimowy teolog” - będzie istną rewelacją dla „entuzjastów Konnersreuth”. Jednym słowem w sposób zupełnie niebywałej reklamy $\mathrm{w}$ świecie naukowym, O. Siwek ogłasza urbi et orbi ${ }^{407}$, że mi da odpowiedź i to odpowiedź nie byle jaką, za którą stoi w każdym razie Gregorianum ${ }^{408}$.

W takich warunkach jakże ja mogę wystąpić z jakimś projektem od siebie, którego następstwem byłoby powstrzymanie odpowiedzi O. Siwka? Oznaczałoby to innymi słowy, kapitulację przed nim, obawę przed jego książką, ale pomijając już te względy, oznaczałoby to z mej strony, że po rozpoczęciu dyskusji naukowej pragnę zamknąć usta mojemu oponentowi, czego nie mam prawa mu czynić. Ja mogę więc tylko stać na tym stanowisku, że skoro O. Siwek chce mi odpowiedzieć, to mu przyznaję wszelkie prawo do tej odpowiedzi i spokojnie wyczekuję jej pojawienia się. Takie stanowisko jest logiczną konsekwencją sporu, który został już raz wyniesiony przed forum publiczne. Można bardzo ubolewać, że tak się stało, to rzecz inna, ale skoro to się już stało, to dalszy rozwój i ostateczne rozegranie tej sprawy nie jest już w ręku moim, ale w ręku mojego oponenta. To nie ode mnie, ale od niego zależy, czy zechce przyjąć milczeniem pojawienie się mojej książki, czy też, jak to zapowiedział, da mi odpowiedź.

Mnie oczywiście wolno będzie na jego odpowiedź dać jeszcze odpowiedź, o ile to uznam po pojawieniu się jego książki za wskazane i potrzebne. Powiem nawet szczerze Waszej Eminencji, że ja z góry już się przygotowałem na to, że O. Siwek da mi odpowiedź i to domyślam się jaką. Albowiem zapowiedział mi walkę aż do końca w jednym z listów swoich pisanych do mnie jeszcze wówczas, gdy moje artykuły w „Ateneum” się nie ukazały. Dlatego na wszelki wypadek na tę odpowiedź O. Siwka pozostawiłem w odwodzie pewne dokumenty, których dotąd nieopublikowałem; sądzę jednak, że będą one dla O. Siwka prawdziwie druzgocące.

Ale to do rzeczy nie należy; ja tylko stwierdzam wobec wyrażonego przez Waszą Eminencję życzenia, ażebym podał jaki[ś] wniosek załatwienia kompromisowego tej sprawy, że ja żadnego wniosku postawić nie mogę i nie mam prawa. Gra w tym wzgląd nie tylko zasadniczy, ale przyznam się, także i osobisty. Albowiem ja nie mam do czynienia z samym O. Generałem, którego charakter tak wysoko cenię, ale mam do czynienia przede wszystkiem z moim oponentem O. Siwkiem. A mam na to smutne bardzo doświadczenie przekręcania na wspak przez niego najniewinniejszych nawet kroków z mej strony, które łączą się z Konnersreuth.

Muszę dla przykładu podać Waszej Eminencji kilka próbek tych metamorfoz, jakie O. Siwek uczynił choćby już tylko w przelotnym zetknięciu się ze mną, a nawet z listami moimi pisanymi do O. Generała.

A więc na przykład, kiedy byłem w Krakowie i po zaproszeniu go na obiad przez ks. Metropolitę podczas mojej bytności odwiedziłem go w domu na [ul.] Wesołej i poruszyłem w rozmowie z nim kwestie z psychologii nowoczesnej, to wystarczyła ta

407 Łac.: miastu i światu.

408 Właściwie: Papieski Uniwersytet Gregoriański w Rzymie. 
półgodzinna rozmowa $\mathrm{z}$ nim, ażeby na prawo i lewo rozgłaszał, że pobierałem u niego lekcje psychologii. To jest naiwne i śmieszne z pewnością, ale dla jego metod znamienne. Ja czytałem list jednego z jego adherentów, w którym ten za nim to zdanie powtarza; następnie pytałem go wówczas w Krakowie, co też on myśli o Konnersreuth; mając pisać książkę zwykłem rozważać z ludźmi nauki te problemy. Prosiłem go bez ogródek, ażeby mi wypowiedział zdanie, co sądzi o moich odczytach w Krakowie. On mnie nieszczerze chwalił, ale zdania swojego o Konnersreuth w niczym mi nie chciał wyjawić i ukrył się przede mną nawet $\mathrm{z}$ planem swoim napisania książki o Konnersreuth, a mimo to rzucał potem cień na mój charakter w kwestiach dotyczących jego książki. To rozgłaszali OO. Jezuici w różnych stronach krzywdząc mnie w ten sposób niesłychanie.

Albo na przykład pisałem list do O. Generała w kwestii zakończenia moich artykułów w „Ateneum”, które ze względu na jego osobę i jego życzenie myślałem inaczej ułożyć, to jest w formie oświadczenia na samym końcu jeszcze raz powtórzonego w kwestii stosunku O. Siwka do racjonalizmu. Niestety, wysłany mój tekst nie został wydrukowany. Otóż O. Siwek powołując się na mój list do O. Generała, pisze do jednej zupełnie obcej mu redakcji, że ja w liście do O. Generała sam się przyznałem, że wobec niego posunąłem się za daleko etc.; albo na przykład czego też on nie uczynił z cytatem mojego listu, w którym mu odmawiałem zgody na jego prośbę, by mu dać zezwolenie na ogłoszenie mnie odpowiedzi i poddałem tę sprawę decyzji O. Generała. Jak to zaznaczyłem w mej przedmowie, O. Siwek przez wyjęcie z tekstu jednego zdania powołuje się na moje słowa w swej książce jako na zachętę z mej strony, by napisał odpowiedź. Kto jest w stanie coś podobnego zrobić z listu prywatnego, to czegóż on nie zrobi z dokumentu innego?

Przyzna mi tedy Wasza Eminencja, że pomijając względy zasadnicze, miałbym głębokie przekonanie, że O. Siwek wszelki krok z mej strony pochwyciłby jako pożądaną dla siebie okazję, ażeby go przekręcić, ażeby wytłumaczyć jako kapitulację moją i cofnięcie się na całej linii przed nim i bodaj czy by nie przydał jeszcze, że to się stało na nakaz Rzymu! Bo przecie teraz świeżo zmyślił wobec ks. Biskupa Przeździeckiego legendę, że S[anctum] Officium chce wkroczyć w tę sprawę dowiedziawszy się, że mam moją książkę tłumaczyć na język niemiecki.

Są to z pewnością względy dodatkowe, ale Wasza Eminencja uzna, że one także grają dużą rolę w tej rozprawie i w tym właśnie wypadku, gdzie O. Siwek ma wszelkie prawo wypowiedzieć się do końca i gdzie projekt z mej strony zepchnięcia tej dyskusji z publicznej rozprawy miałby istotne wszelkie pozory, a nawet cechy tak się nadające do wyzyskania ze strony O. Siwka.

Otóż przedstawiam Waszej Eminencji tę prawdziwą trudność, jaka się nasuwa w rozwiązaniu sporu na wszelkiej innej drodze, jak na tej, na którą spór został zepchnięty i to wciągnięty z niesłychaną reklamą i rozgłosem; jakkolwiek więc w głębi mego serca niesłychanie mi będzie bolesnym iść w tej sprawie do końca, tak ze względu na O. Generała jak i OO. Jezuitów, jakkolwiek rad bym poświęcić naturalną chęć, by rzucić na szalę sporu ostateczne rozstrzygające słowo, to jednak ja z mej strony nie mogę niczego przedsięwziąć, co by spór skierowywało na inne tory, jak na tory ściśle naukowej dyskusji. 
Druga trudność w załatwieniu kwestii rodzi się stąd, że do dyskusji naukowej przymieszała się kwestia moralna, a mianowicie kwestia ataków O. Siwka na mnie.

Albowiem w książce swej nie tylko czyni on aluzję przejrzystą do mego charakteru dając do poznania, iż co innego piszę, a co innego myślę, ale czyni mi publiczny zarzut, iż ja jako katolicki biskup głoszę błędną naukę contra doctrinam christianam $^{409}$ twierdząc, że proroctwa są nieoddzielne od ekstazy. Ponadto O. Siwek na jednym publicznym wykładzie w instytucie uniwersyteckim w Rzymie wobec młodzieży różnych narodowości publicznie po imieniu mnie zaatakował i obrzucił mię po prostu kpinami. Ja mam na to dowód w sprawozdaniu pisemnym jego bezpośrednich słuchaczy, a także w sprawozdaniu pośrednim zakonnic z Rzymu, którym alumni innych narodowości najdokładniej szczegóły tego ataku O. Siwka opowiadali. Wasza Eminencja zrozumie dobrze, że podobny publiczny występ domaga się zadośćuczynienia i to nie tylko dla mojej osoby, ale poniekąd dla prestiżu polskiego Episkopatu, którego jestem członkiem.

Sprawa więc moja z O. Siwkiem nie jest tylko sprawą problemu naukowego, ale z nią się łączy też i problem moralny. Pomijam inne występy O. Siwka jako już mniej znaczące wobec tych, które wymieniłem.

Dziś występuje jeszcze inna trudność w rozwiązaniu prywatnym tej sprawy. Mianowicie, iż pod wpływem OO. Jezuitów i Gregorianum w Rzymie - tak mi przynajmniej doniesiono - broszura O. Siwka skierowana przeciwko mnie rozchodzi sie w Niemczech. Miałem na to sam dowody, bo mi o tym mówili, już też pisali księża z zagranicy i świeccy uczeni; nie wiem w jaki sposób to się dzieje, ale nie ma kwestii, że propaganda z tą broszurą mimo, że nie została wydrukowana, przy pomocy niemieckich jezuitów trwa na całej linii. Ujawniła się ta propaganda najsilniej w tym, że niemiecki związek protestancki i niemiecki racjonalizm użył książki O. Siwka dla uderzenia tak w zjawiska Konnersreuth, jak we mnie, jak w bawarskich XX. Biskupów, którzy właśnie śledzeniem tej sprawy się zajmują. Ponieważ tyle czasu i tyle pracy włożyłem w problem Konnersreuth, nie mogę być obojętny na taki objaw, w który racjonalizm wciąga już nie samego O. Siwka, ale całe Gregorianum. Jak w tej sprawie postąpię, tego ja sam dziś jeszcze nie wiem; przedtem nim nastąpiło, odmówiłem po dwakroć prośbie ze strony wydawnictw niemieckich do tłumaczenia mej książki na język niemiecki. Ale dziś sytuacja zasadniczo się zmieniła i ja jeszcze nie wiem, jak w tej sprawie postąpię i postąpić będę musiał. Gdyby więc ewentualnie przyjść miało do jakiejś rozprawy naukowej w Niemczech, na przykład przez przetłumaczenie mej książki na język niemiecki lub coś podobnego, lękałbym się, by mi w tej kwestii nie pętało rąk jakiekolwiek załatwienie kompromisowe czy inne tego problemu tutaj w kraju. Jest to dla mnie szczególniej z tego względu ważne, że mam na ukończeniu duże dzieło o Konnersreuth, w którym wprawdzie O. Siwkiem się nie zajmuję, ale bądź co bądź dzieło to przede wszystkim dla Niemiec przeznaczam. Nie mogę więc być obojętny na takie uderzenie z tyłu na mnie i na problem, w którym tyle już pracy włożyłem.

W końcu przychodzę do bardzo ważnej kwestii poruszonej przez Waszą Eminencję, tj. zarzutu racjonalizmu, jakoby przeze mnie wedle sądu O. Generała „ogólnie postawionego". Otóż ja przeciwko temu twierdzeniu miałbym poważne zastrzeżenia. Pisząc

${ }^{409}$ Łac.: przeciwko nauce (doktrynie) chrześcijańskiej. 
bowiem odprawę O. Siwkowi zdawałem sobie doskonale z tego sprawę, że ogólnie stawiając zarzut podobny O. Siwkowi mógłbym mu wyrządzić ciężką krzywdę. Z tego powodu bardzo ściśle rozróżniłem w mojej pierwszej jeszcze pracy pomiędzy osobistymi przekonaniami O. Siwka, a jego przewodnią tezą w książce o Konnersreuth; nie tylko broniłem wiary i pobożności O. Siwka w mej pracy, ale wręcz stwierdziłem, że stoi on na przeciwnym biegunie racjonalizmu i że go zwalcza uznając pierwiastek nadprzyrodzony, któremu racjonalizm zaprzecza. Stwierdziłem tylko fakt, iż O. Siwek w zjawiskach mistycznych, na przykład w zjawiskach ekstazy, którą on sam w swej drugiej książce słusznie nazywa istotnym objawem stygmatyzacji, oparł swój sąd o tych zjawiskach jedynie i wyłącznie o analogie z psychopatią, a pominął zupełnie kryteria mistyczne. To nie jest żadna moja opinia, to jest fakt, o którym się każdy przekonać musi.

Na dowód na takie analizowanie rzeczy schodzi się z teza racjonalizmu przytaczam nie moje słowa, ale własne O. Siwka. Na stronnicy 36-tej drugiej swej pracy o literaturze religijnej „areligijnych” pisarzy, pisze on: „Wychodząc z założeń materialistycznych i oparci o metodę pozytywistyczną posługującą się w badaniach kryteriami wyłącznie «pozytywnymi», usiłowali oni sprowadzić całą mistykę do pewnych zjawisk «doświadczalnych» podległych obserwacji zewnętrznej, do pewnych funkcji organicznych. $\mathrm{Na}$ szczęście pogląd ten na mistykę wraz z materializmem i pozytywizmem, które były jego podporą, już się przeżył”.

Z tego tekstu O. Siwka wynika, że rozpatrywanie zjawisk mistycznych tylko jedynie pod kątem analogii psychopatycznych, a więc metod stosowanych do zjawisk doświadczalnych, jest charakterystycznym znamieniem racjonalizmu i to racjonalizmu przestarzałego.

Oczywiście i ja tak samo stwierdzam w mej książce, iż w metodach naukowych wyrzucenie kryteriów mistycznych przy analizie zjawisk mistycznych jest upodobnieniem do metod racjonalistycznych.

To był mój punkt wyjścia w mej pracy, to był główny powód, dla którego się jej podjąłem. Właśnie dlatego, że podobna infiltracja jest nieuświadomiona u autora, tym bardziej należy zwrócić na ten prąd baczną uwagę; im zaś wyższy jest autorytet takiego autora dzięki jego pozycji naukowej, ten może być niebezpieczniejszy wpływ podobnej infiltracji. Tu nie chodzi o to, czy szkodzi ona prestiżowi naukowemu czy nie, to jest rzecz drugorzędna; tu idzie o to, czy zarzut został stwierdzony tekstami czy też nie.

Sądzę, że jest to zupełnie w duchu Kościoła tak na ten problem patrzeć. Dla przykładu podaję tu znaną i rozgłośną sprawę z książką z dziedziny katolickiej egzegezy, wydaną przed paru laty: Vigouroux-Bacuez ${ }^{410}$ (w wydaniu Brassac-Ducher). Autor wychodził ze stanowiska nadprzyrodzonego w tej książce, uznawał porządek nadprzyrodzony jak cudów etc., a jednak z powodów nieuświadomionej u niego infiltracji prądów racjonalistycznych, książka ta dostała się na indeks, a nadto jeszcze ówczesny sekretarz Stanu Gasparri ${ }^{411}$ wydał list ostrzegający przed kierunkami ulegającymi metodom racjonalistycznym.

${ }^{410}$ Właściwie: F. Vigouroux, L. Bacuez, Manuel Biblique ou, Cours d'écriture Sainte a l'usage des séminaires, Paris 1884-1885 ${ }^{1}$.

${ }^{411}$ Zob. w niniejszej publikacji: J. Wołczański, Listy abp. Józefa Teodorowicza do abp. Józefa Bilczewskiego, dokument 145 . 
Jeżeliby się komuś po tym wszystkim jeszcze wydawało, że ja przesadzam i wietrzę racjonalizm tam, gdzie go nie ma, to powołuję się na zdanie jednego autora znanych dzieł, którego nazwisko Waszej Eminencji przy sposobności widzenia się mogę ujawnić. Otóż ten jezuita znał książkę O. Siwka i powiedział znajomym mi kapłanom przebywającym zagranicą, że jest to książka napisana w duchu racjonalistycznym i że on się tylko dziwi, jak mógł konsystorz krakowski na taką książkę dać swoją aprobatę.

Nie cytuję już zdań bardzo poważnych uczonych polskich, z których jeden znany pisarz zakonny, nie dominikanin, mówił mi jaki wstręt wywołało samo czytanie książki O. Siwka w refektarzu z powodu nasiąknięcia duchem racjonalizmu, który nawet krytyczni badacze w tej książce wyczuwali.

Muszę tu tylko jeszcze podnieść, że byłem w mym sądzie niesłychanie ostrożnym, bo wyraźnie zaznaczyłem, że gdyby O. Siwek nie rościł sobie pretensji rozwiązywania Konnersreuth ze stanowiska religii, a ograniczył się li tylko do analogii tych zjawisk z psychopatią, to wówczas mógł i miał prawo pominąć kryteria mistyczne i byłby dzięki nagromadzonemu materiałowi przysłużył się rozwiązaniu problemu Konnersreuth. Na osobnej karcie dołączam Waszej Eminencji dosłowne cytaty, odnoszące się do tych twierdzeń, a wyjęte z moich rozpraw. (Tego już po tak długim liście nie czynię).

Wszystko to co napisałem raz jeszcze przedstawiam jako trudności, wychodząc przy tym z założenia podanego wyżej, że ode mnie nie może wyjść żaden projekt w tej kwestii, którą całą składam dzisiaj w ręce Waszej Eminencji, łącząc dla osoby Waszej Eminencji wyrazy mej najgłębszej i najoddańszej czci.

Lwów, dnia 31 stycznia 1934

\section{Dokument 177}

Kopia: AFKDOPW, teczka 134: Spuścizna abp. Józefa Teodorowicza, sygn. 1614/185 [4], List abp. Józefa Teodorowicza do ks. prałata Stanisława Szpetnara, Lwów 5 II 1934 r.

Kochany ${ }^{\mathrm{a}}$ Księże Prałacie!

Dziękuję Księdzu Prałatowi za przysłane mi słowa tak zacnej, tak bardzo oddanej i tak rozumnej osoby jak pani Grzesiecka ${ }^{412}$. Tylko właśnie dlatego, że tak jest na mnie łaskawa, niechże Ksiądz Prałat cum grano salis ${ }^{413}$ te słowa odważa. Tylko Ksiądz Prałat, niestety, nie czuje wyrzutów sumienia za to, że mnie do tej pracy popchnął, a nawet każdą nazbyt łaskawą pochwałą dla mnie jeszcze się w tym utwierdza, że dobrze zrobił. Cóż ja w tych warunkach mogę z Kochanym Księdzem Prałatem poradzić?

O ile wiem z kół OO. Jezuitów, O. Siwek wprawdzie odpowiedź napisał, ale cenzura Jezuitów w Rzymie nie pozwoliła mu jej drukować.

a Tekst pisany maszynowo na jednej stronicy papieru formatu A4. Brak autografu autora listu.

412 Osoba niezidentyfikowana.

413 Łac.: z odrobiną sceptycyzmu. 
Niestety, nie mogłem korzystnie załatwić sprawy poruszonej przez Księdza Prałata w liście ostatnim; dziś przy olbrzymiej redukcji personelu na poczcie nic się tam osiągnąć nie da.

Łączę dla Kochanego Księdza Prałata wyrazy prawdziwie oddane głębokiej czci. Lwów, dnia 5 lutego 1934

Ks. Prałat Szpetnar

\section{Dokument 178}

Kopia: AFKDOPW, teczka 136: Spuścizna abp. Józefa Teodorowicza, sygn. 1601/185 [4], List abp. Józefa Teodorowicza do redaktora "Czasu”, Lwów luty 1934 r.

Wielmożnya Panie Redaktorze!

W miesiącu lutym na szpaltach „Czasu” pojawiła się krytyka mej książki podpisana przez dr. J.N., opatrzona szczególniejszym zaleceniem ze strony Redakcji Szan[ownego] pisma.

Nie mam najmniejszych pretensji o to, aby książka moja była chociażby ujemnie krytykowana pod jednym wszakże warunkiem: a mianowicie, iż fakty podane przez krytyka odpowiadają prawdzie. Tymczasem krytyka pomieszczona na szpaltach Szan[ownego] pisma opiera się cała na faktach nieprawdziwych i jak w takich razach każdemu autorowi tak i mnie dzieje się przez to krzywda. Nie wątpię, że Redakcja w dobrej wierze krytykę tę przyjęła, jakkolwiek opatrzenie jej tak wyjątkową rekomendacją już angażuje Redakcję samą. Liczę jednak na to, że zechce Redakcja przyjąć sprostowanie faktyczne, które przez moje ręce przesyła ks. kanonik Isakowicz.

Prosząc o uważanie tego listu za poufny, wyrażam pełną nadzieję, iż Szan[owna] Redakcja zadośćuczyni słusznemu życzeniu sprawiedliwości i odpowiedź polecającą li tylko na sprostowaniu faktów w piśmie swym zechce pomieścić.

Z wyrazami głębokiego poważania.

Lwów, dnia [... $]^{\mathrm{b}}$ lutego 1934

\section{Dokument 179}

Kopia: AFKDOPW, bsygn., teczka: Spuścizna abp. Józefa Teodorowicza, List abp. Józefa Teodorowicza do kard. Augusta Hlonda, Lwów 7 II 1934 r.

Wasza $^{a}$ Eminencjo!

a Tekst pisany maszynowo na jednej stronicy papieru formatu A4. Brak adresata, daty dziennej i autografu nadawcy. W górnej partii karty nota ołówkiem: „Nie poszło”.

b Brak tekstu.

a Tekst pisany na maszynie na 2 stronicach papieru formatu A4. Brak autografu autora pisma. 
W liście, który wysłałem Waszej Eminencji był jeden szczegół nieścisły, który, prosiłbym z listu wykreślić. Dotyczy on mianowicie rzekomej rozmowy ks. Biskupa Przeździeckiego z O. Siwkiem.

Przy tej sposobności proszę Waszą Eminencję o wytłumaczenie mnie, iż na zjazd w lutym nie będę mógł przybyć do Warszawy ze względu na moje zdrowie. Jest mi wprawdzie lepiej, nawet względnie dobrze, ale lekarze obawiają się każdego większego wysiłku, gdyż jeszcze nie ma dostatecznego poprawienia stanu mego zdrowia.

Przy tej sposobności przychodzi mi na myśl wspomnienie z Krynicy sprzed roku właśnie, o którym mówiłem Waszej Eminencji. Mianowicie rok temu, gdy był formalny zjazd XX. Biskupów w Krynicy, przywiozła K[atolicka] A[gencja] P[rasowa] w osobie ks. Kaczyńskiego wiadomość z Rzymu, że ksiądz Bross dostał prałaturę. Ani się nawet zająknął gdy to mówił, stwierdził to jako pewnik nieulegający wątpliwości tak, żeśmy wszyscy zaczęli ks. Brossowi gratulować i tylko on jeden przeciwko przyjęciu gratulacji protestował.

Nie śmię $e^{\mathrm{b}}$ oczywiście podsuwać Waszej Eminencji żadnych wniosków, ale jednak sądzę, że jeżeli nie ma wejść w przysłowie okrzyk Moraczewskiego ${ }^{414}$ : „kłamie jak K[atolicka] A[gencja] P[rasowa]!", to w takim razie coś by jednak należało z tym fantem uczynić.

Łączę dla Waszej Eminencji wyrazy najoddańsze mej czci najgłębszej, sługa w Chrystusie.

Lwów, dnia 7 lutego 1934

\section{Dokument 180}

Kopia: AFKDOPW, teczka 130: Spuścizna abp. Józefa Teodorowicza, bsygn., List abp. Józefa Teodorowicza do kard. Augusta Hlonda, Lwów 9 II 1934 r.

\section{Wasza ${ }^{a}$ Eminencjo!}

Jeszcze raz wracam do kwestii poruszonej w liście Waszej Eminencji, a to pod wpływem listu, jaki otrzymuję od ks. Arcybiskupa Sapiehy.

Donosi mi on, że OO. Jezuici pod pseudonimem wznawiają kwestię O. Siwka i jego obrony w „Czasie" ${ }^{\text {"15; }}$; pisze mi, że napisał do nich ostry list w tej sprawie.

Otóż nie chodzi zupełnie o to, iż oni starają się O. Siwka obronić; ale mam w tym jednak potwierdzenie na to, co Waszej Eminencji pisałem. Wysuwałem mianowicie jako

b Zapis zgodny z oryginałem.

${ }^{414}$ Prawdopodobnie: Moraczewski Jędrzej (1870-1944), poseł do Rady Państwa w Wiedniu z ramienia Polskiej Partii Socjalno-Demokratycznej Galicji i Śląska Cieszyńskiego (1907-1918), w czasie I wojny światowej służył w Legionach, 1919-1927 poseł i wicemarszałek sejmu z listy PPSD, a następnie Polskiej Partii Socjalistycznej, 1926-1929 minister robót publicznych, 1931-1939 prezes Centralnego Wydziału Zawodowego Związku Związków Zawodowych. W czasie II wojny światowej organizował pomoc dla poszkodowanych w działaniach wojennych. J. Gołębiowski, Moraczewski Jędrzej Edward, w: Kto byt kim, s. 56.

a Tekst pisany maszynowo na 2 stronicach papieru formatu A4. W górnej partii karty tytułowej odręczna nota: „Nie poszło”. Brak autografu autora pisma.

${ }^{415}$ Zob. w niniejszej publikacji: J. Wołczański, Listy abp. Józefa Teodorowicza do abp. Józefa Bilczewskiego, dokument 18 . 
trudność w załatwieniu sporu naukowego w drodze polubownej, iż ja się będę czuł przez to związany, kiedy równocześnie OO. Jezuici - myślałem pisząc list do Waszej Eminencji tylko o zagranicy - będą pod różnymi pseudonimami czy to w dalszym ciągu atakować, czy w ogóle spór rozwijać. Nie przypuszczałem, iż tak rychło właśnie tutaj ta kwestia zajdzie.

Nie chcę w niczym przesądzać stanowiska, jakie Wasza Eminencja zajmie w całej tej sprawie zapewne po porozumieniu się z O. Generałem, ale przytaczam tylko ten szczegół na potwierdzenie tego, co już pisałem.

Łączę przy tej sposobności dla Waszej Eminencji wyrazy najgłębszej czci, zawsze oddany.

Lwów, dnia 9 lutego 1934

\section{Dokument 181}

Oryg.: AFKDOPW, teczka 140: Spuścizna abp. Józefa Teodorowicza, sygn. 970/420 (8) [7], List dr. Ralpha Waldego Hynka do abp. Józefa Teodorowicza, Praga 9 II 1934 r.

\section{Euere $^{\mathrm{a}}$ Exzellenz!}

Ich habe von Euer Exzellenz die liebenswürdigste Spende erhalten gerade an dem Tage wo nach längerem Aufschieben meine Antwort an P[ater] Restl S.J. ${ }^{416}$ in „Lidove Listy" erschienen ist. Ich beeile mich daher Euerer Exzellenz für eine so ausgiebige Hilfe meinen ergebensten und innigsten Dank zu wollen.

Mit gleicher post sende ich diesen Artikel über den unglücklichen unseren Mitkämpfer Dr. Gerlach was Euere Exzellenz schon wissen durfte. Meine Antwort erregte geradezu eine Aufruhr in dem Collegium P.P. Jesuiten und P[ater] Restl traut sich nicht mehr in einer öffentlichen Debatte auf meinen Vortragen „seinen Mann“ mir gegenüber zu stellen. Hoffentlich vergeht auch ihm die Lust sich weiter für P[ater] Siwek zu exponieren.

Mein deutsches Referat habe ich schon längst Hernn v[on] Lama geschickt und dieser hat es auch schon recht gut benutzen können.

Nun hat mir auch der Verleger von Konn[ersreuther] Tagesblatt um Artikel über Euerer Exzellenz glorreiche Verteidigung von Konn[ersreuth] gebeten, was ich mit größter Freude tun werde.

Sollte ein mal Euere Exzellenz nach Konnersreuth oder München über Prag anfahren, dann würde es mir enorme Ehre und Freude bereiten, Ihr persönlich den Ausspruch meiner speziellen Hochachtung und Ergebenheit darbringen zu können.

In tiefster Ehrfurcht ergeben und nochmals dankender

Dr. R[alph] W[aldo] Hynek

a Tekst pisany czarnym atramentem na 1,5 stronicy papieru formatu A4. W lewym górnym rogu karty tytułowej nadruk firmowy: „Dr.R. Hynek, lékaŕ spisovatel, Praha III, Ječná 37, telefon 31368”.

${ }^{416}$ Osoba niezidentyfikowana 


\section{Dokument 182}

Oryg.: AFKDOPW, teczka 138: Spuścizna abp. Józefa Teodorowicza, sygn. 349/89 [5], List z Wydawnictwa i Drukarni Badenia w Karlsruhe do abp. Józefa Teodorowicza, Karlsruhe 10 II 1934 r.

Karlsruhe, den 10. Februar 1934

Direktion V/Ba

S[eine]r Exzellenz

den Hochwürdigsten Herrn Erzbischof

Dr. J. Teodorowicz

Lemberg/Polen

\section{Eure $^{\text {a Exzellenz! }}$}

Für die prinzipielle Bereiterklärung, die Übersetzung und Veröffentlichung des Buches Eurer Exzellenz über Konnersreuth uns in Verlag zu übergeben, danken wir herzlich. Wir sind bis heute leider noch nicht dazu gekommen, zu dieser Verlagsfrage Stellung zu nehmen, weil wir in den letzten Wochen durch organisatorische Fragen aller Art stark in Anspruch genommen waren.

Um nunmehr möglichst rasch das Buch herauszubringen, sind wir Eurer Exzellenz zu grossem Dank verbunden, wenn es ermöglicht werden könnte, mit der Übersetzung recht bald zu beginnen. Natürlich sind wir auch damit einverstanden, dass der von Eurer Exzellenz vorgeschlagene Übersetzer mit dieser Aufgabe betraut wird. Wir bitten nur, uns die Anschrift dieses Herrn übermitteln zu lassen, damit wir uns mit ihm in Verbindung setzen können.

Wenn sodann Eure Exzellenz schreiben, dass noch ein zweites Buch über Konnersreuth geschrieben wird, so sind wir ebenfalls gerne bereit dieses Buch mit in Verlag zu übernehmen. Um einen Überblick zu bekommen über die Herstellungsmöglichkeit und den Umfang beider Bücher, bitten wir uns wissen zu lassen, wann wir mit der $\mathrm{Zu}$ stellung der Manuskripte rechnen können und wie gross ungefähr der Umfang beider Werke ist.

Wir danken nochmals für das Vertrauen, das Eure Exzellenz uns durch die Überlassung des Verlags der beiden Konnersreuther Bücher entgegengebracht haben und zeichnen mit dem Ausdruck tiefster Verehrung ergebenst

Badenia in Karlsruhe ${ }^{\mathrm{b}-A k t .-G e s . ~ f u ̈ r ~ V e r l a g ~ u n d ~ D r u c k e r e i ~}{ }^{-\mathrm{b}}$

a Tekst pisany maszynowo na dwóch stronicach papieru formatu A4. W górnej centralnej partii karty nadruk firmowy: „Badenia in Karlsruhe A.-G. FÜR VERLAG UND DRUCKEREI, Telephon 6235-6237, Postscheck-Konto Karlsruhe 4844, Steinstraße 17-21”. Nieczytelny autograf autora pisma.

b-b Podłużna pieczęć.

c Autograf nieczytelny. 


\section{Dokument 183}

Kopia: ASK, bsygn., Acta Hlondiana, List abp. Józefa Teodorowicza do kard. Augusta Hlonda, Lwów 14 II 1934 r. Kopia: AFKDOPW, teczka 130: Spuścizna abp. Józefa Teodorowicza, bsygn.

\section{[Wasza Eminencjo!]}

Pozwolę sobie jeszcze raz wrócić do sprawy O. Siwka. Właśnie pisał mi arcybiskup Sapieha, że się pojawił w „Czasie” artykuł117, który pochodzi od Jezuitów w obronie O. Siwka. Ks. biskup krakowski napisał do Jezuitów ostry list i trafił w sedno rzeczy; albowiem wcale nie próbują się bronić, jakoby artykuł ten od nich nie pochodził. Ja artykułu tego w "Czasie” nie czytałem, ale przypuszczam, że to będzie artykuł podobny do tego, który się ukazał w „Dzienniku Poznańskim”"18.

Otóż pracując przez rok nad książką przeciw O. Siwkowi poznałem od razu jego styl, jego sposób argumentacji, słowem poznaję, że autorem tego artykułu jest nie kto inny jak O. Siwek. Pomijam zupełnie treść artykułu i wprost niebywałe metody ze stanowiska nawet moralnej reklamowej analogii O. Siwka. Jakkolwiek piszę o tym Waszej Eminencji to czynię to dla innych względów; mianowicie mam w tym potwierdzenie tego, co Waszej Eminencji pisałem. OO. Jezuici zdaje się zechcą jakichś oświadczeń ode mnie dając mi wzajemnie przyrzeczenie, że O. Siwek nie da mi odpowiedzi; już nawet podobno zabroniono im wydania odpowiedzi przeciw mnie. Ale za to będzie on atakował mnie drogą po prostu zwykłego kłamstwa w przekręcaniu stanu rzeczy na wszystkie strony. Tak się już dzieje zagranicą, skąd mi przysłano artykuł O. Reissmana $^{419}$ widocznie pisany pod wpływem O. Siwka, bo mniej więcej argumentacja jest ta sama.

Kiedy więc ja byłbym związany, to równocześnie pod pozorem zakończenia sporu będę atakowany ze strony Jezuitów i to nie w sposób naukowy, ale jak to jest w tym wypadku, przez kłamstwo w przekręcaniu faktów. Dobrze by było, by Generał wiedział o tym, że chyba w ten sposób na drogę pogodzenia sprawy się nie skierowuje. Ja oczywiście, jeżeli Ojcowie dalej iść będą tą metodą prostego kłamstwa, będę zmuszony wystąpić publicznie w sposób, na jaki ich metody zasługują.

Łączę dla Waszej Eminencji wyrazy mej czci najgłębszej.

Lwów, dnia 14 lutego 1934

Ks. Prymas Hlond - Poznań

a Tekst pisany maszynowo na dwóch stronicach papieru formatu A4. Brak autografu autora pisma.

${ }^{417}$ Ks. J.N., Konnersreuth, „Czas”, 86(1934), nr 36, s. 6.

418 „Dziennik Poznański” - informacyjno-publicystyczna gazeta liberalna o programie narodowym założona przez Hipolita Cegielskiego w Poznaniu. Periodyk ukazywał się w l. 1859-1939. J. Łojek, J. Myśliński, W. Władyka, Dzieje prasy polskiej, Warszawa 1988, s. 41, 60-61.

${ }^{419}$ Osoba niezidentyfikowana. 


\section{Dokument 184}

Kopia: AFKDOPW, teczka 136: Spuścizna abp. Józefa Teodorowicza, sygn. 1596/185 [4], List abp. Józefa Teodorowicza do Wydawnictwa i Drukarni Badenia w Karlsruhe, Lwów 17 II 1934 r.

Hochgeehrter ${ }^{\mathrm{a}}$ Herr!

In Beantwortung Ihres werten Briefes glaube ich, es wird das beste, wenn ich Ihnen das zu übersetzende Buch zuschicke und das tue ich eben. Das Buch kann auch gekürzt werden ohne Schaden für den Inhalt. Der Name und die Adresse des Übersetzers, welchen ich Ihnen anempfehle, lautet: Professor Aleksander Dąbrowski Lwów - Śniadeckigasse 3. Ich habe diesen Professor als einen tüchtigen Übersetzer kennen gelernt und zwar hat er mein Buch über Christus ausgezeichnet ins Deutsche übersetzt. Auch ist er in seiner Arbeit ungemein pünktlich, wenn er ein Termin angibt, so hält er ihn ganz gewiss. Er hat mir gesagt, dass er für die Übersetzung dieses meinen Buches 4- bis 6 Wochen braucht, er kann Ihnen stückweise zum Druck die fertigen Bögen anschicken. Was das andere Buch über Konnersreuth anbelangt, so bin ich durch einen Vertrag mit einer Buchhan[dlung] in Österreich gebunden. Diesen Vertrag habe ich schon vor zwei Jahren mit dieser Buchhandlung abgemacht.

Der Herr Lama hat mir aber geschrieben, dass jetzt große Handelsschwierigkeiten in der Herausgabe eines Buches, welches in Österreich gedruckt und für Deutschland bestimmt ist, wäre ich bereit, das Buch bei Ihnen erscheinen zu lassen. Selbstverständlich wenn die Verleger damit nicht einverstanden sein werden, wäre ich genötigt schon dem österreichischen Verlag das Buch zu überlassen.

Ich Verbleibe mit dem Ausdruck meiner tiefen Hochachtung.

Lwów, 17 II 1934

\section{Dokument 185}

Oryg.: AFKDOPW, teczka 145: Spuścizna abp. Józefa Teodorowicza, sygn. 923/420 (8) [7], List prof. Friedricha Ritter von Lamy do abp. Józefa Teodorowicza, Gauting 17 II 1934 r.

Excellenz ${ }^{\mathrm{a}}$, Hochwürdigster Herr Erzbischof !

Gauting, 17. Februar 1934

Ich bitte, mir für alle Fälle die Besprechung zugehen zu lassen, die der H.H. Kanonikus Dr. Steuer geschrieben hat. Ich werde bemüht sein, sie in einer theologischen Fachzeitschrift unterzubringen; in einer Tageszeitung ist das ja, so gut wie unmöglich, da wir heute keine einzige ausgesprochen katholische Zeitung mehr haben. Es ist mir unmöglich, zu verstehen, wie unser Episkopat sich geradezu widerstandslos diese Waffe nehmen lassen konnte. Es ist nun dahin gekommen, dass auch unsere ehemals

\footnotetext{
a Tekst pisany czarnym atramentem ręką kopisty na 1,5 stronicy papieru formatu A4. W górnej partii karty tytułowej nota: „Kopia listu do Badenii”. Brak autografu autora.

a Tekst pisany maszynowo na dwóch stronicach papieru formatu A4. Autograf odręczny czarnym atramentem.
} 
katholische Presse in den Dienst der Volksverführung gestellt ist, die mit katholischem Christentum nichts mehr zu tun hat und vom Geiste Christi keine Spur an sich trägt. Vielleicht wird es am besten sein, mit der Veröffentlichung der Kritik zuzuwarten, bis die deutsche Ausgabe des Buches herauskommt; sie kann dann zugleich als Empfehlung und Reklame dienen. Aber je eher ich die Uebersetzung der Besprechung erhalte, desto besser; sonst kommt die Sache in Vergessenheit und wenn man sie benötigt, ist sie nicht zur Hand. Der Verlag Badenia hat mir geschrieben, dass er sich um das Uebersetzungsrecht für beide Bücher zu bewerben entschlossen habe. Dass noch erhebliches Interesse für Konnersreuth besteht, beweist die Tatsache, dass mein letztes Jahrbuch nach vier Monaten vergriffen war und eben in neuer Auflage nachgedruckt wird. Auch weiss ich bestimmt, dass Konnersreuth noch eine grosse Zukunft hat. Auf die grosse Verbreitung des Jahrbuches wird wohl die Veröffentlichung der „Mahnung an die Menschheit" nicht ohne Einfluss gewesen sein, die ich dem Buche vorangestellt habe. An ihrer Vermittlung ist jenes halb polnische Mädchen beteiligt, von der ich Ihnen $\mathrm{s}$. Z. gesprochen hatte und über welches Stillschweigen zu wahren ist.

Gerne würde ich über meinen Besuch in K[onnersreuth] etwas mitteilen, wenn es der Mühe wert wäre. Bei Therese Neumann wurde ich diesmal überhaupt nicht vorgelassen und als Grund wurde mir angegeben meine „Schreiberei“. Es ist Resl gleichgültig, ob man gut oder schlecht über sie schreibt, sie persönlich will, man solle überhaupt nicht über sie schreiben und wer über sie schreibt, den mag sie nicht. Ihre Gegner sind noch besser daran als ich, denn für diese betet sie wenigstens. Ihr ist es ein Greuel, dass das Gute von ihr durch Druck verbreitet wird und ich kann diesen Standpunkt ganz gut verstehen; er ist subjektiv zweifellos berechtigt und gehört ganz in das Bild, das wir von Resl kennen. Ich habe ihr aber geschrieben, dass ich ihretwegen allein keine Feder anrühren würde. Ich schreibe um der Wahrheit willen und um den Glauben an den Heiland in dieser Zeit zu stärken und zu verbreiten. Aus diesem Grunde werde ich auch in Zukunft weiterschreiben, gleichgültig ob ich bei Resl in Gnade oder in Ungnade stehe. Man macht mir auch ab und zu Unrichtigkeiten in dem, was ich schreibe, zum Vorwurf, aber wenn ich den Dingen auf den Grund gehe, sind es solche Nebensachen und Belanglosigkeiten, dass man immer wieder nur lächeln kann. Ich habe ihr diesbezüglich geschrieben, dass, wenn solche Unrichtigkeiten unterlaufen, niemand anderer verantwortlich ist, als die Familie Neumann selbst, denn bei jedem Versuch einer Erkundigung erhält nun die Antwort: „Mir sag'n nix!“ Daher muss ich mich immer um andere Zeugen umsehen und dann auf diese verlassen. Dabei ist es mir vorgekommen, dass sich einmal sogar zwei Augenzeugen einer Szene in ihren Angaben widersprochen haben! Die persönliche Auffassung, die man mitbringt, spielt dabei eine grosse Rolle und trägt erheblich zur Bildung des Urteils bei. Infolge der politischen Veränderungen, die natürlich auch bis nach Konnersreuth hinein sich geltend machen, legen sich die Resl nahe stehenden Persönlichkeiten grösste Zurückhaltung auf und verschliessen sich geradezu. Darüber könnte ich Näheres nur mündlich mitteilen. Immerhin war Pfarrer Naber auch diesmal wieder mir gegenüber ganz offen und hat mir viel von seiner Zeit geschenkt. Geändert hat sich nichts, abgesehen natürlich von den Fortschritten von 
Resls Innenleben. Ueber ein paar wichtige Konversionen sammle ich gegenwärtig das Material.

Wie stets bin ich Eurer Excellenz aufrichtigst ergebener

${ }^{\mathrm{b}}$ F[riedrich] R[itter] von Lama ${ }^{-\mathrm{b}}$

\section{Dokument 186}

Oryg.: AFKDOPW, teczka 144: Spuścizna abp. Józefa Teodorowicza, sygn. 1043/420 (8) [7], List o. Odo Staudingera OSB do abp. Józefa Teodorowicza, Salzburg 20 II 1934 r.

Salzburg, Benediktinerkolleg[ium], am 20. II. 1934

Exzellenz! ${ }^{\text {a }}$

Hochwürdigster Herr Erzbischof!

Recht sehr danke ich Eu[rer] Exzellenz für das mir liebevollst gewidmete Werke über Konnersreuth. Da waren Sie zu gütig gegen mich und erwiesen mir viel Ehre. Ich bedauere sehr, es nicht lesen zu können, aber wie ich sehe, ist Konnersreuther Schrifttum das nicht jedermann zugänglich ist, $\mathrm{z}$ [um] B[eispiel] Lavaud; Der gerade Weg, gut verwertet. Meine Meinung wegen der deutschen Ausgabe? Diese verdient keine Beachtung. Ich kenne leider zu wenig den positiven Schalt des Werkes, um mir ein Urteil bilden zu können. Wenn in der Hauptsache nur solche Irrtümer widerlegt werden, die spezifisches „Eigentum“ des P[ater] Siwek (et S.J?) sind und fast nur in Polen verbreitet worden sind, sehe ich keinen genügenden Grund für eine Übersetzung. So weit ich sehe, ist P[ater] Siwek "Werk" in Deutschland nur wenig bekannt geworden. Die Mitglieder des S.J. sind durchaus nicht alle damit einverstanden.

Im Briefe an P[ater] Mager haben mich Exzellenz viel zu wenig angeschwärzt. Er hat ihn mir gezeigt. Aber Exzellenz haben ihm ganz fein, wirklich meisterhaft etwas unter die Nase gerieben: „es soll etwas nach rechts gehen und sich da stabilisieren! Großartig! Wie mich das freut!

Heute war Prälat Hartig ${ }^{420}$ (Domkapitular in München) bei mir und berichtete, Therese Neumann „soll“ gesagt haben, Hilter werde 1 Jahr und 4 Tage regieren. Wie viele würden jubeln, wenn es war wäre!

In aller Ehrfurcht und mit besten Wünschen für das neue und kommende Werk empfiehlt sich Ew[ere] Exzellenz Dankbar ergebener

$\mathrm{P}$ [ater] Odo Staudinger OSB

b-b Nota czarnym atramentem.

a Tekst pisany czarnym atramentem na jednej karcie papieru formatu A4. W lewym górnym rogu nadruk firmowy: „Schriftleitung des Benedictus-Boten”. W górnej partii karty na centralnym miejscu graficzne wyobrażenie godła Zakonu oo. Benedyktynów: krzyż z dwiema poprzecznymi belkami stojący na trzech wzniesieniach oraz PAX. Niżej tarczy inskrypcja: „Ut in omnibus glorificetur Deus”.

${ }^{420}$ Osoba niezidentyfikowana. 


\section{Dokument 187}

Kopia: AFKDOPW, teczka 130: Spuścizna abp. Józefa Teodorowicza, sygn. 1602/185 [4], List abp. Józefa Teodorowicza do kard. Augusta Hlonda, Lwów 26 II 1934 r.

\section{Wasza ${ }^{a}$ Eminencjo!}

Przede wszystkim bardzo gorąco dziękuję Waszej Eminencji za wpaniały list pasterski ${ }^{221}$. Ujmuje on wszystkie nasze bolączki i katualne problemy na bardzo szerokiej płaszczyźnie, a również i kładzie kropkę nad „i” śmiało i odważnie. Jest to naprawdę list wspaniały, piękny, silny i aktualny. Ma on jeszcze tę wielką wartość, że w opinii całej zjednoczył Episkopat w jeden obóz.

Przy tej sposobności posyłam Waszej Eminencji kopię listu O. Generała Ledóćhowskiego do mnie i moją odpowiedź na ten list.

Ks. Metropolita Szeptycki mówił mi, iż był u niego Ks. Biskup z Jugosławii (nie umiem podać brzmienia jega nazwiska: Niedbalow?), który powrócił z audiencji od Ojca św. i Ojciec św. powiedział mu: „Będą wkrótce prześladowania Kościoła tak w Jugosławii, jak i w Polsce".

Łączę dla Waszej Ekscelencji najoddańsze wyrazy czci najgłębszej.

Lwów, dnia 26 lutego 1934

Kardynał Prymas Hlond

\section{Dokument 188}

Oryg.: AFKDOPW, teczka 145: Spuścizna abp. Józefa Teodorowicza, sygn. 365/90 [5], List z Wydawnictwa Antona Pusteta do abp. Józefa Teodorowicza, Salzburg 1 III 1934 r.

S[eine]r Exzellenz dem Hochw[ürdigen] Herrn

Erzbischof Dr. Josef Teodorowicz

Lemberg, Polen

\section{BETRIFFT IHRE NACHRICHT VOM UNSER ZEICHEN M/S/ DATUM}

01.3. [19]34

Euer ${ }^{\text {a }}$ Exzellenz sehr verehrter Herr Erzbischof!

Wir bitten gütigst entschuldigen zu wollen, wenn wir bezüglich des Christus-Manuskriptes solange mit unserer Entscheidung gewartet haben.

a Tekst pisany maszynowo na jednej stronicy papieru formatu A4.

${ }^{421}$ List pasterski Episkopatu Polski „O ducha chrxeścijańskiego w Polsce”, Warszawa 20 II 1934 r., w: Listy pasterskie, orędzia, odezwy Episkopatu Polski 1918-1939, red. A. Gąsior, J. Królikowski, Kraków 2018, s. 237-252.

a Tekst pisany maszyniowo na 1,5 stronicy papieru formatu A4. W górnej centralnej partii karty nadruk firmowy: „Verlag Anton Pustet Pressevereinsanstalten der Diözese Secau SALZBURG SIEGMUND-HAFFNER-GASSE 18, FERNSPRECHER NR. 259, DRAHTANSCRIFT PUSTET SALZBURG". 
Einmal verzögerte sich der Bericht unseres Lektors durch verschiedene Umstände und dann wollten wir auch, bevor wir eine endgültige Entscheidung trafen einen Überblick gewinnen über die politische und wirtschaftliche Entwicklung der Dinge in Deutschland. Die drohende Zuspitzung nach einem kulturellen Kampf hin wirkt sich natürlich in erster Linie auf dem Büchermarkt aus, durch grosse Zurückhaltung der bücherkaufenden Geistlichen, die ja gerade als Käufer für das geplante Buch in Frage kämen.

Die Berichte der Lektoren über das Werk waren sehr zustimmend und anerkennend. Auf Grund dessen wäre es uns eine Freude gewesen, an die Herausgabe des grossen Werkes zu schreiten, wenn uns die äusseren Umstände nicht veranlasst hätten unsere Entscheidung im negativen Sinne zu treffen. Der Umstand, dass die Gesamtanlage des Werkes auf 12 Bände berechnet ist, deren jeder doch einen grösseren Umfang aufweist, würde doch eine sehr umfangreiche finanzielle Beanspruchung bedeuten. Es erscheint uns sehr fraglich bei den eingangs geschilderten kulturellen und wirtschaftlichen Verhältnissen in Deutschland die notwendige Käuferanzahl zu finden, die eine Herausgabe sicherstellen würden.

Wir bitten daher, es gütigst verstehen zu wollen, wenn wir von einer Buchausgabe Abstand nehmen. Diese Entscheidung ist uns umso schwerer gefallen, als wir schon von Anfang an uns um das Werk bemüht hatten und es uns eine Ehre und eine Freude gewesen wäre, die deutsche Ausgabe veröffentlichen zu können. Angesichts der Verhältnisse können wir aber nicht anders entscheiden, zumal unser Verlag je durch die Deutsch-Lateinische Thomasausgabe, eine für den Augenblick sehr anspannende Aufgabe übernommen hat.

Wir bitten Euer Exzellenz uns trotz dieses Bescheides Ihr Wohlwollen zu erhalten und zeichnen in besonderer Verehrung und Wertschätzung ergebenst

b-VERLAG ANTON PUSTET

SALZBURG $^{-b}$ $[\ldots]^{\mathrm{c}}$

1 Manuskript.

\section{Dokument 189}

Kopia: AFKDOPW, teczka 134: Spuścizna abp. Józefa Teodorowicza, sygn. 1597/185 [4], List abp. Józefa Teodorowicza do nieznanego zakonnika, Lwów 10 III 1934 r.

Hochgeehrter ${ }^{\mathrm{a}}$ lieber Pater!

Ich danke Ihnen für Ihren liebenswürdigen Brief, in dem Sie nicht nur mich sondern auch dem eigentlichen Adressaten durchgeschaut haben. Ich bin mit meinem Manuskript über Konnersreuth beinahe zu Ende. Ich glaube, dass bis Ende April wird das ganze Manuskript druckfertig sein. Ich bitte Sie nun sich über Näheres bei der Buchhandlung

b-b Podłużna pieczęć.

Autograf nieczytelny.

a Tekst pisany czarnym atramentem ręką kopisty na czterech stronicach papieru formatu A4. 
„Pustet” zu erkundigen. Im schlimmsten Falle, wenn Pustet jetzt Schwierigkeiten hätte, könnte ich mit Badenia Verhandlungen anknüpfen. Aber das schreibe ich Ihnen nur vertraulich, Sie werden selbst am besten sehen, wie die Sachen stehen, und mir den Rat erteilen, um den ich Sie bitte. Pustet hat im vorigen Jahr gewünscht, damit ich ihm das Manuskript von „Betleem nach Nazaret“ schicke. Nach mehreren Monaten schickte er es mir mit der Bemerkung zurück, dass die Rezension über das Buch zwar günstig ist, aber er fürchtet vor den pecuniären Schwierigkeiten zurück, besonders weil es sich um 12 Bände handelt. Vor allem ist es ein Missverständnis, denn es geht nicht um 12 Bände, sondern um 12 Bücher, welche in 3 Bänden $[\ldots . .]^{\mathrm{b}}$ werden. Dabei kann das erste Buch „Von Betleem bis Nazaret“ separat herausgegeben werden, ohne Rücksicht auf die übrigen Bände. Ich sehe aber aus dem Briefe, das auf die Herausgabe meines Buches bei Pustet nicht zu rechnen ist. Ich Sie auch in dieser Angelegenheit sich bei Pustet erkundigen zu wollen und mir den Rat erteilen, wohin ich mit der Herausgabe dieses Buches mich wenden könnte. Ich danke Ihnen für Ihre Winke in Betreff der Übersetzung meines Buches gegen Siwek. Ich habe Ihren Rat gefolgt, und wenn die Dinge so stehen wie jetzt, werde ich das Buch nicht übersetzen lassen.

Indem ich Ihnen im voraus danke, verbleibe ich mit dem Ausdruck meiner aufrichtigsten und tiefen Hochachtung

${ }^{c-}+$ Teodorowicz ${ }^{-c}$

Lwów, 10 III 1934

\section{Dokument 190}

Kopia: AFKDOPW, teczka 130: Spuścizna abp. Józefa Teodorowicza, sygn. 1593/184 [7], List abp. Józefa Teodorowicza do kard. Augusta Hlonda, Lwów 13 III 1934 r.

Wasza ${ }^{a}$ Eminencjo!

Dziękuję za list właśnie otrzymany od Waszej Eminencji i przesyłam dołączniki do sprawy O. Siwka.

Zwracam uwagę na dwa listy ks. Biskupa Przeździeckiego, w którym jest tendencja, ażeby mnie odwieść od tłumaczenia na język niemiecki mojej książki, z tajemniczą jakąś pogróżką S[anctum] Officium. Źródła tej pogróżki należało szukać tam, gdzie ją wskazał ks. Biskup, tj. na Piazza Borgo di S[anto] Spirito ${ }^{422}$. Otóż jest to niesłychanie ciekawa ilustracja metod i postępowania tej właśnie grożącej strony, iż właśnie został dokonany przekład broszury O. Siwka przeciwko mnie na język francuski. Jest tu we Lwowie na trzeciej probacji jezuita doskonale poinformowany o tych kwestiach, który wobec znajomego mi kapłana mówił właśnie o tym przekładzie francuskim stanowiącym wedle niego dowód, jakie poważne naukowe znaczenie ma ta praca O. Siwka. Ja oczywiście biorę

b Wyraz nieczytelny.

c-c Autograf ręką autora pisma.

a Tekst pisany maszynowo na 8 stronicach papieru formatu A4. Brak autografu autora pisma.

${ }^{422}$ Siedziba Kurii Generalnej Towarzystwa Jezusowego w Rzymie. 
ten przekład z innej zupełnie strony. Chodziło w tym przekładzie niezawodnie o sprawę salwowania prestiżu profesora Gregorianum wobec mojej ostatniej książki, a następnie chodziło i o to, ażeby tą drugą książką przesłonić braki książki pierwszej. W każdym razie rzuca to światło na całą sprawę.

$\mathrm{Z}$ jednej strony tu dążenie do zamknięcia mi ust zagranicą, kiedy z drugiej strony równocześnie przypuszcza się atak na mnie i to pośród pertraktacji o pośrednictwo Waszej Eminencji. Ja nie miałem zupełnie zamiaru tłumaczenia mojego dzieła na język niemiecki; odmówiłem nawet parokrotnie ofertom, które do mnie przyszły z Niemiec, ale czy w ten sposób zaatakowany nie będę w końcu zmuszony do odpowiedzi przez przekład mojej książki, to nad tym poważnie zastanowić się muszę. W każdym razie dobrze by było, aby Generał wiedział o tym, że przecież kroki jakie on czyni mają swoje konsekwencje i muszą je mieć. Wypieranie się wszelkie jest wobec dokumentów, jakie Generałowi przedłożyłem, zupełnie bezcelowe. Także ten jezuita z probacji trzeciego roku przybywający we Lwowie tłumaczył znajomemu mi kapłanowi, że o każdym kroku O. Siwka wie Generał i każdy jego krok jest przez Generała aprobowany.

Dodaję tu jeszcze Waszej Eminencji dwa ustępy z dwu listów O. Siwka przesyłanych do mnie jeszcze wówczas, zanim się pojawiły moje artykuły w „Ateneum”. Otóż w dwóch tych listach jest czarne na białym, iż O. Siwek mistyki wcale nie używał w rozpoznaniu i w sądach o zjawiskach mistycznych. Co więcej! Uważa on użycie mistyki za przesądzenie zjawisk mistycznych, czyli uważa, że użycie mistyki jest dla badania naukowego nie tylko czymś zbędnym, ale nawet wprost szkodliwym. Albowiem przesądza o problemie z góry, kiedy tymczasem badanie naukowe powinno zająć stanowisko wyczekujące.

Otóż te właśnie słowa O. Siwka są dla niego zabójcze. Wobec tego, że on się posługuje tekstem mojego listu w swej pracy i to dwakroć, miałem wszelkie prawo w mojej książce opublikować te jego oświadczenia, które od razu kładą kres całemu sporowi i przedstawiają właściwe oblicze O. Siwka, który stoi na stanowisku zupełnego racjonalizmu w swojej książce. Tego nie uczyniłem; ale proszę Waszą Eminencję jeszcze dzisiaj zachować o tych szczegółach wobec Generała dyskrecję, bo może przyjść czas, gdzie mi te szczegóły będą potrzebne, a nie chciałbym, aby jezuici byli o nich uprzedzeni.

Co do tłumaczenia francuskiego, to nie wiem dokładnie, czy ono się już ukazało w druku i jeżeli jest drukowane, to czy jest opublikowane jako manuskrypt, czy też jako książka. Jeszcze słówko dodam co do przebiegu obecnych krytyk i dyskusji publicznych.

Ks[iądz] Metropolita Sapieha po porozumieniu się ze mną, gdy się książka moja ukazała, zwrócił się do jezuitów z tym, że ja więcej tej kwestii nie chcę poruszać, ale pod warunkiem, że oni będą milczeć; wezwał ich dlatego, aby nic więcej w tej kwestii nie pisali.

Tymczasem jakby w odpowiedzi na to pojawia się [w] „[lustrowanym] K[urierze] C[odziennym]" artykuł uderzający na mnie jak na jakiego herezjarchę, zarzucający mi wprost fideizm. Po stylu, po układzie argumentów, po nacisku na swoje własne ,ja”, poznałem od razu autora. Był nim nie kto inny, tylko O. Siwek. Przez mojego kanonika ks. Isakowicza zostało posłane do tej gazety sprostowanie zupełnie rzeczowe, które sam metropolita poprawił tak, ażeby nie było najlżejszego nawet tonu osobistego. Po tym sprostowaniu czysto rzeczowym, pokazuje się w tym samym piśmie artykulik znowu 
uderzający choć pośrednio na mnie i anonsujący jako rewelację nową odpowiedź, jaka się ma ukazać O. Siwka. Ci naiwni, którzy wierzą jeszcze w zjawiska Konnersreuth, dopiero się doczekają nowych niespodzianek!

Ten artykuł nie był wprawdzie pisany bezpośrednio przez O. Siwka, ale był przez niego inspirowany; ukazał się bowiem pod pseudonimem „Miel”, a to jest pseudonim ks. Weryńskiego, który jak to powszechnie wiadomo, jest agentem O. Siwka.

$\mathrm{Na}$ tym jednak jezuitom nie było dość. Pojawiają się znowu dwa artykuły o Konnersreuth, które znowu pisze nie kto inny tylko O. Siwek. Ks. biskup krakowski natychmiast napisał do jezuitów krakowskich list bardzo silny za te artykuły. Milczenie ich było najlepszą odpowiedzią, że trafił pod właściwy adres. Wszystkie te artykuły tak pisane do „[lustrowanego] K[uriera] C[odziennego]”, jak do „Czasu” i „Dziennika Poznańskiego" opierają się stale na sfałszowaniu mojej przewodniej tezy przez O. Siwka, jakobym ja atakował jego ostrożność naukową duchem Kościoła i wiedzy podyktowaną, a usiłował tylko wszczepić ślepą, naiwną wiarę w nadprzyrodzoność zjawisk w Konnersreuth. W tym właśnie tkwi fałsz i zła wola O. Siwka, któremu akompaniują jego koledzy zakonni. Prawda, że nie wszyscy; są tacy, którzy uważają go za pyszałka dążącego do rozgłosu przez ambicję, a wśród nich sam prowincjał, który chciał nawet, aby do mnie doszło, jakie ma o nim przekonanie. Proszę oczywiście Waszą Eminencję o dyskrecję w tej kwestii.

Otóż wobec tego, tak jak ewentualne kroki moje zagranicą wywołują właśnie jezuici swoim całym postępowaniem, podobnie dzieje się teraz i w kraju. Mój kanonik ks. Bogdanowicz chciał pisać recenzję mojej książki zaraz po ukazaniu się jej, ja go jednak wstrzymałem właśnie dlatego, ażeby nie dolewać oliwy do ognia. Na recenzje, które się ukazały, bardzo zresztą poważne, znakomitego teologa O. Fica i kanonika poznańskiego ks. Steuera nie wywierałem żadnego wpływu i dowiedziałem się o ich recenzjach bardzo spokojnych i rzeczowych dopiero ex post ${ }^{423}$. Jednym słowem stałem na stanowisku, ażeby tej całej sprawie najmniej nadawać rozgłosu. Ale kiedy się ukazały artykuły wprost czelne w „Czasie” i „Dzienniku Poznańskim”, wtedy już pozwoliłem ks. Bogdanowiczowi na odpowiedź. Nawet dołączam ją Waszej Eminencji nie tyle ze względu na treść, ile ze względu na list ks. Biskupa Buchbergera, któremu posłałem w dosłownym tłumaczeniu niemieckim wszystkie ustępy książki O. Siwka, w których się powołuje O. Siwek na świadectwa konsystorza regensburskiego.

À propos jeszcze tego artykułu maleńkie i uboczne uwagi. Ks. Bogdanowicz pomieścił w nim szczegół o doktorze Poray-Madeyskim ${ }^{424}$. Ja nie bardzo wiem, czy dr Poray-Madeyski na którego powołuje się O. Siwek jest właśnie identyczny ze znanym doktorem Poray-Madeyskim, który w Rzymie kręcił się koło jezuitów. Otóż trzeba Waszej Eminencji wiedzieć, że ten doktor szpiegował mnie i ks. Biskupa krakowskiego w czasie kiedy byliśmy w Rzymie za czasów jeszcze mojego poselstwa i ja potem w Warszawie

423 Łac.: później.

${ }^{424}$ Poray-Madeyski Bolesław - autor publikacji na temat Teresy Neumann, m.in. Le cas de la visionaire stigmatisée: Thérèse Neumann de Konnersreuth, Paris 1940. 
czytałem jego referaty o każdym naszym kroku, jakeśmy w Rzymie czynili. Ale to tylko mimochodem piszę, bo sprawa ta do rzeczy nie należy.

Ciekawe jest i naiwne zarazem, iż jezuici tłumaczą się, jakoby O. Siwek nie odpowiadał mi teraz dlatego, aby mię oszczędzić. O tym chyba mógł pomyśleć rok temu wstecz, nadając swe artykuły do naukowego pisma „Ateneum”, a nie publikując je szeroko po świecie przez książkę wobec nieznających sprawy czytelników.

Ale czyżbym ja nie wolał odpowiedzi z otwartą przyłbicą, aniżeli tego rodzaju ataki ukryte, systematycznie a ciągłe? Chcą mię oszczędzić! A przygotowali czy też już wydali francuską książkę, w której na podstawie fikcyjnych cytatów przedstawiają mnie jako nieznającego zasad wiary i błądzącego $w$ kwestii proroctw etc.

Chcą mię oszczędzić! I dlatego szukają pośrednictwa przy równoczesnych atakach z zewnątrz i z wewnątrz! Chyba trzeba wielkiej naiwności, ażeby liczyć na wiarę w takie słowa. To jest prawdą, że Siwek przygotował mi odpowiedź, którą zakazano mu drukować, ale z pewnością odpowiedź musiała być w tym stylu, w jakim są pisane jego artykuły do „Czasu” i „Dziennika Poznańskiego”, tj. przekręcające moje zasadnicze stanowisko.

Tyle o kwestii O. Siwka.

Korzystam z tej sposobności, ażeby poruszyć drugą kwestię, tj. kwestię SS. Niepokalanek, w której mnie Wasza Eminencja o sąd i zdanie zapytywał.

Otóż przede wszystkim zaznaczam, że wobec obstania nuncjusza za dalszym urzędowaniem dotychczasowego wizytatora, mimo listu, który posłał nuncjuszowi ks. Arcybiskup Twardowski ${ }^{425}$ jest faktem, z którym się liczyć należy. Ten wizytator zresztą sam głosi, że go łączą jakieś stosunki z nuncjuszem, który bezwzględnie go będzie popierał. Jeśli tak jest, to nie wiem, czy dyskusja na temat dalszych losów wizytacji w ogóle może być uważana za aktualną.

Co do mnie, to sprawę postawiłbym w ten sposób. Uważam, iż formalnie wizytacja właściwie jest już dawno skończona. Wszystko co należało do zakresu wizytacji, a więc reguła, określenie ról założycielek, aprobata pism Matki Darowskiej, wszystko to już dawno jest załatwione. Formalnie więc nie pozostaje nic więcej do zrobienia. Pamiętam doskonale, jak przed dziesięciu mniej więcej laty, pierwszy wizytator Niepokalanek O. Sobolewski ${ }^{426}$ mówił mi, że uważa właściwie dzieło wizytacji za skończone i będzie czynił odpowiednie przedstawienia w Rzymie. Pod wpływem, mylnych zresztą, pogłosek jakoby Niepokalanki dążyły same do jego usunięcia, nie wdrożył on kroków o jakich mi mówił, raczej uczynił przeciwnie. Ale w każdym razie te słowa jego doskonale pamiętam.

${ }^{425}$ Zob. w niniejszej publikacji: J. Wołczański, Listy abp. Józefa Teodorowicza do abp. Józefa Bilczewskiego, dokument 131.

426 Sobolewski Marian (1865-1922), święcenia kapłańskie w 1888 r. w Zakonie oo. Franciszkanów Konwentualnych, dr filozofii i teologii, 1892-1895 wykładowca w studium zakonnym, 1895-1998 wykładowca filozofii i sekretarz Prowincji we Lwowie, 1898-1904 przebywał w Krakowie, 1905-1913 pracował w Rzymie: postulator spraw beatyfikacyjnych, prokurator misji, prokurator generalny Zakonu, 1914-1918 prowincjał, 1918-1922 gwardian w Krakowie, 1918-1921 wizytator Zgromadzenia ss. Niepokalanego Poczęcia NMP. J. Bar, Sobolewski Marian Jan, w: SPPF, red. H.E. Wyczawski, Warszawa 19981, s. 446-447. 
Przyszedł drugi wizytator Trzemeski ${ }^{427}$, którego nieszczęsną wprost rolę działalności we wnętrzu tego Zgromadzenia przedstawiłem Waszej Eminencji. I on też na końcu uznał jego rolę za skończoną i podał się do dymisji. Ten nowy wizytator po załatwieniu ostatecznych wyborów, a raczej po wprowadzeniu bez wyborów nowego zarządu, literalnie nic więcej nie ma do zrobienia pod względem oczywiście formalnym. I naprawdę on dzisiaj w Zgromadzeniu zupełnie nie rządzi, nawiasem mówiąc stracił też i wszelki prestiż wobec spraw znanych, które się przedarły do wiadomości Zgromadzenia.

A więc o ile by chodziło o załatwienie wizytacji pod względem formalnym, to należałoby sobie tego życzyć, ażeby ten wizytator ostatecznie wizytację zakończył. Każdy wizytator bowiem, który nie zna Zgromadzenia, będzie znowu potrzebował całych lat do zapoznania się z nim i będzie znowu to biedne Zgromadzenie prowadził na drogę nowych eksperymentów. Inaczej się atoli ma rzecz, gdyby się znalazł wizytator, który zna Zgromadzenie i wie czego mu brakuje. Za takiego właśnie człowieka, który by się nadawał na wizytatora - bo dla tej roli wewnętrznej - uważam ks. Brossa. Jak i w czym potrzebuje to Zgromadzenie dziś wewnętrznego i duchowego kierunku i duchowej, i wewnętrznej reformy, na to wskazuje mój list do generalnej przełożonej, który Waszej Eminencji w kopii przesyłam.

Co do $\mathrm{Iki}^{428}$ to prawdopodobnie tak istotnie pojadę. Już skończyłem właśnie dzieło moje o Konnersreuth w niemieckim języku, a teraz biorę się do życia Chrystusa, które się najlepiej pisze nad Adriatykiem. Może by i Wasza Eminencja pomyślał coś o wypoczynku dla siebie? Mówiono mi bowiem, że nie najlepiej wygląda i jest przemęczony.

Całuję pierścień Waszej Eminencji i łączę wyrazy najgłębszej mojej czci, oddany sługa w Chrystusie.

Lwów, dnia 13 marca 1934

\section{Dokument 191}

Oryg.: AKMK, sygn. TS XII/257, List o. Włodzimierza Ledóchowskiego SJ do abp. Adama Stefana Sapiehy, Rzym 21 III 1934 r.

Rzym, 21 marca 1934

Ekscelencjo ${ }^{a}$, Najprzewielebniejszy Księże Metropolito!

Serdecznie dziękuję za łaskawy list z $19 \mathrm{bm}$. O. Siwka wstrzymywałem, by nie odpowiadał i także innej w jego obronie publikacji przeszkodziłem, ale Wasza Ekscelencja choćby tylko z „Gazety Kościelnej” z 25 bm. widzi, jak druga strona postępuje. Posłuszeństwo O. Siwka jest prawie heroiczne, choć sam czuje i ja tego samego się obawiam,

427 Trzemeski Emanuel (1879-1968), święcenia kapłańskie w 1903 r. w Zgromadzeniu oo. Redemptorystów, pracował w Tuchowie, Krakowie, Toruniu, Wrocławiu i Łomnicy Zdroju, pełnił obowiązki magistra nowicjatu, rektora Seminarium Duchownego i 1918-1933 prowincjała Zgromadzenia, 1922-1930 wizytator Zgromadzenia ss. Niepokalanego Poczęcia NMP, później analogicznie Zgromadzenia ss. Nazaretanek. P. Kurlenda, Trzemeski Emanuel, w: TSB, t. 1, red. K. Mikulski, Toruń 1998, s. 238-239.

${ }^{428}$ Ika - miejscowość wypoczynkowa nad Adriatykiem.

a Tekst pisany czarnym atramentem na dwóch stronicach papieru formatu zeszytowego. 
że jak to dłużej potrwa, wpadnie w chorobę nerwową, która może złamać mu całe życie. A nic dziwnego, że tak żywo odczuwa poniewieranie go w taki sposób po całej Polsce pod względem intelektualnym i moralnym.

O intencjach nie sądzę, ale nigdy jeszcze nie widziałem kampanii prowadzonej pod taką egidą i tak oburzającej. Temu trzeba, także zdaniem Ks. kardynała Prymasa, koniec położyć. Dlatego napisałem do Ks. A[rcy]b[isku]pa Teodorowicza robiąc mu propozycję ugodowego załatwienia sprawy przez obustronne łagodzące oświadczenie. Jeżeli Ks. Arcybiskup na to się nie zgodzi, to będę zmuszony przedłożyć Stolicy św[iętej] formalną skargę na Ks. Arcybiskupa. Będzie to dla mnie z wielu względów bardzo bolesnym, bo nigdy w życiu nie byłem zmuszony do takiego kroku, a tu chodzi o polskiego Biskupa tak blisko mi stojącego. Prócz tego obawiam się też, że wobec tego, że Ks. Arcybiskup $\mathrm{w}$ różnych listach tak pisze, jak gdyby niektórzy Biskupi polscy w tej polemice z nim się solidaryzowali, [więc] i na nich cień spadnie.

Wcale nie myślę wszystkiego bronić, co O. Siwek napisał; owszem, już nieraz swe niezadowolenie wyraziłem z powodu tego, że cenzura w Krakowie nie była w należny sposób przeprowadzona; chodzi mi głównie o stronę moralną, rzeczywiście zdaje mi się w bardzo smutnym świetle się przedstawiającą. Może Pan Jezus Zmartwychwstały da, że przecież wszystko w spokoju i miłości się ułoży.

$\mathrm{Z}$ najlepszymi życzeniami na czas wielkanocny całuję ręce Waszej Ekscelencji z najgłębszą czcią uniżony sługa

Wł[odzimierz] Ledóchowski T.J.

\section{Dokument 192}

Oryg.: AFKDOPW, teczka 145: Spuścizna abp. Józefa Teodorowicza, sygn. 1083/420 (8) [7], List ks. prof. Franza Wutza do abp. Józefa Teodorowicza, Eichstätt 22 III 1934 r.

Eichstätt, 22. III. [19]34

Eure $^{\text {a }}$ Eminenz!

Das harte Los meines Freundes Fritz Gerlich macht mir langsam große Sorge, man sagte mir, dass er diesen Sommer im Gefängnis kaum überstehen würde. Da kommt mit nun der verzweifelte Gedanke, mich an Sie, Exzellenz, zu wenden, mit der Bitte, ob Sie nicht Beziehungen anknüpfen könnten zur polnischen Regierung bzw. zum auswärtigen polnischen Amt, dass man von dort aus (durch einen Gesandten) bei der deutschen Regierung Vorstellungen mache, dass man im Ausland es nicht verstehe, dass der bedeutendste Bekämpfer ders Kommunismus (Dr. F[ritz] G[erlich]) heute noch in Schutzhaft sitze.

Da alle meine Briefe im Ausland kontrolliert werden, bringt Ferdl N. ihn über die Grenze. Eine unverfängliche Antwort würde mich sehr freuen: etwa „alles gesund!“

Mit ergebensten Grüßen Euer Exzellenz

Franz Wutz

d Tekst pisany czarnym atramentem na jednej stronicy papieru formatu zeszytowego. 


\section{Dokument 193}

Oryg.: AFKDOPW, teczka 144: Spuścizna abp. Józefa Teodorowicza, sygn. 1042/420 (8) [7], List o. Odo Staudingera OSB do abp. Józefa Teodorowicza, Salzburg 7 IV 1934 r.

Salzburg, Benediktinerkolleg[ium], am 7. IV. [19]34

Exzellenz! $!^{\mathrm{a}}$

Hochwürdigster Herr Erzbischof!

Der Brief an P[ater] Mager hat ein großes, freudiges Echo ausgelöst. Selbst von Jerusalem schrieb jemand, es sei sehr schön von P[ater] Mager, dass er diesen Brief zur Verfugung gestellt habe.

P[ater] Mager ist kein P[ater] Siwek. Das wäre aber ein gar starkes Stück, wenn er sein Buch gegen Exzellenz sogar ins Französische übersetzen ließe.

Wie ich höre, geht es jetzt Gerlich besser. Ein Domkapitular besucht ihn jede Woche. Wegen des positiven Buches habe ich mit Herrn Müller - Pustet-Verlagsleiter - gesprochen. Er hat noch immer Interesse an dem Werk, wünscht das fertige Manuskript zu sehen und möchte sich bis dahin die Entscheidung vorbehalten. Er fürchtet allerdings, dass es bei zu großem Umfang zu teuer werden und zu wenig Absatz finden könnte. Dagegen teilt er nicht die Befürchtung, dass ein österreich[ische] Verlagswerk in Deutschland auf zu große Schwierigkeiten stoßen könnte. Er findet sogar, dass deutsche Bundesländer mit Vorliebe in Österreich bestellen, weil es für den Druck nicht so viele politische Hemmungen gibt. Die Thomas - Ausgabe ist geglückt; der 1. Band erschien bereits in 2. Auflage.

Dem Werke baldige Vollendung und beste Erfolge wünschend, empfiehlt sich in Dankbarkeit und Ehrfurcht Ew[ere] Exzellenz ergebenster

$\mathrm{P}$ [ater] Odo Staudinger OSB

\section{Dokument 194}

Oryg.: AFKDOPW, teczka: Spuścizna abp. Józefa Teodorowicza, sygn. 1062/420 (8) [7], List opata o. Ernesta Vykoukala OSB do abp. Józefa Teodorowicza, Praga 9 IV 1934 r.

Euer ${ }^{\text {a }}$ Exzellenz, Hochwürdigster Neu!

Praha, Abtei Emaus, 9. April 1934

Wollen Exzellenz entschuldigen, dass ich erst heute für die gütige Widmung des grundlegenden Buches über Konnersreuth danke. Ich hoffe dasselbe einstweilen durchstudieren zu können. Leider hat es mir die viele Arbeit um die Feiertage nicht

a Tekst pisany czarnym atramentem na jednej karcie papieru formatu A4. W lewym górnym rogu nadruk firmowy: „Schriftleitung des Benedictus-Boten”. W górnej partii karty na centralnym miejscu graficzne wyobrażenie godła Zakonu oo. Benedyktynów: krzyż z dwiema poprzecznymi belkami stojący na trzech wzniesieniach oraz PAX. Niżej tarczy inskrypcja: „Ut in omnibus glorificetur Deus”.

a Tekst pisany czarnym atramentem na 2,5 stronicach papieru formatu A4. 
ermöglicht. Aber ein Überblick beweist wie kenntnisreich, logisch und geradezu souverän Eu[re] Exzellenz die ganze Frage behandeln. Die Prinzipien, die ich schon in Marienbad in persönlicher Aussprache kennen heute, sind entschieden die einzig richtigen. Wer Paulus und die Evangelien erkennt Ew[ere] Exzellenz, der einzig ist instande und berechtigt, bei solchen Phänomenen mitzusprechen. Die blosen Regeln die Schulweisheit reichen nicht aus. Es tut mir auch immens leid, wie leich man eine Seele, die so heilig lebt und erviel leidet, einfach zu einer [... $]^{\mathrm{b}}$ stempell. [... $]^{\mathrm{c}}$. Es ist auffalend, dass die Jesuiten $[\ldots]^{\mathrm{d}}$ oder $[\ldots]^{\mathrm{e}}$ Feindlich der Erscheinung gegenüberstehen. Sonst haben sie doch wenigstens zwei Eisen im Feuer. Hoffentlich wird das Werk[e] Ew[wer] Exzellenz auch in $[\ldots]^{\mathrm{f}}$ Sprachen $[\ldots]^{\mathrm{g}}$ damit es überall Eingang findet. Es ist ein wahres Lehrbuch der Mystischen Theologie, das mir Ew[ere] Exzellenz als magnus meditator, schreiben konnten. Gott velgelte es.

Mit dem [... $]^{\mathrm{h}}$ bin ich Euer Exzellenz ergebensten

† Ernest Vykoukal O.S.B. ${ }^{429}$

Abt

\section{Dokument 195}

Oryg.: AFKDOPW, teczka 140: Spuścizna abp. Józefa Teodorowicza, sygn. 953/420 (8) [7], List o. dr. Anatazego Fica OP do abp. Józefa Teodorowicza, Lwów 1 V 1934 r.

Ekscelencjo ${ }^{\mathrm{a}}$,

Lwów, dnia 1 maja 1934

Najprzewielebniejszy Księże Arcybiskupie!

Mam zaszczyt przesłać Waszej Ekscelenji adres do O. Lagrange’a, gdyż zeszłej niedzieli zapomniałem o tym.

Adres: Très Révérend Père M. J. Lagrange OP, Convent des Dominicains, Jérusalem P.O.B. 7, Palestine.

$\mathrm{Z}$ wyrazami najgłębszego hołdu

O. Atanazy Fic OP

Dwa wyrazy nieczytelne.

Dwa wyrazy nieczytelne.

Tekst nieczytelny.

Tekst nieczytelny.

Tekst nieczytelny.

g Tekst nieczytelny.

h Tekst nieczytelny.

${ }^{429}$ Zob. w niniejszej publikacji: J. Wołczański, Korespondencja abp. Józefa Teodorowicza zabp. Adamem Stefanem Sapieha, dokument 115.

a Tekst pisany czarnym atramentem na jednej stronicy papieru formatu A4. W lewym górnym rogu graficzne wyobrażenie herbu Zakonu oo. Dominikanów i nadruk firmowy: „Konwent OO. Dominikanów we Lwowie, Nr telef[onu] $4-44$ ". 


\section{Dokument 196}

Oryg.: AFKDOPW, teczka 145: Spuścizna abp. Józefa Teodorowicza, sygn. 1019/420 (8) [7], List prof. Friedricha Ritter von Lamy do abp. Józefa Teodorowicza, Gauting 6 V 1934 r.

Excellenz ${ }^{\mathrm{a}}$, Hochwürdigster Herr Erzbischof!

Durch die Veröffentlichung Ihres Buches über Konnersreuth sind Eure Excellenz im vergangenen Jahre so stark in den Vordergruna getreten, dass Sie auch im neuen Konnersreuther Jahrbuch nolens volens als stark betonte Persönlichkeit erscheinen. Wie ich dies früher bezüglich Dr. Gerlichs tat (der noch immer im Gefängnis sich befindet) so möchte ich auch gerne diesmal Ihr Bild bringen. Daher bitte ich, die Bedenken, die sich nun sofort dagegen erheben werden, gütigst beiseite zu setzen und mir leihweise ein neueres Bild von Eurer Excellenz zu überlassen; für baldige Zusendung wäre ich sehr dankbar. Wie gewünscht werde ich mit keiner Silbe erwähnen, dass eine deutsche Ausgabe Ihres Buches in Vorbereitung ist.

Indem ich Eurer Excellenz meine ehrerbietigsten Grüsse entbiete, bin ich in aufrichtiger Ergebenheit

Gauting b[ei] München, 6. Mai 1934

Friedr[ich] R[itter] von Lama

\section{Dokument 197}

Oryg.: AFKDOPW, teczka 145: Spuścizna abp. Józefa Teodorowicza, sygn. 1020/420 (8) [7], List prof. Friedricha Ritter von Lamy do abp. Józefa Teodorowicza, bmr.

Excellenz $z^{\mathrm{a}}$, hochwürdigster Herr Erzbischof!

Eben erhielt ich ein Kärtchen des mir bereits befreundeten Ministerialrates S. aus Konnersreuth; er befindet sich unterwegs an den Bodensee, wo er sich dauernd niederlassen wird, da, er in Schwerin inmitten einer rein protestantischen Umgebung unmöglich als Katholik leben kann; dazu gehört die Möglichkeit des Teilnahmens am hl. Opfer und der öftere Sakramentenempfang. Seine Konversion ist wohl nach aussen hin das wichtigste Ereignis, das sich im vorigen Jahre in Verbindung mit Resl zugetragen hat. Noch ein Jahr zuvor hätte er sich eher umbringen lassen, als dass er daran gedacht hätte, katholisch zu werden. Auch meine Bücher durften dazu beitragen, besonders auch eine wissenschaftliche Studie über die berühmte Lehninsche Weissagung, an der ich mitgearbeitet habe. Noch als Protestant konnte er sich in letzter Zeit der geberzeugung nicht mehr versagen, dass das Ende des Protestantismus gekommen, seine Auflösung nicht mehr zu verhindern ist. Eben wieder hat eine Hauptsütze des bayerischen Protestantismus, Freiherr von Pechmann, seinen Austritt aus demselben erklärt, weil er mit

a Tekst pisany maszynowo na jednej stronicy papieru formatu A4. Autograf odręczny czarnym atramentem.

a Tekst pisany maszynowo na dwóch stronicach papieru formatu A4. Autograf odręczny czarnym atramentem. Brak miejsca wystawienia i datacji. 
einer Kirche, die dem reinen Heidentum volles Bürgerrecht gewährt, nichts mehr zu tun haben will.

Ich bin Resl durchaus nicht böse über ihr Verhalten gegen mich; es ist nun einmal so, dass die Heiligen so ziemlich in allem anders denken als die anderen Leute. Der Heiland entschädigt mich auf andere Weise.

Ich möchte Eurer Excellenz heute eine grosse Bitte unterbreiten. Zwei brave Frauen hatten zu Beginn des Jahres in Regensburg um Besuchserlaubnis für Konnersreuth nachgesucht und sie nicht erhalten. Ich würde selbst das Gesuch in Regensburg für sie wiederholen, habe mich aber schon für so viele Leute dort verwendet, dass eine Bitte von mir erst recht wenig Aussicht auf Gewährung hat; die Herren in Regensburg sind eben auch nur Menschen. Wenn nun Eure Excellenz darum nachsuchen würden, würde die Besuchserlaubnis ganz gewiss erteilt. Dürfte ich darum bitten? Die eine der beiden ist eine brave katholische Lehrerin in der hintersten Slovakei, die andere eine unter schwerem Schicksal leidende Oberschlesierin. Notwendig wären zwei getrennte Scheine, der eine auf den Namen Marie Varga ${ }^{430}$, der andere auf den Namen Ann Sperlich ${ }^{431}$ lautend. Ich wäre sehr dankbar, wenn Sie Eure Excellenz darum annehmen wollten.

P[ater] Siwek wird nun in der Sache, die mir, wie er schreibt, „eine traurige Berühmtheit" verschafft haben soll, von seinen eigenen Ordensbrüdern einen Denkzettel erhalten, an dem er genug haben wird. Die PP. Jesuiten der Marquette-Universität in Milwaukee ${ }^{432}$ haben von sich aus beschlossen, die Herausgabe einer englischen Ausgabe meines Buches über den Friedensversuch Papst Benedikts XV. zu sorgen. Ich werde natürlich darüber schweigen, bis das Buch erschienen ist, dann aber bekommt er meine Antwort.

Ich entbiete Eurer Excellenz meine wärmsten und ergebensten Grüsse und empfehle mich und die Meinigen in Ihr Gebet

Friedrich R[itter] von Lama

\section{Dokument 198}

Oryg.: AFKDOPW, teczka 140: Spuścizna abp. Józefa Teodorowicza, sygn. 960/420 (8) [7], List kard. Augusta Hlonda do abp. Józefa Teodorowicza, Poznań 9 V 1934 r.

Poznań, dnia 9 maja 1934

Ekscelencjo! ${ }^{\mathrm{a}}$

W poczuciu winy, żem tak długo zwlekał z odpowiedzią na przesłane mi do Rzymu pisma, przede wszystkim bardzo pokornie proszę Waszą Ekscelencję o łaskawe darowanie mi tego opóźnienia. Muszę na swoje usprawiedliwienie przytoczyć, że w tym wypadku wina moja jest tylko materialna. Po swoim powrocie $\mathrm{z}$ Włoch jestem $\mathrm{w}$ bezustannej

430 Osoba niezidentyfikowana.

${ }^{431}$ Osoba niezidentyfikowana.

${ }^{432}$ Milwaukee - miasto w stanie Wisconsis (USA), ok. $150 \mathrm{~km}$ od Chicago.

a Tekst pisany maszynowo z wyjątkiem autografu autora listu na dwóch stronicach papieru formatu A4. W lewym górnym rogu karty tytułowej firmowy nadruk: „Prymas Polski”. 
kolizji z czasem swoim, nie mogąc się w porę pozałatwiać ze sprawami, których się tu w czasie mojej nieobecności nagromadziło co niemiara.

Miałem z Ojcem Ledóchowskim trzy długie rozmowy. Oczywiście, przede wszystkim poruszona została sprawa O. Siwka. Stanęło na tym, że O. Generał postanowił bezpośrednio znieść się z Waszą Ekscelencją. Uznał tę drogę za najprostszą i za najwłaściwszą. Toteż wycofałem się zupełnie $\mathrm{z}$ afery, życząc obu stronom, aby bez trudności ustaliły sposób zakończenia sporu.

Dziękuję za cenne materiały w sprawie Sióstr Niepokalanek. Ponieważ Matka Generalna cofnęła swój wniosek dotyczący księdza Brossa, a niemal równocześnie zrozumiałem z pewnych enuncjacji, że koła urzędowe niechętnie widzą jakąkolwiek ingerencję poza wizytatorem apostolskim, dałem sobie $\mathrm{z}$ tą całą niemiłą sprawą święty spokój i poleciłem księdzu Brossowi, aby i on ze wszystkiego się wycofał. Ze Siostrami Niepokalankami, które znam bardzo mało, utrzymuję już tylko stosunki podyktowane mi zwykłymi względami dla tak pięknej polskiej Kongregacji.

Dawno już nie mam żadnych wiadomości o zdrowiu Waszej Ekscelencji. Sądzę więc, że Ekscelencja zaniechał wyjazdu do Iki. W każdym razie z całej duszy życzę Ekscelencji sił i zdrowia do wykończenia wielkiego dzieła o Chrystusie.

Proszę przyjąć wyrazy najgłębszej czci i oddania, z którym jestem Waszej Ekscelencji powolny i oddany sługa w Chrystusie

${ }^{\mathrm{b}-}+$ August Kard. Hlond ${ }^{-\mathrm{b}}$

Jego Ekscelencja Najdostojniejszy

Metropolita Józef Teodorowicz

Arcybiskup ormiański we Lwowie

\section{Dokument 199}

Kopia: AFKDOPW, teczka 130: Spuścizna abp. Józefa Teodorowicza, sygn. 1585/185 [4], List abp. Józefa Teodorowicza do kard. Augusta Hlonda, Lwów 19 V 1934 r.

\section{Wasza ${ }^{a}$ Eminencjo!}

Bardzo dziękuję za list, który otrzymałem i posyłam Waszej Eminencji kopię ${ }^{\mathrm{b}}$ do O. Generała.

Listu tego, który on mi przysłał nie rozumiem; bo nawet Siwek nie miałby odwagi w ten sposób przeistaczać rzeczy, jak to uczynił Generał. Mógłbym tu siebie podejrzewać o jakącś] stronniczość, bo o moją sprawę idzie, ale dałem czytać list przyjacielowi Generała, księdzu metropolicie Szeptyckiemu i ten nie mógł wyjść ze zdumienia, iż na coś podobnego zdobył się Generał. Tłumaczę to sobie tym jednym o czym mówią jezuici sami, że Generał pozostaje pod nieprzepartym wpływem Siwka i że oni sami są zupełnie wobec tego bezradni.

b-b Autograf odręczny czarnym atramentem.

a Tekst pisany maszynowo na dwóch stronicach papieru formatu A4. Brak autografu autora pisma.

b Brak owego dokumentu. 
Dziękuję Waszej Eminencji za troskę o moje zdrowie; trzymam się jak na mnie jako tako, ale ja już jestem na odejściu, daleko więcej zależy na zdrowiu Waszej Eminencji, niestety, bardzo nieszanowanym i bardzo pomiatanym. A jednak tak nam trzeba steru w tych ciężkich chwilach i tak przełomowych, w których zwłaszcza masoneria uderza na młodzież i na wychowanie.

Nowego premiera ${ }^{433}$ znam i uważam go za porządnego człowieka. Obecnie za parę dni wyjadę do Krynicy; mam nadzieję, że się tam skrzepię. Pracuję już od dłuższego czasu nad życiem Chrystusa, które, o ile mi doda sił, pragnąłbym ukończyć.

Wielka szkoda, że Wasza Eminencja nie może się zająć sprawą SS. Niepokalanek. Niestety, wizytator popierany przez nuncjusza moralnie nie nadaje się do tej roli i boję się bardzo, że chaos i zamieszanie w takich warunkach po prostu może zagrozić temu ze wszech miar tak pożytecznemu Zgromadzeniu.

Prosząc Waszą Eminencję o szanowanie się większe niż dotąd, łączę najoddańsze wyrazy mej czci najgłębszej.

Lwów, dnia 19 maja 1934

\section{Dokument 200}

Kopia: APJK, sygn. 1426, Konopka Włodzimierz TJ. Korespondencja prowincjalska za rok 1934, List o. Włodzimierza Konopki SJ do abp. Józefa Teodorowicza, Kraków 21 V 1934 r.

Kopia

Kraków, dnia 21 maja 1934

Ekscelencjo $^{\mathrm{a}}$, Najczcigodniejszy Księże Arcybiskupie!

Wracając z objazdu domów wschodnich przed $1 \frac{1}{1 / 2}$ tygodnia dowiedziałem się od O. Mirka ${ }^{434}$, że Wasza Ekscelencja życzyłby widzieć się ze mną. Również i ja odkładałem na ten czas złożenie należnego homagium, niestety! Otrzymałem telegraficzną wiadomość o przyspieszonym wyjeździe O. Prefekta Apost[olskiego] Wolnika ${ }^{435}$ do Afryki. Wobec tego pospiesznie musiałem wyjechać, by omówić jeszcze konieczne sprawy. Proszę tedy wybaczyć, że się nie mogłem zgłosić do Waszej Ekscelencji; dowiedziawszy się jednak, że Jego Ekscel[encja] będzie w Krynicy przebywał na kuracji przez dłuższy czas, będę się więc starał tam moje złożyć uszanowanie.

Proszę kornie o Arcypasterskie błogosławieństwo.

${ }^{433}$ Aluzja do prof. Leona Kozłowskiego (1892-1944), pełniącego funkcję premiera rządu polskiego w okresie 15 V 1934 r. - 28 V 1935 r.

a Tekst pisany maszynowo na $1 / 2$ stronicy papieru formatu A4. Brak autografu.

${ }^{434}$ Mirek Stanisław (1892-1978), święcenia kapłańskie w 1916 r. w Zakonie oo. Jezuitów, 1919-1923 studia na UJ, wykładowca religii i j. łacińskiego w kolegium jezuickim w Wilnie, operariusz w Kołomyi i Lwowie, od 1946 r. duszpasterz akademicki we Wrocławiu, 1950-1951 więziony, 1970-1973 ojciec duchowny w Czechowicach, 1973-1978 przebywał w Starej Wsi. Mirek Stanisław, w: EWJ, s. 427.

435 Wolnik Bruno (1882-1960), święcenia kapłańskie w 1913 r. w Zakonie oo. Jezuitów, 1915-1919 kapelan wojskowy, 1920-1925 wicerektor i rektor domu w Krakowie, 1925-1960 misjonarz w Afryce: 1927-1950 
Jego Ekscelencja Najprzew[ielebniejszy]

Ksiądz Metropolita

Józef Teodorowicz

Lwów

\section{Dokument 201}

Oryg.: AFKDOPW, teczka 140: Spuścizna abp. Józefa Teodorowicza, sygn. 952/420 (12) [7], List o. dr. Atanazego Fica OP do abp. Józefa Teodorowicza, Lwów 22 V 1934 r.

Lwów, dnia 22 maja 1934

Ekscelencjo! ${ }^{\mathrm{a}}$

Bardzo przepraszam Waszą Ekscelencję, że nie mogłem na łaskawe zaproszenie stawić się ani wcześniej przeprosić, gdyż w niedzielę, poniedziałek i wtorek odbywa się zjazd orientalistów we Lwowie, gdzie ja też miałem referat, a jako członek czynny wybrany ostatnio musiałem brać udział we wszystkich posiedzeniach, które trwały do 9 wieczorem i później. Dzisiaj wieczorem kończy się już zjazd i od jutra jestem do łaskawej dyspozycji Waszej Ekscelencji.

W tych dniach otrzymałem z Rzymu list (datowany 10/V b.r.) od O. B[ernarda] Przybylskiego O.P. ${ }^{436}$, który dyskretnie poszukiwał francuskiego tłumaczenia drugiej książki ks. Siwka. Oto, co mi pisze O. Przybylski: „W pogoni za tłumaczeniem elaboratu Ks. Siwka doszedłem do końca. Tłumaczenia żadnego dotychczas nie ma i nie będzie. Zgłaszała wprawdzie jakaś «dostojna paniusia z Polski gotowość przetłumaczenia tej książki na jęz[yk] francuski» (słowa Ks. Siwka), ale Ks. Siwek wspaniale z tej oferty zrezygnował, bo tak obecnie obarczony jest pracą naukową, że nie może przejrzeć polskiej swej pracy, a nie chciałby, aby w jęz[yku] francuskim na nowo i w tej samej formie i treści miała być drukowana".

Oto streszczone słowa Ks. Siwka; lecz [O. Przybylski] pewien jest, że dotychczas tłumaczenia tej książki monumentalnej nie ma. W szczerość zaś słów Ks. S[iwka] wierzyć się powinno, nisi aliud probaretur (contrarium) ${ }^{437}$.

Oto list O. Przybylskiego. Mnie osobiście nie bardzo chce się w to wierzyć, aby ta „pani” sama się zgłosiła do tłumaczenia, jeżeli w ogóle zgłosiła się, a nie jest tylko czystym wymysłem.

a Tekst pisany czarnym atramentem na trzech stronicach papieru formatu zeszytowego. W lewym górnym rogu karty tytułowej graficzne wyobrażenie herbu Zakonu oo. Dominikanów i nadruk firmowy: „Konwent OO. Dominikanów we Lwowie Nr tel[efonu] 4 - 44”.

${ }^{436}$ Przybylski Bernard (1907-1979), święcenia kapłańskie w 1933 r. w Zakonie oo. Dominikanów, dr teologii, 1936-1937 wykładowca w studium zakonnym we Lwowie, 1937-1939 duszpasterz akademicki w Poznaniu, 1939-1940 więziony przez Niemców, 1942-1945 przebywał w Warszawie, 1946-1950 prowincjał polskiej prowincji, 1957-1979 twórca i dyrektor Instytutu Tomistycznego, autor artykułów teologicznych głównie z zakresu mariologii. Z. Mazur, Przybylski Bernard Ludwik, w: SPTK, t. 6, red. L. Grzebień, Warszawa 1983, s. 730-735.

${ }^{437}$ Łac.: chyba, że coś innego zostanie dowiedzione. 
List do O. Generała przeczytałem w całości - zwracam go Waszej Ekscelencji. O. Przeor także go czytał i sądzi, że argumentacja jest bardzo rzeczowa, spokojna i delikatna. $\mathrm{Z}$ wyrazami najgłębszego hołdu

O. Atanazy Fic Z[akon] K[aznodziejski]

\section{Dokument 202}

Oryg.: APJK, sygn. 1426, Konopka Włodzimierz TJ. Korespondencja prowincjalska za rok 1934, List abp. Józefa Teodorowicza do prowincjała ooo Jezuitów o. Włodzimierza Konopki SJ, Krynica 4 VI $1934 \mathrm{r}$.

$\dagger$

Drogi ${ }^{a}$, Przezacny Ojcze Prowincjale!

Bardzo mnie wzruszyła niezwykła dobroć i łaskawość Ojca prowincjała, jaką mi okazać raczył w gotowości odwiedzenia mnie w Krynicy, skoro to nie było możliwym już we Lwowie. Jakkolwiek sam we Lwowie prosiłem Ojca Prowincjała o widzenie się i jakkolwiek tak wysoko sobie cenię te względy Ojca Prowincjała, to jednak właśnie dlatego nie chciałbym narażać Ojca Prowincjała na poniesienie aż tak wielkiego trudu dalekiej podróży dla mnie. Dlatego mimo pokusy mojego serca, jednak bardzo a bardzo proszę Ojca Prowincjała, ażeby osobno się nie fatygował aż tu do mnie i by nie przyjeżdżał. Miałem pewną ważną sprawę, którą bardzo pragnąłem poufnie omówić z Ojcem Prowincjałem przed jej załatwieniem, ale z powodu przynaglenia okoliczności już dziś o tej sprawie przesądziłem.

Jeszcze raz gorąco Ojcu Prowincjałowi dziękuję za Jego serce i względy, którym się nadal polecam, kreśląc się zawsze oddanym w głębokiej czci i szacunku.

† Teodorowicz

Krynica, Dom Sióstr Elżbietanek, 4/VI [1]934

\section{Dokument 203}

Oryg.: AFKDOPW, bsygn., teczka: Spuścizna abp. Józefa Teodorowicza, List z Drukarni i Księgarni św. Wojciecha w Poznaniu do abp. Józefa Teodorowicza, Poznań 6 VII 1934 r.

Poznań, dnia 6 lipca 1934

$\mathrm{J}\left[\right.$ ego ${ }^{\mathrm{a}} \mathrm{E}[$ kscelencja]

a Tekst pisany czarnym atramentem na dwóch stronicach formatu karty pocztowej. W lewym górnym rogu nota inną ręką: „Do: sprawy O. Siwka”.

a Tekst pisany maszynowo $\mathrm{z}$ wyjątkiem autografów nadawców na jednej stronicy papieru formatu A4. W górnej partii karty firmowy nadruk: „Drukarnia i Księgarnia św. Wojciecha S.O.O.” i logo instytucji. W lewym górnym rogu nadruk firmowy: „Adres telegraficzny: Albertinum - Poznań. P.K.O. Poznań 200032. Konto Bankowe: Bank Związku Spółek Zarobkowych, Poznań. Konto czekowe: Wrocław 5411. Telefony: 2241, 2678, 3127, 3613, 3614. W odpowiedzi prosimy powołać się na znak: Nr dz. 1690/34. B.W." Niżej nota czarnym atramentem ręką abp. Teodorowicza: „Załatwione”. W dolnej partii karty nota ołówkiem inna ręką: „Przez Bank”. 


\section{Najprzew[ielebniejszy] Ks. Arc[ybiskup] Józef Teodorowicz \\ we Lwowie \\ ul. Ormiańska}

Ekscelencjo, Najdostojniejszy Księże Arcypasterzu!

Kartka Waszej Ekscelencji przyszła pod nieobecność p[ana] inż. Jeleńskiego bawiącego na urlopie.

Czyniąc zadość życzeniu Waszej Ekscelencji przesyłamy równocześnie po 5 egzemplarzy dzieł: „Od Betle[j]em do Nazaretu” i „Zjawiska mistyczne...”. Do przesyłki pozwoliliśmy sobie dołączyć przekaz na P.K.O. na sumę zł 52,50, tj. na należność naszą obliczoną z 50 \% upustu.

Wyrazy czci najgłębszej łączymy

b-[...], H. Grodzka ${ }^{-b}$

\section{Dokument 204}

Kopia: AFKDOPW, teczka 130: Spuścizna abp. Józefa Teodorowicza, sygn. 1592/184 [7], List abp. Józefa Teodorowicza do kard. Augusta Hlonda, Lwów 11 VIII 1934 r.

\section{Wasza ${ }^{a}$ Eminencjo!}

Byłbym już dawno napisał do Waszej Eminencji, ale czekałem na sposobność porozumienia się z Eksc[elencją] Metropolitą Sapiehą, który właśnie był u mnie wczoraj. Przedłożyłem mu mój projekt zareagowania na rzecz tak dla mnie dotkliwą, jaką była uchwała pomieszczona w protokole w sprawie O. Siwka i mojej ${ }^{438}$. Takiego pomieszczenia w protokole sprawy dotyczącej mnie i to sprawy tak dla mnie drażliwej nie mogłem zupełnie zrozumieć, albowiem uchwalona została rezolucja, pomieszczona w protokole, która dotyczy mnie, jakkolwiek pozornie wygląda na odpowiedź daną księdzu. Zdaje mi się jednak, iż trudne jest do pomyślenia, ażeby konferencja biskupów z jednej strony zaszczycała, a z drugiej strony sama siebie zniżała do odpowiedzi na list prywatny księdza przez umieszczenie tego w protokole obrad. Trudno znowu mi przypuścić, że Konferencja działała nieszczerze i pod pozorem odpowiedzi księdzu chciała mi dać nauczkę, a raczej chciała mię poświęcić Generałowi Jezuitów, w tej chwili toczącemu ze mną walkę.

Wasza Eminencja zrozumie, że mam najzupełniejszą słuszność, jeżeli się czuję podobnym aktem $\mathrm{w}$ najwyższym stopniu dotkniętym i jeżeli wyrażam moje zdumienie, ale i moje uczucie wewnętrzne, że stoję przed faktem jak przed zagadką.

Po rozmowie z rozmowie z Księciem Arcybiskupem Sapiehą, który uznał pomieszczenie w protokole tej sprawy za gruby nietakt wobec mojej osoby, dochodzę do przekonania, że zarówno on, jak i Wasza Eminencja nie zwrócił uwagi na protokół. Może być, iż był tylko w tym czynny albo suchy biurokratyzm, albo też, co jest bardzo

${ }^{438}$ Aluzja do noty zawartej w protokole z obrad Episkopatu Polski. Zob w niniejszej części dokument 206.

b-b Autografy pisane czarnym atramentem. Pierwszy z nich nieczytelny.

a Tekst pisany maszynowo na dwóch stronicach papieru formatu A4. W prawym górnym rogu karty tytułowej odręczna nota: „Kopia”. 
prawdopodobne, ręka jednego z Księży Biskupów specjalnie zainteresowanego w tej sprawie. Może być, że są to moje nieuzasadnione domysły, które jednak faktu samego nie zmieniają w niczym, iż rezolucja podobna znajduje się w protokole.

Otóż po porozumieniu się z Księdzem Arcybiskupem Sapiehą, któremu przeczytałem projekt mojej odpowiedzi, przesyłam tę odpowiedź Waszej Eminencji z prośbą, ażeby była w całości odczytana na Konferencji Księży Biskupów ${ }^{439}$. W każdym razie proszę, ażeby Wasza Eminencja zechciał mię zawiadomić, czy się godzi, by załączone tu pismo było na Konferencji oczytane.

Przy tej sposobności muszę zauważyć, że pisząc ostatni list w tej sprawie do Waszej Eminencji myślałem, że to Księża Biskupi zapraszają Ojca Siwka, a nie Komitet złożony z trzech członków; nic też o tym nie wiedziałem, że referat O. Siwka już został opublikowany w streszczeniu, czyli, że nie wiedziałem o tych szczegółach, które uniemożliwiałyby zupełnie Waszej Eminencji uchylenie referatu O. Siwka na zjeździe tomistycznym ${ }^{40}$.

Łączę dla Waszej Eminencji wyrazy mej najgłębszej czci.

Lwów, dnia 11 sierpnia 1934

\section{Dokument 205}

Oryg.: AFKDOPW, teczka 145: Spuścizna abp. Józefa Teodorowicza, sygn. 1018/420 (8) [7], List prof. Friedricha Ritter von Lamy do abp. Józefa Teodorowicza, Gauting 18 VIII 1934 r.

Excellenz ${ }^{\mathrm{a}}$, Hochwürdigster Herr Erzbischof!

Gauting b[ei] München, 18. August 1934

Heute komme ich mit einer Bitte. Würden Eure Excellenz die Güte haben, ein Exemplar Ihres Buches gegen P[ater] Siwek an folgende Adresse zu schicken: Rev. J. Bunse, S.J. ${ }^{441}, 371$ Watson Street, Buffalo ${ }^{442}$, N.Y., U.S. America. P[ater] Siwek hat in einer Angelegenheit, die von sehr grosser Wichtigkeit ist und in der das Diabolische eine sehr grosse Rolle spielt (auch mein Bruder M.SS.C. war daran hervorragend beteiligt) durch ein „wissenschaftliches Gutachten“ in selbstverständlich negativer Weise eingegriffen und es läge mir sehr viel daran, jenem P[ater] Bunse, mit dem ich befreundet bin, Gelegenheit zu geben, sich von den wissenschaftlichen Fähigkeiten P[ater] Siweks zu überzeugen. P[ater] Bunse steht in der erwähnten Sache nicht auf Seite seines Mitbruders.

In Regensburg vollzieht sich mehr und mehr ein Umschwung zum Glauben an das Uebernatürliche, wozu die oben erwähnten Ereignisse erheblich beigetragen haben. Ich begrüsse Eure Excellenz mit dem Ausdruck meiner aufrichtigen Verehrung ergebenst F[riedrich] R[itter] von Lama

439 Zob. w niniejszej części dokument 206.

${ }^{440}$ Międzynarodowy Kongres Tomistyczny odbył się w Poznaniu w dniach 28 - 30 VIII 1934 r. O. prof. Paweł Siwek wygłosił wówczas referat pt.: „Reinkarnacja i jej wynikłości moralne w świetle filozofii”. K. Kowalski, Międzynarodowy Kongres Filozofii Tomistycznej w Poznaniu, CT, 1935, fasc. 1, s. 134-139.

a Tekst pisany maszynowo na jednej stronicy papieru formatu A4. Autograf odręczny czarnym atramentem.

${ }^{441}$ Osoba niezidentyfikowana.

${ }^{442}$ Buffalo - miasto w stanie Nowy Jork (USA). 


\section{Dokument 206}

Kopia: AFKDOPW, bsygn., teczka: Spuścizna abp. Józefa Teodorowicza, List abp. Józefa Teodorowicza do kard. Augusta Hlonda, Lwów 23 VIII 1934 r.

\section{Wasza $^{\text {a }}$-Eminencjo! ${ }^{-b}$}

W protokole ostatniej konferencji Komisji prawnej została pomieszczona rezolucja, która podkreślała brak łączności sporu mojego naukowego z O. Siwkiem, a zaproszeniem O. Siwka z referatem do Poznania. Ponieważ rezolucja dotyczyła mojej sprawy, której skutkiem mej nieobecności na konferencji wyjaśnić nie mogłem, przeto określam ex post moje stanowisko, ażeby ustrzec je przed wszelką dwuznacznością.

Istotnie, gdzie Księża Biskupi w ogóle nie są powołani do komitetu urządzającego kongres międzynarodowy tomistyczny i gdzie jedynie członkiem tego komitetu jest Ksiądz Prymas, któremu przedstawiono gotowe już referaty ogłoszone w dziennikach, tam łączenie jakiejkolwiek sprawy sporu naukowego między mną a O. Siwkiem jakkolwiek ma za tło Konnersreuth, toczył się nie o Konnersreuth, ale o metody w badaniach mistycznych, orzekających o zjawiskach mistycznych z pominięciem zupełnym kryteriów mistycznych o przesądzeniem o nich przez analogie psychopatyczne. Szło mi więc nie o Konnersreuth, jak to wyraźnie zaznaczyłem, ale o metody podważające w ogóle mistykę i wszelką pewność co do prawdziwości wszystkich stanów mistycznych.

Nie mogę przy tym i tego pominąć, iż obok sporu naukowego, spór ten dotyczył kwestii nic niemającej z nauką wspólnego, bo kwestii moralnej. Między innymi spór ten narzucił pytanie, czy jest dozwolona tego rodzaju polemika publiczna zakonnika z biskupem, w której ten zakonnik pomieszczając wyjątki z listów pisanych do niego przez tego biskupa, fałszuje ich znaczenie i sens, tak samo jak tendencyjnie przekręca teksty tez naukowych biskupa, ażeby w ten sposób wykazać ignorancję biskupa? Czy jest dalej dozwolony publiczny atak oparty o przekręcenie tekstu zakonnika na biskupa, zarzucający biskupowi błąd contra doctrinam christianam w kwestii tak zasadniczej jak proroctwa? Czy jest w końcu dozwolone, ażeby zakonnik ów na wykładzie publicznym ${ }^{{ }^{c-}}{ }^{-}$Rzymie $^{-\mathrm{c}}$ kpił z tego biskupa wśród międzynarodowego audytorium, wymieniając jego nazwisko i pozwalając sobie na uwagi, że jeśli kto nie ma wyobrażenia o rzeczy, ten niech się lepiej do pisania nie bierze i czy podobne, bądź co bądź niezwykłe i dotąd nieznane, niemające precedensu metody, obchodzą li tylko jednego biskupa, czy też wiążą pewną solidarnością i innych?

Poruszam te kwestie czysto teoretycznie, powodowany do tego tekstem protokołu, gdyż ani myślałem, ani też myślę o ile to mnie dotyczy, zajmować Najdostojniejszych Księży Biskupów.

Jeżeli mam jaką[ś] prośbę do Najdostojniejszych Księży Biskupów to tylko tę jedną, ażeby jeżeli ktoś poruszy moją jakąś sprawę i jeżeli konfederacja Najdostojniejszych Księży Biskupów będzie uważała tę sprawę aż za tak ważną, że rezolucję odnoszącą się

\footnotetext{
a Tekst pisany maszynowo na trzech stronicach papieru formatu A4.

b-b Nota napisana odręcznym pismem.

${ }^{c-c}$ Fragment dopisany odręcznnym pismem autora listu.
} 
do mnie zechce pomieścić w protokole, to $\mathrm{w}$ takim razie gdyby się coś podobnego zdarzyło, będę bardzo zobowiązany Najdostojniejszym Księżom Biskupom, jeżeli z jaką[ś] kwestią wprzód do mnie się zwrócą o wyjaśnienie.

${ }^{\mathrm{d}}+$ Teodorowicz ${ }^{-\mathrm{d}}$

Lwów, dnia $23^{\mathrm{e}}$ sierpnia 1934

\section{Dokument 207}

Kopia: AFKDOPW, teczka 129: Spuścizna abp. Józefa Teodorowicza, sygn. 1545/185 [4], List abp. Józefa Teodorowicza do o. dr. Atanazego Fica OP, Lwów 16 X 1934 r.

\section{Drogia Ojcze!}

Przybyłem w sobotę do Lwowa z nadzieją, że w niedzielę zaproszę Ojca na partię szachów, aż tu jak grom z nieba pada list Ojca z wiadomością, że jest w Krakowie. Czyż się to godzi swoim przyjaciołom takie niespodzianki urządzać? $Z$ drugiej strony muszę powiedzieć, że się cieszę tym, iż Drogi Ojciec zaczął swe wykłady w Krakowie. To, że Ojciec z Abrahama i jego ziemi potrafi tyle soków dziś wycisnąć jest doprawdy rzeczą zdumiewającą, jednak są to rzeczy niezwykle interesujące i ciekawe dzięki najnowszym odkryciom.

Osobno i bardzo dziękuję Ojcu za obiecaną recenzję mojej książki w „Revue Biblique”; także dziękuję Ojcu za rozmowę z O. Lavaud.

Słyszałemjużoduczestników kongresu tomistycznego w Poznaniu, że wypadłon wprost marnie pod względem naukowego niveau $^{443}$; poza O. Lavaud, Maritain'em ${ }^{444}$ i ks. Stepa ${ }^{445}$ miały być to raczej wykłady popularne, zaś co do Siwka, to jak słyszałem od jego przyjaciela, miał on mówić jak gdyby do dzieci, no i oczywiście ani dotknął św. Tomasza.

Mam moją pracę o życiu Chrystusa w drugim tomie prawie na ukończeniu. Rozszerzyłem jednak ogromnie ponad zamiar pierwotny wstępny dział o religii żydowskiej, nie wymieniając Zielińskiego ${ }^{446}$ jak tylko mimochodem, jednak kwestie podminowane przez niego starałem się w właściwym świetle przedstawić; uważam bowiem, że wpływ tej książki jest ogromnie destrukcyjny. To jednak tak obciąża materiałem samo życie Chrystusa, iż się poważnie nad tym zastanawiam, czy by tego działu może łącznie z ewangeliami omówionymi krytycznie nie wydać osobno, oczywiście w łączności z życiem Pana Jezusa? Wtedy by samo życie Chrystusa zaczęło się od tomu następnego, a nie byłoby w łączności, jak to myślałem z tomem tym, który teraz do druku przygotowuję.

\footnotetext{
e Na maszynie napisano datę 11 sierpnia, którą poprawiono odręcznie na 23 sierpnia.

d-d Autograf własnoręczny autora pisma.

a Tekst pisany maszynowo na dwóch stronicach papieru formatu A4. Brak autografu autora pisma.

${ }^{443}$ Fr.: poziomu.

${ }^{444}$ Właściwie: Maritain Jacques (1882-1973), francuski filozof, teolog i myśliciel polityczny. S. Kowalczyk, Maritain Jacques, w: EK, t. 11, red. S. Wilk, Lublin 2006, kol. 1383-1387.

${ }_{445}$ Zob. w niniejszej publikacji: J. Wołczański, Wybór korespondencji o. Włodzimierza Ledóchowskiego SJ $z$ o. prof. Pawtem Siwkiem SJ, dokument 8.

${ }_{446}$ Zob. w niniejszej publikacji: tenże, Korespondencja abp. Józefa Teodorowicza z abp. Adamem Stefanem Sapieha, dokument 110.
} 
Od O. Lagrange'a otrzymałem nadzwyczaj dobry, serdeczny i piękny list.

Pozostaję w małej nadziei obaczenia się z Drogim Ojcem na Boże Narodzenie i łączę dla Drogiego Ojca zawsze serdeczne i oddane wyrazy szacunku i przyjaźni.

Lwów, dnia 16 października 1934

O. Atanazy Fic - Kraków, OO. Dominikanie

\section{Dokument 208}

Oryg.: AFKDOPW, teczka 141 : Spuścizna abp. Józefa Teodorowicza, sygn. 993/420 (8) [7], List o. Benoît Lavauda OP do nieznanego duchownego, Fryburg 17 X 1934 r.

Mon ${ }^{a}$ Révérend et cher Père,

Fribourg $^{447}$, le 17 oct[obre] 1934

Bien volontiers je ferai le compte rendu de la controverse entre Mgr Teodorowicz et le $\mathrm{P}$ [ère] Siwek au sujet de Thérèse Neumann. J'attends votre résumé français ou latin. Je désirais depuis un certain temps étudier cette controverse. S'il est possible d'acheter sa version allemande, soyez assez bon de me l'envoyer. Si tout est en polonais, ce n'est pas nécessaire,puisque je n'entends rien à la langue polonaise. Mais alors indiquez exactement les titres des ouvrages et toutes les précisions bibliographiques. Si j'avais pu aller à Cracovie, j'aurais essayé de voir Mgr Teodorowicz et lui aurais demandé audience pour parler de cette question.

Veuillez agréer, Révérend et cher Père, mes fraternels hommages en N[otre] P[ère] S[ain]t Dominique

fr[ère] Benoît Lavaud OP

Fribourg

\section{Dokument 209}

Oryg.: AFKDOPW, teczka 140: Spuścizna abp. Józefa Teodorowicza, sygn. 950/420 (8) [7], List o. dr. Atanazego Fica OP do abp. Józefa Teodorowicza, Kraków 9 XI 1934 r.

Kraków, Konwent OO. Dominikanów dnia 9 listopada 1934

Najprzewielebniejszy ${ }^{a}$ Księże Arcybiskupie!

W ostatnim zeszycie (1 Novembre 1934) „La vie spirituelle, ascétique et mystique” jest mały artykuł G. Thibon'a o Teresie Neumann p.t.: „Èlisabeth X et Therése Neumann” (str. [95]-[103]), bardzo rzeczowy i dotyczący głównie metody badań zjawisk Konnersreuth. Autor, krytykujący pracę Dr. Lechler'a ${ }^{448}$ : „Die Rätsel von Konnersreuth im Lichte eines

${ }^{447}$ Fribourg - miasto stołeczne kantonu Fribourg nad rzeką Sarine (Szwajcaria).

a Tekst pisany czarnym atramentem na dwóch stronicach papieru formatu zeszytowego.

a Tekst pisany czarnym atramentem na 2,5 stronicach papieru formatu zeszytowego.

${ }^{448}$ Lechler Alfred (1881-1971) - niemiecki lekarz neurolog. 
neuen Falles von Stigmatisation", stoi na tym samym stanowisku i posługuje się tymi samymi argumentami, co Wasza Ekscelencja w stosunku do prac O. Siwka: z radością to stwierdziłem.

Moje wykłady postępują naprzód, mam wrażenie, dość dobrze. Mam też kilka odczytów dla szerszej publiczności, przeważnie z dziedziny ewangelicznej. Ostatni odczyt mam 11 stycznia 1935, następnego dnia, tj. 12 stycznia wracam do Lwowa.

Z wyrazami najgłębszej czci i hołdu dla Waszej Ekscelencji

O. Atanazy Fic O[rdo] Pr[aedicatorum]

\section{Dokument 210}

Kopia: AFKDOPW, bsygn., teczka: Spuścizna abp. Józefa Teodorowicza, List abp. Józefa Teodorowicza do ks. Jana Wieczorka, Lwów 17 XI 1934 r.

\section{Przezacny ${ }^{a}$ Księże Rektorze!}

Praca moja właściwa o Konnersreuth w niemieckim języku jest w przygotowaniu do druku jeszcze niewydana. Polskie tłumaczenie ma się też później ukazać. Jak z listu Księdza Rektora wnoszę, znana jest Księdzu Rektorowi praca moja kontrowersyjna z O. Siwkiem. Poza tym dziełem „Zjawiska mistyczne i ich tłumaczenia” nie wydałem żadnej pracy, nie mam też żadnego manuskryptu z konferencji moich, jakie miałem o Konnersreuth w Krakowie. Ukazało się wtedy tylko w „Ilustrowanym Kurierze Codziennym” dokładne streszczenie tych odczytów, którego nie posiadam („[[lustrowany] K[urier] C[odzienny]" z dnia 11 XII 1930) ${ }^{449}$.

Uważam jednak za konieczne, by się zaopatrzeć w książkę Helmuta Fahsela tłumaczoną na język polski pt.: „Konnersreuth" ${ }^{\text {”50; }}$ w tej książce jest najbogatszy materiał, który zjawisk Konnersreuth dotyczy.

Miło mi przy tej sposobności dołączyć wyrazy prawdziwie oddane głębokiego poważania.

Lwów, dnia 17 listopada 1934

Ks. Jan Wieczorek ${ }^{451}$ - Radziejów Kujawski ${ }^{452}$

a Tekst pisany maszynowo na jednej stronicy papieru formatu A4. Brak autografu autora listu.

${ }^{449}$ Od czterech lat bez jadta i napoju. Co arcybiskup Teodorowicz widziat w Konnersreuth?, IKC, 31(1930), nr 336, s. 6-7.

${ }^{450}$ H. Fahsel, Konnersreuth: Tatsachen und Gedanken; ein Beitrag zur mystischen Theologie und Religionsphilosophie, Berlin 1931. Przekład w j. polskim: Konnersreuth. Przyczynek do teologii mistycznej i filozofii religijnej, tłum. A. Majewski, Warszawa 1933.

451 Wieczorek Jan (1899-1942), święcenia kapłańskie w 1922 r. we Włocławku, 1922-1923 wikariusz par. Dobrzec, 1923-1925 wikariusz par. Izbica Kujawska, 1926-1937 duszpasterz par. Radziejów Kujawski, 1937-1939 duszpasterz par. Pyzdry, 1939-1940 katecheta w Słupcy, 1940-1942 proboszcz par. Opatówek, 6 X 1941 r. aresztowany przez Niemców i osadzony w obzie koncentracyjnym Dachau, 17 VI 1942 r. zginął tamże; autor broszurek 600 lecie bitwy pod Płowcami i O honor i dobro Polski. Źródło: Jan Wieczorek, www. swzygmunt.knc.pl/MARTYROLOGIUM/.../POLISHRELIGIOUSmartyr2950.ht.... Dostęp: 12 V 2017 r.

${ }^{452}$ Radziejów Kujawski - miasto na Kujawach w pobliżu Inowrocławia. 


\section{Dokument 211}

Kopia: AFKDOPW, teczka 129 i 136: Spuścizna abp. Józefa Teodorowicza, sygn. 1511/185 [4] i 2001/415 [4], List abp. Józefa Teodorowicza do o. dr. Atanazego Fica OP, Lwów 17 XI 1934 r.

\section{Drogi ${ }^{\mathrm{a}}$, Kochany Ojcze!}

Bardzo dziękuję za list ostatni i niezmiernie się cieszę sukcesami Kochanego Ojca; jednym się tylko martwię, że Kraków coraz bardziej pochłania Kochanego Ojca i odstręcza Go od Lwowa. Już nawet Boże Narodzenie we Lwowie zbagatelizował sobie Ojciec na rzecz Krakowa, bo dopiero 11 stycznia zagości tu do nas. Ale spodziewam się, że od stycznia zatrzymamy tu Ojca.

Dziękuję za zwrócenie mi uwagi na istotnie bardzo ciekawy artykuł francuskiego doktora, który nawet najprawdopodobniej do swej pracy załączę. Podejrzewam Ojca o sprawozdanie z kongresu eucharystycznego, które z tonu dopowiada to, czego w treści wyrazić nie można. O referacie O. S[iwka] wyraziła się pewna urszulanka z Krakowa, że był na niveau szóstoklasisty; w tym samym mniej więcej duchu wyraził się o tym referacie przyjaciel O. S[iwka], kapłan przejeżdżający przez Lwów, a studiujący w Rzymie.

Praca moja niemiecka jest już w manuskrypcie gotowa, czeka tylko na korektury. Niestety! Brak mi dziś na to czasu, gdyż widocznie zaraził mnie Ojciec Starym Testamentem, w który wszedłem po uszy. Uważam jednak, że wobec tylu zarzutów i uprzedzeń przeciw Staremu Testamentowi, zwłaszcza wobec pamfletu Zielińskiego, konieczną jest rzeczą rozszerzyć się nad problemem St[arego] Testamentu i użyć takiej pracy za wstęp do życia Chrystusa.

Łączę dla Kochanego Ojca wyrazy zawsze oddane i najserdeczniejsze pozdrowienia zasyłam

${ }^{b-}+$ Teodorowicz ${ }^{-b}$

Lwów, dnia 17 listopada 1934

\section{Dokument 212}

Kopia: AFKDOPW, teczka 134: Spuścizna abp. Józefa Teodorowicza, sygn. 1512/185 [4], List abp. Józefa Teodorowicza do ks. prałata Stanisława Szpetnara, Lwów 27 XI 1934 r.

Kochany ${ }^{a}$, Przezacny Księże Prałacie!

Przysłał mi doktor Witry swoją broszurę o Konnersreuth i prosi mnie, bym ją dał przetłumaczyć na polskie i wydał w polskim języku. Doktor Witry jest specjalistą chorób nerwowych i znany jest z tego, że miał w obserwacji cały zastęp stygmatyków prawdziwych i fałszywych.

Wyjątkowo tylko jemu pozwolił ojciec Teresy Neumann robić w Konnersreuth naukowe obserwacje; ojciec Teresy Neumann sam mi o tym wspominał dodając, iż widział

a Tekst pisany maszynowo $\mathrm{z}$ wyjątkiem autografu autora na 1,5 stronicy papieru formatu A4.

b-b Autograf czarnym atramentem.

a Tekst pisany maszynowo na 1,5 stronicy papieru formatu A4. Niżej datacji nota ołówkiem: „X. Szpetnar". Brak autografu autora pisma. 
w nim prawego i uczciwego człowieka, i dobrego katolika, i dlatego nie lękał się o to, by córkę swoją poddać naukowej obserwacji.

Ja oczywiście nikogo nie znam, kto by się mógł podjąć wydania i tłumaczenia tej książeczki, jak tylko Księdza Prałata. Inna rzecz, czy Ksiądz Prałat zechce lub też może to uczynić. W każdym razie takie parere ${ }^{453}$ znanego lekarza napisane zresztą bardzo popularnie i lekko ma dla Konnersreuth swoje specjalne znaczenie.

Załączając książkę, którą mi przysłał doktor Witry, zasyłam dla Księdza Prałata jak zawsze bardzo oddane wyrazy mej czci i serdeczne pozdrowienia.

Lwów, dnia 27 listopada 1934

\section{Dokument 213}

Kopia: AFKDOPW, bsygn., teczka: Spuścizna abp. Józefa Teodorowicza, List abp. Józefa Teodorowicza do ks. kanonika dr. Alberta Steuera ${ }_{2}$ Lwów 30 XI 1934 r.

Przezacny ${ }^{\mathrm{a}}$ Księże Kanoniku!

Z niesłychanym zainteresowaniem przeczytałem w "Collectanea” ${ }^{54}$ artykuł Księdza Profesora o recenzjach książki O. Siwka ${ }^{455}$. Pomijam już znakomite wprost ujęcie rzeczy, jasne, zwięzłe, utrafiające w sedno rzeczy, a przy tym rzeczowe i obiektywne - ale przede wszystkim sam jestem zobowiązany Księdzu Kanonikowi za tę Jego pracę. Mogę śmiało powiedzieć stosując te słowa do zastępcy redaktora tego pisma: felix culpa! $!^{156}$

Nie jest wprawdzie ten artykuł Księdza Profesora nową recenzją, a jednak jest recenzją i to nie najzwięźlejszą, a zarazem obejmującą syntetycznie główne punkty problemu.

Jestem Księdzu Profesorowi bardzo za to zobowiązany i dziękując łączę wyrazy prawdziwie oddane głębokiej czci.

Lwów, dnia 30 listopada 1934

\section{Dokument 214}

Oryg.: AFKDOPW, teczka 144: Spuścizna abp. Józefa Teodorowicza, sygn. 1056/420 (8) [7], List ks. prałata Stanisława Szpetnara do abp. Józefa Teodorowicza, Jarosław 3 XII 1934 r.

J[ezus $]^{a}$ M[aria] J[ózef]

Ekscelencjo! Arcypasterzu!

${ }^{453}$ Łac.: opinia, ocena, osąd.

a Tekst pisany maszynowo na $1 \frac{1}{2}$ stronicy papieru formatu A4. Brak autografu autora pisma.

${ }^{454}$ Właściwie: „Collectanea Theologica” - zob. w niniejszej publikacji: J. Wołczański, Korespondencja abp. Józefa Teodorowicza $z$ o. Wtodzimierzem Ledóchowskim SJ, dokument 13.

${ }_{455}$ P. Siwek, Metody badań zjawisk nadprzyrodzonych. Problem Konnersreuth (1933). Rec.: A. Steuer, CT, 4(1934), nr 3, s. 260-263; A. Steuer, Konnersreuth, CT, 4(1934), nr 3, s. 374-376.

456 Łac.: szczęśliwa wina.

a Tekst pisany maszynowo z wyjątkiem autografu autora listu i dopisków końcowych na 1,5 stronicy papieru formatu A4. 
Wszystko, co dotyczy Teresy Neumann jest mi miłe. Miły mi list Waszej Miłości w sprawie tłumaczenia przysłanej broszury. Broszurka ta jest zdaniem moim dość powierzchowna, dla ludzi dobrej woli będzie miała jednak znaczenie swoje. Należałoby jednak dać wiele wyjaśnień w tekście, należałoby dać wstęp obszerniejszy. Są tam rzeczy zrozumiałe jedynie dla lekarza, mówiłem to z D[okto]rem Adamem Zysem ${ }^{457}$, oddanym mi człowiekiem - mówił, że te rzeczy fachowe lekarskie sam mi przetłumaczy. Dr Adam Zys rozumie się też na sztuce lekarskiej, przy jego pomocy można by wydać rzecz pięknie. Tylko muszą być przedtem pewne rzeczy wyjaśnione.

Przedstawię rzecz na przykładzie. Czytałem kiedyś u Lamy, że Teresa Neumann chętnie czyta Muta: „Das Geheimniss des Königs” i „Auf dem Kreuz nach”. Dla tego samego przetłumaczyłem jedno i drugie. „Das Geheimniss des Königs” wydałem własnym nakładem $^{458}$. Z trudem wypłaciłem prawie że całą należność, a druga rzecz „Pójdźmy drogą krzyża" właśnie się drukuje nakładem Sercanek w Kielcach ${ }^{459}$. Z Mutem zawarłem umowę, że mu za prawo tłumaczenia zapłacę. Więc rozchodzi się 1) o prawo własności, by potem nie było kłopotu i 2) o nakładcę broszury D[okto]ra Vitry ${ }^{460}$. Do tłumaczenia jak dotąd dokładałem. Książkę „Pójdźmy drogą krzyża” przepisał mi emerytowany germanista. To przepisywanie to robota żmudna. Wykonać to może tylko wykształcony człowiek, by potem z zecerem było niewiele kłopotu.

Do tej broszury dodałbym osobno jako dodatek „Drugi raz w Konnersreuth”. Może by i Ekscelencja co[ś] dodał. Nie chciałbym zmarnować żadnej niteczki Bożej, co wiedzie za ręce. Dlatego na propozycję się godzę, tylko niech Wasza Miłość tę sprawę postawi prawnie dobrze wobec autora. Przypuszczam, że autorowi chodzi nie o pieniądze, tylko o dobrą sprawę. 3) Trzeba prosić autora o klisze, bo to rzecz ułatwi. Niektóre odbitki w tekście są bez wyjaśnienia. 4) Uważałbym, że w polskim wydaniu należałoby dać dyspozycję i wyjaśnienia. 5) Trzeba by coś napisać w polskim wydaniu o samym autorze.

Sprowadziłem sobie właśnie „Konnersreuther Jahrbuch” za rok 1933 (Lamy). Oczekuję pracy Waszej Miłości w języku niemieckim.

Całuję ręce Waszej Miłości!!!

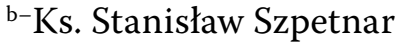

Kliszę z kartki tytułowej i strony 18 mam. Trzeba wyjaśnienia do kliszy na stronie 18. Niewiele mówi klisza na stronie 23.

Jarosław, 3/XII [19]34-b

457 Osoba niezidentyfikowana.

${ }^{458}$ D.W. Mut [właściwie: W. Dunkel], Święta Teresa od Dzieciątka Jezus: czytania duchowne na drodze dziecięctwa duchowego (Tajemnica Króla). Nabożeństwo do świętej Teresy od Dzieciątka Jezus, tłum. S. Szpetnar, Jarosław 1933.

${ }_{459}$ D.W. Mut [właściwie: W. Dunkel], Pójdźmy droga krzyża. O chrześcijańskim cierpieniu, tłum. S. Szpetnar, Kielce-Karczówka 1934.

460 Właściwie: Witry.

b-b Nota czarnym atramentem ręka autora listu. 


\section{Dokument 215}

Kopia: AFKDOPW, teczka 129 i 136: Spuścizna abp. Józefa Teodorowicza, sygn. 1498/185 [4] i 2002/415 [4], List abp. Józefa Teodorowicza do o. dr. Atanazego Fica OP, Lwów 25 XII 1934 r.

\section{Drogi ${ }^{\mathrm{a}}$ Ojcze!}

Serdeczną składam podziękę Kochanemu Ojcu za list, jaki otrzymałem i za życzenia mi przysłane. Z mej strony przesyłam Drogiemu Ojcu najlepsze życzenia, wśród których jest i to, ażeby się nazbyt nie przywiązywał do Krakowa kosztem naszym i Lwowa. Znowu jak widzę, nadzieja powrotu Ojca jest odsunięta.

Osobno dziękuję Drogiemu Ojcu za tak miłe dla mnie informacje; czytałem notatkę w „Homo Dei”"461.

Zdrowie moje istotnie się poprawia mimo dużej pracy nad dalszym tomem życia Chrystusa, który mam na ukończeniu. Wbrew mojemu pierwotnemu planowi praca ta jednak będzie wstępną, niedocierającą bezpośrednio do samego życia Chrystusa. Tytuł tego tomu będzie: „Dwa oblicza judaizmu”. Obejmie ta książka St[ary] Testament z[e] szczególnym uwzględnieniem Zielińskiego, chociaż będę się starał go nie wymieniać i prądy, i partie żydowskie w chwili wystąpienia Chrystusowego. St[ary] Testament zadał mi dużo pracy i w ogóle wlazłem w atmosferę żydowską po uszy tak, że się zanosi na to, że w końcu zamiast piuski będę nosił jarmułkę, a zamiast rewerendy żydowski chałat.

O. Woroniecki ${ }^{462}$ jakoś nie bardzo kontent $\mathrm{z}$ tego mojego pomysłu, który wedle jego zdania oddala mnie od bezpośredniego obrabiania życia Chrystusa. Skłoniła mnie do tego kroku szalona ignorancja elementarnych pojęć o St[arym] Testamencie i łączność St[arego] Testamentu z Nowym, a przy tym z Niemiec idzie nowa fala przeciwko St[are$\mathrm{mu}$ ] Testamentowi. Łączy się wszędzie w jedno pojęcie St[arego] Test[amentu] i talmud. Dlatego dwa te pojęcia rozdzieliłem i przeciwstawiłem sobie. Za bytności Ojca we Lwowie na którą tak się cieszę, pomówię jeszcze z Kochanym Ojcem o tym obszernie.

O. Siwek wcale nie z cnoty jakiejś zaniechał odpowiedzi; posłał ją bowiem gotową do Krakowa, ale cenzorzy ją odrzucili i tylko dlatego drukować jej nie może. Co to będzie za prywatna odpowiedź, to jest istotnie bardzo ciekawe.

Rękopis niemiecki o Konnersreuth jest już gotowy i tylko potrzebuje drobnych poprawek. Ks. Steuer postąpił istotnie jak dżentelman wyjaśniając swoje stanowisko; podziękowałem mu za to. Pisałem obszerny list niemiecki do O. Lavaud we Fryburgu i miałem

\footnotetext{
a Tekst pisany maszynowo $\mathrm{z}$ wyjątkiem autografu autora listu na dwóch stronicach papieru formatu A4.

${ }^{461}$ F. Świątek, Na marginesie polskiej mistyki, HD, 3(1934), nr 6, s. 176-178.

462 Woroniecki Jacek (1878-1949), święcenia kapłańskie w 1906 r. w Lublinie, 1906-1907 kapelan bp. F. Jaczewskiego oraz wykładowca w miejscowym Seminarium Duchownym, 1907-1909 studia specjalistyczne we Fryburgu Szwajcarskim uwieńczone doktoratem teologii, w 1909 r. wstąpił do Zakonu oo. Dominikanów, 1911-1913 duszpasterz akademicki i wicerektor konwiktu księży studentów we Fryburgu Szwajcarskim, 1914-1919 wykładowca w studium zakonnym w Krakowie, 1919-1929 wykładowca na Wydziale Teologicznym, Prawa Kanonicznego i Humanistycznym KUL w Lublinie, 1922-1924 rektor uczelni, 1924-1929 dziekan Wydziału Teologicznego tamże, 1928-1929 prorektor uczelni, 1929-1933 wykładowca Uniwersytetu Angelicum w Rzymie, 1939-1944 dyrektor studium zakonnego w Krakowie, w 2004 r. wdrożono proces beatyfikacyjny. S. Brzozecki, Woroniecki Jacek, w: EK, t. 20, red. zbior., Lublin 2014, kol. 925-927.
} 
mu posłać dosłowne tłumaczenie francuskie artykułów z „Ateneum”"463, które posiadam, a przy tym gotowe już streszczenie niemieckie mej książki. Tymczasem upływa kilka tygodni od wysłania mojego listu, ale odpowiedź od Lavauda nie nadeszła; może być, że list mój nie doszedł.

Jeszcze raz łączę dla Kochanego Ojca bardzo serdeczne i oddane wyrazy czci i przyjaźni

b- + Teodorowicz ${ }^{-b}$

Lwów, dnia 25 grudnia 1934

\section{Dokument 216}

Oryg.: AFKDOPW, teczka 141: Spuścizna abp. Józefa Teodorowicza, sygn. 992/420 (8) [7], List o. Benoît Lavauda OP do abp. Józefa Teodorowicza, Fryburg [Szwajcarski] 26 XII 1934 r.

Fribourg, le 26 Décembre 1934

Excellence ${ }^{\mathrm{a}}$,

Je vous dois d'humbles excuses. Voici un mois que j'ai reçu votre si inéressante et si bienveillante lettre dans laquelle vous avez daigné m'expliquer votre controverse avec le singulier P[ère] Siwek. J'ai lu tous ces détails avec grand intérêt et je regrette bien vivement de ne pas pouvoir lire le polonais pour étudier vos livres sur Konnersreuth. Je n'ai pas encore réuni en volume mes études sur Thérèse Neumann parce que j'ai encore quelques obscurités sur divers points, parce que mes supérieurs ne m' encouragent pas beaucoup à le faire (les derniers événements, les condamnations qui ont dû intervenir en Espagne, les doutes qui pèsent sur les évenements de Beauraing et d'ailleurs dictent beaucoup de réserve sur les phénomènes extraordinaires), et surtout parce que tout mon temps a été pris par des devoirs d'état tout différents. J' écrit cette année un livre sur le mariage, qui ma donné beaucoup de peine. Il est fini, Dieu merci, mais il a pris tous mes loisirs. Dans les mois qui viennent je serai un peu moins surmené. Je serai donc très heureux, Excellence, de prendre connaissance de tout ce que vous aurez la bonté de m'envoyer concernant Konnersreuth, pourvu que ce ne soit pas en polonais. Du reste, j'y pense maintenant. Comme il y a actuellement à Fribourg plusieurs étudiants polonais, je pourrais me faire lire et traduire par eux des textes polonais. Cependant, puisqu' une partie est déjà transcrite en allemand et que le prêtre dont vous me parlez est disposé à résumer le reste en allemand, cela vaudrait mieux pour moi.

Les procédés de discussion du P[ère] Siwek sont vraiment incroyables. Il est très bon que je sois au courant de ses manœuvres. Il va sans dire, Excellence, que je garderai la plus grande discrétion si j'écris quelque chose et je ne ferai pas état de la lettre confidentielle que vous m'avez fait l'honneur de m'écrire.

463 Właściwie: „Ateneum Kapłańskiego”.

b-b Autograf odręczny czarnym atramentem.

a Tekst pisany maszynowo z wyjątkiem autografu autora i adresu na dwóch stronicach papieru formatu A4. 
Depuis quelque temps, j'ai l'impression qu'on parle beaucoup moins de Thérèse Neumann en France et dans les milieux de langue française. Mais ce n'est là qu'une accalmie. Si je puis revenir aux études que je lui ai commencées - et vos divers ouvrages m'y aideront bien; je crois que le public français ferait bon accueil à un livre un peu complet sur la question.

J'ai entendu dire que D[ominus] Mager avait quelque peu changé d'idées et qu'il s'inclinait de nouveau en faveur du caractère surnaturel des faits. Mais je n'ai pas pu avoir confirmation de ce changement d'attitude.

Daignez agréer, Excellence, avec mes remerciements pour votre lettre et les documents que vous me promettez, l'hommage de mon très profond ett religieux respect.

Benoît Lavaud OP

14, rue du Botzet

Fribourg

\section{Dokument 217}

Kopia: AFKDOPW, teczka 134: Spuścizna abp. Józefa Teodorowicza, sygn. 125/19 [6], List abp. Józefa Teodorowicza do ks. prałata Stanisława Szpetnara, Lwów 1 I 1935 r.

Kochany ${ }^{a}$ Księże Prałacie!

Zasyłam najlepsze życzenia świąt, a zarazem przesyłam Księdzu Prałatowi list dr. Witry prosząc Księdza Prałata, by już się z nim bezpośrednio skomunikował.

Nie wiem, czy to pisałem Księdzu Prałatowi, że dr Witry jest pod pewnym względem specjalistą objawów stygmatyzacji, bo cały szereg prawdziwych i fałszywych stygmatów miał w swej obserwacji.

Łączę zajserdeczniejsze wyrazy czci głębokiej.

Lwów, dnia 1 stycznia 1935

Ks. Szpetnar - Jarosław

\section{Dokument 218}

Kopia: AFKDOPW, teczka 136: Spuścizna abp. Józefa Teodorowicza, sygn. 114/19 [6], List abp. Józefa Teodorowicza do ks. prałata Stanisława Szpetnara, Lwów 2 I 1935 r.

Kochany ${ }^{a}$ Księże Prałacie!

Dziękuję najuprzejmiej za list i cieszę się z tego, że broszura będzie przetłumaczona. Tylko Ksiądz Prałat zechce panu Witry jeszcze wytłumaczyć, że ja nie będę mógł

\footnotetext{
a Tekst pisany maszynowo na jednej stronicy papieru formatu A4. Brak autografu autora listu.

a Tekst pisany maszynowo na 1,5 stronicy papieru formatu A4. Brak autografu autora listu i personaliów odbiorcy.
} 
napisać przedmowy. Jest to bowiem dzieło lekarskie; co innego jest przyswojenie tego dziełka językowi polskiemu, a zgoła co innego jest wzięcie poniekąd odpowiedzialności za analizę lekarską, której trafność wprawdzie mogę przyznać, ale nie mogę brać coram publico $^{464}$ za nią odpowiedzialności jako niefachowy. W ogóle w tym dziele, które teraz przygotowuję o Konnersreuth przestrzegam neutralnego stanowiska w tych wszystkich przejawach, które mają związek z fachową medycyną. Myślę, że on sam stanowisko moje doskonale zrozumie i oceni. Przy tym wszystkim trudno mi się angażować publicznie póki sprawa z O. S[iwkiem] nie została definitywnie załatwiona. Słyszałem o tym, że on poniechał wszelkich odpowiedzi publicznej ${ }^{465}$, ale jednak zastrzega sobie jakąś odpowiedź prywatną. Jak ta odpowiedź ma wyglądać, tego oczywiście nie wiem. Ale zrozumie Ksiądz Prałat, że nie jest dla mnie wskazane angażowanie się przed czasem w jakiejkolwiek formie, która by mogła być przez tego zręcznego człowieka choćby dla jednego zwrotu czy słowa wyzyskaną.

Widzę, że Ksiądz Prałat ma jakieś wiadomości bliższe o odrzuceniu przez rodziców żądania księży biskupów co do badania bliższego Teresy Neumann. Czytałem u Lamy, że rodzice Teresy Neumann i profesor Wutz byli zaproszeni przez biskupa na konferencję, po której zaproszono ich także do stołu; to by raczej wskazywało, że epilog tej sprawy zakończył się pomyślnie.

Łączę dla Księdza Prałata wyrazy zawsze oddane głębokiego poważania.

Lwów, dnia 2 stycznia 1935

\section{Dokument 219}

Oryg.: AFKDOPW, teczka 145: Spuścizna abp. Józefa Teodorowicza, sygn. 369/90 [5], List z Wydawnictwa Antona Pusteta do abp. Józefa Teodorowicza, Salzburg 4 I 1935 r.

S[eine]r Exzellenz

Erzbischof Theodorowicz

Lemberg, Polen

BETRIFFT IHR SCHREIBEN VOM IHR ZEICHEN UNSER ZEICHEN M/S 11 DATUM 04.1. [19]35

\section{Euer ${ }^{\text {a }}$ Exzellenz hochverehrter Herr Erzbischof!}

Ich bin Ihnen für Ihren Brief vom 21.12. sehr dankbar. Mit P[ater] Odo Staudinger habe ich bezüglich einer Durchsicht des Buches bereits gesprochen. Er ist bereit, das Manuskript nach Kürzungsmöglichkeiten durchzusehen und wird auch vermutlich in diesen Tagen Euer Exzellenz eigens schreiben. Auch wegen des Titels habe ich mich

${ }^{464}$ Lac.: publicznie, jawnie.

465 Zapis zgodny z oryginałem; powinno być: odpowiedzi publicznych.

a Tekst pisany maszynowo na jednej stronicy papieru formatu A4. W górnej centralnej partii karty nadruk firmowy: „Verlag Anton Pustet Pressevereinsanstalten der Diözese Secau SALZBURG SIEGMUND-HAFFNER-GASSE 18, FERNSPRECHER NR. 259, DRAHTANSCRIFT PUSTET SALZBURG”. 
mit P[ater] Odo Staudinger besprochen. Wir haben uns für folgenden Titel geeinigt und möchten um die Zustimmung Euer Exzellenz bitten: „Konnersreuth im Lichte katholischer Mystik“.

Da mir nun daran liegt, das Buch unbedingt zum Beginn der Fastenzeit herauszugeben - zu diesem Zeitpunkt jährt sich die 10 jährige Wiederkehr der Stigmen - möchte Euer Exzellenz bitten, den restlichen Teil des Manuskriptes raschmöglichst zu senden. Ebenso dringend erbitte ich den Text des Vorwortes zu dem Buch, da ich diesen für Prospekte und Vorankündigungen verwenden möchte. Um nun mit dem Versand der Korrekturen nach Lwów nicht allzuviel Zeit zu verlieren, möchte ich im Einverständnis mit $\mathrm{P}$ [ater] Odo Staudinger vorschlagen, dass diese Korrekturen sowohl hier im Verlag als durch P[ater] Odo Staudinger gelesen werden. Es könnte dadurch sehr viel Zeit erspart werden. Auch hierfür möchte ich um Zustimmung Euer Exzellenz bitten und zeichne in Verehrung und Hochschätzung als Ihr ergebener

b-VERLAG ANTON PUSTET

SALZBURG $^{-b}$

\section{Dokument 220}

Kopia: AFKDOPW, teczka 128: Spuścizna abp. Józefa Teodorowicza, sygn. 903/110 [5], List abp. Józefa Teodorowicza do ks. dr. Stanisława Brossa, Lwów 14 I 1935 r.

Kochany ${ }^{a}$ Księże Prałacie!

W swoim czasie pan Jeleński okazał gotowość, by drukować moją książkę o Konnersreuth po polsku; było to jednak jeszcze przed ukazaniem się książki polemicznej przeciw O. Siwkowi.

Dziś nie wiem, czy pan Jeleński trwa jeszcze w tym swoim zamyśle i dlatego piszę do Księdza Prałata z uprzejmą prośbą, by raczył tę kwestię wysondować. W każdym razie rzecz ta staje się dziś aktualną wobec tego, że Pustet chce zacząć druk mej pracy już w styczniu, a skończyć go na Wielkanoc.

Załączam tu Księdzu Prałatowi listy księgarni wydawniczej w Salzburgu, jak i listy O. Staudingera prosząc o nadesłanie mi ich z powrotem.

Tymczasem zasyłam Księdzu Prałatowi najserdeczniejsze pozdrowienia z zapewnieniem o moim oddanym szacunku i uczuciu dla Osoby Księdza Prałata.

Lwów, dnia 14 stycznia 1935

Ks. Prałat Bross - Poznań

b-b Podłużna pieczęć. Niżej podpis nieczytelny.

a Tekst pisany maszynowo na jednej stronicy papieru formatu A4. Brak autografu autora pisma. 


\section{Dokument 221}

Kopia: AFKDOPW, teczka 134: Spuścizna abp. Józefa Teodorowicza, sygn. 58/19 [6], List abp. Józefa Teodorowicza do ks. prałata Stanisława Szpetnara, Lwów 6 II 1935 r.

\section{Przezacny ${ }^{\mathrm{a}}$ Księże Prałacie!}

Dziękuję za oba listy, które otrzymałem. Z ostatniego listu widzę, że pan Witry stawia warunki pieniężne bardzo wygórowane. Boję się, bym się mimo woli nie stał przyczyną jakich[ś] kłopotów Księdza Prałata.

Bardzo bym się cieszył, gdyby Ksiądz Prałat przybył do Lwowa mimo to, że zawsze się i po cichu lękam, by mi jakiego[ś] nowego Konnersreuth albo mistyki nie narzucił. Ale jakoś się to wszystko ułoży.

Tymczasem łączę dla Kochanego Księdza Prałata najserdeczniejsze pozdrowienia i wyrazy prawdziwie oddane głębokiej czci.

Lwów, dnia 6 lutego 1935

Ks. Prała[t] Szpetnar - Jarosław

\section{Dokument 222}

Oryg.: AFKDOPW, teczka 141: Spuścizna abp. Józefa Teodorowicza, sygn. $991 / 420$ (8) [7], List o. Benoît Lavauda OP do abp. Józefa Teodorowicza, Fryburg [Szwajcarski] 8 II 1935 r.

Excellence ${ }^{\mathrm{a}}$,

Fribourg, le 8 II 1935

Je suis encore plus en retard que la fois précédente pour vous remercier de votre lettre et des précieux documents que vous avez eu la grande bonté de m'envoyer. Je n'ai pas pu lire le livre en polonais, mais seulement l'analyse excellente qui l'accompagnait et qui en donne bien l'idée. Et la longue étude en français. Les citations et les éloges que vous faites de mes petits travaux sur les questions de mystique extraordinaire, dans le cas de Thérèse Neumann en particulier, me rendent tout confus et sont un trop grand honneur pour moi. Je vous écris cette lettre - trop tardive - avec une certaine tristesse, car je suis mis actuellement par l'obéissance dans l'impossibilité de publier quoi que ce soit sur Thérèse Neuman et les sujets touchant à la mystique extraordinaire. Mes supérieurs m'ont assigné une tâche qui me prend absolument tout mon temps en sorte qu'il ne me reste aucun loisir pour ce genre d'études. En outre, ainsi que je l'ai déjà dit, je crois, à Votre Excellence, le révérend Père Gillet ${ }^{466}$ ma fait savoir qu' il trouvait inopportun

\footnotetext{
a Tekst pisany maszynowo na jednej stronicy papieru formatu A4. Brak autografu autora listu.

a List pisany czarnym atramentem na czterech stronicach papieru formatu A4. W lewym górnym rogu karty tytułowej nadruk firmowy: „Maison St-Hyacinthe Fribourg, Suisse, Tel. 1124”.

${ }^{466}$ Gillet Martin Stanislaus (1875-1951), święcenia kapłańskie w 1902 r. w Zakonie oo. Dominikanów, dr filozofii, 1905-1926 wykładowca teologii moralnej w studium zakonnym w Lowanium, Saulchoir i Instytucie Katolickim w Paryżu, 1927-1929 prowincjał, 1929-1946 generał Zakonu, 1946-1951 abp tytularny
} 
que j'écrive sur Thérèse N[eumann]. Il n'est donc pas question actuellement dee publier le volume qui serait presque prêt, ni même de simples articles.

Le père Bruno de Jésus-Marie, directeur des „Etudes Carmélitaines” m’a écrit récemment à propos d'une visite que me fit $\mathrm{D}$ [ominus] Mager et dont je lui avais parlé: „Je suis vraiment heureux que tout soit « en place » entre D[ominus] Mager et vous. La manière dont il avait accepté gentiment d'aller vous trouver m'avait touché. Entre nous, même vis-à-vis de Rome, il n'est pas mauvais d'être en contact avec les sceptiques que nous sommes!...Aujourd'hui, là-bas, on aime les gens prudentissimes". Vous êtes mieux renseigné que moi, Excellence, sur ce qu'on pense à Rome, mais mes supérieurs sont de ceux qui pensent comme le $\mathrm{P}$ [ère] Bruno, et voilà pourquoi j'ai reçu d'eux des conseils qui m'obligent à ne demander le nihil obstat pour aucun travail concernant Konnersreuth. Cela peut changer. C'est pourquoi, si vous le permettez, Excellence, je conserverai l'étude en français que vous m'avez envoyée pour des jours meilleurs qui viendront peut-être bientôt.

Dom[inus] Mager m'a paru beaucoup moins opposé au caracctère surnaturel des faits qu'il ne le paraît dans ses publications. Il voudrait pouvoir examiner à nouveau Thérèse, il élève toujours des doutes sur l'état de repos extatique et affirme que Thérèse, à deux reprises s'est exprimée en sens contraire sur une même relique qu'on lui donnait à discerner. Il m'a lui-même raconté l'avertissement que lui avait donné Thérèse et l'accident qui lui arriva en disant la Sainte Messe, la nécessité où il a été de réduire ou de supprimer ses veilles laborieuses. Il aurait été invité par Mgr l'évêque de Ratisbonne à donner à nouveau son avis et aurait répondu qu'il désirait auparavat pouvoir examiner Thérèse. Il regrettait d'avoir laissé passer dans le „Lexikon für Theologie und Glaube” l'articulet sur Catherine Filljung ${ }^{467}$, rédigé d'après le livre de Ebel ${ }^{468}$, contre lequel, depuis, Mgr l'évêque de Metz a écrit son volume Catherine Filljung, fausse mystique. Par contre, il a répondu aux observations qu' on lui a faites touchant l'autre notice sur Louise Lateau, qu'on ne pouvait pas ne pas être favorable au caractère surnaturel de ses extases de la Passion et de ses stigmates après ce qu'a écrit d'elle le chanoine Thierry ${ }^{469}$. Il m' a beaucoup recommandé la vie de Louise par le ch[anoine] Tierry. Je n'ai lu l'an dernier que le volume antérieur du même auteur sur L[ouise] Lateau et de P[ère] Huchant ${ }^{470}$ qui est, malgré ses longueurs et répétitions, passionément intéressant et décisif.

Je désirerai beaucoup, Excellence, avoir l'honneur de vous rencontrer et pouvoir parler avec vous de toutes ces choses.

Nicei, autor syntetycznych publikacji z dziedziny moralności chrześcijańskiej. K. Bartoszewski, Gillet Martin, w: EK, t. 5, red. zbior., Lublin 1989, kol. 1080-1081.

b Nota autora listu: „Dont il a le contrôle pour les articles intéressant la mystique”.

${ }^{467}$ Filljung Catherine (1848-1915), dominikańska zakonnica z Lotaryngii, mistyczka i wizjonerka. J-B. Pelt, La vérité sur Catherine Filljung. Fausse mystique (1848-1915), Metz 1884.

468 E. Ebel, Soeur Catherine: notes biographiques sur la mystique lorraine Catherine Filljung, religieuse dominicaine, fondatrice de l'Orphelinat de Biding, 1848-1915, Paris 1932.

${ }^{469}$ Osoba niezidentyfikowana.

${ }^{470}$ Osoba niezidentyfikowana. 
Daignez agréer, Excellence, mes hommages de profonde vénération en N[otre] S[eigneur] J[ésus] [Christ]

Benoît Lavaud OP

\section{Dokument 223}

Kopia: ASK, bsygn., Acta Hlondiana, t. 5, cz. 3, List abp. Józefa Teodorowicza do kard. Augusta Hlonda, Lwów 17 III 1935 r.

\section{Wasza $^{a}$ Eminencjo!}

Niezmiernie jestem zobowiązany Waszej Eminencji za starania podjęte w sprawie mojego manuskryptu i raz jeszcze z całego serca za nie dziękuję. Zdaję się, że skończę na tym, iż prześlę Ojcu Świętemu jeden manuskrypt.

Ucieszyły mnie bardzo sprawozdania z Komisji synodalnej warszawskiej, które miałem od bezpośrednich uczestników narad. Główna rzecz była o tym, by raz wyjść z błędnego a beznadziejnego koła. Do tego posłużył projekt Waszej Eminencji, który służy za podstawę zdrową dla synodu. Reszta to jest ścisła forma prawna łatwo się odnajdzie, gdy się już ma w ręku właściwe jądro rzeczy. Byle się tylko nazbyt ze wszystkim nie spieszono, a także by i nadto nie poprawiano. Ważną ogromnie sprawą będzie jeszcze projekt rozkładu nauki religii w systemie nowego czteroklasowego gimnazjum. Jeśli przejdzie projekt warszawski, który na naukę wiary i obyczajów przedstawia jeden tylko i to pierwszy rok, (najniepotrzebniej w świecie przeznaczając dwa lata na historię), a przy tym rok na liturgię, wówczas Biskupi sami wygonią religię ze szkoły. Historia Kościoła i liturgia powinny mieć tylko rolę pomocniczą, nie zaś rugować samą doktrynę.

Co do Niepokalanek to mówiłem z Ks. Biskupem Lisowskim i Ks. Baziakiem ${ }^{471}$ (arcybiskup jest obecnie w Obroszynie ${ }^{472}$ ), obaj się oświadczają za tym, by Wasza Eminencja sprawę tę wziął w ręce. Nie wątpię, że takie też będzie stanowisko Ks. Biskupa Bardy ${ }^{473}$. Jest tam coraz gorzej. Podobno Benedyktyn Van Ost ${ }^{474}$ się sekularyzuje. Jeśliby to było prawdą i to, że osiada się u nich, to byłoby to dla nich najsmutniejsze. Siostry bowiem

a Tekst pisany maszynowo na dwóch stronicach formatu A4.

${ }^{471}$ Zob. w niniejszej publikacji: J. Wołczański, Korespondencja abp. Józefa Teodorowicza z abp. Adamem Stefanem Sapieha, dokument 104.

472 Obroszyn - wieś w pow. Gródek Jagielloński, woj. Lwów; istniała tam letnia rezydencja metropolitów lowskich ob. łac. Często bawił tam abp. Bolesław Twardowski.

${ }^{473}$ Barda Franciszek (1880-1964), święcenia kapłańskie w 1904 r. w Krakowie, dr teologii, 1910-1914 prefekt i wicerektor oraz 1930-1931 rektor Seminarium Duchownego w Krakowie, 1919-1932 wykładowca teologii moralnej w Seminarium Duchownym w Poznaniu, 1925-1928 rektor Instytutu Polskiego w Rzymie, 1931-1933 biskup pomocniczy diec. przemyskiej, 1933-1964 ordynariusz tamże. J. Ataman, Barda Franciszek, w: EK, t. 2, red. F. Gryglewicz, R. Łukaszyk, Z. Sułowski, Lublin 1985, kol. 27-28.

${ }^{474}$ Właściwie: Oost van Karol (1899-1986), belgijski benedyktyn pracujący w Polsce od 1928 r., związany ze Zgromadzeniem ss. Niepokalanek w związku z tłumaczeniem mszału o. Gaspara Lefebvre’a na język polski. Nad przekładem pracowały zakonnice z Jazłowca. Głosił również rekolekcje dla członkiń tegoż Zgromadzenia w Szymanowie. P. Sczaniecki, Ojciec Karol Van Oost, Tyniec 1990, passim. 
się żalą z jednej strony na przymus wywierany przez Przełożoną spowiedzi u niego, a z drugiej strony na zdradzanie przez niego tajemnicy spowiedzi. Oczywiście nie biorę odpowiedzialności za te informacje, choć je otrzymałem świeżo z bezpośredniego otoczenia w Szymanowie ${ }^{475}$. W każdym razie mówiły mi Sacrecoerki ${ }^{476}$ o jego niepoważnych zachowaniu się wobec uczennic za czasu pobytu jego u nich, tak że po roku go usunęły. Podobno to się dziś zaczyna wobec sióstr. Ażeby uchronić się przed wizytacją poszły one za radą przełożonej Samarytanek ${ }^{477}$ i wciągają nuncjusza z jasnym planem zaangażowania się jego bezpośredniego. Niestety, to im się aż nadto łatwo udaje i stąd powstają nowe zamieszania.

Czy by też Wasza Eminencja nie przywołał do siebie panią Sikorską ${ }^{478}$ dla omówienia kwestii archiwum? To by jej wielką zrobiło przyjemność.

Będę się starał w maju na konferencję przyjechać, gdyż zdrowie moje na to już pozwoli, do kwestii zaś nauczania religii, w której wiele pracowałem dużą przywiązują wagę. Obecnie kończę tom, który jest w łączności z moim dziełem o „Życiu Chrystusa” pod tytułem: podwójne oblicza judaizmu. (Stary Testament i faryzeizm). U nas o tym pojęcia nie mają, a książka Zielińskiego „Hellenizm a judaizm”" ${ }^{\text {"79 }}$ wiele narobiła spustoszenia. Jeszcze raz Waszej Eminencji dziękuję za łaskawość i łączę najoodańsze wyrazy czci najgłębszej

Lwów 17/III [1]935

† Teodorowicz

\section{Dokument 224}

Kopia: AFKDOPW, teczka 131: Spuścizna abp. Józefa Teodorowicza, sygn. 178/19 [6], List abp. Józefa Teodorowicza do prowincjała oo. Jezuitów o. Włodzimierza Konopki SJ, Lwów 25 III 1935 r.

Czcigodny ${ }^{\mathrm{a}}$, Drogi Ojcze Prowincjale!

Proszę przyjąć moją serdeczną podziękę za tak cenny dla mnie dowód pamięci Ojca Prowincjała i przesłane mi życzenia. Modlę się, by Bóg we wszystkim Ojca Prowincjała w jego ciężkim urzędzie wspierał i prowadził.

Zawsze oddany w głębokiej czci.

Lwów, dnia 25 marca 1935

${ }^{475}$ Szymanów k. Warszawy - dom generalny Zgromadzenia ss. Niepokalanek.

${ }^{476}$ Neologizm od nazwy własnej Zgromadzenia Sióstr Najświętszego Serca Jezusa (Sacré Couer).

477 Zgromadzenie ss. Benedyktynek Samarytanek Krzyża Chrystusowego erygowała Polka m. Jadwiga Jaroszewska w 1926 r. z myślą o pracy wśród dzieci upośledzonych umysłowo i ludzi z marginesu społecznego.

478 Osoba niezidentyfikowana.

479 T. Zieliński, Hellenizm a judaizm, Warszawa 1927.

a Tekst pisany maszynowo na jednej stronicy papieru formatu A4. Brak autografu autora. Niżej datacji nota pismem maszynowym: „O. Prow[incjał] Konopka - Kraków TJ”. 


\section{Dokument 225}

Kopia: AFKDOPW, teczka 134: Spuścizna abp. Józefa Teodorowicza, sygn. 169/19 [6], List abp. Józefa Teodorowicza do ks. prałata Stanisława Szpetnara, Lwów 28 III 1935 r.

Kochanya, Przezacny Księże Prałacie!

Bardzo dziękuję za list łaskawy; o poleceniu Księdza Prałata pod adresem S[iostry] Fidei $^{480}$; już jej mówiłem. Widzę, że można jednak mieć nadzieję na listy Teresy Neumann. Co do wydania samej książki, to wprawdzie umówiłem się z księgarnią w Salzburgu, ale kto wie, czy z powodu zbyt długiej zwłoki ona podtrzyma swoje zobowiązania. W takim razie byłaby mi propozycja $\mathrm{p}$ [ana] Muta bardzo naręczna; wprawdzie bowiem i jedna księgarnia niemiecka, w której drukuje Lama (Badenia in Karlsruhe) ofiarowała mi się sama z przyjęciem mojego dzieła do wydania, ale księgarnia ta jest zbyt prononsowana już w jednym kierunku.

Jeszcze raz dziękuję Księdzu Prałatowi za pobyt tutaj, z którego tak bardzo rad byłem i polecam się nadal pamięci i sercu Księdza Prałata, zawsze oddany.

Lwów, dnia 28 marca 1935

Ks. Szpetnar

\section{Dokument 226}

Oryg.: AFKDOPW, bsygn., teczka: Spuścizna abp. Józefa Teodorowicza, List o. Odo Staudingera OSB do abp. Józefa Teodorowicza, Salzburg 8 V 1935 r.

Salzburg, Koleg[ium] St. Benedikt, am 8.5. [19]35

$\mathrm{An}^{\mathrm{a}}$ das hochw[ürdigster] Erzbischöfl[iche] Sekretariat!

Eu[re] Hochwürden!

Bitte noch um einige Berichtigungen.

1) 1.Teil bei Gottesliebe wird Lama „Konn[ersreute] Jahrbuches“ 101 angegeben. Ich habe alle diese Jahrb[uches] nachgesehen, bei keinem die betreff. Stelle gefunden. Von Lama, dem ich geschrieben, habe ich noch keine Antwort.

2) 1.Teil Witt wird Ausgabe $1927 \mathrm{u}[$ nd] 1929 angeben. Wo vom Schlecken von Feuersbrunst die Rede ist (Fußnote 82 im gedruckten Werk) ist Seite 36 angegeben. Ist das wichtig bei der Ausgabe v[on] 1929?

Ich habe nur die Ausgabe v[on] 1927. Bei Poulain (Margareta von Ricca) die genaue Seitenzahl oder das Kapitel am Grâces d'raison angegeben werden.

Mit besten Grüßen empfiehlt sich Ew[ere] Hochwürden ergebenst

$\mathrm{P}$ [ater] Odo Staudinger OSB

a Tekst pisany maszynowo na jednej stronicy papieru formatu A4. Brak autografu autora listu.

480 Osoba niezidentyfikowana.

a Tekst pisany czarnym atramentem na dwóch stronicach papieru format listowego. W lewym górnym rogu karty tytułowej nadruk firmowy: „+ PAX“. 
Es wird doch richtig heißen: „Inordinatu corporis motus minime decentes signum esse...."Benedikt XIV. nicht inordinatus (erwähnt gegen Schluss des 10. Teiles: Mirabelli).

\section{Dokument 227}

Oryg.: AFKDOPW, teczka 144: Spuścizna abp. Józefa Teodorowicza, List o. Odo Staudingera OSB do abp. Józefa Teodorowicza, Salzburg 28 V 1935 r.

Exzellenz! ${ }^{\mathrm{a}}$

Salzburg, Benediktinerkolleg[ium], am 28. V. [19]35

Hochwürdigster Herr Erzbischof!

Die neuerliche Bestellung des „Ben[edictus] B[oten]“ war mir eine Überraschung. Ich hatte gar keine Ahnung, dass Exzellenz ihn nicht mehr bekommen. Denn den Versand und die ganze Verwaltung besorgt der Verlag in Innsbruck.

Wie schön von Exzellenz, dass Sie mich nicht vergessen haben, obwohl Sie dazu Grund genug hätten!

Vom Manuskript habe ich bis heute ca. 30 Seiten gelesen. Wohl mancher Heilige oder Selige, dem bereits die die Ehre der Altäre zuteil geworden, würde sich gratulieren, wenn er einen solchen Anwalt in Rom gehabt hätte wie Therese Neumann ihn hat in $\mathrm{Eu}[\mathrm{re}]$ Exzellenz. Bin schon gespannt auf das Folgende und ich werde mir Mühe geben, bald fertig zu werden. Wenn ich nach der bisherigen Einsichtnahme etwas aussetzen darf, so ist es dies: Der Titel des Buches ist viel zu arm, er besagt zu wenig, lässt nicht schließen auf die Eigenart und den großen Reichtum des Inhalts. Vielleicht darf ich vorschlagen: Konnersreuth (oder Therese Neumann) im Lichte der Psychologie und Mystik.

Msgr. Waitz ist derzeit abwesend; und verwendet viel Energie im Dienste der hiesigen Universitätsbestrebungen.

Ein Zank ist entstanden zwischen Fr[iedrich] v[on] Lama und Dr. Witry. Dieser will nächstens Briefe von Lama veröffentlichen, die ihn arg kompromittieren, in denen er als Zensor des bayerischen Episkopats sich aufspielt, von Rationalismus in der bischöflichen Theologie spricht. Tertius gaudens erit $\mathrm{P}[\mathrm{ater}]$ Mager. Dieser ist übrigens recht still geworden in Sachen Konnersreuth.

Werde mit Direktor Müller vom Pustet-Verlag wegen des Werkes Eu[re] Exzellenz sprechen, wenn ich das ganze Manuskript in Händen habe. Es wird an Güte und Gediegenheit alle bisherigen Werke über Konnersreuth weit übertreffen. Die bisherige Einsichtnahme legt mir dieses Urteil nahe.

Wünsche damit Eu[re] Exzellenz recht viel Freude und der guten Sache besten Erfolg. In aller Ehrfurcht verbleibe ich Eu[re] Exzellenz ergebenster

$\mathrm{P}$ [ater] Odo Staudinger OSB

\footnotetext{
a Tekst pisany czarnym atramentem na dwóch kartach papieru formatu A4. W lewym górnym rogu nadruk firmowy: „Schriftleitung des Benedictus-Boten”. W górnej partii karty na centralnym miejscu graficzne wyobrażenie godła Zakonu oo. Benedyktynów: krzyż z dwiema poprzecznymi belkami stojący na trzech wzniesieniach oraz PAX. Niżej tarczy inskrypcja: „Ut in omnibus glorificetur Deus”.
} 


\section{Dokument 228}

Oryg.: AFKDOPW, teczka 140: Spuścizna abp. Józefa Teodorowicza, sygn. 971/420 (8) [7], List dr. Ralpha Waldego Hynka do abp. Józefa Teodorowicza, Praga 8 VI 1935 r.

Praha, dne 8/6 1935

Euere $^{\mathrm{a}}$ Exzellenz!

Mit gleicher Post erlaubte ich mir Euerer Exzellenz meine neuestes Werk über Martertod Christi zukommen zu lassen mit der höflichsten bitte, Euere Exzellenz möge gütigst dasselbe entgegenzunehmen.

Es handelt sich und das hl. Turiner Grabtuch, welches Lener zu zwei ganz überraschenden medizinischen Enthüllungen führte, die gleich das medizinisch Unisinnige (Joh. 19,34) sowie die Propheten bzw. Issaia ganz wissenschaftlich erklären.

Aber es ist eine erstklassige Neuigkeit, die ein größtes Interesse hervorgerufen hat, zumal einen Teil davon auch gleich in Turin („Rivista die Giovanni“, aprile 1935) veröffentlichte. Soeben habe ich einen Verleger aus Chicago dafür bekommen und um die deutsche Ausgabe bewerben sich auch Interessenten.

Ich hoffe, dass Euere Exzellenz sein Hauptinhalt, zumal es lächerlich geschrieben ist auch verstehen wurden. Speziell würde Euere Exzellenz Kapitel 8. Turin und Konnerseruth interessieren.

Dürfte ich wohl Euere Exzellenz ergebend bitten, mögen gefälligst einen polnischen oder ukrainischen Verleger darauf aufmerksam machen, es wäre mir sehr lieb wenn es auch in diesen Sprachen für unseren lieben Heiland erscheinen möchte.

Indem ich nochmals meine höflichste bitte wiederhole empfehle mich dem Segen Eueren Exzellenz der ergebenste

Dr. R[alph] W[aldo] Hynek

\section{Dokument 229}

Oryg.: AFKDOPW, teczka 140: Spuścizna abp. Józefa Teodorowicza, sygn. 924/420 (8) [7], List dr. Ralpha Waldego Hynka do abp. Józefa Teodorowicza, Praga 3 XII 1935 r.

Euere $^{\text {a Exzellenz! }}$

Mit größter Freude habe ich Ewerer Exzellenz heutigen freundlichen Brief entnommen, dass Ewere Exzellenz sich wiederum ganz wohl und gesund fühlen. Gott sei Dank!

Auch hat mich riessig die Anteilnahme von Ewerer Exzellenz an meinem vorletzten Buch - „Der Martertod Christi“481 - gefreut. Nun ist es in ca 2 Bogen meistens ärztliche Sachen, schon deutsch gedruckt und erscheint binnen 14 Tagen. Es wurden Teile vom selben von mir auch italienisch veröffentlicht, in Chicago wird es englisch erscheinen

a Tekst pisany czarnym atramentem na 1,5 stronicy papieru formatu A4. W lewym górnym rogu nadruk firmowy: „Dr. R.W. Hynek, lèkař spisowatel, Praha II, Ječná 37, telefon 31368”.

a Tekst pisany czarnym atramentem na dwóch stronicach papieru formatu A4.

${ }^{481}$ R.W. Hynek, Der Martertod Christi im Lichte dem moderner medizinischen Wissenschaft, Eger 1935. 
und in Polen - polnisch. Von der deutschen Ausgabe kann man andere Übersetzungen vorbereiten. Deo gratias.

Ich habe mir erlaubt das soeben erschienene Meditationsbuch zum Heiligsten Antlitz Christi - also auch eine direkte und indirekte Flucht Konnersreuths mit Widmung Ewerer Exzellenz zukommen lassen. Ich hoffe jedoch, dass das Tschechische und Polnische nicht er gar differieren, dass Ewer Exzellenz wenigstens den Sinn meiner Zeilen nicht entnehmen werde können. Wird die Verdeutschung des Martertodes Verbreitung finden, dann möchte ich es auch deutsch übersetzen lassen, denn das Objekt Portrait das wahre Photo Christi - ist eine noch außerhalb der hl. Theresia vom Kinde Jesu u[nd] v[om] heiligst[en] Antlitz nicht geringer bekannte und mystische verarbeitete Tatsache.

Übrigens ist es nur ein Versuch, der neben meiner sonstigen Berufs und Standestätigkeit in bloßen 6 Wochen niedergeschrieben wurde. Übrigens wird Euere Exzellenz, als ganz berufene Autorität, allein das Urteil fällen lassen können. Ich habe bloß den Eindruck, dass nach Konnersreuth, das heilige Grabtuch von Turin wiederum ein anderes, mächtiges Echo des Gekreuzigten in unseren Tagen leiden hat.

Indem ich nochmals meine aufrichtige Freude über die Genesung Ewerer Exzellenz ausdrücke, zeichne mich in tiefster Ehrfurcht ergeben

Prag, am 3/XII 1935

Dr. R[alph] W[aldo] Hynek

P.S. Ein Photo de heiligst[en] Antlitzes ist beigelegt.

\section{Dokument 230}

Oryg.: AFKDOPW, teczka 144: Spuścizna abp. Józefa Teodorowicza, sygn. 1803/62 [5], List o. Odo Staudingera OSB do abp. Józefa Teodorowicza, Salzburg 6 XII 1935 r.

Salzburg, Benediktinerkolleg[ium], am 6. XII. [19]35

Exzellenz ${ }^{\mathrm{a}}$,

Hochwürdigster Herr Erzbischof!

Vor allem ein inniges Deo Gratias! dafür, dass Exzellenz wieder gesund sind. Der Büchermarkt darf sich freuen, durch neue Werke von Ihrer Exzellenz beehrt und bereichert zu werden.

Vorgestern war ich bei Direktor Müller im Pustetverlag und frug ihn, ob er noch Interesse habe für Ihr Werk. Er bejaht und wünscht, dass es schon im Frühjahr nächsten Jahres erscheinen könne. Er hat wirklich sehr viel Mut, Idealismus und meist auch recht guten Erfolg. Andere Verleger würden monatelang und noch länger es sich überlegen.

Also wenn Exzellenz die Güte haben, auch den 2.Teil zu senden, wird es dem Herrn Direktor Müller ganz erwünscht kommen. Ich bin zu sehr Stümper, um mir ein Urteil

Tekst pisany czarnym atramentem na dwóch stronicach papieru formatu A4. W lewym górnym rogu nadruk firmowy: „Schriftleitung des Benedictus-Boten”. W górnej partii karty na centralnym miejscu graficzne wyobrażenie godła Zakonu oo. Benedyktynów: krzyż z dwiema poprzecznymi belkami stojący na trzech wzniesieniach oraz PAX. Niżej tarczy inskrypcja: „Ut in omnibus glorificetur Deus”. 
über das große Werk erlauben zu dürfen. Aber wenn Sie dennoch mir gestatten, Ausstellungen zu machen, werde ich jene Stellen zusammenschreiben, wo ich mir erlaube, anderer Ansicht zu sein, und $\mathrm{Eu}[\mathrm{re}]$ Exzellenz mitteilen.

Vorige Woche hielt ich in Innsbruck und Hall Vortrage über: „Wie steht es um Konnersreuth?" Das Interesse war groß. Ich versuchte zu zeigen, dass die mystischen Erscheinungen in Konnersreuth seit 1926 nicht ab, sondern zugenommen haben.

Auch das Dezemberheft des B.B. brachte wenigstens etwas über Konnersreuth unter „Kurze Mitteilungen“, was ich in Zukunft öfter zu tun gedenke.

Im August war in Banneux ${ }^{482}$, Boring ${ }^{483}$, Onkerzele ${ }^{484}$ und hatte beste Eindrücke gewonnen. Vorige Woche, am 29. Nov[ember] erfolgte wieder eine große plötzliche Heilung an der Erscheinungsstelle in Boring. Es war am 3. Jahrestag der 1. dortigen Erscheinung. Was sagt P[ater] Bruno dazu, jener P[ater] Bruno, von dem ich in Belgien das hübsche Sprüchlein hörte:

„Le Pére Bruno sonna l'alarme,

Le ciel et l'enfer en armes.

Mais à tout son vacarme

Dieu répondra: Va, Carme!"

In einigen Woche wird auch das „Konner[sreuter] Jahrbuch“ 1934 erscheinen. R[itter] v[on] Lama musste lange auf das Imprimatur warten. Diese Gefahr besteht für Ihr Werk, ganz abgesehen von seinem Werte, unter der Regierung S[einer] Exzellenz Sigismund Waitz nicht im mindesten.

In der Hoffnung, dass es heute in einem Jahre als wertvolle Weihnachtsgabe versandt wird, empfiehlt sich in aller Ehrfurcht Euer Exzellenz ergebenster

$\mathrm{P}$ [ater] Odo Staudinger OSB

\section{Dokument 231}

Oryg.: AFKDOPW, teczka 136: Spuścizna abp. Józefa Teodorowicza, sygn. 1820c/61 [5], List z Wydawnictwa Antona Pusteta do abp. Józefa Teodorowicza, Salzburg 11 XII 1935 r.

Euer ${ }^{\mathrm{a}}$ Exzellenz!

Hochw[ürdigen] P[ater] Odo Staudinger teilte mir mit, dass das Manuskript „Konnersreuth" vor dem Abschluss steht. Ich sage ihm, dass wir nach wie vor bereit sind, das Buch herauszugeben.

Nur legte ich P[ater] Odo Staudinger nahe, Euer Exzellenz zu ersuchen, soweit es möglich ist, doch einige Kürzungen des Manuskriptes vorzunehmen. Das Buch würde sonst zu umfangreich und damit zu teuer und als Folge davon schwer absetzbar sein.

${ }^{482}$ Banneux - miejscowość we wschodniej Belgii k. Liège, znana z objawień maryjnych z $1933 \mathrm{r}$.

${ }^{483}$ Boring - miejscowość w Belgii.

${ }^{484}$ Onkerzele - wioska we Flandrii Wschodniej (Belgia).

a Tekst pisany maszyniowo na jednej stronicy papieru formatu A4. W górnej centralnej partii karty nadruk firmowy: „Verlag Anton Pustet Pressevereinsanstalten der Diözese Secau SALZBURG SIEGMUND-HAFFNER-GASSE 18, FERNSPRECHER NR. 259, DRAHTANSCRIFT PUSTET SALZBURG”. 
Wenn es daher Euer Exzellenz möglich wäre, Stellen, die ohne Nachteil für das Gesamtwerk weggelassen werden können, eine Kürzung vorzunehmen. Dann habe ich P[ater] Odo gebeten, Euer Exzellenz nahe zu legen, ein kurzes Vorwort zu dem Buch zu schreiben, das Sinn und Aufgabe des Buches darstellt. Aus dem Inhaltsverzeichnis geht ja hervor, dass das Buch im Spiegel des Geschehens von Konnersreuth gleichzeitig ein Werk über Mystik ist. Das im Vorwort etwas zu sagen, schiene mir ratsam.

Ebenso hätte ich Euer Exzellenz gebeten, ob es möglich wäre, diesen weiter gefassten Charakter des Buches auch im Titel zum Ausdruck zu bringen, entweder in der Form, dass man das Thema „Neue Mystik“ vielleicht sogar als Haupttitel wählt und Therese von Konnersreuth als Untertitel. Oder, falls das Eurer Exzellenz nicht entsprechen würde, in einem Untertitel diesen Gedanken zum Ausdruck zu bringen.

Hoch[würdiger] P[ater] Odo sendet Eurer Exzellenz in den nächsten Tagen das Manuskript mit einigen Korrekturvorschlägen zu. Ich wäre Eurer Exzellenz dann sehr dankbar, wenn ich diesen Teil schon in den ersten Januartagen zurückhaben könnte, um die Drucklegung dann sofort in Angriff zu nehmen. Das umfangreiche Werk wird doch einige Zeit für die Drucklegung benötigen und ich möchte das Buch unbedingt zu Beginn der Fastenzeit fertig haben. Zu diesem Zeitpunkt jähren sich ja die Konnersreuther Ergebnisse zum zehnten mal, sodass das Buch so quasi ein Jubiläumswerk auch ist.

Jedenfalls darf ich Eurer Exzellenz sagen, dass ich mich über den Abschluss des Buches freue und gerne hoffe, dass auch eine entsprechende Aufnahme in den beiden Lesekreisen der Fall sein wird.

In Verehrung und Hochschätzung bin ich Ihr ergebener im Diktat gezeichnet

b-VERLAG ANTON PUSTET

$$
\text { SALZBURG }^{-b}
$$

$$
[\ldots]^{\mathrm{c}}
$$

\section{Dokument 232}

Oryg.: AFKDOPW, teczka: Spuścizna abp. Józefa Teodorowicza, sygn. 370/90 [5], List z Wydawnictwa Antona Pusteta do abp. Józefa Teodorowicza, Salzburg 11 XII 1935 r.

S[eine]r Exzellenz

Hochw[ürdigen] Herrn

Erzbischof Theodorowicz

Lemberg, Polen

BETRIFFT IHRE NACHRICHT VOM IHR ZEICHEN UNSER ZEICHEN M/S DATUM 11.12. [19]35

Euer ${ }^{\mathrm{a}}$ Exzellenz!

b-b Podłużna pieczęć.

Autograf nieczytelny.

a Tekst pisany maszyniowo na jednej stronicy papieru formatu A4. W górnej centralnej partii karty nadruk firmowy: „Verlag Anton Pustet Pressevereinsanstalten der Diözese Secau SALZBURG SIEGMUND-HAFFNER-GASSE 18, FERNSPRECHER NR. 259, DRAHTANSCRIFT PUSTET SALZBURG”. 
Hochw[ürdigen] P[ater] Odo Staudinger teilte mir mit, dass das Manuskript „Konnersreuth" vor dem Abschluss steht. Ich sagte ihm, dass wir nach wie vor bereit sind, das Buch herauszugeben.

Nur legte ich P[ater] Odo Staudinger nahe, Euer Exzellenz zu ersuchen, soweit es möglich ist, doch einige Kürzungen des Manuskriptes vorzunehmen. Das Buch würde sonst zu umfangreich und damit zu teuer und als Folge davon schwer absetzbar sein. Wenn es daher Euer Exzellenz möglich wäre, Stellen, die ohne Nachteil für das Gesamtwerk weggelassen werden können, eine Kürzung vorzunehmen. Dann habe ich P[ater] Odo gebeten, Euer Exzellenz nahe zu legen, ein kurzes Vorwort zu dem Buch zu schreiben, das Sinn und Aufgabe des Buches darstellt. Aus dem Inhaltsverzeichnis geht ja hervor, dass das Buch im Spiegel des Geschehens von Konnersreuth gleichzeitig ein Werk über Mystik ist. Das Vorwort etwas zu sagen, schiene mir ratsam.

Ebenso hätte ich Euer Exzellenz gebeten, ob es möglich wäre, diesen weiter gefassten Charakter des Buches auch im Titel zum Ausdruck zu bringen, entweder in der Form, dass man das Thema „Neue Mystik“ vielleicht sogar als Haupttitel wählt und Therese von Konnersreuth als Untertitel. Oder, falls das Euer Exzellenz nicht entsprechen würde, in einem Untertitel diesen Gedanken zum Ausdruck zu bringen.

Hochw[ürdigen] P[ater] Odo sendet Euer Exzellenz in den nächsten Tagen das Manuskript mit einigen Korrekturvorschlägen zu. Ich wäre Euer Exzellenz dann sehr dankbar, wenn ich diesen Teil schon in den ersten Januartagen zurück haben könnte, um die Drucklegung dann sofort in Angriff zu nehmen. Das umfangreiche Werk wird doch einige Zeit für die Drucklegung benötigen und ich möchte das Buch unbedingt zu Beginn der Fastenzeit fertig haben. Zu diesem Zeitpunkt jähren sich ja die Konnersreuther Ereignisse zum zehnten Mal, sodass das Buch so quasi ein Jubiläumswerk auch ist. Jedenfalls darf ich Euer Exzellenz sagen, dass ich mich über den Abschluss des Buchs freue und gerne hoffe, dass auch eine entsprechende Aufnahme in beiden Leserkreisen der Fall sein wird.

In Verehrung und Hochschätzung bin ich Ihr ergebener

b-VERLAG ANTON PUSTET
SALZBURG ${ }^{-\mathrm{b}}$
$[\ldots .]^{\mathrm{c}}$
Im Diktat gezeichnet

\section{Dokument 233}

Oryg.: AFKDOPW, teczka 144: Spuścizna abp. Józefa Teodorowicza, sygn. 1809/61 [5], List o. Odo Staudingera OSB do abp. Józefa Teodorowicza, Salzburg 1 I 1936 r.

Salzburg, Benediktinerkolleg[ium], am 1. I. [19]36

b-b Podłużna pieczęć.

c Autograf nieczytelny. 
Allgemeine ${ }^{\mathrm{a}}$ Anmerkung. Es wird höflichst ersucht dem Pater Siwek nun als Pater N.N. im Laufe des Buches zu bezeichnen.

Exzellenz, Hochwürdigster Herr Erzbischof!

Auf Grund Ihres gütigen Briefes erlaube ich mir folgende Bemerkungen zu unterbreiten:

1) Titel: Der von Exzellenz vorgeschlagen will weder Dr. Müllers noch mir gefallen. Ich schlage vor, Konnersreuth und katholische Mystik, oder Konnersreuth im Lichte der kath[olische] Mystik.

2) Ein kurzes (1-2 Seiten) Vorwort wäre angebracht, in welchem Exz[ellenz] die Leitidee Ihres Werkes recht klar zeichnen.

3) Korrekturbögen: Wünschen Exz[ellenz] die Druckkorrekturen zu machen oder überlassen Sie das dem Verlag? Im letzten Fall ginge der Druck natürlich rasch voran.

4) Seite 6: 4. Zeile: Wann (Jahr) hielt Dr. Hermann Neugarten ${ }^{485}$ bewussten Vortrag? Fußnote: Angabe der Seite und des Verlags erwünscht.

5) Seite 13: Fußnote: Leben der hl. Theresia: Angabe des Kapitels wäre wohl besser statt Seitenzahl.

6) Seite 22: Welches „Konnesr[euter] Jahrbuch“? (Jahr!)

7) Seite 23 letzte Zeile: Soll es nicht: schon schau! statt schon, schon heißen?

8) Seite 25 (27): 2. Absatz: Ist es wirklich von und durch Belege feststellbar, dass sich $\mathrm{Th}$ [erese] N[eumann] nach Leiden sehnt (nicht bloß geduldig leiden)?

9) Seite 26: 8 Zeile: Da ist ein Wort ausgefallen bei „dass man darüber nicht kann“. Vermutlich soll "reden“ oder "schreiben“ ergänzt werden.

10) Seite 31 Fußnote: Kann der Verlag angegeben werden?

11) Seite 36 Fußnote: Welches Werk von Egmont? Seite? Verlag?

12) Seite 42 Fußnote: Angabe des Buchtitels erwünscht. In der 2. Zeile haben Exz[ellenz] nach movestian ein $V$ gemacht. Warum?

13) S[eite] 48 letzter Absatz 3. Zeile „ganz besonders in den Beziehungen“. Ich fürchte, dass der Eindruck, den diese Worte machen, viel schlimmer ist als Sie wollen. Könnten Sie diese Wendung nicht besser formulieren oder die ersten 3 Zeilen dieses Absatzes streichen? Die Benennung der Zustände erfolgte ja vom „geheimnisvollem Sekretariat“!

14) S[eite] 54: Es fehlt die Angabe der Schrift, die das Zeugnis Dr. Willemins enthält. Gut wäre die genaue Angabe, wo (Kapitel) Benedikt XIV. Bewusstes sagt. Auch möchte ich empfehlen, dies in der Hauptsache den Aufsatz von Prälat Geiger (persona gratissima im Hause Neumann) einzuschalten, besonders die Bedingungen des Vaters und das Erlebnis mit Gemma Galgani. Schicke den Aufsatz (in der „Schildwache“). Wenn es Ihnen einmal nicht mehr notwendig, ist mir Rücksendung erwünscht. Das Kapitel

a Tekst pisany czarnym atramentem na dwóch stronicach papieru formatu A4. W lewym górnym rogu nadruk firmowy: „Schriftleitung des Benedictus-Boten”. W górnej partii karty na centralnym miejscu graficzne wyobrażenie godła Zakonu oo. Benedyktynów: krzyż z dwiema poprzecznymi belkami stojący na trzech wzniesieniach oraz PAX. Niżej tarczy inskrypcja: „Ut in omnibus glorificetur Deus”. Brak zakończenia i autografu autora.

${ }^{485}$ Osoba niezidentyfikowana. 
„Untersuchung" ist das am meisten umstrittene; dies bedarf es besonders Aufklärung. Im Weiterem folgt die Erklärung über IV. Teil III. Kapitels.

15) S[eite] 74 Fußnote: Statt Chateau wird es wohl besser heißen: „Seelenburg“, Seitenzahl weglassen.

16) S[eite] 88 Fußnote: letzte Zeile bei 1925 steht ein Fragezeichen. Ist das ein Tipp-Fehler? Fragezeichen weglassen.

17) S[eite] 96: 2. Absatz, 3. Zeile. „Dann sie verpflicht“ Dunkel ist des Wortes Sinn. Den ganzen Satz streichen.

18) S[eite] 105, drittletzte Zeile: „Folge nagen Betens“. „Folge langen Betens“

19) S[eite] 107, 2. Absatz, 5. Zeile: nach Neumann fehlt der Satzgegenstand.

20) S[eite] 113, 3. Absatz vorletzte Zeile: „sie besitzt ... kein Bett“ Ist das auch wahr? Glaub's nicht recht.

21) S[eite] 120 Fußnote: Wie heißt das Werk von Marechal?

22) S[eite] 121. Zeile 8: Welcher Kanonikus ist gemeint?

23) S[eite] 122, 2. Zeile: mit einem wahren „Pietismus“. Ist das der richtige Ausdruck für das, was Ex[zellen]z sagen wollen?

24) S[eite] 132, 1. Fußnote: Ebendaselbst findet sich nicht bei Gerlich, sondern Witt und umgekehrt bei Witt muss es heißen S[eite] 64 (nicht 65), nicht 86 sondern 89, nicht 87. 2. und 3. Absatz sind auf S.131 unterzubringen "bald kommt eine 2. Vision“, die in Wirklichkeit die 1. war. Werde all das richtig stellen. [... $]^{\mathrm{b}}$.

\section{Dokument 234}

Oryg.: AFKDOPW, teczka 145: Spuścizna abp. Józefa Teodorowicza, sygn. 371/90 [5], List z Wydawnictwa Antona Pusteta do abp. Józefa Teodorowicza, Salzburg 21 I 1936 r.

S[eine]r Exzellenz

Hochw[ürdigen] Herrn

Erzbischof Theodorowicz

Lemberg, Polen

BETRIFFFT IHRE NACHRICHT IHR ZEICHEN UNSER ZEICHEN M/S DATUM 21.1. [19]36

Euera Exzellenz!

Verzeihen Sie, wenn ich mich heute wieder mit der Bitte an Sie wende, den restlichen Teil des Konnersreuth-Manuskriptes doch umgehend hierher zu senden. In Übereinstimmung mit P[ater] Odo Staudinger möchten wir das Buch raschmöglichst

\footnotetext{
b Brak zakończenia.

a Tekst pisany maszyniowo na jednej stronicy papieru formatu A4. W górnej centralnej partii karty nadruk firmowy: „Verlag Anton Pustet Pressevereinsanstalten der Diözese Secau SALZBURG SIEGMUND --HAFFNER-GASSE 18, FERNSPRECHER NR. 259, DRAHTANSCRIFT PUSTET SALZBURG”.
} 
herausbringen, sodass das Werk bis zur Fastenzeit fertig ist. Da es aber einen sehr grossen Umfang hat, bedarf es seitens der Druckerei doch einiger Zeit bis es so weit ist, und das wäre eben nur möglich, wenn das vollständige Manuskript zur Hand wäre.

Ich bitte daher Euer Exzellenz ganz dringend, gütigst besorgt sein zu wollen, dass wir das Manuskript in den nächsten Tagen erhalten.

Ebenso erbitte ich dringend das Vorwort, da ich gerade dieses als Text für Voranzeigen benötige.

Mit Verehrung und Hochschätzung bin ich Euer Exzellenz ergebenster

b-VERLAG ANTON PUSTET

SALZBURG $^{-b}$

$[\ldots]^{\mathrm{c}}$

\section{Dokument 235}

Oryg.: AFKDOPW, teczka 145: Spuścizna abp. Józefa Teodorowicza, sygn. 372/90 [5], List z Wydawnictwa Antona Pusteta do abp. Józefa Teodorowicza, Salzburg 28 I 1936 r.

S[einer] Exzellenz

Erzbischof Theodorowicz

Lemberg, Polen

BETRIFFT IHRE NACHRICHT VOM IHR ZEICHEN UNSER ZEICHEN M/S 154 DATUM 28.1. [19]36

Euer ${ }^{\mathrm{a}}$ Exzellenz!

Mit verbindlichem Dank bestätige ich Ihr Telegramm vom 27. d[ieses] M[onats] Leider kann ich nun Ihrem Wunsche um Rücksendung des 2., 3. und 4. samtliche Teile gehen am 29. ds. ab. Teils im Augenblick nicht entsprechen, da hochw[ürdigen] P[ater] Odo Staudinger für etwa 2 Wochen verreist ist. Den dritten Teil, den er mir seinerzeit gegeben hat, schicke ich mit gleicher Post an Euer Exzellenz ab. Vielleicht können Euer Exzellenz diesen Teil für ev[en]t[uel]l vorgesehene Änderungen vorweg nehmen und druckfertig machen. Die anderen Teile schicke ich nach, sobald ich dieselben von P[ater] Odo Staudinger zurückerhalte.

Ich bitte, Euer Exzellenz, noch einmal darauf hinweisen zu dürfen, dass ein raschester Abschluss des druckfertigen Manuskriptes von Nöten ist, wenn dieses eben noch rechtzeitig für die Fastenzeit erscheinen soll. Und dass es zu diesem Zeitpunkt erscheint, ist mir ausserordentlich wichtig, da gerade zu diesem Zeitpunkt der zehnte Jahrestag der Erscheinung ist. Darum bin ich Euer Exzellenz nochmal um rascheste Zusendung, auch

b-b Podłużna pieczęć.

Autograf nieczytelny.

a Tekst pisany maszynowo na jednej stronicy papieru formatu A4. W górnej centralnej partii karty nadruk firmowy: „Verlag Anton Pustet Pressevereinsanstalten der Diözese Secau SALZBURG SIEGMUND-HAFFNER-GASSE 18, FERNSPRECHER NR. 259, DRAHTANSCRIFT PUSTET SALZBURG”. 
evtl. in Teilen, des druckfertigen Manuskriptes verbunden und zeichne mit Verehrung und Hochschätzung

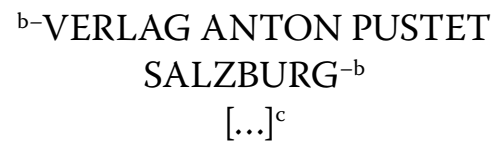

\section{Dokument 236}

Oryg.: AFKDOPW, teczka 144: Spuścizna abp. Józefa Teodorowicza, sygn. 1810/61 [5], List o. Odo Staudingera OSB do abp. Józefa Teodorowicza, Berchtesgaden 28 I 1936 r.

Exzellenz ${ }^{\mathrm{a}}$,

Berchtesgaden, am 28. 1. [19]36

Hochwürdigster Herr Erzbischof!

Bin seit Sonntag (26. M.) voraussichtlich auf einige Wochen hier zur Aushilfe. Heute erhielt ich Nachricht von Pustet, dass Exzellenz den 2.3.4. Teil zurückwünschen. Das wird besorgt.

Das Kapitel „Zerrbilder" macht mir noch zu schaffen. Gab es P[ater] Alois Mager zu lesen, um sein Urteil zu vernehmen. Er meinte, es sei viel zu weitschweifig, es könne ohne Schaden weg bleiben.

Meine Meinung ist diese: Da die Kontroverse zwischen Exzellenz und P[ater] Siwek auf Polen beschränkt blieb, soll es dabei bleiben. Ich wünsche darum aus diesem Kapitel alles Polemische weg; es mögen die Leitideen angegeben werden. Das zu tun und unterlassen ist, damit keine Zerrbilder entstehen und dann die 12 Merkmale echter Offenbarung nach der hl. Theresia angeben und sie auf Konnersreuth anwenden. Also ganz sachlich, ganz positiv, nichts Polemisches. Das ist meine Meinung. Darf ich das Kapitel in diesem Sinne umarbeiten? Oder wollen es Exzellenz nicht lieber und besser selber tun?

In ehrfurchtsvoller Begrüßung Euer Exzellenz ergebenster

$\mathrm{P}$ [ater] Odo Staudinger OSB z[ur] Z[eit] Berchtesgaden, (Bayern), Pension Seimler

\section{Dokument 237}

Oryg.: AFKDOPW, teczka 140: Spuścizna abp. Józefa Teodorowicza, sygn. 964/420 (8) [7], List dr. Ralpha Waldego Hynka do abp. Józefa Teodorowicza, Praga 7 II 1936 r.

b-b Podłużna pieczęć.

c Autograf nieczytelny.

a Tekst pisany czarnym atramentem na dwóch połówkach kart papieru formatu A4. W lewym górnym rogu nadruk firmowy: „Schriftleitung des Benedictus-Boten”. W górnej partii karty na centralnym miejscu graficzne wyobrażenie godła Zakonu oo. Benedyktynów: krzyż z dwiema poprzecznymi belkami stojący na trzech wzniesieniach oraz PAX. Niżej tarczy inskrypcja: „Ut in omnibus glorificetur Deus”. 
Eure $^{\text {a Exzellenz! }}$

Prag, am 7. Februar 1936

Ich war sehr erfreut durch Erinnerungen und Grüße von Ewerer Exzellenz, die mir von Lwów unser h[och]w[ürdiger] Herr Abt Vyskocil ${ }^{486}$ aus Emaus überbracht hat, leider war ich wiederum durch Grippe und Existenzfragen verhindert, mich schon früher Ewerer Exzellenz zu bedanken, was ich jetzt von meiner ganzen Seele tue.

Hoffentlich hat Ewer Exzellenz mein verdeutschtes Buch über den Martertod Christi erhalten soeben erscheint es slovakisch in Bratislava ${ }^{487}$ und die nächste Lieferung wird polnisch sein, durch meinen Kollegen und Freund W. Karnowski ${ }^{488}$ in Posen bei Św. Wojciecha ${ }^{489}$ gedruckt. Furs italienische war dies Buch allein Padre Gemelli, Rektor und Arzt von der mailändischen Universität übertragen.

Nun wir in Tschechoslowakei und Bayern freuen uns sehr auf das Werk Ewerer Exzellenz über Konnersreuth, dass bestimmt in jeder Ansicht ein Capolavor der genannten Konnersreuthliteratur sein wird. Es möge nun Gott die Gesundheit von Ewerer Exzellenz festigen und in jeder Hinsicht stärken! Wird es denn doch vor Ostern erscheinen?

Ich weiß es selber recht gut, wie innig meine beiden letzten Werke: „Martertod“ und "Mysterien" nicht meiner ganzen Konnersreuth Tätigkeit verbunden sind und und wie sehr zuerst das „lebendige Ebenbild des Gekreuzigten von Konn[ersreuth]“ und jetzt das authentische Bildnis Christi von Torin mein geistiges Leben gestärkt und bereichert haben. Denn schließlich beides ist eins und dasselbe. Die Predigt, das Apostolat des für uns Gekreuzigten nur das ist die Hauptsache. Weiter habe ich mich etwas in den Inhalt der Stigmatisation d[as] h[eist] die Mystik des Leidens, vertieft und da hätte ich an Ewere Exzellenz, als erprobter Kenner dieser Sache die innigste Bitte um etwaige Anweisungen, Literaturangaben etc. was diesen geheimnisvollen Abschnitt der Mystik des Kreuzes, sowie der Mystik des Gekreuzigten nach St. Paulus anbelangen möge.

Schließlich ist auch das nicht wunderbar dass in Konn[ersreuth] quasi der Spiritus agens ist wie hl. Theresia v[on] Kreuze Jesu und in den "Mysterien" wiederum die hl. Theresia vor heiligsten Antlitz? Denn ohne ihre Inspiration hätte ich niemals dieses Werk zustande gebracht.

Mit dem III Franziskaner Orden tun wir jetzt einen Vortragsfilm über diese Passion des Herrn vorbereiten, um damit ein reges Apostolat anzufangen.

Indem ich mich Ewerer Exzellenz ergebend empfehle, verbleibe ich mit Ausspruch besonderer Hochachten

Dr. R[alph] W[aldo] Hynek

a Tekst pisany czarnym atramentem na dwóch stronicach papieru format A4.

${ }^{486}$ Osoba niezidentyfikowana.

${ }^{487}$ Bratysława - największe miasto Słowacji; dziś stolica kraju.

${ }^{488}$ Osoba niezidentyfikowana.

489 Zapis zgodny z oryginałem; poprawnie: Wydawnictwie i Księgarni Św. Wojciecha. 


\section{Dokument 238}

Oryg.: AFKDOPW, teczka 145: Spuścizna abp. Józefa Teodorowicza, sygn. 920/420 (8) [7], List prof. Friedricha Ritter von Lamy do abp. Józefa Teodorowicza, Gauting 3 III 1936 r.

Gauting, 3. März 1936

\section{Excellenz ${ }^{\mathrm{a}}$,}

Hochwürdigster Herr Erzbischof !

Heute morgens erhielt ich Ihren ausführlichen Brief. Vielen Dank dafür! Was meine gute Schweizerin betrifft, so ist sie, seit ihre Konversion den Angehörigen bekannt geworden ist, vollkommen abgeschlossen und niemand, der ihr wohlwollend gesinnt ist, wird zugelassen. Sie wird von Vater und Schwester fortgesetzt moralisch misshandelt und nachdem ich hörte, die Schwester beschimpfe sie ein „verrücktes Mensch, das mit dem Teufel im Bund stehe", muss ich annehmen, dass da allerlei auffallende Dinge bereits vorgehen. Es hat ja die Fastenzeit begonnen und die Freitagsleiden sind schon lange da. Ich suche ihr durch einen noch gutgesinnten Bruder von ihr Erleichterung zu verschaffen. Wenn man aber die Türe bis Ostern zusperrt, dann hab ich nichts dagegen. Ich bin nahezu sicher, dass am Karfreitag die Male bluten und dann kann man wenigstens nicht uns Katholiken beschuldigen, wir hätten das gemacht.

Was P[ater] Pio $^{490}$ betrifft, wurden Sie von P[ater] Gemelli wissentlich falsch berichtet. Er war vor Jahren in San Giovanni, als noch die einschränkenden Bestimmungen Roms in Kraft waren, und wollte P[ater] Pios Stigmen sehen und untersuchen. Der Pater hat ihm freundlich erwidert, das sei gegen den Befehl seines Oberen, er dürfe die Stigmen nicht zeigen. Ob er, P[ater] Gemelli einen schriftlichen Ausweis des P[ater] Provinzial oder General habe, dass er, P[ater] Pio, die Male zeigen dürfe. Gemelli musste das verneinen und P[ater] Pio bedauerte, ihm daher nicht dienen zu Können. Gemelli war schwer verletzt und sah darin einen Vorwand, unter dem man ihm einen Betrug verheimlichen wolle. Er hat niemals die Wundmale gesehen, nie sie untersucht. Er hat aber, was er zu Eurer Excellenz gesagt hat, auch zu anderen gesagt und in Vita e Pensiero einen Artikel geschrieben, in dem er nur Franz von Assisi ${ }^{491}$ und Katharina von Sien ${ }^{492}$ - weil von der Kirche anerkannt! - als echte Stigmatisationen gelten liess; in allen anderen Fällen seien sie lediglich Effekte von Hysterie etc.! Darauf hat ihm der römische Arzt Dr. Festa ${ }^{493}$, der $\mathrm{P}$ [ater] Pios Wundmale wiederholt und in längeren Zeitabständen gründlich untersucht

a Tekst pisany maszynowo na dwóch stronicach papieru formatu A4. Autograf autora odręczny czarnym atramentem.

${ }_{490}$ Św. o. Pio z Pietrelciny/Forgione Francesco (1887-1968), święcenia kapłańskie w 1910 r. w Benewencie (Włochy) w Zakonie oo. Kapucynów, od 1916 r. przebywał w klasztorze w San Giovanni Rotondo, stygmatyk i wizjoner, beatyfikowany w 1999 r., kanonizowany w $2002 \mathrm{r}$.

${ }_{491}$ Zob. w niniejszej publikacji: J. Wołczański, Korespondencja abp. Józefa Teodorowicza z o. Włodzimierzem Ledóchowskim SJ, dokument 13.

${ }^{492}$ Św. Katarzyna ze Sieny (1347-1380), włoska tercjarka dominikańska, mistyczka, doktor Kościoła, kanonizowana $\mathrm{w} 1461 \mathrm{r}$.

${ }^{493}$ Festa Giorgio (1860-1940), włoski lekarz, opiekował się zdrowiem o. Pio z Pietrelciny, został wyznaczony przez przełożonego Zakonu oo. Kapucynów do badań stygmatów zakonnika, wyniki obdukcji zwarł w publikacji Misteri di scienza e luci di fede. Stigmate del Padre Pio da Pietrelcina. Źródło: Giorgio Festa Wikipedia, https://en.wikipedia.org/wiki/Giorgio_Festa. Dostęp: 10 V 2017 r. 
hat, in seinem Buche „Tra i misterli della Scienza e le luci della Fede ${ }^{\text {“494 }}$ ausführlich erwidert und hat ihn vollauf widerlegt. Und dieses Buch veröffentliche ich nun, aber ich nehme noch die Rücksicht, dass ich jenes Kapitel daraus, das speziell P[ater] Gemelli gewidmet ist, einstweilen nicht bringe, nachdem such sein Artikel gegen P[ater] Pio bisher in Deutschland unbeachtet blieb. Uebrigens sind die Einschränkungen seitens Roms seit ein paar Jahren aufgehoben, wie mir der P[ater] Provinzia1 schrieb, und zwar war das die Wirkung des Buches Dr. Festas. Ich erlaube mir, Ihnen die Korrekturfahnen zu schicken; das Buch selbst Kommt erst in den nächsten Wochen heraus.

Bezüglich der Anastasia Wolozyn ${ }^{495}$ war es meine selbstverständliche Absicht, die Entwicklung erst einmal abzuwarten, aber ich wollte mir für alle Fälle im voraus das Material sichern und bin ich heute schon herzlich für alles dankbar.

Es hat mich sehr überrascht zu hören, dass Ihr Buch nun doch bei Pustet in Salzburg herauskommt. Schade, denn bei den gegenwärtigen Devisenbestimmungen in unserem Lande wird es nahezu unmöglich sein, das Buch zu beziehen. Ich möchte Eure Excellenz sehr dringend bitten, mir die Korrekturbogen zur Einsicht zugehen zu lassen, um ein ausführliches Referat für mein Jahrbuch 1935 vorzubereiten, mit dessen Ausarbeitung ich bereits begonnen habe. Es wird jedenfalls der Verbreitung Ihres Buches sehr gute Deinste leisten, wenn es unter den rund 6000 Lesern meines Jahrbuches bekannt wird. Ich begrüsse Eure Excellenz in bekannt aufrichtiger Verehrung ergebenst

Friedr[ich] R[itter] von Lama

\section{Dokument 239}

Oryg.: AFKDOPW, teczka 140: Spuścizna abp. Józefa Teodorowicza, sygn. 919/420 (8) [7], List dr. Ralpha Waldego Hynka do abp. Józefa Teodorowicza, Praga 4 III 1936 r.

Euere $^{a}$ Exzellenz!

Mit großer Freude habe ich den Brief von Ewerer Exzellenz empfangen und freue mich wirklich aufrichtig auf Ihr wichtiges Buch über Konnersreuth.

Mein Freund R[itter] v[on] Lama hat mir soeben mitgeteilt, er hätte für Ewere Exzellenz noch eine sehr wichtige Mitteilung betreffs des Buches zu machen, bitte sich darum gütigst an ihn zu wenden.

$[\ldots]^{\mathrm{b}}$ denn Konnersreuth eben 10 Jahre in Erscheinung, desto größere Bedeutung wird daher Ihr fachmännisches Buch $[. . .]^{c}$ mit sich wünsche ihm wirklich den besten Erfolg.

In Christo hochachtungsvoll ergebenster

Prag, am 4 März 1936

Dr. R[alph] W[aldo] Hynek

\footnotetext{
${ }^{494}$ G. Festa, Tra i misterli della Scienza e le luci della Fede, Roma 1933.

495 Osoba niezidentyfikowana.

Tekst pisany czarnym atramentem na jednej stronicy papieru format A4.

Tekst nieczytelny.

Tekst nieczytelny.
} 


\section{Dokument 240}

Oryg.: AFKDOPW, teczka 145: Spuścizna abp. Józefa Teodorowicza, sygn. 373/90 [5], List z Wydawnictwa Antona Pusteta do abp. Józefa Teodorowicza, Salzburg 11 III 1936 r.

S[eine]r Exzellenz

Herrn Erzbischof

Dr. Theodorowicz

Lwów, Polen

BETRIFFT IHRE NACHRICHT VOM/ IHR ZEICHEN/ UNSER ZEICHEN M/C/ DATUM 11.3. [19]36

Euer ${ }^{\mathrm{a}}$ Exzellenz!

Auf Ihre Anfrage kann ich Ihnen mitteilen, dass Ihr „Konnersreuth“ - Werk bereits in Satz ist und wohl in den allernächsten Tagen schon ausgesetzt sein wird.

Vereinbarungsgemäss liest Pater Odo Staudinger die Korrekturen. Wenn diese Arbeit rasch vorstatten geht, rechnen wir damit, dass das Werk noch vor Ostern fertig sein wird.

Mit dem Ausdruck meiner Verehrung und Hochschätzung bin ich Euer Exzellenz ergebener

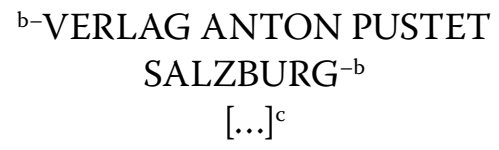

\section{Dokument 241}

Oryg.: AFKDOPW, teczka 145: Spuścizna abp. Józefa Teodorowicza, sygn. 374/90 [5], List z Wydawnictwa Antona Pusteta do abp. Józefa Teodorowicza, Salzburg 14 III 1936 r.

S[eine]r Exzellenz

Salzburg, am 14. III. 1936

Erzbischof Teodorowicz

Lwów, Polen

Euer ${ }^{\mathrm{a}}$ Exzellenz!

Gestern gingen irrtümlich Korrekturfahnen und ein Teil des Manuskriptes des Werkes „Konnersreuth im Lichte der Mystik und Psychologie“ an die Adresse Euer Exzellenz

a Tekst pisany maszyniowo na jednej stronicy papieru formatu A4. W górnej centralnej partii karty nadruk firmowy: „Verlag Anton Pustet Pressevereinsanstalten der Diözese Secau SALZBURG SIEGMUND-HAFFNER-GASSE 18, FERNSPRECHER NR. 259, DRAHTANSCRIFT PUSTET SALZBURG”.

b-b Podłużna pieczęć.

c Autograf nieczytelny.

a Tekst pisany maszyniowo na jednej stronicy papieru formatu pocztówki. W górnej centralnej partii karty nadruk firmowy: „Verlag Anton Pustet Pressevereinsanstalten der Diözese Secau SALZBURG SIEGMUND-HAFFNER-GASSE 18, FERNSPRECHER NR. 259, DRAHTANSCRIFT PUSTET SALZBURG". 
ab. Da Pater Odo Staudinger hier die Korrekturen liest, wären wir für rasche Rücksendung von Manuskript und Fahnen sehr verbunden.

Mit dem Ausdruck unserer besonderen Verehrung

${ }^{\mathrm{b}}$ VERLAG ANTON PUSTET

SALZBURG $^{-\mathrm{b}}$

$[\ldots]^{\mathrm{c}}$

\section{Dokument 242}

Oryg.: AFKDOPW, teczka 144: Spuścizna abp. Józefa Teodorowicza, sygn. 1041/420 (8) [7], List o. Odo Staudingera OSB do abp. Józefa Teodorowicza, Salzburg 24 III 1936 r.

Salzburg, Benediktinerkolleg[ium], am 24. III. [19]36

Exzellenz ${ }^{\mathrm{a}}$, Hochwürdigster Herr Erzbischof!

War bis 14. März in Berchtesgaden ${ }^{496}$ zur Aushilfe, nicht zur Erholung. Als ich zurück kam, erkundigte ich mich bei Pustet nach der Fortsetzung Ihres Manuskriptes. Direktor Müller war sehr überrascht, dass es mir nicht in die Hände gekommen. Durch ein Versehen war es gleich in die Setzerei gekommen, wo man noch an der Arbeit ist. Über 200 Fahnen sind schon abgezogen. Das Manuskript werde ich wohl in den nächsten Tagen bekommen. Die Druckbogen kann ich leider nicht alle durchsehen, da Herr Müller große Eile hat, m. E. zu [...] $]^{\mathrm{b}}$ ich unmöglich den ganzen Tag wegen anderer vieler Arbeit und auch wegen des für meine schwachen Augen zu kleinen Druckes über den Druckfahnen sitzen kann. Doch bin ich in Verbindung mit Dr. Dietrich ${ }^{497}$, der alles liest und die letzte stilistische Feile anlegt. In zweifelhaften Fällen werde ich ihnen die Korrekturbogen zugehen lassen. Da m. E. das Buch vor Ostern doch nicht mehr erscheint, würde ich es nicht für überflüssig halten, wenn Exzellenz sich alle Korrekturen zukommen ließen. Es ist mir arg, dass mir ein Bock wie der auf Spalte 14 entgangen ist.

Dass Lama eine Inhaltsangabe Ihres Buches vor dessen Erscheinen bringt, ist ausgeschlossen. Denn er kommt mit seinem Sachbuch im [... $]^{c}$ in der 2. Jahreshälfte. Das von 1934 erschien um Weihnachten 35. Wann es sich technisch machen lässt, möchte ich nicht abraten, ihm die Druckfahnen zugehen zu lassen zugleich mit der Bitte, Exzellenz auf die etwaige Fehler aufmerksam zu machen. Falls es sich nicht machen lässt, kann es gut die wenigen Wochen bis zum Erscheinen sich gedulden. Doch ist meine unmaßgebende Meinung, dass es nicht schaden, sondern nur von Nutzen sein könnte, wenn

b-b Podłużna pieczęć.

Autograf nieczytelny.

a Tekst pisany czarnym atramentem na dwóch kartach papieru formatu A4. W lewym górnym rogu nadruk firmowy: „Schriftleitung des Benedictus-Boten”. W górnej partii karty na centralnym miejscu graficzne wyobrażenie godła Zakonu oo. Benedyktynów: krzyż z dwiema poprzecznymi belkami stojący na trzech wzniesieniach oraz PAX. Niżej tarczy inskrypcja: „Ut in omnibus glorificetur Deus”.

${ }^{496}$ Berchtesgaden - miejscowość w Bawarii (Niemcy).

b Tekst nieczytelny.

497 Osoba niezidentyfikowana.

c Tekst nieczytelny. 
ihm sein Wunsch erfüllt würde. Das war aber ein Meisterstück von Schlauheit, dass Exzellenz P[ater] Mager im Vorwort unterbrachten ihm eine so goldene Brücke bauten!

Nun haben Sie ja selber in Lwów eine Stigmatisierte, die Nastja! Wieder was für den „Ben[edictus] Boten“. Ich kann mir das schelmische Lächeln Eu[re] Exzellenz vorstellen, wenn Sie die Zeilen lesen. Ich bin sogar so kühn, Exzellenz zu bitten, nach Fertigstellung des Bandes über Konnersreuth mir etwas über Nastja, sei es durch Ihren Sekretär oder sonst jemand, besorgen zu wollen (womöglich auch Photos). Es soll ihr in der Ekstase Christus erschienen sein in Begleitung eines deutschen Mädchens, das seit 10 Jahren die Stigmata tragt und gesagt haben, dieses Mädchen werde 1936 sterben. Nun, da können wir gespannt sein. Vedderemo!

Für recht bald recht große Freuden mit Ihrem Buche wünschend, empfiehlt sich $\mathrm{Eu}[\mathrm{re}]$ Exzellenz ehrfurchtsvoll ergebener

P[ater] Odo Staudinger OSB

\section{Dokument 243}

Oryg.: AFKDOPW, teczka 144: Spuścizna abp. Józefa Teodorowicza, sygn. 1040/420 (8) [7], List o. Odo Staudingera OSB do abp. Józefa Teodorowicza, Salzburg 25 III 1936 r.

Salzburg, 25. III. [19]36

Eminenz! ${ }^{\mathrm{a}}$

Gestern war ich wieder bei Pustet. Die Arbeit geht gut voran. Sie drängt, wie man mir sagte, weil sie als Frühjahreserscheinung bereits gemeldet worden ist. Bei zu großem Vorzug wäre zu viel Geld für Propaganda verpulvert. Dr. Dietrich, Verlagsangestellter, besorgt die Korrekturen. Ich bemühe mich, ihn zu unterstützen.

In ehrfurchtsvoller Ergebenheit

P[ater] Odo Staudinger OSB

\section{Dokument 244}

Oryg.: AFKDOPW, teczka 140: Spuścizna abp. Józefa Teodorowicza, sygn. 962/420 (8) [7], List dr. Ralpha Waldego Hynka do abp. Józefa Teodorowicza, Praga 9 IV 1936 r.

\section{Euere $^{\text {a }}$ Exzellenz!}

Gerade habe ich den Brief von Ewerer Exzellenz mit ausführlichen Bericht über die stigmatische Nastjana erhalten nun beeile ich mich Ewerer Exzellenz meinen sinnigsten Dank somit aufrichtigsten Wunsch von frohen und segensreichen Ostern

a Tekst pisany czarnym atramentem na rewersie karty pocztowej. W prawej kolumnie nota: „Exzellenz dem Hoch[würdigen] Hernn Erzbischof Dr. Jo[sef] Teodorowicz, Lwów, Polen, Orm[i]anskagasse 9”. W górnej partii karty dwa austriackie znaczki pocztowe I stempel pocztowy: „Salzburg 25 III [19]36”. Na awersie fotografia fragmentu portalu kościoła opactwa oo. Benedyktynów w Ligugè - Francja.

a Tekst pisany czarnym atramentem na 1,5 stronicy papieru formatu A4. 
auszusprechen. Freue mich schon riesig auf das angekündigte Buch von Ewer Exzellenz über Konnersreuth. Voriges Jahr haben wir in Ost Böhmen auch einen Fall von „Stigmatisierten" gehabt. Als Mitglied einer bischöflichen Kommission habe ich aber ihre Wunden als durch Gilletrasiermesserklinge entstandene erklärt mir seit der Zeit hört man nichts über die betreffende Person.

Wenn bei Nastjana sich um „Apporte“ von Blumen etc. handelt, gehört dieser Fall wirklich mehr in Metapsychologie als in Mystik wie sich soeben der Fall aus Bukowina $^{498}$, den Gräfin Wasilewska ${ }^{499}$ beschrieb, hieß die Betreffende.

Man kann in vielen Sachen gar nicht genug vorsichtig vorgehen. Freund, Biologe, Univ[ersität] Prof[essor] Dr. Babre ${ }^{500}$ hat mich auch damals in der Untersuchungskommission begleitet und den Fall Frau Hladik ${ }^{501}$ auch als vollkommen negativ beurteilt.

Ewerer Exzellenz nochmals innigst dankbar zeichnet sich in Christus ergebenster Dr. R[alph] W[aldo] Hynek

Prag, am 9/IV 1936

\section{Dokument 245}

Oryg.: AFKDOPW, teczka 145: Spuścizna abp. Józefa Teodorowicza, sygn. 375/90 [5], List z Wydawnictwa Antona Pusteta do abp. Józefa Teodorowicza, Salzburg 27 IV 1936 r.

S[eine]r Exzellenz dem Hochwürdigsten Herrn Erzbischof

Dr. Josef Teodorowicz

Lemberg, Polen

BETRIFFT IHRE NACHRICHT VOM IHR ZEICHEN UNSER ZEICHEN DR. D/L DATUM 27. IV. 1936

Euer ${ }^{a}$ Exzellenz!

Hochwürdigen Pater Odo Staudinger übermittelt uns Schreiben Euer Exzellenz vom 23. IV., auf das zu antworten wir uns beeilen wie folgt: Es ist uns selbstverständlich ausserordentlich peinlich, dass Euer Exzellenz nachträglich doch damit rechneten, Korrekturbogen des Werkes über Konnersreuth zu erhalten. Da wir aber ursprünglich von Pater Odo Staudinger damit beauftragt wurden, die Korrekturen selbst hier an Ort und Stelle einzulesen, haben wir es unterlassen, Euer Exzellenz mit der Zusendung der Korrekturen zu behelligen.

${ }^{498}$ Bukowina - region historyczny w Europie Wschodniej pomiędzy Karpatami Wschodnimi a środkowym Dniestrem.

499 Osoba niezidentyfikowana.

500 Osoba niezidentyfikowana.

501 Osoba niezidentyfikowana.

a Tekst pisany maszynowo na 1,5 stronicy papieru formatu A4. W górnej centralnej partii karty nadruk firmowy: „Verlag Anton Pustet Pressevereinsanstalten der Diözese Secau SALZBURG SIEGMUND-HAFFNER-GASSE 18, FERNRUF 259". 
Wie Euer Exzellenz richtig vermerken ist es jetzt leider zu spät, denn das Werk ist im Druck bereits bis über die Hälfte vorgeschritten.

Wie die Rezensionsexemplare betrifft, die Euer Exzellenz verschicken wollen, so bitten wir Euer Exzellenz um eine Liste der Adressen derjenigen Personen, an die Rezensionsexemplare versandt werden sollen; dies geschieht dann vom Verlag aus.

Soweit Euer Exzellenz Exemplare persönlich versenden möchten, bitten wir um die Aufgabe der Zahl, aber auch um gütige Angabe der Adressen, damit Doppelsendungen vermieden werden können. Ausserdem werden wir selbstverständlich Rezensionsexemplare an die grossen Zeitungen und Zeitschriften des gesamten deutschen Sprachgebiets senden.

Wir bitten Euer Exzellenz den Ausdruck unserer tiefsten Verehrung entgegennehmen zu wollen und verbleiben Euer Exzellenz ergebenster

b-VERLAG ANTON PUSTET

SALZBURG $^{-\mathrm{b}}$

Dr. Dietrich ${ }^{\mathrm{c}}$

\section{Dokument 246}

Oryg.: AFKDOPW, teczka 144: Spuścizna abp. Józefa Teodorowicza, sygn. 1807/61 [5], List o. Odo Staudingera OSB do abp. Józefa Teodorowicza, Salzburg 23 IV 1936 r.

Salzburg, Benediktinerkolleg[ium], am 23. 4. [19]36

Exzellenz ${ }^{\mathrm{a}}$, Hochwürdigster Herr Erzbischof!

Bin fest an der Arbeit mit der Korrektur der Druckbögen. Es werden fast 600 Seiten $\mathrm{v}$ [on] Lama hat die Abzüge erhalten. Wenn er stilistische Korrekturen machen darf, auch inhaltliche, so bitte ich, es ihm direkt mitteilen zu wollen. Eine Erwähnung im Vorwort ist deswegen nicht notwendig. Auch Dr. Dietrich verzichtet darauf. Was Exzellenz im Bezug auf mich ergänzten (im Manuskript), ist glücklicherweise in der Druckerei übersehen worden, so dass die Vorsehung, die höchste Gerechtigkeit, dafür gesorgt hat, dass es nicht hineinkomme. Da u[nd] dort sind noch stilistische Härten, wo ich gern die geübte Hand Lamas heranziehen möchte. Das Werk dürfte in etwa 18 Tagen erscheinen. Es soll etwas ganz tadelloses werden.

Ehrfurchtsvoll empfiehlt sich Ew[ere] Exzellenz ergebenster

P[ater] Odo Staudinger OSB

Ob bei Elisabeth X. nicht die wenigen Zeilen von Witry in seiner Broschüre „Die Resl" nicht auch genügten?

b-b Podłużna pieczęć.

Autograf odręczny pisany czarnym atramentem.

a Tekst pisany czarnym atramentem na dwóch $1 \frac{1}{2}$ kartach format A4. W lewym górnym rogu nadruk firmowy: „Schriftleitung des Benedictus-Boten”. W górnej partii karty na centralnym miejscu graficzne wyobrażenie godła Zakonu oo. Benedyktynów: krzyż z dwiema poprzecznymi belkami stojący na trzech wzniesieniach oraz PAX. Niżej tarczy inskrypcja: „Ut in omnibus glorificetur Deus”. 


\section{Dokument 247}

Oryg.: AFKDOPW, teczka 144: Spuścizna abp. Józefa Teodorowicza, sygn. 1808/61 [5], List o. Odo Staudingera OSB do abp. Józefa Teodorowicza, Salzburg 24 IV 1936 r.

Exzellenz ${ }^{\mathrm{a}}$,

Hochwürdigster Herr Erzbischof!

Habe heute S. 185-219 des Umdruckes gelesen. Darf ich mehrere Schwierigkeiten zur baldigsten Lösung vorlegen? Bei Analyse der Geisteskräfte, ist Fargues, Op. S. 199 zitiert. Welches Werk ist damit gemeint. Oder ist Farges, „Les phenomenes mystiques“ gemeint? S. 212 des Umbruchs heißt es, dass der Rest die Betrachtung des Leidens Christi im gewöhnlichen Zustand versucht ... doch so ergriffen wird. Dass für sie diese Betrachtung unmöglich wird.

[S.] 219: „Th[erese] N[eumann] wehrt sich dagegen, die Leidensgeschichte in ihrem natürlichen Zustande zu trachten“. Wenn ich mich nicht irre, kam eine ähnliche Stelle auch früher ein mal vor. Ist das nicht ein gewisser Widerspruch? Sollen wir es so lassen?

Bei Dublanchy („Die mystische Bindung“) ist „Dict[ionaire] de th[eologie] cath[olique]" col. 2041 angegeben. Welcher Band? Im Manuskript (Zitat Benedikt XIV.) heißt es ,... in Castro animae mansion T. habe geschrieben mansione", habe geschrieben „mansione“. Wird wohl stimmen.

In ehrfurchtsvoller Empfehlungen Eu[re] Exzellenz ergebenster

$\mathrm{P}$ [ater[ Odo Staudinger OSB

\section{Dokument 248}

Oryg.: AFKDOPW, teczka 144: Spuścizna abp. Józefa Teodorowicza, sygn. 1805c/61 [5], List o. Odo Staudingera OSB do abp. Józefa Teodorowicza, [Salzburg] 29 IV 1936 r.

29. 4. [19]36

Exzellenz! ${ }^{\mathrm{a}}$

Darf es im 6. Teil statt „Hungererscheinungen“ $u[n d]$ regelmäßig statt „Hunger“ nicht „Nahrungslosigkeit“ heißen? T. Mages ${ }^{502}$ meint, letzteres sei zu schreiben.

a Tekst pisany czarnym atramentem na dwóch $\frac{1}{2}$ kartach format A4. W lewym górnym rogu nadruk firmowy: „Schriftleitung des Benedictus-Boten”. W górnej partii karty na centralnym miejscu graficzne wyobrażenie godła Zakonu oo. Benedyktynów: krzyż z dwiema poprzecznymi belkami stojący na trzech wzniesieniach oraz PAX. Niżej tarczy inskrypcja: „Ut in omnibus glorificetur Deus”.

a Tekst pisany czarnym atramentem na karcie pocztowej. Na awersie podłużna pieczęć: „Absender P. Odo Staudinger OSB, Salzburg Kolleg. St. Benedikt” i nota: „Exzellenz Hoch. Herrn Erzbischof Dr. Teodorowicz, Lwów, Orm[i]asnkagasse 9 Polen“. W prawym górnym rogu cztery znaczki austriackie pocztowe i stemple pocztowe: „Salzburg 29 IV [19]36“.

502 Osoba niezidentyfikowana. 
Da ich noch gar weiß, ob die Drucker Ihre Antwort abwarten will, es sollen täglich 2 Bogen durch die Maschine laufen - wäre mir ein Telegramm lieb. „Ja“ würde mir sagen, dass ich statt „Hunger“ Nahrungslosigkeit schreiben darf.

In ehrfurchtsvoller Ergebenheit

P[ater] Odo Staudinger OSB

\section{Dokument 249}

Oryg.: AFKDOPW, teczka 144: Spuścizna abp. Józefa Teodorowicza, sygn. 1806/61 [5], List o. Odo Staudingera OSB do abp. Józefa Teodorowicza, Salzburg 2 V 1936 r.

Exzellenz! ${ }^{\text {a }}$

Salzburg, Benediktinerkolleg[ium], am 2 V [19]36

Verzeihen Exzellenz, dass ich erst heute die betreffenden Stellen sende, wo das Zitat nicht stimmt. Wenn die Richtigstellung nicht mehr zur rechten Zeit kommt, schreibe ich einfach, wo von der Ekstase die Rede ist: „Poulain“ 3. Teil. Bei den Visionen und Offenbarungen (Manus. 284): Poulain, 4. Teil.

Also machen sich Exzellenz bitte nicht mehr zu viel Mühe! Das Werk dürfte nächste Woche im Druck fertig, mit der Auslieferung übernächste Woche begonnen werden.

In ehrfurchtsvoller Ergebenheit

P[ater] Odo Staudinger OSB

\section{Dokument 250}

Oryg.: AFKDOPW, teczka 144: Spuścizna abp. Józefa Teodorowicza, sygn. 1804/61 [5], List o. Odo Staudingera OSB do abp. Józefa Teodorowicza, Salzburg 8 V 1936 r.

Salzburg, Koleg[ium] St. Benedikt, am 8.5. [19]36

$\mathrm{An}^{\mathrm{a}}$ das hochw[ürdigster] Erzbischöfl[iche] Sekretariat!

Eu[re] Hochwürden!

Bitte noch um einige Berichtigungen.

1) 1.Teil bei Gottesliebe wird Lama „Konn[ersreuter] Jahrbuches“ 101 angegeben. Ich habe alle diese Jahrb[uches] nachgesehen, bei keinem die betreff. Stelle gefunden. Von Lama, dem ich geschrieben, habe ich noch keine Antwort.

2) 1.Teil Witt wird Ausgabe $1927 \mathrm{u}[$ nd] 1929 angeben. Wo vom Schlecken von Feuersbrunst die Rede ist (Fußnote 82 im gedruckten Werk) ist Seite 36 angegeben. Ist das wichtig bei der Ausgabe v[on] 1929?

a Tekst pisany czarnym atramentem na $1 \frac{1}{2}$ karty papieru format A4. W lewym górnym rogu nadruk firmowy: „Schriftleitung des Benedictus-Boten”. W górnej partii karty na centralnym miejscu graficzne wyobrażenie godła Zakonu oo. Benedyktynów: krzyż z dwiema poprzecznymi belkami stojący na trzech wzniesieniach oraz PAX. Niżej tarczy inskrypcja: „Ut in omnibus glorificetur Deus”.

a Tekst pisany czarnym atramentem na dwóch stronicach papieru format listowego. W lewym górnym rogu karty tytułowej nadruk firmowy: „+ PAX“. 
Ich habe nur die Ausgabe v[on] 1927. Bei Poulain (Margareta von Ricca) die genaue Seitenzahl oder das Kapitel am Grâces d'raison angegeben werden.

Mit besten Grüßen empfiehlt sich Ew[ere] Hochwürden ergebenst

$\mathrm{P}$ [ater] Odo Staudinger OSB

Es wird doch richtig heißen: Inordinatu corporis motus minime decentes signum esse... Benedikt XIV. nicht inordinatus (erwähnt gegen Schluss des 10. Teiles: Mirabelli).

\section{Dokument 251}

Oryg.: AFKDOPW, teczka 144: Spuścizna abp. Józefa Teodorowicza, sygn. 1805a/61 [5], List o. Odo Staudingera OSB do abp. Józefa Teodorowicza, [Salzburg] 9. 5. [19]36

Exzellenz! $!^{\mathrm{a}}$

9.5. $[19] 36$

Heute morgen berichtete ich noch an Pustet, dass bei Lama die Quelle (1.Teil Fußnote 7) die Quelle unvollständig zitiert sei und ich den Bogen auf meine Verantwortung nicht drucken lassen könne. Heute Abend erfuhr ich, dass der Herr Direktor gestern Abend abgereist ist, meine Mitteilung also nicht empfangen hat.

Der vorletzte Bogen mit den Fußnoten bis J. 528 wurde heute vorm. ganz ausgedruckt (2200 Stück), der letzte Bogen in 500 Stück. Der Expressbrief bekam ich heute nachmittag.

Wollen Exzellenz bitte dem Verlag mitteilen, was Sie wünschen, ob man vielleicht einen Zettel „Berichtigungen“ einlegen soll. Den Expressbrief bekam ich heute nachmittags.

Werde, so Gott will, am Mittwoch auf mehrere Wochen verreisen. Abs[ender] Innsbruck, Hungerburg (bei Prof. Schlenz ${ }^{503}$ ).

In ehrfurchtsvollen Ergebenheit

$\mathrm{P}$ [ater[ Odo Staudinger OSB

Das Werk wird am Montag (11.) oder Dienstag versandfertig werden.

a Tekst pisany na karcie pocztowej czarnym atramentem. Na awersie nota: „Absender - Ih[re] Exzellenz, dem Hochwürdigsten Herrn Erzbischof Dr. Jos[ef] Teodorowicz, Lwów, Polen, Orm[i]anskagasse 9“. W prawym górnym rogu nieczytelne dwa stemple pocztowe, jeden firmowy znaczek z godłem Austrii, po dwóch innych zostały ślady.

${ }^{503}$ Schlenz Johann (1867-1939), czeski duchowny katolicki, dr teologii, 1895-1899 katecheta w Reichenberg (Liberec), 1900-1906 prof. gimnazjalny tamże, w 1906 r. został wykładowcą historii Kościoła i prawa kanonicznego w Seminarium Duchownym w Leitmeritz, 1914-1935 prof. prawa kanonicznego na Wydziale Teologicznym Uniwersytetu w Pradze, w roku akad. 1917/18 dziekan fakultetu, 1935-1939 emeryt; autor prac naukowych. A.K. Huber, Schlenz Johann, w: ÖBL, Bd.10, herausg. von P. Csendes, Wien 1994, s. 188.

b Niżej autografu podłużna pieczęć z napisem: „P. Odo Staudinger OSB, Salzburg Kolleg[ium] St. Benedikt". 


\section{Dokument 252}

Oryg.: AFKDOPW, teczka 145: Spuścizna abp. Józefa Teodorowicza, sygn. $376 / 90$ [5], List z Wydawnictwa Antona Pusteta do abp. Józefa Teodorowicza, Salzburg 15 V 1936 r.

S[eine]r Exzellenz dem Hochwürdigsten Herrn

Salzburg, 15.5.1936 B/S

Erzbischof Teodorowicz

Lwów, Polen

$\mathrm{Eu}[\mathrm{re}]^{\mathrm{a}}$ Exzellenz

Hochwürdiger Herr Erzbischof!

Wir bestätigen mit ergebenstem Dank Eu[er] Exzellenz Schreiben vom 06. d[ieses] $\mathrm{M}$ [onats]. Das Buch ist inzwischen fertig geworden und gestatten uns 2 Exemplare mit gleicher Post als Kreuzband vorauszuschicken. Die restlichen Autorenexemplare folgen im Postpaket.

Die Versendung der Rezensionsexemplare werden wir nach der uns übersandten Liste vornehmen. Visitenkarten mit deutschem Aufdruck haben wir in Druck gegeben. Selbstverständlich senden wir an alle angegebenen Herren gebundene Exemplare.

Leider war es uns nicht mehr möglich, im Buch selbst einen Hinweis auf die Arbeit des hochw[ürdigen] Herrn P[ater] Staudinger bei der Drucklegung des Werkes zu bringen. Jedenfalls werden wir dem hochw[ürdigen] Herrn Pater einstweilen ein gebundenes Exemplar überreichen.

$\mathrm{Eu}[\mathrm{rer}]$ Exzellenz ergebenster

b-VERLAG ANTON PUSTET

SALZBURG $^{-b}$

$[\ldots]^{\mathrm{c}}$

Mit gleicher Post: 2 Exemplare „Konnersreuth”.

\section{Dokument 253}

Oryg.: AFKDOPW, teczka 145: Spuścizna abp. Józefa Teodorowicza, sygn. 377/90 [5], List z Wydawnictwa Antona Pusteta do abp. Józefa Teodorowicza, Salzburg 22 V 1936 r.

Salzburg, 22.5.1936 B/S

S[eine]r Exzellenz dem hochwürdigsten Herrn

Erzbischof Teodorowicz

Lemberg, Polen

a Tekst pisany maszyniowo na jednej stronicy papieru formatu A4. W górnej centralnej partii karty nadruk firmowy: „Verlag Anton Pustet Pressevereinsanstalten der Diözese Secau SALZBURG SIEGMUND-HAFFNER-GASSE 18, FERNSPRECHER NR. 259, DRAHTANSCRIFT PUSTET SALZBURG".

b-b Podłużna pieczęć.

c Autograf nieczytelny. 
Euera Exzellenz!

Hochwürdigster Herr Erzbischof!

Von Herrn F[riedrich] Ritter von Lama erhielten wir das beigefügte Schreiben, das wir Eu[rer] Exzellenz zur Einsichtnahme ergebenst übersenden.

Mit dem Ausdruck unserer vorzüglichsten Hochachtung zeichnen wir als Eu[rer] Exzellenz ergebenster

Beilage: 1 Brief.

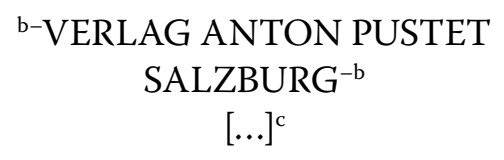

\section{Dokument 254}

Oryg.: AFKDOPW, teczka 145: Spuścizna abp. Józefa Teodorowicza, sygn. 379/90 [5], List z Wydawnictwa Antona Pusteta do abp. Józefa Teodorowicza, Salzburg 29 V 1936 r.

S[einer] Exz[ellenz]

Hochw[ürdigen] Herrn

Erzbischof Dr. Josef Teodorowicz

Lwów, Polen

BETRIFFT IHRE NACHRICHT VOM IHR ZEICHEN UNSER ZEICHEN M/C DATUM 29.5.[19]36

Euera Exzellenz, hochwürdigster Herr Erzbischof!

Vergangene Woche ist nun das Konnersreuth-Buch glücklich fertig geworden und hat auch seinen Weg in die Welt bereits angetreten. Auch sind bereits einige Urteile von jenen Herrn eingelaufen, denen wir auch Ihre Veranlassung hin Besprechungsexemplare zugeschickt haben. Ich freute mich feststellen zu können, dass diese Besprechungen ausserordentlich günstig und zustimmend sind.

Wenn das Werk nun auch über den ursprünglich vorgesehenen Umfang durch die später hinzugekommenen Erweiterungen hinausgekommen ist, und damit in seinen Herstellungskosten höher gekommen ist, als der nach dem ursprünglichen Manuskript festgesetzte Preis ausmachte, so hoffen wir doch durch eine vermehrte Nachfrage diese Kalkulationsschwierigkeit beheben zu können. Um ein kleines Entgegenkommen

a Tekst pisany maszyniowo na jednej stronicy papieru formatu A4. W górnej centralnej partii karty nadruk firmowy: „Verlag Anton Pustet Pressevereinsanstalten der Diözese Secau SALZBURG SIEGMUND-HAFFNER-GASSE 18, FERNSPRECHER NR. 259, DRAHTANSCRIFT PUSTET SALZBURG”.

b-b Podłużna pieczęć.

c Autograf nieczytelny.

a Tekst pisany maszyniowo na jednej stronicy papieru formatu A4. W górnej centralnej partii karty nadruk firmowy: „Verlag Anton Pustet Pressevereinsanstalten der Diözese Secau SALZBURG SIEGMUND-HAFFNER-GASSE 18, FERNSPRECHER NR. 259, DRAHTANSCRIFT PUSTET SALZBURG”. 
möchten wir Euer Exzellenz allerdings bitten, u. zw. dahingehend, dass wir das das Honorar statt von dem vertraglich vorgesehenen broschierten Exemplar vom ungebundenen Exemplar rechnen dürfen. Das entspricht einem Betrag von. 1.100. - statt S. 1.300 - pro 1.000 Ex[em]pl[are]. Damit wären wir auch in der Lage, die nicht geringen Korrektur und Lektoratskosten zu decken, die wir mit dem Manuskript hatten. Nach Erhalt Ihrer Nachricht werden wir Ihnen den Honorarbetrag überweisen.

Wenn ich zum Schluss noch eine persönliche Bitte äussern darf, so wäre es die, Euer Exzellenz zu ersuchen, in ein Ex[em]pl[ar] eines Werkes eine persönliche Widmung für mein Bibliotheksexemplar zu schreiben. Vielleicht würde sich P[ater] Odo Staudinger ebenfalls über ein solches Ex[em]pl[ar] freuen. Ich lasse Euer Exzellenz mit gleicher Post 2 Exemplare zugehen.

Mit verehrungsvoller Begrüssung bin ich Euer Exzellenz ergebener

${ }^{\mathrm{b}-V E R L A G ~ A N T O N ~ P U S T E T ~}$ SALZBURG $^{-b}$ $[\ldots]^{\mathrm{c}}$

per Post: 2 Teodorowicz, „Konnersreuth”.

\section{Dokument 255}

Oryg.: AFKDOPW, teczka „Listy NN do abpa”: Spuścizna abp. Józefa Teodorowicza, sygn. 1798/61 [5], List z redakcji „Schriftleitung des Rosenhain“, Gauting k. Monachium 13 VI 1936 r.

Gauting bei München, den 13. Juni 1936

A.M.R.

S[eine] $\mathrm{r}^{\mathrm{a}}$ Exzellenz

den hochwürdigsten Herrn Erzbischof Theodorowics

Lwów (Lemberg) Polen

Euer Exzellenz,

aufrichtigen Dank für die gütige Zuschrift vom 26. vor[igen] Monats und die mir neuerdings gesandten Manuskripte. Ich werde, sobald ich Zeit habe, alles nach und nach bearbeiten, mit den Verlegern unterhandeln und veröffentlichen, was man nur drucken kann. Materielle Bedingungen, die ich erwähnte, sind, mir zu sagen, was Euer Exzellenz für die Veröffentlichung Ihrer Schriften in deutscher Sprache als Lizenzgebühr wünschen, d[as] $\mathrm{h}$ [eisst] ob Euer Exzellenz etwas wünschen. Vorerst ist es ja ganz unmöglich Geld ins Ausland zu zahlen. Wenn von Euer Exzellenz etwas gefordert würde, dürfte ich die Schriften nicht übernehmen und nicht veröffentlichen. Euer Exzellenz werden mich verstehen. Alles andere Geschäftliche hier zu Lande werde ich schon mit dem Verleger regeln.

b-b Podłużna pieczęć.

Autograf nieczytelny.

a Tekst pisany maszynowo z wyjątkiem autografu autora na 1,5 stronicy papieru formatu A4. W lewym górnym rogu karty tytułowej nadruk firmowy: „SCHRIFTLEITUNG DES ROSENHAIN, Postscheck-Konto: München Nr. 32113, Fernruf: Gauting Nr. 88322“. 
Das Buch über Konnersreuth, das Euer Exzellenz schrieben, ist mir leider noch nicht zugegangen. Ich wartete von Tag zu Tag, doch traf es nicht ein. Gern werde ich es in meinen beiden Zeitschriften empfehlen, auch in anderen Zeitungen darüber schreiben. Frau Maria Grzesiecki hat mir seinerzeit von der Arbeit geschrieben. Ich weiss also wie sehr ihr das baldige Erscheinen des Buches am Herzen lag und so ist es sicher, dass sie durch ihre Leiden und ihr Beten die Verausgabung des Werkes beschleunigt hat. Auch mir hat sie durch ihre Gebete in einigen wichtigen Angelegenheiten schon geholfen.

Ich erwarte gerne die baldige Zusendung des Buches über Konnersreuth, das Euer Exzellenz verausgabten. Sofort werde ich es in meinen Zeitschriften empfehlen.

Indem ich bitte, meiner und meiner Arbeiten beim heiligen Opfer zu gedenken, verbleibe ich Euer Exzellenz stets dankbar ergebener

\section{Dokument 256}

Oryg.: AFKDOPW, teczka: Spuścizna abp. Józefa Teodorowicza, sygn. 380/90 [5], List z Wydawnictwa Antona Pusteta do abp. Józefa Teodorowicza, Salzburg 25 VI 1936 r.

S[eine]r Exzellenz

Hochw[ürdigen] Herrn

Erzbischof Dr. Josef Teodorowicz

Lwów, Polen

BETRIFFT IHRE NACHRICHT VOM IHR ZEICHEN UNSER ZEICHEN M/C DATUM 25.6. [19]36

Euer ${ }^{\text {a }}$ Exzellenz! Hochverehrter Herr Erzbischof!

Verbindlichen Dank für Ihren liebenswürdigen Brief v[om] 17 ds. Inzwischen haben wir die von Ihnen erwähnte Kritik bekommen, die als eine der ersten grundsätzlichen für die weitere Werbung recht wertvoll sein wird. Falls zu gleicher Zeit lief von Prof. Sattler ${ }^{504}$ aus Köln eine ebenfalls sehr umfangreiche Besprechung ein, die allerdings noch in keiner Zeitschrift erschienen ist, die aber ebenfalls mit dazu beitragen wird, dem Buch viele Freunde zuzuführen. Der Hinweis Euer Exzellenz auf eine Besprechungsagentur, die in Frage kommende Besprechung sammelt, würde vom Verlag sehr zustimmend begrüsst werden. Haben Euer Exzellenz an eine bestimmt Ihren bekannte Agentur gedacht? Oder sollen wir vom Verlag aus eine solche ausfindig machen? Was an Besprechungen hier einläuft werden wir von Zeit zu Zeit regelmässig an Euer Exzellenz weiterleiten.

\footnotetext{
b Autograf napisany czarnym atramentem nieczytelny.

a Tekst pisany maszyniowo na jednej stronicy papieru formatu A4. W górnej centralnej partii karty nadruk firmowy: „Verlag Anton Pustet Pressevereinsanstalten der Diözese Secau SALZBURG SIEGMUND-HAFFNER-GASSE 18, FERNSPRECHER NR. 259, DRAHTANSCRIFT PUSTET SALZBURG”.

${ }^{504}$ Osoba niezidentyfikowana.
} 
Die von Euer Exzellenz erwähnten Korrekturen werden wir im Einverständnis mit $\mathrm{P}$ [ater] Odo Staudinger zusammenstellen und auf einem losen Blatt gedruckt dem Buch beilegen. Ebenso haben wir vorgemerkt, dass die Honorarrate an P[ater] Skwierawski ${ }^{505}$, Wien überwiesen wird. Der Betrag ging in diesen Tagen ab.

Bezüglich Übersetzungen liegt auf Grund des Verlags-Vertrages die Sache so, dass diesbezügliche Abmachungen mit unserem Verlag und dem fremden, die Übersetzung erwerbenden Verlag getroffen werden müssen. Selbstverständlich sind in einem solchen Falle Vermittler, wie der einflussreiche P[ater] Garrigou Lagrange sehr wichtig. Wenn uns Euer Exzellenz die Adresse des hochw[ürdigen] Herrn Paters mitteilen könnte, könnten wir vom Verlag aus die weiteren Verhandlungen führen und Sie dann laufend über den Fortgang informieren. In die von Ihnen erwähnten beiden Anschriften wurden Besprechungsexemplare gesandt. Gerne hätte ich Euer Exzellenz noch gefragt, ob von Ihnen aus an Pfarrer Naber und Therese Neumann 1 Ex[em]pl[ar] geschickt wurde, da beide doch vermutlich am Buch interessiert sind.

Mit verehrungsvoller Begrüssung bin ich Euer Exzellenz ergebenster

b-VERLAG ANTON PUSTET
SALZBURG-b
$[\ldots]^{c}$

\section{Dokument 257}

Oryg.: AFKDOPW, teczka 140: Spuścizna abp. Józefa Teodorowicza, sygn. 963/420 (8) [7], List dr. Ralpha Waldego Hynka do abp. Józefa Teodorowicza, Praga 25 VI 1936 r.

\section{Eure $^{\text {a }}$ Exzellenz!}

Soeben habe ich erfahren, dass bei Euch in Lemberg sollte zu einem neuen Fall von Stigmatisation bei einem Ukrainer Mädchen gekommen sein und dieselbe sollte von einer Kommission als echt vorgefunden sein.

Nachdem Eure Exzellenz zu Sicht an den Quellen dieser Geschehnisse sich befinden, wollte wollte um ich um gefälligste Angabe näherer Daten sowie etwaiger Kommissionsmitglieder $[\ldots]^{\mathrm{b}}$ ergebenst bitten, damit ich davon kath[olische] Öffentlichkeit benachrichtigen könnte.

Das Buch Euer Exzellenz uber Konnersreuth wird hier schon mit Sehnsucht mit Spannung erwartet. Vor Ostern war hier auch Ritter v[on] Lama einen Vortrag über Konnersreuth abhalten.

Ich hoffe, dass Eure Exzellen mir diese meine höflichste Bitte nicht übel nehmen wird und ich zeichne mich mit besonderem Ausdruck meiner Ergebung Eurer Exzellenz

Prag, am 25/6 1936 Dr. R[alph] W[aldo] Hynek

\footnotetext{
${ }^{505}$ Osoba niezidentyfikowana.

b-b Podłużna pieczęć.

c Autograf nieczytelny.

a Tekst pisany czarnym atramentem na dwóch stronicach papieru formatu A4.

b Tekst nieczytelny.
} 


\section{Dokument 258}

Oryg.: AFKDOPW, teczka 145: Spuścizna abp. Józefa Teodorowicza, sygn. $381 / 90$ [5], List z Wydawnictwa Antona Pusteta do abp. Józefa Teodorowicza, Salzburg 10 VII 1936 r.

Euer Exzellenz

Den hochwürdigsten Herrn Erzbischof J. Teodorowicz

Lwów/Polen

BETRIFFT IHRE NACHRICHT VOM IHR ZEICHEN UNSER ZEICHEN Dr. D/E DATUM 10.7.[19]36

Euer ${ }^{a}$ Exzellenz, hochwürdigster Herr Erzbischof!

Wir danken bestens für das freundliche Schreiben vom 06. Juli und bitten Euer Exzellenz ergebenst, mit der eigentlichen Beantwortung dieses Briefes sich kurze Zeit gedulden zu wollen, bis Herr Direktor Müller von seinem Urlaub zurückkommt. Das Dedikationsexemplar an den Hochwürdigsten Herrn Bischof Schrembs ${ }^{506}$ in Cleveland senden wir gleichzeitig ab.

Mit dem Ausdruck ganz besonderer Hochschätzung Euer Exzellenz ergebenster

${ }^{\mathrm{b}-V E R L A G ~ A N T O N ~ P U S T E T ~}$

SALZBURG ${ }^{-b}$

$[\ldots]^{\mathrm{c}}$

\section{Dokument 259}

Oryg.: AFKDOPW, teczka 145: Spuścizna abp. Józefa Teodorowicza, sygn. 382/90 [5], List z Wydawnictwa Antona Pusteta do abp. Józefa Teodorowicza, Salzburg 18 VIII 1936 r.

S[einer] Exzellenz

Hochw[ürdigen] Herrn Erzbischof Dr. Josef Teodorowicz

Lwów

Polen

BETRIFFT IHRE NACHRICHT VOM IHR ZEICHEN UNSER ZEICHEN M/C DATUM 18.8.[19]36

a Tekst pisany maszynowo na jednej stronicy papieru formatu A4. W lewym górnym rogu karty nadruk firmowy: „VERLAG ANTON PUSTET Pressevereinsanstalten der Diözese Secau SALZBURG, SIEGMUND-HAFFNER-GASSE 18, Fernsprecher Nr. 259, Drahtanschrift PUSTET SALZBURG".

${ }_{506}$ Schrembs Joseph (1866-1945), duchowny niemiecki pochodzenia żydowskiego z Bawarii, święcenia kapłańskie w 1889 r. w USA, 1900-1911 proboszcz par. Grand Rapids (Michigan), I-II 1911 r. biskup pomocniczy diec. Grand Rapids, 1911-1921 biskup ordynariusz diec. Toledo (Ohio), 1921-1945 biskup diec. Cleveland (Ohio), w 1939 r. mianowany arcybiskupem ad personam. Żródło: Joseph Schrembs, https:// en.wikipedia.org/wiki/Joseph_Schrembs. Dostęp: 14 IV 2017 r.

b-b Podłużna pieczęć.

c Autograf nieczytelny. 
Euera Exzellenz, hochwürdigster Herr Erzbischof!

Darf ich Euer Exzellenz meinen ganz verbindlichen Dank für das so freundlich übersandte Widmungsexemplar aussprechen, dessen Widmung mich ganz besonders gefreut hat.

Den Monat Juli über war ich in Urlaub und komme daher erst heute dazu Euer Exzellenz Brief v[on] 6.7. zu beantworten, der wohl aber im Wesentlichen schon während meiner Abwesenheit durch meinen Mitarbeiter erledigt wurde. Ich hoffe, Sie konnten bereits mit $\mathrm{P}$ [ater] Odo Staudinger über die fraglichen Dinge Fühlung nehmen.

Mit dem Ausdruck ganz besonderer Hochschätzung bin ich Euer Exzellenz ergebener

b-VERLAG ANTON PUSTET

SALZBURG $^{-\mathrm{b}}$

$[\ldots]^{\mathrm{c}}$

\section{Dokument 260}

Oryg.: AFKDOPW, teczka 144: Spuścizna abp. Józefa Teodorowicza, sygn. 1802/61 [5], List o. Odo Staudingera OSB do abp. Józefa Teodorowicza, Salzburg 25 VIII 1936 r.

Salzburg, Benediktinerkolleg[ium], am 25. 8. [19]36

Exzellenz ${ }^{\mathrm{a}}$, Hochwürdigster Herr Erzbischof!

Der Weltenbummler V. St. ist heute noch in Salzburg, aber nachmittags will er bereits in Orth bei Gmunden ${ }^{507}$ 6.6., Pensionat, auf etwa 14 Tage weilen und im Sept[ember] oder Okt[ober] will er nach Belgien. P[ater] Alois Mager ist bereits abgereist. Er fährt im Sept[ember] als Schiffskaplan von Hamburg nach Argentinien. Stabilität: pro torto orbe terrarum!

Das von Dr. Deutsch finde ich unverschämt. Vielleicht lernt ihn jetzt Dr. Wunderle besser kennen. Ihr Brief an Wunderle ist ein chef d'oeuvre ${ }^{508}$ von Liebenswürdigkeit. Der hat ihm sicher sehr wohlgetan. Freut mich für ihn.

Die Schw[ester] Carisia ${ }^{509}$ mein ich, übergeben wir im Ergänzungszettel. Es sind doch nur wenige, die ganz eingeweiht sind in den Fall. Für diese genügen wohl nur einige Zeilen nicht und die anderen brauchen nichts davon zu wissen.

a Tekst pisany maszynowo na jednej stronicy papieru formatu A4. W lewym górnym rogu karty nadruk firmowy: ,VERLAG ANTON PUSTET Pressevereinsanstalten der Diözese Secau SALZBURG, SIEGMUND-HAFFNER-GASSE 18, Fernsprecher Nr. 259, Drahtanschrift PUSTET SALZBURG”.

b-b Podłużna pieczęć.

c Autograf nieczytelny.

a Tekst pisany czarnym atramentem na jedenj stronicy papieru format A4. W lewym górnym rogu karty nadruk firmowy: „Schriftleitung des Benedictus-Boten”. W górnej partii karty na centralnym miejscu graficzne wyobrażenie godła Zakonu oo. Benedyktynów: krzyż z dwiema poprzecznymi belkami stojący na trzech wzniesieniach oraz PAX. Niżej tarczy inskrypcja: „Ut in omnibus glorificetur Deus”.

${ }^{507}$ Gmunden - miasto austriackie w Alpach Salzburskich.

${ }^{508}$ Fr.: arcydzieło.

509 Osoba niezidentyfikowana. 
Während des Druckes habe ich wiederholt auf das Imprimatur aufmerksam gemacht. Doch der hiesige Weihbischof und Generalvikar Dr. Filzen ${ }^{510}$, der sich persönlich für das Werk interessierte und schon während des Druckes Einsicht nahm, sagte bestimmt: Werke von Bischöfen brauchen kein Imprimatur!

Wegen der Mitbeteiligung an event[uell] Übersetzungen werde ich mich heute beim Verlag erkundigen und ich hoffe, dass Sie bald befriedigenden Aufschluss erhalten.

In ehrfurchtsvollen Ergebenheit Eur[e] Exzellenz erg[ebenst]

$\mathrm{P}$ [ater] Odo Staudinger OSB

\section{Dokument 261}

Oryg.: AFKDOPW, teczka 145: Spuścizna abp. Józefa Teodorowicza, sygn. 1813/61 [5], List z Wydawnictwa Antona Pusteta do abp. Józefa Teodorowicza, Salzburg 11 IX 1936 r.

$\mathrm{An}^{\mathrm{a}}$ das Sekretariat

S[einer] E[xzellenz] des Hochw[ürdigen] H[errn] Erzbischofs

Dr. Josef Teodorowicz

Lwów, Polen

BETRIFFT IHRE NACHRICHT VOM IHR ZEICHEN UNSER ZEICHEN L/DATUM 11.IX.1936

Wir bestätigen dankend Ihr Schreiben vom 27. VIII. betreffend einen Ergänzungszettel für die I. Auflage des Werkes „Konnersreuth“. Wir haben den Zettel in der von Hochw[ürdigen] Pater Staudinger korrigierten Form setzen lassen, bitten Sie freundlichst auf den beiliegenden Abzügen die Korrektur einzulesen und uns dann 1 Exemplar zum Druck zurückzusenden. Die Berichtigung wird allen noch unverkauften Exemplaren der I. Auflage beigelegt.

Was eine eingehende Korrektur der Anmerkungen für eine eventuelle Neuauflage in einem späteren Zeitpunkt betrifft, senden wir Ihnen wunschgemäss alles Material, das uns diesbezüglich zuging und bitten die Korrekturen auf dem Druckbogen so anzubringen, dass alle Veränderungen auf diesem Exemplar ersichtlich sind. Dieses Exemplar nehmen wir dann zur Berücksichtigung bei einer Neuauflage in Verwahrung.

Mit dem Ausdruck unserer ganz besonderen Hochschätzung ergeben

b-VERLAG ANTON PUSTET

SALZBURG $^{-\mathrm{b}}$

$$
[\ldots]^{\mathrm{c}}
$$

${ }^{510}$ Osoba niezientyfikowana.

a Tekst pisany maszynowo na jednej stronicy papieru formatu kartyy pocztowej. W lewym górnym rogu karty nadruk firmowy: „VERLAG ANTON PUSTET Pressevereinsanstalten der Diözese Secau SALZBURG, SIEGMUND-HAFFNER-GASSE 18, Fernsprecher Nr. 259, Drahtanschrift PUSTET SALZBURG”.

b-b Podłużna pieczęć.

c Autograf nieczytelny. 


\section{Dokument 262}

Oryg.: AFKDOPW, teczka 145: Spuścizna abp. Józefa Teodorowicza, sygn. 378/90 [5], List z Wydawnictwa Antona Pusteta do abp. Józefa Teodorowicza, Salzburg 15 IX 1936 r.

Honorarabrechnung ${ }^{\mathrm{a}}$

Hochwürdigen Herrn Erzbischof

Dr. Josef Teodorowicz, Lwów

für die Zeit vom 13.5.[19]36 bis 30.6.[19]36

betr[ifft] „Konnersreuth“

Erschienen am 13.5. [19]36: $2000 \mathrm{Ex}[\mathrm{em}] \mathrm{pl}[\mathrm{are}]$

Verkauft bis 30.6. [19]36: $592 \mathrm{Ex}[\mathrm{em}] \mathrm{pl}[\mathrm{are}]$

Bestand am 30.6. [19]36: $1408 \mathrm{Ex}[\mathrm{em}] \mathrm{pl}[\mathrm{are}]$

Zahlungen:

20.6. Honorar für 700 Ex[em]pl[are] 10 \% v. S. 11 S. 770.

05.07 Überweisung Wien Skwierawski S. 770.

b-VERLAG ANTON PUSTET

SALZBURG $^{-b}$

Salzburg, am 15. September 1936

\section{Dokument 263}

Oryg.: AFKDOPW, teczka 145: Spuścizna abp. Józefa Teodorowicza, sygn. 1815/61 [5], List z Wydawnictwa Antona Pusteta do abp. Józefa Teodorowicza, Salzburg 16 IX 1936 r.

Salzburg am 16. September 1936

$\mathrm{B} / \mathrm{S}$

$\mathrm{Eu}[\mathrm{re}]^{\mathrm{a}}$ Hochwohlgeboren!

Um Ihnen ein Bild über die Herbstarbeit unseres Verlags zu geben, erlauben wir uns, Ihnen anbei unsere VORANZEIGE NEUER BÜCHER HERBST 1936 ergebenst zu überreichen und wären Ihnen sehr verbunden, wenn wir mit Ihrer Mitarbeit an den Aufgaben des Verlages durch empfehlende Hinweise in Ihren Freundes- und Bekanntenkreisen rechnen dürften.

Mit ergebensten Empfehlungen

a Tekst pisany maszynowo na jednej stronicy papieru formatu A4. W górnej centralnej partii karty nadruk firmowy: „VERLAG ANTON PUSTET SALZBURG”.

b-b Pieczęć podłużna.

c Autograf nieczytelny.

a Tekst pisany maszynowo na jednej stronicy papieru formatu kartyy pocztowej. W lewym górnym rogu karty nadruk firmowy: „VERLAG ANTON PUSTET SALZBURG, SIEGMUND-HAFFNER-GASSE 18, Fernsprecher Nr. 259, Drahtanschrift PUSTET SALZBURG". 
Anbei:

Voranzeige neuer Bücher

b-VERLAG ANTON PUSTET

SALZBURG $^{-b}$

Herbst 1936

\section{Dokument 264}

Oryg.: AFKDOPW, teczka 145: Spuścizna abp. Józefa Teodorowicza, sygn. 1814/61 [5], List z Wydawnictwa Antona Pusteta do abp. Józefa Teodorowicza, Salzburg 29 IX 1936 r.

Salzburg, am 29 IX 1936

$A n^{a}$ das Sekretariat

S[einer] E[xzellenz] des Erzbischofs J[osef] Teodorowicz

Lwów

Wir bestätigen dankend den Eingang der Lebensdaten S[eine]r Exzellenz des hochwürdigsten Herrn Erzbischofs und senden in der Anlage noch einen Abzug der „Ergänzungen“ zu dem Werk „Konnersreuth”, und glauben Sie richtig zu verstehen, dass Sie einen solchen Abzug mit den Worten „das andere Exemplar“ in Ihrem Briefe meinten.

Mit dem Ausdruck vorzüglichster Hochschätzung

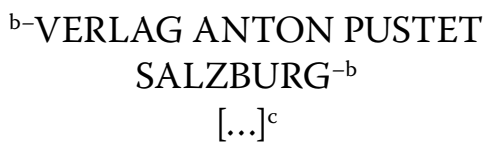

\section{Dokument 265}

Oryg.: AFKDOPW, teczka 142: Spuścizna abp. Józefa Teodorowicza, sygn. 1777/61 [5], List ks. Josepha Nabera do abp. Józefa Teodorowicza, Konnersreuth 11 XI 1936 r.

Konnersreuth, den 11. Nov[ember] [19]36

Abschrift

Excellenz! ${ }^{\mathrm{a}}$

Hochwürdigster Herr Erzbischof !

Excellenz haben ja wohl zunächst den offenen Brief des H[errn] Dr. Deutsch gegen Ihr Buch über Theres Neumann erhalten. Mir hat ihn kürzlich mein H[ochwürdigen] $\mathrm{H}$ [errn] Diöcesanbischof Buchberger von Regensburg zur Kenntnis u[nd] Stellungnah-

b-b Podłużna pieczęć.

c Autograf nieczytelny.

a Tekst pisany maszynowo na jednej stronicy papieru formatu A4. W lewym górnym rogu karty nadruk firmowy: „VERLAG ANTON PUSTET Pressevereinsanstalten der Diözese Secau SALZBURG, SIEGMUND-HAFFNER-GASSE 18, Fernsprecher Nr. 259, Drahtanschrift PUSTET SALZBURG”.

b-b Podłużna pieczęć.

c Autograf nieczytelny.

a Tekst pisany maszynowo na 1,5 stronicy papieru formatu A4. 
me übersandt. Aus dem Buche Euerer Excellenz, das ja H[errn] Benefiziat Härtl hier übersandt worden ist, habe ich neben dem eifrigsten Bestreben, den Stoff möglichst erschöpfend zu behandeln $u[n d]$ neben der gerade zu auffalenden Schärfe mit der Excellenz hier beobachtet haben, zu meiner grossen Freude eine so wohlwollende Einstellung zu Theres Neumann $\mathrm{u}[\mathrm{nd}]$ den ausserordentlichen Vorgängen, deren Trägerin sie ist, ersehen können, wie sie wohl nicht sehr viel in solchen Kreisen zu finden ist. Diese Einstellung hat einen alten schon von Dr. Gerlich bekämpften Feind der Th[erese] N[eumann] auf den Plan gerufen, den Arzt Dr. Deutsch, der niemals hier gewesen. Über dieses „ungezogene Pamphlet“, wie dessen offenen Brief ein deutscher Bischof nannte, mit seiner „empörenden Verdächtigung der Theres Neumann“ über dieses „Sammelsurium von Verleumdungen, Lügen, Verdrehungen u[nd] Beleidigungen“, wie mir ein Schriftsteller aus dem Dominikanerorden schreibt, habe ich an den H[ochwürdigen] $\mathrm{H}$ [errn] Bischof in Regensburg ein über 20 Seiten langes Stellungnahmeschreiben gerichtet Bischof Buchberger scheint durch die unverschämte Broschüre geschreckt zu sein $\mathrm{u}[$ nd] erklärt in einem Schreiben an mich „eine einwandfreie Untersuchung der Nahrungslosigkeit der Th[eres] N[eumann] für eine Gewissenspflicht der Familie Neumann". Der Vater Neumann erklärt aber, solange er ein offenes Auge habe, komme ihm die Theres nicht aus dem Hause zu einer Untersuchung. Die Gründe des Vaters kennen ja Excellenz wohl. Die ganze Sache wäre so argschlimm nicht, wenn sie nicht in die Öffentlichkeit gebracht $\mathrm{u}[$ nd] dann von allen möglichen Zeltungen $u[n d]$ Schriften über die Welt getragen würde. Dazu scheint nun das bischöfl. Ordinariat Regensburg selber beizutragen. Ein Oberpfarrer aus Freiburg i[n] B[reisgau] hat mir einen Ausschnitt aus dem dortigen Diöcesankirchenblatt (Konradsblatt) übersandt, in dem steht: „Das bischöfliche Ordinariat Regensburg bedauert sehr das Erscheinen des Buches «Konnersreuth im Lichte der Mystik und Psychologie» von Erzbischof Dr. Josef Teodorowicz. Gegen diese Veröffentlichung konnte der katholische Arzt Dr. Josef Deutsch ernste Bedenken geltend machen“. Das schreibe ich Excellenz nicht, um gegen meine kirchliche Oberbehörde zu hetzen - ach, wie sehr wünschte ich, dass wir ein Herz u[nd] eine Seele wären - sondern mit der Bitte Excellenz möchten uns im Kampfe für das Wirken des Heilands hier wirksam unterstützen. Bevor das Buch Euerer Excellenz in zweiter Auflage erscheint, wäre es gut, dasselbe bezüglich der Vorkommnisse die darin berichtet werden, von solchen, die sie genaukennen, durchsehen zu lassen. Ich habe bemerkt, dass manche derselben nicht so recht stimmen. Das soll aber für Exzellenz, die so genau $\mathrm{u}$ [nd] scharf beobachtet $\mathrm{u}$ [nd] geschlussfolgert haben, kein Vorwurf sein, sondern für diejenigen, die es in den ersten Berichten nicht genau genommen haben.

In tiefster Ehrfurcht verbleibe ich Euerer Excellenz ergebenster

Naber Pf[a]r[rer] 


\section{Dokument 266}

Kopia: AFKDOPW, teczka 134: Spuścizna abp. Józefa Teodorowicza, sygn. 826/110 [5], List abp. Józefa Teodorowicza do ks. prałata Alberta Steuera, Lwów 19 XI 1936 r.

\section{Przezacny ${ }^{\mathrm{a}}$ Księże Prałacie!}

Dopiero teraz odpisuję na łaskawy list dziękując z całego serca za tak śliczną, tak wyczerpująco, tak syntetycznie i filozoficznie ujętą recenzję̨ $e^{511}$. Żałuję tylko, że pokazuje się ona w piśmie w obrębie Polski.

Przy tej sposobności dziękuję bardzo księdzu Prałatowi raz jeszcze za cenzurę dzieła "Od Jahwy do Mesjasza” i pozwalam sobie przesłać egzemplarz tej mojej pracy.

Łączę przy tej sposobności dla Księdza Prałata moje prawdziwie oddane wyrazy głębokiej czci.

Lwów, dnia 19 listopada 1936

Ks. Steuer - Poznań

\section{Dokument 267}

Kopia: AFKDOPW, teczka 136: Spuścizna abp. Józefa Teodorowicza, sygn. 1781/61 [5], List abp. Józefa Teodorowicza do nieznanego redaktora, Lwów 23 XI 1936 r.

Hochgeehrter ${ }^{\mathrm{a}}$ Herr Redakteur,

Lwów, am 23. XI. 1936

Ich habe eben Ihren Brief erhalten und erwidere hiermit die von Ihnen an mich gerichtete Frage, ob ich auf den offenen Brief, den Dr. Deutsch gegen mich gerichtet, eine Antwort erteilen werde? Nein! Ich selbst werde ihm nicht antworten und zwar aus folgenden Gründen:

1-o. Vor allem betrifft Dr. Deutschens Kritik nur einen Teil meines Buches, was sonst der Autor selbst zugibt und zwar die Krankheiten und Genesungen Theresens. Diese Partie wurde in mein Buch unter dem Titel : „Im Vorhofe der Stigmatisation eingereiht". Der Titel selbst zeugt schon davon, dass ich das Stigmatisationsproblem nicht auf Theresas Krankheiten und Genesungen, sondern hauptsächlich auf seelische Erscheinungen und Erlebnisse, wie auch auf innere Prüfungen stützte. Wenn auch Dr. Deutsch in seinem Angriffe gegen mich vollkommen Recht hätte, so würde dadurch kaum das Hauptthema meines Buches berührt werden, denn die Stigmatisation kann zu Stande kommen und kommt tatsächlich oft vor, ohne dass ihr irgendwelche Erkrankungen oder wunderbare Genesungen vorangingen. Es kann somit dem Dr. Deutsch von

\footnotetext{
a Tekst pisany maszynowo na $1 / 2$ stronicy papieru formatu A4. Brak autografu autora listu.

${ }^{511}$ J. Teodorowicz, Zjawiska mistyczne i ich ttumaczenia (Konnersreuth), Poznań 1933. Rec.: A. Steuer, AK, 33(1934), s. 83-90.

a Tekst pisany maszynowo na dwóch stronicach papieru formatu A4. W lewym górnym rogu karty tytułowej nota czarnym atramentem: „Ab..... An Lama”. Brak zakończenia i autografu autora.
} 
jedem andern diesbezüglich eine Antwort erteilt werden und gewiss werden sich solche finden, die das tun, aber für mich als Autor des Buches kommt es schwer einen Nebenumstand, ja einen sogar für die Ausführungen entbehrlichen Umstand gewissermassen zum Zentrum einer Diskussion zu machen, was sehr leicht einen Anschein erwecken könnte, der gegen die ganze Einstellung des Buches sprechen würde.

2-o ist es der Ton des Briefes selbst, der mir jegliche Antwort unmöglich macht. Dieser Ton lässt sich kaum qualifizieren und dürfte jeden Adressaten, an den ein ihm ganz fremder Mensch ein Schreiben richtete, nicht nur von der moralischen Pflicht einer Antwort befreien, aber sogar die traurige Notwendigkeit aufzwingen einen in solchem Tone gehaltenen Angriff mit Schweigen zu übergehen.

3-o Dr. Deutsch greift in seinem offenen Briefe hauptsächlich meine vermeintlichen medizinischen Thesen an. Diese Thesen verunstaltet er gänzlich. Er behauptet z[um] $\mathrm{B}$ [eispiel] dass ich die Meinung verteidige, als ob Therese Neumann tatsächlich an Wirbelverrenkung gelitten hätte und im Zusammenhange damit erblindet wäre, dass ich ferner an Dr. Seidls Diagnose in betreff der Blinddarmentzündung festhalte u.v.a., während ich eben im Bezug auf all diese Erscheinungen mich ausdrücklich erkläre, dass ich die diesbezüglichen Diagnosen für nicht genug sicher halte und das Problem des Wunders auf dieselben stützen zu können. Ich habe zwar von Wahrscheinlichkeitsbeweisen, die ich ansammelte, erwähnt aber das endgültige Urteil habe ich (mit Ausnahme des die tiefen Wunden und deren plötzliche Heilung betreffenden Tatbestandes) der Medizin vorenthalten. Davon zeugen ja meine eigenen Worte (siehe S. 128 meines Buches): „Kann man sich unter diesen Umständen die Heilung von diesen Krankheiten auf natürliche Weise erklären? Die Ansichten sind diesbezüglich was die Mehrheit der Krankheiten betrifft geheilt. Ich selbst will in dieser Angelegenheit keinen Standpunkt einnehmen, bin jedoch der Ansicht, dass diese Frage, bei der Meinungsverschiedenheit der Ärzte, wissenschaftlich genommen, offen bleiben muss“.

Diese Worte sind jedem klar, für diejenigen jedoch, die dieselben nicht verstehen oder nicht verstehen wollen, oder gar verunstalten, für die habe ich keine Antwort. Jede Diskussion muss vor allem die Wahrheit als Hintergrund haben.

4-o: $\mathrm{Zu}$ allerletzt ist noch ein Grund vorhanden, der mir nicht gestattet dem Dr. Deutsch persönlich zu antworten: er hat nämlich in dem an mich gerichteten Brief Konnersreuth als einen gotteslästerlichen Betrug gestempelt und in seinem offenen Briefe spricht er vom „Verdacht eines ständigen Betrugs in Konnersreuth“ und dies in einem Ton der einer formellen Verleumdung gleichkommt. Ich kenne die Neumann'sche Familie, deren Grundzug eben eine grosse Wahrheitsliebe bildet. Die Erziehung, die Therese von ihrem Vater erhielt war vor allem auf streng $[. . .]^{\mathrm{b}}$.

b Brak zakończenia. 


\section{Dokument 268}

Oryg.: AFKDOPW, teczka 144: Spuścizna abp. Józefa Teodorowicza, sygn. 451/190 [7], Dekret Kongregacji Świętego Oficium Stolicy Apostolskiej w sprawie książki abp. J. Teodorowicza „Konnersreuth im Lichte der Mystik und Psychologie" i jego dalszych badań w tym zakresie, Rzym 23 XI 1936 r. Kopia: ASK, bsygn., Acta Hlondiana, Dekret Kongregacji Świętego Oficium Stolicy Apostolskiej w sprawie książki abp. J. Teodorowicza „Konnersreuth im Lichte der Mystik und Psychologie" i jego dalszych badań w tym zakresie, Rzym 23 XI 1936 r.

Ex aedibus S[ancti] Offici die 23 XI [19]36

Excellentia ${ }^{a}$ Rev[erendissi]ma,

Suprema haec S[acra] Congregatio in convento plenario habito feria IV, II novembris 1936, descrevit quae sequuntur relete ad librum ab Excellentia] T[ua] Rev[erendissi]ma aditum, cui titulus „Konnersreuth im Lichte Mystik und Psychologie”.

"Libri supradicti impediendas esse versione et novas impressiones rettrahenda pro posse exemplaria a mercatura libraria; ipse autem autor se abstineat a quacumque supra hoc argumento activitate".

Quae dum, Tecum communico ad executionem mandanda, impensam meam observantiam Tibi obtestor ac permaneo

E[xcellentiae] T[uae] Rev[erendissi]mae
add[icti]mus
${ }^{b-}+\mathrm{D}\left[\right.$ onato] Card. Sbarretti ${ }^{512}$
Episcopus Sabiniensis et Mandebusis Secretarius $^{-b}$

Ex[celenstissi]mo ac Rev[erendissi]mo

Dom[ino] Josepho Teodorowicz

Archiepiscopo Leopolien Armenorum

a Tekst pisany maszynowo z wyjątkiem autografu nadawcy na formularzu urzędowym na jednej stronicy papieru formatu A4. W lewym górnym rogu karty graficzny znak herbu Stolicy Apostolskiej, niżej nadruk: „Suprema Sacra Congregatio Sancti Officii Num[erus] prot[ocolli] 761/27. (In responsione fiat mentio huius numeri)".

b-b Tekst pisany czarnym atramentem.

${ }^{512}$ Sbaretti Raffaele Donato (1856-1939), święcenia kapłańskie w 18789 r. w Rzymie, dr teologii i obojga praw, duszpasterz w Spoleto, pracownik Kongregacji Propagandy Wiary i Sekretariacie Stanu Stolicy Apostolskiej, 1893-1900 audytor Delagatury Apostolskiej w USA, 1900-1901 biskup Hawany (Kuba), w 1901 r. mianowany arcybiskupem tytularnym i delegatem apostolskim na Filipinach, 1902-1910 delegat apostolski w Kanadzie, od 1910 r. przebywał w Rzymie jako pracownik kongregacji: w 1916 r. kreowany kardynałem, w 1919 r. mianowany prefektem Kongregacji Soboru, 1930-1939 sekretarz Świętego Oficjum. M. Bräuer, Handbuch der Kardinäle 1846-2012, Berlin-Boston 2014, s. 237. 


\section{Tłumaczenie $^{\mathrm{b}} \mathrm{z}$ j. lacińskiego}

Św[ięta] Kongregacja Św[iętego] Officjum

Wydane w Św[iętym] Officjum dn[ia] 23 XI 1936

Num[er] prot[okołu] 761/27

(w odpowiedzi należy się powołać na niniejszy numer)

Najdostojniejszy Ekscelencjo,

Święta Kongregacja na zebraniu plenarnym, które się odbyło w środę 11-go listopada, postanowiła co następuje odnośnie do książki wydanej przez Waszą Ekscelencję pod tytułem: „Konnersreuth im Lichte der Mystik und Psychologie”.

"Zabrania się wszelkich tłumaczeń oraz nowych nakładów wyżej wzmiankowanej książki - należy wedle możności wycofać z obiegu wydane już egzemplarze - sam autor zaś niech się wstrzyma od wszelkiej na tym polu działalności”.

Przekazuję Tobie niniejsze zarządzenia, zapewniam o mojej dla Ciebie czci i pozostaję Waszej Ekscelencji najoddańszy

† D[onato] Card. Sbarretti

Biskup Sabiński i Mandebuski

Sekretarz

J[ego] Ekscelencja Najprzewielebniejszy

Ks. Arcybiskup ob[rządku] orm[iańskokatolickiego]

Józef Teodorowicz

Lwów

\section{Dokument 269}

Kopia: AFKDOPW, teczka 127: Spuścizna abp. Józefa Teodorowicza, sygn. 450/190 [7], List abp. Józefa Teodorowicza do prefekta Kolegium ormiańskiego w Rzymie bp. François Agagianiana, Lwów 28 XI 1936 r.

Excellence ${ }^{\mathrm{a}}$ Reverendissime,

Je m'adresse aujourd'hui à Votre Excellence avec une prière bien ardente et intime dans une affaire importante, que voici:

b Tekst pisany na maszynie na jednej stronicy papieru formatu A4. Oryg.: AFKDOPW, teczka 144: Spuścizna abp. Józefa Teodorowicza, sygn. 465/190 [7], Dekret Kongregacji Świętego Oficium Stolicy Apostolskiej w sprawie książki abp. J. Teodorowicza „Konnersreuth im Lichte der Mystik und Psychologie” i jego dalszych badań w tym zakresie, Rzym 23 XI $1936 \mathrm{r}$.

a Tekst pisany maszynowo na trzech stronicach papieru formatu A4. Brak autografu autora. W lewym górnym rogu karty tytułowej nota czarnym atramentem: „S. E. Msgr. Francesco Aghagianian, Roma (105), Piazza S. Nicola de Tolentino, Collegio armeno". 
Je viens de publier l'année courante un livre allemand intitulé: „Konnersreuth im Lichte der Psychologie und Mystik” („Konnersreuth à la lumière de la mystique et psychologie"), fruit d'une étude approfondie et d'examens exactes, qui m'absorbaient durant plusieurs années. Ce livre fut très bien accueuilli par la critique.

Le R. P. Garrigou-Lagrange, m'écrivait entre autre, après avoir remis ce livre à deux d'entre les Dominicains de l'Angelico pour l'approfondir, une lettre pleine de louanges (J'en joins la copie).

Récemment parut dans les „Etudes Carmelitaines” (octobre de l'a. c.) la critique du R[évérend] P[ère] A. Mager O.S.B. professeur en théologie et versé dans les questions mystiques, qui quoique se rangeant du côté opposé à Konnersreuth, rend néanmoins justice à mon travail, soulignant ses valeurs et son objectivité.

Je ne mentionnerai point ici toutes les autres critiques, très favorables elles aussi, qui me parvinrent de toutes parts.

Il n'y a qu'un seul personnage, M[onsieur] Deutsch, docteur en médecine à Lippstadt (Allemagne), qui publia contre moi une lettre ouverte. Cette lettre cependant ne touche qu'à une seule question celle des maladies de Thérèse Neumann précédant sa Stigmatisation et que je n'avais traitées que comme chose secondaire et n'ayant rien de commun avec la thèse principale du livre.

Ce qui est plus: M[onsieur] Deutsch faussa les principales idées de mon livre et en émit une critique tout superficielle et insuffisante. Tout ce que je viens de mentionner plus haut sur l'accueil favorable dont jouit mon livre partout où il était parvenu, je ne l'écris point dans le but de me vanter - que Dieu m'en préserve - mais uniquement dans le but de relater les choses dans leur véritable jour.

Voici cependant que je reçois aujourd'hui un écrit de Rome dont je joins une copie sous ce plis.

Je ne puis Vous dire quel coup ce fut pour moi. Voir soudain détruit le labeur de tant d'années, qui avait absorbé toutes mes forces et qui était joint à tant de peines et inconveniants: voyages réitérés, entrepris spécialement dans le but de mieux connaître Konnersreuth, etc. Mais j'accepte ce coup de la Main divine comme une lourde croix et je me soumets sans restriction aucune aux décisions du St. Office.

Je me déclare prêt - afin de ne pas perdre le fruit de tant de travail - de refaire à nouveau le livre entier selon les indications reçues de la St. Congrégation.

C'est pour dans ce but, que je viens demander à Votre Excellence de vouloir bien sonder l'affaire et de me dévoiler quelles furent les causses immédiates d'une démarche pareille.

Ensuite je prie Votre Excellence de vouloir m'indiquer la voie qu'il faudrait choisir afin d'obtenir de la part de sphères intéressées des indications touchant à la réédition de mon livre, à savoir ce qu'il faudrait y éviter ou changer.

Appuyé sur ces informations préliminaires, je pourrais envoyer à Rome l'un de mes chanoines très bien versé dans mon livre, ayant des connaissances justes et claires sur son idée-maître.

Je désirerais qu'il puisse sur place discuter les points en questions et préparer une nouvelle édition du livre. 
Votre Excellence aura l'extrême bonté de me faire savoir si mon projet est réalisable. Pour mieux informer Votre Excellence, je cite ici un exemple presque analogue, qui se passa avec le livre du Prélat Adam, professeur à la faculté de théologie de l'université de Tübingen ${ }^{513}$ (Allemagne) traitant sur l'Eglise et intitulé: „Das Wesen des Katholizismus” (L'Essence du catholicisme). Après que ce livre fut traduit dans presque toutes les langues et au moment où sa propagation atteint l'apogé, il reçut un ordre analogue à celui que je viens de recevoir, où il était dit cependant expressement qu'à cause de graves erreurs cette mesure fut prise. C'est alors qu'il reçut, je ne sais plus par quelle voie, des informations spéciales de la Congrégation lui indiquant ce qu'il fallait changer ou ce qui était à omettre. Guidé par ces indications il réédita son livre sous une toute autre forme et voici qu'aujourd'hui ce livre est lu et connu partout dans l'univers catholique.

Encouragé par cet exemple, il me semble qu'il n'existe point d'obstacle, que je n'entreprenne, moi aussi, une réédition de mon livre, ce que, je l`espère, on voudra bien me faciliter.

Je ne m'efforce guère de Vous redire quelle serait ma gratitude si Votre Excellence voudrait bien s'occuper de cette affaire, qui aujourd'hui constitue une tragédie pour moi.

Depuis trois ans je souffre d'une grave maladie de coeur. Les médecins m'ayant interdit toute peine et même toute émotion, me voici aujourd'hui ébranlé et boulversé jusqu'au fond de mon être ...

Me recommandant aux prières et à la charité de Votre Excellence, je demeure avec l'expression de ma plus profonde vénération de Votre Excellence Rssme le serviteur dévoué en $\mathrm{N}$ [otre] S[eigneur].

\section{Dokument 270}

Kopia: AFKDOPW, teczka 133: Spuścizna abp. Józefa Teodorowicza, sygn. 1172/61 [5], List abp. Józefa Teodorowicza do ks. Josepha Nabera, Lwów 28 XI 1936 r.

Lwów, am 28 XI 1936

Abchrift

Pfarrer Naber

Konnersreuth

Lieber ${ }^{\mathrm{a}}$, hochverehrter Herr Pfarrer,

Ich danke Ihnen herzlichst für Ihren Brief und sende Ihnen mein Buch mit einer Dedikation.

Es war dies ein Versehen seitens der Verlagsbuchhandlung, dass man Ihnen mein Buch nicht zugeschickt hat, wiewohl ich ihr dies ganz ausdrücklich empfahl. Ich danke Ihnen für Ihre liebenswürdigen Worte und für die wohlwollende Beurteilung meines Buches. Leider haben Sie vollkommen recht, wenn Sie behaupten, dass sich in dasselbe

513 Tübingen - miasto w kraju związkowym Badenia-Wirtembergia (Niemcy).

a Tekst napisany maszynowo na 5,5 stronicach papieru formatu A4. 
so manche Ungenauigkeiten einschlichen. Der Hauptgrund dessen ist darin zu suchen, dass ich erst im Herbste das Buch veröffentlichen wollte, um dasselbe noch einmal gründlich durchzulesen, die Zweifel in der Besprechung mit Ihnen und mit andern Personen zu lösen und das ganze Manuskript überhaupt auszubessern. Denken Sie sich: die Verlagsbuchhandlung drängte mich, aus Geschäftsrücksichten das Manuskript schon im Frühjahr, ja schon im Jänner l. J. auszuliefern. Sie hatte eine derartige Eile, dass mir die Korrektur nicht einmal zugeschickt wurde. Der gute Pater Staudinger hat dieselbe zwar sehr fleissig und verständig geführt, aber niemand kann den Autor selbst in dieser Arbeit richtig vertreten.

Der Verlag jedoch, der seine Fehler jetzt einsieht, hat sich dazu bewegen lassen einen Berechtigungszettel in die noch zu druckenden Exemplare einzufügen. Dies soll gerade jetzt geschehen, deshalb kommt mir Ihr Brief wahrlich wie eine Vorsehung vor. Denn auf Grund Ihres Briefes kann ich in der Interesse unserer Gemeinsache Sie dringend bitten, mir alle die Stellen in meinem Buche anzugeben, die entweder unrichtig oder nicht genau sind.

Dr. Deutschens Pamphlet auf Konnersreuth wird eine entsprechende Antwort binnen kurzem erhalten. Ich selbst halte es unter meiner Würde einem öffentlichem Verleumder und Fälscher (er hat meine Stellung gänzlich gefälscht) eine Antwort zu erteilen.

Er schrieb noch vorher einen derartig impertinenten Brief an mich, dass ich denselben unbeantwortet liess. Der Mann scheint mir von einem Grössenwahn befallen zu sein, der mit moralischer Skrupellosigkeit enge verbunden scheint. Leider tritt er als Verteidiger des deutschen Episkopats auf, gegen einen fremden Eindringlich (der bin ich) und als derjenige, der einen „sakrallegen Weltbetrug” entlarvt - diese Worte hat er ausdrücklich im Briefe an mich gebraucht. Es hat einer meiner Domherrn, der ein sehr gescheiter Kopf ist, den Plan gefasst, dem Dr. Deutsch, eine Antwort zu erteilen. Aus der ersten Probe, die er mir zusandte er war vorläufig nicht in Lwów - sehe ich, dass diese Antwort ausgezeichnet ist. Ich wende mich nur an Sie, lieber Herr Pfarrer, mit der Bitte meinem Domherrn in seiner schwierigen Arbeit behilflich zu sein und zwar auf folgende Weise: Einer der Hauptangriffe des Dr. Deutsch besteht darin, dass er die Stellung des Vaters des Therese als ungehorsam gegen die kirchliche Behörde stempelt. Selbstverständlich macht sich, nach der christlichen Moral, Herr Neumann keineswegs eines Ungehorsams der Kirche gegenüber schuldig. Aber nach außen hin ist dieser Vorwurf sehr verlockend für einen jeden, der die Prinzipien der christlichen Moral nicht kennt. Ich weiss vom verstorbenen Gerlich (er veröffentlichte dies sogar in seinem "geraden Wege"), dass H[err] Neumann nicht abgeneigt ist seine Tochter einer neuen Überwachung zu übergeben und zwar unter gewissen Bedingungen. Leider während es die ganze Welt weiss, dass sich das Regensburger Ordinariat mit der Bitte um eine neue Untersuchung an $\mathrm{H}[\mathrm{err}]$ Neumann wandte, so weiss eigentlich niemand was für eine Antwort Herr Neumann seinem Bischofe gab. Es kommt mir somit der Gedanke mich an H[err] Neumann mit einer entsprechenden Anfrage zu wenden und diesen Brief will ich an dieses Schreiben anschliessen. Ich bitte Sie nunmehr die Situation zu 
sondieren, und wenn Sie vermuten, dass es ihm schwer fällt meinen Brief zu beantworten so brauchen Sie ihn überhaupt nicht zu übergeben. Aber vielleicht wird $\mathrm{H}$ [err] Neumann doch zur Erkenntnis kommen, das seine derartige Erklärung seinerseits die Verteidigung seiner Stellung mit sich bringt.

Er wird jetzt immer heftiger und heftiger und heftiger angegriffen; wenn er somit eine Erklärung gibt, worin er mich in Kenntnis setzt, dass er dem Wunsche seines Bischofs nachkommen wolle, und dass er nur diejenigen Bedingungen stelle, die seinen Befürchtungen gegenüber Gewähr leisteten, dann hat er seinen prinzipiellen Standpunkt verteidigt.

Nur probeweise schliesse ich an diesen Brief das Projekt eines Briefes für H[err] Neumann an, so wie ich ihn mir als Antwort auf das Schreiben des Domherrn Bogdanowicz vorstelle.

Und jetzt folgt die zweite Bitte: Ich habe einst bemerkt, dass Therese während sie sich aufrichtete, einen Schmerz im Rücken verspürte. Dieselbe Beobachtung machte auch $\mathrm{P}$ [ater] Bruno. Es ist möglich, dass trotz der wunderbaren Genesung noch irgendwelche Spur der früheren Wirbelverrenkung zurückblieb. Wenn dies der Fall wäre, so würde ein für alle Mal die Frage gelöst sein, ob denn wirklich Therese, wie es Gehrlich behauptete, eine Luxation hatte. Die etwaige Feststellung eines derartigen Überbleibsels der früheren Wirbelverrenkung wäre ein packender Beweis für die Wahrheit der Burckhardt-Gerlichischen Hypothese. Das liesse sich jedoch auf ganz einfache Weise aufklären und zwar mittelst einer Röntgenaufnahme. Was sagen Sie Herr Pfarrer zu diesem neuen Plan? Ich halte es für eine Kleinigkeit, wenn sich Therese in Gesellschaft ihres Vaters oder ihrer Mutter oder gar in Ihrer Gesellschaft nach Waldsassen begäbe und dort unter Dr. Seidls Leitung eine Aufnahme ihres Rückens machen liesse. Dies würde ja nur etwa 5 Minuten dauern, sie braucht sich ja nicht einmal auszukleiden, sie fühlt keinen Schmerz dabei, keine psychische Einwirkung; es wird nur einfach eine Photographie des Rückgrats aufgenommen. Ist das Wunder in gewissem Sinne vollkommen gewesen, dann ist die Aufnahme unnütz, denn es bleibt keine Spur vor dem früheren Leiden - es ist aber möglich, dass die Photographie Überreste früherer Krankheit ergibt und dann haben wir den Beweis der für unsere These entscheidend ist. Dann kann Dr. Deutsch nicht mehr von einer Erotomanie bei Therese Neumann sprechen und schreiben.

Bei dieser Gelegenheit wäre es vielleicht auch möglich eine Bestätigung von Dr. Seidl zu erhalten, dass er nämlich die Durchliegewunden bei Therese Neumann jahrelang beobachtete, dass die Wunden tief gewesen sind, dass die angewandten Arzneien zur Genesung nicht verhalfen. Man braucht dem Dr. Seidl nicht zu sagen für wen und wozu sein Zeugnis nötig ist - er braucht sich bloss auf die Tatsachen zu stützen. Selbstverständlich weiss ich nicht, ob er mit diesem Vorschlag einverstanden ist, darum schreibe ich auch nicht selbst an ihn und bitte Sie auch in dieser Angelegenheit seine Stellung zu sondieren. Dies sind meine Projekte, die ich ihnen unterbreite, und wenn sie damit einverstanden sind und inwiefern Sie dieselben befördern können, bitte ich Sie um Mithilfe.

Jetzt komme ich zur wichtigsten Frage: Ich schliesse Ihnen hier die Abschrift eines Briefes von Prof. Wunderle an, aus der Sie ersehen können, was für ein Sturm gegen Konnersreuth seitens der Opposition losgeht. Man muss es gut überlegen, ob angesichts 
solcher Angriffe, wo sich die schwarzen Wolken der Feinde immer mehr und mehr verdichten, nicht die höchste Zeit wäre, den früheren Entschluss des H[err] Neumann wieder aktuell zu machen. Ich meine den Entschluss von dem ich eben schrieb, dem Wunsche des Bischofs unter gewissen Bedingungen nachzukommen. Diese Bedingungen würden, wie ich glaube, die Ausschliessung jeglicher klinischen Vorgänge betreffen, wie auch vielleicht die Wahl, der zu Kontrolle bestimmten Ärzte. Gesetzt den Fall, dass das Ordinariat in Regensburg auf diese Bedingungen eingeht, dann hat Neumann zu seinem Schutz die Abschrift seines Briefes. Ich glaube, dass in diesem Moment ein weiteres Beharren auf dem negativen Standpunkte in mancher Hinsicht höchst gefährlich wäre. Es ist zum ersten Mal geschehen, dass diese biedere, gläubige, katholische Familie von Dr. Deutsch eines Betruges beschuldigt wurde. Der Stein ist im Rollen, es werden gewiss mehr Angriffe folgen, gegen die man hilflos ist. Gewiss ist Theresens Vater dazu berufen, aber die Bedingungen, die er aufstellt, wenn nur dieselben nicht zu überspannt sind, werden für ihn Bürge leisten. Anderseits ist er verpflichtet seinen guten Namen, den er sich durch sein biederes, ehrliches Leben verdiente, für sich und seine Familie in Schutz zu nehmen. Der Standpunkt einer bloss negativen Resistenz ist unzureichend, um diesem jetzt neu entspannten Sturme Widerstand zu leisten. Auch befürchte ich die Konsequenzen einer solchen Stellung, die einerseits durch die Opposition terrorisierten Bischöfe, anderseits durch die Pläne der Feinde Konnersreuths, sehr leicht eine Katastrophe herbeiführen könnte. Es kann dazu kommen, dass Herr Neumann schon nicht vom Bischofe gezwungen, wohl aber von andern feindlichen Faktoren bedrängt seine Tochter doch einer Überwachung wird übergeben müssen.

Mit dieser Möglichkeit muss man jetzt nach Wunderles Briefe rechnen. Ich schreibe dies als bester Freund Konnersreuths, der ja so viel Beweise erbrachte, wie ihm Konnersreuths Schicksale als die der Gottessache am Herzen liegen, der nicht nur für Therese Neumann aber auch für ihre allernächste Familie so viel Sympathie mitbringt und der jetzt in Anblicke einer grossen Gefahr vor derselben warnt. Auch Kath[arine] Emmerich wurde von der staatlichen Behörde untersucht (siehe Weseners Tagebuch) bitte somit $\mathrm{H}[\mathrm{err}]$ Neumann aufmerksam zu machen, was für Folgen er für seine Tochter herbeiführt, wenn er weiter auf seinem Standpunkte verharrt.

Indem ich Ihnen nochmals für Ihren Brief und alle Informationen, die Sie mir gaben meinen aufrichtigsten Dank ausspreche, verbleibe ich Ihnen stets ergeben

(m.p.) J[ózef] Teodorowicz

P.S. Schon nach Beendigung meines Briefes erhielt ich einen Brief aus Rom, aus dem ich klar ersehe, dass zwar nicht unmittelbar aber mittelbar sich dort eine Wendung gegen Konnersreuth vollzieht oder gar vollzogen hat. Ich sage dies auf Grund eines offiziellen Aktes. Man muss auch mit der Eventualität rechnen, dass auch seitens der Bischöfe etwas zustande kommen könnte, was eine unverhoffte und für Konnersreuth ungünstige Stellung bedeuten sollte. In dieser Sachlage, die sich jetzt entwickelt, besteht die Möglichkeit, dass unberufene Faktore leicht Konnersreuth in ihre Hände flossen. Sie müssen also Hochwürdiger Herr Pfarrer jetzt Initiative erfassen, denn eine bloss 
negative Obstruktion muss, menschlicher Weise genommen als Problem von Konnersreuth zugrunde richten.

Ich bitte Sie, wie auch den H[err] Neumann, die dem Dr. Deutsch künftig gegebene Antwort als striktes Geheimnis zu bewahren.

Vielleicht könnten Sie mir ganz vertraulich die Abschrift von der dem Hochwürdigsten Bischof Buchberger durch Neumann erteilten Antwort übersenden.

\section{Dokument 271}

Kopia: AFKDOPW, teczka 138: Spuścizna abp. Józefa Teodorowicza, sygn. 453/190 [7], List bp. François Agagianiana do abp. Józefa Teodorowicza, Rzym 1 XII 1936 r.

Roma, (105) 1 Déc[embre] 1936

Excellence ${ }^{a}$ Réverendissime,

Je m'empresse d'informer Votre Excellence que votre honorée en date du 28 Novembre m'est parvenue, ainsi que les feuilles incluses.

Je me rends compte parfaitement de la douleur dont Votre coeur doit être saisi, et j'y prends part avec mes prières.

Je ne manquerai pas à faire tout mon possible pour satisfaire les désirs de Votre Excellence et au plus tôt je Vous écrirai.

Veuillez agréer, Excellence, les sentiments de ma profonde vénération et estime de Votre Excellence Réverendissime le serviteur dévoué en N[otre] S[eigneur].

† François Agagianian ${ }^{514}$

\section{Dokument 272}

Kopia: AFKDOPW, teczka 131: Spuścizna abp. Józef Teodorowicz, sygn. 809/110 [5], List abp. Józefa Teodorowicza do ks. prałata Zygmunta Kaczyńskiego, Lwów 5 XII 1936 r.

\section{Przezacny ${ }^{\mathrm{a}}$ Księże Prałacie!}

Dziś zwrócono się do mnie z agencji P[olskiej] A[gencji] T[elegraficznej] ${ }^{515} \mathrm{w}$ sprawie mej najnowszej książki, któtej recenzję chce podać w swym piśmie. Dlatego, że to trochę dziwnie wygląda, że P.A.T. pierwsza interesuje się książkami Ks. Ks. Biskupów

a Tekst pisany maszynowo z wyjątkiem autografu autora na jednej stronicy papieru formatu A4. W lewym górnym rogu nadruk firmowy: „Pont[ificio] Collegio Armeno, Piazza S. Nicola da Tolentino 31”.

${ }^{514}$ Zob. w niniejszej publikacji: J. Wołczański, Korespondencja abp. Józefa Teodorowicza z abp. Adamem Stefanem Sapieha, dokument 119.

a Tekst pisany maszynowo na $1 / 2$ stronicy papieru formatu A4. Brak autografu autora listu.

${ }^{515}$ Polska Agencja Telegraficzna - instytucja powołana do życia w 1918 r. z siedzibą we Lwowie, Krakowie, a później w Warszawie. Wydawała 14 biuletynów dotyczących wydarzeń społeczno-politycznych, gospodarzych, sportowych i kulturalnych w Polsce tłumaczonych na obce języki, co stanowiło zasadnicze źródło informacji o kraju dla ośrodków zagranicznych. W latach 1945-1991 funkcjonowała na emigracji, po czym w 1991 r. zintegrowała się z krajową Polską Agencją Prasową. E. Ciborska. Polska Agencja Prasowa: tradycje i wspótczesność, RHPP, 1998, nr 1/1-2, s. 172, 174, 179. 
i pierwsza wydaje recenzje o nich, przeto zawiadamiam o tym szczególe Księdza Prałata łącząc dla niego wyrazy poważania i głębokiego szacunku.

Lwów, dnia 5 grudnia 1936

Ks. Kaczyński

\section{Dokument 273}

Oryg.: AFKDOPW, bsygn., teczka: Spuścizna abp. Józefa Teodorowicza, List ks. Josepha Nabera do abp. Józefa Teodorowicza, Konnersreuth 11 XII 1936 r.

Konnersreuth, den 11. Dez[ember] 1936

Abschrift

Excellenz! $!^{a}$

Hochwürdigster, verehrtester Herr Erzbischof !

Mit grossem Interesse habe ich von dem Brief Euerer Excellenz Kenntnis genommen. $\mathrm{Zu}$ Weihnachten gedenkt Herr Professor Wutz von Eichstätt hieher zu kommen u[nd] werden wir dann die einzelnen Punkte U. Vorschläge Ihres Briefes miteinander $\mathrm{u}[\mathrm{nd}]$ mit Theres $u[n d]$ ihrem Vater besprechen.

Zunächst ist mir durch Theres Neumann während des erhobenen Ruhezustandes aufgetragen worden, Excellenz zu schreiben, Sie möchten es, soviel nur immer möglich vermeiden, die Angelegenheit mit dem offenen Brief des Dr. Deutsch in die Öffentlichkeit zu bringen oder bringen zu lassen, möchten also Ihre Antwort an Dr. Deutsch nicht im Buchhandel erscheinen lassen, sondern höchstens als Manuscript an die Deutsch seinen offenen Brief auch geschickt heben wird, vor allem wohl an die deutschen Bischöfe u[nd] Mystisch interessierte Persönlichkeiten. Es solle, hiess es in der Ekstase, ein neuer Kampf möglichst vermieden werden. Sehr gut wäre es, wenn Excellenz etwa auf das hin, was ich Ihnen letzhin aus dem Freiburger Kirchenblatt mitgeteilt habe, Anlass nehmen könnten, das bischöfliche Ordinariat Regensburg über die Broschüre von Deutsch aufzuklären, da gerade dieses dadurch, dass es jetzt auf den offenen Brief Deutsch hin Erlaubniserteilungen ohne Grundangabe ablehnt, den Verdacht erweckt, dass etwas gegen Konnersreuth vorliegen müsse. Ich hab ja wohl schon selbst in einem Bericht von über 20 Seiten mich über das Pamphlet von Deutsch dem Hochwürdigsten Herrn in Regensburg gegenüber geaüssert, aber der Pfarrer ist, heisat es, Partei. Ich bin zwar nicht besorgt darum, dass der Heiland, was er mit Theres Neumann angefangen, auch zu einem guten Ende führen werde, aber doch möchten wir unserseits auch dazu beitragen, was in unseren Kräften liegt.

Indem ich demütig für Theres Neumann u. mich um den hohepriesterlichen Segen bitte, versichere ich zu bleiben Euerer Excellenz ergebenster

Naber

Pf[arre]r

a Tekst pisany maszynowo na 1,5 stronicy papieru formatu A4. 


\section{Dokument 274}

Kopia: AFKDOPW, teczka 127: Spuścizna abp. Józefa Teodorowicza, sygn. 445/190 [7], List abp. Józefa Teodorowicza do bp. François Agagianiana, Lwów 14 XII 1936 r.

Lwów, le 14. XII 1936-a

\section{${ }^{\mathrm{a}-}$ Copie}

Excellence ${ }^{\mathrm{b}}$ Révérendissime,

Je savais bien à qui m'adresser ... La lettre de V[otre] E[xcellence] si bienveillante m’a été une vrai consolation. Je remercie V[otre] E[xcellence] du fond de mon cœur d'avoir voulu vous occuper de mon affaire. Pour mieux orienter V[otre] E[xcellence], je m'empresse de lui transmettre un détail encore qui, je l'espère, ne tardera pas à jeter une lumière plus vive sur les secrets mobiles de l'affaire.

Encore avant d'avoir publié mon livre allemand concernant Konnersreuth, j'ai polémisé sur ce sujet à deux reprises avec le R[évérend] P[ère] Siwek SJ, professeur au Gregorianum de Rome qui, dans son analyse de phénomènes de Konnersreuth, avait entièrement éliminé les critères psychologiques et mystiques pour ne se servir et ne s'appuyer que sur la psychanalyse.

Mon premier travail était une réponse critique aux méthodes (leurs principes et conséquences) mises en œuvre par l'auteur. Après quoi, il publia un second livre qui me força d'écrire un gros volume polonais dans le but de défendre mes thèses, entièrement déformées par l'auteur.

Le Supérieur Général des Jésuites, jugeant que ma critique pourrait nuire au professeur du Gregorianum, suspect de rationalisme, ne tarda pas de m'engager à ce que je m'entende avec le père Siwek dans le but de faire cesser le différend. Je ne pus y consentir pour certaines causes graves que j’allais communiquer au Général. Celui-ci en fut fort piqué.

Dans mon livre récent, je n'avais pas mentionné, même pas d'un seul mot, la personne du père Siwek.

Or, sans en être sûr, je suppose que tout comme il arriva dans l'attaque dirigée contre Charles Adam ${ }^{516}$, dont je fis mention dans ma dernière lettre et dont le principal moteur furent les Jésuites, de même il en est dans le cas présent. C'est sans nul doute eux qui contribuèrent à ce que le St. Office traitât l'affaire de la sorte. Il était d'ailleurs dans leur intérêt de démontrer que celui qui osa attaquer un professeur du Gregorianum, se trouve lui-même dans l'erreur. Je m'affermis d'autant plus dans ma conviction, que je reçus récemment une lettre du personnage le plus engagé dans l'affaire, je veux dire de S[on] E[xcellence] l'évêque Buchberger de Regensburg, d'où il apparaît manifestement qu'il n'avait fait aucune démarche dans ce sens à Rome.

En remerciant V[otre] E[xcellence] encore une fois de son extrême bonté, je saisis l'occasion pour lui présenter l'expression de ma plus profonde vénération de Votre Excellence le serviteur tout dévoué en N[otre] S[eigneur].

a-a Nota czarnym atramentem.

516 Zob. w niniejszej publikacji: J. Wołczański, Korespondencja abp. Józefa Teodorowicza z abp. Adamem Stefanem Sapiehą, dokument 119.

b Tekst pisany maszynowo na 1,5 stronicy papieru formatu A4. Brak autografu autora. 


\title{
Dokument 275
}

Kopia: AFKDOPW, teczka 133: Spuścizna abp. Józefa Teodorowicza, sygn. 1171/61 [5], List abp. Józefa Teodorowicza do ks. Josepha Nabera, Lwów 21 XII 1936 r.

Lwów, den 21 XII 1936

\author{
Abschrift \\ Pfarrer Joseph Naber \\ Konnersreuth
}

Liebera ${ }^{\mathrm{a}}$, Hochverehrter Herr Pfarrer,

Ihr Brief hat mir grosse Freude bereitet. Der mir im ekstatischen Zustande von Therese gegebene Rat entspricht mir vollkommen und ich werde dem selben Folge leisten. Die zu druckende Arbeit wird als Manuskript erscheinen. Diese Erklärung hat mich geistig gehoben, da, wie ich sehe, meine Arbeit in dem Ratschlusse der Vorsehung auch ihre Rolle spielt. Im Momente wo die ganze Feindschaft gegen Konnersreuth im Angriffe gegen mich und mein Buch losgeht, ist mir dies eine wahre Erquickung und Erhebung gewesen.

Es freut mich auch sehr was Sie mir schreiben über ihre Bereitwilligkeit alles zu tun, was menschlich gesagt, sich in dieser Angelegenheit tun liesse. Ich habe keinen Moment daran gezweifelt, dass Sie diesen Standpunkt gegenüber neuen und schweren Anfechtungen einnehmen werden. Ich erwarte jetzt viel von den Beratungen die Sie, hochverehrter Herr Pfarrer mit Prof. Wutz und Herrn Neumann unternehmen werden. Ich werde auch innig beten, auf dass Gott Ihnen das notwendige Licht verleihe. Die Hauptsache und der Kernpunkt des ganzen Problems ist die neue Überwachung - ich erhalte Briefe von den besten und ergebensten Freunden Konnersreuths, die sich einstimmig in dieser Richtung erklären. Jetzt ist die Sachlage ganz anders als sie früher gewesen. Jetzt wird der Widerstand gegen die Überwachung mit dem Ungehorsam gegen die Bischöfe identifiziert und auch die besten werden davon betroffen - ich will den Ausdruck skandalisiert nicht gebrauchen. Nach der stürmischen Anfechtung Dr. Deutschens wird die ganze Familie eines Betruges beschuldigt und was früher undenkbar gewesen, das wird jetzt nach diesem Durchbruch zu den weitgehendsten Folgen führen müssen. Über die Möglichkeit einer Einwirkung seitens unberufener und feindseliger Faktore in dieser Angelegenheit, habe ich ihnen schon früher geschrieben.

Ich habe an Bischof Buchberger einen Brief gerichtet und schickte Ihnen die Abschrift desselben, wie auch die Antwort des Bischofs. Ich könnte, wenn es nötig wäre zwischen dem Bischof und der Familie Neumann vermitteln. In Rom arbeitet man stark gegen Konnersreuth und man muss auch mit diesem Umstand ernst rechnen. Ich kann vorläufig nicht alles schreiben, es kommt aber die Zeit, wo ich es tue.

Bei dieser Gelegenheit muss ich Sie noch um etwas bitten: die Antwort an Dr. Deutsch wird in diesen Tagen fertig sein. Es wäre selbstverständlich von allergrösster Wichtigkeit wenn diese Antwort durch Belege an Konnersreuth gestärkt wäre. Ohne Hoffnung

Tekst pisany maszynowo na 3,5 stronicach papieru formatu A4. 
auf eine neue Überwachung kann sich gewiss manches erzielen, aber im grossen und Ganzen wird sie zu schwach sein gegenüber der ganzen tragischen Sachlage. Es ist nur die wahre Kriese im Konnersreuther Probleme eingetreten und ich bete auf dass Gott alles zum besten lenke. Ich habe noch praktische Fragen, die ich Ihnen Hochverehrtester Herr Pfarrer hier unterbreite:

1-o. Dr. Deutsch erhob den Vorwurf gegen Sie, dass Sie der erste gewesen sind, der die Nachrichten über Konnersreuth in den Zeitungen verbreitete. Ich weiss, das es so nicht ist - bitte Sie jedoch um nähere Angaben und Information wer der erste gewesen ist der diesbezüglich die ersten Berichte in der Presse erstattete. Es wäre auch gut und wünschenswert, wenn sie mir etwas Näheres und Konkretes über Ihre Zurückhaltung, die mir bekannt ist, berichten könnten.

2-o. Was ist eigentlich mit diesem Intermezzo zwischen Therese und den Mallersdorfer Schwestern gewesen? Sie erzählte mir, dass sie die Mallersdorfer Schwestern beredeten, sie solle ins Kloster eintreten, sie wehrte sich dagegen - daraus hätte sich eine wahre Quälerei der Therese gegenüber entspannen, worunter sie heftig litt. Ich weiss jedoch nicht wie sie die Sache eigentlich verhielt und zweifle ob es passend wäre solche intime Vorgänge in die Öffentlichkeit zu bringen - jedenfalls scheint es mir dass das was Therese über das Verhalten der Mallersdorfer Schwestern in ihrer Gegenwart äusserte, nicht im Zustande der gehobenen Ruhe erfolgte. Wenn Sie mir etwas Näheres darüber berichten können, so bitte es zu tun.

3. Wie ist der Vorwurf Dr. Deutschens in betreff der von Therese Neumann bezogenen Rente (in einer Berufsgenossenschaft) zu beantworten?

Könnten Sie nicht, Hochverehrter Herr Pfarrer mir die Kopie Ihres an die Regensburger Ordinariat gerichteten Briefes in betreff Dr. Deutschens Verleumdung ausleihen. Selbstverständlich werde ich nichts davon verraten. Es könnte sich aber so manches Detail darin finden, das in der Antwort zu berücksichtigen wäre.

Bei dieser Gelegenheit wiederhole ich noch einmal meine Bitte in betreff der Röntgenaufnahme. Vielleicht hat die Vorsehung für eine kritische Stunde den entscheidenden Sieg für die Thesen des verstorbenen Gerlichs vorbehalten. Vor dem Arzte dürfte man eine derartige Aufnahme dadurch begründen, dass Therese bis heute zuweilen Schmerzen im Rückgrat empfinde, daher wolle man sich überzeugen, ob denn drin etwas nicht stecke.

Ich will mich nicht mehr wiederholen und berühre nicht die Frage der Wichtigkeit einer Erklärung seitens des Herrn Neumann. In solch einem Ansturm von Verdächtigungen und Verleumdungen ist diese Erklärung zur Notwendigkeit geworden. Ich glaube auch, dass diese Massnahmen, die zum Zwecke haben Therese durch ausserkirchliche Faktoren zu einer Observation zu zwingen, durch eine derartige Erklärung, wenn nicht gehemmt, so doch entkräftet werden. Das entscheidende bleibt aber immer die neue Überwachung. Es ist auch vom oportunischen Standpunkte besser sich freiwillig einer neuen Beobachtung zu ergeben als sich dieselbe durch Zwang aufdringen zu lassen.

Und jetzt auch eine Bitte, dass Sie mich nämlich Theresens Gebeten besonders anempfehlen. Ich habe körperlich viel zu leiden und möchte noch, wenn es Gottes Willen 
ist, mein Lebenswerk über Christum zu Ende bringen. Ich habe schon früher der Therese scherzend erwähnt, dass ich durch sie mich von meinem Lebenswerke abgewandt habe. Sie antwortete mir lachend, dass es sich hier nicht um Therese sondern um den Heiland und um die Seelen handle. Ich bitte Sie nun, auf dass sie durch ihr Gebet dahinwirke, dass mir Gott die notwendigen Gnaden und, insofern es sein Wille ist, die notwendige Gesundheit verleihe.

Ich schliesse auch noch meine besten Weihnachtswünsche, die ich ebenfalls dem $\mathrm{H}$ [errn] Prof. Wutz, dem H[errn] Benefiziat Härtl, der Familie Neumann und speziell der Therese entbiete und verbleibe mit dem Ausdruck meiner tiefsten Hochachtung.

Ihnen stets ergeben

(m.p.) + Teodorowicz

\section{Dokument 276}

Kopia: AFKDOPW, bsygn., teczka: Spuścizna abp. Józefa Teodorowicza, List abp. Józefa Teodorowicza do o. Odo Staudingera OSB , Lwów 22 XII 1936 r.

Lwów, den 22 XII 1936

Hochverehrter ${ }^{\mathrm{a}}$, lieber Pater,

Herzlichen Dank für Ihren Brief, der für mich nur in diesem Punkte schmerzlich gewesen, dass Sie so viel leiden müssten.

Was unsern Freund P[ater] Mager anbelangt, so haben Sie vollkommen Recht, er ist in der Tat ein Virtuose, ein Paganini ${ }^{517}$ in der Kunst zu faszinieren, die so weit geht, dass der Zuhörer schon seine eigene Melodie zu vernehmen glaubt, die doch am Ende nicht die Seinige ist. Ich bewundere wahrlich diese durch und durch französische Art von Courtoisie, Subtilität und Geist bei Pater Mager. Ich danke Ihnen herzlichst, dass Sie sich trotz Ihrer Krankheit der ganzen Sache annahmen und erwarte den Brief von Pustet.

Was Dr. Deutsch anbelangt so entspriesst dies alles, was er schreibt aus dreifacher Quelle:

1-o ist er ein grosser Hasser von Konnersreuth. Der Hass bildet gewissermassen seine Stärke, denn er weiss alles zu konzentrieren, was diesen Hass nur sättigt oder sättigen kann. Dies ist auch der Grund warum sein Brief einen Eindruck machen kann.

2-o ist für ihn dieser Hass als objektiven Forscher in der Durchführung seiner Thesen verhängnissvoll, den er wird einfach zum Fälscher, zum ganz bewussten Fälscher. Der verstorbene Gerlich hat seine Schrift vorbereitet, worin u[nter] a[nderen] Dr. Deutschens Fälschungen nachgewiesen werden, und Gerlich nannte ihn schon Fälscher. Jetzt ist es ein Kinderspiel nachzuweisen, wie er meine Zitate gefälscht hat um nur seine Thesen über den "gotteslästerlichen Betrug" in Konnersreuth nachzuweisen.

a Tekst pisany maszynowo na 2,5 stronicach papieru formatu A4. W lewym górnym rogu karty tytułowej nota czarnym atramentem: „Pater Staudinger”. Brak zakończenia.

517 Paganini Niccolò (1782-1840), włoski skrzypek i kompozytor. 
3-o ist er wissenschaftlich zum Probleme, das er zu lösen sucht, nicht gewachsen. Den Mangel an wissenschaftlicher Bildung ersetzt er durch einen selbstbewussten, leidenschaftlichen, hochmütigen Ton.

Dies ist wenigstens meine Meinung über die Person und den Wert der Schrift dieses Herrn. Da Ganze wird von einem gewissen, prophetischen Pathos beseelt, dieser spezifischen Art mancher patentierter Katholiken, die stets im Munde den Dienst für die Kirche führen im Grunde aber sich zu Führern und Richter der Kirche aufwerfen. Man müsste naiv sein um zwischen den Linien nicht zu lesen, dass Dr. Deutschens Brief eigentlich gegen die deutschen Bischöfe gerichtet ist, und zwar gegen ihre vermeintliche Leichtgläubigkeit und ihren Langmut. Der Pfarrer Naber schrieb mir, dass einer der deutschen Bischöfe in einen an ihn gerichtetem Briefe, Dr. Deutschens Broschüre „ein ungezogenes Pamphlet" nennt - und dass ein gelehrter Dominikaner diesbezüglich folgendes äußert: Dr. Deutschens offener Brief ,ist ein Sammelsurium von Verleumdungen, Lügen, Verdrehungen und Beleidigungen".

Sie haben vollkommen Recht, dass Theresens Überwachung zur Notwendigkeit geworden ist. Ich habe dasselbe an die allernstlichsten Freunde von Konnersreuth geschrieben und habe die Hoffnung nicht verloren, dass man die ernst erwägen wird. Der Regensburger Bischof ist ein sehr guter Herr, aber... . Ich schrieb ihm vor Kurzem einen ziemlich starken Brief - er entschuldigt sich in seiner Antwort bemerkt aber hierbei, dass er einen Dankesbrief an Dr. Deutsch erstattete und zwar aus dem Grunde, dass letzterer seine Arbeit als Manuskript veröffentlichte. Da ist der gute Bischof Buchberger wie abgemalt. Jetzt ist die grosse Krise im Konnersreuther Problem eingetreten, welche die Feinde zu ihren Gunsten auszunützen suchen, die aber Gott zum besten, so hoffe ich, lenken wird.

Soeben erhielt ich Ihren zweiten Brief samt dem Manuskript und dem Buche, wofür ich Ihnen meinen herzlichsten Dank ausspreche. Wem soll ich die Gebühr für das Buch erstatten? Was die dem Dr. Deutsch gegebene Antwort anbelangt, so gehört eine ganze Reihe von Vorgängen gar nicht in das Bereich der Medizin, somit kann man einen Arzt damit nicht belästigen und beherrschen. Anderseits werden die entsprechenden in das Gebiet der Medizin gehörenden Stellen Fachärzten unterbreitet und ihre diesbezüglich geäusserten Ansichten der Antwort angeschlossen.

Mit dem Pfarrer Naber bin ich in regem Briefwechsel und werde Ihnen vielleicht binnen Kurzem etwas Positives in Betreff von Konnersreuth berichten können.

Und nun sende ich Ihnen, dem Pater Mager sowie allen Hochverehrten Paters meine innigsten Weihnachtswünsche und indem ich meine Arbeit Ihrem Herzen und Ihrer Liebe empfehle, verbleibe ich mit dem Ausdruck meiner ausgezeichneten Hochachtung Ihnen stets ergeben $[. . .]^{\mathrm{b}}$.

b Brak zakończenia. 


\section{Dokument 277}

Kopia: AFKDOPW, teczka 133: Spuścizna abp. Józefa Teodorowicza, sygn. 1779/61 [5], List abp. Józefa Teodorowicza do ks. Josepha Nabera, Lwów 28 XII 1936 r.

\section{Abschrift}

Lwów, den 28 XII 1936

Hochverehrter Herr Pfarrer

Joseph Naber

Konnersreuth

Hochverehrter ${ }^{\mathrm{a}}$ Herr Pfarrer,

Ich bitte Sie mir möglichst raschmitzuteilen, wie sich der Fall des Zwistes zwischen Therese Neumann und den sie derzeit beobachtenden Mallersdorfer Schwestern zugetragen hat.

Nebenbei berühre ich noch einmal manche Fragen, die ich in meinem früheren Briefe berührt habe.

1. Ich ergänze meine Bemerkungen über die Röntgenaufnahme des Rückgrates wenn eventuell mein diesbezügliches Projekt angenommen wird, so wäre es notwendig nicht nur den Rückgrat, aber zugleich Herz und Lunge zu röntgenieren, da die Gestaltung des Rückgrats manchmal von Herz und Lunge abhängt, wie mir dies Fachärzte sagten. Ich glaube aber das dies sub uno geschehen kann.

2. Es wäre angewiesen, dass Dr. Seidl folgendes Zeugnis ausstellte: „Dem Wunsche des Herrn Neumanns entsprechend stelle ich folgendes ärztliches Zeugnis aus über den Verlauf der Krankheit bei seiner Tochter Therese Neumann mit spezieller Rücksicht auf die Aufliegewunden. Ich konstatiere hiermit:

a) Dass Therese in den Jahren ... auf Aufliegewunden litt ... .

b) Diese Aufliegewunden waren tief .... .

c) Die Heilung dieser Wunden erfolgte plötzlich auf folgende Weise: ... .

d) Was die Narben anbelangt, so stellte ich fest ... Selbstverständlich ist die Ausfüllung dieser Punkte Dr. Seidls Sache.

3. Wie so ergab es sich, dass die ursprünglich angestrebte aber nicht durchführbare Beobachtung in einer Klinik nicht zustande kam?

4. Wenn sich Herr Neumann zu einem Verteidigungsbriefe entscheiden würde, so wäre es wünschenswert in demselben mit Rücksicht auf Dr. Deutschens Beschuldigung hervorzuheben, dass Theresa sehnlichst wünsche einer Beobachtung unterzogen zu werden. Man könnte sich auch darin auf eine vom Generalvikar Dr. Schlegelmann ${ }^{518}$ stammende Schrift (vom 4 X 1927) berufen, worin es ausdrücklich berichtet: „Der umfangreiche eingehende Bericht des Herrn Sanitätsrat Dr. Seidl mit einem Passus aus der Hand des Herrn Universitätsprofessor Dr. Ewald nötigt in Verbindung mit den zwei

a Tekst pisany maszynowo na 2,5 stronicach papieru formatu A4. Brak zakończenia.

${ }^{518}$ Osoba niezidentyfikowana. 
Gruppentagebüchern der vier Schwestern zu der Überzeugung, dass die ursprünglich angestrebte, aber nicht durchführbar gewesene Beobachtung in einem Spitale oder in einer Klinik auch keinen besseren Erfolg hätte bringen können, die somit gewonnene naturwissenschaftliche Grundlage bietet erst den Boden für die philosophisch-theologische Prüfung des Phänomens...".

Aus diesem Berichte erfolgt, dass ohne Rücksicht darauf was dem Herrn Neumann versprochen wurde, aus obigen Berichte klar ersichtlich ist, dass die naturwissenschaftliche Grundlage gewonnen wurde, dass sie den Boden für die philosophisch-theologische Prüfung des Phänomens bildet, dass somit von weiteren Nachforschungen nach Abschluss der Beobachtung nicht mehr die Rede sein wird.

Ich wiederhole hier nicht mehr die übrigen schon besprochenen Punkte:

5. In einer politischen sehr verbreiteten Zeitung fand ich in einer Korrespondenz aus Deutschland eine merkwürdige Notiz vor, die sich vollkommen mit der im Briefe Prof. Wunderles geäusserten Androhung deckt. Wenn schon ein fremder, ausländischer Korrespondent derartiges schreibt, so können wir uns vorstellen, wie weit die Dinge gerückt sind. Diese Zeitung „Ilustrowany Kurier Codzienny” hat die besten Korrespondenten in allen Weltteilen. Sie berichtet eben dass unberufene Faktoren entschlossen sind die Überwachung Theresens selbst zu übernehmen, um den Betrug zu demaskieren, vor aller Welt bloszustellen und der Betrugsaffäre einmal ein Ende zu mach.

Die Sache ist, wie Sie sehen fortgeschritten und es ist der letzte Moment, wo man mit einem entscheidenden Schritte zuvorkommen könnte, indem man die von der kirchlichen Behörde erwünschte Beobachtung zu stande kommen lässt.

Wir stehen jetzt nicht mehr vor dem Dilemma: neue Überwachung oder keine Überwachung, sondern wir stehen vor dem Dilemma entweder eine Überwachung die im kirchlichem Bereiche mit notwendigen Klauseln zustande kommt oder eine andere Überwachung, die sich mit Namen nicht nenne, die ohne eine jegliche Rücksichten durchgeführt wird.

Jedes weitere Verharren auf bloss negativem Standpunkte, kann, wie gesagt, die Katastrophe herbeiführen.

Ich verbleibe mit dem Ausdruck meiner ausgezeichneten Hochachtung.

\section{Dokument 278}

Kopia: AFKDOPW, bsygn., teczka: Spuścizna abp. Józefa Teodorowicza, List bp. François Agagianiana do kard. Donato Sbarretti, [Rzym] 18 I 1937 r.

18 gennaio 1937

Kopia

$\mathrm{A}^{\text {a }}$ Sua Eminenza Reverendissima

Il Sig[nor] Card. Donato Sbarretti

a Tekst pisany na maszynie na jednej stronicy papieru formatu A4. W górnej partii karty nota w j. polskim: „Wyjaśnienie dane św[iętej] Kongregacji przez J[ego] E[kscelencję] Ks. Biskupa Agagianiana. List z dnia 10 [sic!] stycznia 1937 r." 
Vescovo di Sabina e Poggio-Mireteto

Segretario della Suprema S[acra] Congr[egazione] del S[an]t[o] Offizio

Eminenza Reverendissima,

Mons. Teodorowicz, Arcivescovo Armeno di Leopoli mi partecipa di aver ricevuto un venerato ufficio di coteste Suprema con ciu gli stata comunicata la decisione della congregatione plenaria dell' 11 Novembre 1936 circa il libro da lui edito del titolo: „Konnersreuth im Lichte der Mystik und Theologie" - per ciu vengono proibite le traduzione e la ristempa del sudetto libro, gli si impone di ritrarne le copie per quanto possibile, dal commercio, e di astenersi da qualunque attivita circa ikl detto argomento.

Mons. Teodorowicz dopo aver detto: „Je me aoumets sans restriction aucune aux décisions du St. Office” aggiunge: „Je me declare prêt, afin de ne pas perdre le fruit de tant de travail, de refaire à nouveau de livre entier selon les indications reçues de la St. Congregation. Je prie V[otre] E[xcellence] de vouloir m'indiquer le voie qu'il faudrait choisir, afin d'obtenir des sphères intéressées des indications touchant à la réedition de mon livre, à savoir ce qu'il foudrait y éviter ou changer. Appuyé sur ses informations préeliminaires, je pourrais envoyer à Rome l'un de mes chanoines, très bien versé dans mon livre, ayant des connaissances justes et clairs sur son idée-maitre. Je desirerais qu'il puisse sur place discuter les pointes en questions et préparer une nouvelle édition du livre. Votre Excellence aura l'extrême bonté de me faire savoir si ce projet est réalisables".

Nel Sottomettere quanto sopra alla benevola considerazione di Vostra Eminenza, reste in umile attesa sue venerate comunicazioni.

Di Vostra Eminenza Rev[erendissi]ma

† F[rançois] A[gagianian]

\section{Dokument 279}

Oryg.: AFKDOPW, teczka 138: Spuścizna abp. Józefa Teodorowicza, sygn. 456/190 [7], List bp. François Agagianiana do abp. Józefa Teodorowicza, Rzym 21 I 1937 r.

Roma (105), le 21 Janvier 1937

Excellence,

Je prie tout d'abord Votre Excellence de bien vouloir m'excuser si j'ai retardé de Vous donner quelques informations au sujet de l'affaire en question.

Par la présente je tiens à vous faire savoir que je me suis occupé jusqu'ici à en avoir quelques éclaircissements à vive voix, malheureusement mes essais personnels n'ont abouti à rien de précis, c'est pourquoi je fus obligé d'adresser une lettre au St. Office, dont j'ai l'honneur de vous faire parvenir une copie. Aussitôt, que j'aurais une réponse de la Congrégation, ce sera mon devoir de Vous mettre au courant du contenu.

a Tekst pisany maszynowo z wyjątkiem autografu autora listu na jednej stronicy papieru formatu A4. W lewym górnym rogu karty tytułowej nadruk firmowy: „Pont[ificio] Collegio Armeno, Piazza S. Nicola da Tolentino". 
Entre-temps Votre Excellence ne fera pas mal d'exposer son projet directement à la Congrégation susmentionnée, si par hasard jusqu'aujourd'hui ne l'a pas fait déjà.

Veuillez agréer, Excellence, avec mes meilleurs voeux de santé et de consolation spirituelle, mes sentiments d'estime et de respect, de Votre Excellence

${ }^{b}$-le très dévoué serviteur en $\mathrm{N}$ [otre] S[eigneur]

† François Agagianian ${ }^{-b}$

\section{Dokument 280}

Kopia: AFKDOPW, teczka 133: Spuścizna abp. Józefa Teodorowicza, sygn. 1773/61 [5], List abp. Józefa Teodorowicza do ks. Josepha Nabera, Lwów 26 I 1937 r.

Lwów, den 26 I 1937

Abschrift

Hochverehrter Herr Pfarrer

Joseph Naber

Konnersreuth

Hochverehrter ${ }^{\mathrm{a}}$ Herr Pfarrer,

Ungeduldig erwarte ich die Antwort aus Konnersreuth. Diese Antwort kann nicht auf eine zu grosse Distanz verschoben werden. Es kommen mir auch Zuschriften von den besten Freunden Konnersreuths, die einstimmig besagen, dass die einzige Antwort auf Dr. Deutschens Schmähschrift die Überwachung sei. Ich gebe Ihnen nur einen kleinen Beweis, wie tief diese Schrift eingreift. Ein Professor hat für eine deutsche Schrift die Kritik meines Buches geschrieben. Das betreffende Blatt hat ihm nach der Veröffentlichung der ersten Hälfte seiner Kritik die zweite Hälfte mit der Zuschrift zurückgeschickt: „In Lippenstadt hat ein Arzt, Dr. Deutsch eine Broschüre veröffentlicht, in der er scharf gegen Konnersreuth Stellung nimmt und Beweise anführt, die Hand und Fuss haben". So stichhaltig ist für diese Herren die Kritik gewesen. Ich wiederhole noch einmal, dass jetzt das Problem ganz anders gestellt worden ist. Weiteres Widerstreben gegen Überwachung bedeutet schon einen Skandal. Man könnte sogar irgendwelcher innern Stimme nicht vertrauen, wenn sich dieselbe dagegen erklären würde, denn selbst im Fall wenn Gott es anders wollte, wie es bei Gemma Galgani der Fall war, so ist es trotzdem die Pflicht der Beteiligten, an die Grundsätze des Gewissens festzuhalten. $\mathrm{Zu}$ diesen gehört gewiss das Gegenarbeiten gegen einen Skandal. So tat es Gemma Galgani. Sie wurde durch innere Stimmen unterrichtet, dass es zu einer Prüfung nicht kommen werde, trotzdem hat sie nichts unternommen um der Überwachung entgegenzuarbeiten. Ich brauche es übrigens Hochverehrter Herr Pfarrer, nicht zu wiederholen, Sie wissen es selber wohl, dass es so ist. Sie schreiben mir ja: „doch möchten wir unserseits

b-b Autograf czarnym atramentem.

a Tekst pisany maszynowo na 1,5 stronicy papieru formatu A4. Brak autografu autora. 
auch dazu beitragen, was in unsern Kräften liegt". Ich schreibe Ihnen dies bloss deshalb um Sie über die öffentliche Meinung zu unterrichten. Die Pression wird immer stärker und die einzige Kraft des von Dr. Deutsch veröffentlichenen Briefes liegt eben in diesem Punkte, der jetzt Freunde und Feinde Konnersreuths vereinigt, nämlich in der Notwendigkeit einer erneuten Überwachung. Die Bedingungen dieser Überwachung lassen sich ganz gut, ohne irgend ein Risiko für Therese Neumann mit dem Wunsche des Regensburger Ordinariates vereinbaren. Theresens Vater muss es verstehen, dass wenn er die Saite überspannt, er zum Mittäter des Unglücks seiner Tochter werden könne. Aus allem kann man leicht ersehen, dass schon ein Schritt seitens der höchsten, kirchlichen Behörde in Vorbereitung stehe. Man kann nicht weiter zögern und die Gottessache aufs Spiel setzen. Jedenfalls bitte ich Sie, Hochverehrter Herr Pfarrer mich baldigst benachrichtigen zu wollen, wie es mir der Sache stehe.

Bei dieser Gelegenheit bitte ich Sie dem Gebete und Leiden Theresens einen sehr bedeutenden katholischen Gelehrten anzuempfehlen, der an einer überaus grossen, psychischen Depression leidet. Auch eine andere Bitte noch hat mir eine Mutter in betreff ihres krankes Sohnes vorgetragen. Aber an ersterer ist mir vor allem gelegen.

Ich verbleibe mit dem Ausdruck meiner tiefsten Hochachtung.

\section{Dokument 281}

Kopia: AFKDOPW, teczka 136: Spuścizna abp. Józefa Teodorowicza, sygn. 767/110 [5], List abp. Józefa Teodorowicza do niezidentyfikowanego duchownego [ks. dr. Alberta Steuera?], Lwów 27 I 1937 r.

Przezacny ${ }^{\mathrm{a}}$ Księże Prałacie!

Bardzo dziękuję Księdzu Prałatowi za przysłaną mi tak znakomitą recenzję, która krótko a jasno ujmuje całą syntezę mojego dzieła.

Co do dr. Deutscha, to się przygotowuje odprawa dla niego, w której się wykaże to, o czym zdaje się Księdzu Prałatowi już pisałem, iż jest on fałszerzem i to na grubą skalę. On po prostu sfałszował nie tylko myśl, ale dosłownie szczegóły pojedyncze mojej książki i dopiero dzięki temu przedstawia się z triumfem jako zwycięzca.

Byłbym zobowiązany Księdzu Prałatowi, gdyby mi zechciał wyjaśnić, jak się to stało, że redakcja pisma, która nie chciała przyjąć drugiego artykułu Księdza Prałata potem go nareszcie przyjęła. Chciałbym wiedzieć, czy ten fakt jest w związku z opinią o dziele dr. Deutscha.

Składając raz jeszcze serdeczną podziękę Księdzu Prałatowi łączę wyrazy mojej czci głębokiej.

Lwów, dnia 27 stycznia 1937

a Tekst pisany maszynowo na jednej stronicy papieru formatu A4. Brak adresata i autografu nadawcy. 


\title{
Dokument 282
}

Kopia: AFKDOPW, teczka 133: Spuścizna abp. Józefa Teodorowicza, sygn. 1776/61 [5], List abp. Józefa Teodorowicza do ks. Josepha Nabera, Lwów 28 I 1937 r.

Lwów, den 28 I 1937

\author{
Abschrift \\ Pfarrer Naber
}

Hochverehrter ${ }^{a}$ Herr Pfarrer,

Ich schreibe wieder einen Alarmbrief an Sie. Heute habe ich Dr. Aigners ${ }^{519}$ Umlaufschreiben an die gesamte Ärztekammer gelesen, mit der Aufforderung, dass sich alle für Dr. Deutsch einsetzten. Aus dem ganzen aber gewinne ich den Eindruck, dass es der Eingang und so zu sagen der erste Schritt zum geplanten Verfahren ist, von dem ich Ihnen bereits schrieb. Es ist mir klar, dass Prof. Wunderle eben von Aigner sprach, als von demjenigen der den bekannten Schritt unternehmen wollte und jetzt gewiss schon unternommen hat. Es lässt sich aus den Worten dieses Briefes der ganze Plan durchblikken. Es werden die deutschen Bischöfe hierbei beschuldigt, dass sie zu allem schweigen. Nicht nur gegen mich sondern auch gegen Kardinal Kaspar und Erzbischof Waitz ist der Angriff gerichtet. Der Plan geht dahin das Schweigen der Bischöfe zur Begründung einer solchen Observation, wie die von der ich Ihnen erwähnte, und zu deren Rechtfertigung zu gebrauchen. Da die Bischöfe schweigen, so wollen sich die Ärzte an einen andern Faktor wenden: sie sehen durchaus wie richtig ich die Situation beurteile, wenn ich auf Entscheidung drang. Heute ist es noch Zeit, morgen kann es zu spät sein. Wenn Herr Neumann fernerhin in seiner Hartnäckigkeit beharrt, muss er die Verantwortlichkeit übernehmen, dass seine Tochter ohne oder gegen seinen Willen einer Überwachung unterzogen wird, die in der Richtung sich bewegen wird, dass die Wahrheit um keinen Preis siege. Sie werden mich wohl verstehen, und was ich mit Worten nicht ausdrücke, werden Sie selbst ergänzen.

\section{Dokument 283}

Oryg.: AFKDOPW, teczka 145: Spuścizna abp. Józefa Teodorowicza, sygn. 383/90 [5], List z Wydawnictwa Antona Pusteta do abp. Józefa Teodorowicza, Salzburg 30 I 1937 r.

Salzburg, am 30. I. 1937

An das Sekretariat

S[einer] E[xzellenz] des Hochw[ürdigen] H[errn] Erzbischofs

Dr. Josef Teodorowicz

Lwów, Polen

a Tekst pisany maszynowo na jednej stronicy papieru formatu A4. Brak pełnej wersji i autografu autora.

519 Zob. w niniejszej publikacji: J. Wołczański, Korespondencja abp. Józefa Teoodrowicza z prof. Stefanem Dąbrowskim, dokument 23. 
Sehr ${ }^{a}$ geehrte Herren!

Mit Schreiben vom 11. IX. 1936 übersandten wir Ihnen Korrekturabzüge eines Berichtigungszettels zu den Anmerkungen des Werkes Konnersreuth von S[eine]r Exzellenz des Hochwürdigen Herrn Erzbischof. Auf Ihr Ersuchen übersandten wir Ihnen mit Schreiben vom 29. IX nochmals ein Duplikat und ersuchten Sie um Korrektur, damit dieser Berichtigungszettel in Druck gehen könne.

Wir haben nun niemals eine Korrektur, oder eine bezügliche Äusserung von Ihnen erhalten und fragen höflich an, ob Sie vielleicht auf diesen Berichtigungszettel der Anmerkungen keinen Wert mehr legen, in welchem Falle wir den Schriftsatz in der Drukkerei ablegen lassen würden.

Mit dem Ausdruck vorzüglicher Hochschätzung

\section{b-VERLAG ANTON PUSTET SALZBURG $^{-b}$ $[\ldots]^{\mathrm{c}}$}

\section{Dokument 284}

Kopia: AFKDOPW, teczka 134: Spuścizna abp. Józefa Teodorowicza, sygn. 757/110 [5], List abp. Józefa Teodorowicza do ks. prałata Alberta Steuera, Lwów 5 II 1937 r.

Przezacny ${ }^{\mathrm{a}}$ Księże Prałacie!

Bardzo dziękuję za list, jaki mi ksiądz Prałat przysłał. Nie wiem czy pisałem o tym Księdzu Prałatowi, że jeden z niemieckich biskupów nazwał pracę Deustcha „ein ungezogenes Pamphlet ${ }^{\text {"520 }}$. Jest to istotnie pamflet na Konnersreuth, w którym ten autor uderza w ogóle na biskupów, iż się dali zwieść światowej oszustce. Ten atak jest ukryty, ale wyciągnięty będzie na światło dzienne. Niestety, racjonalizm poznał się w jednej chwili na tej pracy i jej znaczeniu, i dzisiaj czyni z Deutscha sztandarowego człowieka, i wzywa lekarzy do uderzenia na Konnersreuth. Znany z[e] swoich występów przeciw cudom w Lourdes profesor Aigner wydał taką odezwę i jest plan, ażeby po raz wtóry przeprowadzić już przez czynniki rządowe nadzór nad Konnersreuth. Trzeba wiedzieć, że Deutsch uchodzi za katolika.

Dziękując raz jeszcze Księdzu Prałatowi za Jego pismo i łaskawość, łączę wraz z serdecznymi pozdrowieniami moje oddane wyrazy.

Lwów, dnia 5 lutego 1937

\section{Ks. Steuer}

a Tekst pisany maszynowo na jednej stronicy papieru formatu karty pocztowej. W lewym górnym rogu karty nadruk firmowy: „VERLAG ANTON PUSTET Pressevereinsanstalten der Diözese Secau SALZBURG, SIEGMUND-HAFFNER-GASSE 18, Fernsprecher Nr. 259, Drahtanschrift PUSTET SALZBURG”.

b-b Podłużna pieczęć.

c Autograf nieczytelny.

a Tekst pisany maszynowo na jednej stronicy papieru formatu A4. Brak autografu autora listu.

${ }^{520}$ Niem.: niegrzecznym pamfletem. 


\section{Dokument 285}

Oryg.: AFKDOPW, teczka: ?, Spuścizna abp. Józefa Teodorowicza, sygn. 382a/90 (5), Pismo z Wydawnictwa Verlag Anton Pustet do abp. Józefa Teodorowicza, Salzburg 15 II 1937 r.

\section{Honorarabrechnung ${ }^{\mathrm{a}}$}

Hoch[verehrter] Herrn Erzbischof Dr. Joseph Teodorowycz ${ }^{\text {, Lwów }}$ Für die Zeit vom 1.7.[19]36 bis 31.12.[19]36

Kontostand zu Ihner Gunsten am:

Konnersreuth

Lagerbestand am 30.6.[19]36 - $\quad-1408 \mathrm{Ex}[\mathrm{em}] \mathrm{pl}[\mathrm{are}]$

verkauft bis 31.12.[19]36 - $\quad 313 \operatorname{Ex}[\mathrm{em}] \mathrm{pl}[\mathrm{are}]$

Bestand am 31.12.[19]36 - 1095 Ex[em]pl[are]

Abgerechnet wurde ein Drittel der 1. Aufl.

verkauft nächste Abrechnung erfolgt nach

Verkauf von 1000 Ex[em]pl[are].

Salzburg, am 15. Februar 1937

\section{Dokument 286}

Oryg.: AFKDOPW, teczka 138: Spuścizna abp. Józefa Teodorowicza, sygn. 210/239 [7], List ks. dr. Stanisława Brossa do abp. Józefa Teodorowicza, Poznań 15 II 1937 r.

Poznań, dn[ia] 15 lutego 1937

Aleje Marcinkowskiego 22

Ekscelencjo ${ }^{\mathrm{a}}$,

Najdostojniejszy Arcypasterzu!

Dowiaduję się, że Wasza Ekscelencja w tych dniach obchodził rzadki jubileusz 50-lecia kapłaństwa.

Pozwalam sobie Waszej Ekscelencji choć spóźnione, lecz nie mniej szczere życzenia przesłać, by Wasza Ekscelencja jeszcze w jak najdłuższe lata cieszył się zdrowiem i głębokim duchem Swoim całemu narodowi polskiemu długo jeszcze hetmanił.

W tej myśli prosząc Boga o obfite łaski i błogosławieństwo dla Waszej Ekscelencji, złożyłem Najświętszą Ofiarę w dniu wczorajszym w intencji Waszej Ekscelencji.

a Tekst pisany maszynowo na drukowanym formularzu na jednej stronicy papieru formatu A4. W górnej partii karty nadruk firmowy: „VERLAG ANTON PUSTET SALZBURG”. W prawym dolnym rogu karty firmowa pieczęć: „DIREKTION VERLAG ANTON PUSTET SALZBURG”. Autograf autora pisma nieczytelny.

b Forma zgodna z oryginałem.

a Tekst pisany maszynowo $\mathrm{z}$ wyjątkiem autografu autora listu na jedenej stronicy papieru formatu A4. W lewym górnym rogu karty tytułowej firmowy nadruk: „Ks. Dr Stanisław Bross Dyrektor Naczelnego Instytutu Akcji Katolickiej w Polsce, L. dz... 
Piszę szczerze - tęskno mi już by zobaczyć Waszą Ekscelencję, a tak trudno mi się droga do Lwowa układa. Odwołano zebranie w Warszawie na miesiąc marzec. Po zebraniu wybiorę się do Lwowa.

Kongres Międzynarodowy Chrystusa Króla ${ }^{521}$, Międzynarodowy Radiowy ${ }^{522}$ sprawiają mi wiele kłopotu. Chcę na kilka dni uciec z Poznania, by w spokoju opracować cały program Studium Społecznego ${ }^{523}$, które urządzam w Warszawie we wrześniu.

Ks. Biskup Radoński był w Rabce na wypoczynku. Z towarzystwa nie bardzo był zadowolony. Obok Warszawy był też Łuck ${ }^{524}$.

Całuję z najgłębszą czcią ręce Waszej Ekscelencji, szczerze oddany

${ }^{b}$ Ks. Stanisław Bross ${ }^{-b}$

\section{Dokument 287}

Oryg.: AFKDOPW, teczka 145: Spuścizna abp. Józefa Teodorowicza, sygn. 384/90 [5], List z Wydawnictwa Antona Pusteta do abp. Józefa Teodorowicza, Salzburg 16 II 1937 r.

S[einer] E[xzellenz]

Hochw[ürdigen] Herrn

Erzbischof Dr. Josef Teodorowicz

Lwów, Polen

Betrifft Ihre Nachricht vom/ Ihr Zeichen/ Unser Zeichen M/C/ Datum 16.02.1937

Euer ${ }^{a}$ Exzellenz! Hochverehrter Herr Erzbischof!

Ich bestätige mit verbindlichem Dank Ihren Brief v[om] 11. ds. und bedauere mit Ihnen die ungerecht fertige Hetze, die Dr. Deutsch gegen Konnersreuth und Ihr Buch entfaltet. Ich habe die Schrift von Dr. Deutsch, die übrigens im Buchhandel nicht erhältlich ist und nur direkt von ihm an Persönlichkeiten geschickt wird, gelesen und muss sagen, dass man eine solche, jede wissenschaftliche Basis entbehrende Darstellung nur bedauern kann, ganz abgesehen von der grundsäzlichen Haltung des Autors. Auf eine Anforderung Ihres Sekretariats hin, habe ich bei Dr. Deutsch mehrere Exemplare seiner Schrift bestellt, sie aber nicht erhalten. 1 Ex[em]pl[are] erhielt ich lediglich durch einen Freund, der zufällig in Besitz der Schrift kam.

${ }^{521}$ Międzynarodowy Kongres Chrystusa Króla odbył się w Poznaniu w dniach 25-29 VI 1937 r.

522 Właściwie: Zjazd Międzynarodowego Katolickiego Biura Radiowego miał miejsce w Poznaniu w dniach 27-29 V 1932 r.

${ }^{523}$ III Studium Katolickie zorganizowano w Warszawie w dniach 5-10 IX $1937 \mathrm{r}$.

${ }^{524}$ Aluzja do metropolity warszawskiego kard. Aleksandra Kakowskiego (1862-1938) i biskupa ordynariusza diec. łuckiej Adolfa Szelążka (1865-1950).

b-b Autograf czarnym atramentem.

a Tekst pisany maszynowo na 1,5 stronicy papieru formatu A4. W górnej centralnej partii karty nadruk firmowy: „Verlag Anton Pustet Pressevereinsanstalten der Diözese Secau SALZBURG SIEGMUND-HAFFNER-GASSE 18, FERNSPRECHER NR. 259, DRAHTANSCRIFT PUSTET SALZBURG". 
Ich will Ihnen nun heute mitteilen, dass ich mich für die von Ihnen angedeutete Erwiderungsschrift schon interessierte. Ich hätte Sie gerne gebeten, mir eine nähere Darstellung zu geben, welcher Art diese sein soll. Ihren Schreiben entnehme ich, dass es mehrere Mitarbeiter sind. Ist das Manuskript schon fertig und kann ich es zur Einsicht haben?

Erschwerend bei der Werbung für Ihr Buch ist der Umstand, den Sie ja auch selbst andeuten - dass verschiedene Vertreter des deutschen Episkopates durchaus die Haltung von Dr. Deutsch billigen.

Gerade im Rheinland ist man vielfach dieser Meinung und zwar in durchaus aufgeschlossenen guten katholischen Kreisen. Das Freiburger Erzdiözesanblatt „Konradsblatt" liess in einer der letzten Nummern direkt eine Warnung herumgehen, dass es das Erscheinen Ihres Buches bedauert: „Das bischöfliche Ordinariat Regensburg bedauert sehr das Erscheinen des Buches: «Konnersreuth im Lichte der Mystik und Psychologie» von Erzbischof Dr. Josef Teodorowicz. Gegen diese Veröffentlichung konnte der katholische Arzt Dr. Josef Deutsch ernste Bedenken geltend machen“.

Aber das wird immer das Schicksal solcher Erscheinungen sein, angegriffen und missdeutet und verkannt zu werden. Jedenfalls darf ich Ihnen sagen, dass ich als Verleger trotz diesen Angriffen und ablehnender Haltungen massgebender katholischer Kreise es nicht bedaure, Ihr Buch verlegt zu haben. Ich würde es heute trotzdem wieder tun und freue mich, der Sache gedient zu haben, auch wenn der geschäftliche Erfolg nicht so sehr zustande kommt.

Mit verehrungsvoller Begrüssung bin ich Ihr ergebener

\author{
$[\ldots]^{\mathrm{b}}$ \\ c-VERLAG ANTON PUSTET \\ SALZBURG ${ }^{-\mathrm{c}}$
}

\title{
Dokument 288
}

Kopia: AFKDOPW, bsygn., teczka: Spuścizna abp. Józefa Teodorowicza, List abp. Józefa Teodorowicza do ks. Leona Isakowicza, Lwów 18 III 1937 r.

\section{Mója Drogi!}

Bardzo Ci dziękuję za Twoje dobre serce, za pamięć Twoją i przysłane mi życzenia. Cieszę się niewymownie, że rekolekcje tak dobrze Ci poszły.

Martwię się tylko chorobą ks. Magierowskiego ${ }^{525}$, któremu oczywiście daję pozwolenie na to, by nie odmawiał brewiarza.

\footnotetext{
b Autograf nieczytelny.

c-c Pieczęć podłużna.

a Tekst pisany maszynowo na jednej stronicy papieru formatu A4. Brak autografu autora.

525 Magierowski Józef (1878-1950), święcenia kapłańskie w 1902 r. w Zakonie oo. Reformatów, w 1935 r. został inkardynowany do archidiec. lwowskiej obrządku ormiańskokatolickiego, 1935-1945 proboszcz par. Łysiec, w ramach ekspatriacji wyjechał na Śląsk Opolski: 1945-1949 administrator par. Stary Budków, 19491950 rezydent w klasztorze ss. Jadwiżanek w Czarnowąsach gdzie zmarł. T. Zaleski, Stownik biograficzny duchownych ormiańskokatolickich oraz duchownych rzymskokatolickich pochodzenia ormiańskiego w Polsce w latach 1750-2000, Kraków 2001, s 271,
} 
Co do św. Jana, to jeszcze cisza głucha. Wszystkie korekty są od dawna w Poznaniu. Nareszcie kończę Deutscha i dziś mogę powiedzieć, że będzie pokonany na całej linii; myślę, że będą zawstydzeni ci, którzy go zasłaniają i bronią spośród katolików. Wykażę bowiem, że w swoich naukowych tezach jest on racjonalistą i to racjonalistą starej daty, i starej szkoły.

List do ks. Biskupa Lisowskiego właśnie wysyłam; nie przemęczaj się tylko zbyt, oszczędzaj swoje siły.

Zasyłam Ci bardzo serdeczne pozdrowienia wraz z błogosławieństwem.

Lwów, dnia 18 marca 1937

Ks. Isakowicz

\section{Dokument 289}

Kopia: AFKDOPW, teczka 136: Spuścizna abp. Józefa Teodorowicza, sygn. 698/110 [5], List abp. Józefa Teodorowicza do niezidentyfikowanego duchownego krakowskiej archidiecezji, Lwów 27 III $1937 \mathrm{r}$.

\section{Kochany ${ }^{a}$, Przezacny Księże Prałacie!}

Udaję się do Księdza Prałata w następującej sprawie. „Ilustrowany Kurier Codzienny” uderzył znowu na mnie via Agram, przedstawiając fałszywie, jakoby niemiecki profesor uderzył na mnie za moją książkę o Konnesreuth. Ja miałbym mianowicie sprzeciwiać się wszelkiej ponownej obserwacji T[eresy] Neumann, którą właśnie ten profesor uważa za nieodzowną. Oczywiście to wszystko jest z palca wyssane. Albowiem w książce mej o Konnersreuth popieram stanowisko XX. Biskupów wyrażających życzenie poddania T[eresy] Neumann obserwacji, a nawet czyniłem w tym celu zabiegi. Mam zaś za sobą recenzenta mojej książki, wspomnianego profesora, który mimo odmiennego stanowiska nawet bardzo moją książkę wynosi i chwali. Redakcja „I[lustrowanego] K[uriera] C[odziennego]" podała tę wiadomość, jako telegram z Agramu.

Otóż na to odpowiedział mój kanonik ks. Kwapiński ${ }^{526}$ wyjaśnieniem skierowanym do redakcji z prośbą o jego umieszczenie na łamach pisma; redakcja zbyła to milczeniem i wyjaśnienia nie pomieściła. Mógłby wprawdzie ks. Kwapiński żądać sprostowania na

a Tekst pisany pismem maszynowym na 2,5 stronicach papieru formatu A4. Po datacji nota odręczna autora czarnym atramentem: „Z Nowego Sącza Ksiądz w odstawce z krakowskiej diecezji wciąż mnie molestuje o przyjęcie względnie zalecenie go komuś: kto to jest?".

${ }^{526}$ Kwapiński Wiktor (1883-1957), święcenia kapłańskie w 1908 r. w Zgromadzeniu Księży Misjonarzy św. Wincentego a Paulo, w 1914 r. inkardynowany do archidiec. lwowskiej obrządku ormiańskokatolickiego, 1922-1934 administrator par. Brzeżany, kanonik gremialny Kapituły Katedralnej we Lwowie, kurator Muzeum Archidiecezjalnego, 1939-1945 kanclerz Kurii Archidiecezjalnej, aresztowany 26 XI 1945 r. przez NKWD został skazany 8 III 1946 r. na 10 lat łagrów, konfiskatę mienia i pozbawienie praw publicznych na 5 lat, zwolniony 9 IX 1946 r. i wydalony do Polski: osiadl na terenie archidiec. wrocławskiej, od 1948 r. kapelan w szpitalu w Międzylesiu. J. Wołczański, Martyrologium księży ormiańskokatolickich w archidiecezji lwowskiej po II wojnie światowej w świetle źródeł sowieckich, w: Polacy w Armenii, red. E. Walewander, Lublin 2000, s. 204 nn.; T. Zaleski, Stownik, s. 68-69. 
podstawie paragrafu obowiązującego do umieszczenia sprostowania, ale nie wiem czy to warto. Z drugiej strony nie chciałbym stwarzać precedensu ignorowania przez redakcję „I[lustrowanego] K[uriera] C[odziennego]” odpowiedzi na jej ataki prowadzone przeciw mojej książce via Rzym.

Wobec tego sam nie wiem, co czynić należy. Mnie nie zależy na tym, aby pomieścić sprostowanie, ale w każdym razie byłoby wskazane, ażeby redakcji „I[lustrowanego] K[uriera] C[odziennego]" udzielić monitum ${ }^{527}$, by sobie nie pozwalała na podobne wybryki. Jeżeli by Ksiądz Prałat był tego samego zdania, to wówczas prosiłbym o odpowiednie odniesienie się do redakcji w tej sprawie.

Dołączam tu jeszcze sprawę drugą, już nie moją osobistą. Był u mnie ks. Huet ${ }^{528}$, który kończył studia w Rzymie, a obecnie jest katechetą w Stryju ${ }^{529}$. Prosił o poparcie u krakowskiego profesora Wichera, do którego się udawał ze swą pracą z zakresu teologii pastoralnej. Odmówiłem mu tego poparcia otwarcie mówiąc, iż wiem, że na tę posadę kandyduje zasłużony ks. Machay ${ }^{530}$ i że nie należy stwarzać pozorów, iż jakąś inną kandydaturę popieram. Wtedy on mnie zapewnił, że nie myśli kandydować na Kraków, a chciałby dostać posadę we Lwowie po profesorze Gerstman[n]ie ${ }^{531}$. Po takim zapewnieniu napisałem kilka słów do profesora Wichera; potem jednak powstały wątpliwości, dlaczego ks. Huet jedzie do Krakowa, a nie zdaje egzaminu we Lwowie. Nie chcę przypuścić, by był nieszczery, ale w każdym razie chciałem o tym poinformować ks. Prałata. Ks. Huet jest dobrym kapłanem, ale znowu nie wygląda na typ gruntownego i uczonego pracownika, natomiast jest bardzo zręczny. Podczas kiedy ks. Machay dał się wciągnąć w pracę najniewdzięczniejszą, w życiorys biskupa krakowskiego, to ks. Huet z lekkością zadziwiającą złożył pracę wprost z dziedziny niepastoralnej, w jakiej przy tym podręcznika tak łatwo jest pisać. Oczywiście, jeśli myśli o Lwowie to dobrze. Na wszelki wypadek jednak sądzę, że nie jest zbytecznym wspomnieć o tym Księdzu Prałatowi.

527 Łac.: ostrzeżenie.

528 Huet Stanisław (1904-1961), święcenia kapłańskie w 1927 r. we Lwowie, dr filozofii i teologii, 19291937 katecheta w Stryju, 1937-1939 katecheta we Lwowie, w 1938 r. habilitacja z teologii pastoralnej na Wydziale Teologicznym UJ, 1939-1945 kapelan zakonnic we Lwowie, po ekspatriacji kapelan Szpitala Ubezpieczalni Społecznej w Zabrzu, 1949-1954 prof. kontraktowy Wydziału Teologicznego UJ, 1953-1956 narzucony przez władze państwowe wikariusz generalny archidiec. krakowskiej, 1954-1961 prof. teologii moralnej szczegółowej na Wydziale Teologicznym ATK w Warszawie, aktywny członek Komisji Duchownych i Świeckich Działaczy Katolickich przy Froncie Jedności Narodu, sztandarowy członek Ruchu Księży „Caritas” i członek władz naczelnych Zrzeszenia Katolików Caritas, autor kilku publikacji z dziedziny teologii moralnej. F. Greniuk, Huet Stanistaw, w: EK, t. 6, red. zbior. Lublin 1993, kol. 1280.

529 Stryj - miasto powiatowe, woj. Stanisławów.

530 Machay Ferdynand (1889-1967), święcenia kapłańskie w 1912 r. w Krakowie, wikariusz na Orawie, podczas I wojny światowej kapelan wojskowy, 1920-1922 administrator par. Podszkle, 1922-1924 studia w Paryżu, w 1930 r. doktorat, 1930-1933 wikariusz katedry w Krakowie, 1933-1937 penitencjarz kościoła Mariackiego tamże, 1937-1944 proboszcz par. pw. Najśw. Salwatora tamże, 1938-1939 senator RP, 19411944 wykładowca w krakowskich Seminariach Duchownych, 1944-1967 archiprezbiter kościoła Mariackiego, autor artykułów z dziedziny historii oraz katolickiej nauki społecznej, odznaczony godnością protonotariusza apostolskiego. Z. Skwierczyński, Machay Fredynand, w: EK, t. 11, red. zbior., Lublin 2006, s. 694-696.

531 Zob. w niniejszej publikacji: J. Wołczański, Korespondencja abp. Józefa Teodorowicza z abp. Adamem Stefanem Sapiehą, dokument 104. 
Mówił mi X[iążę] Czartoryskiis32, że Metropolita spędzi święta na Cejlonie i to jest imponujące.

Zasyłam dla Kochanego Księdza Prałata moje życzenia świąteczne najlepsze i kreślę się zawsze oddany

${ }^{\mathrm{b}-}+$ Teodorowicz

Z Nowego Sącza Ksiądz w odstawce ${ }^{533}$ z krakowskij archidiecezji wciąż mnie molestuje o przyjęcie względnie zalecenie go komuś. Kto to jest? ${ }^{-b}$

\section{Dokument 290}

Kopia: AFKDOPW, teczka 136: Spuścizna abp. Józefa Teodorowicza, sygn. 458/190 [7], List abp. Józefa Teodorowicza do kard. Augusta Hlonda, Lwów 27 III 1937 r.

Wasza ${ }^{a}$ Eminencjo,

Korzystając z tego, że Wasza Eminencja jedzie teraz do Rzymu, zwracam się do Waszej Eminencji z prośbą w mojej sprawie: załączam tu Waszej Eminencji odpis pisma z Kongregacji, które wyjaśnia całą sytuację. Pismo to wprawdzie nie może się równać postawieniu mej książki na indeksie, ale w każdym razie jest pod pewnym względem jego wskazaniem.

Nie potrzeba wielu domysłów na to ażeby wiedzieć, skąd wyszła inicjatywa i jaki był bezpośredni i osobisty cel tych, którzy się przyczynili do tego kroku ze strony św. Officii. To jednak do rzeczy nie należy i staję przed tym aktem jak przed faktem dokonanym.

$\mathrm{Z}$ mej strony zastosowałem się do rozporządzenia S[anc]t [um] Officium ${ }^{534}$ : napisałem zaraz do księgarni wydawniczej Pusteta, zaś na prośbę tłumaczenia tej książki na język francuski odpowiedziałem, że obecnie zgodzić się na to nie mogę. Także nie przedsięwziąłem żadnych kroków wobec oferty przedstawionej mi przez O. Garrigou-Lagrange OP, a poruszającej kwestie tłumaczenia książki na język angielski. Także przygotowaną pracę w sprawie wydania tej książki w języku polskim przerwałem. Rozpoczęta przeze mnie odpowiedź Doktorowi Deutschowi wyjdzie nie pod moim nazwiskiem.

Rzecz naturalna bardzo musiało zależeć mi na tym, by się dowiedzieć, jakie są powody tego kroku, co S[anc]t[um] Officium zarzuca mej książce, gdyż dowiedziawszy się o tym mógłbym pomyśleć o wydaniu nowej książki, napisanej już wedle wskazówek udzielonych mi przez Sanctum Officium.

${ }^{532}$ Zob. w niniejszej publikacji: J. Wołczański, Listy abp. Józefa Teodorowicza do abp. Józefa Bilczewskiego, dokument 75 .

b-b Fragment czarnym atramentem.

${ }^{533}$ Tu: w znaczeniu zawieszony w czynnościach duszpasterskich.

a Tekst pisany na maszynie na 3 stronicach papieru formatu A4. Brak autografu autora pisma.

${ }^{534}$ Pismem z dnia 23 XI 1936 r. Święte Officium zabroniło abp. Teodorowiczowi jakichkolwiek tłumaczeń książki pt. Konnersreuth im Lichte der Mystik und Psychologie (Salzburg 1936). Poleciło również wycofanie ze sprzedaży całego nakładu. ASK, sygn. 22/53 [8], Kopia pisma Świętego Officium do abp. J. Teodorowicza, Rzym 23 XI 1936, ss. 2. 
Nie chcąc zajmować Waszej Eminencji moją sprawą udałem się do Biskupa Franciszka Agagianiana ob[rządku] orm[iańskiego], a ten wystosował pismo do kongregacji, które tu w odpisie załączam. Na to pismo nie otrzymał on jednak odpowiedzi.

Sposób ten postępowania Sancti Officii jest po prostu wobec katolickiego Biskupa czymś, co trudno wytłumaczyć, bo jeśliby nawet ktoś próbował tłumaczyć ten krok Kongregacji podjęty bez odniesienia się do Biskupa i bez podania mu motywów tradycyjną normą postępowania, to znany Waszej Eminencji fakt z książką Karola Adama "O istocie katolicyzmu”535, jest już precedensem, który powinien być przede wszystkim zastosowany do katolickiego Biskupa.

Mam prawo więc dowiedzieć się o tym, dlaczego nastąpiło to zarządzenie, co zarzuca Kongregacja mej książce, a po precedensie z księdzem Adamem ma ona zadośćuczynić memu życzeniu i umożliwić mi wydanie tego dzieła z odpowiednimi zmianami.

Wobec tego nie pozostaje mi nic innego, jak udanie się $\mathrm{w}$ tej sprawie wprost do Ojca św. i dlatego proszę Waszą Eminencję, by zechciał w formie jaką uzna za najstosowniejszą, najłaskawiej doręczyć Ojcu św. to moje pismo. Jeśliby Wasza Eminencja uznał, że należy coś w tym piśmie opuścić lub zmienić i gdyby jeszcze czas był na to, to mógłbym to jeszcze uczynić. Prosiłbym w takim razie o wskazówki listem expres.

Załączam tu dla Waszej Eminencji różne recenzje pism, które myślałem dołączyć do mojej petycji do Ojca św.

Otóż to jest cel mojej prośby, którą składam w ręce Waszej Eminencji. Prośbę tę zaniosłem ze stanowiska osobistego, ale sądzę, że moralnie łączy się ona w ogóle ze stanowiskiem Episkopatu polskiego, zwłaszcza wobec napadu Dr. Deutscha na obcych, nie niemieckich, cudzoziemskich Biskupów. Zresztą Wasza Eminencja sam to najlepiej zrozumie, tak że nie potrzebuję na ten temat nic więcej pisać.

Pozostaje mi jeszcze przejść wszelkie możliwości właściwych pobudek tych zarządzeń wobec mojej książki. Uczynię to na osobnym arkuszu.

Składam tedy sprawę tę z całą ufnością w ręce Waszej Eminencji w tej nadziei, że sam uczyni te kroki, które w danych warunkach uzna za najlepsze i najskuteczniejsze.

Nie potrzebuję Waszej Eminencji pisać, jaki to dla mnie cios moralny, już nie ze względu na kilka lat, jakie włożyłem w tę pracę, ale na prestige ${ }^{536}$ mych prac naukowych w ogóle, które, o ile Bóg da mi siły i zdrowie, chciałbym skończyć. Uderzenie w jedno dzieło jest uderzeniem we wszystkie, jeśli nie bezpośrednim to pośrednim.

Całuję pierścień Waszej Eminencji, a modląc się gorąco za Waszą Eminencję, załączam wyrazy mej czci głębokiej, zawsze oddany.

[P.S.] Może być, że znajdę czas, by Waszej Eminencji napisać w sprawie okólnika Ministra Oświaty, który otrzymałem, jak go otrzymali zapewne wszyscy Księża Biskupi.

Lwów, dnia 27 III 1937 r.

535 Właściwie: K. Adam, Istota katolicyzmu, Poznań $1931 \mathrm{r}$.

${ }^{536}$ Franc.: prestiż, poważanie. 


\section{[Załącznik]}

Przypuszczalne motywy zarządzeń św. Oficjum:

1. Powodem najbliższym i najbezpośredniejszym byłyby uchybienia czy błędy przeciw doktrynie katolickiej, ze stanowiska teologii, czy też mistyki, czy w ogóle innych nauk.

a) Ze stanowiska teologii i mistyki: Posiadam ocenę O. Garrigou-Lagrange, który dał tę książkę do przestudiowania dwóm znanym teologom zakonu swego i wydał o niej orzeczenie dodatnie. Jeden właśnie z tych teologów podał projekt tłumaczenia tej książki na język angielski.

Drugie orzeczenie wydał znany profesor teologii na Uniwersytecie Fryburskim O. B[enoit] Lavaud OP.

Nawet O. Mager mimo całej swej chwiejności wobec Konnersreuth podnosi szczególnie wartość mej książki. A ze stanowiska (nawiasem mówiąc) błędnego, przekreślonego przez pracę Poulain' ${ }^{537}$ pragnąłby tylko, i to ewentualnie, większego pogłębienia w sprawie stanów mistycznych Teresy Neumann. Ponieważ skłonny jestem sądzić siebie raczej ostrzej, aniżeli mnie sądzą inni, wyrażam w końcu przypuszczenie, iż może teoria poznawalności cudu, aczkolwiek nie błędna, jednak za mało jest wyjaśniona.

b) Co do innych gałęzi nauk to nasuwałaby się, przede wszystkim kwestia medycyny. Lecz jak wyrażają to jednomyślnie recenzje Dr. Hynka z Pragi, Prof. Krebsa ${ }^{538}$ i innych, ja właśnie usunąłem się od wszelkich sporów i orzeczeń w dziedzinie medycyny, oświadczając wyraźnie, że kwestii tych nie tykam jako laik i pozostawiam je jedynie ocenie lekarzy. Sprawa ta zresztą jest przeze mnie tak jasno postawiona, że Dr Deutsch tykając jej był zmuszony uciec się do sfałszowania moich zasadniczych tekstów. Zresztą kwestia medycyny gra w książce mojej rolę zupełnie podrzędną, gdyż cały nacisk położony jest na stronę teologii mistycznej.

c) Kwestią zestawienia objawów mediumistycznych i okultystycznych ze stanami ekstaz omawiałem $\mathrm{z}$ najwytrawniejszym, może jedynym spośród niemieckich uczonych znawcą tych spraw, z P[anem] Geheimrat Ludwigiem. Recenzję jego mej książki w końcowym ustępie dołączam do recenzji innych. Dr Ludwig oddaje mi świadectwo, że w tych kwestiach książka moja jest bez zarzutu.

d) Jeśli chodzi o kwestię analogii między histerią a ekstazą, omawiałem ją szeroko we Wiedniu ze znanym pisarzem niemieckim, profesorem Uniwersytetu Wiedeńskiego i specjalistą właśnie w tym dziale Dr. Allersem. W głównej i zasadniczej części mej książki tam gdzie chodzi o stany pamięci Teresy Neumann podczas ekstazy, powołałem się na zdanie Prof. Allersa, która to kwestia rozstrzyga o prawdziwości lub nieprawdziwości ekstazy, wypowiedziane w rozmowie ze mną. I znów Dr Deutsch musiał sfałszować tezę tę, by móc uderzyć w nią w swym liście otwartym (drukowanym jako manuskrypt).

537 Postać niezidentyfikowana.

${ }^{538}$ Krebs Hans Adolf (1900-1981), lekarz i biochemik niemiecki pochodzenia żydowskiego, laureat Nagrody Nobla w dziedzinie fizjologii i medycyny (1953). Nagrody Nobla, red. B. Tarnowska, Warszawa 2001, s. 123. 
e) Przedstawienie faktów z życia mistycznego Teresy Neumann oparte jest przede wszystkim na ścisłej bardzo mej własnej obserwacji. Oczywiście musiałem też uwzględnić informacje osób postronnych i tu niezawodnie mógł się zakraść jeden czy drugi błąd informacyjny, spowodowany może nie dość ścisłymi danymi tego, na którego zdaniu się oparłem. Ale i tu proboszcz z Konnersreuth Naber obiecał mi rewizję najściślejszą tych właśnie tekstów i o ile by zaszła potrzeba skorygowania ich. To są już rzeczy drobne i nic nieznaczące.

2. Mógłby mi być uczyniony zarzut, który mi właśnie czyni Dr. Deutsch, jakobym w sprawie Konnersreuth utrudniał biskupowi z Regensburga, który ojcu Teresy Neumann wyraził życzenie, by ten poddał córkę swą powtórnemu badaniu.

Tu Dr Deutsch próbuje mówić, jakobym pierwszy obserwację uważał za wystarczającą, a drugą za zbędną i w ten sposób działał przeciw stanowisku episkopatu niemieckiego. Na to odpowiadam:

a) Przede wszystkim wszystko, co napisałem o Teresie Neumann, głównie rysy jej duszy, charakter ogólny jej ekstaz, jest tylko dalszym rozwojem tych myśli, jakie Bisk[up] Buchberger i Kard. Faulhaber wypowiedzieli o niej w swych kazaniach. Pod tym względem jest moje stanowisko w zupełnej zgodzie ze stanowiskiem Episkopatu niemieckiego.

b) Co do powtórnej obserwacji zająłem stanowisko bardzo wyraźne w mej książce, usprawiedliwiając stanowisko Biskupów niemieckich, a nadto sam poczyniłem kroki, ażeby przez wpływ na ojca Teresy umożliwić zrealizowanie się życzeń Biskupów niemieckich. Odpowiednie ustępy z mej książki załączam w odpisie.

3. Wzgląd na stan umysłów w Niemczech.

a) Gdybym ja był pierwszym z Biskupów, którzy pisali o Konnersreuth, mogłaby powstać kwestia, czy występowanie Biskupów w tej sprawie jest wskazana? Ale gdy moja praca powstaje po szeregu wypowiedzeń się, czy wystąpień innych Biskupów, to wszelki podobny argument traci na sile.

Moja praca następuje po pracy Biskupa Salzburskiego Waitza, Kardynała praskiego Kaspara, po kazaniu Biskupa Buchbergera (czerwiec 1929) i Kardynała Faulhabera (listopad 1927), a wreszcie po artykule o Konnersreuth Biskupa Buchbergera w „Lexikon für Teologie und Kirche" (1935) $)^{539}$.

b) Przypuszczenie, jakoby książka moja nie była na czasie wobec rozdrażnienia umysłów spowodowanego odmiennością poglądów na Konnersreuth, upada zupełnie wobec odniesienia się do tej sprawy dwóch najpoważniejszych kierowników opinii przeciwnej O. Magera i Ks. Prof. Wunderlego. Mager pisze o mej książce, że jest „obiektywną” i oddaje jej pochwały. Wunderle dziękuje mi w liście prywatnym za moje stanowisko w odniesieniu do niego i innych krytyków.

${ }^{539}$ Pomyłka autora; bp M. Buchberger nie opublikował takiego tekstu w cytowanym dziele. Natomiast znajduje się tam inne opracowanie: M. Schulien, Neumann Therese, w: LThK, Bd.7, herausg. von M. Buchberger, Freiburg im. Br. 1935, kol. 512-515. 
c) W ten sposób książka moja w gruncie rzeczy przyczynia się raczej do uspokojenia umysłów. List otwarty Deutscha jest tu bez znaczenia, nie posiada żadnej naukowej wartości, jest jednym szeregiem sfałszowanych tekstów mej książki i wydarzeń w Konnersreuth. Jeden z Biskupów niemieckich nazwał ten list jego otwarty „Ein ungezogenes Pamphlet ${ }^{\prime 40}$. Zresztą Dr Deutsch, człowiek niezmiernej osobistej ambicji, nie po raz pierwszy występuje przeciw mnie w tej sprawie.

d) Jeżeli Konnersreuth jest w ogóle znakiem Bożym, to właśnie dziś w najcięższych dla Niemiec katolickich czasach potrzeba jest, by znak ten „został wywyższony”, a nie chowany pod „korzec”, bo właśnie na to Pan Bóg daje te znaki, by ludzi na duchu podnieść i pokrzepić.

W takim razie książka moja pod pewnym względem idzie po linii myśli Bożej i nie kurczy jej.

\section{Dokument 291}

Kopia, ASK, bsygn., Acta Hlondiana, t. 54, List abp. Józefa Teodorowicza do papieża Piusa XI, Lwów 27 III 1937 r.

\section{Très ${ }^{\mathrm{a}}$ Saint Père,}

L’archevêque de Lwów soussigné, humblement prosterné aux pieds de Votre Sainteté, vient Lui présenter une prière dans la question que voici: j’ai publié l'année dernière un livre allemand intitulé „Konnersreuth im Lichte der Mystik und Psychologie”.

Le but principal de cet ouvrage n'était pas autant une interprétation des phénomènes qui se produisirent à Konnersreuth, que plutôt la mise en lumière des questions mystiques en général avec égard spécial à l' insuffisance des méthodes employées jusqu'ici pour expliquer ces phénomènes.

Le fait de Konnersreuth n'y intervint donc qu'en qualité d'exemple caractéristique et expérimental, propre à expliquer certains de ces phénomènes. Ainsi, après l'avoir longuement examiné, j'allais déposer le fruit de mes expériences dans ce livre, tenant d'autre part amplement compte du vaste mouvement mystique se manifestant de nos jours.

Mon ouvrage présenta donc un enseemble renfermant d'un côté le résultat d'un travail sérieux voué à la question de Konnersreuth mayant absorbé durant plusieurs années d'autre part il constitua pour ainsi dire l'oeuvre de ma vie en tant qu'il visait à l'élucidation des problèmes mystiques auxquels j'avais consacré une grande partie de mon labeur.

Le premier qui mavait amené à aborder ce sujet dans un livre à part fut - comme je l' avais d'ailleurs souligné dans l'avant-propos de mon ouvrage - le R[évérend] P[ère] Alois Mager OSB, professeur à la faculté de théologie de Salzbourg.

${ }^{540}$ Niem.: niegrzeczny pamflet.

a Tekst pisany maszynowo na 3,5 stronicach papieru formatu A4. W górnej partii karty nota pismem maszynowym: „Pismo J[ego] E[kscelencji] Ks. Arcybiskupa Teodorowicza skierownae do jego Świątobliwości Papieża Piusa XI, które J[ego] Em[inencja] Ks. Prymas Hlond doręczyć miała Ojcu św.. 
En effet, la question de Konnersreuth ne fut examinée jusqu'à l'heure que par les médecins, qui, hélas, sont souvent enclins à affirmer péremptoirement que tout ce qui appartient à la vie mystique n'est que pathologie s'apparentant à l' hystérie, la psychasthénie, le somnambulisme etc. Le profit de leurs efforts fut donc presque nul. Les critères mystiques qui, à mon avis, sont seuls capables de résoudre le problème, y furent totalement méconnus. Telle fut une publication issue de la plume d'un médecin allemand, le dr Deutsch, parue en 1932.

Mais soudain, un coup inattendu et extrêmement douloureux vint s'effondrer sur moi: je reçois de la part du St. Office un décret, dont je joins la copie sous ce pli, qui m’ordonne de faire disparaître, s'il se peut, mon livre du commerce libraire et de ne plus m'en occuper ainsi que des traductions qui pour le moment restent interdites.

Aussitôt après l'avoir reçu, je m'adressais à Rome. Profitant de services bienveilants de SE l'évêque Agagianian du rite arménien, je fis part au St. Office de ma soumission entière et sans restriction aucune à tous ses ordres, ne demandant qu'une faveur: qu'on m' informât sur les causes immédiates d'une sentence si pénible et si inopinée, afin que je puisse entreprendre une correction des textes avec possibilité de rééditer l'ouvrage. Le cas de Charles Adam, auteur allemand célèbre, et de son livre sur "L'essence du catholicisme” en constitue un précédent de mémoire récente.

La teneur du décret mentionné ci-dessus m'expose en outre aux attaques de certains auteurs lä̈ques rationalisants: telle dr Deutsch qui, après avoir attaqué il y a quelques années les phénomènes de Konnersreuth, publia récemment contre moi une lettre ouverte (parue comme manuscrit). Il faussa complètement mes textes ainsi que mon attitude en face du problème. Un des évêques allemands désigna cette lettre du nom de "pamphlet incivil” („ein ungezogenes Pamphlet”).

Tout en m'imposant le silence, ce décret m'ôte la possibilité de me défendre. Ce silence cependant pourrait être injurieux non seulement à ma personne, mais encore à la dignité épiscopale elle-même et préjudicieux non seulement au cas de Konnersreuth mais encore à l'opinion saine que portent sur l'ensemble de ces phénomènes les catholiques des pays allemands.

D'autre part, les critiques multiples et favorables qui affluent chaque jour des catholiques, même adversaires et des non-catholiques, me sont une preuve de l' actualité de mon ouvrage.

En face de la phalange des auteurs, même catholiques, qui se laissent entraîner hors mesure par l'empire des méthodes expérimentales, prônées par des psychologues indépendents, il semble qu'une analyse foncière de la question, basée sur les critères de la théologie mystique était d'actualité; car si les phénomènes de Konnersreuth, comme tout l'indique, sont vrais, le signe d'en haut exige, surtout par le temps qui court, d'être mis à la portée de tous.

Daignez donc, Très Saint Père, en cette année qui est le cinquantenaire de mon sacerdoce, exaucer mon humble prière et me faire signifier par le St. Office quelles sont les objections à la diffusion de mon livre, tout en me facilitant une réédition de mon ouvrage, remanié selon les indications reçues. 
En déposant aux pieds de Votre Sainteté avec une grande confiance ma prière exposée ci-dessus, j’implore la bénédiction apostolique.

Et que Dieu.....

Lwów, le 27 III 1937

(-) J[oseph] Teodorowicz

P. S. Votre Sainteté voudra bien m'excuser de faire encore mention d'un fait presque analogue au mien qui se passa avec l'évêque hongrois de sainte mémoire Mgr Prohászka ${ }^{541}$. Je n'ai nullement l'intention de me comparer à lui en ce qui concerne ses talents, sa vie apostolique et sainte, mais je viens de lire dans ses mémoires qu'il avait passé par un creuset de souffrances et d' épreuves pareilles aux miennes et ne put s'en relever jusqu'à la fin de sa vie qu'il avait menée et terminée en vrai saint. Il écrit qu' après avoir reçu le décret du St. Office, il se rendit aussitôt auprès de Pie X pour le supplier qu'on évite, même au cas où on ne pourrait pas lui rendre justice, d'émettre de pareils actes, au moins pour les temps à venir, contre des évêques sans s' être entendu avec eux et sans leur en avoir donné la moindre explication. Et il ajoute que le St. Père lui rendit parfaitement raison.

Je ne désire nullement en tirer des conséquences ou analogies pour mon cas, mais je veux avouer simplement que la lecture de ce passage mavait inspiré le désir de m'adresser directement au Vicaire du Christ pour chercher auprès de Lui aide et soutien. Je déclare d'avance d'accepter avec soumission entière et filiale tout ce que Votre Sainteté ordonnera.

Non seulement par égard au cinquantenaire de mon sacerdoce, qui par ce coup imprévu et soudain se voit troublé et voilé de tristesse, mais surtout par égard à mes autres travaux touchant à la vie de Notre Seigneur, j'ose supplier Votre Sainteté de vouloir m'accorder la grâce susmentionnée.

Il ne s'agit plus de ma personne. J'ai accepté cette lourde croix de la main du Tout-Puissant. Qu'il daigne m'aider à la porter aussi longtemps que bon Lui semble. Ce coup cependant, en frappant l"un de mes travaux, les atteint tous et je suis à présent en train de les achever, désirant les voir menés à bon terme.

Ma prière, tout en étant personnelle, vise un but impersonnel et m'est en vue de la gloire de Dieu bien à cœur.

\section{Dokument 292}

Oryg.: AFKDOPW, teczka 140: Spuścizna abp. Józefa Teodorowicza, sygn. 448/190 [7], List kard. Augusta Hlonda do abp. Józefa Teodorowicza, Poznań 28 III 1937 r.

${ }^{541}$ Zob. w niniejszej publikacji: J. Wołczański, Listy abp. Józefa Teodorowicza do abp. Józefa Bilczewskiego, dokument 101. 
Ekscelencjo! ${ }^{\mathrm{a}}$

Śpieszę donieść, że w tej chwili otrzymałem ekspresową przesyłkę. Zapoznam się ze sprawą i jutro napiszę.

Z najgłębszą czcią i oddaniem jestem Waszej Ekscelencji powolny sługa i brat

† August Kard. Hlond

\section{Dokument 293}

Oryg.: AFKDOPW, teczka 140: Spuścizna abp. Józefa Teodorowicza, sygn. 448/190 [7], List kard. Augusta Hlonda do abp. Józefa Teodorowicza, Poznań 29 III 1937 r.

Poznań, dnia 29 marca 1937 r.

Ekscelencjo! ${ }^{\mathrm{a}}$

Najdostojniejszy Księże Arcybiskupie!

Jestem wprost przerażony obrotem, jaki wzięła sprawa wiadomej publikacji. Najserdeczniej z Waszą Ekscelencją współczuję, bo wmyślam się w tragizm położenia. Chciałbym Waszą Ekscelencję tym pocieszyć, że to samo spotkało św. Jana Bosko ${ }^{542}$, gdy wydał żywot św. Jana Apostoła i na wstępie poruszył dogmatyczną stronę kwestii rzymskiej siedziby Papieży. Nazywał to Św. Jan Bosko najboleśniejszym krzyżem, jaki go spotkał w ciągu całego tak umęczonego żywota.

Dopiero w najbliższych dziesięciu dniach zadecyduję o terminie swego wyjazdu do Rzymu. Zależy to od ustalenia terminu pewnych posiedzeń w Kurii rzymskiej, w których z ważnych względów chciałbym wziąć udział. Bardzo chętnie wręczę Ojcu świętemu pismo Waszej Ekscelencji i od siebie sprawę serdecznie poprę.

Z najgłębszą czcią i oddaniem jestem Waszej Ekscelencji powolny sługa i brat w Chrystusie

† August Kard. Hlond

J[ego] E[kscelencja] Najprzewielebniejszy

Ks. Arcybiskup Józef Teodorowicz

Metropolita Lwowski ${ }^{b}$

we Lwowie

\footnotetext{
a Tekst pisany czarnym atramentem na jednej stronicy papieru formatu A4. W lewym górnym rogu znak wodny - herb kard. Augusta Hlonda.

a Tekst pisany maszynowo $\mathrm{z}$ wyjątkiem autografu autora pisma na 1,5 stronicy papieru formatu A4. W lewym górnym rogu karty tytułowej firmowy nadruk: „Prymas Polski”.

${ }^{542}$ Św. Jan Bosko (1815-1888), włoski duchowny, założyciel Towarzystwa św. Franciszka Salezego (Salezjanów), święty Kościoła katolickiego (1934).

b Błąd autora; abp. Teodorowicz nie posiadał statusu metropolity, lecz arcybiskupa archidiecezji lwowskiej obrządku ormiańskokatolickiego.
} 


\section{Dokument 294}

Kopia: ASK, bsygn., Acta Hlondiana, t. 5, cz. 8, List abp. Józefa Teodorowicza do kard. Augusta Hlonda, Lwów 3 IV 1937 r. Kopia: Toż, AFKDOPW, teczka 130: Spuścizna abp. Józefa Teodorowicza, sygn. 462/190 [7].

Lwów, 3 kwietnia 1937

Wasza $^{a}$ Eminencjo,

Prawdziwie wzruszony jestem listem Waszej Eminencji. Nie tylko Wasza Eminencja zgodził się przedstawić moją prośbę Ojcu św., ale raczył mi okazać tyle zrozumienia i tyle współczucia w tym moim doprawdy bardzo a bardzo ciężkim krzyżu.

Pokrzepił mnie Wasza Eminencja przytoczeniem nieznanego mi szczegółu o św. Janie Bosco.

Znam inny szczegół o Biskupie Prohaszce, którego podobny cios spotkał ze strony św[iętego] Officium. Ja nawet dołączam go do listu do Ojca św., o ile by Wasza Eminencja uważał za wskazane, by i to Ojcu św. przedstawić. Opuszczam tylko z pamiętnika Biskupa Prohaszki to co mówi o sobie, iż po tym ciosie strona uczuciowa przywiązana do Stolicy św. została śmiertelnie ugodzona. Tego nie chciałem pisać, zwłaszcza, że Bóg mnie w tym krzepi duchowo i wewnętrznie. Skoro się pisze o Stygmatyczce będącej ekspiacją za grzechy, trzeba wziąć samemu udział w krzyżu i cierpieniu. Im ono dotkliwsze, tym jest lepsze. Ekwiwalentem tego ciosu są dla mnie listy z różnych stron świata, z których widzę jak wiele dobrego ta książka czyni. Posłałem Waszej Eminencji ocenę znanego pisarza duńskiego (Villama Grönbeka ${ }^{543}$ ) w piśmie Pastorów duńskich. Był u mnie przed paru dniami konsul rumuński z Hamburga ${ }^{544}$, człowiek zresztą niewierzący, który mi za tę książkę dziękował i mówił, że pożyczał ją wielu protestantom, którzy byli nią nadzwyczaj ukrzepieni. Dostałem też głęboki, piękny i krzepiący list od jakiegoś bardzo świątobliwego kapłana ze Strassburga ${ }^{545}$. Przytaczam tych parę szczegółów z ostatnich kilku dni. Sam wydawca pisma pisze mi o błogosławionych skutkach, jakie książka wywiera na umysły i dodaje od siebie, że nigdy nie będzie żałować, że ją wydał.

Dla orientacji załączam tu Waszej Eminencji list z Rzymu pisany do mnie przez Biskupa Przeździeckiego [w] r[oku] 1933 i gen[erała] Ledóchowskiego, który jeszcze przed wydaniem mej książki, jak widać, czynił zabiegi w św. Kongregacji.

Jeszcze raz Waszej Eminencji z głębi serca za wszystko dziękuję, w modłach moich żywo pamiętam o Waszej Ekscelencji, prosząc przede wszystkim o tak potrzebne dla nas wszystkich zdrowie Waszej Eminencji.

Całuję pierścień i kreślę się najoddańszym sługą

† Teodorowicz

a Tekst pisany maszynowo na czterech stronicach papieru formatu A4.

${ }^{543}$ Postać niezidentyfikowana.

${ }^{544}$ Hamburg - miasto w północnych Niemczech.

545 Strassburg - miasto w północno-wschodniej Francji. 


\section{[Załączniknr 1: List bp. Henryka Przeździeckiego do abp. Józefa Teodorowicza ${ }^{546}$ ]}

21 X 1933 Rzym

Ekscelencjo!

Zwrócono się do mnie w Rzymie w sprawie związanej z odpowiedzią Ekscelencji na książkę ks. Siwka, mianowicie o tym, że podobno odpowiedź Ekscelencji ma być tłumaczeniem na inne języki. Otóż chodzi o to, aby przed tłumaczeniem Ekscelencji zwrócili się do S[anctum] Officium z zarzutami, które Najdostojniejszy Arcypasterz czyni ks. Siwkowi w związku cum doctrina christiana ${ }^{547}$. Podjąłem się tego zadania mając na uwadze, że może moje pismo dopomoże Ekscelencji w czymkolwiek i dlatego pismo wysyłam z Rzymu, nie czekając na powrót do kraju.

Łączę wyrazy najgłębszej czci oddany w Chrystusie Panu

† Henryk Przeździecki bp

[Załącznik nr 2: Fragment listu o. Włodzimierza Ledóchowskiego SJ do abp. Józefa Teodorowicza $\left.{ }^{548}\right]$

Ekscelencjo, Najprzewielebniejszy Księże Biskupie! $!^{\mathrm{b}}$

Rzym, dnia 29 III 1934

[...] Przy tej sposobności sądzę, że muszę także wyjaśnić sprawę Ks. Biskupa Przeździeckiego, pisanego z Rzymu do Waszej Ekscelencji. Z tego listu W[asza] E[kscelencja] wnioskował, że za sprawą tłumaczenia książki W[aszej] E[kscelencji] chce się wciągać Św[ięte] Oficjum i niejako nim grozić. Pozwalam sobie zwrócić uwagę W[aszej] E[kscelencji], że list ks. Biskupa Przeździeckiego wprawdzie nie był jasny, bo naprędce pisany, ale z niego z pewnością nie wynikało, że Św[ięte] Oficjum zajmuje się sprawą tłumaczenia książki W[aszej] E[kscelencji] i że ze strony jego są jakieś pod tym względem plany. Sens listu ks. B[iskupa] Przeździeckiego był ten, że sam Ekscelencja z zarzutami mógłby się zwrócić do Św[iętego] Oficjum. Rozmowę z ks. biskupem Przeździeckim najdokładniej pamiętam. Wyraziłem przed nim żal głęboki z powodu całej tej polemiki, dlatego osobisty, że pochodzi od dostojnika, z którym łączyły mnie dawniej tak ścisłe węzły, do tego stopnia, że ilekroć był ciężko atakowany zawsze najserdeczniej go broniłem, a teraz słyszę, że chce obecną sprawę rozciągać i na inne kraje. Prosiłem wtedy B[iskupa] Przeździeckiego, czy nie mógłby w tej sprawie pośredniczyć. Mówiłem, jak zupełnie inaczej w podobnych wypadkach rzecz się przedstawiała w takich np. Niemczech czy we Francji. Kiedy tam jeden, drugi Ojciec poszedł za daleko i było nawet niebezpieczeństwo, że Św[ięte] Oficjum tą sprawą się zajmie, to Ks[ięża] Biskupi z własnej woli stawali w obronie naszego Ojca, bo nie jest to w interesie Kościoła jakiegoś kraju jeżeli jacyś księża jego

${ }^{546}$ Zob. w niniejszej publikacji: J. Wołczański, Korespondencja abp. Józefa Teodorowicza z bp. Henrykiem Przeździeckim, dokument 9.

${ }^{547}$ Łac.: nauki (doktryny) chrześcijańskiej.

${ }^{548}$ Zob. pełny tekst w niniejszej publikacji: J. Wołczański, Korespondencja abp. Józefa Teodorowicza zo. Włodzimierzem Ledóchowskim SJ, dokument 11.

b Błąd kopisty; w oryginale: Arcybiskupie. 
są podejrzani o prawowierność. A tutaj kiedy mi się zdaje, że dla i Polski coś zrobiłem, nawet profesora uniwersytetu jakieś błędy są tak rozgłaszane.

Sądzę, mówiłem, znając głęboką miłość W[aszej] E[kscelencji] do Polski, że zamiast polemiki lepiej by było, jeżeliby W[asza] E[kscelencja] zwrócił się do Św[iętego] Oficjum i przedłożył niebezpieczeństwo, jakie by mogło z tej książki Kościołowi zagrażać. Chociaż W[asza] E[kscelencja] o zarzucie co do Św[iętego] Oficjum później w listach już nie wspomina, początkowego jego przypuszczenia, że Ekscelencja mógł mnie o coś podobnego podejrzewać, nie mogłem sobie w inny sposób wytłumaczyć, jak tylko silnym podnieceniem pod wpływem może nie dość jasnego listu ks. Przeździeckiego. Wszak podobne postępowanie, które się W[aszej] E[kscelencji] na myśl nasunęło, byłoby z mojej strony niesłychanie niemądrym. Od 26 lat jestem w Rzymie i znam może lepiej niż wielu innych sposób postępowania Kongregacji Rzymskich, a w szczególności Św[iętego] Oficjum i wiem dobrze, jak sekret jest tu ściśle schowany; zresztą byłbym sam związany sekretem Św[iętego] Oficjum gdybym coś podobnego wiedział. Oprócz tego taki sposób postępowania byłby z mojej strony niską intrygą, a z łaski Bożej prócz Recaldów i Bremerów nikt mi tego jeszcze nie zarzucił. [...]

Wł[odzimierz] Ledóchowski TJ

\section{Dokument 295}

Kopia: AFKDOPW, bsygn., teczka: Spuścizna abp. Józefa Teodorowicza, List abp. Józefa Teodorowicza do ks. Josepha Nabera, Lwów 28 I 1937 r.

\section{Abschrift \\ Pfarrer Naber}

Hochverehrter ${ }^{\mathrm{a}}$ Herr Pfarrer,

Ich schreibe wieder einen Alarmbrief an Sie. Heute habe ich Dr. Aigners Umlaufschreiben an die gesamte Ärztekammer gelesen, mit der Aufforderung dass sich alle für Dr. Deutsch einsetzten. Aus den ganzen aber gewinne ich den Eindruck, dass es der Eingana und so zu sagen der erste Schritt zum geplanten Verfahren ist, von dem ich Ihnen bereits schrieb. Es ist mir klar, dass Prof. Wunderle eben von Aigner sprach, als von demjenigen der den bekannten Schritt unternehmen wollte und jetzt gewis schon unternommen hat. Es lässt sich aus den Worten dieses Briefes der ganze Plan durchblikken. Es werden die deutschen Bischöfe hiebei beschuldigt, dass sie zu allem schweigen. Nicht nur gegen mich sondern auch gegen Kardinal Kaspar und Erzb[ischof] Waitz ist der Angriff gerichtet. Der Plan geht dahin das Schweigen der Bischöfe zur Begründung einer solchen Observation, wie die von der ich Ihnen erwähnte, und zu deren Rechtfertigung zu gebrauchen. Da die Bischöfe schweigen, so wollen sich die Ärzte an einen andern Faktor wenden: Sie sehen daraus wie richtig ich die Situation beurteilte, wenn

a Tekst pisany maszynowo na jednej stronicy papieru formatu A4. Brak zakończenia i autografu autora. 
ich auf Endscheidung drang. Heute ist es noch Zeit, morgen kann es zu spät sein. Wenn Herr Neumann fernerhin in seiner Hartnäckigkeit beharrt, muss er die Verantwortlichkeit übernehmen, dass seine Tochter ohne oder gegen seinen Willen einer Überwachung unterzogen wird, die in der Eichtling sich bewegen wird, dass die Wahrheit um keinen Preis siege. Sie werden mich wohl verstehen, und was ich mit Worten nicht ausdrücke, werden Sie selbst ergänzen.

\section{Dokument 296}

Oryg.: AFKDOPW, teczka 140: Spuścizna abp. Józefa Teodorowicza, sygn. 1712/65 [5], List kard. Augusta Hlonda do abp. Józefa Teodorowicza, Poznań 28 IV 1937 r.

Poznań, dnia 28 kwietnia 1937 r.

Ekscelencjo! ${ }^{\mathrm{a}}$

Bardzo serdecznie dziękuję Waszej Ekscelencji za łaskawe zaproszenie mnie na mieszkanie do siebie, z którego z wdzięcznością skorzystam. Dziękuję też za marcowy numer „Hochlandu” ${ }^{499}$, w którym z wielkim zainteresowaniem przeczytałem artykuł w znanej sprawie.

Dnia 10 maja wyjadę do Rzymu, gdzie pozostanę tylko 8 dni i spełnię zlecenia Waszej Ekscelencji. Ponieważ pragnę udać się do Rzymu „bez akompaniamentu”, nie rozgłaszam zamierzonej podróży.

Z najgłębszą czcią i oddaniem jestem Waszej Ekscelencji powolny sługa i brat w Chrystusie

${ }^{\mathrm{b}}+$ August Kard. Hlond ${ }^{-\mathrm{b}}$

J[ego] E[kscelencja] Najprzewielebniejszy

Ks. Arcybiskup Józef Teodorowicz

we Lwowie

\section{Dokument 297}

Kopia: AFKDOPW, teczka 13: Spuścizna abp. Józefa Teodorowicza, sygn. 447/190 [7], List abp. Józefa Teodorowicza do kard. Augusta Hlonda, Lwów 6 V 1937 r.

Wasza $^{a}$ Eminencjo,

Lwów, dnia 6 V 1937 r.

\footnotetext{
a Tekst pisany maszynowo z wyjątkiem autografu autora na jednej stronicy papieru formatu A4.

549 „Hochland” - niemieckie czasopismo katolickie założone przez Carla Mutha, ukazywało się w l. 19031941 i 1946-1971.

b-b Własnoręczny podpis.

a Tekst pisany maszynowo na 5 stronicach papieru formatu A4. Brak autografu autora pisma.
} 
Stokrotne dzięki za list ostatni: cieszę się osobno z tego, iż będę mógł powitać Waszą Eminencję w moim domu.

Dziś donoszę Waszej Eminencji wprost rewelacyjne szczegóły: Wczoraj przejeżdżała przez Lwów do Stanisławowa ${ }^{550}$ przybywająca wprost z Rzymu Urszulanka (S. Beata Bartlówna $\left.{ }^{51}\right)$. Otóż ta widziała się z księdzem Bogdanowiczem i opowiedziała mi, co następuje: w Rzymie po pojawieniu się mojej książki bawił O. Richstaetter SJ (z Aachen ${ }^{552}$ ) znany wróg Konnersreuth, który choć nigdy tam nie był napisał o Konnersreuth, nie nazywając go zresztą wcale $\mathrm{w}$ "Stimmer der Zeit” ${ }^{553}$ artykuł, podając najfałszywsze szczegóły o zjawiskach tamtejszych. Ten sam O. Jezuita po wydaniu mej książki, prostując parę szczegółów dotyczących właśnie jego artykułów wyraża się o mojej książce z dużym uznaniem, podkreślając jej wartość („Das grosse, eingehende Werk - pisze on - worin die Probleme Konnersreuth mit so grosser Belesenheit, von so vielen Seiten eine neue Beleuchtung erfahren") ${ }^{554}$. Otóż ten Jezuita robił propagandę w Rzymie przeciw mej książce i mnie. Był on u Urszulanek ze mszą św. i Przełożona Główna, niemkab, podejmowała go śniadaniem $w$ parlatorium ${ }^{555}$. Wtedy to zaczął on rozwodzić się nad tym, że Jezuici niemieccy muszą za wszelką cenę moją książkę zniszczyć, że podjęte są starania, ażeby tę książkę dać na indeks, a w każdym razie oni tę książkę wykupują, bo uważają ją za wysoce szkodliwą. Wspominając też o „lekarzach katolickich”, którzy przeciw tej książce występują miał na myśli D[okto]ra Deutscha, który, jak się pokazuje jest tylko narzędziem w ręku Jezuitów.

Szczegóły te wszystkie stąd znane są owej zakonnicy, iż przełożona główna widząc, iż chodzi tu o polskiego biskupa, wezwała ją zaraz i opowiedziawszy cały przebieg rozmowy z O. Richstaetterem, zaczęła ją wypytywać o książkę i jej autora.

Sam napisałem w tej chwili list do Richstaettera, którego kopię przesyłam Waszej Eminencjic, ażeby Wasza Eminencja z nią zrobił, co będzie uważał za wskazane.

Jezuici robią wprost światową propagandę przeciw tej książce, bo wbrew zapewnieniom Dr. Deutscha, że drukuje ową pracę jako manuskrypt, broszura jego wychodzi obecnie w języku francuskim na półkach księgarskich u Lethielleux ${ }^{556}$ już zapowiedzianym zostało jej bliskie ukazanie się.

${ }^{550}$ Stanisławów - miasto wojewódzkie w Małopolsce Wschodniej.

${ }^{551}$ Właściwie Barthel de Weydenthal Beata (1886-1970) - urszulanka Unii Rzymskiej, śluby wieczyste złożyła w 1926 r., pracowała jako nauczycielka, wychowawczyni i dyrektor szkół prowadzonych przez Zgromadzenie m.in. we Lwowie, Kołomyi, Stanisławowie. Informacje uzyskane w Archiwum Prowincjalnym Urszulanek Unii Rzymskiej w Krakowie, Kraków 12 II 2015.

${ }_{552}$ Aachen (Akwizgran) - miasto w kraju związkowym Nadrenia Północna-Westfalia (Niemcy).

553 „Stimmer der Zeit” - czasopismo naukowe wydawane przez Jezuitów od $1865 \mathrm{r}$. Zawiera publikacje na temat szeroko pojętej kultury chrześcijańskiej. Siedziba redakcji mieści się w Monachium.

${ }^{554}$ Niem.: wielkie, szczegółowe dzieło, w którym dowiadujemy się o problemach Konnersreuth z ogromną erudycją, na nowo naświetlone na tak wielu stronach.

b Zapis zgodny z oryginałem.

555 Parlatorium - sala w klasztorze przeznaczona na spotkania i rozmowy z gośćmi, rozmównica.

c Brak owego dokumentu.

${ }^{556}$ Lethielleux - francuska oficyna wydawnicza założona w 1864 r. w Paryżu, specjalizująca się w publikacji dzieł religijnych. 
Pokaże się jednak, że mimo Jezuitów, Dr Deutsch jest w ścisłym związku ze znanym Dr. Aignerem, który jako prezes ateistyczno-monadystycznego towarzystwa odznaczył się jako głośny wróg cudów w ogólności, w szczególności zaś cudów w Lourdes ${ }^{557}$.

Tyle w tej sprawie. Nie wiedząc gdzie Eminencja jest, posyłam dwa listy identyczne do Rzymu i Poznania.

Przy tej sposobności pozwolę sobie jeszcze zwrócić uwagę Waszej Eminencji, że już rok mija, jak o książce „O Masonerii”558, która kursuje wszędzie i wywołuje wielki skandal udowodniono Ks. Kaczyńskiemu, iż z encyklopedii masońskiej wypisał artykuł o masonerii (plagiat). Plagiata ${ }^{559}$, który w dodatku robi wyciągi z dzieła masońskiego, nie powinien być 24 godziny dłużej na czele organu, który jest organem Biskupów ${ }^{560}$.

Jeżeli wprost z Rzymu, poza Arcybiskupem ${ }^{561}$, przyszedł nakaz usunięcia Ks. Wyszyńskiego $^{562}$ z Wydziału Teologii, za daleko mniejszą rzecz ${ }^{563}$, to co mówić o takim niebezpiecznym skandalu? Ale mam jeszcze rzecz inną: mianowicie zrobił się w Warszawie wielki skandal moralny około osoby Ks. Kaczyńskiego. Miał bowiem za sekretarkę dwukrotną rozwódkę, kalwinkę, którą przyjmował na obiady i jeździł z nią autem. Dziś zapadła ona na chorobę kobiecą i leży w szpitalu. Opowiadał mi o tym Ks. Wądołowski ${ }^{564}$, który przybył tu z Warszawy i bawił we Lwowie jeden dzień. Mówił, że cała Warszawa tylko o tym sobie opowiada.

Dowiedziałem się o tym od Ks. Bogdanowicza, że ktoś udawał się do Waszej Eminencji ze skargą na moją diecezję. Bardzo dziękuję Waszej Eminencji, że był łaskaw zapytać się, co było na rzeczy? Sam nie wiem, co by to miało znaczyć? Wśród księży nie ma żadnego skandalu. Kapituła moja żyje wzorowo, zgodnie między sobą. Zakład wychowawczy ${ }^{565}$ przez lata zamknięty, dziś jest w kwitnącym stanie. Jedynie zakon-

557 Lourdes - miasto w południowo-zachodniej Francji, słynie z objawień Matki Bożej.

${ }^{558}$ Chodzi o broszurę Masoneria czym jest, a czym nie jest, Poznań 1935, wydaną nakładem poznańskiego Wydawnictwa św. Wojciecha.

559 Właściwie: plagiator.

560 Błędne wyrażenie autora; rzecz dotyczy nie „organu Biskupów” lecz Katolickiej Agencji Prasowej organu prasowego Konferencji Episkopatu Polski.

561 Aluzja do metropolity lwowskiego ob. łac. abp. Bolesława Twardowskiego.

${ }^{562}$ Wyszyński Michał (1890-1972), święcenia kapłańskie w 1915 r. we Lwowie, 1915-1916 wikariusz par. Kamionka Strumiłowa, 1916-1918 studia specjalistyczne w Innsbrucku, dr teologii, 1918-1921 wikariusz par. Czerniowce, 1921-1924 wikariusz katedry lwowskiej, 1921-1925 starszy asystent przy Bibliotece Zakładów Naukowych Wydziału Teologicznego UJK we Lwowie, w 1925 r. habilitacja w zakresie prawa kanonicznego, 1925-1930 zastępca prof. prawa kanonicznego na Wydziale Teologicznym UJK, 1930-1938 prof. nadzwyczajny, w 1938 r. zmuszony do odejścia na emeryturę, podczas II wojny światowej kapelan Powstania Warszawskiego, 1946-1953 prof. Uniwersytetu Mikołaja Kopernika w Toruniu, od 1954 r. prof. prawa rzymskiego na Uniwersytecie Wrocławskim i prawa kanonicznego Seminarium Duchownego we Wrocławiu, autor publikacji naukowych w obu tych dziedzin. J. Mandziuk, Wyszyński Michat, w: SPTK, t. 7, red. L. Grzebień, Warszawa 1983, s. 458-460; J. Wołczański, Wydział Teologiczny Uniwersytetu Jana Kazimierza we Lwowie 1918-1939, Kraków 2002, s. 395 nn.

${ }^{563}$ Rzecz dotyczyła rzekomego romansu ks. M. Wyszyńskiego z lwowską dentystką.

564 Wądołowski Zygmunt (1892-1971), kapłan archidiecezji warszawskiej, święcenia kapłańskie w 1918 r., doktor teologii, kapelan szpitalny, współzałożyciel i redaktor „Tygodnika Warszawskiego”. Katalog kościotów $i$ duchowieństwa archidiecezji warszawskiej na rok 1937, Warszawa 1937, s. 56.

565 Odniesienie do Zakładu Wychowawczego im. Torosiewicza we Lwowie. 
nice ${ }^{566}$ pozostawiają bardzo wiele do życzenia, ale liczę na Ks. Prałata Brossa, na jego wizytację, którą będę zawdzięczał pozwoleniu Waszej Eminencji. Nie rozumiem, do czego by miało się odnosić jakieś tajemne oskarżenie mej diecezji?

Dziękuję raz jeszcze Waszej Eminencji za wszystko z głębi serca, całuję pierścień Waszej Eminencji z czcią i szacunkiem najgłębszym, oddany Waszej Eminencji sługa.

\section{Dokument 298}

Oryg.: AFKDOPW, teczka 140: Spuścizna abp. Józefa Teodorowicza, sygn. 1712/65 [5], List kard. Augusta Hlonda do abp. Józefa Teodorowicza, Rzym 15 V 1937 r.

Rzym, dnia 15 maja $1937 \mathrm{r}$.

$\dagger$

Ekscelencjo! ${ }^{a}$

W piątek otrzymał Ojciec św. pismo Waszej Ekscelencji. Nie wiedział o niczym, albo nie pamiętał, trapi się bowiem, że teraz zupełnie ostatnie swoje zarządzenia zapomina. Już przedtem mówiłem o sprawie Waszej Ekscelencji z J[ego] Em[inencją] Ks. Kardynałem Stanu, który wiedział o postanowieniu św. Oficjum, ale nie znał bliżej motywów dekretu. Wspomniał tylko o tym, że wobec wypadków w Niemczech, Konnersreuth wymaga niezmiernie ostrożnego traktowania. Z O. Ledóchowskim nie było mowy o tym zagadnieniu; sam go nie poruszał, a ja $\mathrm{z}$ umysłu ${ }^{567}$ unikałem tego tematu, nie mając w tym względzie żadnych poleceń ze strony Waszej Ekscelencji.

Co do zastrzeżeń, o których wspominał Mons[ignore] Pacini ${ }^{568}$ wobec Ks. Kan[onika] Bogdanowicza, nie mogłem się nic konkretnego dowiedzieć w Sekretariacie Stanu. Byli moimi pytaniami zaskoczeni i zdziwieni. Wnioskuję z tego, iż jeśli są skargi, to leżą w św. Kongregacji Wschodniej, z której atoli tą razą z umysłu unikałem kontaktu. Kto wie, czy Mons[ignore] Pacini nie powiedział więcej, niż zamierzał i wiedział.

Pojutrze ruszam w drogę powrotną. Uchwały Synodu Plenarnego ${ }^{569}$ zostały z drobnymi poprawkami przyjęte po wyczerpującej analizie, która trwała siedem godzin i zajęła dwie sesje św. Kongregacji Soboru.

566 Aluzja do klasztoru Zakonu ss. Benedyktynek ormiańskich we Lwowie.

a Tekst pisany czarnym atramentem na 2 stronicach papieru formatu A4. W lewym górnym rogu karty tytułowej nadruk: „Prymas Polski”.

567 Tu w znaczeniu: celowo, $\mathrm{z}$ rozmysłu.

${ }^{568}$ Pacini Alfredo (1888-1967), święcenia kapłańskie w 1913 r. w Lucca (Włochy), wykładowca w miejscowym Seminarium Duchownym, od 1924 r. pracownik dyplomacji watykańskiej: 1924-1933 sekretarz Nuncjatury Apostolskiej w Jugosławii, 1935-1944 audytor nuncjatury w Warszawie, 1944-1946 radca nuncjatury we Francji, w 1946 r. otrzymał sakrę arcybiskupa tytularnego Germia, 1946-1949 nuncjusz na Haiti i San Domingo, 1949-1960 nuncjusz w Urugwaju, 1960-1967 nuncjusz w Szwajcarii, w 1967 r. kreowany kardynałem. Źródło: Alfredo Pacini, https://pl.wikipedia.org/wiki/Alfredo_Pacini. Dostęp: 17 I 2016 r.

569 Aluzja do uchwał I Synodu Plenarnego w dniach 26-28 VIII 1936 r. w Częstochowie. 
Z wyrazami najgłębszej czci i oddania jestem zawsze Waszej Ekscelencji powolny sługa i brat w Chr[ystusie]

† August Kard. Hlond

\section{Dokument 299}

Oryg.: AFKDOPW, teczka 141: Spuścizna abp. Józefa Teodorowicza, sygn. 223/239 [7], List prowincjała oo. Jezuitów Włodzimierza Konopki SJ do abp. Józefa Teodorowicza, Lwów 26 V 1937 r.

$\dagger$ Lwów, 26/V 1937

Ekscelencjo! ${ }^{\mathrm{a}}$

Najczcigodniejszy Księże Arcypasterzu!

Szczerze cieszę się, że z okazji 50 lat Kapłaństwa mogę złożyć Ekscelencji jak najgorętsze życzenia, zwłaszcza przeobfitych łask i darów Bożych, by Ekscelencja jeszcze w długie lata mogła tak owocnie pracować na chwałę Bożą na niwie Kościoła św. i dla dobra naszej ojczyzny. Z mej strony obiecuję na tę intencję me niegodne modlitwy.

Proszę nie brać mi za złe, że osobiście nie przyszedłem złożyć powinne życzenia, ale obecnie daję rekolekcje moim [... $]^{\mathrm{b}}$, a w piątek w pełni przygotowań nie chciałbym przeszkadzać. Wiem, że Ekscelencja nie weźmie mi tego za złe, a z mej strony modlitwami będę się starał uzupełnić me niedociągnięcia.

Prosząc kornie o arcypasterskie błogosławieństwo, całuję czcigodne ręce Ekscelencji, Najczcig[odniejszego] Księdza Arcybiskupa, najoddańszy w X[rystusie] sługa

Włodzimierz Konopka TJ

\section{Dokument 300}

Oryg.: AFKDOPW, teczka: Spuścizna abp. Józefa Teodorowicza, bsygn., List kard. Donato Sbarretti do abp. Józefa Teodorowicza, [Rzym] 28 V 1937 r.

Kopia

del palazzo di S[anto] Offizio 28 maggio 1937

Suprema Sacra Congregazione del Santo Offizio

Num[ero] di Protoc[olo] 761/27

(nella riposta si prega di citare questo numero)

Eccelenza ${ }^{a} \operatorname{Rev}[$ erendissi]ma,

Questa Suprema S[acra] Congregazione non ha mancato di prendere in considerazione quanto Vestra Eccelenza Rev[erendissi]ma ha prospettate circa il disagio, in ciu viene

a Tekst pisany czarnym atramentem na jednej stronicy papieru formatu A4.

b Wyraz nieczytelny.

a Tekst pisany na maszynie na jednej stronicy papieru formatu A4. W górnej partii karty nota: „Drugi Dekret św[iętego] Officjum w sprawie książki Arcybiskupa Teodorowicza «Konnersreuth im Lichte der Mystik und Psychologie»". 
a trovarsi, in sequite alle decisioni comunicatele con foglio n. 761/27 in data 23 novembre 1936, ed ha altamente aprezzato le ottime disposiozioni, con cui si dichiara pronta ad accetara ogni suggerimente di questa S[acra] Congregazione per le eventuali correzioni da introdurre nel suo libro.

Veramente la regione della misura adottata da questa Suprema non deve ripetersi che dal desiderio di evitare l'inasprimento della controversia suscitata sull'argomento di Konnersreuth, imporre cioe il silenzo sulla questione finche non sia giunto il momento opportuno di occuparsi autorevolmente dell'argomento. E cio Tanto piu che, allo stato della cose, e attesta la delicata situazione della Chiesa nel Reich, vi a motivo di temere complicazioni per altri interventi, che sono con fondamento providibili.

Misura prudenziale, quindi, e non giudizio dottrinale sul libro di V[ostra] E[ccelenza] sui quale quaesta Suprema non ha intese affato pronunziarsi; tale carattere di misura prudenziale rivelasi anche della circonstanza che, nel Decreto in parole, si invita V[ostra] E[ccelenza] e non occuparsi piu altro della questione.

Quanto al ritiro degli esemplari delle edizioni gia divulgate, questa Suprema subordinava tale invito alla possibilita di effentuarle („pro posse”), quindi non e intenzione della $\mathrm{S}$ [acra] Congregazione di costringere V[ostra] E[ccelenza] a far cio che le fosse di grave incomodo finanziario e di troppo fastidiosa conseguenze per la di Lei posizione e per di lei prestigio di Arcivescovo.

Per nuove edizioni e traduzioni da farsi, la cosa potrà essere riesaminata quando l'attuale aituazione fosse cambiata e i giusti timori sopra detti fossero dissipati.

Nelle fiducia che queste dilucidazioni siano per V[ostra] E[ccelenza] pienamente tranquilizzanti mi confermo con distintastima di V[ostra] E[ccelenza] Rev[erendissi]ma dev.mo Card. Sbaretti

Vescovo di Sabina e Poggio Misteto Segretario

\section{Dokument 301}

Oryg.: AFKDOPW, teczka 140: Spuścizna abp. Józefa Teodorowicza, sygn. 466/190 [7], List kard. Augusta Hlonda do abp. Józefa Teodorowicza, Poznań 23 VI 1937 r. Kopia: ASK, bsygn., Acta Hlondiana, t. 4, cz. 4, List kard. Augusta Hlonda do abp. Józefa Teodorowicza, Poznań 23 VI 1937 r.

[Poznań, dn[ia] 23. 6. [19]37

Ostrów Tumski 1]

\section{Ekscelencjo! ${ }^{\mathrm{a}}$}

Najserdeczniej gratuluję nadzwyczajnego rzymskiego sukcesu ${ }^{570}$. W danych okolicznościach nie mógł być on pełniejszy. Znać w tym rękę Papieża, z czego bardzo się cieszę.

a Tekst pisany maszynowo z wyjątkiem autografu autora na jednej stronicy papieru formatu A4. W oryginale brak daty i miejsca nadania.

570 Na skutek interwencji Piusa XI, Święte Officium dekretem z dnia 28 V 1937 r. anulowało wcześniejszy zakaz. ASK, sygn. 22/53 [8], t. 54, Kopia pisma Świętego Officium do abp. J. Teodorowicza, Rzym 28 V 1937, s. 29. 
Nic nie wiedziałem o tym, że na dworcu w Stanisławowie chcieli mnie widać także Żydzi, bo nikt mi tego nie zakomunikowa ${ }^{571}$. Może i lepiej, że tak się stało.

Żałuję bardzo, że nie będziemy mogli powitać tutaj Waszej Ekscelencji, ale rozumiem dobrze stanowisko lekarzy i dlatego wcale nie nalegam. Zwłaszcza po jubileuszowych trudach należy się Waszej Ekscelencji dużo wypoczynku. Otrzymałem tom: „Herold Chrystusa na tle epoki" ${ }^{772}$. Gratuluję i bardzo dziękuję.

Z prośbą o westchnienie na intencję Kongresu Chrystusa Króla ${ }^{573}$ jestem z najgłębszą czcią Waszej Ekscelencji, powolny sługa i brat w Chrystusie

${ }^{\mathrm{b}-}+$ August Kard. Hlond ${ }^{-\mathrm{b}}$

Jego Ekscelencja

Najprzewielebniejszy

Ks. Arcybiskup Józef Teodorowicz

$\mathrm{W}[\mathrm{e}]$ Lwowie

\section{Dokument 302}

Oryg.: AFKDOPW, teczka 138: Spuścizna abp. Józefa Teodorowicza, sygn. 449/190 [7], List bp. François Agagianiana do abp. Józefa Teodorowicza, Rzym 27 VI 1937 r.

Roma (105), 27/VI 1937

Excellence ${ }^{\mathrm{a}}$,

Je m'empresse à repondre à Votre venerée lettre datée du 20 Juin courant, pour Vous exprimer mes sentiments d'intense joie, que j'ai eprouvé à l'anonce des bonnes nouvelles, qui ont consolé, certes enormement Votre coeur touché par une épreuve si inattendue et si douloureuse. Je ne puis Vous dire, combien je suis heureux à présent, en sachant que tout, c'est résolu d'une manière hautement honorable pour la personne vénérée de Votre Excellence.

Je vois que divine Providence exigeait un tel sacrifice comme meilleure préparation aux fêtes jubilaires. Votre Excellence en acceptant avec une résignation vraiment édifiante la lourde croix, comme vous l'appeliez dans une de vos lettres, Vous avez démontré, que Vous savez souffrir en silence pour l'amour de Jésus et voici que la Vierge des Grâces est venue Vous consoler juste au cours des solennités jubilaires. Comme jadis j’ai pris part à Vos douleurs, maintenant je me rejouis bien volontiers avec Vous et j'en bénis le Seigneur du fond de mon coeur.

571 Aluzja do wizyty kard. Augusta Hlonda w Stanisławowie na uroczystościach związanych z kronacją łaskami słynącego obrazu Matki Bożej Łaskawej z kościoła ormiańskokatolickiego $30 \mathrm{~V} 1937 \mathrm{r}$.

572 J. Teodorowicz, Jezus Chrystus, t. 3: Herold Chrystusa na tle epoki, Poznań 1937.

573 Międzynarodowy Kongres Chrystusa Króla odbył się w Poznaniu w dniach 25-29 VI 1937 r.

b-b Włąsnoręczny autograf.

a Tekst pisany maszynowo $\mathrm{z}$ wyjątkiem aytografu autora na jednej stronicy papieru formatu A4. W lewym górnym rogu karty nadruk firmowy: „Pont[ificio] Collegio Armeno, Piazza S. Nicolo da Tolentino, 31”. 
Avec ces sentiments, je prie Votre Excellence d'agréer mes sentiments de profonde vénération de Votre Excellence, tout dévoué en N[otre] S[eigneur]

${ }^{b-}+$ F[rançois ] Agagianian ${ }^{-b}$

A Son Excellence Msgr. Joseph Teodorowicz

Archevêque du rite arménien

à Lwów

\section{Dokument 303}

Oryg.: AFKDOPW, bsygn., teczka: Spuścizna abp. Józefa Teodorowicza, List z Wydawnictwa i Drukarni Badenia w Karlsruhe do abp. Józefa Teodorowicza, Karlsruhe 28 VI 1937 r.

Karlsruhe, den 28. Juni 1937

Direktion

$\mathrm{V} / \mathrm{Ba}$.

S[eine]r Exzellenz

dem Hochwürdigsten Herrn Erzbischof

Dr. Josef Teodorowicz

Lemberg/Polen

\section{Eure $^{\text {a }}$ Exzellenz!}

Die Zustellung der restlichen Korrekturfahnen Nr. 26-112 hat sich leider etwas verzögert durch eine Aussprache mit unseren Lektoren. Für diesen Teil kommt nur in Frage, was wir in unserem Schreiben vom 20.02.1937 andeuteten. Es sind eine Reihe von Stellen enthalten, die nach unserer Ansicht gekürzt oder ganz gestrichen werden sollten. Wie Eure Exzellenz wissen, sind in der letzten Zeit in Deutschland eine Anzahl Werke erschienen, die sich ebenfalls mit dem Leben Jesu befassen. Es ist also bei uns in den für die Verbreitung des Werkes in Frage kommenden Kreisen eine ziemliche Vertrautheit mit dem Stoff vorhanden, die es wünschenswert erscheinen lässt, dass gewisse Stellen nicht in dem Umfang noch behandelt werden, wie dies noch vor wenigen Jahren vor Erscheinen dieser Werke nötig gewesen wäre und wie es in Polen, da dort solche Werke nicht vorliegen, sogar unumgänglich ist.

Es kommen ferner noch Stellen dazu, die sich fast ausschliesslich an den polnischen Leser wenden und für den deutschen keine Bedeutung haben.

Alle Stellen, deren Kürzung oder Streichung wir für erwägenswert halten, haben wir in der einen Fertigung der Korrekturfahnen mit Rotstift angestrichen und eingeklammert. Eure Exzellenz möchten wir nun bitten, unter Zugrundelegung unserer Bedenken

\footnotetext{
b-b Fragment napisany czarnym atramentem.

a Tekst pisany maszynowo na dwóch stronicach papieru formatu A4. W górnej centralnej partii karty nadruk firmowy: „Badenia in Karlsruhe A.-G. FÜR VERLAG UND DRUCKEREI, Telephon 6235-6237, Postscheck-Konto Karlsruhe 4844, Steinstraße 17-21".
} 
diese Stellen zu prüfen und zu entscheiden, ob und in welchem Umfang Eure Exzellenz unseren Vorschlägen zustimmen wollen. Die zweite Fertigung der Korrekturfahnen erbitten wir uns mit den Korrekturen zurück.

Mit dem Ausdruck ehrerbietigster Hochachtung bleiben wir Euer Exzellenz ergebenste

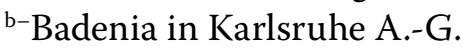

für Verlag und Druckerei ${ }^{-b}$

$[\ldots]^{\mathrm{c}}$

P.S. Soeben teilt uns Herr von Lama mit, dass Eure Exzellenz ihm das Manuskript der Antwort an Herrn Dr. Deutsch übergeben und ihm es überlassen habe, für die Herausgabe und den Verlag in Deutschland besorgt zu sein. Herr von Lama bietet uns das Manuskript an. Wir sind bereit, diese Arbeit in Verlag zu übernehmen. Wir haben noch Herrn von Lama gebeten, uns zuerst das Manuskript zur Einsicht zu überlassen.

\section{Dokument 304}

Oryg.: AFKDOPW, bsygn., teczka: Spuścizna abp. Józefa Teodorowicza, List z Wydawnictwa i Drukarni Badenia w Karlsruhe do abp. Józefa Teodorowicza, Karlsruhe 20 VII 1937 r.

Karlsruhe, den 20. Juli 1937

Direktion

$\mathrm{V} / \mathrm{Ba}$.

S[einer] Exzellenz

dem Hochwürdigsten Herrn Erzbischof

Dr. Josef Teodorowicz

Lemberg/Polen

Eure Exzellenz!

Für Ihr Schreiben vom 15.7.1937 danken wir bestens. Wir nehmen an, dass der erste Abschnitt wohl Ihr Werk „Von Bethlehem nach Nazareth“ betrifft. Wir haben ja die Stellen gekennzeichnet, die wir für eine Kürzung empfehlen möchten. Es liegt nun bei Eurer Exzellenz zu entscheiden, ob die Kürzung durchgeführt werden soll oder nicht. Wir möchten selbstverständlich nicht „das Kind mit dem Bad ausschütten“.

Von der als Antwort gegen Deutsch gedachten Broschüre haben wir, wie Ihnen wohl Herr von Lama schon mitgeteilt haben wird, einen Teil "Das Wunder" erhalten und auch schon mit dem Satz begonnen. Da wir gerne recht bald einen Überblick über den Umfang erhalten würde, bitten wir Eure Exzellenz um umgehende Zusendung des

b-b Pieczęć podłużna.

Autograf nieczytelny.

a Tekst pisany maszynowo na jednej stronicy papieru formatu A4. W górnej centralnej partii karty nadruk firmowy: „Badenia in Karlsruhe A.-G. VERLAG UND DRUCKEREI, Telephon 6235-6237, Postscheck-Konto Karlsruhe 4844, Steinstraße 17-21". 
restlichen Manuskriptes. Wir haben auch wegen dieses Werkes gegenüber Herrn von Lama Bedenken wegen des Umfanges geäussert, besonders dann, wenn dieses Werk als Antwort auf die doch sehr dünne sowohl dem Inhalt wie dem Umfang nach) Schrift des Herrn Deutsch gedacht sein sollte.

Mit dem Ausdruck ehrerbietigster Hochachtung bleiben wir Eurer Exzellenz ergebenste

b-Badenia in Karlsruhe

A.-G- für Verlag und Druckerei ${ }^{-b}$ $[\ldots]^{\mathrm{c}}$

\section{Dokument 305}

Kopia: ASK, bsygn., Acta Hlondiana, t. 4, cz. 4, List kard. Augusta Hlonda do abp. Józefa Teodorowicza, Poznań 11 XII 1937 r.

Ekscelencjo! ${ }^{a}$

W jednym z pism hitlerowskich znalazłem załączone artykuły w sprawie Konnersreuthu. Pozwalam sobie przesłać je Waszej Ekscelencji, a zarazem zapytuję uprzejmie o zdrowie i powodzenie.

Z serdecznymi życzeniami świątecznymi i wyrazami najgłębszej czci jestem Waszej Ekscelencji powolny sługa i brat w Chr[ystusie]

P[oznań], 11 XII [19]37

$\mathrm{Hl}[$ ond $]$

\section{Dokument 306}

Kopia: ASK, bsygn., Acta Hlondiana, t. 5, cz. 3, List abp. Józefa Teodorowicza do kard. Augusta Hlonda, Lwów 13 XII 1937 r.

Wasza $^{a}$ Eminencjo, Lwów, dnia 13 XII 1937 r.

Jestem prawdziwie wzruszony dowodem łaskawości i względów Waszej Eminencji, a zarazem wprost podziwiam, jak stać Waszą Eminencję na baczenie na takie kwestie, jak właśnie artykuł przysłany mi w piśmie. Jest to dla mnie oczywiście informacja niesłychanie cenna, za którą z głębi serca dziękuję.

Kiedyś opiszę Waszej Eminencji obszernie o sprawie Konnersreuth, której dziś bronią w Rzymie Kardynał Kaspar i Arcybiskup Salzburski ${ }^{574}$.

b-b Pieczęć podłużna.

c Autograf nieczytelny.

a Tekst pisany maszynowo na jednej stronicy papieru formatu A4.

a Tekst pisany maszynowo na jednej stronicy papieru formatu A4.

${ }^{574}$ Funkcję tę w latach 1934-1941 pełnił abp Sigismund Waitz (1864-1941). 
Jak mnie świeżo z Konnersreuth informują, Teresa Neumann oświadczyła Biskupowi Buchbergerowi, że gotowa uciec z domu, by się poddać obserwacji wbrew woli ojca, ale stawia za warunek, aby Biskup się zobowiązał zapewnić jej utrzymanie do końca życia.

Żałuję bardzo, że nie mogę być na Konferencji dla stanu mego zdrowia. Jeśli mi wolno uczynić jaką̧śs] uwagę, to lękam się o jedno. Jak ze wszystkiego widzę, Żydzi zagrożeni na polu ekonomicznym starają się rozbudzić prąd za parcelacją ziemi u chłopów i tak odwrócić uwagę od siebie. Dlatego Kościół musi być niesłychanie ostrożny, aby z jednej strony nie stać się narzędziem interesów żydowskich, a z drugiej zaś strony, by nie pójść na żadne kompromisy z falą radykalizmu i komunizmu idącą na nas.

Jak to przyznali biskupi hiszpańscy w swym liście, omylili się w swej całej taktyce chcąc pozyskać kompromisowe-radykalne sfery. Tę samą rolę spełniło Centrum w Niemczech - niestety pod wpływem Rzymu, a naporem hitleryzmu, który dzięki Centrum doszedł do władzy. We Francji idą na ten kierunek ludzie tej miary co Maritain i inni.

Dziękuję przy sposobności Waszej Eminencji za zainteresowanie się mym zdrowiem, które po Rabce względnie jest doskonałe, jakkolwiek nie pozwoli mi na ekspedycje takie, jak do Warszawy. Siedzę w domu i piszę. Nową książkę o Chrystusie Panie mam już na ukończeniu ${ }^{575}$.

Jeszcze raz najgoręcej dziękuję Waszej Eminencji za Jego tak cenną pamięć i całując pierścień Waszej Eminencji kreślę się z wyrazami oddanymi najgłębszej czci

† Teodorowicz

\section{Dokument 307}

Oryg.: AFKDOPW, teczka 138: Spuścizna abp. Józefa Teodorowicza, sygn. 359/89 [5], List z Wydawnictwa i Drukarni Badenia w Karlsruhe do abp. Józefa Teodorowicza, Karlsruhe 22 I 1938 r.

Karlsruhe, den 22. Januar 1938

Direktion

$\mathrm{V} / \mathrm{Ba}$

S[einer] Exzellenz

dem Hochwürdigsten Herrn Erzbischof

Dr. Josef Teodorowicz

Lwow/Polen

Euere $^{\text {a }}$ Exzellenz!

Auf das Schreiben Eurer Exzellenz vom 18. I erwidern wir, dass wir selbstverständlich gerne die gewünschten 20 Autorenstücke zur Verfügung stellen. Wir bitten, uns die Anschriften zu übermitteln und gleichzeitig die Karte Eurer Exzellenz uns zugeben zu

575 Anonsowana publikacja nie ukazała się drukiem.

a Tekst pisany maszynowo na jednej stronicy papieru formatu A4. W górnej centralnej partii karty nadruk firmowy: „Badenia in Karlsruhe, A.-G. FÜR VERLAG UND DRUCKEREI, Telephon 6235-6237, Postfach - Konto Karlsruhe 4844, Steinstraße 17-21". 
lassen, damit wir, wann es sich um Anschriften in Deutschland handelt, sie von hier aus direkt zustellen können.

Mit dem Ausdruck ehrerbietigster Hochachtung bleiben wir Euer Exzellenz ergebenste

${ }^{\mathrm{b}}$-Badenia in Karlsruhe

A.-G. für Verlag und Druckerei ${ }^{-b}$ $[\ldots]^{\mathrm{c}}$

\section{Dokument 308}

Oryg.: AFKDOPW, teczka 145: Spuścizna abp. Józefa Teodorowicza, sygn. 384a/90 [5], List z Wydawnictwa Antona Pusteta do abp. Józefa Teodorowicza, Salzburg 15 II 1938 r.

Honorarabrechnung ${ }^{\mathrm{a}}$

Hochw[ürdigen] Herrn S[eine]r Exzellenz dem hochwürdigsten Herrn

Erzbischof Dr. Josef Teodorowicz

Lemberg, Polen

für die Zeit vom 01.7.[19]37 bis 31.12.[19]37

Kontostand zu Ihren Gunsten am 30. 6. [19]37 S. 770.

„Konnersreuth“ Lagerstand am 30.06. [19]37: 916 Ex[em]pl[are].

Verkauf: 82 Ex[em]pl[are].

Verbleiben: 834 Ex[em]pl[are].

Resthonorar: 3. Rate: S. 770

9.9.[19]37 Gutschrift halber Anteil für amerikanische und englische Rechte: S. 625

31.12.[19]37 Saldo zu Ihren Gunsten: S. 2165.

Salzburg, am 15 Febr[uar] 1938

${ }^{\mathrm{b}-D i r e k t i o n}$

Verlag Anton Pustet SALZBURG ${ }^{-b}$ $[\ldots]^{\mathrm{c}}$

\section{Dokument 309}

Kopia: ASK, bsygn., Acta Hlondiana, t. 5, cz. 7, List abp. Józefa Teodorowicza do kard. Augusta Hlonda, Lwów 26 II 1938 r.

Lwów, dnia 26 II 1938 r.

b-b Podłużna pieczątka.

c Autograf nieczytelny.

a Tekst pisany maszynowo na jednej stronicy papieru formatu A4. W górnej partii karty nadruk firmowy: „VERLAG ANTON PUSTET SALZBURG”.

b-b Nadruk firmowy.

c Autograf nieczytelny. 


\section{Wasza ${ }^{a}$ Eminencjo!}

Jestem prawdziwie wzruszony pamięcią Waszej Eminencji i szczególnie dziękuję za przysłaną mi niemiecką gazetę o Konnersreuth. Wyszła już odpowiedź, której jeszcze nie dostałem $\mathrm{z}$ księgarni. Pseudonim autora jest Veremundus ${ }^{576}$. Podobno kryje się pod tym pseudonimem znany autor niemiecki zajmujący się mistyką - Bruno Grabiński ${ }^{577}$ z Wiesbadenu ${ }^{578}$. Drugą odpowiedź przygotowuje dr Hynek z Pragi ${ }^{579}$.

Ciekawe jednak i niesłychanie silne są artykuły w „Kirchenzeitung” ${ }^{580}$. Jeden jest poprzedzony wstępem Biskupa Salzburskiego Waitza, co jest tym dziwniejsze, że artykuł zwraca się przeciw Biskupowi Regensburskiemu Buchbergerowi. Drugi artykuł księdza Nabera, który pierwszy raz się odezwał w sprawie Konnersreuth w bardzo prostych i silnych słowach.

O swojej pracy już nie piszę nic, gdyż p[an] Stefan Dąbrowski ${ }^{51}$ musiał mówić Waszej Eminencji o tym.

Jestem prawdziwie zdumiony, jak Wasza Eminencja wszystkim się interesuje i niczego z oczu nie spuszcza.

Przy tej sposobności wyrażam podziękowanie i uznanie dla prześlicznego wydawnictwa, nawet w jego zewnętrznej formie - uchwał Synodu ${ }^{582}$.

Modląc się o zdrowie Waszej Eminencji, łączę dla Waszej Eminencji moje najoddańsze wyrazy najgłębszej czci

† Teodorowicz

\section{Dokument 310}

Oryg.: AFKDOPW, teczka 138: Spuścizna abp. Józefa Teodorowicza, sygn. 361/89 [5], List z Wydawnictwa i Drukarni Badenia w Karlsruhe do abp. Józefa Teodorowicza, Karlsruhe 16 II 1938 r.

$\mathrm{V} / \mathrm{K}$

Karlsruhe, den 16. Februar 1938

Direktion

S[einer] Exzellenz

dem Hochwürdigsten Herrn Erzbischof Dr. Josef Teodorowicz

Lemberg/Polen

a Tekst pisany maszynowo na jednej stronicy formatu A4.

576 Veremundus [B. Grabiński], Weltbetrug in Konnersreuth? Hungert Therese Neumann nicht? „Theater"? Mystik und Pseudomystik, Colmar 1937

577 Grabiński Bruno - niemiecki autor znanych prac z dziedziny mistyki, m.in. Das Phänomen der Stigmatisation. Mit einer Würdigung der Stigmatisationsfälle aus neuester Zeit, München 1929.

578 Wiesbaden - miasto i uzdrowisko w środkowych Niemczech.

579 R.W. Hynek, Zur Abwehr Neuer Beitrag zur Lösung des Konnersreuther Problems, Karlsruhe 1938.

580 Właściwie: „Katholische Kirchenzeitung” - gazeta o tematyce religijnej wydawana w Salzburgu w l. 1861-1939.

${ }_{581}$ Zob. w niniejszej publikacji: J. Wołczański, Listy abp. Józefa Teodorowicza do abp. Józefa Bilczewskiego, dokument 124.

${ }^{582}$ Uchwaty I Plenarnego Synodu w Polsce odbytego w Częstochowie w dniach 26-28 VIII 1936 oraz orędzie Episkopatu Polskiego w sprawie uchwat Synodu, Poznań 1938. 


\title{
Euer ${ }^{\text {a }}$ Exzellenz!
}

Für das Schreiben vom 12. Februar 1938 mit der Liste der Namen, an die Besprechungsstücke geschickt werden sollen, danken wir bestens. Die in dem Schreiben Eu[re] Exzellenz erwähnten Visitenkarten lagen leider nicht bei. Wir dürfen daher Ew[ere] Exzellenz bitten, uns diese noch zugehen zu lassen.

In ehrerbietiger Hochachtung

\author{
b-Badenia in Karlsruhe \\ A.-G. für Verlag und Druckerei ${ }^{-b}$ \\ $[\ldots]^{\mathrm{c}}$
}

\section{Dokument 311}

Kopia: ASK, bsygn., Acta Hlondiana, t. 5, cz. 4, List abp. Józefa Teodorowicza do kard. Augusta Hlonda, Lwów 10 III 1938 r.

Lwów, dnia 10 III 1938

Wasza $^{a}$ Eminencjo!

Bardzo dziękuję Waszej Eminencji za tak dla mnie cenne słowa zachęty, które mi Wasza Eminencja przesyła. Dziękuję osobno za świeżo przysłany mi dokument ataków Aignera sprzymierzonego niestety z katolikiem (Dr Deutsch), mającym taki wpływ na chorego zresztą człowieka, jakim jest biskup Buchberger.

Jeszcze raz dziękując, łączę wyrazy mojej czci bardzo oddanej i głębokiej, sługa w Chrystusie

† Teodorowicz

\section{Dokument 312}

Kopia: ASK, bsygn., Acta Hlondiana, t. 5, cz. 4, List abp. Józefa Teodorowicza do kard. Augusta Hlonda, Lwów 21 III 1938 r.

Wasza $^{a}$ Eminencjo!

Lwów dnia 21 marca 1938 r.

Dziękuję Waszej Eminencji za łaskawy list, tak mi cenny i za zachętę, jaką otrzymuję od Waszej Eminencji w głoszeniu moich przemówień ${ }^{583}$.

a Tekst pisany maszynowo na $1 \frac{1}{2}$ stronicy papieru formatu A4. W górnej centralnej części karty nadruk firmowy: „Badenia in Karlsruhe A.- G. FÜR VERLAG UND DRUCKEREI, Telephon 6235-6237, Postscheck - Konto Karlsruhe 4844, Steinstraße 17-21".

b-b Podłużna pieczęć.

c Autograf nieczytelny.

a Tekst pisany maszynowo na jednej stronicy papieru formatu A4.

a Tekst pisany maszynowo na trzech stronicach formatu A4.

${ }^{583}$ Aluzja do transmitowanych przez Polskie Radio rekolekcji wielkopostnych głoszonych przez abp. Józefa Teodorowicza w dniach 6, 13, 20, 27 III, 3 IV i 10 IV 1938 r. we Lwowie. J. Teodorowicz, Kuszenie Chrystusa. Wielkopostne konferencje radiowe, Kraków 1938; M. Szczepaniak, Spirala pomówień czy walka o dusze? Wokót polityki w kazaniu radiowym abp. Teodorowicza, ŚSHT, 2013, t. 1, s. 129-146. 
Dziękuję osobno za nowy przysłany wycinek niemiecki, z którego widzę, [że] racjonalista Aigner wybornie uchwycił słabą i połowiczną pozycję Regensburskiego Biskupa w sprawie Konnersreuth. Wyzyskał on ją wprost w niemiłosierny sposób.

Pisał mi p[an] Dąbrowski, iż mówił z Waszą Eminencją o moim rzekomym sprzeciwie w sprawie przeprowadzania drugiej obserwacji ${ }^{584}$. Mówię o „rzekomym” sprzeciwie, gdyż jeszcze w książce mojej wyrażałem zdanie, że druga obserwacja, skoro jej Biskupi żądają -powinna się odbyć. Wobec tego jednak, że jak widzę z listu p[ana] Dąbrowskiego, Wasza Eminencja raczył się tym zainteresować, pozwalam sobie przesłać odpis mojego listu do p[ana] Dąbrowskiego.

Skorzystam ze sposobności, aby Waszej Eminencji osobne jeszcze wyrazić podziękowanie za klasyczny wprost komentarz do ustaw synodalnych ${ }^{585}$, który ujmuje najważniejsze nasze problemy. Dopiero teraz zapoznaję się z treścią tego listu lepiej i widzę, jak szerokie są, a zarazem jak realne i aktualne problemy w nim poruszone.

Całuję pierścień Waszej Eminencji i łączę wyrazy najgłębszej czci

† Teodorowicz

\section{[Załącznik nr 1: List abp. Józefa Teodorowicza do prof. Stefana Dąbrowskiego ${ }^{586}$ ]}

Lwów, dnia 17 marca 1938 r.

Kochany Panie Profesorze,

Bardzo dziękuję Panu Profesorowi za list Pański, który mi sprawił bardzo dużą pociechę. Bo nareszcie nie różnimy się właściwie w naszym stanowisku zasadniczym wcale.

Panu Profesorowi zależy całkiem słusznie na tym, aby Teresa Neumann była poddana obserwacji dlatego, że żądają tego Biskupi i domaga się Kongregacja.

Lecz ja w mej książce, a więc przed dwoma laty, pisałem to samo i robiłem starania, by druga obserwacja przyszła do skutku, właśnie dlatego, że tego sobie życzyli XX. Biskupi. Takie same stanowisko już jest zajęte przeze mnie w tej nowej pracy. W szczególności wspominam o projekcie Pana Profesora szklanego domu.

Tak samo nie będę o to kopii kruszył, jak długa ma trwać ta obserwacja - czy 2 tygodnie, czy jak tego żąda Deutsch - miesiąc. Z tego względu nie mam nic przeciw, jeśli Pan Profesor wyrazi - jak Hohn ${ }^{587}$ to czyni - potrzebę nowej obserwacji.

Tak samo zaznaczył Pan Profesor w swej pracy różnicę zasadniczą pomiędzy samą obserwacją, która wystarczy dla stwierdzenia, iż nie ma oszustwa, a klinicznymi zabiegami. Dzięki właśnie temu rozróżnieniu zgadzam się na to, aby prawie cała praca Pana Profesora była umieszczona. Prosiłem tylko o skreślenie ostatniego ustępu, który wywołuje u czytelnika wrażenie, że cały problem obserwacji polega na klinicznych

\footnotetext{
${ }^{584}$ Nawiązanie do postulatu ponownych badań medycznych Teresy Neumann.

${ }^{585}$ Orędzie Episkopatu Polski w sprawie uchwat I Plenarnego Synodu Polskiego, Warszawa 1 I 1938, w: Uchwaty I Plenarnego Synodu w Polsce odbytego w Częstochowie w dniach 26-28 VIII 1936 oraz orędzie Episkopatu Polskiego w sprawie uchwat Synodu, Poznań 1938, s. 3-28.

${ }_{586}$ Zob. w niniejszej publikacji: J. Wołczański, Korespondencja abp. Józefa Teodorowicza z prof. Stefanem Dąbrowskim, dokument 57.

587 Osoba niezidentyfikowana.
} 
zabiegach. Ten ustęp przyczynić się mógł tylko do tego, że Neumann córki swej pod obserwację nie odda. Nikt bowiem nie ma prawa narzucać klinicznych zabiegów, a on się zastrzegł przeciw temu.

Ja nie mówię o tym, o czym pisałem Panu Profesorowi poprzednio, tj. o zasadniczym stanowisku Kościoła w tym względzie zawartym w aktach i bullach kanonizacyjnych. Pomijając już inne względy, byłaby dla mnie ogromna szkoda, gdyby Pan Profesor sam swojej pracy nie podpisał, nie tylko ze względu na samą pracę i jej wartość, lecz zależało mi bardzo, by imię Pana Profesora w Niemczech jako uczonego zabłysło. Prosiłem Pana Profesora o Jego udział i rzeczywiście praca Pana Profesora - wedle orzeczenia Prof. Koskowskiego ${ }^{588}$ - jest znakomitą.

Dodam tu jeszcze i to, że powoływanie się na Dr. Ewalda, iż ma słuszność nie odpowiada stanowisku, jakie Dr Ewald zajął. Bo racje Dr. Ewalda są zupełnie inne niż racje Pana Profesora. Ewald nie apeluje do nowych klinicznych zabiegów. Ale to już drobiazg, którego dotykam mimochodem. Dlatego sądziłem, że Pan Profesor może ogólnie zaznaczyć, bo tego domagają się Biskupi i żądać, by to Überwachung odbyło się w takich warunkach, jakie dzisiaj nauka za najlepsze przewiduje, tj. w szklanym domu.

O nowych zabiegach można by pisać z zastrzeżeniami, aby uchylić niejasność i nieścisłość, iż one dla samej obserwacji nie są konieczne, lecz mogą posłużyć dla zaspokojenia ciekawości lekarskiej. To zresztą wynika z założenia Pana Profesora.

Dziękuję Panu Profesorowi i Pani za słowa tak łaskawe, a dla mnie tak cenne o moich przemówieniach $^{589}$. Zastosuję się też do życzenia Pana Profesora i w następnym przemówieniu, odpowiada mi to bardzo. A ta lekkomyślność, z jaką się u nas traktuje zabór Austrii ${ }^{590}$, a usadowienie się w środkowej Europie Niemiec, jest wprost nie do pojęcia! Trzeba istotnie zaślepienia takiego organizmu Związku Ludowo-Narodowego, ażeby Niemcom dostarczać materiału dla usprawiedliwiania ich gwałtu, który dziś spotyka Austrię, a jutro się na nas zamierzy. Polska staje się obecnie zupełnie osamotniona: $\mathrm{z}$ jednej strony Niemcy, z drugiej strony przez nich popierana Ukraina, tam znów Litwa wroga, w końcu Rosja. I w takich to warunkach obóz narodowy pieje prawie peany w cześć hitleryzmu.

Będę bardzo zobowiązany Panu Profesorowi, jeżeli zechce ostatecznie rozstrzygnąć całą sprawę z manuskryptem. Już trzeci urgens dostaję z Niemiec, gdzie mi piszą, że dalej czekać nie mogą, gdyż sprawa przestanie być zupełnie aktualną.

Łączę dla Państwa moje bardzo serdeczne pozdrowienia i zawsze oddane wyrazy mej czci głębokiej.

${ }^{588}$ Zob. w niniejszej publikacji: J. Wołczański, Korespondencja abp. Józefa Teodorowicza z abp. Andrzejem Szeptyckim, dokument 34.

589 Aluzja do rekolekcji radiowych abp. Teodorowicza głoszonych wiosną $1938 \mathrm{r}$.

${ }^{590}$ Nawiązanie do aneksji - tzw. Anschlussu Austrii, dokonanego 12-13 III 1938 r. przez III Rzeszę. 


\section{Dokument 313}

Kopia: AFKDOPW, teczka 135: Spuścizna abp. Józefa Teodorowicza, sygn. 386/90 [5], List abp. Józefa Teodorowicza do Wydawnictwa Antona Pusteta, Lwów 26 III 1938 r.

Lwów, 26.III.1938

Hochverehrter ${ }^{\mathrm{a}}$ Herr,

Eben bekomme ich Ihre Schrift vom 15.II. [[aufenden] J[ahres] aus der ich vernehme, dass einer amerikanische resp. englische Übersetzung meines Buches zustande gekommen ist. Ich wuste nichts davon, dass eine Übersetzung ins Englische überhaupt in Aussicht gewesen ist. Zwar haben się das Recht nach unserem Vertrage über eine neue Übersetzung zu befügen aber ich hätte in diesem Falle speciell gewünscht in Kenntnis gesetz zu werden und zwar in Verbindung mit dem Briefe den ich an się am 11.II.1937 gerichtet habe. Jestz stehe ich vor einer vollzogenen Tatsache, die sich nicht rückgängig machen kann, ich bitte Się aber mir Näheres über den einentlichen Sachverhalt berichten zu wollen.

Ich zeichne achtungsvoll.

P.T.

Verlag Anton Pustet

Salzburg

Sigmund Hofnergasse 18

Österreich

\section{Dokument 314}

Kopia: AFKDOPW, teczka 135: Spuścizna abp. Józefa Teodorowicza, sygn. 385/90 [5], List abp. Józefa Teodorowicza do Wydawnictwa Antona Pusteta, Lwów 4 IV 1938 r.

Lwów, den 4.IV.1938 r.

Hochverehrter ${ }^{\mathrm{a}}$ Herr,

Nachdem ich auf meinen an Się gerichteten Brief von 26.II.I[aufenden] J[ahres] nach keine Antwort erhielt, bitte ich Sie nochmals mich gefälligst in Kentniss setzen zu wollen, ob die englische Übersetzung meines Buches „Konnersreuth” bereits erschienen ist. Falls dies geschah ersuche ich Sie höflichst mir die gebürende Anzahl der Autorenexemplare zukommen zu lassen.

Hochachtungsvoll.

An den werten Verlag

Anton Pustet

SALZBURG

Simund Hafnergasse 18

a Tekst pisany maszynowo na jednej stronicy papieru. Brak autografu autora pisma.

a Tekst pisany maszynowo na jedenj stronicy papieru formatu A4. Brak autografu autora pisma. 


\section{Dokument 315}

Kopia: AFKDOPW, teczka 138: Spuścizna abp. Józefa Teodorowicza, sygn. 362/89 [5], List z Sekretariatu abp. Józefa Teodorowicza do Wydawnictwa i Drukarni Badenia w Karlsruhe, Lwów 1 IX 1938 r.

Lwów, 1 IX 1938

An den werten Verlag „Badenia“

Karlsruhe, Steinstraße 21

Hochgeehrter ${ }^{\mathrm{a}}$ Herr,

Ich bin besorgt, was eigentlich in Betreff der Herausgabe des Buches über Konnersreuth vorgeht? Das Manuskript wurde an den Herrn Mut verschickt, aber er schreibt gar nichts, er hat nicht einmal berichtet, ob er das Manuskript bekommen hat. Ich fürchte, ob ihm nichts etwas passierte und deshalb auf jeden Fall wende ich mich direkt an Sie. Stilistisch wären nur diejenigen Stellen zu verbessern, welche im Maschinendruck gestrichen sind. Da Dr. Radlo jetzt mehrere Tage in Konnersreuth gewesen ist, so wäre es gut im Vorwort noch den Passus hinzufügen.

"Ich bin mehrere Tage in Konnersreuth gewesen, und ich habe mit Erlaubnis der Familie und Therese N[eumann] die Untersuchungen vom medizinischen Standpunkt geführt". Da die Arbeit Dr. Hyneks in kurzer Zeit erscheint, so bitte die Stellen im Briefe wo diese Arbeit zitiert wird, genau anzuführen.

Im Vorwort soll noch informiert werden, dass die Antwort auf die letzte Publikation Dr. Deutsch „Ärztliche Kritik an Konnersreuth“591 separat erscheinen wird. Wären Sie bereit die Antwort auf diese Publikation im Druck veröffentlichen? Diese Antwort ist schon bereits im Manuskript fertig. Bitte mich jedenfalls benachrichtigen zu wollen.

Ich verbleibe mit dem Ausdruck meiner tiefen Hochachtung

Das Sekretariat des Erzbischofs Teodorowicz Lwów

Armeniergasse Nr 7

\section{Dokument 316}

Oryg.: AFKDOPW, bsygn., teczka: Spuścizna abp. Józefa Teodorowicza, List abp. Józefa Teodorowicza do niezidentyfikowanej osoby, bmr.

Przezacny ${ }^{a}$ Panie Prezesie!

Udano się do mnie z Niemiec z prośbą gorącą, ażebym poruszył prywatnie i poufnie w poselstwie polskim w Berlinie sprawę dr. Gerlicha. Otóż przede wszystkim poinformuję Pana Prezesa, o co tu idzie.

\footnotetext{
a Tekst pisany maszynowo na jednej stronicy papieru formatu A4. Brak autografu autora.

${ }^{591}$ J. Deutsch, Ärztliche Kritik an Konnersreuth! Wunder oder Hysterie?, Lippstadt 1938.

a Tekst pisany maszynowo na trzech stronicach papieru formatu A4. Brak zakończenia, datacji, autografu autora pisma.
} 
Dr Gerlich był dawniej redaktorem wielkiego dziennika monachijskiego „Münchener Nachrichten"; w ostatnich czasach redagował tygodnik, który się rozchodził w dziesiątkach tysięcy egzemplarzy. Ten tygodnik był w najbliższym czuciu z ówczesnym rządem monachijskim i jego ostrze było zwrócone przeciwko hitleryzmowi. $\mathrm{Z}$ drugiej atoli strony w tym samym tygodniku prowadził dr Gerlich niesłychanie szeroko zakrojoną i bardzo skuteczną kampanię z bolszewizmem rosyjskim; udało mu się bowiem jakąś tajemną drogą mieć korespondentów w Bolszewii poinformowanych dobrze o ruchu w Rosji jak żadne pismo inne.

Tu dodaję dodatkowo jeden szczegół. Gerlich był kalwinem i człowiekiem zupełnie niewierzącym. Pojechał do Konnersreuth ażeby, jak mówił, zdemaskować oszustwo katolickie. Tymczasem bliższe badania zjawisk w Konnersreuth przyprowadziły go do wiary i dr Gerlich przeszedł na katolicyzm i stał się jego gorącym wyznawcą. Takim go poznałem, gdy przed dwoma laty odwiedziłem go w Monachium. Jest to człowiek niepospolity tak pod względem umysłu, jak i charakteru.

Przewrót hitlerowski wywarł w pierwszym rzędzie na nim całą swoją zemstę. Napadnięto go w domu, pobito do utraty przytomności, wybito mu jedno oko, drugie zaś ma zagrożone i wtrącono do więzienia, w którym po dziś dzień przebywa, mimo iż mu obiecano wolność za złożenie przyrzeczenia, że z hitleryzmem więcej walczyć nie będzie. Przyrzeczenie to złożył, ale wolności nie otrzymał. I właśnie pisze do mnie jego przyjaciel dr Wutz, że stan zdrowia dr. Gerlicha jest dziś tak opłakany, że jeśliby jeszcze ten rok musiał pozostać w więzieniu, to tego stanowczo nie przeżyje. Stąd rozpaczliwa prośba dr. Wutza skierowana do mnie.

Jakkolwiek bardzo pragnąłbym pomóc temu nieszczęśliwemu a prawdziwie bohaterskiemu człowiekowi, to jednak ja wcale nie znam pana Lipskiego ${ }^{592}$, a nadto nie wiem, czy by w ogóle pan Lipski mógł tę sprawę poruszyć w ten sposób, ażeby na siebie nie ściągnąć pozorów, iż się miesza do spraw wewnętrznych Niemiec. Może by to mogło nastąpić w formie, w której by wyraził pan Lipski albo kto[ś] inny pewne zdziwienie, że człowiek tak zasłużony w zwalczaniu bolszewizmu rosyjskiego jeszcze cierpi w więzieniu, skoro przecie[ż] dalszych ataków jego na hitleryzm obawiać się już nie potrzeba, każdej bowiem chwili mógłby on być zamknięty, a zresztą z upadkiem dawnego rządu monachijskiego usunęły się wszelkie podstawy dla podobnej propagandy.

Czy taka forma jednak byłaby możliwa - tego ja nie wiem; przyszło mi na myśl, że czasem mniej urzędowa forma może być tylko skuteczniejsza w podobnych wypadkach, w których się nie ma właściwie żadnego punktu zaczepienia. I tu mi przyszło na myśl zwrócić się do Pana w tej sprawie. Czy by Pan Prezes nie uważał za stosowne rzucić gdzieś w kołach wpływowych niemieckich czy za pobytu w Berlinie, czy teraz w Warszawie podobne zdziwione pytanie: czym się to tłumaczy, że człowiek tak szeroko znany

${ }^{592}$ Lipski Józef (1894-1958), od 1919 r. w polskiej służbie dyplomatycznej: 1919-1922 sekretarz legacyjny Poselstwa RP w Londynie, później na tym samym stanowisku w Paryżu i Berlinie, w 1933 r. mianowany posłem nadzwyczajnym i ministrem pełnomocnym w Berlinie, 1934-1939 ambasador RP w Berlinie, 19391940 żołnierz WP we Francji, 1940-1946 w sztabie Naczelnego Wodza w Londynie, po 1945 r. przedstawiciel rządu emigracyjnego w USA. Lipski Józef, w: Kto byt kim, s. 102. 
dotąd zostaje w więzieniu mimo swych wielkich i niezaprzeczonych zalet $\mathrm{w}$ zwalczaniu bolszewizmu? Byłby to rodzaj jakby zawstydzenia niemców $w^{\mathrm{b}}$, które czasem silniej działa jak argumenty polityczne. A może i za widzeniem się z panem Lipskim mógłby Pan Prezes w jakiejś formie tę sprawę przedstawić?

Katolickie Niemcy byłyby niesłychanie wdzięczne za to i zobowiązane Panu Prezesowi, i rządowi polskiemu; potrzeba bowiem wiedzieć, że sprawa aresztowania dr. Gerlicha wywarła w kołach austriackich tak ogromne wrażenie, iż jak mi niemcy mówili, ona stała się powodem, że w pierwszych zaraz chwilach ruchu hitlerowskiego odwrócono się od Niemiec. Taki bowiem krwawy i brutalny napad na człowieka bądź co bądź zasłużonego dawał miarę charakteru.

\section{Dokument 317}

Kopia: AFKDOPW, teczka 137: Spuścizna abp. Józefa Teodorowicza, bsygn., Nota tegoż.

Jeszcze ${ }^{a}$ słówko pro domo sua ${ }^{593}$. Dotykam jeszcze rzeczy zupełnie prywatnej i osobistej związanej z publikacją moich artykułów o książce O. Siwka. Oto z kół zbliżonych do O. Siwka rozpuszczane były i są po dziś dzień wiadomości w tym duchu, jakoby ja do mej krytyki starał się wyciągnąć nieomal w podstępny sposób na zwierzenia O. Siwka, które następnie wykorzystałem dla krytyki. Z góry się zastrzegam, że nie winię w tej mierze o nie O. Siwka nie mając do tego realnej podstawy, mimo, że autorowie rozpuszczanych wieści nie [na] O. Siwka, tylko na inne źródło się powołują. Natomiast wiadomości te powtarzane i rozpowszechniane uporczywie w jakiejś niepochwytnej formie dotykają mnie osobiście i dlatego muszę je raz wyjaśnić.

Kontakt z O. Siwkiem w sprawie Konnersreuth miałem dwukrotny: raz osobisty, a drugim razem pisemny. Pierwszy raz zetknąłem się z O. Siwkiem [... $]^{\mathrm{b}}$ w Krakowie, gdy miałem odczyty o Konnersreuth i wtedy pragnąłem się dowiedzieć szczegółów związanych z tą sprawą u O. Siwka, tak jak to czynię z reguły z ludźmi, którzy dla swej wiedzy zawodowej mogą jakieś światło na tę sprawę rzucić. Ojciec Siwek uznał jednak za stosowne zająć [stanowisko] wobec mych pytań w szczególności odnoszących się do jego sądu o Konnersreuth wymijające i pełne rezerwy, czego mu zresztą zupełnie za złe nie mam. Tylko nie mogłem mieć żadnego ukrytego planu, by wyciągnąć O. Siwka na coś takiego, z czego bym dla krytyki jego książki mógł skorzystać z tej prostej przyczyny, że O. Siwek ukrył przede mną w ogóle, że ma zamiar cokolwiek pisać o Konnersreuth, mimo że w parę miesięcy zaczął publikować swe artykuły w „Przeglądzie powszechnym"594 i gotował pracę, która uprzedzała ukazanie się mej pracy. Nie myślę wchodzić w moralną stronę tego stanowiska, tylko stwierdzam fakty, które wykluczały z góry

\footnotetext{
b Forma zgodna z oryginałem.

a Tekst pisany czarnym atramentem ręką abp. J. Teodorowicza na dwóch stronicach papieru formatu A4. Brak miejsca wystawienia dokumentu, autografu autora i datacji.

${ }^{593}$ Łac.: we własnej sprawie.

b Dwa wyrazy nieczytelne.

594 Właściwie: „Przeglądzie Powszechnym”.
} 
przemyślanie z mej strony o odpowiedzi na książkę o której „poczęciu się” nic w ogóle nie wiedziałem.

Drugi mój kontakt listowny datuje się z czasu, kiedy już po napisaniu mej odpowiedzi na książkę O. Siwka tuż przed wysłaniem mej pracy do druku powiedziałem o tej krytyce mojej O. Siwkowi. Po wywiązanej stąd korespondencji w jednym ze swych listów Ojciec Siwek, nawiasem dodam zupełnie przeze mnie o to nie pytany i nie proszony, sam sua sponte ${ }^{595}$ napisał mi, że w swej książce mistyki nie używał, gdyż to by było petitio principi ${ }^{596}$. Otóż ten szczegół był świetnym potwierdzeniem z ust autora całej mojej analizy wówczas już gotowej i skończonej. Bo sam autor przyznał się do odważnego zarzutu w mej pracy, iż pisząc swoją książkę mistyki nie uwzględnił. To oryginalne wyznanie byłoby wtedy tylko do wykorzystania, gdyby cała książka nie była sama przez się żywym na to dowodem. Oczywiście szczegół ten cały zachowałem w zupełnej dyskrecji. Ale jeden szczegół zawdzięczam autorowi. Oto jego próbę uzasadnienia, że posługiwanie się mistyką stwarza petitio principi. Na taki pomysł byłbym istotnie sam nigdy nie wpadł i argument ten zbiłem w mej pracy ale w ten sposób, że nikt się nie mógł domyśleć, kto w ten sposób rzecz postawił. Dziś dopiero to czynię, gdy zmuszony jestem wyjąć z rezerwy dla wyjaśnienia tej przykrej osobistej sprawy i obronienia się przed niepochwytnymi argumentami wkraczającymi na dziedzinę moralną. Skoro już do tego zostałem sprowadzony, że się na rzeczy powołać muszę, które chciałem utrzymać w ukryciu, to pozostaje mi zapytanie skierowane do Ojca Siwka. Na co się zdadzą wszelkie wywody Ojca, skoro sedno mej pracy, samo jej założenie i przeprowadzenie jest potwierdzone nie tylko przez książkę, ale i przez własne słowa i własne wyznanie autora? Nie potrzebuję chyba nic więcej uczynić jak wszystkim wywodom autora przeciwstawić jego własne słowa.

\section{Dokument 318}

Oryg.: AFKDOPW, bsygn., teczka: Spuścizna abp. Józefa Teodorowicza, Nota nieznanego autora, bmr.

Ks. S[iwek] zarzuca, że nigdzie nie mówi o polepszeniu w chorobie: U[waga:] str. 99100. Dowód: bo mówi we futurum $^{597}$. Resp[onsum ${ }^{598}$ : Kontekst jest tak niejasny i niezdarny, że czytający de facto rozumie na str. 140 (Konnersreuth) futurum jako futurum historicum ${ }^{599}$.

Dowód: na str. 139 mowa jest we fut[urum], a odnosi się do przeszłości. Na str. 141 mówi o przyspieszeniu uzdrowienia... przez dodanie emocji, która by resztki emocji...

595 Łac.: z własnej woli.

596 Łac.: błąd niedostatecznego uzasadnienia.

a Tekst pisany czarnym atramentem, ale nie ręką abp. J. Teodorowicza na pięciu stronicach formatu zeszytowego. Brak datacji i autografu autora.

597 Łac.: czas przyszły.

598 Łac.: odpowiedź.

599 Łac.: czas przyszły historyczny. 
etc. „Nie będzie to”... znów we futur[um], a potem, jako o fakcie przeszłym: „Tę emocję... otrzymała Teresa”.

W książce „Metody badań” poruszone są kryteria teologiczne (głównie moralne); wzięta razem z pierwszą pracą daje pewną całość, którą by zatytułować można: „K[onnersreuth] w świetle nauki i religii”.

Uciekanie się w ostatniej pracy do kryteriów moralnych jest najlepszym dowodem, że pierwsza praca była niekompletna i że uwagi „At[eneum] Kapł[ańskiego]” są słuszne.

Przesłanki jednak dane w obydwu pracach uprawniałyby już do wniosku niekorzystnego na rzecz Teresy N[eumann], a nie do zawieszenia sądu. Pewna więc dysproporcja między przesłankami a wnioskiem non constat. Kryteria moralne ujemnie świadczą. U[wagi] str. 87 i nast[ępne].

Ks. S[iwek] mówi, że gratiae gratis datae ${ }^{600}$ mogą posiadać i źli ludzie. R[esponsum:] To jest możliwe, ale sam autor zaznaczył, że nikt nie buduje na samej tylko możliwości str. 86. Na ogół gratia sanctificans i gratia gratis data idą w parze, nie ma między nimi związku ontologicznego jak np. między łaską poświęcającą a cnotami nadprzyr[odzonymi] albo darami Ducha św., ale jest łączność moralna. Gdyby Bóg dał grzesznikowi taką łaskę darmo daną, ten mógłby jej nadużyć; Bóg non proscit margaritas ante porcos ${ }^{601}$. Gratia datis data jest łaską społeczną w życiu Kościoła i Bóg daje ją na ogół tylko tym, którzy w tym Kościele żywym przez łaskę poświęcającą zajmują wysokie stanowisko (w znacz[eniu] duchowym).

Nie zawsze możemy mieć pewność metafizyczną lub fizyczną, że dane zjawisko przewyższa siły natury. Często musimy się zadowolić pewnością moralną. „Haec atributo intrinsece moralis corroborari potest metaphysice ex consideratione attributorum Dei, attenda scilicet infinita Dei bonitate, sapientia, veracitate, providentia, cui omnes circumstantiae subjacent. Cum enim omnes circumstantione tam physicae quam morales sunt in faworem miraculi, si in hoc casu esset tantum apparens Miraculum ex fallacia daemonis, Deus permitteret; nos invincibiliter induci in errorem contra id quod Ipsi debemus et est necessarium nostrae saluti”. G[arigou]-Lagrange, „De Revelatione”, Romae 1925, p. 357-[358].

Gdzie logika u Ks. Siwka?

a) Zarzucał on, że T[eresa] N[eumann] nie jest pokorna, bo pokazuje stygmaty.

b) Trudność została usunięta uwagą w „At[eneum] Kapł[ańskim]”, że T[eresa] N[eumann] nie pokazuje stygm[atów], bo stygmaty na rękach są widoczne, [a] innych stygmatów nie pokazuje.

c) Na to odp[owiada] Ks. Siwek: „Jeszcze by tego potrzeba, by pokazywała innym stygmat boku!" str. 86.

Ks. Siwek dowodzi, że niektórzy się gorszą z T[eresy] N[eumann]. Czy i z Pana Jezusa nie gorszyli się ludzie?

${ }^{600}$ Łac.: łaski darmo dane.

${ }^{601}$ Łac.: Bóg nie rzuca pereł przed świnie. 


\section{Dokument 319}

Kopia: AFKDOPW, teczka 140: Spuścizna abp. Józefa Teodorowicza, sygn. 858/262 [7], Fragmenty tekstów o. Aloisego Magera OSB., o. Reginalda Garrigou-Lagrange OP i o. C. Richtstättera SJ dotyczących kwestii Teresy Neumann, bmr.

\section{Copie $^{\mathrm{a}}$}

1) Dom Alois Mager OSB, Doyen de la Faculté de Théologie de Salzbourg (voir „Etudes Carmélitaines” octobre 1936, p. 154/55/56 passim)

[...] Notons tout d'abord que le livre de Monseigneur Teodorovicz prend une place à part dans la littérature sur Konnersreuth. Non seulement l'auteur aborde la question d'un point de vue nouveau - le seul exact à mon avis - mais il le traite avec une connaissance personnelle approfondie de Thérèse et de son milieu. Puis, il tient largement compte de l'opinion des adversaires et évite soigneusement toute polémique personnelle [...].

En félicitant l'auteur, nous devons le remercier de nous avoir communiqué ses expériences. Elles embrassent dans son ensemble toute la personnalité religieuse de Thérèse Neumann d'une façon attirante. On ne pourra s'en passer quand on voudra étudier à fond la question de Konnersreuth. En traçant de la Stigmatisée une image sympathique, l'auteur ne refuse pas, avec autoritarisme, d'avoir égard aux opinions contraires. Il reste bien objectif et, avec son caractère affable, ne trahit même pas le nom de son principal adversaire. Ceci ne l'engagea pas dans la controverse.

Le livre de l' archeveque de Lemberg est sans doute un sommet dans la littérature de Konnersreuth.

\section{2) Lettre du $R$ [évérend] $P$ [ère] Reginalda Garrigou-Lagrange adressée à Msgr.} Teodorovicz (passim)

Depuis plusieurs jours je veux vous remercier du beau livre que vous m'avez fait l'honneur de m'adresser sur Th[hérèse] Neumann de Konnersreuth. Je ne lis pas assez facilement l' allemand pour bien m' en rendre compte, mais je l'ai fait lire autour de moi en particulier par notre P[ater] Prieur le P[ater] J. Peters ${ }^{602}$, Hollandais, et par le Recteur de l' Angelico qui en sont très contents. Ce dernier me prie même de vous proposer d'en faire faire une traduction anglaise par une personne de sa connaissance.

Monseigneur, vous étudiez le cas depuis de longues années, avec le concours de bons médecins, professeurs de l'Université; je me rappelle ce que vous m'en disiez à Salzbourg, quand je vous y ai rencontré. J'espère aussi que votre livre, Evcellence, apporte

\footnotetext{
a Tekst pisany maszynowo na 1,5 stronicy papieru formatu A4. Brak miejsca wystawienia dokumentu i datacji.

${ }^{602}$ Osoba niezidentyfikowana.
} 
une vraie lumière malgré certaines objections qui continuent. Ces saintes personnes sont discutées jusqu'à la mort, en cela aussi elles sont configurées à Notre Seigneur.

\section{3) Extrait d'une lettre du R[évérend] P[ère] C. Richtstätter SJ}

Euer Exzellenz haben mir die Ehre erwiesen Namen in dem grossen un eingehendem Worke über Konnersreuth zu ersühnen, worin die dortigen Probleme mit so grosser Belesenheit von so vielen Seiten eine neue Beleuchtung erfahren.

\section{Dokument 320}

Kopia: AFKDOPW, teczka 135: Spuścizna abp. Józefa Teodorowicza, sygn. 1783/61 [5], List abp. Józefa Teodorowicza do prof. Georga Wunderle, bmr.

\section{Hochverehrter ${ }^{a}$ Herr Professor,}

Ich danke Ihnen für Ihren Brief und bitte meine Verzögerung in der Antwort dadurch rechtfertigen zu wollen, dass ich im Kurort Erschöpfung halber verweile und mir die Ärzte erst jetzt gestatteten längere Briefe zu schreiben.

Ich danke Ihnen für ihren Brief nicht nur deshalb, weil Sie mein Buch, trotz Ihrer Einstellung zu Konnersreuth, im Allgemeinen wohlwollend beurteilen, aber auch speziell deshalb, weil Sie so aufrichtig und offenherzig mir Ihre Einwendungen vorstellen.

Ich glaube jedoch, dass nach näherer Prüfung in den von Ihnen aufgezeichneten Punkten und Einwendungen sich so manches klären liesse.

\section{Christus Orakel}

Sie schreiben mir in Ihrem werten Briefe: „Ich muss offen gestehen, dass ich das Christus Orakel für nicht genügend erklärt halte. ... Übrigens ist das Christus - Orakel auch so gemeint gewesen, dass der Heiland über unmögliche Kleinlichkeiten und andere unzugängliche Dinge (z[um] B[eispiel] das Schicksal der Verstorbenen) Auskunft erteilt. Das ist für mich eine theologische Unmöglichkeit“.

Aber für mich ist es ebenfalls so. Und in dieser Hinsicht bin ich mit Ihnen völlig einverstanden. Sie finden aber in einem Buche Stellen, wo ich betreff der Fehlbarkeit Thereses mich länger mit denjenigen auseinandersetze, die den Aussagen Thereses die Unfehlbarkeit zuschreiben, und auf die Gefahr einer derartigen Deutung, die mit der mystischen Theologie nicht vereinbar ist, hinweise.

Ich unterscheide jedoch zwischen denjenigen, die diese Erscheinungen falsch deuten und zwischen Therese Neumann selbst, die für den diesbezüglichen Missbrauch nicht verantwortlich ist, da die Art und Weise ihrer Aussagen keineswegs die Möglichkeit einer derartigen Deutung berechtigt, ja eine derartige Deutung geradezu ausschliesst. Ich habe Beweise geliefert, das Therese Neumann weder im normalen noch im extatischen

a Tekst pisany maszynowo na trzech stronicach papieru formatu A4. Brak zakończenia, autografu autora i datacji. 
Zustande sich überhaupt und am wenigsten als Orakel Christi erachte und in der Extase spreche ich im Besonderen vom Erlöser in der dritten Person. Dieser Umstand bringt den entscheidenden Beweis dafür, dass es nicht der Heiland ist, der durch sie spreche, denn sie müsste dann das „ich“ für sich in Anspruch nehmen. Dies ist der einzige, jedoch essentionelle Beweis und darüber hinaus kann man ja nichts mehr sagen und braucht auch nichts mehr zu sagen für die endgültige Beweisführung.

Sie schreiben mir Herr Professor: „Bezüglich der Stigmatisation habe ich jüngst unter der Zustimmung der Anwesenden (auch P[ater] Thibon ${ }^{603}$ war dabei) die Möglichkeit einer natürlichen Stigmatisation (natürlich nicht bloss als Artefakt verteidigt und an den mir persönlich bekannten Fall Dr. Lechlers Bezug genommen“.

Ich habe jedoch (S. 287) deutlich angemerkt: „Indem ich die beiden Meinungen für und gegen die Möglichkeit einer natürlichen Stigmatisation anführe, entscheide ich nicht weder für die eine noch für die andere .... ."

Sie schreiben weiter: „Die Darstellung Eurer Exzellenz von diesem Falle (d.h. von Lechlers Falle) ist im Wesentlichen unzutreffend, wie ich es aus eigener persönlichen Beschäftigung und Anschauung erklären muss".

Aber ich habe mich in die Darstellung dieses Falles gar nicht eingelassen. Weder habe ich die Wahrheit desselben befürwortet, noch auch die Wahrheit desselben bestritten. Ich habe ja geschrieben: „Wäre der von Lechler angeführte Fall untrüglich sicher, dann könnte man von einem gut gelungenen Experimente sprechen. Ich habe dem Dr. Lechler einzig den Vorwurf gemacht, dass er in seiner Untersuchung die Anwendung jener Massregeln unterliess, die zur Beglaubigung eben dieses Falles unumgänglich notwendig sind.

Was das Urteil über Lechlers Fall anbelangt, so zitiere ich S. 304 Thibon und S. 310 Dr. Witry, von dem ich noch einen Privatbrief bekam, in welchem er mir folgendes über Urteil eines bekannten, völlig materialistisch eingestellten Arztes, mitteilt: „Ich weiss nicht, ob ich Ihnen berichtet habe, dass Dr. N. vor zwei Jahren bei uns in Metz zu Besuche war. Er erzählte und eingehend seine Reise zu Dr. Lechler, wo er unter allen Kautelen die Elisabeth $\mathrm{X}$ untersuchen wollte, aber er fand nur mala fides und artifiziell hervorgerufene Stigmen bei ihr".

Dieser erklärte mir (wie es im Buche S. 310 steht) dass „Dr. Lechler, der übrigens die Anstalt Lebenswende verlassen hat, das Opfer einer Mystifikation und eines Betruges geworden ist".

\section{S p r a c h e}

Sie schreiben weiter: „Ich kann die Darstellung E.E. nicht als Lösung meiner auf S. 497 zitierten Zweifels ansehen. Es handelt sich darum die allerersten Besprechungen zwischen Therese Neumann und Prof. Wutz zu erfassen".

Aber zu den Zeugnissen Prof. Wutzens selbst müssen noch die des Professors Mayr hinzugefügt werden, der bei ersten Besprechungen zugegen gewesen und mich

${ }^{603}$ Zob. w niniejszej publikacji: J. Wołczański, Korespondencja abp. Józefa Teodorowicza z bp. Henrykiem Przeździeckim, dokument 10. 
eingehend darüber unterrichtete (siehe S. 492) und die Gerlichs, der diese ersten Gespräche stenographisch aufnahm.

$\mathrm{Zu}$ der Feststellung, dass ihr Aramäisches sich von den Prof. Wutzens und anderer Gelehrter unterscheide, kommt noch der von mir auf S. 497 besprochene Fall. Dieser Fall schliesst jegliche Möglichkeit einer Suggestion auch für alle anderen Fälle aus.

$\mathrm{N}$ ahrungs losigkeit

Sie schreiben: „Natürlich kann ich auch heute noch nicht von dem Wunsche abstehen die Nahrungslosigkeit möglichst exakt untersuchen zu lassen. Ich habe immer betont, dass ich bei dieser Untersuchung keinerlei Quälerei zulassen werde“. Ich unterschreibe Wort für Wort diese These, sie ist durchaus richtig aufgefasst und ist in meinen Erörterungen inbegriffen.

\section{Dokument 321}

Oryg.: AFKDOPW, teczka 138: Spuścizna abp. Józefa Teodorowicza, sygn. 1796/61 [5], List z redakcji „Konnersrether Sonntagsblatt” do abp. Józefa Teodorowicza, Waldsassen, 4 II br.

Waldsassen (Bayer. Ostmark.), den 4. Februar

S[eine]r Exzellenz

dem Hochwürdigsten Herrn

Erzbischof Dr. Teodorowicz

Lemberg

$\mathrm{Eu}[\mathrm{re}]^{\mathrm{a}}$ Exzellenz!

In letzter Zeit mehren sich in Deutschland die Angriffe gegen Konnersreuth und das von Eu[re] Exzellenz verfasste Werk „Konnersreuth im Lichte der Mystik und Psychologie“. Bevor wir selbstständig uns mit diesen Vorgängen befassen, wollten wir nicht versäumen, $\mathrm{Eu}[\mathrm{re}]$ Exzellenz davon in Kenntnis zu setzen und die ergebenste Frage erlauben, ob nicht $\mathrm{Eu}[\mathrm{re}]$ Exzellenz selbst dagegen Stellung nehmen wollen. Wir würden Ihnen gerne die Seiten unseres Konnersreuther Sonntagsblattes zur Verfügung stellen, wie wir auch bereit wären, falls $\mathrm{Eu}[\mathrm{re}]$ Exzellenz mit einer Gegenschrift antworten wollte, diese in unserem Verlag nehmen, da ihr dadurch von vorneherein ein grosser Leserkreis gesichert wäre.

Besonders in der Heimat Dr. Deutsch und im katholischen Rheinland bringt dieser Vorkämpfer gegen Konnersreuth grosse Beunruhigung unter die Bevölkerung, sodass wir schon von verschiedenen Seiten angegangen worden sind, dazu Stellung zu nehmen. Wir wollten aber zuerst noch uns mit Ew. Exzellenz in Verbindung setzen.

a Tekst pisany maszynowo na jednej stronicy papieru formatu A4. Brak daty rocznej. W górnej partii karty nadruk firmowy: „KONNERSREUTHER SONNTAGSBLATT, SENDBOTE DER BARMHERZIGEN LIEBE GOTTES, WOCHENSCHRIFT FÜR DIE KATHOLISCHE FAMILIE UND NACHRICHTENBLATT ÜBER DIE VORGÄNGE IN KONNERSREUTH, DRUCK UND VERLAG VON ALBERT ANGERER, VERLAGSANSTALLT, WALDSASSEN“. 
So sehen wir Eu[re] Exzellenz gefälligen Antwort entgegen und sind mit katholischem Gruss!

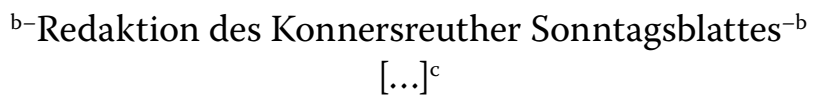

\section{Dokument 322}

Kopia: AFKDOPW, teczka 129: Spuścizna abp. Józefa Teodorowicza, sygn. 1209/420 (12) [7], List abp. Józefa Teodorowicza do ks. Fahsela w Berlinie, bmr.

\section{Hochverehrter ${ }^{\mathrm{a}}$ Herr Kaplan!}

Ich lese eben Ihr sehr interessantes Buch über Konnersreuth. Leider konnte ich es nicht bis zu Ende lesen, weil es mir der große Freund von Konnersreuth, Bischof Lisowski, weggenommen hat. Aus dem aber, was ich schon durchgelesen habe, ersehe ich, dass Sie im kurzen bündigen Abschnitt in einem verhältnismäßig nicht großem Buche ein wahres Arsenal der bisher noch nicht bekannten Tatsachen zusammen gestellt haben. Ich freue mich, dass ich in meiner Arbeit ihr Buch benutzen kann. Ich bin sehr gespannt über die Rezensionen Ihrer Arbeit. Ich wende mich aber mit einer Bitte an Sie, zu der Ihr Buch Anlass gibt. Sie zitieren das Buch Dr. Imberts ${ }^{604}$ über die Stigmatisierung, welches nicht mehr zu bekommen ist. Ich werde Ihnen somit sehr dankbar sein, wenn Sie mir diese Buch auf eine kurze Zeit ausleihen und mir „auf meine Rechnung“, was die Kosten anbelangt, übersenden könnten.

Ich verbleibe mit dem Ausdruck meiner aufrichtigsten Hochachtung.

Hochwürdiger Kaplan Fahsel

Berlin - N.W. 87

Flotovstrasse 1

\section{Dokument 323}

Oryg.: AFKDOPW, teczka 144: Spuścizna abp. Józefa Teodorowicza, sygn. 1805b/61 [5], List o. Odo Staudingera OSB do abp. Józefa Teodorowicza, bmr.

\section{Hoch[würdigster $]^{a}$ Herr Sekretär!}

\footnotetext{
b-b Podłużna pieczęć.

Autograf nieczytelny.

a Tekst pisany maszynowo na 1,5 stronicy papieru formatu A4. Brak miejsca wystawienia dokumentu, datacji oraz autografu autora.

${ }^{604}$ Osoba niezidentyfikowana.

a Tekst pisany czarnym atramentem ręką abp. J. Teodorowicza na karcie pocztowej. Brak miejsca i roku wystawienia.Na awersie podłużna pieczęć: „Abdender: P[ater] Otto Staudinger OSB, Salzburg Kolleg[ium] St. Benedikt” oraz nota czarnym atramentem: „Hochw[ürdigen] Erzbischöfl[ichen] Sekretariat, Lwów Or$\mathrm{m}$ [i]anskagasee 9, Polen“. W prawym górnym rogu firmowy znaczek z godłem Austrii, nieczytelne dwa stemple pocztowe i ślady po dwóch innych znaczkach.
} 
Meine letzten Fragen: III. Teil wird ein Gespräch mit Alois angeführt $\mathrm{u}$ [nd] als Fußnote Zj. 111-112. Was soll das heißen? War es nur mündliches Gespräch, bisher nicht gedruckt, dann konnte man die Fußnote wohl so füllen: oder „Das Gespräch fand statt im Jahre?" Richstaetter, „Der Kirchenlehrer der Mystik“, ist wohl ist wohl in „Stimmen der Zeit" 1930, Juni?

Ergebenste Grüße und Empfehlungen in Eile. Druck und Papier sind sehr gut. Exc[ellenz] möge sich freuen!

$\mathrm{P}$ [ater] Odo Staudinger OSB

\section{Dokument 324}

Kopia: AFKDOPW, teczka 137: Spuścizna abp. Józefa Teodorowicza, bsygn., List abp. Józefa Teodorowicza do nieznanego zakonnika, bmr.

\section{Hochverehrter ${ }^{\text {a }}$ Pater!}

Ich bitte Sie mir Ihre Broschüre über Konnersreuth unter meiner jetzigen Adresse gegen Postnachnahme schicken zu wollen. Es interessiert mich alles, was über Konnersreuth geschrieben wird, da ich gerade über die Stigmatisierte eine Arbeit verfasse. Aus dem Grunde werde ich dem hochwürdigen Pater für die etwaigen Winke sehr dankbar. Pfarrer Wegmann aus Wien hat mich noch dazu vor [... $]^{\mathrm{b}}$ Monaten aufgemuntert, mich an den hochwürdigen Pater in dieser Angelegenheit zu wenden. Ich wäre sogar geneigt, insoferne es mir nur die Umstände erlauben würden, entweder jetzt in der Rückreise oder spätestens im Juli Sie zu besuchen um manches persönlich zu besprechen. Bitte mir nun nur auf jede Eventualität bekannt zu geben, wann ich Sie in Salzburg treffen könnte. Für jetzt bitte ich Sie um die nähere Aufklärung in Betreff des Vortrages, den Professor Mayer in Wien während des Religionskongresses gehalten hat. Speziell interessiert mich die von Professor Mayer neu aufgerollte Reaction über [... $]^{\mathrm{c}}$.

Ich möchte gerne darüber näheres wissen und eine Anzeige über diesbezügliche Literatur besitzen. Wäre es nicht meinerseits zu viel an Sie die Bitte zu richten, mir etwas Näheres darüber berichten zu wollen? Vielleicht wird irgendwo der Vortrag des Professors gedruckt, denn die tufalls angabe, die ich im Wiener Journal gelesen habe, scheint mir mangelhaft und einseitig, vielleicht sogar tendenziös angegeben zu sein. Ich bedaure sehr, dass sich sogar im katholischen Lager ein Kampf um Konnersreuth entsponnen hat, der schon ins persönliche Gebiet hinübergeht. Ich brauche desto mehr aus dem Grunde gut orientiert zu werden, und ich vertraue darauf, dass schon aus Rücksicht auf die Sache, mir behilflich sein wird. Prinzipiell halte ich dafür, dass die Vorgänge in Konnersreuth natürlich nicht erklärlich seien, dass das gesamte Material ganz ausreichend

\footnotetext{
a Tekst pisany czarnym atramentem ręką abp. J. Teodorowicza na trzech stronicach papieru formatu zeszytowego. Brak autografu autora, miejsca wystawienia dokumentu i datacji. Tekst z tzw. kurrentschriftu przepisała Pani Gerlinde Stohl - dyrektorka Muzeum w Sierndorfie an der March (Austria), za co zechce przyjąć szczere podziękowanie.

b Brak tekstu.

c Brak tekstu.
} 
ist, um das beweisen zu können, und dass weder die Medizin noch die psychologische Philosophie ohne die Mystik im Stande seien, das Problem zu lösen. Ich habe den Eindruck, dass man auch unter den Katholiken zu viel auf die noch nicht erprobten philosophischen Probleme Rücksicht nimmt, und dieselben in das Gebiet des mystischen Lebens hineinführt, anstatt die Prinzipien der Mystik klar vor den Augen der Welt festzusetzen. Ich schreibe diese Seiten auf einer wankenden Barke und bitte mir deshalb die undeutliche Form des Briefes nicht übel zu nehmen.

Mit dem Ausdruck meiner tiefen Hochachtung.

\section{Dokument 325}

Kopia: AFKDOPW, teczka 138: Spuścizna abp. Józefa Teodorowicza, bsygn., List abp. Józefa Teodorowicza do nieznanego kardynała, bmr.

\section{Eminenz! ${ }^{\text {a }}$}

Ich danke Eurer Eminenz für den Brief, den ich eben erhalten habe. Es ist gewiss die Folge meiner Übereilung in dem Schreiben an Eure Eminenz knapp vor meiner Abreise von München, dass ich nicht alles klar zu legen vermochte, woran es mir angekommen ist, indem ich das Konnersreuthproblem mit Eurer Eminenz besprechen wollte, und wozu ich ein Stück des Manuskriptes übermittelt habe. Eben deshalb, weil das bloß ein Bruchstück meiner größeren Arbeit dieses Manuskripts gewesen ist, worin ich nur im Allgemeinen die wissenschaftliche Methoden bespreche und auch das nicht im Ganzen, habe ich gar nicht im Sinne gehabt, Eure Eminenz in irgendeiner Weise in das Urteil zu engagieren. Wie ich in meinem Briefe geschrieben habe, war es mir sehr daran gelegen, Eure Eminenz um Rat zu fragen und mit Eurer Eminenz überhaupt das Problem besprechen, und das Bruchstück des Manuskripts, welches ich schon Prüfer Seiner Exzellenz, dem Regensburger Bischof zugeschickt habe und dessen Abschrift mir mit zugefälliger Weise aufbewahrt wurde, sollte mir als die Anknüpfung für das Gespräch dienen. Da ich speziell aber auch Eure Eminenz in der Richtung interessieren wollte, da ist der Grund dessen auch darin gewesen, weil Eure Eminenz eine so klassische Erklärung über Forschungsmethoden in Betreff Konnersreuth erlassen haben, die zu meiner Orientierung diente. Aber speziell und vor allem wünschte ich es dringend, in einen Kontakt in Betreff Konnersreuth mit Eurer Eminenz und mit dem Hochw[ürdigen] Bischof von Regensburg zu kommen, weil ohne diese so wichtige Fühlungnahme ich so sehr leicht in meinem Werke manches vorbringen könnte, was den in erster Linie verantwortlichen Faktoren nicht genehm sein könnte. Und wie begründet ist mein Wunsch gewesen, davon zeugt eben der Brief Eurer Eminenz worin ich von einem, mir bisher ganz unbekannten Umstand erfahre, der so allerwichtig in Rücksicht auf meine Arbeit ist. Ich wusste zwar von der Besuchssperre in Konnersreuth, aber der

\footnotetext{
a Tekst pisany na 3,5 stronicach papieru formatu A4. Brak autografu autora, miejsca wystawienia dokumentu i datacji. Tekst z tzw. kurrentschriftu przepisała Pani Gerlinde Stohl - dyrektorka Muzeum w Sierndorfie an der March (Austria), za co zechce przyjąć szczere podziękowanie.
} 
Grund dieser Besuchssperre war in der Fälschung der Erlaubnisse (durch einen niedrigen Priester?) angegeben, dagegen erfahre ich aus dem Briefe Eurer Eminenz, dass tiefere, mir unbekannte Gründe da vorliegen.

Sehr wichtig finde ich die Bemerkung Eurer Eminenz von den voreiligen Urteilen über Konnersreuth, die sooft schon nach paar Wochen so leichtsinnig gefällt werden. Meist sind die exotischen Gäste, aber auch oftmals die katholischen Gelehrten begehen diesen großen Fehler, dass sie über die Dine über Konnersreuth schreiben, welche gar nicht in Wirklichkeit existieren, wie ich es z.B. einem Professor am Gregorianum (dem Pater Siwek) eingeredet und bewiesen und bewiesen habe aus Anlass der Veröffentlichung seines Briefes über Konnersreuth in der polnischen Sprache. Eben dieser Umstand und dabei die völlige Verkennung der mystischen Prinzipien war für mich der Grund gewesen, dass ich mich überhaupt entschlossen habe, über Konnersreuth zu schreiben. Nicht als ob ich mir zumuten könnte, dass gerade mein Urteil reif zum Entschlusse wäre, aber ich wollte wenigstens einen Versuch machen, das Material aufzusammeln, alle Tatsache festzusetzen und dieselben im Lichte der Philosophie und Mystik zu beleuchten. Ich folgte darin der Anregung und dem Rate der besten Kenner der Mystik, besonders im Ausland (Rom). Trotz alledem eilte ich nicht mit meiner Arbeit, mit der ich schon das dritte Jahr beschäftigt bin, und zwar sehr intensiv beschäftigt. Mein Brief sollte schon im vorigen Jahre erscheinen, als mir aber seine Exzellenz, Bischof Buchberger im vorigen Jahre geschrieben hat, dass ich vorsichtig, und zwar sehr vorsichtig vorgehen dürfe, folgte ich seinem Rate und prüfte noch einmal alle Dinge und ich verschob die Veröffentlichung. Ich schreibe davon Eurer Eminenz bloß aus dem Grunde, damit Eure Eminenz daraus ersehen könnten, dass es mir jedenfalls mit meiner Arbeit ernst sei, und dass ich auch vollends die große Verantwortung erkenne, die ich durch die Veröffentlichung eines solchen Briefes auf mich lade. Eben aus dem Grunde habe ich es für notwendig erachtet, mit Eurer Eminenz das Problem zu besprechen, nicht etwa deshalb, um mich mit dem Namen Eurer Eminenz zu [... $]^{\mathrm{b}}$ denn ich will mich und ich kann nicht mich überhaupt auf Eure Eminenz berufen, und seine hohe Stellung in irgendwelcher Weise, sondern einzig und allein, um die Fühlungnahme mit dem deutschen Episkopat die tiefere Leitlinie und Orientierung zu bekommen, dasselbe gilt besonders auch von seiner Exzellenz, dem hochw[ürdiger] Bischof von Regensburg, den ich wegen seiner Gelehrsamkeit, seines Charakters und Tugend besonders persönlich hoch verehre.

Ich freue mich, dass der Brief Eurer Eminenz die Gelegenheit dargeboten hat, meinen Standpunkt zu beleuchten und falls Eure Eminenz meine Gründe anerkennen würden, so werde ich sehr Eurer Eminenz verpflichtet sein, wenn mich Eure Eminenz auf der Audienz in München empfangen wollte. Ich will auch seine Exzellenz, den Bischof Buchberger in Regensburg, auf meiner Rückreise besuchen, falls er zu Hause sein würde. Ich kehre von hier nach Hause gegen 18. September. Mehr oder weniger um diese Zeit könnte ich nach München kommen.

In tiefer Ehrfurcht Eurer Eminenz ergeben.

b Wyraz nieczytelny. 


\section{Dokument 326}

Kopia: AFKDOPW, teczka 138: Spuścizna abp. Józefa Teodorowicza, bsygn., List abp. Józefa Teodorowicza do nieznanego biskupa, bmr.

\section{Eure ${ }^{\mathrm{a}}$ Exzellenz!}

Ich habe leider den Brief Eurer Exzellenz erst in Salzburg bekommen. Wie gerne würde ich bereit gewesen sein, Eure Exzellenz in Marienbad abzuwarten, wenn ich gewiss wäre, dass Eure Exzellenz noch zeitig für meine Fahrt nach Salzburg ankommen werden. Es liefen zwar dumme Gerüchte um, dass Eure Exzellenz kommt, aber es ließ sich trotz meines fleißigen Nachfragens nichts Näheres feststellen und vor allem das Datum des Kommens nicht. Es liegt mir so sehr am Herzen, mit Eurer Exzellenz die bekannten Probleme zu besprechen, dass ich auf der Rückreise, wenn Eure Exzellenz erlauben, meine Besuch in Regensburg zu machen, bereit wäre, oder sonst wo, mir Eure Exzellenz den Ort bestimmen. Das, was ich Eurer Exzellenz geschickt habe (auf Anordnung Faulhabers) ist nur ein Bruchstück, welches noch dazu aus Versehen meines Sekretariats nur teilweise ohne die ersten zwei Abschnitte übermittelt wurde. Die große Liebenswürdigkeit, die mir Eure Exzellenz durch die Bereitwilligung der Besprechung der Probleme mir erwiesen hat, lässt mir die Hoffnung aufkommen, dass ich überhaupt mit Eurer Exzellenz meine Einstellung zu den Problemen Konnersreuth besprechen und Bemerkungen und Anweisungen Eurer Exzellenz benutzen werde können. Daran ist mir aber viel gelegen. Überhaupt weiß ich die große verantwortliche $[\ldots]^{\mathrm{b}}$, als Bischof über dieses Problem zu schreiben, will ich dasselbe so erfassen, damit meine Bearbeitung und mein Brief mit dem Standpunkte des deutschen Episkopates im speziellen Eurer Exzellenz entspreche und mit demselben und den Grundlinien übereinstimme. Außer Eurer Exzellenz könnte nur der Kardinal Faulhaber der einzige gewesen sein, mit dem ich darüber sprechen konnte. Inwieferne ich aber aus seinem Briefe vernehmen kann, der die Antwort auf meinen diesbezüglichen Schritt gewesen ist, ist er vielleicht zu anfällig oder durch irgend eine andere Ursache [... $]^{c}$, oder um näher in das Problem eingehen zu wollen oder zu können. Dabei abgesehen von dem großen persönlichen Vertrauen, welches ich zu Eurer Exzellenz habe, ist Eure Exzellenz in erster Linie und gewissermaßen einzige, der berufen ist, über das Problem das Urteil zu fällen. Außer diesen so für mich hochwiegenden Rücksichten habe ich noch ein praktisches und meiner Ansicht nach allerwichtigstes Ziel im Auge, das sich nicht absolut ohne das Besprechen mit Eurer Exzellenz verifizieren lässt. Ich meine die so notwendige und von Eurer Exzellenz so berechtigt erforderte Bewachung Therese Neumanns in Rücksicht auf ihre Nahrungslosigkeit. Ich habe schon darüber Eurer Exzellenz geschrieben. In diesem Jahr nach meiner abermaligen Besprechung mit Therese Neumann bin ich nur in meiner

\footnotetext{
Tekst pisany czarnym atramentem na jednej stronicy papieru formatu A4. Brak autografu autora, miejsca wystawienia dokumentu i datacji. Tekst z tzw. kurrentschriftu przepisała Pani Gerlinde Stohl dyrektorka Muzeum w Sierndorfie an der March (Austria), za co zechce przyjąć szczere podziękowanie.

b Wyraz nieczytelny.

c Wyraz nieczytelny.
} 
Auffassung der Sachlage nur darin bestärkt geworden, dass man nur durch sie allein alles durchführen könne, was in den Grenzen der Situation sich durchführen ließe. Sie will ernst dem Wunsche ihres Bischofs nachkommen in wieferne dies in ihrer Lage nur möglich wäre, und das, was sie zu dieser Rücksicht zu tun geneigt wäre, $[. . .]^{\mathrm{d}}$ sich zur Bestehung der Probe genügen. Ich habe sogar einen ganz konkreten Plan, den ich Eurer Exzellenz vorlegen will. Deshalb bitte ich um die Nachricht, wann und wo ich Eure Exzellenz treffen könnte. Bis zum ungefähr 18. diesen Monats bleibe ich hier. Selbstverständlich bin ich mir dessen bewusst, dass für den Brief ich allein in der Öffentlichkeit die Verantwortung trage und deshalb werde ich mich weder auf Eure Exzellenz noch auf irgend einen anderen hochwürdigen Bischof berufen ausgenommen dieser [... $]^{\mathrm{e}}$, dass er direkt bei $[. . .]^{\mathrm{f}}$ Eurer Exzellenz wäre.

\section{Dokument 327}

Oryg.: AFKDOPW, bsygn., teczka: Spuścizna abp. Józefa Teodorowicza, List ks. Johanna Westrmayra do abp. Józefa Teodorowicza, bmr.

\section{Euere $^{\mathrm{a}}$ Exzellenz!}

Hochwürdigster Herr Erzbischof!

Gnädigster Herr!

Euere Exzellenz haben sich die große Mühe gegeben, mir ehrfurchtsvollst Unterzeichnetem mit unverdienter Aufmerksamkeit in deutscher Übersetzung den in Betracht kommenden Abschnitt zu schicken. Ich habe ihn mit größtem Interesse gelesen und mit angenehmsten Gefühlen von der wohlwollenden Beurteilung meiner Rezensionen Kenntnis genommen. Euere Exzellenz erwerben sich ein nicht geringes Verdienst um die Konnersreuther Sache, indem Sie die mystische Theologie zur maßgeblichen Norm nehmen. Ich habe seinerzeit in den Artikeln der Augsburger Postzeitung auch mit Nachdruck darauf hingewiesen, dass für die Konnersreuther Frage die theologische Mystik an erster Stelle zuständig sei und einige Kriterien derselben als Maßstab an das Konnersreuther Geschehen angelegt. Allerdings kann ich die bisher geübte $\mathrm{Zu}$ rückhaltung eben aus Gründen der Mystiktheologie noch immer nicht ganz aufgeben. Leider gestattet mir die starke berufliche Inanspruchnahme nicht mehr, mich mit der Ko[nnersreuth]er Frage noch ex professo zu beschäftigen.

Ich weiß nicht, ob Euere Exzellenz die Rücksendung Ihres Manuskriptes wünschen. Inzwischen behalte ich es auf. Möge Gott auch das Ko[nnersreuth]er Problem einer glücklichen Lösung zuführen!

Wyraz nieczytelny.

Wyraz nieczytelny.

Wyraz nieczytelny.

a Tekst pisany czarnym atramentem na jednej stronicy papieru formatu A4. Brak miejsca wystawienia dokumentu i datacji. 
Ehrfurchtsvollst verharrt Eurer Exzellenz ergebenster

Johann Westermayr

Regens

\section{Dokument 328}

Kopia: APJK, sygn. 4375, Siwek Paweł SJ. Korespondencja z lat 1937-1980, List ks. Henryka Weryńskiego do redakcji „Więzi”, bmr., [1966 r.].

ODPIS

List do Redakcji

\section{Arcybiskup ${ }^{a}$ Teodorowicz, ks. prof. Siwek i pewne powiedzonko}

Do ciekawego listu ks. Wincentego Helenowskiego, zamieszczonego w kwietniowym zeszycie „Więzi” (1966 r.) ${ }^{605}$, jest niezbędny komentarz i zasadnicze sprostowania także są konieczne.

1) Nie jest prawdą, że arcybiskup Teodorowicz „pozostawił na boku Pana Jezusa, by ujeżdżać Siwka...”. Sprawa pisania kilkutomowego dzieła chrystologicznego w niczym nie tangowała głośnej polemiki z ks. prof. Siwkiem w sprawie oceny zjawisk w Konnersreuth i vice versa ${ }^{606}$. Ks. arcybiskup Teodorowicz przestał drukować dalsze tomy swego szeroko zakrojonego dzieła nie dlatego, by móc „ujeżdżać Siwka”. Przestał drukować, ponieważ śp. ks. prałat Jan Korzonkiewicz ${ }^{607}$, ceniony biblista, do którego wiedzy i inteligencji ks. arcybiskup Teodorowicz miał pełne zaufanie przestrzegł go, że - nie mając naukowego przygotowania z dziedziny biblistyki - naraża się na popełnianie (przy najlepszej swojej woli) gaf i nieścisłości, które mogą go skompromitować. Zdołał też przekonać go, że zamiar przerasta jego siły.

Należy z największym szacunkiem ocenić decyzję ks. Arcybiskupa Teodorowicza. Choć to nie było ani łatwe, ani miłe, zawiesił drukowanie dalszych tomów. W pewnym sensie był to heroizm. Ale nie „pozostawił na boku Pana Jezusa”. Pracował nad dalszymi tomami i powierzył Siostrom pewnego Zgromadzenia Zakonnego ${ }^{608}$ teksty do tych tomów: bez planu wydawania. Od czasu do czasu drukował pewne fragmenty w organie prasowym Kurii Metropolitalnej Ormiańskiej „Gregoriana”, jako artykuły (np. o „Kazaniu na górze").

a Tekst pisany na maszynie na 3,5 stronicach papieru formatu A4. W lewym górnym rogu karty tytułowej nota odręczna niebieską kredką: „Odpisałem 16 V [19]66”.

605 W. Helenowski, Proboszczowie i wikarzy, „Więź”, 1966, nr 4, s. 125.

${ }^{606}$ Łac.: na odwrót.

607 Korzonkiewicz Jan (1877-1932), święcenia kapłańskie w 1902 r. w Krakowie, dr teologii, 1908-1920 wykładowca biblistyki na Wydziale Teologicznym UJ, habilitacja w 1909 r., w 1917 r. prof. nadzwyczajny, 1915-1920 rektor Seminarium Duchownego w Krakowie, w 1919 r. mianowany kanonikiem gremialnym Kapituły Katedralnej tamże, 1922-1932 proboszcz katedry, autor publikacji z dziedziny biblistyki, teologii pastoralnej i publicystyki. M. Jagosz, Korzonkiewicz Jan, w: SPTK, t. 6, red. L. Grzebień, Warszawa 1983, s. $144-153$.

${ }^{608}$ Zapewne aluzja do Zgromadzenia ss. Zmartwychwstanek. 
Informacje moje opierają się na rozmowach z ks. Korzonkiewiczem, z którym miałem zaszczyt przyjaźnić się w ostatnich latach jego życia.

2) Wprost zaskakującą jest nonszalancja, z jaką ks. Helenowski potraktował polemikę pomiędzy ks. arcybiskupem Teodorowiczem a ks. prof. Siwkiem. Oto jego słowa: „Znany uczony ks. Siwek ogłosił w prasie głośny artykuł. Ks. arcybiskup przerwał pisanie swego dzieła, a ostrze pióra obrócił na polemikę z ks. profesorem Siwkiem...”.

a) Ani słowem nie zaznaczył ks. Helenowski, o jaką to chodziło polemikę. A przecież polemika odbiła się echem zagranicą.

b) To nie o „głośny artykuł” ks. Siwka poszła sprawa. Sprawa poszła o całą postawę ks. Siwka w ocenie zjawisk w Konnersreuth i w ocenie „bohaterki” tych zjawisk stygmatyczki bawarskiej Teresy Neumann.

Sprawa poszła o książkę ks. Siwka pt.: „Konnersreuth w świetle nauki i religii” wydaną w Krakowie. Kiedy ks. arcybiskup Teodorowicz stanął w obronie niemieckiej stygmatyczki, ks. Siwek wydał drugą poważną książkę pt.: „Metody badań zjawisk nadprzyrodzonych".

Trzeba być w zgodzie z prawdą historyczną nawet wówczas, gdy chodzi o kilkuwierszowy list do Redakcji. Sprawa zakończyła się całkowitym zwycięstwem ks. Siwka. Już wydana w r. 1950 w Paryżu książka ks. Siwka pt.: „Une stigmatisée de nos jours”609 przechyliła poważną szalę na jego stronę. Ale o przypieczętowaniu zwycięstwa zadecydowała jego książka angielska pt.: „The riddle of Konnersreuth" 610 wydana w r. 1953 w Stanach Zjednoczonych w Milwaukee i w r. 1954 w Irlandii w Dublinie ${ }^{611}$. Jak wysoko została oceniona ta książka angielska świadczy o tym fakt, że przedmowę do niej napisał ówczesny sekretarz Kongregacji Obrzędów ks. arcybiskup Alfons Carinci ${ }^{612}$, chwaląc z całym uznaniem metodę autora w badaniu zjawisk nadprzyrodzonych. „Przez to dzieło - pisze arcybiskup Carinci - zasłużył się autor bardzo wobec Nauki i wobec Kościoła, a w szczególności wobec Św[iętej] Kongregacji Obrzędów...”.

Ks. prof. Siwek doczekał się tej wielkiej satysfakcji, że zagranicą ta książka uchodzi za „Standard Work”, a Kongregacja Obrzędów uznając w metodzie autora "modello del genere" - według słów arcybiskupa Carinci - przyjęła tę książkę jako substrat do orzeczeń Kongregacji w sprawach stygmatów.

Tak - w elementarnym skrócie - przedstawia się sprawa polemiki, którą skwitował ks. Helenowski w sposób całkiem niepoważny. Przypuszczam, że ks. Helenowski byłby się powstrzymał od powtórzenia nieszczęśliwego i mało kulturalnego powiedzonka (o „ujeżdżaniu Siwka”), gdyby zdawał sobie sprawę z wymiarów i doniosłości tej sławnej

${ }_{609}$ P. Siwek, Une stigmatisée de nos jours: étude de psychologie religieuse, Paris 1950.

610 Tenże, The riddle of Konnersreuth. A psychological and religious study of Theresa Neumann, Milwaukee 1953.

${ }^{611}$ Tenże, The riddle of Konnersreuth. A psychological and religious study, Dublin 1954.

${ }^{612}$ Carinci Alfonso (1862-1963), święcenia kapłańskie w 1885 r. w Rzymie, w 1917 r. otrzymał sakrę biskupią i mianowany został konsultorem Kongregacji Obrzędów, 1930-1960 sekretarz tejże Kongregacji, w 1945 r. mianowany arcybiskupem tytularnym. Źródło: Alfonso Carinci, https://it.wikipedia.org/wiki/Alfonso_Carinci. Dostęp: 6 V 2017 r.

b-b Autograf czarnym atramentem. 
polemiki. Dla ks. arcybiskupa Teodorowicza mogła się skończyć tragicznie. Jego niemiecka książka w obronie zjawisk w Konnersreuth była już na krawędzi indeksu, jak to stwierdziłem u bardzo dobrze poinformowanych. Sprawę przetrzymano i zatuszowano, by oszczędzić zbyt wielkiej przykrości arcybiskupowi. Niedługo potem zmarł i sprawa zeszła definitywnie $\mathrm{z}$ wokandy.

${ }^{\mathrm{b}-K s . ~ H e n r y k ~ W e r y n ́ s k i ~}{ }^{\mathrm{b}}$

P.S. Ks. Helenowski pisze, że ks. arcybiskup Teodorowicz opracowywał dzieło pt.: „Żywot Chrystusa Pana”. Czy pod jakim tytułem? Wiemy, że z serii, którą sobie planował, wydał następujące tomy:1) „Od Jahwe do Mesjasza”, 2) „Herold Chrystusa na tle epoki”, 3) „Od Betlejem do Nazaretu”.

Redakcja 